\title{
السلطة التقديرية لهيئة التحكيه في الإثبات (دراسة تأصيلية مقارنة)
}

\author{
shel \\ د. اطلعت يوسف خاطر \\ أستاذ قانون المرافعات المساعد \\ كليتالحقوقـ جامعت المنصورة
}




\section{هقدمة}

يعد التحكيم من أهم وسائل فض المنازعات فى الوقت الحاضر ، لما يتميز به من السرعة والسرية والمرونـة وحريـة طرفي التحكيم فى اختيـار هيئة التحكيم، واختيـار إجر اءات التحكيم،. وبالتالي يتجنب بعض سلبيات قضاء الدولة'(')

ويعد الإثبات في مجال الدعوي التحكيمية من أهم إجراع|تها التي يتعين إدارتها من قبل هيئة التحكيم بعناية وحرص، ليتمكن كل طرف من أطراف خصومة التحكيم من تقديم أساس وحجج دافعة للحصول علي حقه، فكل خصم يتبـارى في تقديم الأدلـة التي تبرهن صدق دعواه، ودحض أدلة خصمه تحت رقابة وتقدير هيئة التحكيم(؟). لذا كان اهتمـام مختلف التشريعات التحكيميـة وقواعد التحكيم الـصادرة عن مراكز التحكيم بموضوع الإثبات.

ويلاحظ أن ازدياد ثقة الخصوم بـور هيئة التحكيم وحسن استخدامها سلطتها في الإثبات يساعد فى التنفيذ الاختياري لحكم التحكيم، ومنع تعريض الحكم للبطلان أو الطعن عليه بالاستئناف في بعض الأنظمة القانونية التي تأخذ بهذا الطعن مثل القانون الفرنسي، كما أن سلطة هيئة التحكيم في الإثبات تتأسس على قاعدة أصولية قوامها

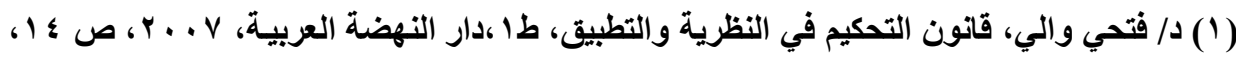

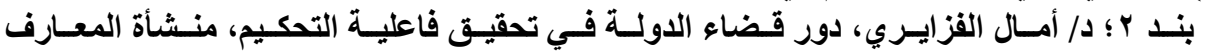

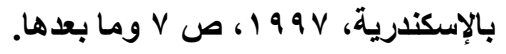

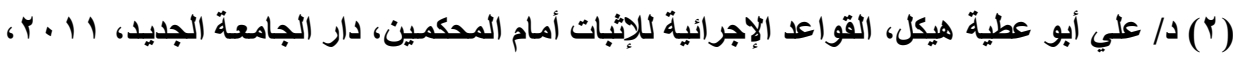


وجوب اطمئنان المتقاضي إلى قاضيه، وأن قضاءه لا يصدر إلا عن الحق وحده دون

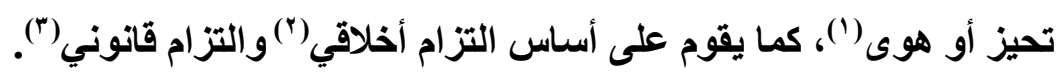

ونظرا لأن هيئة التحكيم يـتم تشكيلها عن طريـق الخصوم(4)، ومـن أشـخاص

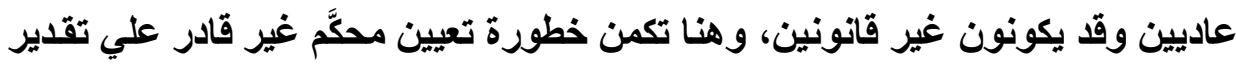

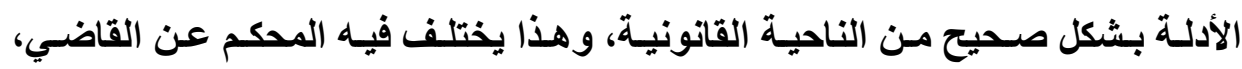

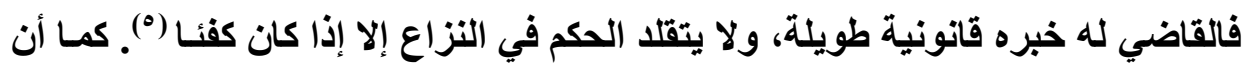

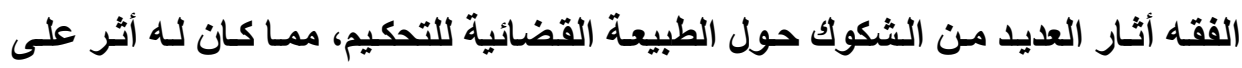

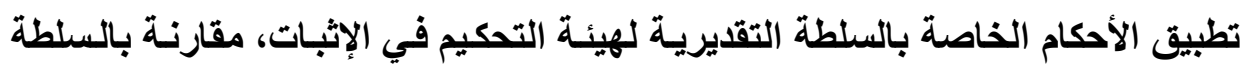
التقديرية لقاضي الدولة. ونشير فى هذه المقدمة إلى النقاط الآتية:

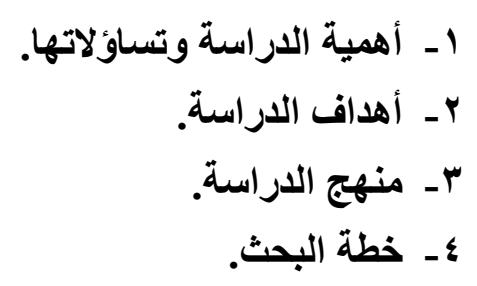

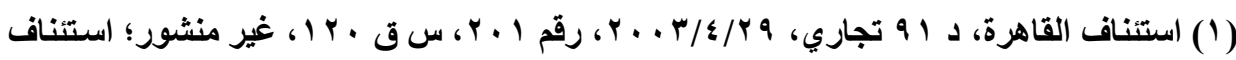

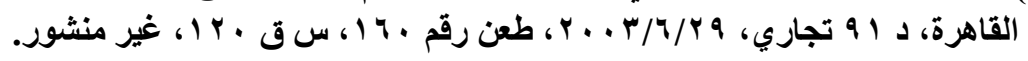

(2) X. de MELLO, «réflexion sur les règles déontologiques élaborées par l'international bar association pour l'arbitres internationaux», Rev. arb., 1988, p. 339.

(3) CA Paris, 20 novembre 1997, Rev. arb., 1999, p. 329.

(4) $X$. de MELLO, «réflexion sur les règles déontologiques élaborées par l'international bar association pour l'arbitres internationaux», Op. cit., p. 339, spec. P.343.

(5) Ph. GRANDUEAU, note sous la CA Paris, 28 octobre 1999 et CA Paris, 30 novembre, Rev. arb., 2000, p. 299, spec. p. 309. 
تحتل قواعد الإثبات أهمية خاصة، هو الوسيلة التي يتوصل بها صساحب الحق علـي إقامـة الـليل علـي قيامـة هـذا الحـق أمسام التحكيم، فـالحق موضـوع التقاضسي يتجرد من كل قيمة ما لم يقم الدليل علي قيامـه. فالدليل قوام حياة الحق، بل هو الذي يحيـي الحـق ويحميـه، ويـثنل الإثبـات الجانـب الأكبر مـن نـشـاط الخصوم والمحكـم. فمن يدعي حقا يتعين عليه تقديم الأدلة والمستندات التي تبرهن علي وجود الحق، فعبء إثبـات الادعـاء يقع علـي عـاتق مـن يدعيـه مراعيـا في ذلكت الشروط القانونيـة

وإذا كان القاضي يتمتع بسلطة تقديرية واسعة عندما يقوم بعمل قضائي (')، فبان للمحكم سلطات تقديريـة واسـعة في وصوله لإصدار حكم في النزاع المعروض عليه، وإذا كان القانون والفقه قد عالجـا السلطة التقديريـة للقاضي خاصـة في تقدير الأدلة، سواء في المجال المدني أو الجنائي، إلا أنهم لم يتعرضا للسلطة التقديرية لهيئة التحكيم بشكل كـاف، وهذه السلطة التقديريـة ماز الت محل نقـاش وخلاف، وذلك لعدم وجود إلت نصوص تعرفها أو تحدد حالاتها وآثار ها.

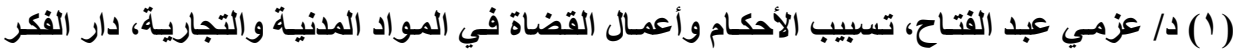

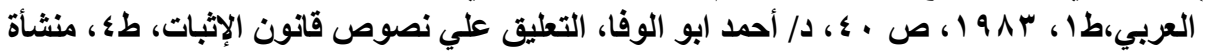

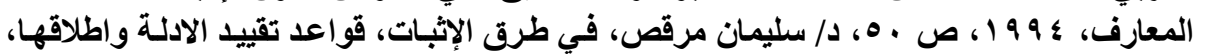

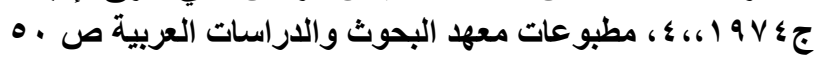
Marcel o stati, Le standard juridique, These, Paris, 1927, p. 30 
وفي الواقع أن سلطة المحكم التقديريـة ترتبط أوثق الارتبـاط بتحديد دور إرادة المحكم في تكوين العمل التحكيمي. ودور المحكم مثل دور القاضس، حيث يعتبر العمل القضائي ككل مجرد نشاط ذهني إرادي لاكتشاف حقائق موجوده فعلا' ') ويرجع اختيارنا لموضوع البحث إلى أهمية الإثبات في مرحلة خصومة التحكيم،

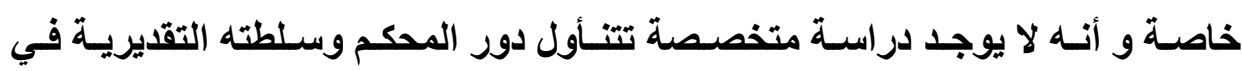
الإثبات بشكل كامل. كما أن هناتك الكثير من المشكلات التي يثيرها موضوع الإثبات أمام هيئة التحكيم، كما أنه يوجد اختلاف في الحلول التشريعية والقضائية بشأن سلطة هيئة التحكيم في الإثبات. وذلك لأن هيئة التحكيم غير مقيدة بإجراءات المرافعات بصفة عامة ما لم يوجد اتفاق علي خلاف ذلك، لذا ذهب جانب من الفقه إلى أن الإجراءات المتبعة أمام هيئة التحكيم لا تعتبر قضائية(؟) لأنها لا تتصل بخصومة أمسام محكمة تتبع جهة قضائية)(").

ويكتسب البحث في هذا الموضوع " السلطة التقديرية لهيئة التحكيم في الإثبات " أهمية كبري، باعتباره يتناول أهم الموضوعات التي يقوم عليها التحكيم، وهي دور هيئة التحكيم في خصومة التحكيم، وإذا نظرنـا إلى عناصر التحكيم، فإنـا نجد أن أهم واخطر عناصر التحكيم هي خصومة التحكيم، وأدق الموضوعات في خصومة التحكيم تتعلق بالسلطة التقديريـة لهيئة التحكيم في الإثبات، وخاصـة تحديل مدي سلطتها في الأمر والإلزام بتقديم أدلة الإثبات، وذلك بهدف الوصول إلى حل للنزاع المطروح على هيئة التحكيم، بمـا يحقق العدالـة والاستقرار لمراكز الخصوم. ومن هنـا تمثل السلطة

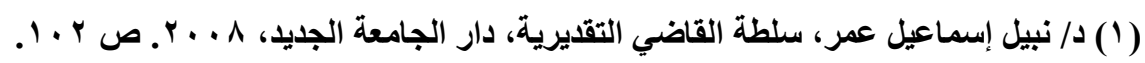

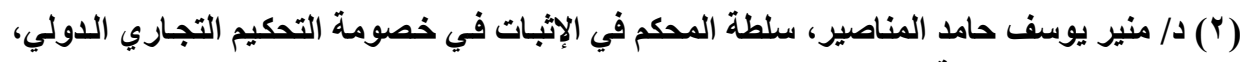

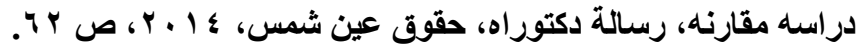

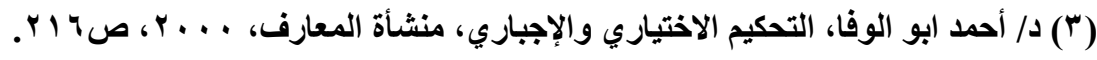

مجلة البحوث القانونيتّ والإقتصاديت 
التقديريـة لهيئة التحكيم في الإثبـات أهميـة عمليـة، لأن عدالـة التحكيم تقتضي حسن

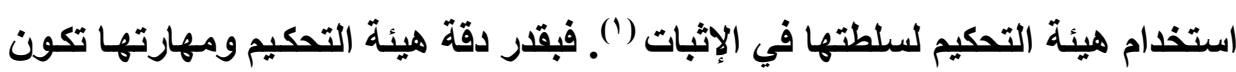
سلامة إجراعات التحكيم وصحة الحكم الصادر. ولاشك في أن الدراسة التجريدية ولو في بعض مراحلها هي من أشتى الأمور وأصلبها، وإذا مـا حأولنـا البحث عن تحديد منضبط للسلطة التقديريـة لهيئة التحكيم بوجـه عـام، فِان الصعوبة تظهر بشكل حـاد، وبالذات حينمـا نحسأول البحث عن نقطة البدأية والنهائة التي منها ننطلق إلى التحديد المجرد لحدود هذه السلطة. وذلك لتشعب لهب الموضوعات، فهل نبحث في طبيعة النزاع المطروح علي هيئة التحكيم لكشف حدود سلطتها التقديرية؟ أم ننظر لجوهر نشاط المحكم؟ واذا نظرنا إلى جوهر نشاط المحكم، هل نرتكز علي محل هذا النشاط أي وقائع النزاع والقانون المطبق عليه؟ أم ننظر إلى المجهود العقلي الذي يغلف هذا المحل بغية إعمال القانون أو قواعد العدالة؟ وهل يجب أن نمد نطاق البحث إلى المساهمة التي يقدمها الخصوم في أعمال وتكوين هذه السلطة

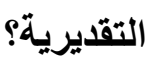
ونظرا لأن التحكيم يتـولاه أفراد غير معينين مسن قبـل الدولـة، حيـث يعينهم الخصوم ويخولونهم السلطة القضائية بناء على اتفاقهم، فإنه يثار تساؤل حول الطبيعة القانونية لاور المحكم في الإثبات؛ هل لهم دور أيجابي أم دور سلبي، ومن ثم هل من

(1) J.-Cl. DUBARRY et E. LOQUIN, «la désignation comme arbitre de l'avocat de l'une des parties», obs. sous CA Versailles, 14 novembre 1996, RTD com. 1997, p 234; CA Paris, 6 avril 1990, Rev. arb., 1990, p. 880; M. HENRY, Le devoir d'indépendance de l'arbitre, thèse, Paris, sous la direction de P. MAYER, soutenue le 28 novembre 1996, p. 59; $M$. HENRY, " Les obligations d'indépendance et d'information de l'arbitre à la lumière de la jurisprudence récente' Rev. arb., 1999, p. 194. 
الضروري أن يتقيد المحكم بنفس السلطات المخولة للقاضس؟ أم لا يشترط ذلك؟ كمـا يثور التساؤل عن الحالات التي يستخدم فيها المحكم سلطته التقديريـة في الإثبات، فمـا مدي نطاق سلطته في الإثبات ؟ ومـا هي الضوابط التي تحكم هذه السلطة. ومـا هي الجزاعات التي تترتب علي الانحراف في هذه السلطة؟ وهل دور هيئة التحكيم في هي الإثبات توجيهي إرشادي فحسب أم أنه يتدخل بهدف الكثف عن الحقيقة غير مرهون بمواقف الخصوم؟ وهل هيئة التحكيم يتوقف دورهـا علي الترجيح بين أدلـة الخصوم وتـوازن بينهـا؟ أم أنهـا تملكت زمسام المبـادرة بالسعي لمعرفـة الحقيقة كمـا هو الشأن بالنسبة للقضاء؟

وإذا كان موضوع السلطة التقديرية لهيئة التحكيم يزخر بالعديد من التساؤلات

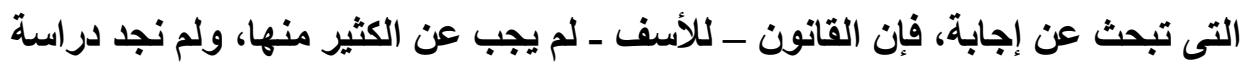

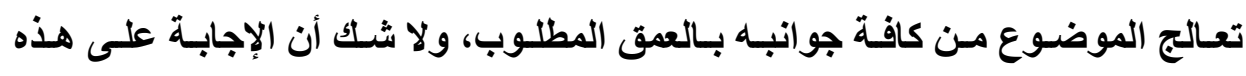
التساؤلات تقتضى التعرض لبيان مفهوم الإثبات ودور الخصوم فيسه، ثم بيـان سلطة هيئة التحكيم في الإثبات، ومدي نطاق هذه السلطة، والضوابط التي تلتزم بها الهيئة عند ممارستها لسلطتها، وأثر مخالفة هذه الضوابط. في الواقع هناك ثمة صعوبة في بحث هذا الموضوع،وذلك لكونه موضوعا يتسم بالطابع العملي، الأمر الذي أثثار عند اختياري لهذا الموضوع بعض الصعوبة، وخاصة وأنه لم يكن الطريق سـهلا ولا ممهدا، خاصـة في مرحلة جمع المعلومـات من مختلف المراجع القانونية والأحكام والنصوص القانونية. يضاف إلي ذلك تنوع صور السلطة التقديرية لهيئة التحكيم وتناثرهـا في شتي جوانب القواعد الإجرائية، واختلاف الفقه والقضاء في تطبيقها، فضلا عن قصور الدراسات الفقهية، يجعل هذه الدراسـة محفوفة بالصعوبات، وهذه الصعوبة لم تحل دون التعرض لهذا المسألة القانونية نظر الأهميتها وخطورتها في الواقع العملي. وبـالرغم من هذه الصعوبات إلا أنها لـم تكن بحال من 
الأحوال لتثبط من عزيمة الباحث، أو تضعف من هته في البحث، وذلك تحقيقا للغأية، ألا وهي ضبط السلطة التقديرية لهيئة التحكيم في الإثبات. وذلكك بهدف تحقيق فائدة

$$
\begin{aligned}
& \text { عملية وعلمية في ذات الوقت. } \\
& \text { r- أهداف البحث: }
\end{aligned}
$$

تهلف الدارسة إلى بحث السلطة التقديرية لهيئة التحكيم في الإثبات في خصومة

$$
\text { التحكيم، وتهذف إلى الآتي: - إلى }
$$

- بيان مفهوم الإثبات أمام هيئة التحكيم، ودور الخصوم في الإثبات ـ ـ تحديد أدلة الإثبات التحكيمية، ومدي تثابها بأدلة الإثبات أمام القاضي المداني. - بيان موقف الأنظمة التحكيمية من أدلة الإثبات أمام هيئة التحكيم. ـ ـ تحديد مفهوم السلطة التقيرية لهيئة التحكيم. ـ ـ تحديد دور هيئة التحكيم في الإثبات - بيان نطاق السلطة التقليرية لهيئة التحكيم في الإثبات - رسم الضوابط التى يتعين على هيئة التحكيم الالتزام بها في حالة استخدام سلطئل

$$
\text { التقديرية في تقدير الأدلة. }
$$

- بيان قو اعد الرقابة علي السلطة التقليرية لهيئة التحكيم مقارنة بقضاء الاولة. - - بيان الجزاء المترتب علي مخالفة قواعد الإثبات. - رسم حدود المسئولية المدنية لهيئة التحكيم عند إخلالها بواجب التهي التقدير المنطقي. - الخروج ببعض النتائج والتوصيات

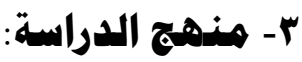

نظرا لأن موضوع الإثبات لـه شتق عملي وشتق نظري، فإنـا سنتبع المنهج

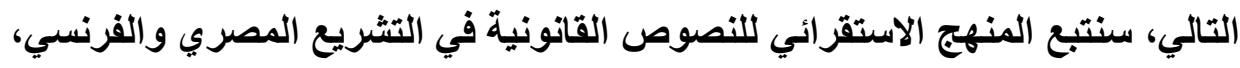


وقواعد المراكز وغرف هيئات التحكيم، ثم نتنأول تلك النصوص بالتحليل المنهجي، ثم المنهج التأصيلي في رصده لمسا تتضمنه أحكام القضاء المصري و القرنسي وأحكام مراكز التحكيم، ومحاولة تأصيلها للخروج منها بالمبادئ التي يمكن أن تثكل عددا من فن التهاهي

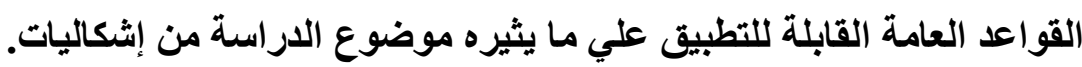

وبالتالي سوف نستخدم المنهج التحليلي المقارن، وذلك بارسة وتحليل سلطة

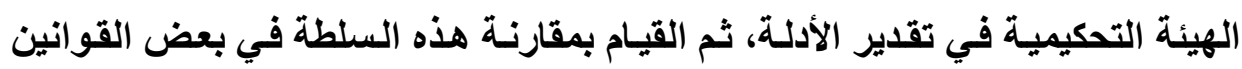

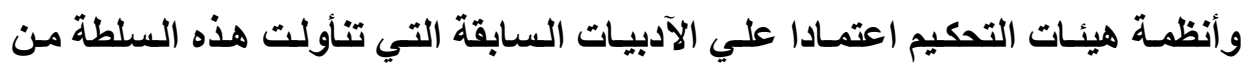

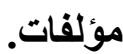
ونستند في هذه الدراسة إلى كل من القانون المصري والقانوني الفرنسي -

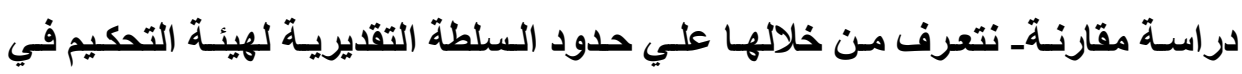

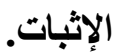

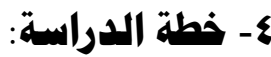

يدور موضوع البحث حول السلطة التقايريـة لهيئة التحكيم في الإثبات، ولهذه

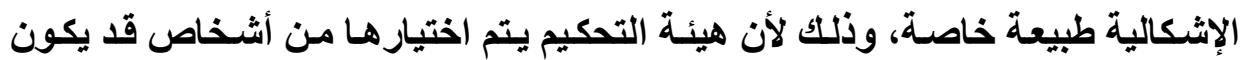

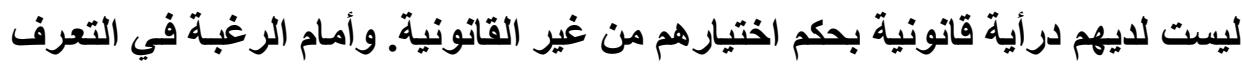

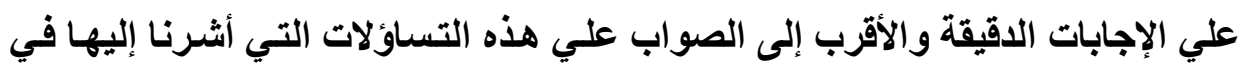

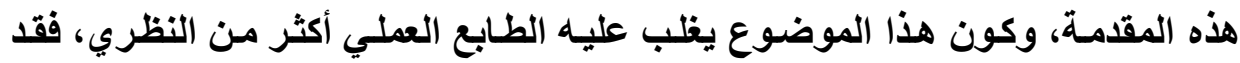
رأيت أن نعالج موضوع الاراسة من خلال الخطة الآتية: • مبحث تمهيدي: مفهوم الإثبات أمام هيئة التحكيم ودور الخصوم. • • الفصل الأول: دور هيئة التحكيم في الإثبات وسلطتها التقديرية. • الفصل الثاني: ضوابط السلطة التقديرية هيئة التحكيم في الإثبات. 


\section{المبحث تمهيدي \\ هفهوم الإثبات أهام هيئة التمكيم ودور الفصوم}

تعد إجراعات الإثبات من أهم مراحل الخصومة، حيث تؤدي إلى إثبات الحقوق،

وبالتالي الفصل في النزاع، فكل خصم يتباري في تقديم الأدلة التي تبرهن صدق دعواه، ودحض أدلة خصمه تحت رقابـة وتقدير هيئة التحكيم('). ويلاحظ أن الحق موضوع التهي التحكيم يتجرد من كل قيمة إذا لـم يقم الدليل على وجوده(×)، وبـالرغم من أن الإثبات ليس عنصرا من عناصر الحق، وإنما أمر خارج عنه، حيث إن الحق ينشأ من مصادره طبقا للقانون بصرف النظر عن وسيلة إثباته إلا أن وجود الحق مرتبط بإثباته. إذن يعد

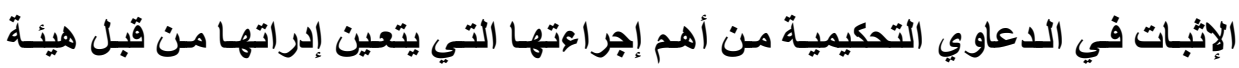
التحكيم بعنائة وحرص، ليتمكن كل من طرفي الخصومة التحكيمية مـن تقديم أسس

$$
\text { وحجج دفاعه للوصول إلى حقه. }
$$

ويقتضي بحث السلطة التقديريـة لهيئة التحكيم في الإثبـات التمهيد لـه بمـا

يثيره هذا الموضوع من مفاهيم، ومـا يقترن بـه مـن مصطلحات، ونري أنها من المفيد بيان مفهوم الإثبات أمسام هيئة التحكيم. ثم نعـالج دور الخصوم في الإثبات أمسام هيئة

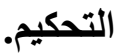

سنشير في هذا المبحث إلى ماهية الإثبات أمام هيئة التحكيم، ودور الخصوم في

الإثبات أمام هيئة التحكيم، وذلك في المطالب الآتية:

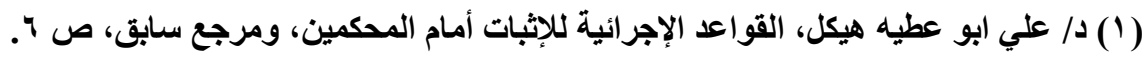

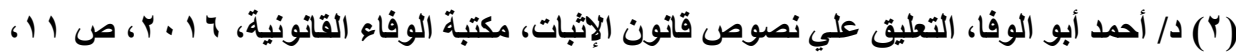

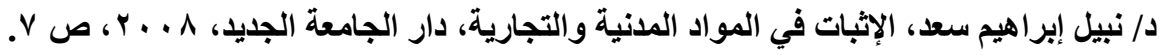




\section{المطاب الأول \\ هاهية الإثبات التمكيمي لمون}

في الواقع، يقوم تنظيم الإثبات على التوازن بين اعتبارين أساسيين: العدالة

واستقرار التعامل، والإثبات التحكيمي يؤدى إلى حقيقة واجبة الاحترام، وهذه الحقيقة قد تتعارض مع الحقيقة الو اقعية أو قد تتباعد عنها أو تتقارب منها أو قد تتفق معها،

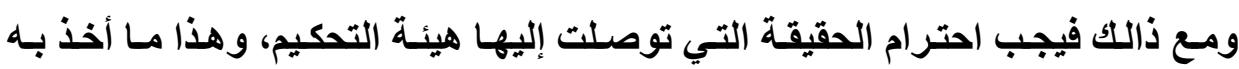
المشرع المصري، حيث نص في المادة ــ تحكيم علي أن أحكام التحكيم تحوز الحجية. سنثير في هذا المطلب إلى تعرف الإثبات أمام هيئة التحكيم، وخصائصه، ومحله، وذلك

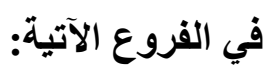

\section{الفرع الأول \\ تعريف الإثبات}

سنشير إلـى تعريـف الإثبـات في اللغـة، ثم تعريفـه الاصطلاحي في علـم القانون، وذلك في النقاط الآتية:

\section{أولأ: التعريف اللغوي للإثبات:}

هو من فعل ثبت وثبت-وثباتاـوثبوتا أى استقر (')، ويقال صح وتحقق والتثبيت

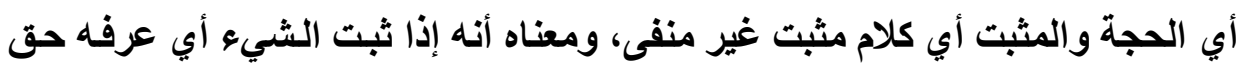

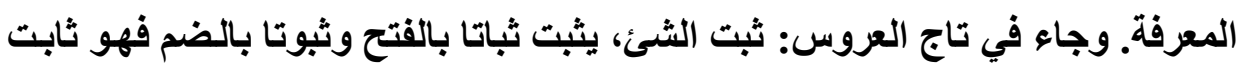




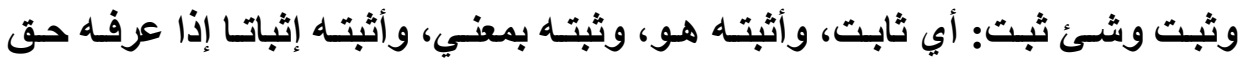
المعرفه('). وجاء في لسان العرب، تأكيد الحق بالبينة، والبينة هي الدليل أو الحجة)(')،

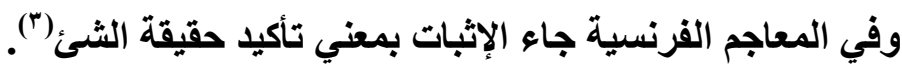

\section{ثانيا: التعريف القانوني للإثبات:}

ذهب البعض إلى تعريف الإثبات بأنه تأكيد حق متنازع فيه له أثر قانوني بالدليل

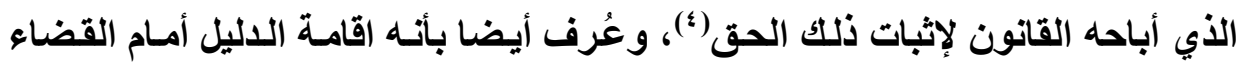

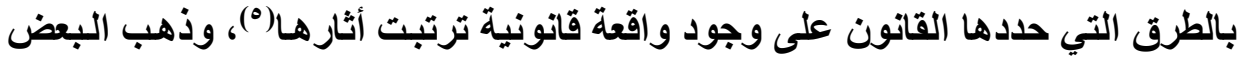

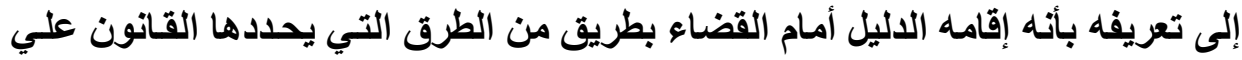
وجود أو صحه و اقعة قانونية متنازع فيها بين الخصوم("). ويري البعض أن الإثبات إقامة الدليل أمام هيئة التحكيم بطريق من الطرق التي حددها القانون الواجب التطبيق أو يتفق عليها أطراف الخصومة التحكيمية وإقناعها

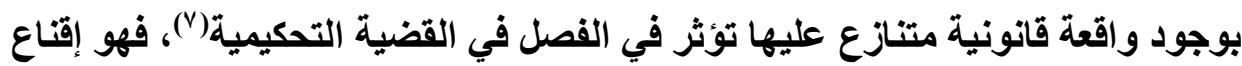
هيئة التحكيم بادعاء أو بآخر من جاتب هذا الخصم أو ذأك.

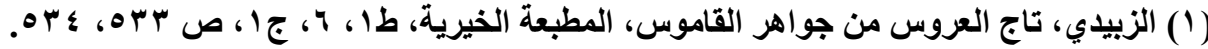

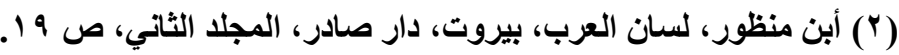

(َ) Henri Bejoint, le Robert Methodique du france actuel.

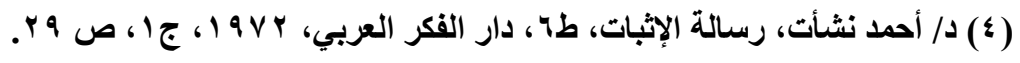

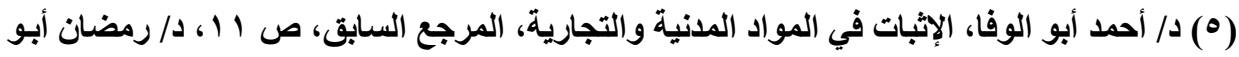

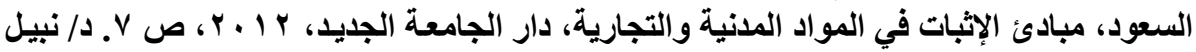

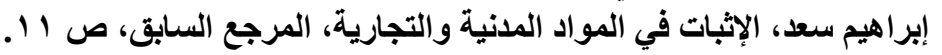

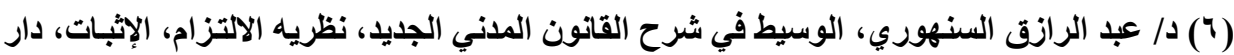

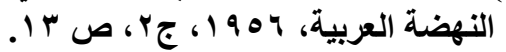
(V) دالمنير يوسف حامد المناصير، سلطة المحكم في الإثبات في خصومة التحكيم التجاري الدولي،

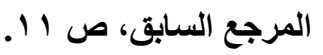


حيث إن الدليل يقدم من قبل الخصوم أمام القضاء أو التحكيم وبالطرق المعتبرة

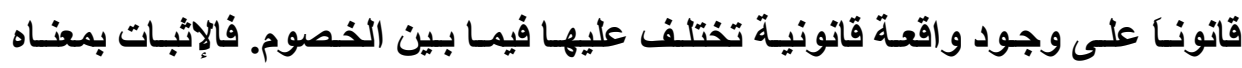

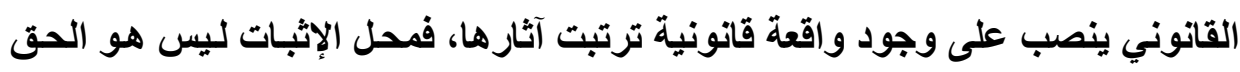

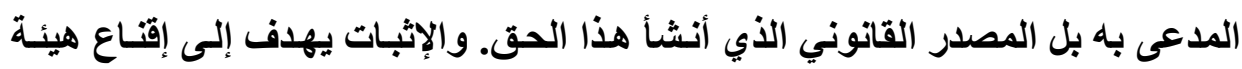

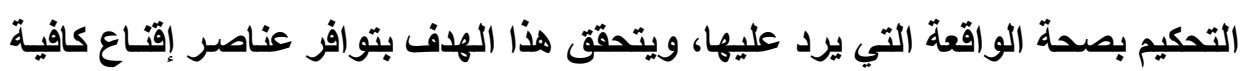

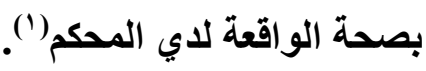

ومن جانبنا نري بأن الإثبات في الخصومة التحكيمية هو إقامة الدليل أمسام هيئة

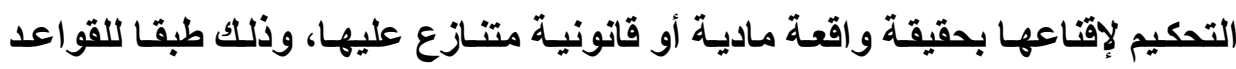

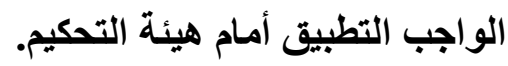

\section{الفرع الثاني \\ خصائص الإثبات أهام هيئة التمكيم}

في الواقع، يري بعض الفقه أن الإثبات يجري أمسام هيئة التحكيم، كما يجري أمام قضاء الدولة، ويكون بأدلة الإثبات المقررة قانونا بالنسبة للواقعة المراد الثراد إثباتها وبالنظر إلى قوة كل دليل وأهميته في تكوين اقتناعها(") في حقيقة الأمر، هذا الاتجاه

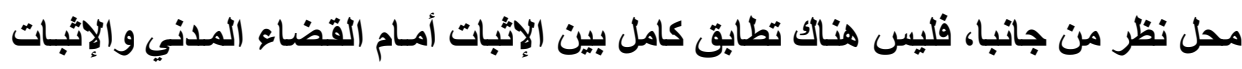

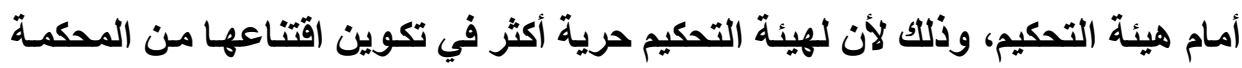

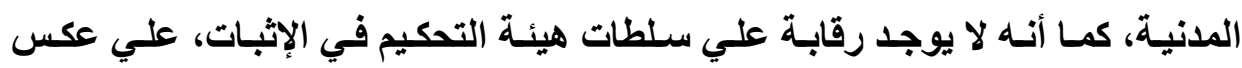

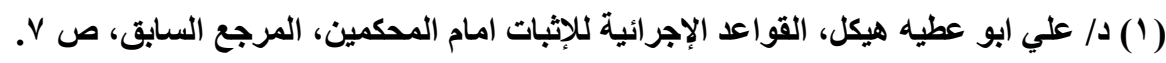

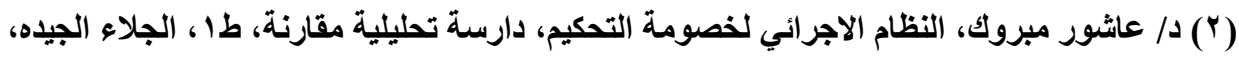

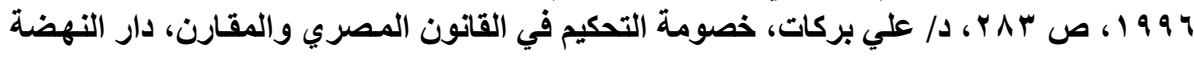


قاضي الدولة، لذا نري أن خصائص الإثبات أمام هيئة التحكيم لها طبيعة خاصسة، تتميز عن الإثبات الأي يجري أمام قضاء الدولة. كما أن أدلة الإثبات وإن كانت متشابه في

النظم القانونية المختلفه إلا أن بعضها يعد في مجال التحكيم لله خصوصيه معينة. في حقيقة الأمر، يخضع الإثبات في مجـال التحكيم لقواعد عامـه مشتركه في مختلف النظم القانونية التي لا تختلف بحسب طبيعة التحكيم، سواء كان تحكيما دوليا أم تحكيما داخليا.

ويتمثل خصائص الإثبات أمام هيئة التحكيم في الآتي:

\section{ا- حرية الفصوم وهيئة التمكيم في تحديد إجراءات الإثبات:}

نصت المادة هr من قانون التحكيم المصري، علي أن "لطرفي التحكيم الاتفـق

علي الإجراءات التي تتبعها هيئة التحكيم...، فإذا لم يوجد مثل هذا الاتفـاق كان لهيئة التحكيم، مـع مراعـاة أحكـام هــا القـانون، أن تختــار إجـراعات التحكيم التـي تراهـا مناسبة"، وقد نص قانون المرافعات الفرنسي الجديد في المـادة ـ ؟ ؛ ا علـي أن ينظم المحكمـون إجـراءات التحكيم دون أن يكونـوا ملـزمين باتبـاع القواعدالمعتمــده أمسام المحاكم، إلا إذا كان الأطراف اتفقو علي خلاف ذلك في اتفاق التحكيم. فيستفاد من هذه النصوص أن هيئة التحكيم لها حرية في تنظيم إجراعات الإثبات أمامها، في حالـة عدم

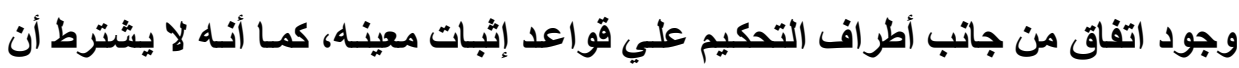
تطبق هيئة التحكيم قواعد الإثبات المتبعه أمام قضاء الدولة. في الواقع، نظام الإثبات أمام هيئة التحكيم لـه خصوصيه يتميز بيها وتتفق مـع طبيعه التحكيم، حيث يمكن اللجوء إلى تطبيق قو اعد إثبات لقانون معين، أو يتم إنشاء قواعد إثبـات خاصـة مسن جانب هيئة التحكيم أو أطراف التحكيم، أو يمكن للأطراف تخويل هيئة التحكيم سلطة تحديد هذه الإجراءات، أو يخويل شخص من الغير تولي 
تحديد قواعد الإثبات الواجبه التطبيق أو اللجوء إلى مركز تحكيم تتضمن لاتحته قواعد

إذا في نظام التحكيم، يكون الإثبات الحر، هو المسيطر علي نظام التحكيم، علي عكس نظام الإثبات أمام قضاء الدوله، حيث يحدد القانون أدلـه الإثبات وقوة كل دليل، ويمنح القاضي بعض السلطات التقديريـة في الأدله التي لم يحدد القانون قوتها مثل الشهاده والقرائن القضائية) (')

ونخلص من ذلك أن نظام الإثبات أمام هيئة التحكيم أكثر مرونة من الإثبات أمسام القضاء، بمعنى أن الإثبات أمام قضاء الدولة لا يتم إلا بالطرق القانونية وفقا للإجراءات المرسومة لكل منها، كما أن القاضي لا يستطيع تكوين عقيدته بغير هذه الطرق(؟).

\section{r- عدم هراقبة هيئة التمكيم في تطبيتق قواعد الإثبات.}

في الواقع، نظام الإثبات أمسام هيئة التحكيم يمنح المحكم سلطة كبيرة في أن يكون لله دور أيجابي في التحكيم، فهو يملك مساعدة الخصوم في استكمال ما نقص من أدلتهم، بـل ولـه الحق في أن يقضي بعلمـه الثخصي بالوقائع بعد أن يكون قد أجري بثأنها مبدأ المواجهة، وله أن يأخذ بكل طرق الإثبات من أجل الوصول إلى الحقيقة. فهذا النظام يهاف إلى اطلاق حريه المحكم في تكوين عقيدته في الدعوي بالطريقة التي ير اها مناسبة(")، دون الرقابة عليه من محكمة الطعن. وذلك علي عكس نظام الإثبات Arb., 1999, p. 103, note lalive; Cass. Civ., 1re, 20 fev. 2000, Rev. Arb., 2001, p. 54, note T. Caly. 
أمام قضاء الدوله، حيث يتقيد القاضي بقواعد معينة يجب مراعاتها، ولا يملك الخصوم الاتفاق علي عدم تطبيقها أمام القاضي، ولا يملك القاضسي مخالفتها، حيث يترتب علي ذلك بطلان حكم القاضي أمام محكمة الاستئناف.

ونلاحظ أنه لا يوجد رقابة علي هيئة التحكيم عند حدوث خطأ من هيئة التحكيم

في فهم أو تفسير قواعد الإثبات، أو الخطأ في الواقع، وذلك لأن حكم التحكيم في النظام المصري غير قابل للطعن عليه بطرق الطعن المنصوص عليها قانونـا، ولا يخضع إلا لاعوي البطلان، وليس من ضمن حالاتها المنصوص عليها علي سبيل الحصر، مراقبة هيئة التحكيم في فهم وتفسير قواعد الإثبات(')، أو الخطأ في الواقع. ب- الطبيـعة القضائية للإثبات أمهام هيئة التصكيم

في حقيقة الأمر، بالنسبة لإجراءات الإثبات التي تكون هيئة التحكيم قد أمرت بها أو اتخذتها قبل انتهاء الاتفاق علي التحكيم، فقد ذهب البعض مـن الفقهـ علـي عدم الاعتداد بها علـي أسـاس أنها لا تعتبر إجراعات قضائية(؟). ويري البعض البه إمكانيـة الاستئناس بها إذا كاتت مدونة في محاضر أو تقارير (").

(1) Cass. Civ. 2e, 29 nov. 1995, Rev. Arb., 1996, p. 235, note E. Loquin. B. Moreau, A. Beregoi, et autre, arbitrage commercial, D,. 2014, no 222. Cass. Civ., 2e 17nov. 1976, D. 1977, p. 577 note Boré, Rev. Arb. 1977,p. 281, note Robert; Cass. Civ., 2e, 28 avr. 1980, Bull. Civ., II, no 88, Gaz. Pal., 1980, p. 490, note Viatte; CA paris, 1re dec. 1995, Rev. Arb., 1996, p. 529, obs. Fouchard.

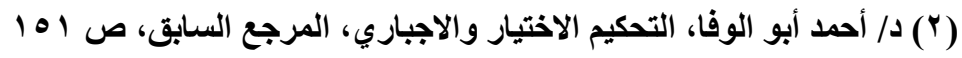

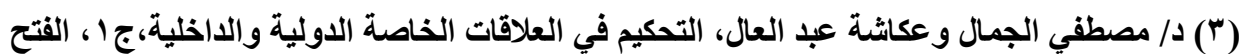

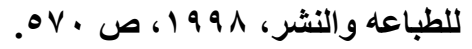


في الواقع نري أن الإثبات أمسام هيئة التحكيم يتفق مـع الإثبـات أمسام المحساكم القضائية بأن له حجية الأمر المقضي، وذلك نظرا للطبيعة القضائية للإثبات(') وهذه الطبيعة تثبت للإثبات أمام القضاء وأمام هيئة تحكيم. وأن تحديد نطاق الإثبات القضائي على هذا النحو يؤدى إلى نتيجة منطقية، وهى أن ما يثبت عن طريق القضاء أو التحكيم يصبح حقيقة قضائية واجبة الاحترام، أما ما يثبت عن غير طريق القضاء أو التحكيم، فلا يعتبر حقيقة ثابتـة لا تتغير وإنمـا هي قابلـة للتغيير والتبديل وإثبـات عكسها بكل

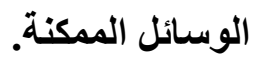

وتطبيقا لذلك يجب علي المحكمة القضائية إذا رفعت أمامهـا دعوي صدر فيها حكم تحكيم أن تحكم بعدم قبولها لسبق الفصل فيها بحكم تحكيم. وذلك احترامـا للحجية التي يحوزها الإثبات في حكم التحكيم. ونخلص من ذلكك إلى أنـا إذا وقع الاختيـار علـي قانون إثبات معين سواء من جانـب الأطـرف أو مـن جانـب هيئسة التحكـيم تعيسين الالتـزام بقواعـده الموضـوعية والإجرائية وإلا كـان الحكم عرضـة للبطلان، مـع مراعـاة أن لهيئة التحكيم الحريـة في لهي تقدير الأدلة المقدمة، وهذا التقييم للأدلة لا يخضع للمراجعة القضائية(؟)، مثنال ذلك إذا رفضت هيئة التحكيم سماع شهادة أو طلب اللجوء إلى خبير، فإن قرارها عادة لا يؤثر علي صحة حكم التحكيم، لان هذا القرار نابع من حريتها في التقدير، مع مراعاة حقوق الاففاع في ذلك.

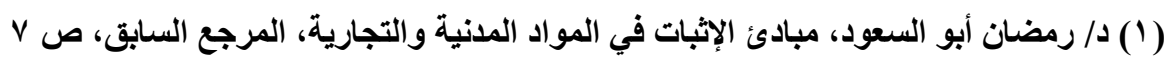

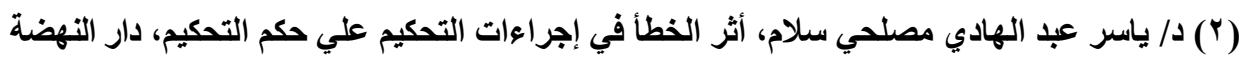

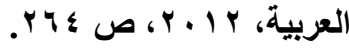




\section{الفرع الثالث \\ همل الإثبات أهام هيئة التهكيم التئر}

سنشير إلى ماهية محل الإثبات، وشروطه، وذلك في النقاط الآتية:

أولا: هاهية همل الإثبات

محل الإثبات ليس الحق المتنازع عليه، بل إن محله الواقعة القانونية المنشئة

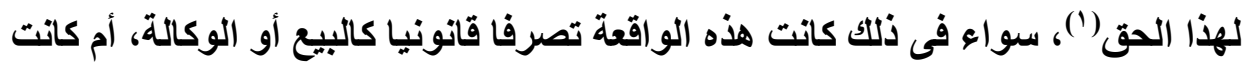

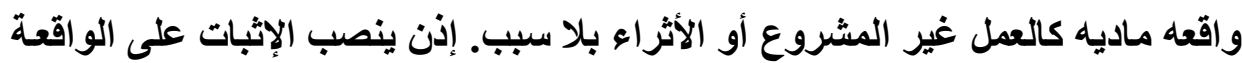
التي يرتب عليها القانون أثرا قانونيا، ويشترط في هذه الواقعة أن تكون متتازعا عليها وأن تكون معتبرة كأساس للحق المدعى به، بحيث لو ثبتت الواقعة تؤدى إلى إقناع هيئة التحكيم بوجود الحق المدعى بهان(")

وبالتالي فإن محل الإثبات ينصب أساسـا على الواقعة مصدر الحق المدعى بـه

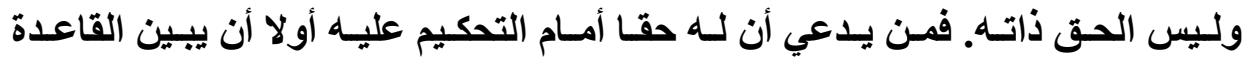

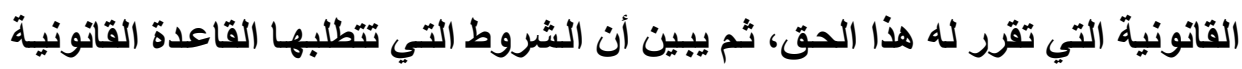

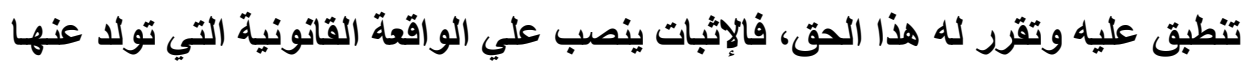

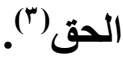

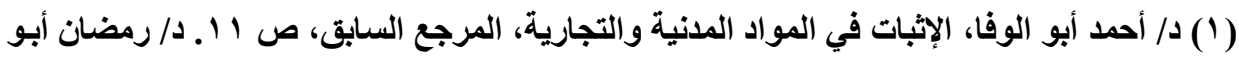

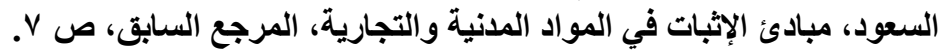

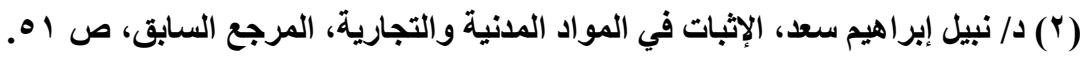

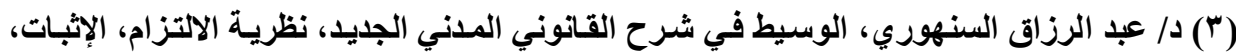

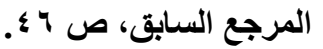


ا- هل الإثبات ينصب علي الواتعة هصدر الحق وليس الحق ذاته:

عندما يثور النزاع بين الخصوم فِإن محل النزاع يكون حول وجود الحق أو زواله أو إلحاق وصف به أو عليه، فيجب على الخصم الذى يدعى هذا أن يثبت ذلك، بلت فمل الإثبات إذن هو الادعاء بوجود الحق أو زواله.

والواقعـة القانونيـة التي ينصب عليهـا الإثبـات، إمسا أن تكون تصرفا قانونيـا

(كسابرام العقود) أو مجرد أفعـال ماديـة مـن فعل الإنسـان كارتكـاب جريمـة أو مـن فعل

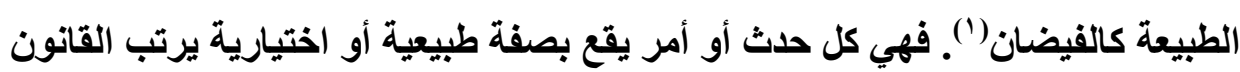
عليها أثرا، إمـا انشاء لحق جديد أو تعديل أو انقضاء لحق قائم، والوقائع الماديـة يجوز إثباتها بكافة طرق الإثبات، فهي تقع دون سبق توقع أو إعداد، فطبيعه هذه الوقائع لا تستلزم نوعا معينا من الأدله(؟)، أما التصرفات القانونية فهي علي خلاف ذلك، فقد نص

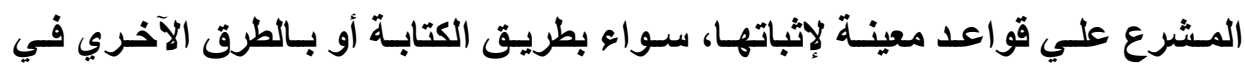

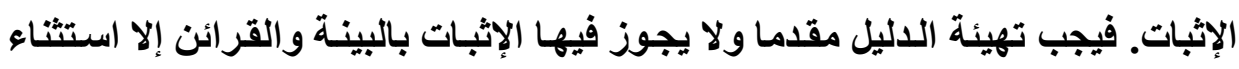
بالنسبة لبعض التصرفات القانونيةة(")، باعتبار أن هذه التصرفات من أعمال الإرادة. ونري أنه يمكن للهيئة أو لأطراف التحكيم، الاتفاق علي أن يكون الإثبات في التصرفات القانونية بكافة طرق الإثبات.

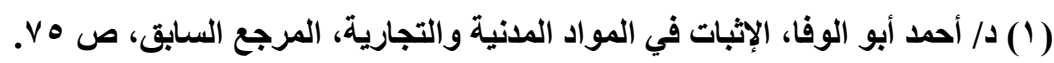

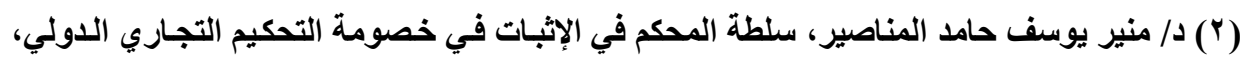

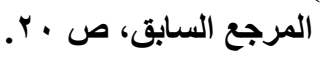

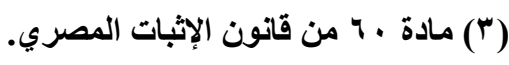




\section{r- هل الإثبات هو الواقع لا القانون (1):}

محل الإثبات هو الواقعة القانونية، وبهذا فِان مهمة الخصم هي اقامة الدليل

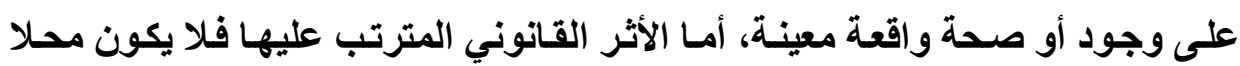

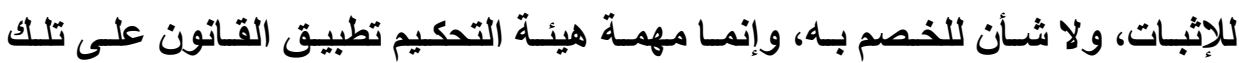
الواقعة، فقو اعد القانون إذن لا تكون محلا للإثبات. لأن المحكم هو قاض، وهو خبير بقواعد القانون الواجبه التطبيق علي النزاع. فهناكل تثابه بين علاقة المحكم بالقانون

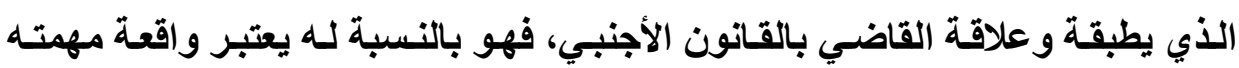
بالنسبة له تقتصر علي التأكد من وجوده.

ووجه ذلك أن الغأيـة من الإثبات هي أن يؤكل كل خصم من الخصوم مزاعمهـ للمحكم الذي أقام حكما يفصل بينهم، وذلك حتى يحظى باقتناعه فيصدر الحكم لصالحه، ومن هنا كان عنصر الواقع هو المحل الذي يطالب الخصوم بإثباته للمحكم. ويري بعض الفقه أنه وإن كان الإثبات يرد علي الوقائع، فلا يلزم الأطراف طبقا

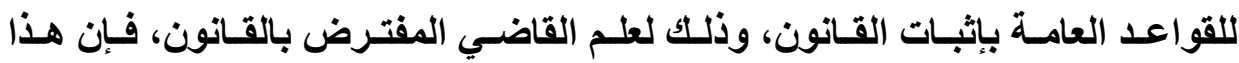
الافتراض لا يوجد بالنسبة للمحك، خاصة إن كان من غير رجال القانون، فيجب علي الخصم الذي يستند إلى قاعدة قانونيـة أن يشير إلى هذه القاعدة وإلـى تفسيرها

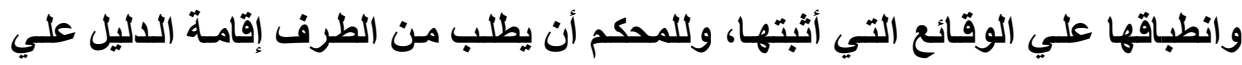

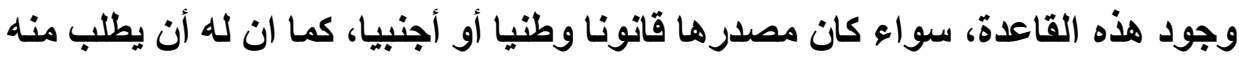

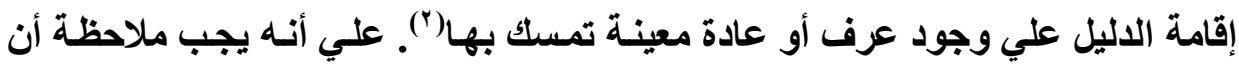

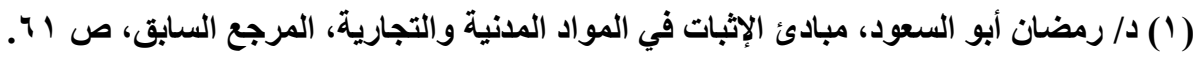

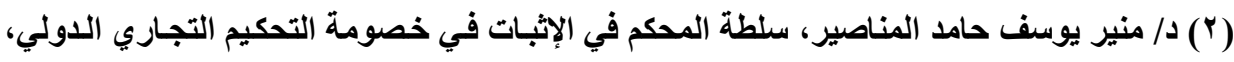

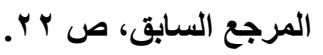


اقامة الدليل علي وجود قاعدة قانونية لا يعتبر إثباتـا بـالمعني القـانوني، فالدليل الذي يقدمه الخصم ليس لله سوي قيمة إعلامية يخضع لتقدير المحكم(').

في الواقع، لا نتفق مـع الر أي السابق، فـالمحكم يقوم بعلم القاضس، وبالتـالي يفترض علمه بالقانون، افتراضا لا يقبل إثبات العكس، وهذه القاعدة تطبق أمام المحكم وكذلك أمسام القاضسي، ذلك علـي أسـاس أن القاضسي منـوط بـه مـن قبل الدولـة تطبيق القانون، كذلك المحكم منوط به من قبل أطراف اتفاق التحكيم علي تطبيق القانون علي النزاع أو الحكم طبقا لقواعد العدالة. فيجب إذن إثبات الواقعة التي يترتب علي وجودها الأثر القانوني المتنازع عليه، ولكن لا يجوز إثبـات أن هذا الأثر يترتب علي وجـود هذه الواقعـة بإثبـات القاعدة القانونية التي تقضي بترتيب ذلك الأثر علي وجود هذه الواقعة(؟). وذلك لأن الإثبات يرد علي الوقائع وليس القانون، ومهمة هيئة التحكيم هي تطبيق القانون علي الواقعة التي يتم الاليل عليها بالطرق المحده لتستخلص أثرها القانوني وتقتضي في الخصومة وفقا له، فالقاعدة القانوني ليست محلا للإثبات ("). في الواقع هذه القاعدة يـرد عليها بعض القيود، فيمـا يتعلق باثبـات العرف أو القانون الأجنبي أو العادة الاتفاقية، وذلك علي النحو التالي:

(1) د ا فتحي والي، التحكيم في المنازعات الوطنية والتجارية الدولية، علما وعملا، منشاة المعارف،

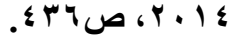
(Y) د آمنير يوسف حامد المناصير، سلطة المحكم في الإثبات في خصومة التحكيم التجاري الدولي،

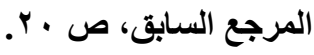
(ए) د/ علي ابو عطيه هيكل، القواعد الإجرائية للإثبات امام المحكمين، المرجع السابق، ص 9. 


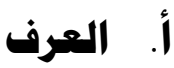

يعترف القضاء للعرف بقمية القاعدة القاتونيـة التي يجوز التمسك بها أمسام المحاكم، كما يجوز لهذا الأخير تطبيقا تلقائيا في حالـة ثبوت العرف لايهـ ثبوتـا تامسا، والعرف يشكل مصدرا مستقلا للقواعد القانونية عندما يقوم بذاتهه ولا يحال إليه بنص في القانون. والعرف كقاعدة قانونية يفترض مبدئيا علم القاضسي بـه، غير أنسه يصعب علي القاضي العلم بكل الأعراف، لذا إذا تمسك الخصم بعرف معين وكـان القاضسي علي غير علم به، فأنه يكلف الخصم بتقديم الاليل علي وجوده وتحديد مضمونه. وإذا كانت القاعدة أن العرف يتسأوى مـع القاعدة التشريعية في افتراض علم القاضسي بـه والمحكم(')، إلا أن العمل قد جري علي أن يقوم الخصوم بتأكيده و إثباتهـ جريا وراء مصالحهم،أما العرف المحلي، فلا يفترض علم القاضسي بـه ولا علم المحكم به(") ومن ثم يقوم صاحب المصلحة من الخصوم بإثباته شأنه شأن الوقائع. والواقع أنه إذا كان اختيار المحكم علي أساس أنه علي علم بالعرف التجاري في مهنة معينة، فيجب عليه أن يكون ملمـا بهذا العرف، لأنه شرط في اختيـاره من قبل الأطراف، فلا حاجة للأطر اف في إثبات العرف أمام المحكم.

\section{با القانون الأجنبي}

قد يكون القـانون الواجب التطبيق على موضوع النزاع قانونـا اجنبيا، وذلك بمقتضى اتفـاق الخصوم، في الواقع في المجـال القضائي ذهب جانب مـن الفقهـ إلى لـ

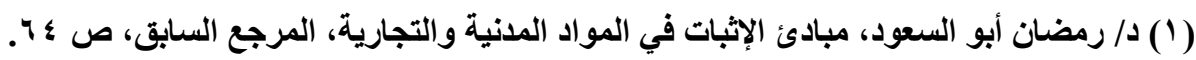

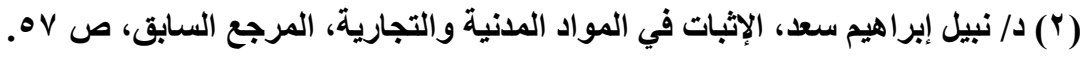


افتراض علم القاضي به، بينما ذهب رأي آخر إلى أن القانون الأجنبي بمثابة واقعة من

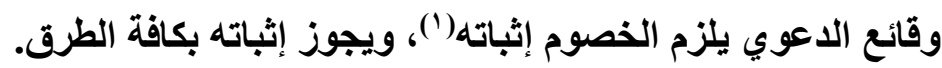

وإذا كان موضوع الإثبات ينصب أسناسا علي الوقائع المتنازع عليها بين طرفي الخصومة، سواء كانت وقائع مادية أو تصرفات قانونية، فإنها يمكن أن ينصب الإثبات علي أمسور فنيه تخضع لتقدير الخبراع، ومن المتصور في مجـال التحكيم أن تخضع بعض جوانب أحدي القوانين المختلف عليها بين الأطراف للإثبات، ويصدق ذللك علي إجراءات التحكيم التي تتبني النظام القانوني الانجلو الأمريكي، إذ يتم إثبات الجوانب المختلف عليها في أحدي القوانين الأجنبية بالاستعانة بشهادة خبير قانوني في شـأن القانون الأجنبي(). أمـا في النظم القانونيـة الآخري فيعد تطبيق القانون الأجنبي من المسائل القانونية التي يقتضي من المحكم العلم بهاب(") ونري أنه في مجال التحكيم، فأنه يجب إثبات القانون الأجنبي أمام هيئة التحكيم عن طريق الخصوم، ولا يفترض علم هيئة التحكيم به، وذلك لأن الأطراف هم من اتفقو

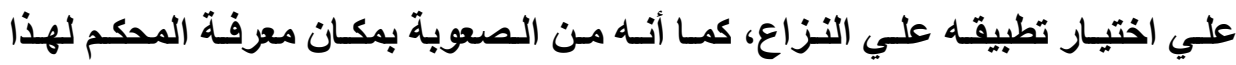
القانون، وبتطبيقاته القضائية، خاصة وأن المحكم قد يكون من غير رجال القانون.

\section{المعادة الاتفاقية}

العادة الاتفاقية تستمد قوتها من اتجاه إرادة المتعاقدين إليها صراحة أو ضمنا، ومن ثم فإن إثباتها يقع على عاتق الخصم الذى يتمسك بها، وإذا كان لا يجوز للقاضسي

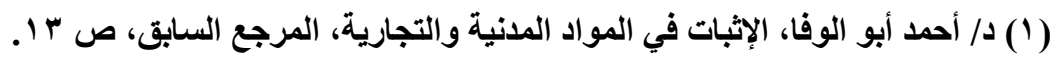

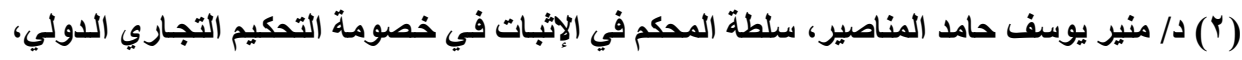

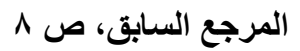

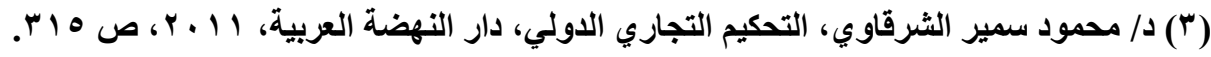


أن يقضى في شأنها بعلمه الشخصي ('). إلا أنتا نري أنه يمكن أن يكون اختيار المحم من بين فئة التجار الأين لايهم علم بالعادة الاتفاقية في مجـال النزاع، ويكون اختياره

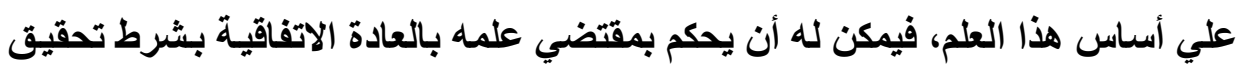
مبدأ المواجهة بثأن هذه العادة الاتفاقية واحترام حقوق الدفاع. ثانيا شروط محل الإثبات أمام هيئة التحكيم نصت المادة ب من قانون الإثبات المصري علي أنها " يجب أن تكون الوقائع المراد إثباتها متعلقة بالدعوى ومنتجة فيها وجائزا قبولها". فيشترط في الواقعة محل الإثبات أن تكون واقعة محددة، وممكن إثباتها وجائز قبولها، ومتناز عا عليها، ومتعلقة بالدعوي ومنتجة فهيا،وهذه الثروط عامة تطبق علي محل الإثبات أمام قضاء الدولة،

$$
\text { وأمام التحكيم. }
$$

فيشترط في الواقعة محل الإثبات الشروط الآتية:

\section{ا - يجب أن تكون الواقعة همددة")}

وهذا الشرط منطقي، لأنه من يطرق بـاب القضاء أو التحكيم يجب أن يدعى

بشيء محدد، لأن الواقعة غير المحدة تبقى بطبيعتها غير قابلة للإثبات(").

وكذلك يجب أن تكون الواقعة محددة تحديدا كافيا حتى يمكن التحقق من أن

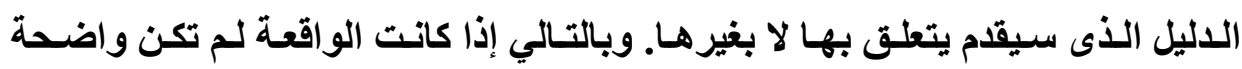

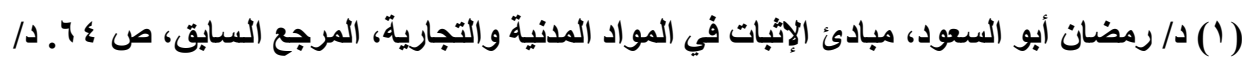

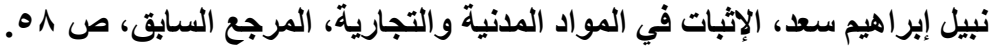

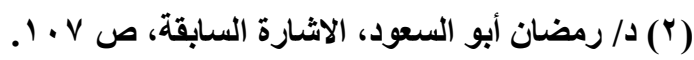

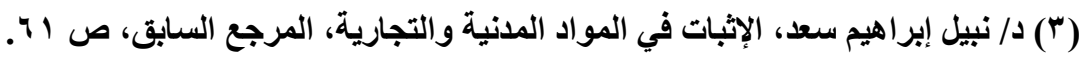

مجلتّ البحوث القانونيت والإقتصاديت اسب 
الحدود ظـاهرة المعالم فسوف تكون مجهولة، والمجهول لا يقبل الإثبات الذي يعتبر تأكيدا ويقينـا، فمن يـاعي ملكيته لشيء معين يجب عليه أن يعين سبب كسبه لهذه

$$
\text { الملكية (تصرف قانوني - ميراث - تقادم) }
$$

وقد تتنوع الواقعة إلى إجابية وسلبيه، فالواقعة الأيجابيه يسهل إثباتها بإثبات الأمر الوجودي الدال عليها ـ مثثل: واقعة التعاقد أو وقوع الفعل الضار أو النـافع. أمسا الواقعة السلبيه، وهي يمكن إثبتاتها عن طريق إثبات واقعة أيجابية منافيـة لها ــ مثل: ادعاء المريض أن الطبيب قصر بعلاجه.

\section{r- بيب أن تكون الواقعة همكنة:}

يقصد بذلك أن تكون الواقعة ممكنة الحدوث حتى يمكن إثباتها(')، فالمستحيل لا يصح عقـلا إثباتـه ولا يجوز السماح بـه حرصـا على وقت المحكمـة. فلا يكون إثبـات الواقعة مستحيلا، لأنه اذا كان كذلك فلا يصح عقلا طلبه فلا تكليف بمستحيل، وحتى تكون الواقعة ممكنة الإثبات يجب أن تكون ممكنة الوقوع عقلا ولو في حالات نـادرة، وقد تكون الواقعة متصورة أو مقبولة عقلا، ومع ذلك يستحيل إثباتها.

\section{r- يجب أن تكون الواقعة هتنازعا فيها:}

إن الإثبـات لا يكـون إلا أمسام القضضاء أو التحكيم ولا يرفـع إليهمــا الا الوقـائع المتنازع حولها بين الخصوم()، فإذا لم تكن الواقعة محل نزاع، فليس هنالك مـا يـعو إلى رفعها، ولا تكون هناك حاجة لإثباتها. لأن الخصم مسلم بصحتها، فهنا يجب علي

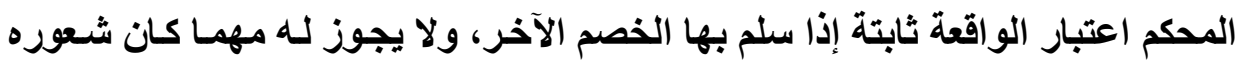


أو اعتقاده أن يجعل ثبوتها محل تقدير من جانبه، ويكفي لاعتبار الواقعة ثابتة، وبالتالي

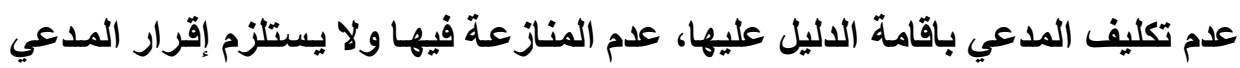

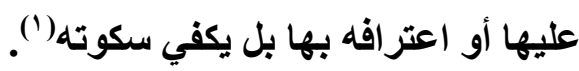
ويجب لاعتبار الواقعة متناز عا فيها كما قالت محكمة النقض المصرية أن يكون الاعتراض علي الواقعة قاطعا وصريحا وشاملا وغير مخالف للنظام العام" (")

\section{§- يبب أن تكون الواقعة متعلقة بالدعوى:}

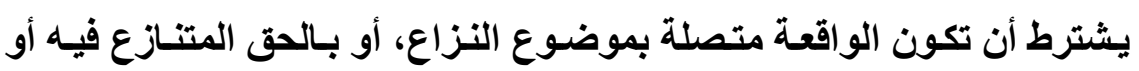

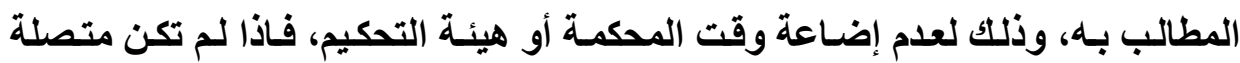
بموضوع الدعوى، فلا يجوز أن تكون محلا للإثبات. وجب علي هيئة التحكيم أن تقضي برفض التحقيق ولو من تلقاء نفسها"(") ويمكن للخصم التمسك أمسام هيئسة التحكيم بواقعـة بليلـه للواقعـة الأصلية،

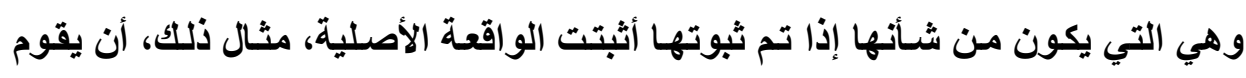

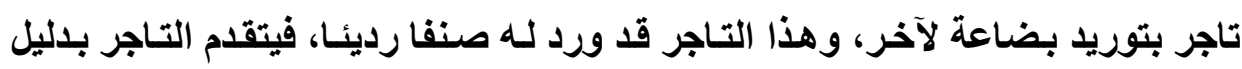

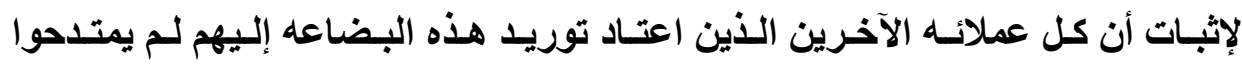

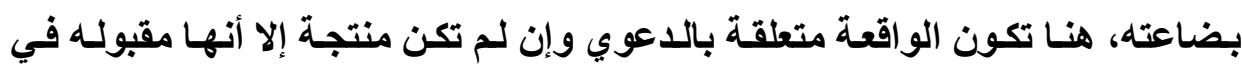

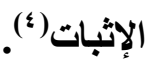

(1) د/ علي ابو عطيه هيكل، القواعد الإجرائية للإثبات امام المحكمين،المرجع السابق، ص م ـ 1.

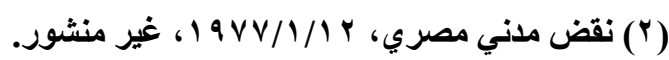

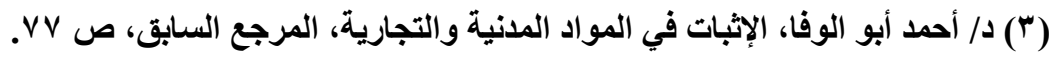

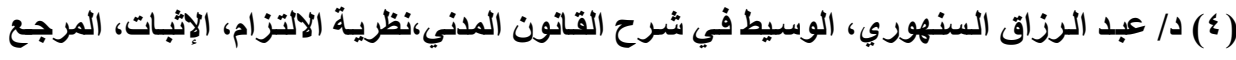

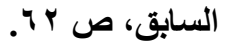


أ. يجب أن تكون الواقعة المطلوب إثباتها مصدر الحق المدعى به.

ب. أن تكون الواقعة المطلوب إثباتهـا ليست متعلقة بموضـوع الدعوى، ولكنهـا متصلة اتصالا وثيقا بالواقعة المتعلقة بموضوع الدعوى.

0- يجب أن تكون الواقعة هنتجة في الدعوى(ا):

يشترط أن يكون الوقعه منتجية في اللاعوي التحكيمية، ويكون ذلك إذا كـان شأن الواقعة إذا ثبتت أن توصل إلى إقناع المحكم بأحقية ما يدعى به أو تؤدى إلى قيام

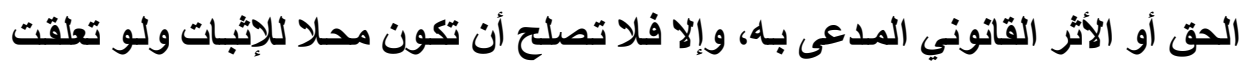
بموضوع الدعوى.

\section{7- تكون الواقعة جائزة الإثبات قانونا:}

يجب أن تكون والواقعة جائزة القبول وليست واقعة مستحيلة الوقوع أو غير قابلة للإثبات، ويجب أن لا يمنع القانون إثباتها، وقد يمنع القانون إثبات واقعة ما لأنها: أ. مخالفة للنظام العام أو الأداب() (إثبات دين مصدره المقامرة) ب. يعد إثباتها افشاء لسر المهنة (حفاظا على أسرار المهنة) ج. إذا كان إثباتها يتعارض مع قرينة قانونية قاطعة، فلا يجوز إثبات عدم صحة إنهاء حكم قضائي لمخالفة ذلك لحجية الأمر المقضي.

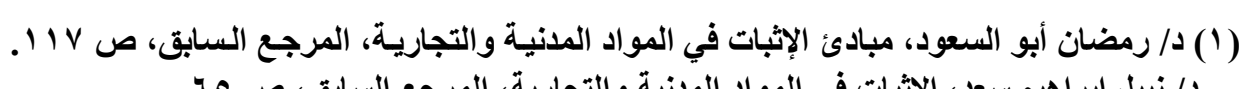

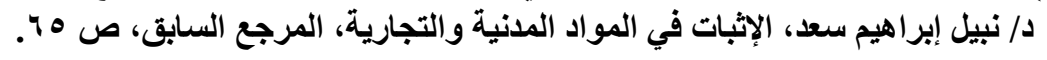

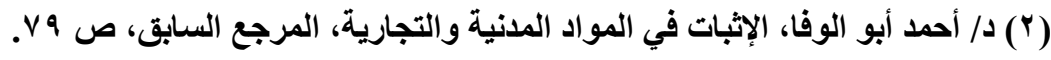


ونخلص مما سبق إلى أن المحكمين لا يملكون رفض إثبات وقائع النزاع التي تدخل في نطاق اتفاق التحكيم، وتوافر فيها شروط الو اقعة القانونيه محل الإثبات، وهي التهي

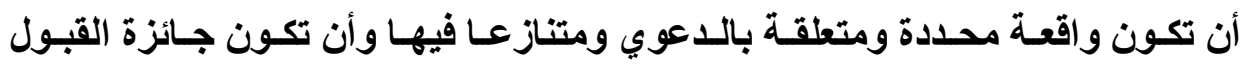
ومنتجة في الدعوي(') وعند توافر الثروط المثار إليها في الواقعة محل الإثبات ينشأ الحق في الإثبات، وعلي هيئة التحكيم أن تسمح لمن يتمسك بها أن يشتبها بجميع الطرق القانونية، وعدم توافر تلك الشروط أو بعضها ينشئ للخصم الآخر الحق بالطلب من التهن

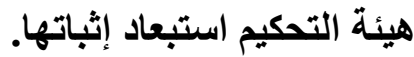

\section{دور الفصوم في الإثبات أهام هيئة التحكيم}

يخضع الإثبـات أمسام هيئسة التحكيم لقو اعد عامـة مشتشركة في مختلف النظم القانونية، وقد ذهبت بعض الانظمة القانونية إلى النص علي قو اعد خاصة بأدلة الإثبات

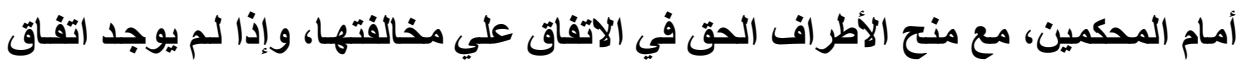

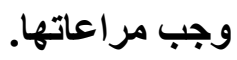
في الواقع حق الخصم في الإثبات هو حق مقس، ومكمل لحقه في الالتجاء إلى القضاء أو إلى التدكيم، ويقابل حق الخصم في إثبات مـا يدعيه، حق خصمه في نفيها. فالمبدأ في نظام الإثبات بشكل عام أن الدعوى ملك الخصوم، (†) وعلى ذلك فِإن الإثبات (1) د/ منير يوسف حامد المناصير، سلطة المحكم في الإثبات في خصومة التحكيم التجاري الدولي،

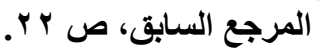

(2) MOTULSKY, Relation méthodique de droit positif, these, loyon,1947, p. 25. 
أيضا حق للخصوم (') فبإذا كـان الإثبات عبئـا يفرض على المدعى لإثبات مـا يدعيه وتقديم الدليل على ادعائه، فهو فى نفس الوقت حق له لا يستطيع القاضي أو المحكم أن يحرمه منه أو يحجبه عنه، وإلا كان حكمه مشوبا بعيب ويستوجب نقضه.

ويعد تعيين الخصم الذي يقع عليه عبء الإثبات في غأيسة الأهميه، وذلك أن تكليف أحد أطراف الخصومة بالإثبات يجعل الخصم الآخر في مركز أفضل، لأنسه يقف

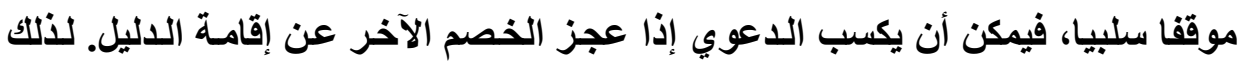
يجب علي هيئة التحكيم أن تحدد الخصم الذي يتحمل عبء الإثبات، كمـا يجب عليها أثناء الخصومة أن تمكن الخصم من إبداء مـا لايهه من أدلة ومستتدات، كمـا عليها أن تستجيب لطلبات إجراء الإثبات التي يطالبها، كسماع الشهود أو ندب الخبير، وعليها أثناء إصدار التحكيم، أن تشير إلى أدلة الخصوم وطلباتهم، وتبين أسباب قبولها أو رفضها. ويجب عليها أن تعتد بالأدله، وأن تفحصها وتقدرها وتستند إليها في حكمها. وألا تكون قد أخلت بحق الخصم في الدفاع.

سنشبير إلى دور الخصوم في تحديد إجراعات الإثبات، وذلك في الفرع الأول، ونبحث حدود حق الخصوم في الإثبات، وذلك في الفرع الثاني، ثم نعالج عبء الإثبات،

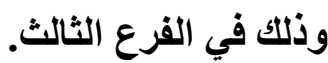

\section{الفرع الأول}

\section{دور الخصوم في تحديد إجراءات الإثبات}

في الواقع يحكم سير إجراءات الإثبات أمسام القضاء لنظام رسمه القانون، فلا

يجـوز للقاضـي أو للخصوم مخالفتـه، أمسا بالنسبة لخصومة التحكيم، فنجــ أن إرادة

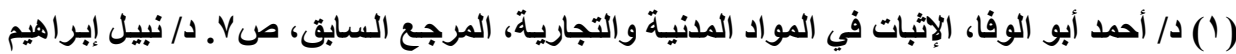

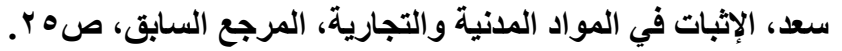


الأطراف لها دور كبير في تنظيم هذه القواعد، وذلك لنشأة الاتفاقية للتحكيم، كمـا أن سلطة هيئة التحكيم لها دور في هذا المجال، طالما احترمت الضمانات الأساسية الواجب

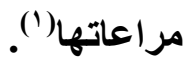

\section{أولا: تهديد إجراءات الإثبات في التشريعات الوطنية}

في حقيقة الأمر، من المستثر عليه في كافة أنواع التحكيم إعمال مبدأ " سلطات إرادة الخصوم في تحديد النظام الإجرائي لخصومة التحكيم"(؟)، ومـع منح المحكمين سلطة في حالة عدم وجود اتفاق للخصوم، ولكن الأصل هو مبأ سلطان إرادة الخصوم

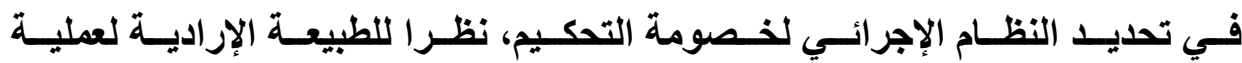
التحكيم،وباعتبار أن التحكيم اتفاقي النشأة قضائي الأثر (").

ولا يوجد شكل معين يحكم وينظم إجراءات الإثبات أمام هيئة التحكيم، فالمسألة

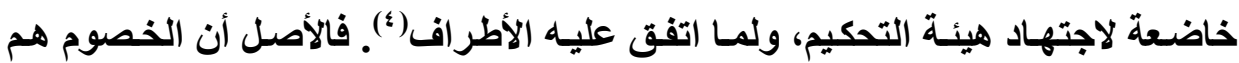

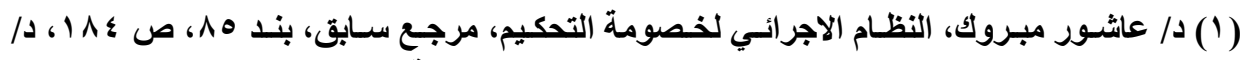

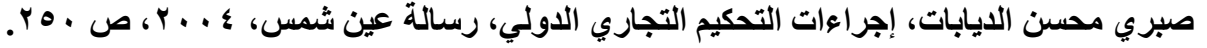

(2) Ph FOUCHARD, L'arbitrage commercial international, D., 1965, no 471 et s; J. ROBERT, l'arbitrage droit interne et droit interntional, Dalloz., 6e éd.1993, p. 54 et s.

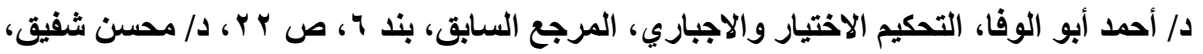

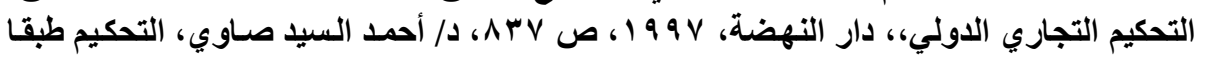

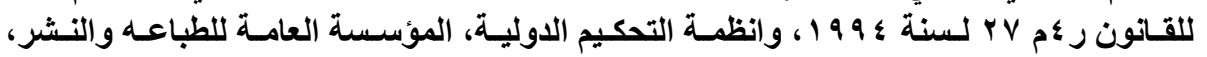

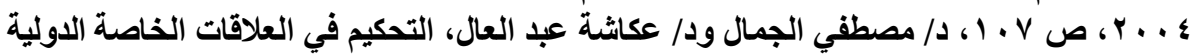

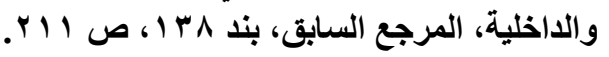

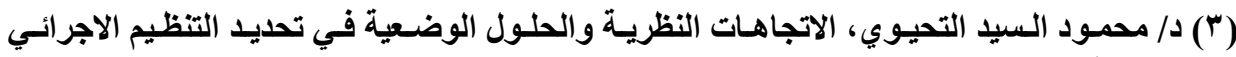

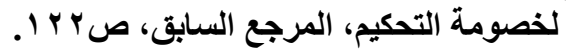

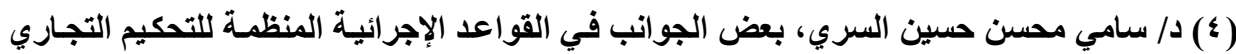

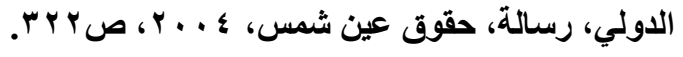


المعنيون بتنظيم إجراعات الإثبات أمام هيئة التحكيم، ولهم سلطة واسعة في هذا الصدد.

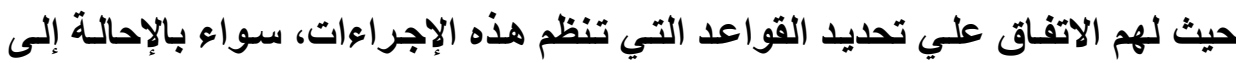
قواعد قانونية، أو القيام بتنظيم خاص لها بشرط ألا يخالف القواعد المتعلقة بالنظام العام في الإثبات. مثل مراعاة حقوق الدفاع. في الواقع يخضع الإثبات أمام هيئة التحكيم لقواعد عامسة مشتركة في مختلف

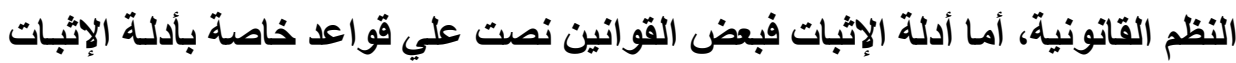
أمام المحكمين، غير أن هذه القواعد الخاصة يجوز للأطراف الاتفـق علي مخالقتها، فإذا لم يوجد اتفاق وجب مراعاتها' (') ويلاحظ أنه إذا لـم يتفق أطراف التحكيم علي تحديد القواعد الواجب التطبيق علي الإثبات فيكون لهذه الهيئة سلطة اختياره، وقد يرجع عدم الاتفاق بين الأطراف إلى إلى

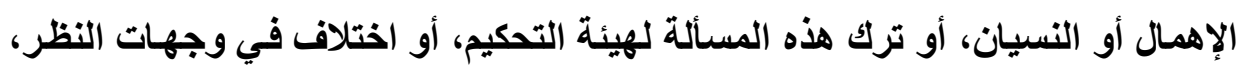
ويتصور انعقاد الاتفاق علي التحكيم دون أن يثتمل علي تحديد قواعد الإثبات الواجبة

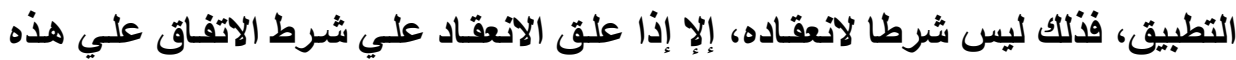

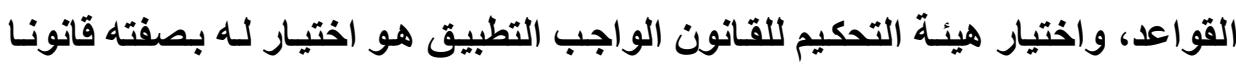
حاكما لقواعد الإجراعات أمام هيئة التحكيم. وحرية هيئة التحكيم في تحديد التنظيم الإجرائي لخصومة التحكيم ليست مطلقة،

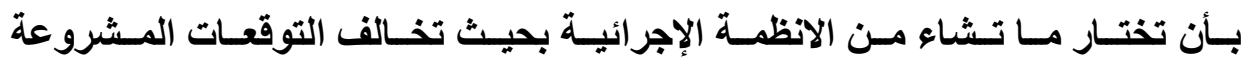
للطرفين()، بل عليها أن تلخل هذه التوقعات في الحسبان. بـأن تختـار نظامـا إجرائيا،

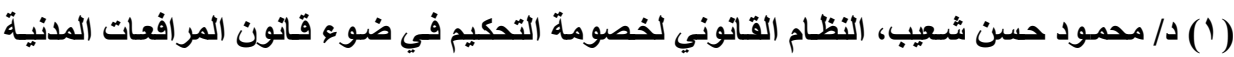

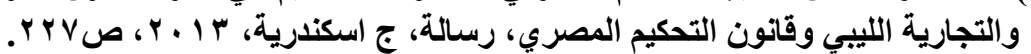
(ץ) د/ مصطفي الجمال ود/ عكاشة عبد العال، التحكيم في العلاقات الخاصة الدولية والداخلية، المرجع

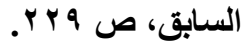


وطنيا أو اجنبيا أو دوليا، أكثر ملاعمة، أي لله علاقة بالنزاع، مثل قانون بلد المقر أو الو التون

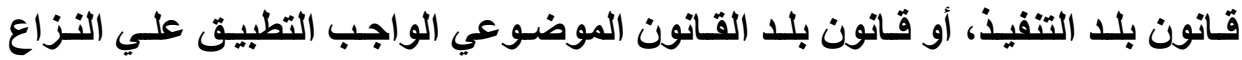
موضوع، مع مراعاة أنه عند اختيار نظاما إجرائيا يكون معتمدا لاي أحل مراكز التحكيم

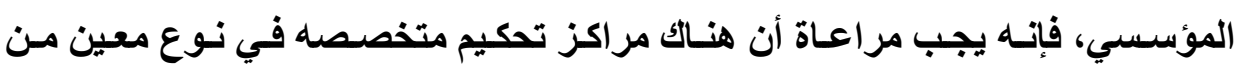
المناز عات مثل مر اكز تحكيم منازعات الاستثمار.

ولم تنص المادة ه r تحكيم علي قواعد المتعلق بتحديد الإجراءات الإثبات، لذا

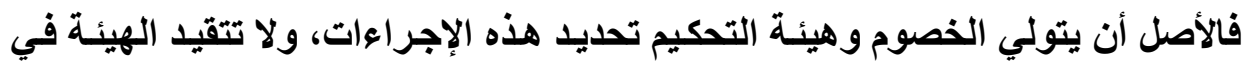

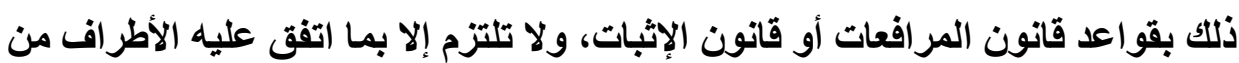

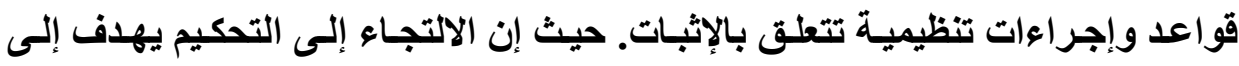

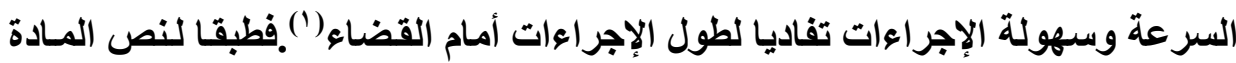

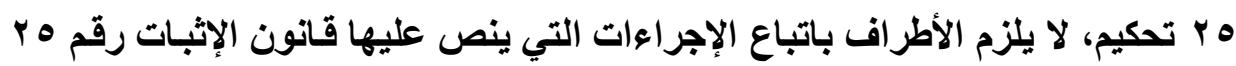

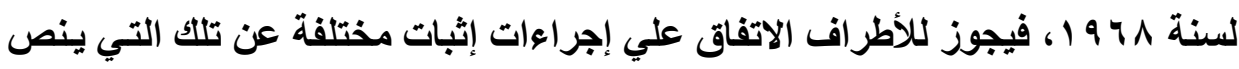

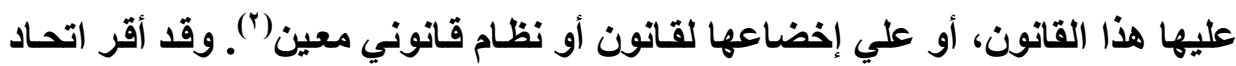

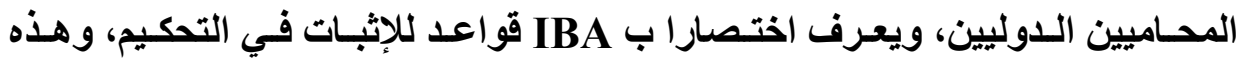

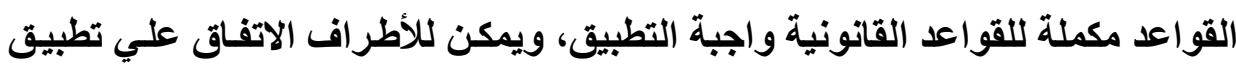

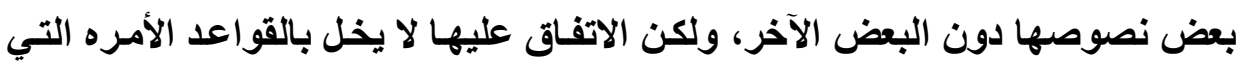

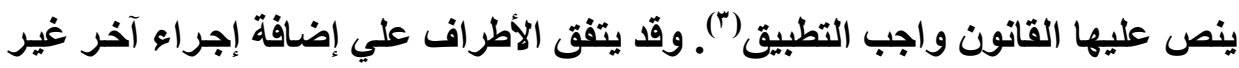

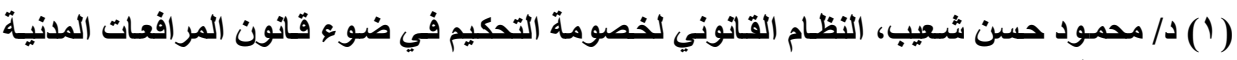

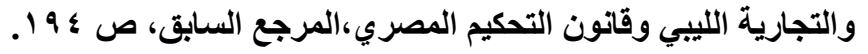
(ץ) د/ فتحي و الي، التحكيم في المناز عات الوطنية والتجارية الدولية، علمـاو وعملا، المرجع السابق،

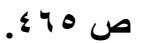

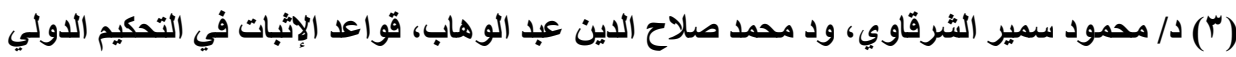

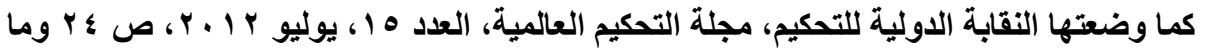


التي ينص عليها القـانون الذي يحكم الإجراءات، كالاتفـاق علي تطبيق نظام الشهادة

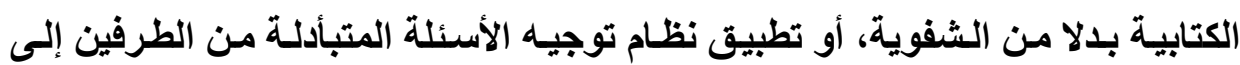

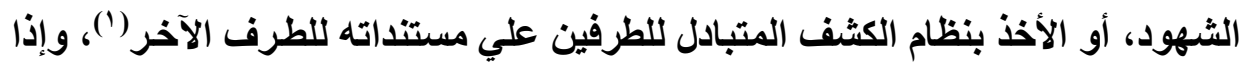

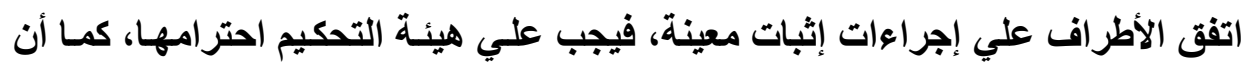
لهيئة التحكيم - عند عدم اتفاق الأطرافــ أن تقرر إجراءات الإثبات التي تراها مناسبة، هـئه

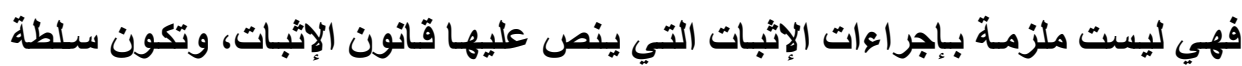
الأطر اف أو سلطة الهيئة في هذا الثأن، هي نفس سلطتهم بالنسبة لإجراعات التهات التحكيم

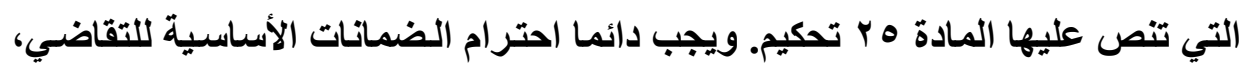
فيجب علي هيئة التحكيم احترامها ولو اتفق الأطراف علـي إجراعات إثبات تخالفها،

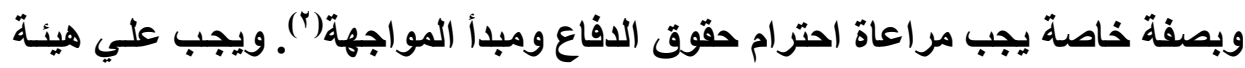

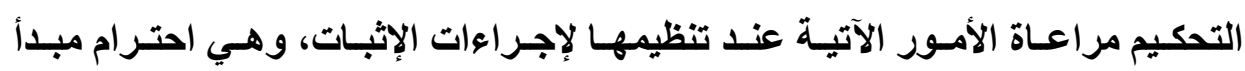
المسأواه، وذلك بإعطاء كل طرف نفس المساحة الزمنيـة لعرض حجبه وأدلته دون

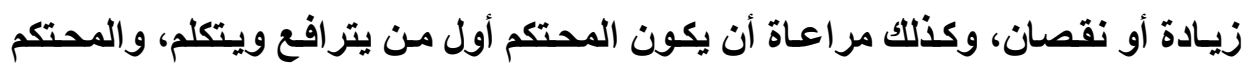
ضده التالي له، يعقبة ويقدم دفاعه وردوده وطلباته المقابلة) (باته ويجب علي هيئة التحكيم أن تحترم مبدأ المواجهة أثناء تنظيم إجراءات الإثبات، وذلك بتمكين كل خصم من معرفة مـا قدمـه الخصم الآخر. ويجب عليها أن تثبت في حكمها أنها اكتفت بتقديم المستتدات المكتوبـة، وأنـه تم تبادلها بـالنحو الصحيح بين الأطر اف، وتم تمكينهم من الاطلاع عليها ومناقثة والرد علي ما جاء بها، كل ذلك حتي (1) د/ أكثم الخولي، بدء التحكيم وسيره طبقا لنظام التوفيق والتحكيم التجاري لغرفة تجارة وصناعة

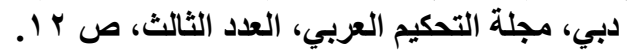

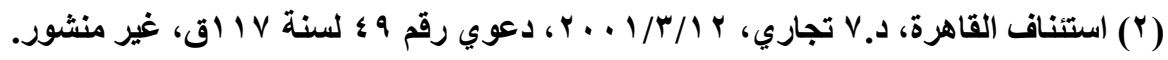

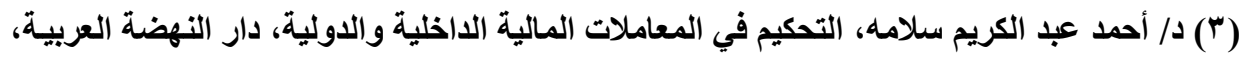

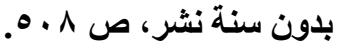


لا يتعرض الحكم للطعن عليه بـالبطلان لخروجه عي مبدأ المواجهة('). ويمتـ التظظيم إلى الإجراءات الكتابية التي توضـح موقف كل طرف وروئيته في الرد علي ادعاءات

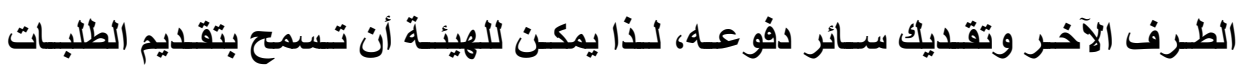
والمستتـات المكتوبـة دون اسـتلزام حضور الخصوم بأنفسهم أو مسن يمـثلهم ودون إجراء مناقشة شفهية(؟). ويلجأ إلى ذلك عادة في تحكيم الصنف أو النوع في البضائع والمعدات، عندما يثور الخلاف حول مدي مطابقتها للمواصفات في تجارة تلك البضائع والمعدات ولما اتفق عليه الطرفان.

ويري جاتب من الفقه(")، أن هناك تعارضـا ظاهريـا بين نص المسادة هب تحكيم

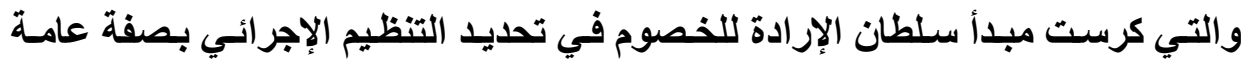

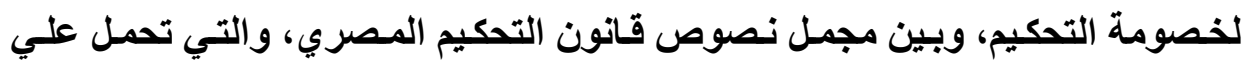

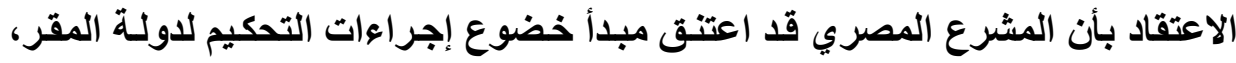
سواء في خصومة التحكيم أو في الخصومة القضائية، والأي يؤكد هذا الاعتقاد المـادة الأولي من قانون التحكيم والتي تنص علي سريان أحكام هذا القانون علي كل تحكيم أيا

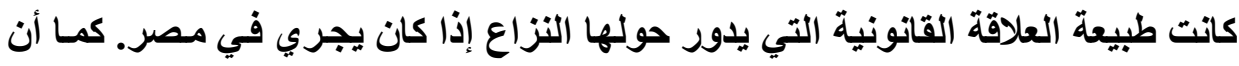

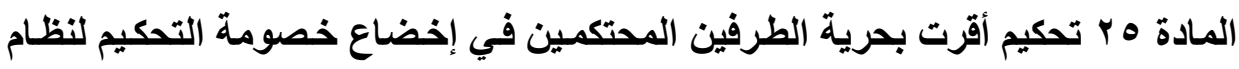

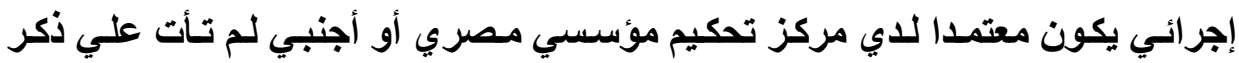
حريتهما في إخضاع خصومة التحكمي لقانون وطني من قوانين الدول الآخرى، ويذهب موني جاتب آخر من الفقه إلى أن هذا التعارض يكون ظاهريـا، حيث يتميز قانون التحكيم

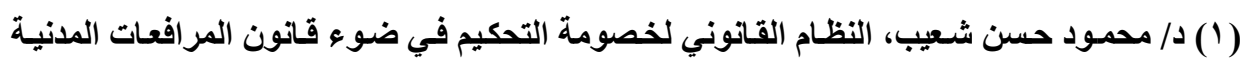

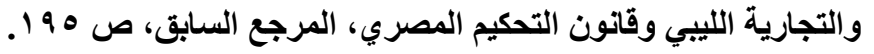

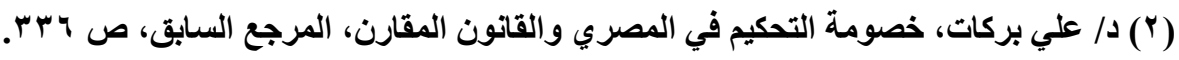
(r) د/ مصطفي الجمال ود/ عكاشة عبد العال، التحكيم في العلاقات الخاصة الدولية والداخلية، المرجع

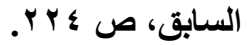


المصير بنزعة تحررية واضحه، وبصفة خاصة في تحديد النظام الإجرائي لخصومة

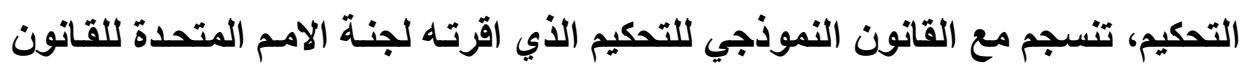

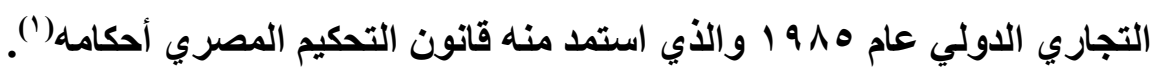

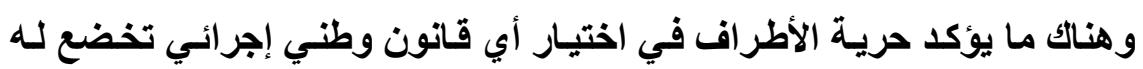

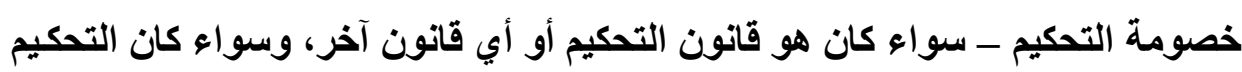

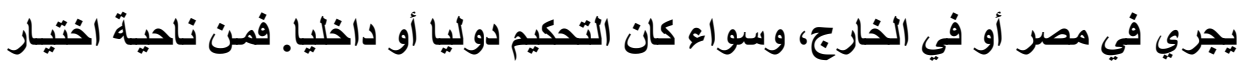

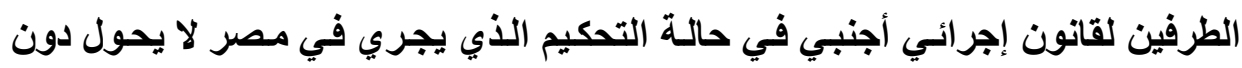

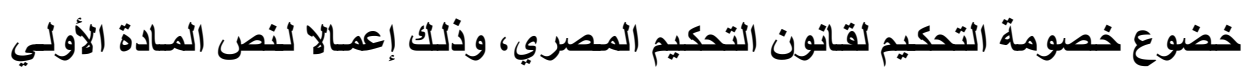
منه، حيث يطبق القانون الأجنبي المختار في حالة المسأل التي أورد في شـأنها قانون التون

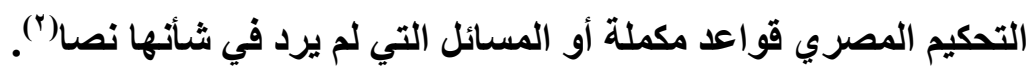

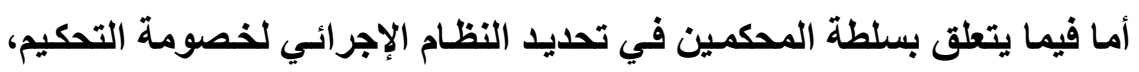

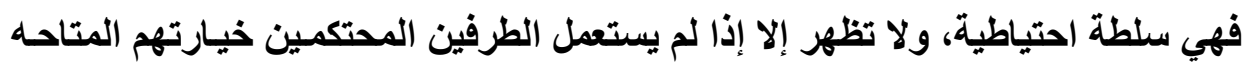

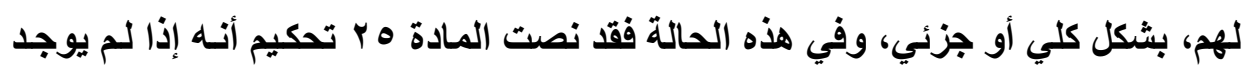

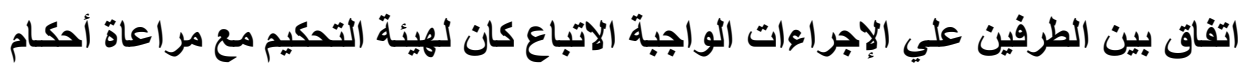
هذه القانون أن تختار إجراءات التحفين التحيم التي تراها مناسبة.

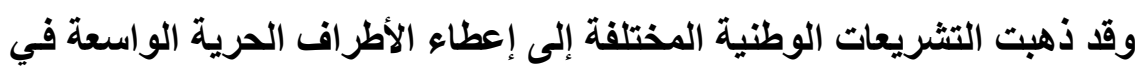

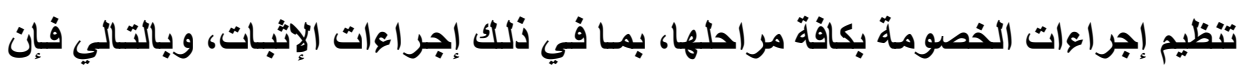

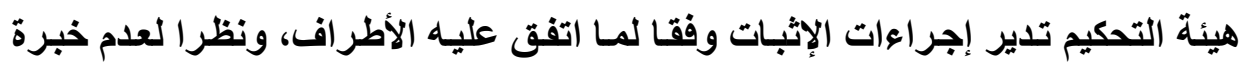

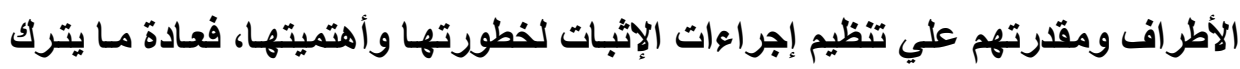

(1) د/ أحمد السيد صاوي، الوجيز في التحكيم التحكيم، دار النهضة العربية، ـ 1 بـ، بند ـ 9، ص $\therefore \cdot \mathrm{V}$ (Y) دا مصطفي الجمال ود/ عكاثة عبد العال، التحكيم في العلاقات الخاصة الدولية والداخلية، المرجع

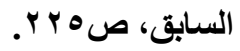


أمر تنظيمها لهيئة التحكيم لتقرر الإجراعات التي تراها صالحة ومناسبة وفقا لما نصت

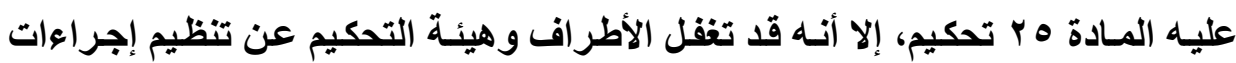
الإثبات بطريقة مباشرة أو غير مباشرة، وبالتالي يثور التساؤل عن مدي إمكاتية تطبيق قواعد الإثبات المطبقة أمام المحاكم، خاصة في حالة غياب نصوص التير التحكيم عن تنظيم هذا الموضوع. نلاحظ أن التشريعات المختلفة قد اتبعت أحد الاتجاهين الآتيني: الاتجاه الأول: يري تطبيق إجراءات الإثبات المطبقه أمام المحاكم في حالة غيـاب

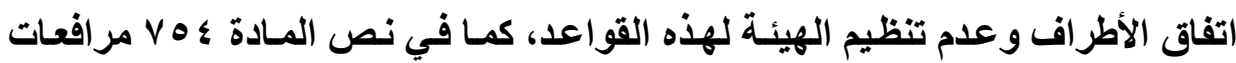

ويلاحظ علي هذا الاتجاه الآتي:

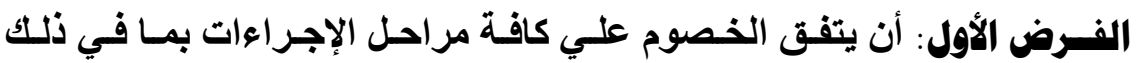

$$
\text { إجراءات الإثبات ولاقيد عليهم في ذلك. }
$$

الفرض الثاني: في حالة غياب إرادة الأطراف في الاتفاق علي إجراعات معينة،

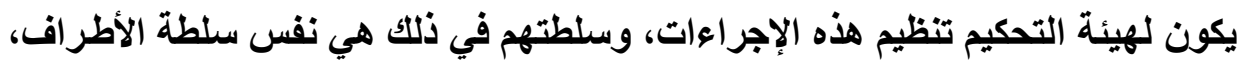

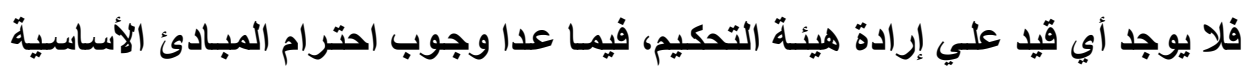

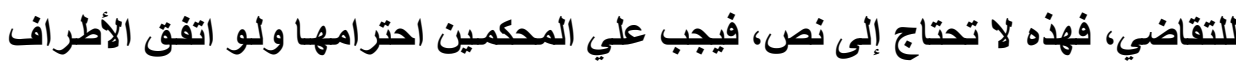
علي إجراءات الإثبات تخالقها.

الفرض الثالث: إذا غاب اتفاق الأطراف ولم ينظم هيئة التحكيم هذه الإجراءات، وجب مراعاة قواعد الإثبات المتبعة أمام المحاكم، وهذا لا يعني التطبيق المطلق لهذه القواعد، بل لابد من مواعتها بمانبا يتفق ونظام التحكيم.

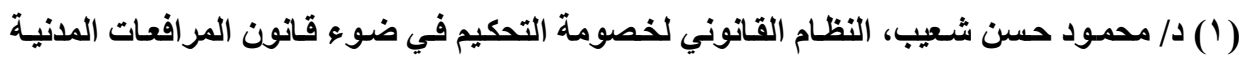
والتجارية الليبي وقانون التحكيم المصري، المرجع السابق، ص • بـآ. 
وقد ذهب بعض الفقه(') إلى أن القاعدة العامـة هي تطبيق المحكمين القواعد والمواعيد المقررة في الأحكام الخاصـة بإجراعات الإثبات في قانون المر افعـات أو في القانون الخاص بالإثبات، ما لم يتفق الأطر اف علي إعفائهم من التقيد بقواعد المرافعات أو كانوا مفوضين بالصلح، وتتبع هذه القواعد بالنسبة لجميع طرق الإثبات، فتتبع في

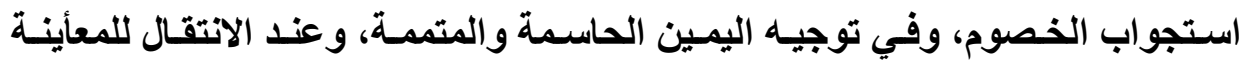

$$
\text { وسماع الشهود وندب الخبراء وفي تحقيق الخطوط. }
$$

الاتجاه الثاني: يمنح هيئة التحكيم ذاتها مهمة تحديا إجراءات الإثبات المناسبة، في حالة غياب اتفاق الأطراف، وذلك بمراعاة ما هو منصوص عليه في قانون التحكيم.

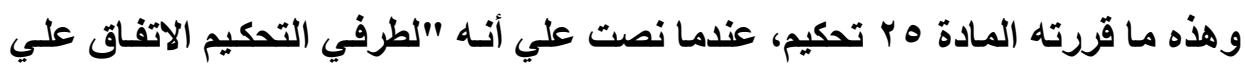
الإجراءات التي تتبعها الهيئة بمـا في ذلك حقها في إخضاع هذه الإجراءات للقواعد الناقذه في أي منظمة أو مركز تحكيم في جمهورية مصر أو خارجها، فإن لـ يوجد مثل هذا الاتفاق كان لهيئة التحكيم مع مراعاة أحكام هذه القانون أن تختار إجرعات التحكيم التي تراها مناسبة. وهذا ما أخذ به القانون الفرنسي. والواقع أن دور مركز التحكيم هو مساعدة الأطراف في تحديد الإجراءات، وليس له دور قضائي، حيث إن الدور القضائي

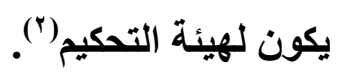
وبالنسبة للمشرع المصري فنجد أنه يطلث الحريـة للأطراف في الاتفـاق علي القواعد الإجرائية في الإثبات أمام المحكمين دون أي تقييد بالقواعد المنصوص عليها

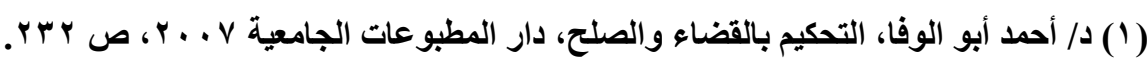
(2) T. CLAY, L'arbitre, op. cit., $n^{\circ}$ 209, CA Paris, 15 sept. 1998, op. cit., $\mathrm{n}^{\circ}$,p. 103, note lalive; Cass. Civ., 1 re, 20 fev. 2000, op. cit., ${ }^{\circ}$, p. 54, note T. Caly. 
في قانون الإثبات، غير أن هذه الحرية لا تمتد إلى المبادئ الأساسية للتقاضي باعتبارها من النظام العام (')، مثل مراعاة حقوق الدفاع ومبدأ المواجهة. وفـي حالــة غيـاب الاتفـاق، يكـون لهيئة التحكيم اختيـار إجـراءات الإثبـات المناسبة، ولكن علي عكس سطلة الأطر اف، فسلطتها هنـا مقيدة بموجـوب مراعـاة إجراءات الإثبات المنصوص عليها في قانون التحكيم، وبالتالي لا يجوز لهيئة التحكيم تجاهل هذه القواعد وتنظيمها قواعد جديدة، وكل مـا علي هيئة التحكيم هو تكملة هذه القواعد بما تراها مناسبا. وقد ذهب بعض الفقه إلى أنه يتقيد المحكم بطريق الإثبات التي عينها المشرع في القانون، وبذلك يمكن للقانون حمائة أطراف النزاع من مخـاطر تحكم هيئة التحكيم وأخطائها عند اختيار البينه، ولا يكفي أن تكون الواقعة جائزة الإثبات فحسب، بل يجب أن تكون جائزة الإثبات بالاليل المطلوب تقديمه، وفقـا لنظام الإثبات الواجب التطبيق، ولهذا فإنه لا يقبل سماع شاهد لإثبات واقعه لا يجوز إثباتها إلا بالكتابة، ولا يقبل توجيه اليمين المتممة إذا انعدم الاليل أو وجد دليل كامل في الدعوي(؟) ونري أن للمحم سلطات واسعة في تحديد إجراعات الإثبات لخصومة التحكيم، إلا أن هذه السلطات ينبغي ألا تترك طليقة، وذلك ضمانا لحقوق أطراف التحكيم، ويمكن رصد أهم القيود الواردة في هذا الثأن بما يلي:

(1) B. Moreau, A. Beregoi, et autre, arbitrage commercial, op. cit., no 211. (r) د/ منير يوسف حامد المناصير، سلطة المحكم في الإثبات في خصومة التحكيم التجاري الدولي،

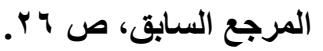




\section{القيد الأول: الالتزام بفهوي هـا اتفق عليه الخصوم:}

يقتضي مبدأ حيـاد المحكم ألا يخرج عن حدود ولأيته كمـا حددها الاتفـاق علي التحكيم، ليس فقط في عناصر النزاع الثلاثة وإنما في السلطة الإجرائية التي يمارسـها عند تحديد قواعد الإثبات، فإذا اتفق الخصوم علي ضرورة المرافعات الشفوية فإنها لا يجوز للمحكم أن يضع نصا يحظر ذلك، ويكتفي بالمستتدات المكتوبة"('). القيد الثاني: هلاء هة الإجراءات للنززاع:

ينبغـي علـي المحكـم أن يأخــ بعسين الاعتبـار عناصـر الملاعمـة، وملاءمــة الإجـراءات لطبيعة النـزاع، وهي سـلطة موضـوعيه لا تقوم علـي الاعتبـار الثخصي التقديري لوجهة نظر المحكم، ومن مقتضيات ذلتك المواعمة بين طبيعة النزاع وظروف نـشأته، وأسـاسـهـ القـانوني ومفاصـله، وبـين الإجـراعات الازمــة لـسمة، ومــع إقامـة التوازن بين مختلف عناصر شريعة التحكيم من سرعة وسرية ومرونـة، ولا ينبغي أن يطغي عنصر علي عنصر أخر. فبإذا كانت فكرة الوقت فيمـة غاليـة من مكونـات فكرة العدالة ذاتها، باعتبار أن العدالة هي إعطاء كل ذي حق حقة في الوقت المناسب، إلا أنه ينبفي أن تطفي هذه الفكرة علي باقي مكونات فكرة العدالة. وتكون سلطة هيئة التحكيم بالنسبة لاتخـاذ إجراءات الإثبات المتعلقة بالدعوي

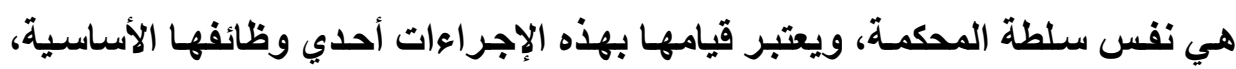
فلهيئة التحكيم ولو من تلقاء نفسها أن تسمع الشهود أو تقرر الانتقال للمعأينة أو تتدب أحد أعضائها للقيـام بذلك، أو تقرر الاستعانه بـالخبراء في مسائل معينه، كمـا لها أن تأمر بإخطار الخصوم من أجل استجوابهم، وهي لا تتقيد عند اتخاذهـا هذه الإجراعات 
بمكان معين، فيمكن أن تتم هذه الإجراعت بأكثر من مكان، وهذه مـا نصت عليه المـادة ^ r تحكيم.

والأصلـ أن تتخذ هذه الإجراعات مـن هيئة التحكيم مجتمعة في حالـة تعدد المحكمين، إلا أنها قد لا يكون ميسرا في جميع الأحوال لكون المكـان الواجب إجراء الإثبات فيها بعيدا عن مقر الهيئة، لهذا يمكن لهيئة التحكيم السماح بانتداب أحدهم للقياك بأحدي إجراءات الإثبات بشرط إثبات ذلك في محضر الجلسة. كمـا هو منصوص هو

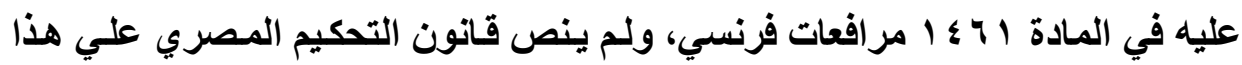
الأمر، إلا أن الفقه لا يمانع من قيام الهيئة بانتداب أحدهم بالقيام بالإجراء.

\section{ثانيا: تهديد قواعد الإثبات في التمكيم الدولي}

وإذا كـان الأصل هو ترك المجـال بشكل مباشـر أمسام إرادة الخصوم في تحديـ

قانون الإثبات المطبق علي خصومة التحكيم أو بشكل غير مباثر بطريق الإحالة إلى نظام إجرائي معين، ففي الواقع العملي لا يستعمل الخصوم هذا السلطة من حيث المبدأ،

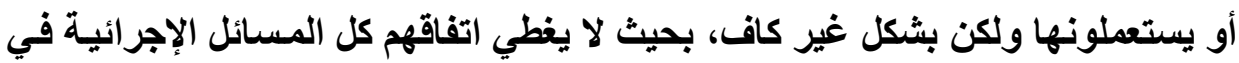
خصومة التحكيم، نظرا لعدم إلمـامهم بعلـم المرافعـات والإثبـات وتطبيقاتهـه في الدول المختلفه، وعندئذ يثور التساؤل ويصفة خاصة في مجال التحكيم الدولي، عمـا إذا كـان يجب البحث عن حل وضعي في تنازع القوانين، وذلك بتطبيق قاعدة اسناد معينة، أم أن الحل يتم خـارج نطاق نظريـة تنـازع القوانين، ويمكن التمييز بين اتجـاهين في هذا الصدد، اتجاه تقلييا يربط الحل بنظرية تنازع القوانين(')، واتجاه حديث، يحرر الحل من

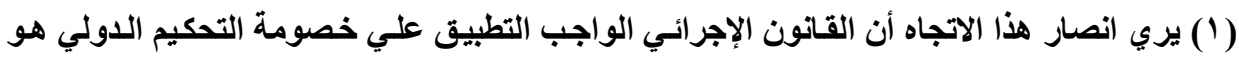

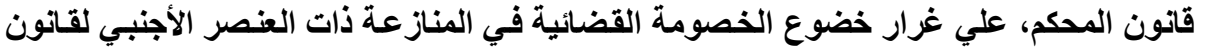

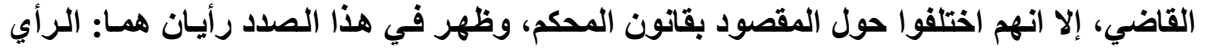
الأول: قانون المحكم هو قانون الإرادة: يذهب انصار هذا الاتجاه إلى أن القانون الواجب التطبيق $=$ 
هذه النظريـة، ويترك المسألة برمتها لمبدأ سلطان إرادة الخصوم في تحديد النظـام الإجرائي ـ خاصة قو اعد الإثبات _ لخصومة التحكيم، وسلطة المحكمين (') وتتجة أغلبية نظم التحكيم ومؤسساته إلى تحرير مسألة تحديد النظام الإجرائسي ـ خاصـة نظـام الإثبـات ـ لخصومة التحكيم الـدولي مـن قيد نظريـة تنـازع القوانين، وإعطـاء المجـال فسيحا أمسام سـلطة المحكسين وإرادة الخصوم في تحديــ القواعـ

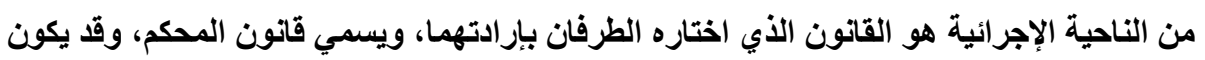

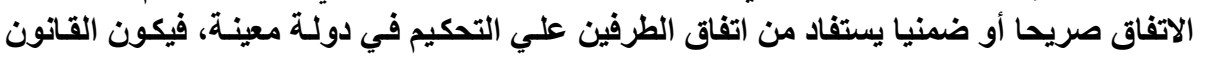

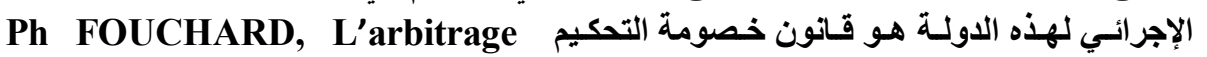
commercial international, op, cit, p, 499

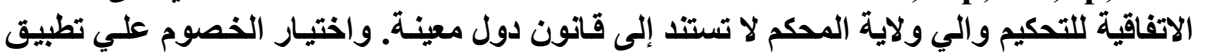

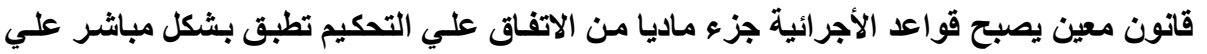

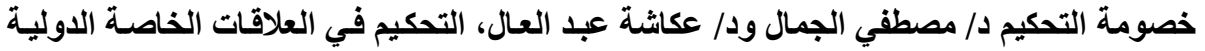

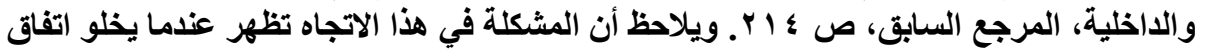
التحكيم من الإشارة إلى قانى العانون معين.

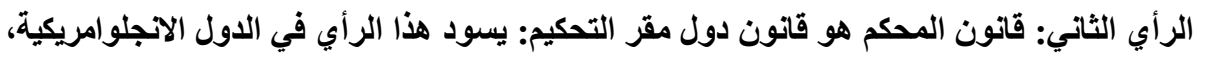

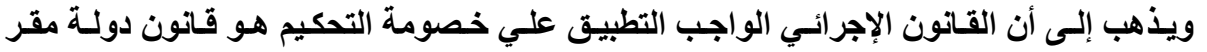

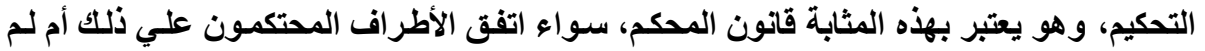

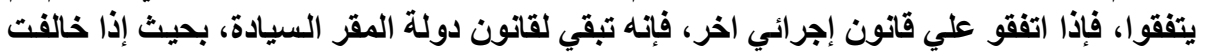

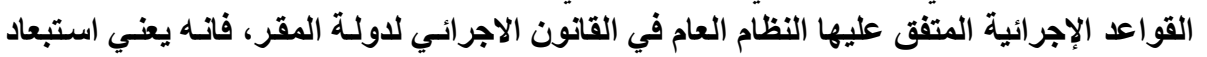

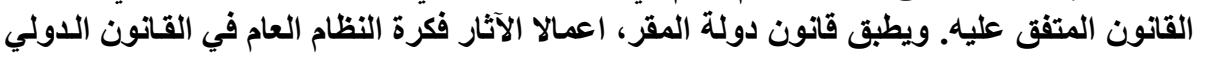

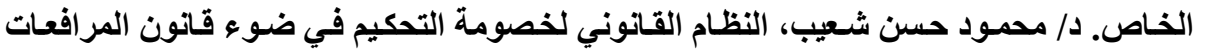

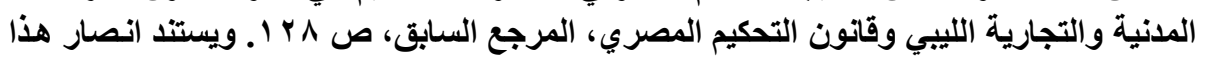

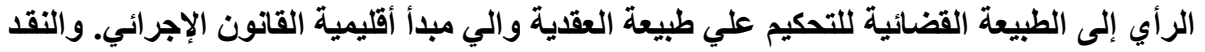

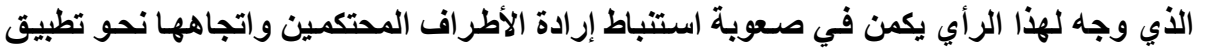

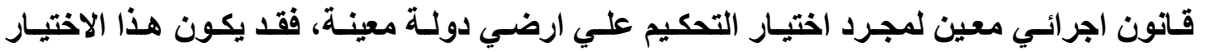

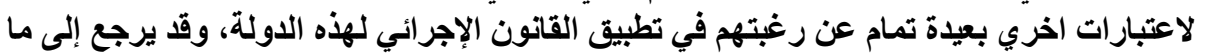

$$
\text { يسمي بالمزاج الأسياحي. }
$$

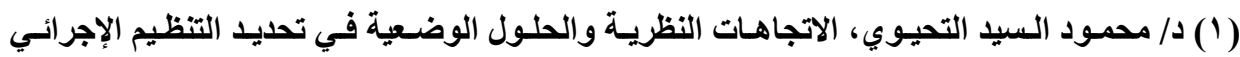

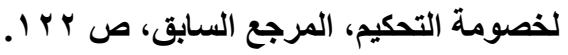


الإجرائية الواجبة التطبيق علي خصومة التحكيم الدولي، بغير اربتاط بقانون إجرائي

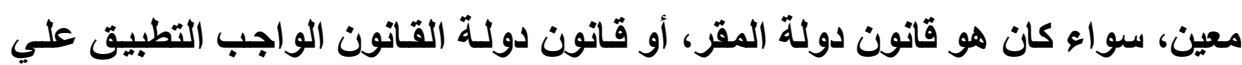
موضوع النزاع. ويرجع ذلكك لصعوبة تطبيق فكرة الإسناد، فليس النظام الدولي قاعدة إسناد

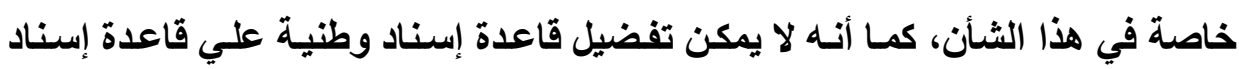
وطنية أخري، لأنه لا يتو افر لاي المحكمين عناصر هذا التفضيل (') وقد انتقد الاتجاه الحديث في تحديد التنظيم الإجرائي لخصومة التحكيم علي أسـاس أنه قد يهلد الضمانات الأساسية للتقاضي عن التحرر مـن القيود الإجرائية

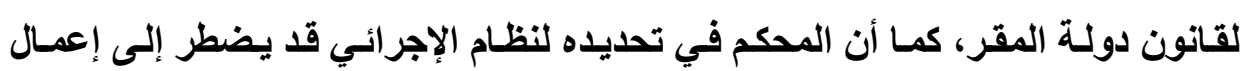
قانون إجرائي وطني مغني لضمان فاعلية التنفيذ(؟). ويلاحظ أن الشريعات الداخلة ومر اكز التحكيم المؤسسي، والتشريعات الدولية

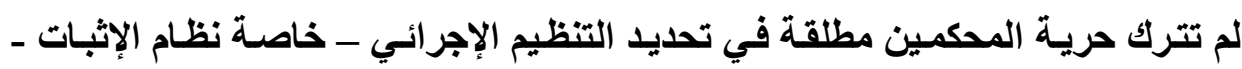
لخصومة التحكيم، بل قيدت هذه الحرية بقيدين أساسيين: القيد الأول: احترام النظام العام الدولي في التحكيم الدولي، واحترام النظام العام الاخلي في التحكيم الداخلي. القيد الثاني: احترام ضمانات التقاضي الأساسية بثكلها التقليدي علي الأقل،

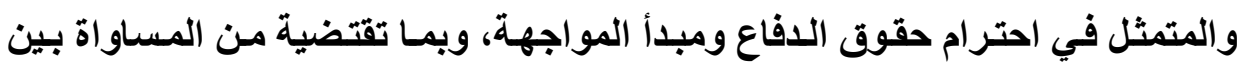

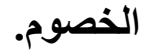

(1) د/ مصطفي الجمـال و د/ عكاشـة عبد العال، التحكيم في العلاقات الخاصـة الدوليـة والاذاخلية،

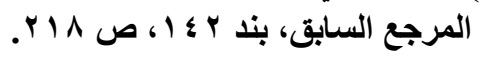

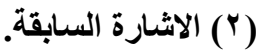


في الواقع للأطراف والمحكمين الذيار في حيد إجراءات الإثبات بين الأوضساع الآتية: - n

الوضع الأول: خلق قواعد الإثبات المطبقة علي خصومة التحكيم المنظورة بين

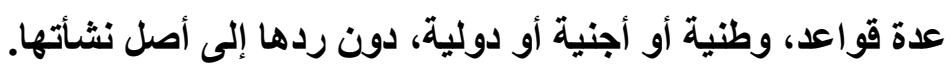
الوضع الثاني: اختيار قانون معين للإثبات، سواء كـان وطنيا أو أجنبيا، دون التقيا بقانون دولة المقر، أو قانون دولة التنفيذ بالضرورة. الوضـع الثالـث: الإحالة إلى نظام يكون معتمدا في دولـة أو مركز تحكيمي

$$
\text { مؤسسي وطني أو اجنبي أو دولي. }
$$

الوضع الرابع: الإحالة إلى قانون دول المقر،اؤ قانون دولة التنفيذ.

و الغالب يكون ذلك في التحكيم الدولي، ولكن لا مـانع من تطبيق نفس الآليات

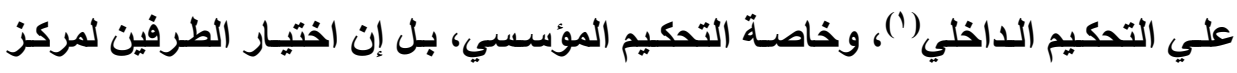

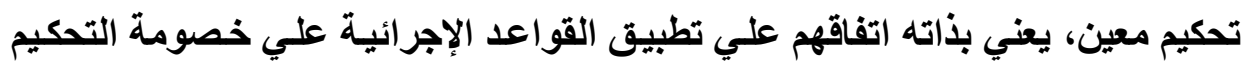

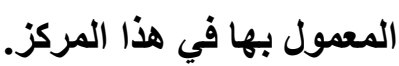
بالنسبة لأنظمة التحكيم في الدول العربية، فإن منها مـا لا يقيم التفرقة بين التحكيم الدولي والتحكيم الداخلي، أو علي الأقل فيمـا يتعلق بمسألة تحديد التتظيم

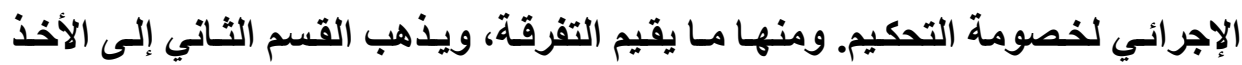
بالتفرقة ولكن لا يرتب عليها نتائجها في مجال الإثبات. ودون أن ترتب علهيا نتائجها

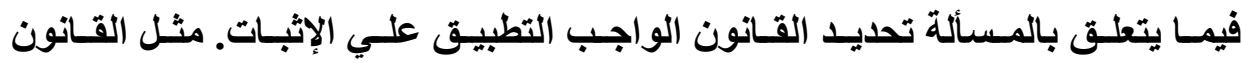


المصري، والقانون السوري والقانون الأردني، والقانون العماني، والقانون السعودي، والقانون الإماراتي، والقانون الكويتي، والقانون العراقي.

فمن الملاحظ أن قانون التحكيم المصري لم يفرق بين التحكيم الداخلي والتحكيم الدولي فيما يتعلق بنظام الإثبات في خصومة التحكير. مـع أن هذا القانون يطبق علي كافة أنواع التحكيم، سواء كان دوليا أو داخليا أو مدنيا أو تجاريا. إذا الأصل طبقا لنص المادة ه ب تحكيم هو إعمال مبدأ سلطان إرادة الخصوم في تحديد النظام الإجرائي للإثبات لخصومة التحكيم، فبإذا لم إذا لم يجد اتفـاق فإن هيئة التحكيم تتولي تنظيم مسألة الإجراءات، وسلطة المحكمين سلطة احتياطية. يلاحظ علي نص هذه المـادة أن المشرع المـصري لـم يأخذ فيمـا يتعلق بتحديـا التظظيم الإجرائسي للإثبات فـي خصومة التحكيم بالاتجـاه القائـل بـأن يتم ذلك علـي ضـوء نظريـة تنـازع القوانين في التحكيم الـدولي، فلـم يـرجح بين قـانون دولـة دون قـانون دولـة أخري، وانما ترك الحرية لهيئة التحكيم('). ولهيئة التحكيم نفس الخيارات المتاحه للخصوم في هذا الثأن أيا كان نوع التحكيم، مع مراعـاة أن التحكيم الوطني الذي يجري في مصر يخضع أصلا لقانون التحكيم المصري، وتظل للقـانون المختـار من قبل هيئة التحكيم ولأية احتياطية في حالة القواعد المكملة فيه، وفي حالة سكوته عن حكم مسألة معينة. ففي الواقع العملي في مصر كمـا هو الغالب في اغلب الدول العربية، نجد أن الخصوم ليست للديهم القدرة العملية الكافية لتحديد قواعد الإثبات لخصومة التحكيم، ولألك فهم عادة ما يكتفون بالإحالة إلى قانوني إجرائسي معين، أو نظام إجرائي يكون 
معتمدا لاي مركز أو منظمة تحكيم مؤسسي. وقد يتم اتفاق الأطراف صراحة أو ضمنيا علي نظام الإثبات المصري.

ويالنسبة للنظـام الفرنسـي، فقد فرق القـانون الفرنسي بـين التحكيم الـدولي والتحكيم الداخلي في التظيم الإجرائسي لخصومة التحكيم، وقد أخذت عنه العديد من أنظمـة التحكيم في الـدول العربية، منهـا قـانون أصـول المحاكمـات اللبنـاني، والقـانون الجزائي، والقانون التونسي، والقانون المغربي، والقانون البحريني.

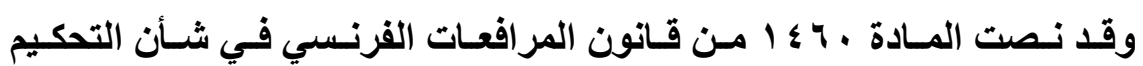
الــاخلي، إجـراعات خـصومة التحكـيم وذلـك بقولهــا" يـنظم المحكــون الإجـراعات التحكيمية دون أن يكونوا ملزمين باتباع القواعد المعتمدة من قبل المحاكم، إلا إذا كان الأطراف قد اتفقوا علي خلاف ذلك في عقد التحكيم، إلا أن المبادئ الأساسية للاعوي

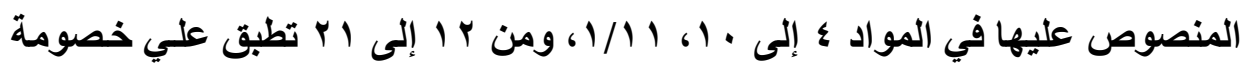
التحكيم، وإذا وجد أحد عناصر الإثبات في حيـازة أحد الأطراف يجوز للمحكم أن يـأمر بإبراز دليل الاثبات". وهذه المواد المحال إليها تهدف إلى تحقيق ضمانات التقاضي في خصومة التحكيم ('). أما بشأن التحكيم الدولي، فقد نصت المـادة ب و ؛ أ مرافعات فرنسي علي أنسه يجوز أن يحدد اتفاق التحكيم مباثرة أو بالإحالة إلى نظام تحكيم الإجراءات التي يجب اتباعها في خصومة التحكيم، ويجوز أيضا إخضاع هذه اللاعوي إلى قانون إجراعات معين يحدده اتفاق التحكيم، وفي حالة غياب النص علي ذلك في اتفاق التحكيم. يطبق

(1) R. PERROT, l'application a l'arbitrage des regles de nouveua code de procedure civile, Rev. Arb., 1980,p. 643 
المحكم الإجراعات التي يراها مناسبة إمـا مباشرة أو بالإشـارة إلى قانون معين أو إلى نظام تحكيمي معين".

فيلاحظ أن المـشرع الفرنسـي طبـق القاعـدة العامسة وهـي مبــأ سـلطان إرادة الأطراف المحتكمين في تحديد التظيم الإجرائسي لخصومة التحكيم في شـأن التحكيم الدولي، وقد منح لهيئة التحكيم سلطة واسعة في تحديد هذا النظام الإجرائي، وكان أقل حرصا علي النص علي وجوب احترام ضمانات التقاضسي الأساسية والتي حصر علي الإشارة إليها في التحكيم الداخلي. ويلاحظ أن المشرع اللبنـاني قد أخذ موقفا مغأيرا لموقف المشرع الفرنسي، حيث ألزم الخصوم باتبـاع قواعد المرافعات العاديـة إلا إذا اتفق الأطر اف المحتكمون علي عكس ذلك، أمـا المشرع اللبنـاني، فقد ألزم المحكمين بتطبيق أصول المحاكمـات المدنية إلا ما لا يتفق منها مع القواعد الخاصة بالتحكيم('). ومن ناحية أخري فقد خول المشرع اللبناني للخصوم سلطة إعفاء المحكم أو المحكمين من تطبيق أصول المحاكمـة العادية أو بعضها. ويقصد بالأصول القواعد العادية، ولا يقصد بها ضمانات التقاضي. حيث ذهب المشرع إلى استثناء القواعد التـي تتعلق بالنظـام العـام. مثل مبدأ حيـاد المحكم، ومبدأ المواجهة وحقوق الدفاع. وأمسا في التحكيم الدولي، فقد نصت المسادة 11 أصول محاكمات، علي أنه " يجوز أن تحدد اتفاقية التحكيم مباشرة أو بالاحالة إلى نظام للتحكيم الأصول التي تتبع في الخصومة التحكيمية، ويجوز أيضا إخضاع هذه الخصوم لقانون معين من قوانين أصول المحاكمة يحدد في الاتفاقية، إن لم يرد نص في الاتفاقية يطبق المحكم بحسب مقتضي الحال الأصول التي يراها مناسبة أمام مباشرة أو بالالتجاء إلى قانون معين أو إلى نظام للتحكيم". فيلاحظ علـي المشرع اللبنـاني أنـه 
كرس مبدأ سلطان الإرادة في تحديد التظيم الإجرائي لخصومة التحكيم الدولي، كما هو سائد في التشريعات المقارنة، سواء بجواز الاتفاق مباشرة علي وضع قواعد إجرائية خاصة بكل خصومة علي حده، أو بالاحالةّإلى قانون إجراء معين. سواء كـان القانون اللبناني أو غير أو الإحالة إلى نظام تحكيمي معين.ويلاحظ أن هذه الحرية ليست مطلة بـل مقيدة بـاحترام ضـمانات التقاضـي الأساسية، وبـصفة خاصـة بمبـأ المواجـة بـين

والواقع أن التحرر من الثكليات الإجرائية ليس تحررا كـاملا، وذلك حتي يمكن إخضاع حكم التحكيم للرقابة القضائية للاحقة. ويلاحظ أن المشرع اللبناني قد حدد ثلاثة مستويات لاختيـار التنظيم الإجرائسي لخصومة التحكيم شـأنه شـأن القـانون الفرنسي:

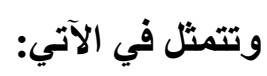

- ترك للخصوم حرية وضع التنظيم لخصومة التحكيم بأنفسهم.

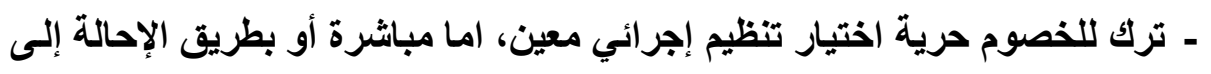
قانون معين أو مركز تحكيم معين. ـ إمكانية الاتفاق علي تطبيق قانون المرافعات لاولة المقر، وعندئـذ قد يكون هو قانون أصول المحاكمات المدنية اللبناني.

\section{تنظيم إجراءات الإثبات في التشريعات الدولية وهراكز التمكيم}

يلاحظ أن التشريعات الدولية في التحكيم قد اتخذ بعضها موقفا معينـا وصريحا من مسألة تحديد التظظيم الإجرائسي للإثبات لخصومة التحكيم، ولم تشذذ أنظمـة مراكز التحكيم الدوليـة الدائمسة عن تكريس مبـدأ سـلطان إرادة الخصوم في تحديد التنظيم الإجرائي لخصومة التحكيم، مع منح المحكين سلطة تحديد النظام الإجرائي لخصومة 
لقد نظمـت قواعد اليونسترال الـصادرة عن الأمسم المتحدة للقـانون التجـاري الدولي القواعد الاجرأيئة للتحكيم في الفصل الثالث، حيث جـاء في المـادة هـ 1 أنـه مـع مراعاة أحكام هذه القواعد، لهيئة التحكيم ممارسة التحكيم بالكيفية التي تراهـا مناسبة شـريطة أن تعامـل الطرفين علـي قدم المسـاواة وان تهيـأ لكك منهـا في جميع مراحل الإجراعات فرصه كاملة لعرض قضيته" ومفاد ذلك أن قواعد التحكيم التجاري الدولي التي وضعتها لجنـة الامم المتحدة للقانون التجاري الدولي لم تشر صراحة إلى مبدأ سلطان إرادة الخصوم في تحديد التظظيم الإجرائي لخصومة التحكيم، بل عهدت بذلك إلى هيئة التحكيم مباشرة، وخولت لها سلطة واسعه، إلا أنها قد حرصت علي التأكيد علي أهــ ضـــانات التقاضـي، وهـو مبـدأ المسـاواة بـين الخـصوم فـي خـصومة التحكيم. وخصوصا في استعمال حقوق الدفاع، وبعض النصوص ألزمت الهيئة بمبدأ المواجهة .$(10619)$

وقد أفرد القـانون النمـوذجي للتحكيم التجـاري اللدولي الفصل الخـامس لسير إجـراءات التحكيم، واسـتهلة بالمـادة 1 ا مبـدأ المسأوه بـين الخصوم في إجراءات خصومة التحكيم، باعتباره من الضمانات الأساسية للتقاضي، ثم نصت المسادة 9 التصنه علي كيفية وضع النظام الإجرائي لخصومة التحكيم، وقد اختلف في ذلتك عن وقواعد لجنة الامم المتحدة للقانون التجاري الدولي الصادر 9 لو ا، وقد كرس مبدأ سلطان الإرادة الخصوم في تحديد التظظيم الإجرئي لخصومة التحكيم، بـأن منحهم مكنة الاتفـق علي الإجراءات الواجب اتباعها في خصومة التحكيم، فإن لم يكن ثمة مثل هذا الاتفـاق، فقد خول لهيئة التحكيم مـع مراعاة أحكام هذا القـانون، أن تسبر في التحكيم بالكيفيـة التي تراها مناسبة، وتثثمل السلطة المخولة لهيئة التحكيم البت في قبول الأدلة المقدمـة

وصلتها بالموضوع وجدواها. 
وقد نـصت المـادة هـ 1 مـن نظـام غرفـة التجـارة الدوليـة ببـاريس إلى ضـرورة تطبيق القواعد الإجرائية الواردة في نظام التحكيم لاي غرفة التجارة الدولية ببـاريس، لأنتا بصدد مركز تحكيم مؤسسي، مع عدم إغفال مبدأ سلطان إرادة الخصوم في إمكانية

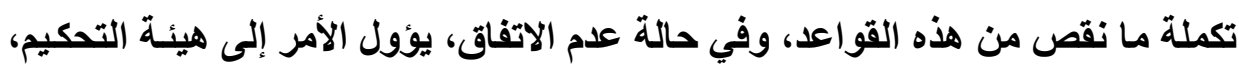
وقد أشـارت هذه المـادة إلى إمكانية الإحالة إلى قانون إجرائسي وطنـي معين يطبث علي الإثبات في خصومة التحكيم. وقد نصت المـادة هـ 1 علـي إلزام محكمة التحكيم بـأهم إلما ضمانات التقاضي وهي العدالة وعدم الانحياز، والمسأواه بين الخصوم في إجراءات التحكيم. و إلى ضمانة التسبيب للأحكام الصادرة. وقد كرس نظام مركز القـاهرة الإقليمي للتحكيم مبدأ سلطان الإرادة في تحديد

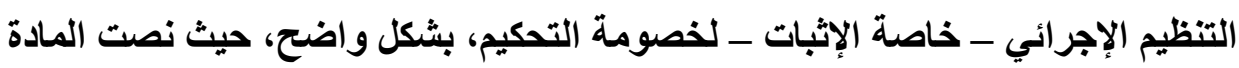
الأولي منه علي أنه " إذا اتفق طرفا عقد كتابة علي إحالة المنازعة المتعلقة بهذا العقد الإبات إلى التحكيم وفقا لنظام التحكيم مركز القاهرة الإقليمي للتحكيم التجـاري الدولي وجب التب عندئذ تسوية هذه المنازعات وفقا لهذا النظام مع مراعاة التعديلات التي قد يتفق عليها الطرفان كتابة. وتنظم هذه القواعد التحكيم إلا إذا تعارض بين قاعدة فيها ونص من نصوص القانون الواجب التطبيق علي التحكيم، لا يجوز للطرفين مخالفته، إذ تكون الأرجحية عندئذ لذلك النص. وقد نصت المادة 10 من نظام مركز القاهرة الإقليمي علي أنه " مع مراعاة أحكام هذه القواعد، لهيئة التحكيم ممارسة التحكيم بالكيفية التي تراها مناسبة شريطة أن تعامل الطرفين علي قدم المساواة وأن تهيئ لكل منهمـا في جميع مراحل الإجراءات فرصة كاملة لعرض قضيته". 


\section{تنظيم قواعد الإثبات في التمكيم المطلق أو الحر}

ويلاحظ أنه في التحكيم الحر (') وهو الذي يعفي فيه المحكم من تطبيق قواعد

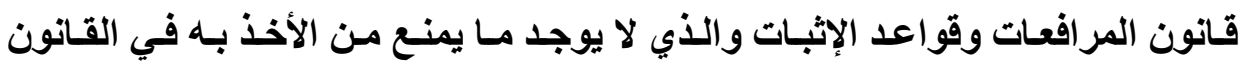

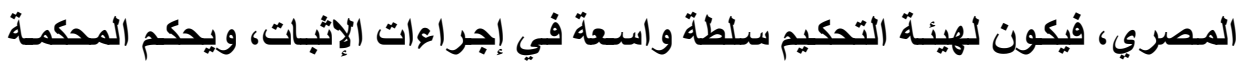

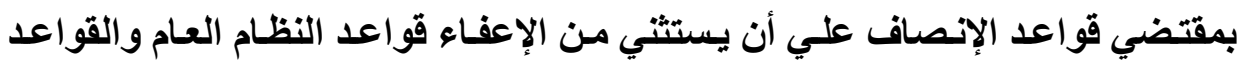

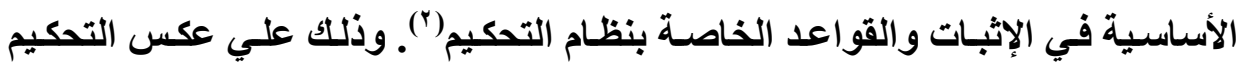

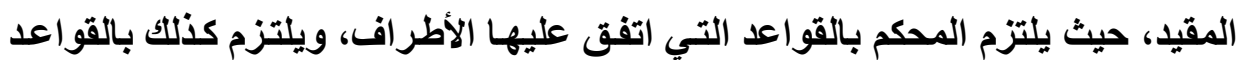
القانونية التي اتفق علي تطبقها في إجراءات الإثبات.

ويكون للمحكم حرية واسعه في إجراعات التحكيم، وييرز الفـارق الهام بين هذا المحكم وقاضي الدولة، حيث يتضمن استبعاد تطبيق قاعد القانون التي يعملها قاضي

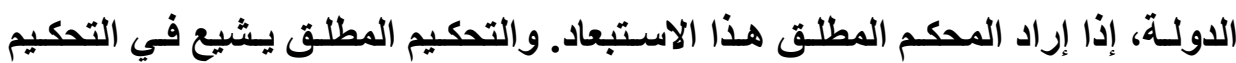
الدولي لفوائده الجمة، ولكنه ينظوي علي مخاطر كثيرة تنشأ عن احتمال وقوع المحكم

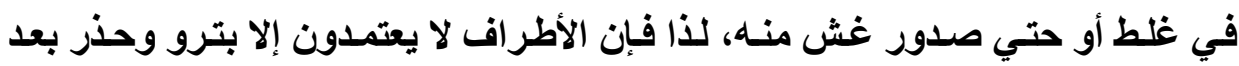

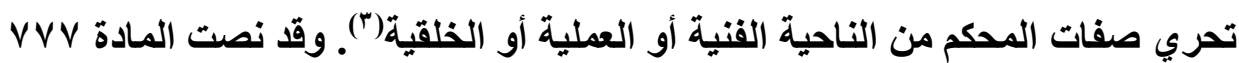

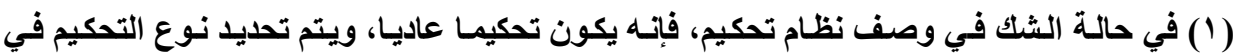

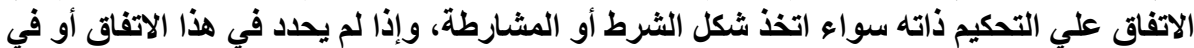

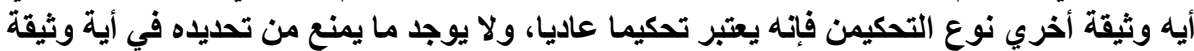

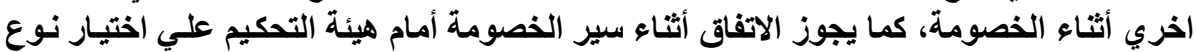
أخر من التحكيم غير العادي.

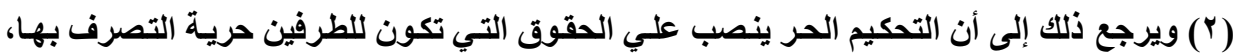

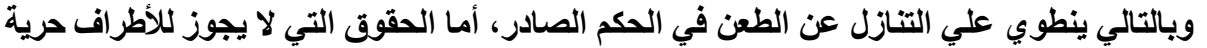

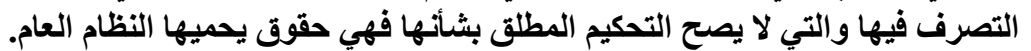

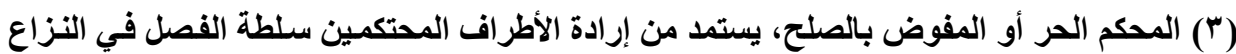

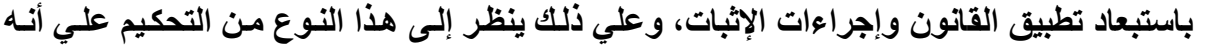

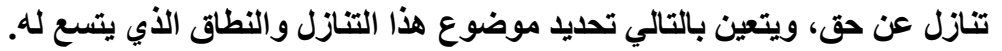


أصول محاكمات علي أنه " في التحكيم المطلق يعفي المحكم أو المحكمون من تطبيق

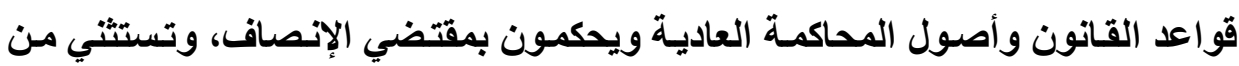

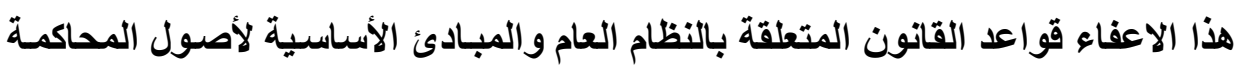

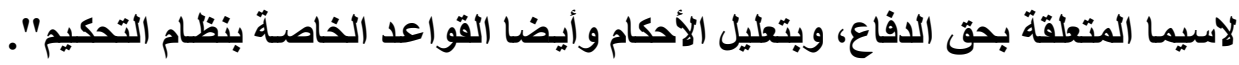
ويلاحظ أن الإعفاء المحكم المفوض بالصلح هو إعفاء تشريعي وليس اتفاقيا. مع إلزام

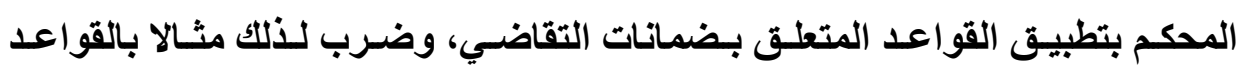
المتعلقة بالنظام العام وحقوق الدفاع، وتعليل الأحكام.

\section{الفنرع الثاني \\ هدود هق الخصوم في الإثبات أُهام هيئة التمكيم}

في الواقـع يجـوز للأطراف الاتفـاق علـي عدم تطبيـق القواعد القانونيـة في

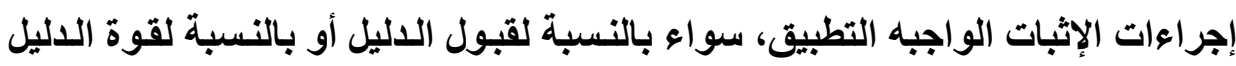

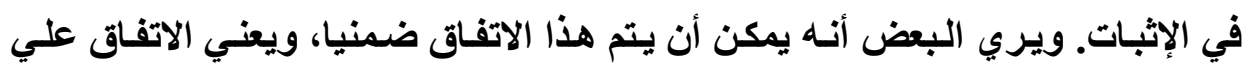

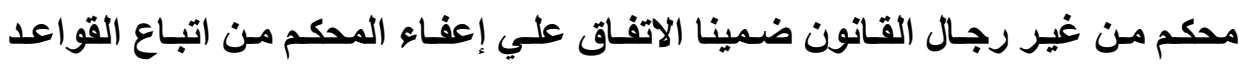

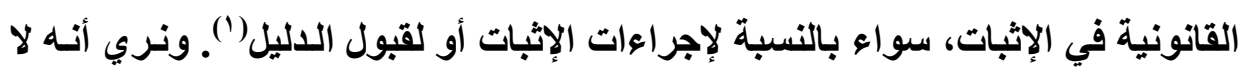

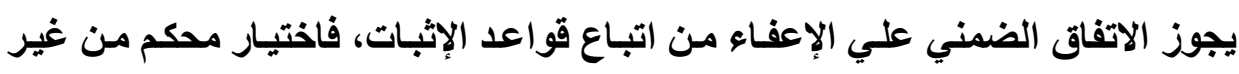
رجال القانون لا يشير ضمنيا إلى الاعفاء من اتباع القواعد القانونية في الإثبات. ويتقيد حق الخصوم في الإثبات بمجموعة من المبادئ تتمثل في تقيد الخصوم

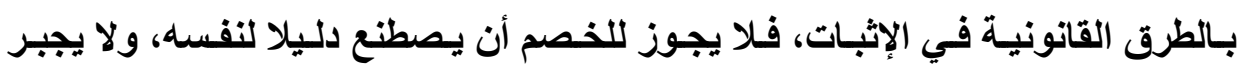

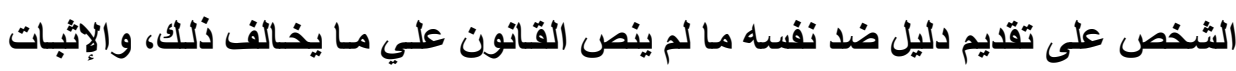
جائز إلى قفل باب المرافعه، وسنشير إلى ذلك في النقاط الآتية:

(1) د إنحي والي، التحكيم في المنازعات الوطنية والتجارية الدولية، علمـا وعملا، المرجع السابق، 
أولا: تقيد حق الفصوم في الإثبات بالطرق القانونية للإثبات (1) إذا اختار أطراف التحكيم أو هيئة التحكيم قانونـا معينـا لتطبيقهـ علـي إجراءات الإثبات، فيجب علي أطراف التحكيم التقيا بالإجراءات التي نص عليها القانون في تقايم الأدلة، فالإثبات ليس واجبا على الخصوم فحسب، بل هو حق لكل خصم(")، ولذلك فبإن الواجب يقتضي ألا يثبت ادعاءه نفيا أو إثباتا بطريق لم يشرعه القانون المتفق علي تطبيقه لإثبات مثل هذا الادعاء، وإنمـا عليه أن يلتزم باستعمال حقه بالإثبات بـالطرق التي يحددها القانون، ومتى التزم بذلك فليس للقاضـي أو المحكم أن يمنعه من إثباته،

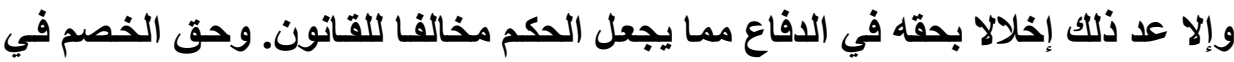

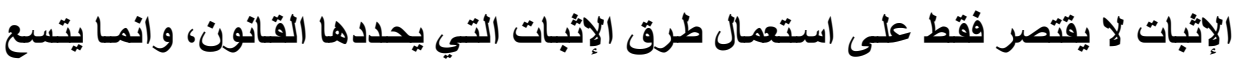
ليثمل حق الخصم في مناقشة مـا يقدمـه خصمه من أدلة لإثبات ادعائهـ نفيـا أو إثباتـا

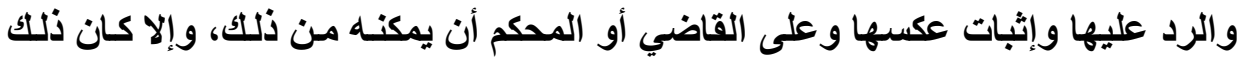

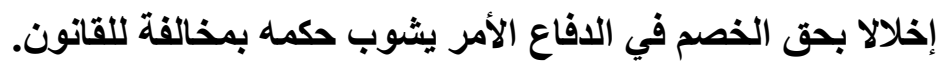

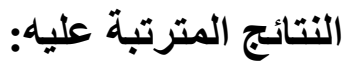
ا - يتقيد حق الخصوم بالطرق التي حددها القانون(")، فلا يجوز له إثبات بغير الكتابة

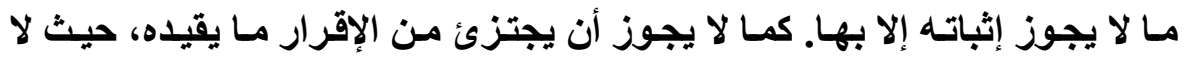

$$
\text { يجوز تجزئة القرار. }
$$

r - ويتقيد حق الخصوم أيضا بالإجراعات والأوضاع التي رسمها القانون لتقديم الاليل.

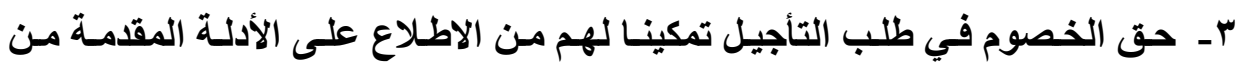
الخصم والرد عليها

( (1) د/ رمضان أبو السعود، مبادئ الإثبات في المو اد المدنية والتجارية، المرجع السابق، ص99 ب.

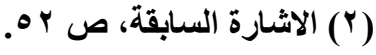

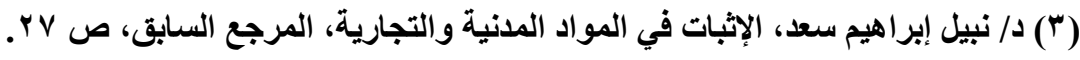


ـ - لا يجوز للمحم أن يتحرى أدلة الإثبات بنفسه بعيدا عن الخصوم وأن يقضي بعلهـ

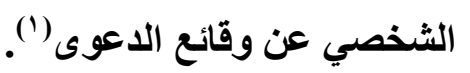

هـ الدق في نفي أدلة الخصم، وهذا يجسد مبدأ المساواة بين الخصوم في المراكز الإجرائية.

צـ الاعتراض على تقديم الاليل، وذلك لعدم مراعاة طرق الإثبات أو إجراعات الإثبات. V- الحق في توجيه اليمين الحاسمة للخصم. (مقيد بعدم جواز التعسف في استعمال

^- حق الخصم في الاستشهاد بالثهود، إجراء المعأينة، المطالبة بتعين الخبيز، إلزام الخصم أو الغير بتقديم الدفاتر و السندات في حوزتها.

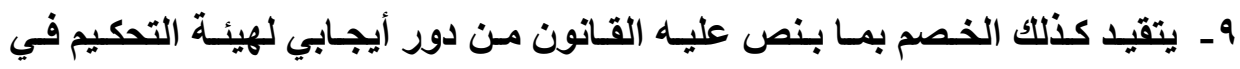
إجراعات الإثبات، ومن سلطة تقديرية في تقدير الأدلة.

ثانيا: لا يجمز للذصم أن يصطنع دليلا لنفسه (")

ومن المبادئ التي يتقيد بها الخصوم في الإثبات، عدم جواز أن يصطنع دليلا لنفسه، فيجب أن يكون الدليل الذى يقدمه الخصم محتجا به على خصمه صادرا من هذا الأخير(")، إذ لا يلتزم الشخص إلا بمـا يصدر عنه، فالورقة المكتوبـة لكى تكون دليلا كاملا في الإثبات يجب أن تكون موقعة أو بخط يا من تنسب إليه. إذن الشخص لا لإيلتزم

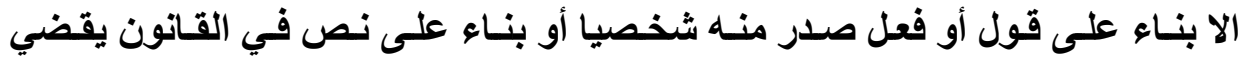
بإلزامـه، ومن ثم لا يملك شخص إلزام غيره بقول أو فعل لم يصدر عنه صراحة أو لوكي

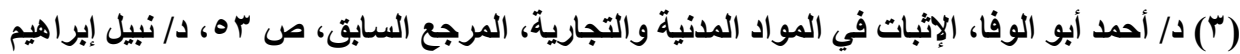

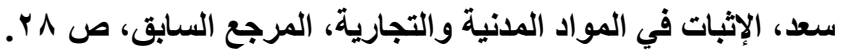


ولكن يلاحظ أن هذه القاعدة يرد عليها بعض الاستثناعات تثمثل في الآتي:

1ـ دفاتر التجار لا تكون حجة على غير التجار، ومـع ذلك فبان البيانـات المثبتة فيها تصلح أساسا يجيز للقاضي والمحكم أن يوجه اليمين المتممة إلى أحد الطرفين فيما يجوز إثباته بشهادة الشهود.

r - تكون دفاتر التجار إلزامية حجة لصاحبها ضد خصمه التاجر إذا كـان النزاع متعلقا بعمل تجاري متى كانت الافاتر منتظمة.

وتسقط هذه الحجية باللدليل العكسي، والذي يجوز أن يؤخذ من دفاتر الخصم

المنتظمة

\section{ثالثا: لا يمبر الشخص على تقديم دليل ضد نفسه مها لم ينص القانون علي ها}

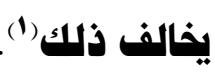

كقاعدة عامـة، لا يجوز إجبـار الخصم علي تقديم دليل ضـ نفسه مـا لم ينص القانون علي ما يخالف ذللك، ويوجب عليه تقديم مستند مـا. وذلكك لأنـه أذا كـان الإثبات حقا للخصم الا أن هذا الحق في الإثبات مقيد بألا يصطنع الشخص دليلا لنفسه وألا يجبر

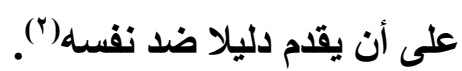

فالواقع أنه لا يجوز إجبار الخصم على أن يقدم دليلا ضد نفسه، وإذا كان الإثبات

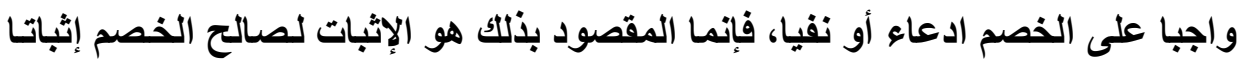

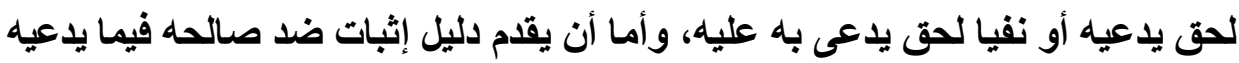

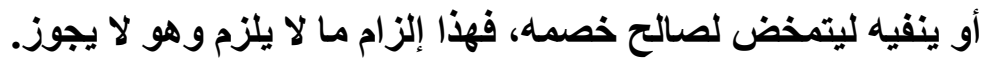

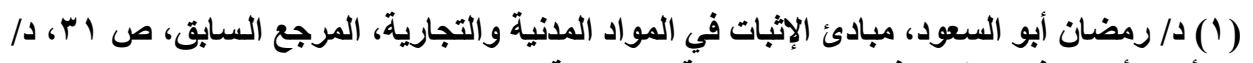

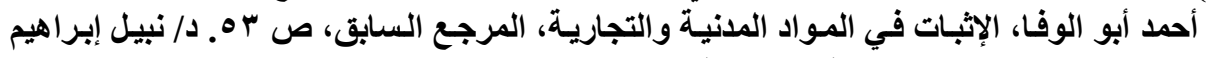

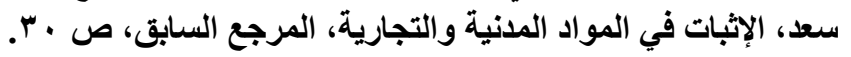

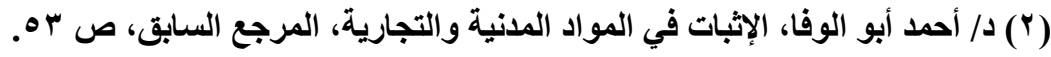




\section{استثناء هن هذه القاعدة}

يجوز للخصم أن يطلب إلزام خصمه بتقديم أيـة أوراق منتجة في الداعوى تكون

تحت يده، وذلك في الأحوال الآتية(')

1- إذا كان القانون يجيز مطالبته بتقليمها أو بتسليمها.

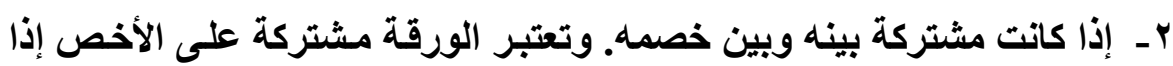

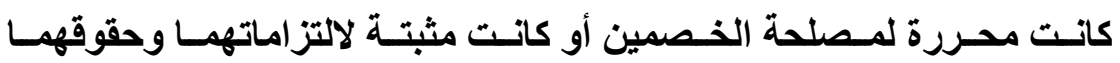

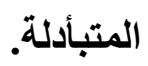

r- إذا استتد إليها خصمه في أية مرحلة من مراحل الدعوى.

\section{رابعا: الإثبات جائز إلى قفل باب المرافعه}

في الواقع، من مقتضيات حق الإثبات توفير الفرصه حتي اللحظة الأخيره لكل

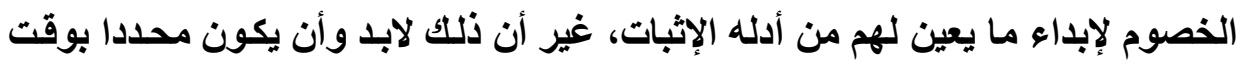

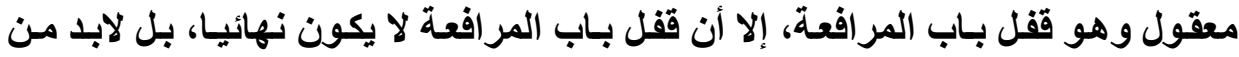
الاستجابه لمعطيات الواقع العملي التي قد تبرر وفي ظروف استثنائية تأخر الخصم في

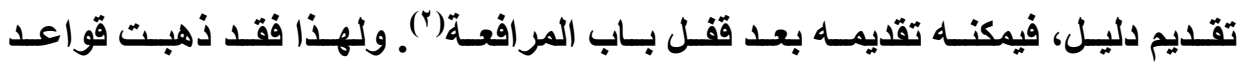

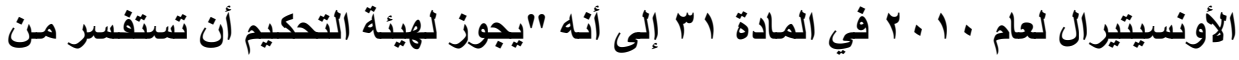

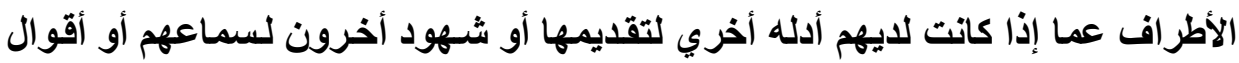
أخري للإدلاء بها، فإذا لم يكن لايهم شئ من ذلك جاز لهيئة التحكيم أن تعلن اختتام

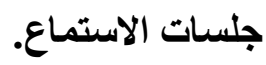


ويجوز لهيئة التحكيم أن تعيد فتح بـاب المرافعة مـن جديد بمبادرة من تلقـاء نفسها أو بناء علي طلب أحد الأطراف، وذلك لوجود أدله تري أنها ضرورية للحكم في

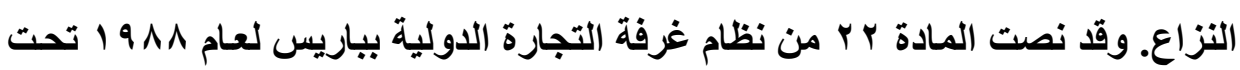
بند قفل باب المرافعة علي أنـه " تعلن محكمة التحكيم عن قفل بـاب المرافعه إذا رأت أنها قد أتاحت فرصه كافية لسماع الأطراف، ولا يجوز بعد هذا التاريخ تقديم أية مذكرة كتابية أو ادعاء أو دليل، إلا إذا طلبت محكمة التحكيم ذلك أو سمحت بـه" وهذه المسادة

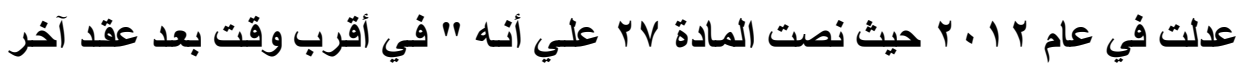
جلسه مغلقـة متعلقة بالمسـائل التي سيفـل فيهـا بحكم أو بعد تقديم أخر مـذكرات مسموح بها بخصوص تلكك المسائل إذا حصل ذلك بعد الجلسة المـكورة تقوم هيئة التحكيم: بإعلان ققل باب المرافعات الخاصة بالمسائل التي سيتم الفصل فيها بحكم. ولا يجوز بعد قفل المرافعات تقديم أي مذكرة أو حجة أو أي دليل بخصوص المسائل التي سيتم الفصل فيها بحكم، إلا إذا طلبت هيئة التحكيم أو سمحت به. وبالتالي فإن إعادة فتح بـاب المرافعه هو من صـلاحية هيئة التحكيم وهذا مـا

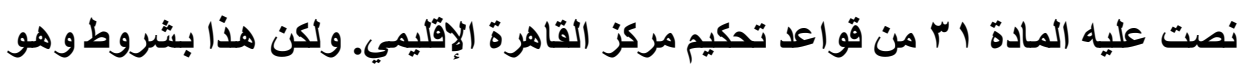

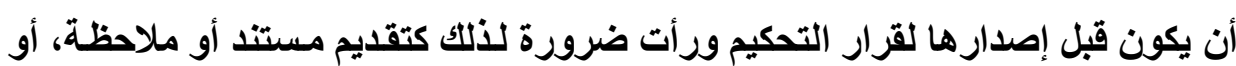
إذا رأت ضرورة استيضاح الأطراف في تفسير مستند يشوبه الغموص، وهذا مـا نصت عليه المادة ج ج من القواعد السويسريه للتحكيم الدولي. والمـادة ه ب من نظام تحكيم الهيئة الأمريكية للتحكيم.

ويلاحظ أن قانون التحكيم المصري والفرنسي لم يعالجا هذه الجزئية. ونري أنـه. يفضل أن يعـالج المشرع المصري والفرنسي هذه الجزئيـة نظرا لأهميتها في الواقع

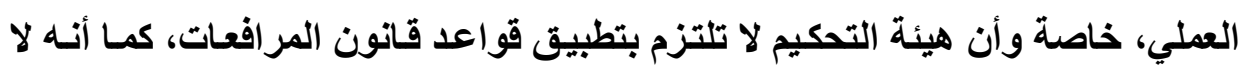


يجوز استئناف الحكم الصادر من الهيئة في النظام المصري، فلا يمكن للخصوم تدارك ما فاتهم من وسائل دفاع.

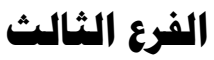

\section{الفصم المتحمل عبs الإثبات أهام هيئة التحكيم الهئ}

إن تعيسين الخصم الـذى يكلف بالإثبـات أمسر بـالغ الخطر في سـير الـدعوى

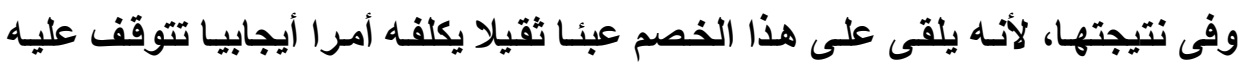
نتيجة الدعوى بينما يكتفى من خصمه بـأن يقف في الدعوى موقفا سلبيا ممـا يجعله بذلك في مركز دون مركز خصمه. فمن يقع عليه واجب أو عبْ الإثبات للواقعة محل النزاع يكون في مركز أضعف من مركز خصمه. وفي الواقع القاضى والمحكم لا يملكـان تحدد الخصم الذي يحمل عبء الإثبات، وذلك لأنه لا يتقق ومبدأ حياد القاضى في النزاع المطروح عليه، لذلك يتولى المشرع نفسه وضع القاعدة التى تعين من يقع عليه عبء

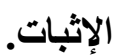

المقرر قانونا أن يقع علي من يدعي وجود واقعة معينة عبء إثباتها، وقد نصت

المادة الأولي من قانون الإثبات المصري علي أنها " علي الدائن إثبات الإلتزام وعلي المدين إثبات التخلص منه". وقد نصت المادة ه إب ا من القانون المدني الفرنسي علي أن من يطلب تنفيذ التزام معين أن يقدم اللاليل علي وجوده، وحق الخصم الآخر في إثبات العكس. وقد أكلات علي ذللك محكمة النقض الفرنسية('). وبالتالي من ادعي وجود

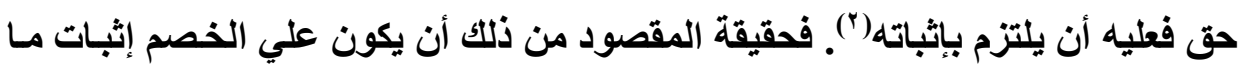

(1) Cass. Com, 10 dec. 2004, Gaz. Pal., N026, 2005, p. 36.

(2) Loen Mazeaud, J. Mazeaud et F. chabas, lecons de droit civile introduction a l etude du droit, 12 èd. Montchrestien, 2000, p. 510. 
ياعيه ولخصمة نفيه، سواء أكان هذا الخصم أو ذاتك هو المدعي أو المدعي عليه، أو خصم متـخل في اللاعوي أو مختصم فيها، وسـواء كـان مـا يدعيه أو طلب أصلـي أو عارض أو دفع موضوعي أو دفع شكلي أو دفع بعدم القبول الدعوي (') في الواقع هذا النص يعتبر تطبيقا لمبدأ عام يسرى على جميع أنواع الروابط المالية(؟) فحسب، فالمبدأ إذن " أن البينة على من ادعى "والمقصود بالبينة الإثبات الأى يتطلبه القانون وليس المقصود بالمـدعى هو رافع اللدعوى وإنمـا إلى كل خصم يـدعى على خصمه أمـرا فالمدعى عليه في الدعوى اذا ما ابدى دفعا معينـا يصبح مدعيا بـه، ويقع عليه عبء إثباته طبقا لقاعدة "صاحب الدفع مدع" وعلى ذلك فبان عبء الإثبات يمكن أن ينتقل من خصم إلى اخر.

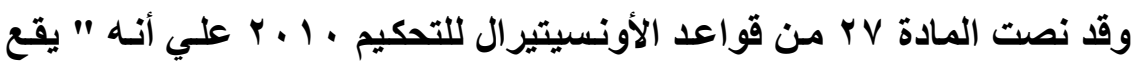
علي عاتق كل طرف عبء إثبات الوقائع التي يستتد إليها في تأييد دعواه أو دفاعه". وهذا ما نصت عليه المادة rV من قواعد مركز القاهرة للتحكيم، وكذلك هذا مـا نصت

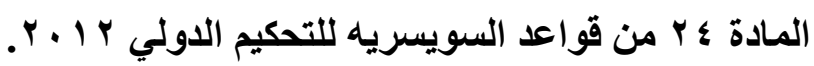
وبالتالي فإن عبء الإثبات يقع علي عاتق المحتكم في الخصومة التحكيمية، ويقع علي عاتق المحتكم ضده نفي ما اثبته المحتكم. وللطرفي التحكيم أن يلجأ إلى كافة طرق الإثبات، سواء كانت تقليدية أو حديثة، وإطلاق مبدأ حريـة الإثبات في أي تحكيم يجري("). وتحديد الخصم الذي يتحمل عبء الإثبات يكون بناء علي الطلب، إلا أنه يمكن

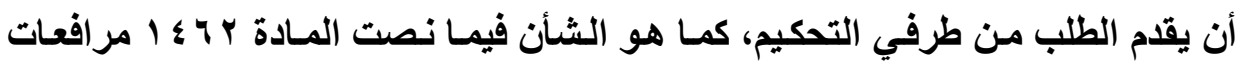




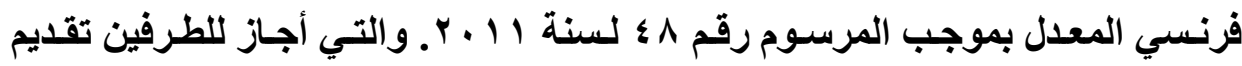
الطلب، فعليمها إثبات طلب كل وأحد منهما.

ويلاحظ أن من يتحمل عبء الإثبات ليس مطالبا بإثبات كامل قاطع للحق، وإنما

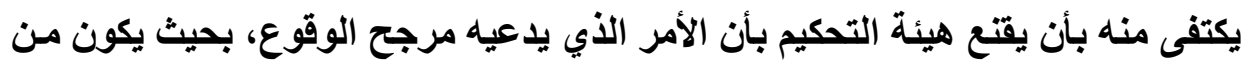

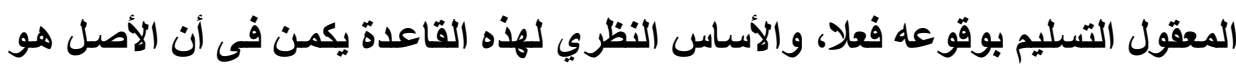

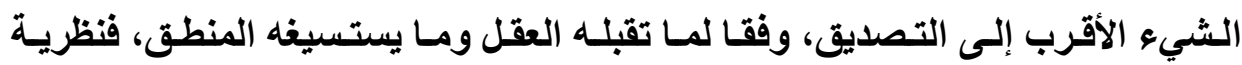

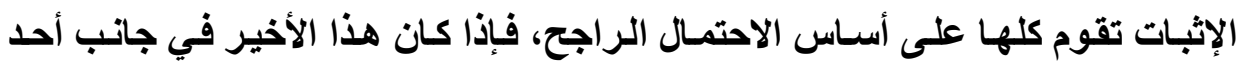

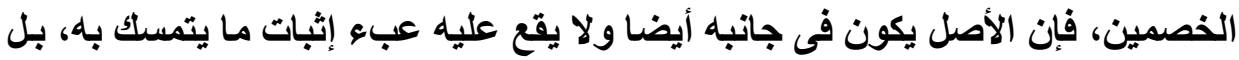

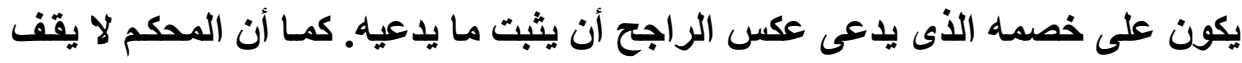

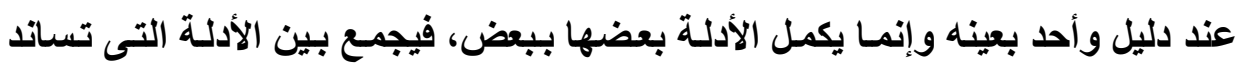
وجهة النظر التى يرجحها. هناك بعض المبادئ التي تحكم عبء الإثبات تتمثل في الآتي: 1- القاعدة: البينة على من ادعى خلاف الثابت أصلا أو عرضا أو ظاهر|(1)، ومقتضى

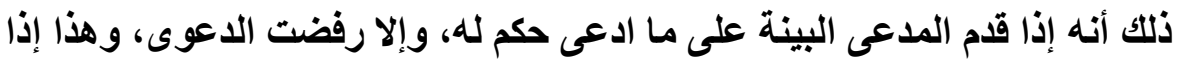
كاتت الواقعة المراد إثباتها أيجابية أم سلبية. r- الثابت اصلا: يختلف باختلاف نوع الحق المطالب به حسب ما اذا كان (حقا شخصيا

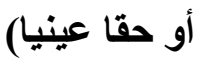




\section{أ. في نطاق الهقوق الشخصية:}

الثابت اصلا هو براءة الذمة والعارض شغلهاه')، إذ الالتزام أمر عارض في

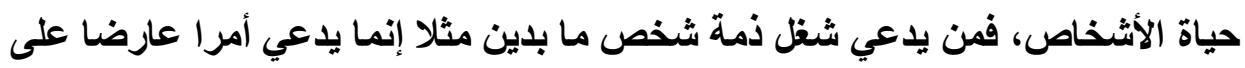

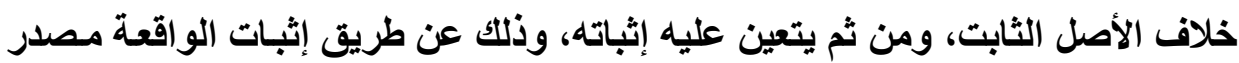
هذا الدين، فاذا اخفق بذلك خسر دعواه، وأمسا اذا أثبت المتحكم الواقعة مصدر الداين،

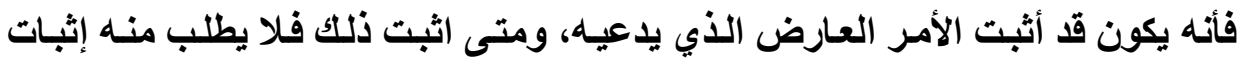

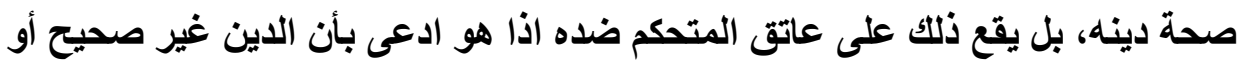
أنه قد أوفى به قبل ذلك، فيقع عليه عبء إثبات مـا يدعيه لا لأنها يدعي خلاف الأصل

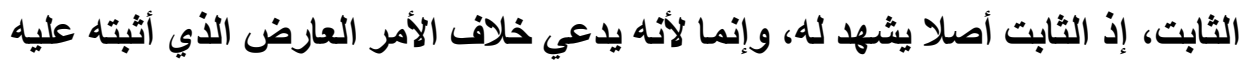
خصمه، لذلك ففي نطاق الحقوق الثخصية يحمل عبء الإثبات من يدعي خلاف الثابت

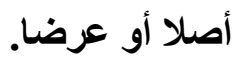

\section{ب. أها في نطاق الحقوق العينية:}

الأصل في الحقوق العينية هو الأمر الظاهر، فالثابت أصلا يقتضي القول بأن

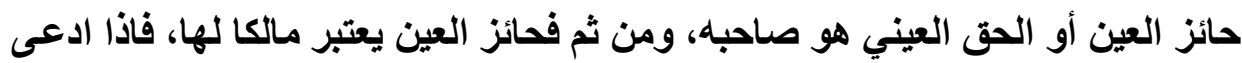
غير الحائز ملكيته للعين كان مدعيا خلاف الأصل الظاهر فيتعين عليه إثبات دعواهي، وذلك بإثبات الواقعة سبب اكسابه ملكية العين، فاذا لم يستطع إثبات ذلك رفض المحكم

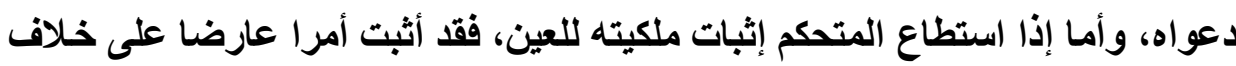
الوضع الظاهر، فاذا لم يسلم المتحكم ضده بالملكية للمدعي بعد إثباته دعواه كان عليه

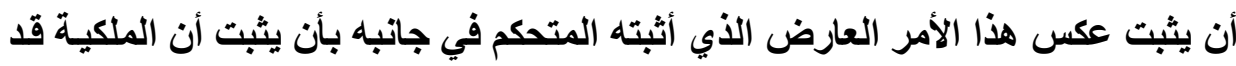


انتقلت إليه بعد ذلك بأي سبب من أسباب كسب الملكية، وحينئذ يصبح هو مدعيا خلاف الثابت عرضا، ومن ثم ينتقل إليه عبء الإثبات، والأصل في العقود الصحة، ومن يدعى يلى بطلان العقد يقع عليه عبء إثبات ذلك، لأنه ياعى على خلاف الثابت أصلا وهو صحة

ج. بالنسبة للأهاية: الأصل هو كمال الأهلية للشخص البـالغ سن الرشد مـا لم تسلب منه ا (هليته د. بالنسبة للإرادة: الأصل فيها أن تكون سليمة خالية من العيوب. ه. بالنسبة للسبب: فإن كل التزام لم يذكر له سبب في العقد يفترض أن له سببا مشروعا ما لم يقم الدليل على غير ذلك. r- عبـs الإثبات في حالة القرائن القانونية: والقرائن القانونية هي نتائج تستخلص من واقعة معروفة للاستدلال على واقعة غير معروفة، ويلجأ المشرع إلى هذه الوسيلة في الحـالات التي يبدو فيها عبء إقامـة فئه الدليل على أمر معين عبئا بالغا جدا، والقرينة القانونية ليست دليلا من الأدلة التي يثبت فيت بها المدعى دعواه، وإنما هي قاعدة يعفى بها المشرع المدعى في ظروف معينة من عبء الإثبات كلـه أو بعضه بـأن يعتبر مدعيا بـأمر ثابت فرضسا، وبالتـالي يلقى على المدعى عليه عبء إثبات العكس، حيث أنه خلاف الثابت فرضا. في حقيقة الأمر، القاعدة هي "البينة على مـن ادعى خلاف الثابت فرضـا"، وبالتالي فمن يدعي عكس القرينه فعليه إثبات ما ياعيه. والقرائن القانونية يجوز إثبات عكسها لذلك، فهي تسمى بـالقرائن البسيطة أو غير القاطعة، ولا يترتب عليها سوى تخفيف عبء الإثبات أو نقل محل الإثبات من الواقعة الأصلية إلى واقعة بديلة سهلة الإثبات. 


\section{צ- تنقل عبs الإثبات بين طرفي الدعوى:}

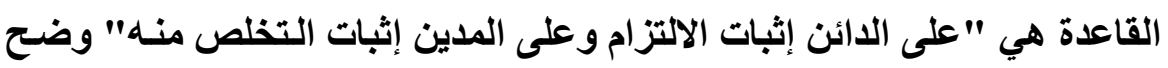
هذا النص كيف ينتقل عبء الإثبات من الدائن إلى المدين(')، فاذا افلح الدائن فى إثبات الثات الثات

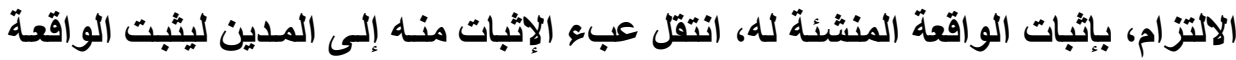
التى يدعى أنها قد ترتب عليها انقضاء ذلك الالتزام. فالواقع أن الأمر الغالب هو أن المتحم إنما يدعي خلاف ما هو ثابت أصلا، ومن يدعي خلاف الثابت أصلا يقع عليه عبء الإثبات لأن الأصل الثابت لا يشهـ لـه، بل يشهـ لغيره وهو المتحكم ضده، ولذلك يحمي القانون هذا الأخير والقصد من هذه

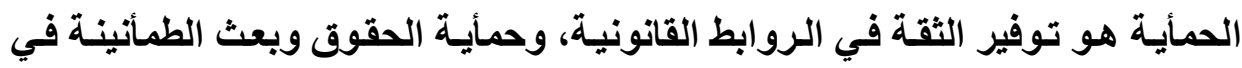

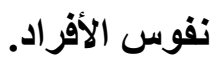

\section{ه- عدم تعلق قاعدة ” البينة علي المدعي" بالنظام العام:}

إن تطبيق القاعدة البينه علي المدعي لا تتعلق بالنظام العام(")، وبالتالي يجوز

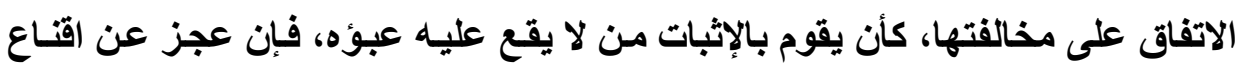

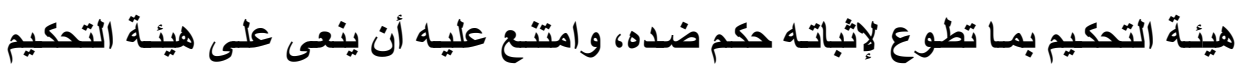

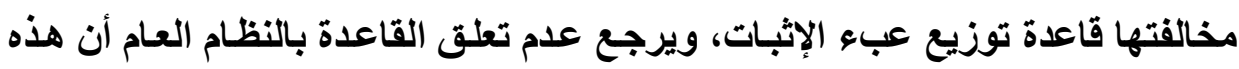

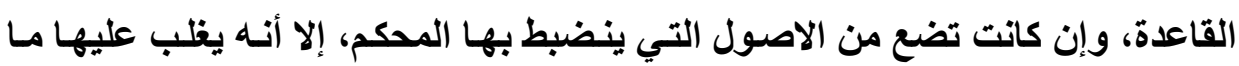

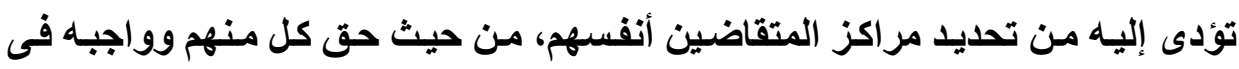

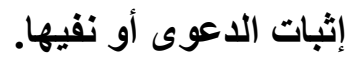

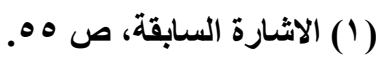

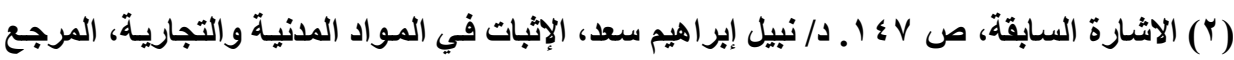

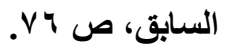




\section{خلاصة المبحث التهـيديدي}

في الواقع مرحلـة إثبـات الحقوق المتـــازع عليهـا هـي المرحلـة الشائكة في مراحل الـدعوي التحكيميـة، بـل هـي محسور الخصومة، يتعساون فيهـا كل مـن المحكم وأطراف التحكيم، ويختلف دور كل منهم بـاختلاف مراكزهم في الدعوي: المحتكم يقع عليه عبء إثبات الواقعة التي يـعيها، والمحتكم ضده يتعين عليه نفي هذا الادعاء بتقديم الوقائع التي تلدحض حجج خصمه.

ويجب علي هيئة التحكيم أن تحدد الخصم الذي يتحمل عبء الإثبات، كما يجب

عليها أثناء الخصومة أن تمكن الخصم من إبداء ما لديه من أدلة ومستندات، كما عليها أن تشتجيب لطلبات إجراء الإثبات التي يطالبها، كسماع الثهود أو ندب الخبير. والمحكم الـذي يمحص ويـدقى في الوقـائع والأدلـة والبـر اهين المقدمسة في الدعوي من أجل التوصل من خلال الوقائع والأدلة والبراهين المقدمة في الدعوي إلى الحقيقة، وهذا الدور الذي يؤديه المحكم في هذه المرحلة الهامـة مـن مراحل الدعوي يختلف بحسب الإجراء أو الدليل الذي ارتكن إليه الخصم، وهذا مـا سنشير إليهه في هي منه

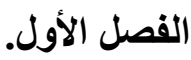




\section{الفصل الأول \\ دور هيئة التمكيم في الإثبات وسلطتها التقديرية}

يحكم سبر إجراءات الإثبات أمام القضاء لنظام رسمه القانون، فلا يجوز للقاضي أو للخصوم مخالفته، وسلطة القاضي في الإثبات قد نظمها القانون بقواعد محددة يلتزم بيها القاضي، حيث بين وسائل الإثبات وسلطة المحكمة بشأن الإثبات ودور الخصوم، وذلك حتـي يـتمكن القاضـي مسن الوصسول إلـى الحقيةـة. وقـد تبنـي المشرع المـصري والمشرع الفرنسي نظـام الإثبـات المختلط (')، وابتعد عن نظـام الإثبـات الحر ونظـام الإثبات المقيد.

أما بالنسبة لخصومة التحكيم، فنجد أن إرادة الأطر اف لها دور كبير في تنظيم إجراءات الإثبات، وذللك لنشأة الاتفاقيـة للتحكيم، كمـا أن لهيئة التحكيم دوراً في تنظيم هذه الإجراءات، ولا قيـ علـي سـلطة الأطراف وهيئة التحكيم غير احترام الضمانات الأسساسية للتقاضي مثل حقوق الدفاع ومواجهة والمساواة بين الخصوم(؟) ومن الجدير بالذكر أن دور هيئة التحكيم في الإثبات وسلطتها التقديريـه يثير العديد من التساؤلات، وتتمثل في: هل هيئة التحكيم ستتبع نظام الإثبات الحر أم المقيد

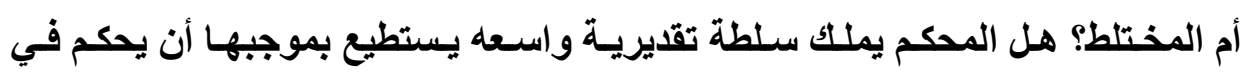

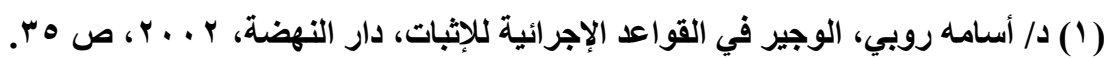

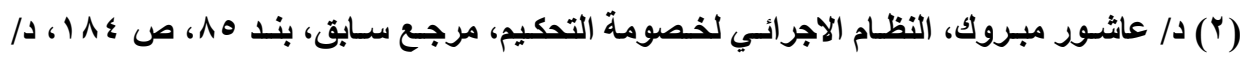

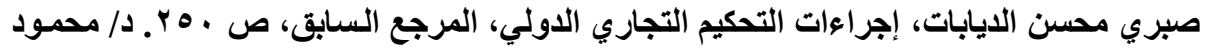

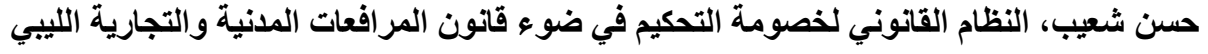

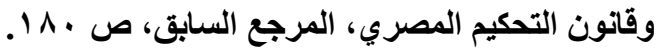


الدعوي بحسب العقيدة التي تكونت لايسه بكامل حريته، دون أن يتقيد في ذلك بطرق معينة في الإثبات؟، ومـا هو نطاق وحدود السلطة التقديريـة لهيئة التحكيم؟ وهل هي سلطة مطلقة أم مقيده؟، وما هي شروط ممارسة تلك السلطة؟ وهل تملك هيئة التحكيم سلطة الأمر والإجبار للخصوم بثأن الإثبات والتي يحوزها قضاء الدولة؟ أم يجب عليها الاستعانه بقضاء الدولة في كل إجراء يتطلب الأمر والإجبار؟ سنشير في هذا الفصل إلى دور هيئة التحكيم في الإثبـات، وذلك في المبحث الأول، ونعالج سلطة هيئة التحكيم في تقدير أدلة الإثبات في المبحث الثاني، وذلك علي النحو التالي: - n 


\section{المبحث الأول \\ دور هيئة التمكيم في الإثبات}

إذا كاتت القاعدة بالنسبة للمحكمة القضائية تملك الأمر من تقاء نفسها أو بناء

علي طلب أحد الخصوم باتخاذ ما تراه مناسبا من إجراعات الإثبات وأدلة الإثبات، بشرط

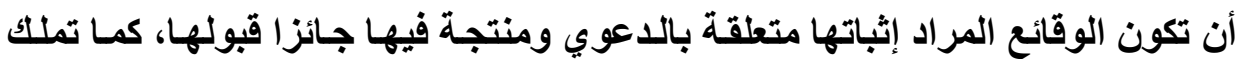
العدول عما تأمر به من إجراءات الإثبات بشرط أن تبين أسباب العدول بالمحضر (')، وتملك عدم الأخذ بنتيجة الإجراء، وتستخلص قضاءها من جميع طرق الإثبات، ممـا أمرت به، وما في ملف الخصومة من مستتدات وقرائن(؟) تسبيب العدل عن الإجراءات الإثبات

في الواقع، لهيئة التحكيم دور أيجابي في إجراعات الإثبات في التحكيم، فلها الأمـر بـأي إجراء مـن إجراعات الإثبـات(")، فيمكن لها أن تطلب مـن الخصوم تقديم مستندات أخري غير التي قدموها، أو دعوة شهود آخرين للإدلاء بشهادتهم إذا كانت الأقول التي أدلي بها الثهود السابقون غير كافية، كذلك للهيئة الاستعانة بخبير أو أكثر

(1) CA Paris, 27 fev. 1964, Rev. Arb., 1964, p. 49, B. Moreau, A. Beregoi, et autre, arbitrage commercial,op. cit., no 222.

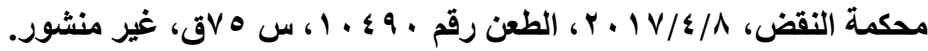

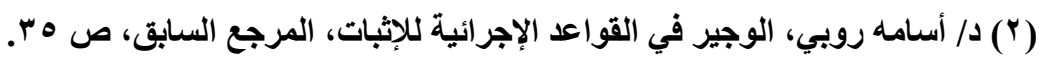

(3) B. Moreau, A. Beregoi, et autre, arbitrage commercial, op. cit., no 222.

مجلتم البحوث القانونيتّ والإقتصاديت 
لابداء رأيه حول نقطة محددة في النزاع(')، وشـأن الهيئة في ذلك شـأن قضاء الدوله بالنسبة لوسائل الإثبات التي يمكن استخد/مها للوقف علي حقيقة النزاع. سنشير إلى سلطة الهيئة في اتخاذ أو رفض إجراءات الإثبات وذلك في المطلب الأول، أما المطلب الثاني، فيخصص لبحث سلطة هيئة التحكيم في إلزام الخصوم أو إن إن الغير بإجراءات الإثبات، وذلك علي النحو التالي:

\section{المطلب الأول \\ سلطة الهينة في اتخاذ أو رفض إجراءات الإثبات}

يتمتع المحكم بسلطات واسعه في مجال الإثبات تمكنهـ من تحقيق العدالـه بين أطراف التحكيم، مثل قاضسي الدولة، إلا أن هذا الأخير يتقيد بتشريعات الدولة والتي تهدف إلى تحقيق الصالح العام والخاص، ولكن المحكم يقدم بتحقيق المصلحة الخاصة

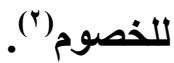

سنعالج الاتجاهات التحكيمية في الاتجاهـات التحكيمية في تحديد نطاق سلطة هيئة التحكيم في الإثبات، وذلك في الفرع الأول، ثم نبين سلطة هيئة التحكيم في اتخـاذ إجراءات الإثبات الوقتية أو التحفظية، وذلك في الفرع الثاني، ونبحث أدلة الإثبات التي تملك هيئة التحكيم اتخاذها أو رفضها، وذلك في الفرع الثالث.

(1) Cass. Civ., 2e 25 mars 1999, Rev. Arb., 2000, p. 267.

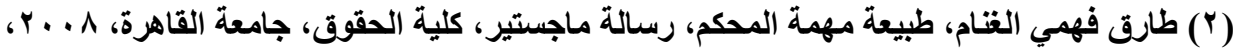




\section{الفرع الأول}

\section{الاتجاهات التحكيسية في تهديد نطاق سلطة هيئة التمكيم في الإثبات}

سنثير إلى الاتجاهات الدولية في تحديد نطاق سلطة هيئة التحكيم في الإثبات،

ثم نبين موقف المشرع المصري و الفرنسي، وذلك في النقاط الآتية:

أولا: الاتجاهات الدولية في تحديد نطاق سلطة هيئة التمكيم في الإثبات

لقد اختلفت الاتجاهـات حول المذهب الذي يجب علي القاضس أن يسلكه في

الإثبات للوصول إلى الحقيقة فيمـا يعرض عليه من منازعات، حتي يتمكن من منح

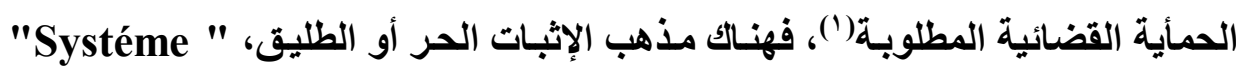
de la prevue Morale au libre محدودة في تحري الحقيقة والتقيب عنها بأية وسيلة يراهـا مناسبة، وهذا هو السائد

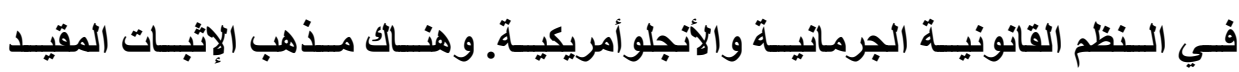
"Systéme de la prevue Légale"

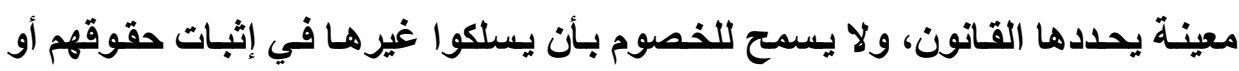

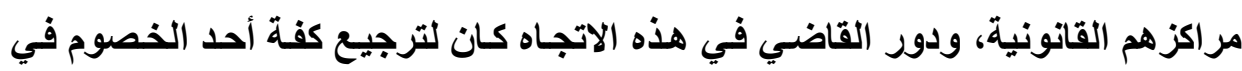

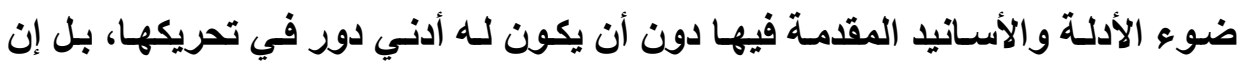

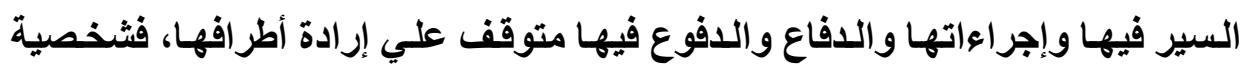

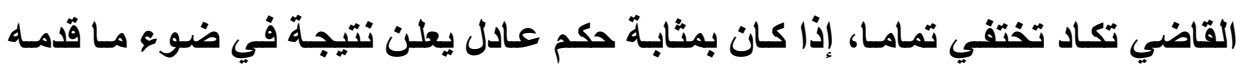

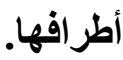

(1) د/ أحمد ابو الوفا، الإثبات في المواد المدنية والتجارية، المرجع السابق، ص 17. 
وهناك مذهب الإثبات المختلط، وهو الذي يجمع بين الإثبات المطلق والمقيد، بحيث يكون الإثبات في المواد التجاريـة في الأصل حرا مـا لـم يفيد بمـا قد يقيده بـه

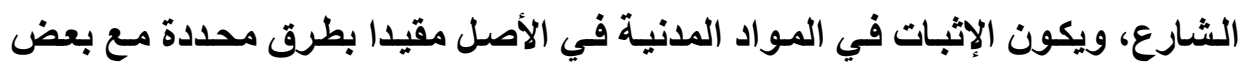
المرونة التي تعطي للقاضي سلطة فعالة في تيسير الإثبات وإدارته(')

ويلاحظ أن هذا الاختلاف في مذاهب الإثبات في النظام القضائي قـ انعكس علي نظام الإثبـات أمسام هيئات التحكيم(؟) ففي النظم الأنجلوأمريكية، يكون لهيئة التحكيم سلطة كبيرة في توجيه وإدارة عملية الإثبات وتوظيف الأدلة، حيث تعطي اهتمامـا أكبر لإجراءات التحقيق والإثبات الشفوي، ويكون من حق محامي الخصم استجواب الشهود مباشرة وكذلك مواجهتهم طبقا لمسا هو معروف هنـاك بنظام المكاشفة أو الاستجواب

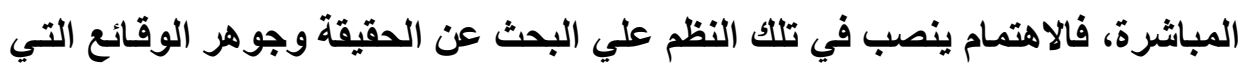
حدث، والتي يستطيع الأطراف الكثف عنها بكل الطرق، ويكون لكل طرف من أطراف التحكيم حق الاطلاع علي كل وثائق ومستندات القضية، حتي يتمكن من إعداد وتهيئة

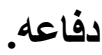

في النظم اللاتتية وما تأثر بها، تكون سلطة هيئة التحكيم شبة مقيدة، فينصب الاهتمـام علـي الأدلـة الكتابيـة، ولا يكون للخصم إلا أن يختـار وينتفي مـن المستندات والوثائق المكتوبة ما يؤيد ادعاءاته، كما أن هيئة التحكيم تركز إهتمامها في الفصل في ادعاءات الخصوم النظرية وحقيقتها كما تبدو من المستندات والوثائق المقدمـة، وليس كما تجسدها الوقا ئع التي حدثت.

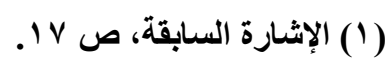

(2) J. THORENS, l'arbitre international au point de rencontre des traditions de droit civil et de la common law, Melange, P. LALIVE, , 1993 , p.693 
وإذا كانت النظم القانونية الأنجلو أمريكية تجعل للشهادة دورا كبيرا في مجال الإثبات، وذلك علي عكس النظم القانونية الاتينية التي تهتم بالأدلة الكتابية، إلا أنه في

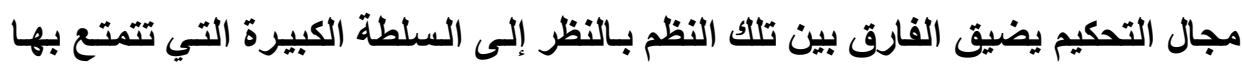
هيئة التحكيم تجاه تقدير قيمة الدليل المستمد من شهادة الثهود، فلا تثريب علي هيئة التحكيم إن هي طرحت شهادة الثهود في التحقيق الذي تجرية لعدم اقتناعها.

وأصبح دور المحكم مثل القاضي في أغلب الانظمة القانونية، فله دور في إدراة الخصومة وتقدير الأدله المعروضه عليه، ولم يعد دور المحكم مقصورا علي مراقبة توافر الثروط المطلوبه في الاليل محل الإثبات، أو في تقدير مـا يعرض عليه من أدلنة

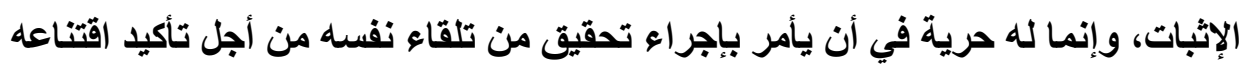
في الدعوي المعروضه عليه(')

\section{ثانيا: اتجاه النظام الصري والفرنسي في الإثبات أهام هيئة التمكيم}

طبقا للنظام المصري والفرنسي تدير هيئة التحكيم إجراءات الإثبات وفقا لمـا

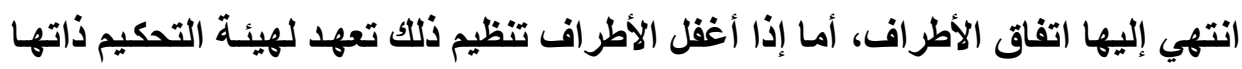

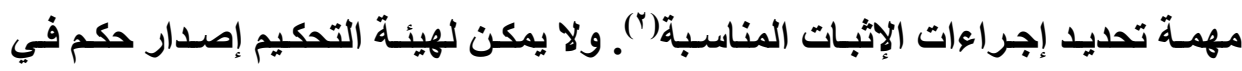

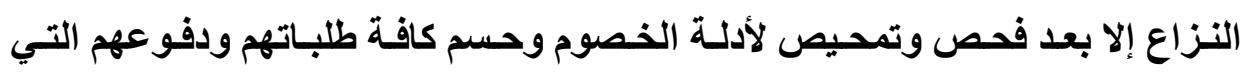
ساقو ها. ويقتضي قيام هيئة التحكيم بدورها في حسم النزاع تمكين كل خصم من تقديم (1) د/ منير يوسف حامد المناصير، سلطة المحكم في الإثبات في خصومة التحكيم التجاري الدولي،

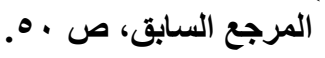

B. Moreau, A. Beregoi, et autre, arbitrage commercial, op. cit., no 222. (ץ) دالساسر صبد الهادي مصلحي سلام، أثثر الخطأ في إجراءات التحكيم علي حكم التحكيم، المرجع B. Moreau, A. Beregoi, et autre, arbitrage commercial, op. cit., no 222. 
مستتداته وأدلته التي يرتكز عليها، سواء بنفسه أو بواسطة من يمثله، ثم تقوم هي بعد ذللك بتقييم الأدلة وتقرر الأخذ بها أم لال').

فـي النظـام المـصري والقرنسـي، لهيئة التحكيم الـسلطة الكاملـة فـي الأمـر بأدلـه الإثبـات التـي تراهـا مناسـبة لتحقيـق فـي النـزاع وتكـوين عقيــتها، وسـلطتها في ذلك نفس سلطة المحكمة()، فلها من تلقاء نفسها أن تسمع الثهود وتعأين الامكنهـ

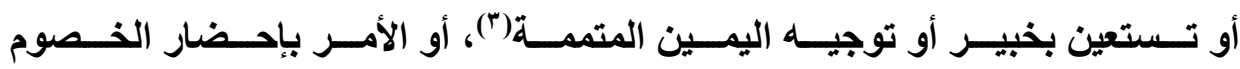
واستجوابهم(") وبالنسبة لليمسين الحاسـة، فيري البعض عدم جواز توجيهها في (التحكيم (0)

وقد نص المشرع المصري إلى ذلك بشكل صريح، عندما نص في المسادة بـ تحكيم علي أنه: لهيئة التحكيم أن تجنمـع في أي مكان تراه مناسبا للقيـام بإجراء من

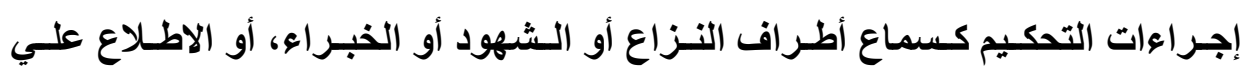

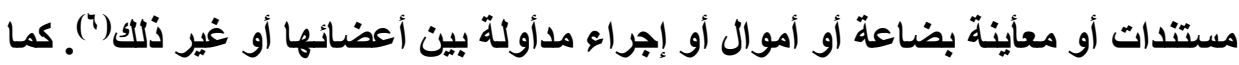

$$
\text { (1) د/ ياسر عبد الهادي مصلحي سلام، الاشارة السابقة، ص ع ؟Y }
$$

(2) Cass. Civ. 2e, 29 nov. 1995, op. cit., p. 235, note E. Loquin. B. Moreau, A. Beregoi, et autre, arbitrage commercial, op. cit., no 222.

(r) د/ فتحي والي التحكيم في المنازعات الوطنية والتجاريـة الدولية، علمـاو عمـلا، المرجع السابق،

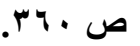

B. Moreau, A. Beregoi, et autre, arbitrage commercial, op. cit., no 204

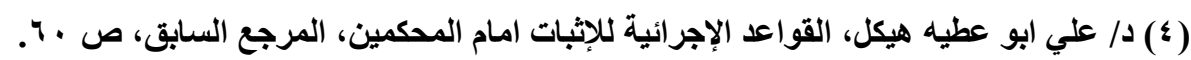

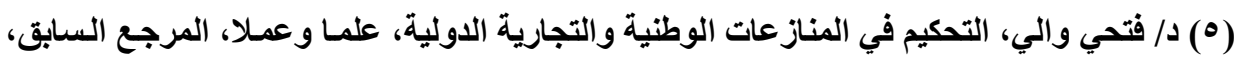
ص . מ. מ

(6) B. Moreau, A. Beregoi, et autre, arbitrage commercial, op. cit., no 222. 
نص المشرع الفرنسي في المادة V\ \ ا مرافعات فرنسي علي حق هيئة التحكيم سماع الشهود، ولها أن ترفض سماعهم (').

وللهيئة كما تملك الأمر باتخاذ إجراء من إجراءات الإثبات في النظام المصري

والفرنسي، فهي تملك سلطة رفض ما تراه من إجراعات الإثبات، إذا تبين لها أنـه غير مجد بالنظر إلى ظروف الدعوي، وهو ما ثابت فيها من أدلة والوقائع التي تكفي التكوين

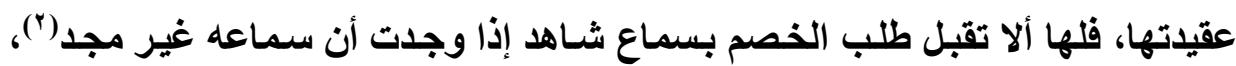
ويجب أن تستعمل سـلطتها هذه بحذر (")، فيجب أن تبين في حكمها الأسـباب التي اعتمدت عليها في عدم إجابتها لهذا الطلب، وإلا كـان حكمها بـاطلا لمخالفته حقوق

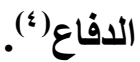

وتملك الهيئة العدول عما أمرت به من أدلة الإثبات، وذلك إذا وجدت في أوارق

الاعوي ما يكفي لتكوين عقيلتها، أو إذا قدم لها دليل يغتي عما امرت به، لا تجبر هيئة التحكيم علي تنفيذ إجراء لم تعد تري ضرورته، كما أنه من بـاب المحافظة علي الوقت والجها عدم الإصرار علي تنفيذ إجراء لم يعد منتجةا في الدعوي(*)، ويذلك يمكن لهيئة

(1) CA Paris, 15 mars 1984, Rev. Arb., 1985, p. 287.

(2) CA Paris, 15 mai 1984, Rev. Arb., 1985, p. 287.

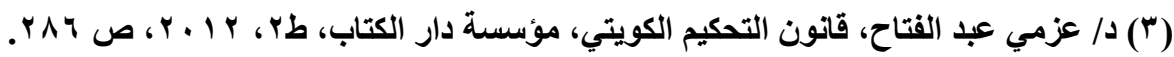

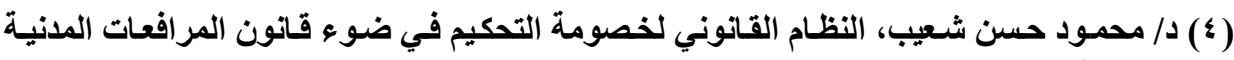

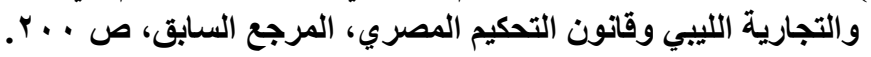

CA Paris, 10 nouv. 1989, Rev. Arb., 1991, p. 651, obs. Pellerin, CA paris, 11 juill. 1991, Rev. Arb., 1991, p. 671, obs. Loquin, CA Paris, 13 mars 1992, Rev. Arb., 1993, p. 107, obs. Jarrosson, CA Paris, 13 nouv. 1997, Rev. Arb., 1998, p. 719, obs. Derains.

(0) د/ أحمد أبو الوفا، التعليق علي نصوص قانون الإثبات، المرجع السابق، ص V • 1، د/ أحمد السيد

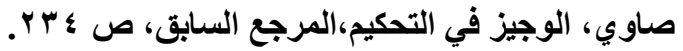


التحكيم أن تعدل عن قرارها باستجواب أحد الخصوم، متي رأت في عناصر الدعوي مـا يغنيها عن ذلك (') ، وهو أمر خاضع لتقديرها، كما لها أن تعدل عن إلزام خصم بتقديم وروقة تحت يده()، كما لها أن تعدل عن انتاب خبير (") .

واذا طلب أحد أطراف التحكيم اتخـاذ إجراء مـن إجراءات الإثبات، فبإن لهيئة التحكيم السلطة التقديرية الكاملة في الاستجابة لـه أو رفضه، ولهذا فإن لها ألا تقبل طلب الخصم سماع شاهد إذا وجلت أن سماعه غير مجد("). علي أنها يجب أن تستعمل سلطتها هذه بحذر. فإن قررت الهيئة رفض طلب اتخـاذ إجراء معين في الإثبات، فيان عليها أن تسبب هذا الرفض، وإلا فإن حكمها قد يعتبر منتهكا لحقوق الدفاع إذا ترتب علي الحكم الإخلال بهذا الحق(ْ). وإذا حجزت الـدعوي التحكيميـة للحكم، وقدم أحد الطرفين طلبـا لتقح بـاب المرافعة لاتخاذ إجراء من إجراءات الإثبات كسماع شهود أو معائة أو إحالة إلى خبير، أو طلب إتخاذ الإجراءات في مذكرته في فترة حجز الاعوي للحكم، فإن إجابته إلى طلبه تتوقف علي ما بقي من معاد التحكيم، فإن كان يكفي فقط للمدأولة أو لإتمامها فإن لهيئة

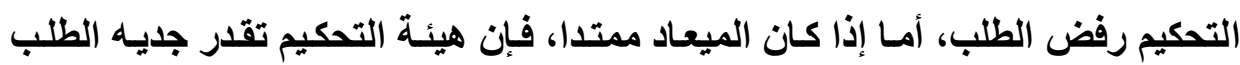
وتفتح باب المرافعة أو تقبل الطلب إذا كان الطلب مبنيا علي سبب جدي(")

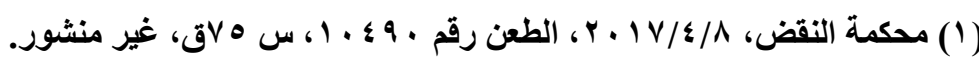

(2) B. Moreau, A. Beregoi, et autre, arbitrage commercial, op. cit., no 204.

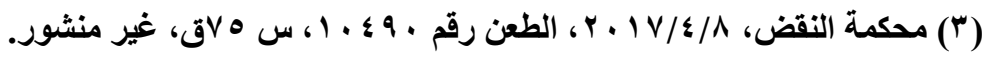

(4) CA Paris, 15 mai 1984, op. cit., p. 287.

(•) د/ فتحي والي، التحكيم في المنازعات الوطنية والتجارية الدولية، علمـا وعملا، المرجع السابق،

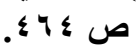

(6) B. Moreau, A. Beregoi, et autre, arbitrage commercial, op. cit., no 285. 
وقد حكم في فرنسـا بأنسه إذا حجزت هيئة التحكيم الدعوي للحكم مـع السماح

بمذكرات بالنسبة لنقطة معينة، فأنها تكون محقة في رفضها طلب اتخـاذ إجراء من

إجراءات الإثبات متعلقة بنقطة اخري غير التي سمح بالمذكرات لتوضحيها' '.

ويلاحظ أن سلطات هيئة التحكيم في شـأن تنظيم إجراءات الإثبات في خصومة

التحكيم تتقيد باحترام الثروط الورادة في اتفـاق التحكيم()، وقانون التحكيم المصري

فيما يتعلق بالقواعد الإجرائية، خاصة ضمانات التقاضي أمام هيئة التحكيم(").

ويثار التساؤل حول مـا إذا كـان هيئة التحكيم ملزمـة بتسبيب قرارهـا في قبول

الإثبات بدليل معين أو العدول عن الدليل؟

في الواقع اختلف الققه حول هذه المسألة، وذلك علي النحو التالي:

يري جاتب من الفقهه أنه يجب علـي هيئة التحكيم تسبيب قراراهـا إذا تضمنت

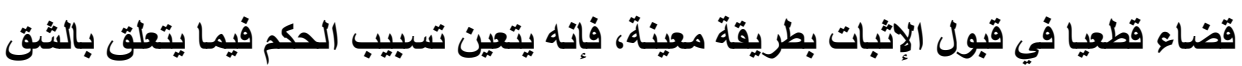

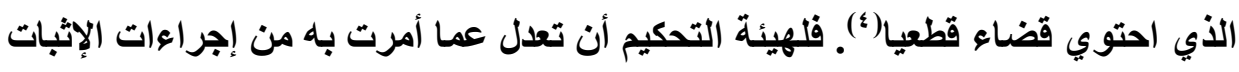

(1) Cass. Civ., 31 mai 1976, Rev. Arb., 1977, p. 50.

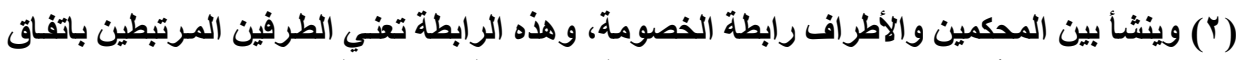

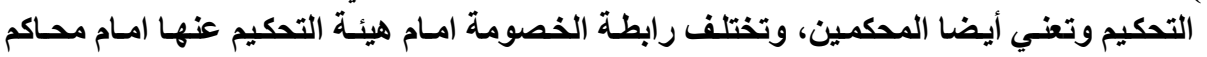

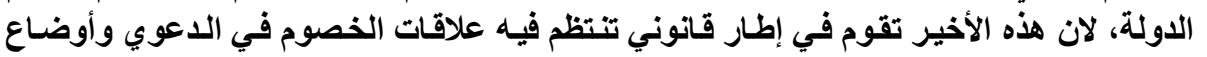

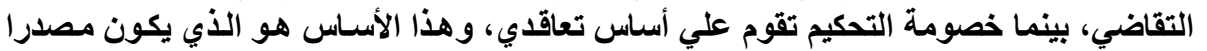

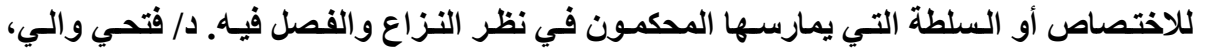

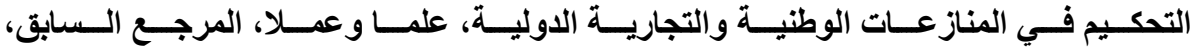

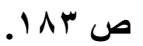

(ए) د/ نبيل إسماعيل عمر، التحكيم في المواد المدنية والتجاريـة الوطنية والدولية، المرجع السابق،

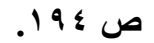

B. Moreau, A. Beregoi, et autre, arbitrage commercial, op. cit., no 211.

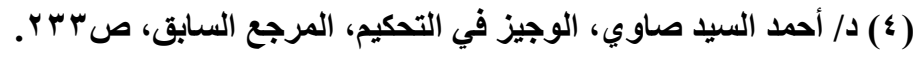


بشرط أن تبين أسباب العدول بمحضر الجلسه، كما يجوز لها ألا تأخذ بنتيجة الإجراء

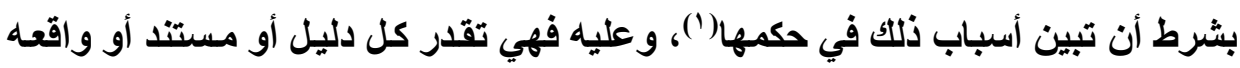

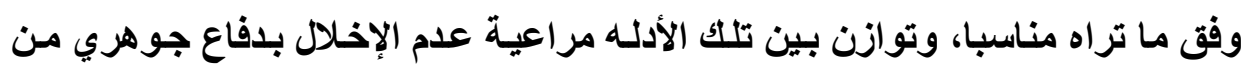

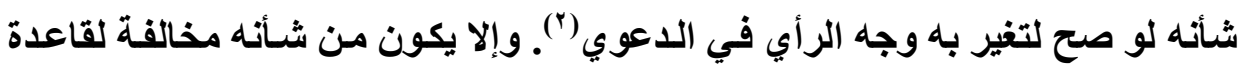

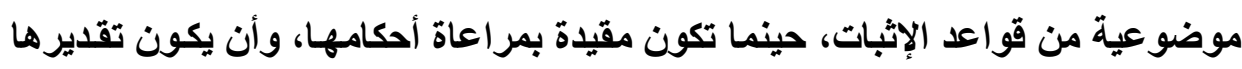

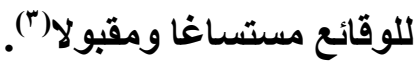
وقد ذهبت محكمة النقض المصرية الي أن " من المقرر - في قضاء هذه

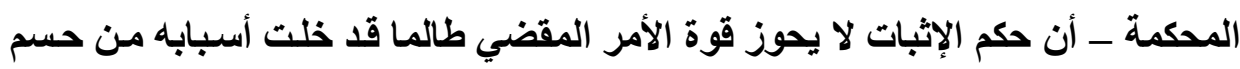

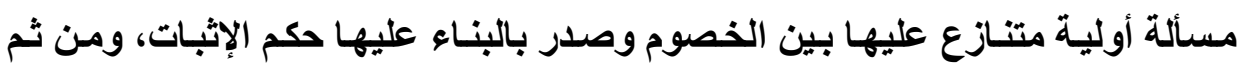

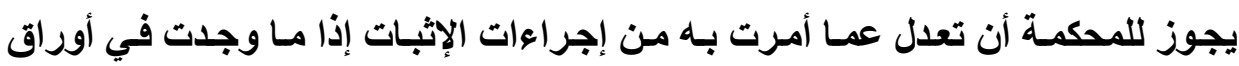
الاعوى ما يكفي لتكوين عقيدتها للفصل في موضوع النزاع كما لها ألا تأخذ بنتيجة الإجراء بعد تنفيذه، والمشرع وإن تطلب في نص المادة التاسعة من قانون الإثبات بيان أسباب العدول عن إجراء الإثبات في محضر الجلسة، وبيان أسباب عدم الأخذ بنتيجة

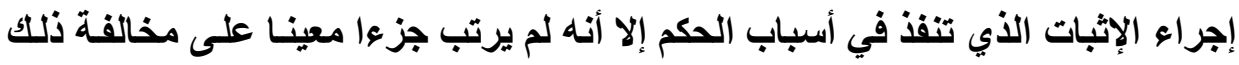

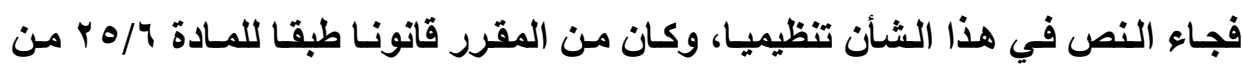

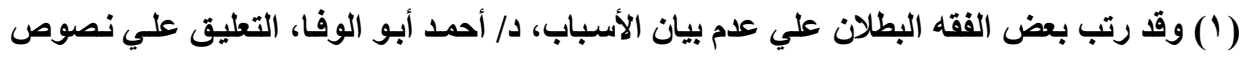

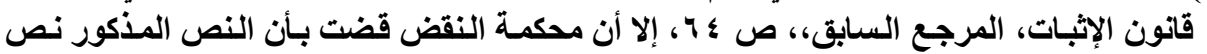

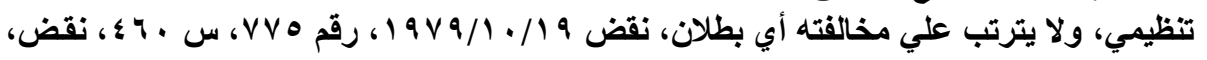
ا

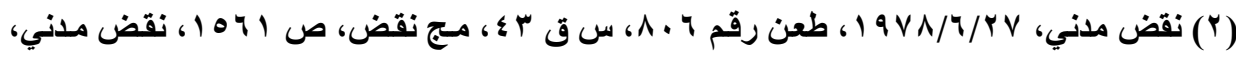

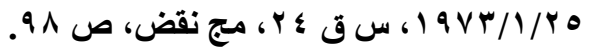

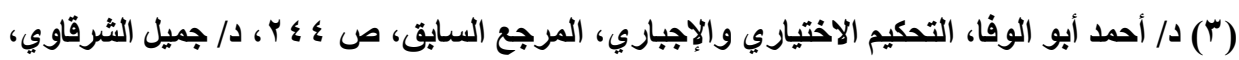

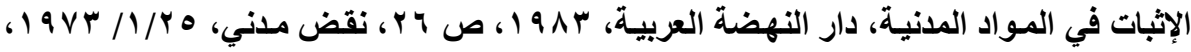

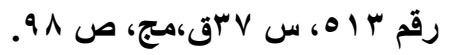


قواعد اليونسترال أن هيئة التحكيم هـي التي تقرر قبـول الأدلـة المقدمـة أو رفضها، ووجود صلة بينها وبين موضوع النزاع أو انتفـاء هذه الصلة، وأهمية الدليل المقدم، ومن ثم فإن وسـائل الإثبات ومنهـا نـلب الخبراء هـي من المسائل التي تخضع لتقدير هيئة التحكيم وصولا لوجه الحق في الدعوى شأنها شأن المحاكم"('). ويذهب جاتب آخر من الفقه(؟) أنه لا تلتزم هيئة التحكيم بتسبيب قرارهـا باتخاذ إجراء معين أو العدول عن إجراء من إجراءات الإثبات، لان لها سلطة تقديريه في ذلتك. كما أن هيئة التحكيم لا تلتزم بإصدار حكم إذا أمرت باتخاذ إجراء من إجراءاء إت الإثبات، مـا لــ يكن ملزمـا باتبـاع قواعد قـانون المرافعـات أو قـانون الإثبـات، أو عـارض أحــ الخصوم لأي سبب من الأسباب في اتخـاذ ذلك الإجراء، كمـا إذا رفض مثثلا أن يستمع

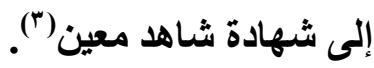
وفي حالة كون المحكم مفوض بالتحكيم بالصلح، فهو غير مقيد بإصدار حكم بالإثبـات بطريقـة معينـه، إلا أنـهـ ملـزم بإخطـار جميع الخصوم باتخــاذ مـا يـأمر بـه مـن إجراءات الإثبات، وإلا كاتت الإجراءات باطله. ومن جانبا نري أنـه لا تلتزم الهيئة بتسبيب مـا تأمر بـه مـن إجراعات الإثبات، وذلك علي أساس أن لها في هذا الثأن سلطة تقديرية، فلا يعيب حكمها عدم استعمالها هذه السلطة، ولكن نري أنه إذا رفضت اتخاذ إجراء من إجراءات الإثبات أو عدلت عن اتخاذ إجراء معين، فإنه يجب عليها تسبيب قرارها علي أساس احترام حقوق الدفاع.

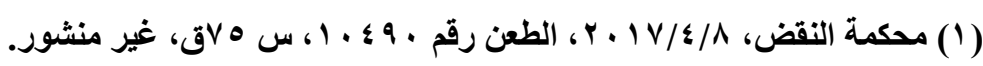

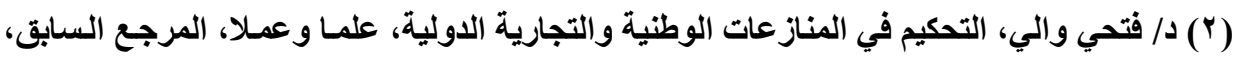
ص

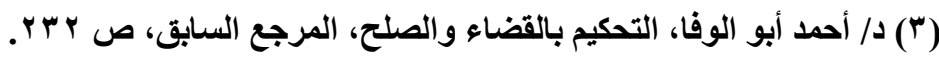


ويلاحظ أن العدول عن إجراءات الإثبات يتعلق فقط بمـا اتخذته من إجراءات

فلا يتعداها إلى ما قد يكون الهيئة قد أصدرته من أحكام باتخـاذ إجراعات الإثبات، إذا كانـت هـذه الأحكـام تتضمن قضاء قطعيـا فـي مسـألة تتعلـق بجـواز الإثبـات أو عـدم

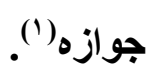

ولهيئة التحكيم كمـا هو الشأن بالنسبة للمحكمة، أن تعدل عمـا أمرت بـه مـن

إجراءات الإثبات(؟) ، ذلك أنـه قد تقدم للهيئة، بعد الأمر، أدلـة إثبات تغتـي عن الدليل الذي امرت بتقديمه، أو قد تبين لها أن الدعوي من الأدلـة الآخري مـا يكفي لتكوين اقتتاعها، ويري البعض أنه لا تلتزم الهيئة علي خلاف القاضسي بتسبيب عدولها عن

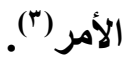

وتطبيقا لذلك فقد نصت المادة • ب من اللانحة التنفيذية لنظام التحكيم السعودي

علي أنه " لهيئة التحكيم أن تعدل عمـا أمرت بـه من إجراعات الإثبات بشرط أن تبين أسباب العدول في محضر الجلسة، ويجوز للهيئة إلا تأخذ بنتيجة الإجراء مـع بيـان

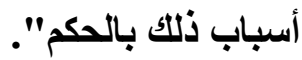

ونخلص مما سبق أن لهيئة التحكيم السلطة التقديرية الكاملة في اتخـاذ إجراعات

الإثبات(£)

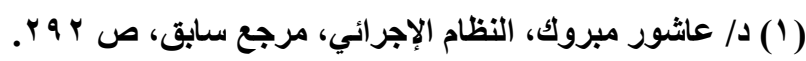

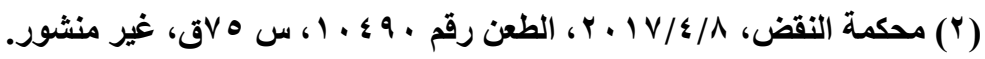

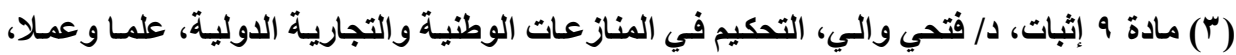

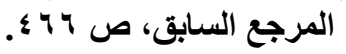
(؛) د/ وجدي راغب الرسالة، النظرية العامة للعمل القضائي في قانون المرافعات، رسـالة دكتوراه،

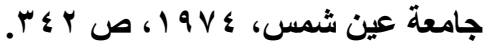


في النظام المصري والفرنسي، سواء من تلقاء نفسها أو بنـاء علـي طلب أحد الخصوم، ولها نفس سلطات قضاء الدولة(')، متي تطلبت ظروف النزاع ذلك، ففي حالة عدم كفاية المستندات التي قدمها الخصوم لتكوين عقيدتها، وذلك مـع مراعاة مـا اتفق عليه الخصوم، أو ما ورد بثأنه نصوص خاصة تتعلق بالنظام العام().

\section{الفرع الثاني \\ ساطة هيئة التمكيم في اتخاذ الإجراءات التمفظية والهقتية المتعاقة بالإثبات}

تثير الإجراعات التحفظية والوقتية والسلطة التي تملك الأمر بها مشكلة حقيقية عنــــوجـود اتفـاق علـي التحكيم حـول التـزاع الـذي يطلب بـصدده اتخــاذ مثـل هـذه الإجراعات، خاصـة في مسسائل الإثبـات. حيث قد يتطلب طبيعـة النـزاع اتخـاذ بعض الإجراءات الوقتية أو المستعجلة، مثل الأمر باجبراء معائنه حالة متعلقة بـالنزاع وبيـان الأضر ار التي لحقت بها والتي يخشي زوال معالمها، أو سماع شهادة شـاهد مشرف

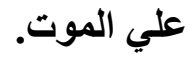

ويثور التساؤل هل تملك هيئة التحكيم اتخـاذ الإجراعات التحفظية والوقتية في

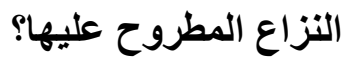

لقد اختلفت الآراء حول هذا الموضوع، ويمكن إجمال ذلك في الاتجاهات الآتية: الاتجاه الأول: يري اختصاص قضاء الدولة باتخاذ الإجراعات الوقتية والتحفظية المتصلة بالمنازعة المتفق بشأنها علي التحكيم علي نحو قاصر عليه، وحظر بصفة

(1) E. Loquin note sous Cass. Civ. 2e, 29 nov. 1995, op. cit., p. 235.

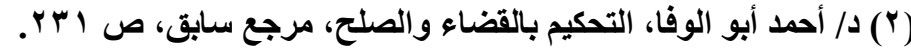


مطلقة علي هيئة التحكيم الأمر باتخاذ أي إجراعات تحفظية أو وقتية، ولا يجوز للهيئة ممارسة هذه الإجراءات ولو اتفق الخصوم علي حقها في إصدار قرارات وقتية وأو

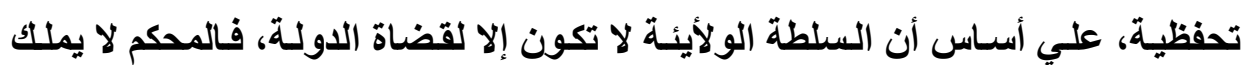
سلطة الأمر (').

ويستند أنصار هذا الاتجاه إلى الحجج الآتية: - المحكم لا يملك سلطة الإجبار، لا في مواجهة الأطراف ولا في مواجهة الغير. ولا

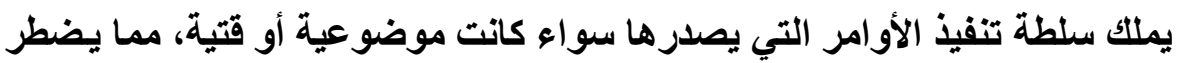
الخصوم إلى اللجوء إلى القضاء لإصدار أمر بالتنفيذ(). - قد تجد أحداث تتطلب اتخـاذ إجراعات وقتيـة أو مستعجلة، في وقت غير أوقات انعقاد هيئة التحكيم، أو يصعب انعقادها بالسرعة الكافية لاتخاذ الإجراء المطلوب، وذلك بعكس القضاء المتاح دائما وبصورة مستمرة"("). الاتجاه الثاني: يستند هذه الاتجاه علي إرادة الأطر اف ذاتها، فبإذا كانت هذه الإرادة قد خولت المحكم سلطة الفصل في المنازعة القائمة بينهم، فأنها أيضا يمكنها أن تخول لهذا المحكم الفصل في المسائل التحفظيـة والوقتيـة المتصلة بالمنازعـة المتفق

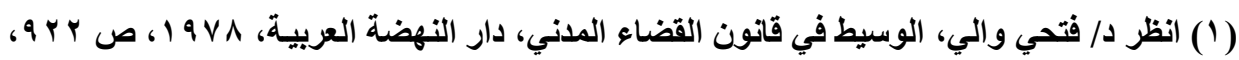

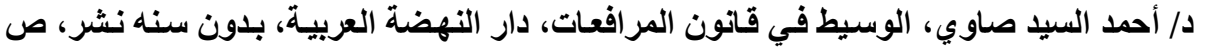
(r) د/ حفيظة السيد الحداد، مدي اختصاص القضاء الوطني باتخاذ الإجراءات الوقتية والتحفظية، دار

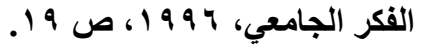

FOUCHARD Ph., GAILLARD E. et GOLDMAN B., traite de l' arbitrage commercial international, LITEC, 1996, p. 720.

(T) د/ حفظية السيد الحداد، الإثارة السابقة. 
بشأنها علي التحكيم، سواء عبرت الأطراف عن تلكت المنازعة بشكل صريح أو من خلال الإشارة إلى لائحة من اللوائح المنظمة للتحكيم' (1).

ويـذهب أنصار هذا الاتجـاه إلى أن الهيئسة المختصة بنظر الطلبـات الوقتيـة

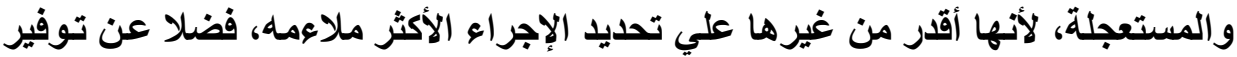

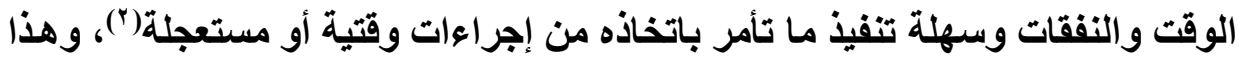
ما أخذت به المادة الحادية عثر من غرفة التحكيم بباريس بقولها بأن أطراف التحكيم

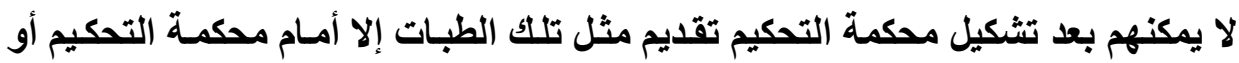

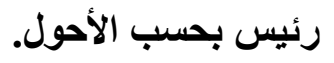

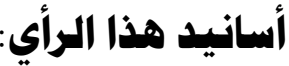

يري أنصار هذه الاتجاه أن منح هيئة التحكيم سلطة اتخـاذ الإجراءات الوقتية والتحفظية يرجع بصفة أساسية إلى القوة الملزمـة لاتفـاق التحكيم، وإلى مبدأ سلطان الإرادة، فالأطراف باتفاقهم علي اللجوء أي التحكيم يكونون قد أعلنوا عن رغبتهم في استبعاد القضاء عن نظر النزاع من جميع جوانبه، وبالتالي فالسماح للمحاكم بالتدخل لاتخاذ أي إجراء يعد خرقا للقوة الملزمه لاتفاق التحكيم ومبدا سلطان الإرادة("). المحكم هو الأقدر علي تقدير مدي جدية الإجراء المطلوب والوقت المناسب للقيام به، بحكم خبرته بموضوع النزاع.

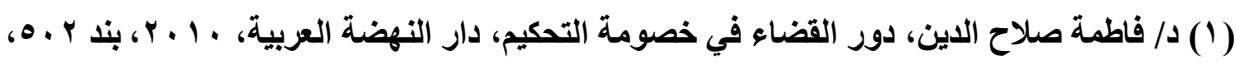

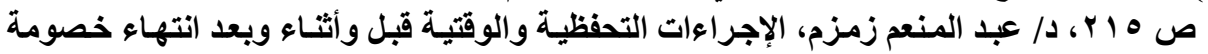

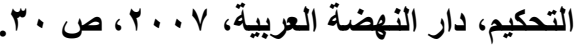

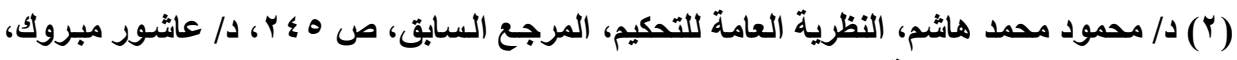

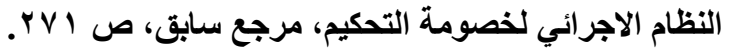

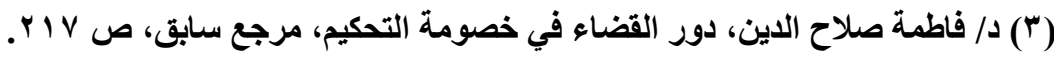


إذا كان المحكم فاقداً لسلطة الإجبـار، إلا أنـه يحظى بـالاحترام التلقائي من قبل الأطر اف، ويمكن للمحم يأخذ بعين الاعتبار مسلك الطرف سئ النية عند إصداره للحكم النهائي.

وقد أخذت محكمة النقض الفرنسية بهذا الرأي في بعض أحكامها، حيث قضت بأنه لا يجوز للأئن بعد تشكيل هيئة التحكيم أن يلجأ إلى القضاء طلبا لنفقة وقتية وإنما تملك هيئة التحكيم وحدها الفصل في مثل هذا الطلب('). وقد أيد الفقه الفرنسي هذا لهاء

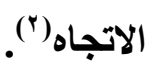

الاتجـاه الثالـث: يتوسط هذا الرأي الاتجـاهين السابقين، حيث يقرر إمكانية التعاون بين كل من القضاء والتحكيم في الحصول علي الحمأيـة الوقتية أو المتسعجلة، حيث يكون للأطراف حرية الالتجاء إلى أيهما، أو يقرروا ولأية أحدهما علي الآخر. فلا يمكن لهم قصر الاختصاص علي هيئة التحكيم فقط، فقد توجد بعض العقبـات القانونيـة والمادية تحول دون قيام المحكم باتخاذ الإجراعات الوقتية أو المستعجلة، لذا فقد تتطلب الضرورة الاستعانه بقضاء الدولة، لذا فقد ذهبت أغلب التشريعات الحديثة وقواعد التحكيم إلى تقريـر إمكاتيـة اللجوء إلى قضاءالدولة لمعاونـة هيئة التحكيم في اتخـاذ

$$
\text { الإجراءات الوقتية والمستعجلة)("). }
$$

في الواقع نري أن الرأي الثالث هو الأقرب إلى الصواب، وذلك لأنها يحقق

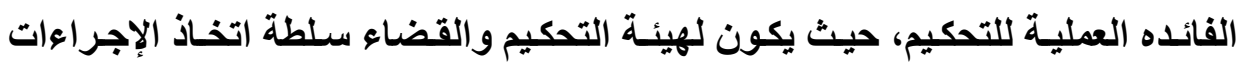

(1) Cass. Civ. 14 mars 1984, Rev. Arb., 1985, p. 69; Cass. Civ., 6 mars 1990, Rev. Arb., 1990, p. 633.

(2) B. Moreau, A. Beregoi, et autre, arbitrage commercial, op. cit., no 202.

(3) T. Clay, L'appui du juge à l'arbitrage, Cah. Arb., 2011, p. 331. 
الوقتية والمستعجلة المتعلقة بالإثبات، لأن هنـاك بعض حالات الاستعجال التي تتطلب السرعة اللازمة لاتخاذها مثل إجراء سماع شـاهد مشرف علي الموت أو إجراء معأينة

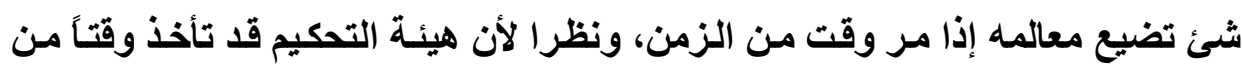
الزمن لانعقادها، لذا يكون للأطراف الحق في اللجوء إلى القضاء، والواقع اللجوء إلى هي هن

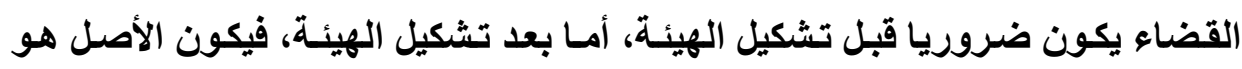
اللجوء إلى هيئة التحكيم لاتخاذ الإجراعات التحفظية.

ولا شك أن الضرورة العملية تقتضي بقاء القضاء العادي أو المستعجل مختصا بنظر المسائل الوقتية والمستعجلة، حتي في ظل وجود القضاء، وأن ذلك لا يتعارض مـع اختصاص هيئة التحكيم بنظر المسائل المرتبطة بموضوع اتفاق التحكيم، وأن اللجوء إلى القـضاء لنظر هـذه المسـائل الوقتيـة والمستعجلة، لا يعتبر نـزولا عـن اتفـاق (التحكيم (')

وبالتـالي يجـوز لهيئـة التحكيم أو لأي مسن الطـرفين بموافقـة الهيئة، طلـبـ

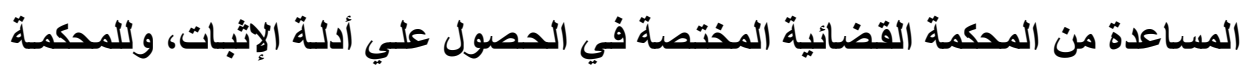
القضائية أن تبذل قصاري جهدها في تنفيذ الطلب في حدود سلطتها، ووفقا للقواعد المعمول بها أمامها بشأن الحصول علي أدلة الإثبات(). فقد تم الاستقرار منذ أمد طويل فيل

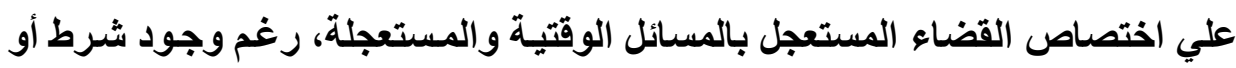
مشارطة التحكيم، لأن ذلك لا يمنع من اللجوء إلى القاضي لطلب إثبات حالة، وأن لهذا الأخير الحق في تقدير مدي توافر عنصر الاستعجال(").

(1) دا علي بركات، خصومة التحكيم في القانون المصري والقانون المقارن، رسالة، حقوق القـاهرة،

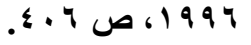

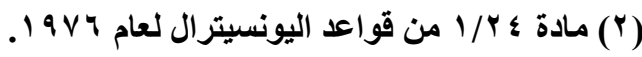

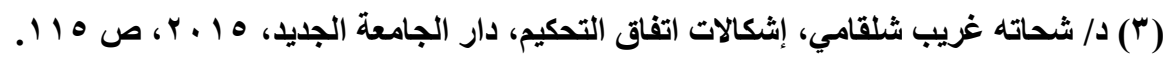


وهذا ما نصت عليه المادة جr من قواعد اليونسترال، حيث قضت بأنـه" لهيئة التحكيم أن تتخذ بناه علي طلب أحد الطرفين ما تراه ضروريا من تدابير مؤقتة بشأن الموضوع محل النزاع، بما في ذلك إجراعات المحافظة علي البضائع المتنازع عليها، كأمر بأيداعها لدي الغير أو بيع السلعة القابلة للتلف" ثم جاعت الفقرة الثالثة، ونصت الثراع علي صلاحية قيام المحاكم باتخاذ التدابير الوقتية، بقولها بأن " الطلب الذي يقدمه أحد الطرفين إلى سلطة القضائية لاتخاذ تدابير مؤقتة لا يعتبر مناقضا لاتفاق التحكيم". وهنا بعض التشريعات تعقد الاختصاص أصـالة لهيئة التحكيم واستثناء لقضاء الاولة، فعلي سبيل المثال النظام التونسي الذي يسند إلى محكمة التحكيم فقط الأمر باتخاذ الإجراءات الوقتية والتحفظية طالما بدءأت إجراءات التحكيم، إلا أن هذا لا يحول

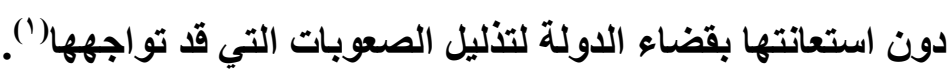
في حين أن بعض الأنظمة تعقد هذا الاختصاص أصالة لقضاء الدولة،، ولكنها لا تمانع في نفس الوقت من اسنادة إلى هيئة التحكيم عن طريق اتفاق الخصوم، وهذا مـا

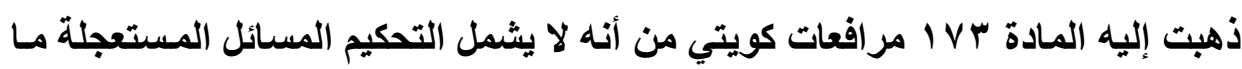
لم يتفق علي ذلك صراحة. وبالنسبة للقانون المصري، فقد وزع الاختصاص بين قضاء الدولة والتحكيم، فقط نصت المادة \& 1 و צr من قانون التحكيم علي أنه، يجوز للمحكمة المشار إليها في المـادة 9 من هذا القانون أن تأمر بنـاء علي طلب أحد طرفي التحكيم، باتخـاذ تدابير مؤقتة أو تحفظية، سواء قبل البدء في إجراءات التحكيم أو اثثـاء سيرها. كمـا نصت المادة ؛ Y من نفس القانون علي أنـه " يجوز لطرفي التحكيم الاتفـاق علـي أن يكون 
لهيئة بنـاء علـي طلب أحدهم، أن تـأمر أيـا منهم باتخـاذ مـا تراه من تدأير مؤقتـة أو تحفظية تقتضيها طبيعة النزاع، وأن تطلب تقديم ضمان كاف لتنطية نفقات التببير الذي التي

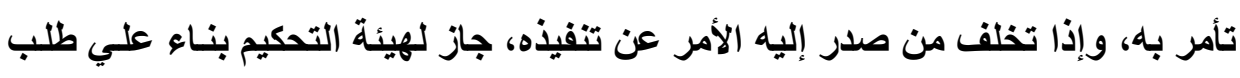
الطرف الآخر، أن تبإذن لهذا الطرق في اتخـاذ الإجراءات الازمسه لتنفيذه، وذلك دون التهن

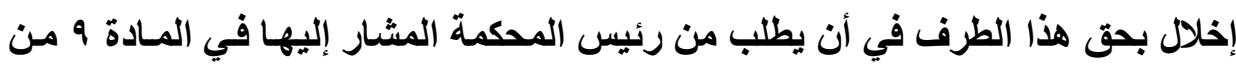

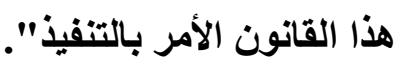

ويستفاد من نص قانون التحكيم المصري في المـادة ؛ ا علي أن النص علي النصاء

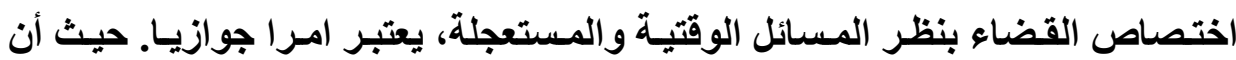

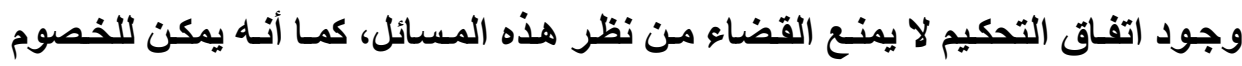
الاتفـاق في اتفـاق التحكيم علي قصر اتخـاذ التـابير الوقتية أو التحفظية علي هيئة

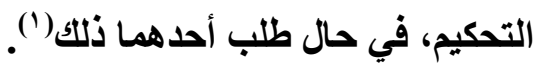
ففي النظـام المـصري قضضاء الدولـة هو صـاحب الاختصاص الأصسيل باتخــاذ الإجراءات الوقتية والتحفظية، وهنا يثار التساؤل هل يمكن اتفاق الخصوم علي استبعاد التهاد

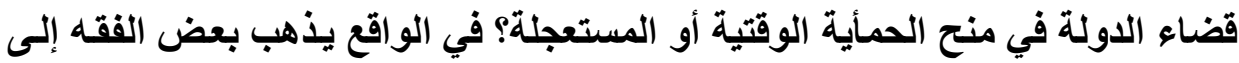
أن اختصاص القضاء المستعجل يتعلق بالنظام العام، ولا يجوز للخصوم التنـازل مسبقا

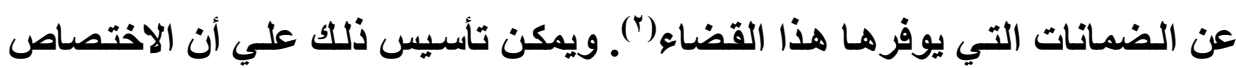

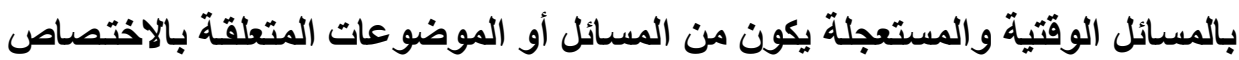

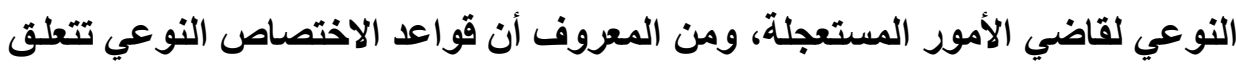

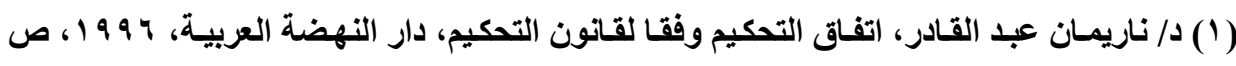


بالنظام العام، ولا يجوز الاتفاق علي ما يخالفها، وبالتـالي هي من الاختصاص الأصيل للقضاء، ولا يمكن قبول التحكيم بشأنها علي الاستقلال، كما أنها لا تعد من الاختصاص الأصيل لهيئة التحكيم وإن كان ذلك لا يمنع المسائل الوقتية والمستعجلة إذا كاتت تتعلق بموضوع اتفاق التحكيم دون سواه('). وبالتـالي فالاتفاق علي التحكيم لا يعني ذلك سلب جهة القضاء ولأيتها بنظر المسائل الوقتية والمستعجلة، فإذا كـان الاتفـاق علي التحكيم يعد استثناء علي الأصل العام، وهو اختصاص قضاء الدولة، فإن ذلك يعني الأخذ بهذا الاستثناء، وعدم العودة إلى الأصل وهو قضاء الدولة، ولكن في حدود موضوع اتفاق التحكيم فقط، ودون سلب

لحق القضاء المستعجل في نظر تلك المسائل باعتباره صاحب الاختصاص الأصيل(؟).

\section{الفرع الثالث}

\section{أدلة الإثبات التي تملك هيئة التمكيم اتخاذها أو رفضها}

قد يتفق الأطراف علي تطبيق قواعد قانونيـة معينه علي الإثبات، فيجب علي هيئة التحكيم الالتزام بها، في بعض الأحوال لهيئة التحكيم الفصل دون التقيد بقواعد المرافعات أو قواعد قانون الإثبات، وجدير بالإشارة في هذا الصدد أن المشرع إذا أعفي المحكم من التقيد بقواعد المرافعات، فإن هذا الاصطلاح ينطبق علي إجراءات الإثبات،

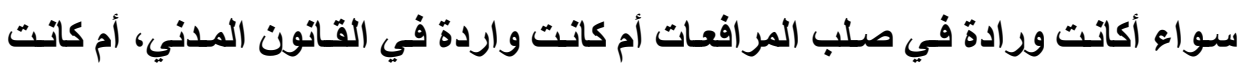
ورادة في قـانون مستقل للإثبـات، وعلـي العكس فـإن هذا الإعفــاء يمتـد إلى القواعد الموضوعيه للإثبات ولو كانت ورادة في قانون المرافعات.

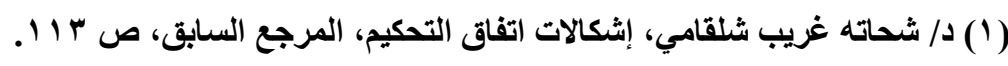

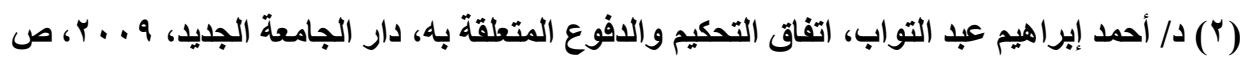


وكقاعد عامة في التشريعات التي توجب علي المحكمين اتباع قواعد المرافعات

يكون عليهم اتباع الأصول والمواعيد المقررة في قواعد الإثبات أو في باب إجراءات

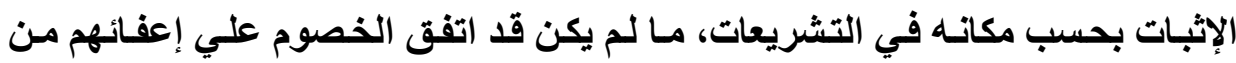
التقيد بقواعد المرافعات أو كانوا مفوضين بالصلح. وتتبع هذه القواعد بالنسبة لجميع طرق الإثبات، فتتبع في استجواب الخصوم، وكـان الاتجـاه قبل تعديل القانون الفرنسي أن المحكم لا يملك استجواب الخصوم، ولا يملك تحقيق الخطوط، ولكن أصبح الآن في القانون المرافعات الفرنسي الجديد الملك يملك كافة إجراعات الإثبات، بل ويملك الحكم علي الخصم المتخلف بالغرامـة التهديده، والقاعدة في فرنسا وبجليكا ومصر هي أن المحكم يملك الأمر بمـا يراه من إجراءات الإثبات فيما عدا ما اتصل بالتزوير (') وتتبع الإجراءات المنصوص عليها في القانون في حالة توجيه اليمين الحاسمه أو المتممهـ وعند الانتقال، وعند سماع الشهود وعند ندب أحد الخبراء وفي تحقيق

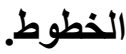

\section{أولا: هدي حرية هيئة التمكيم في اتخاذ إجراءات الإثبات}

إذا كان القاعدة في قانون الإثبات المصري أن المحكمة القضائية تملك من تلقاء

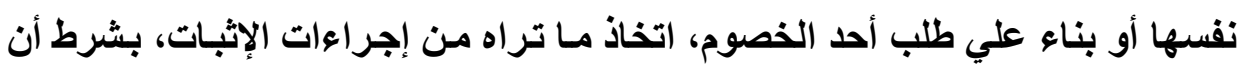
تكون الوقائع المراد إثباتها متعلقة بالدعوي منتجة فيها وجائزا قبولها، وتملك المحكمة

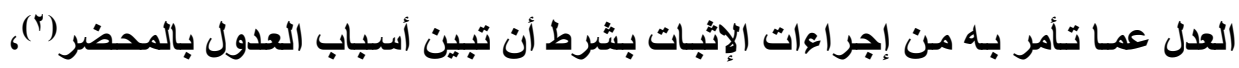

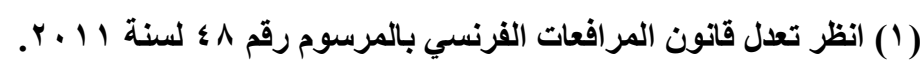

(2) CA Paris, 27 fev. 1964, op. cit., p. 49. 
وكذلك تملك عدم الأخذ بنتيجة الإجراءات بشرط أن تبين أسباب ذلك في الحكم، وإذا

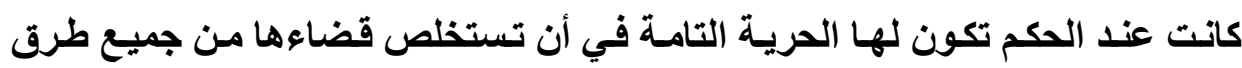

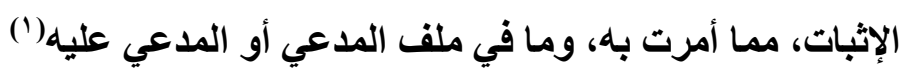
وهنا يثار التساؤل عن مدي حرية هيئة التحكيم في اتخاذ أدلة الإثبات؟، ومدي التزامها بقواعد وإجراءات الإثبات المنصوص عليها في القانون؟ في الواقع، هيئة التحكيم تملك ما تملكه المحكمة من اتخاذ أدلة الإثبات من تلقاء

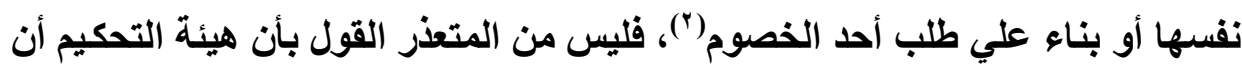

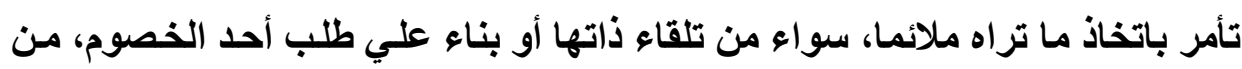

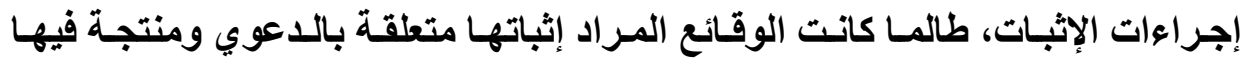

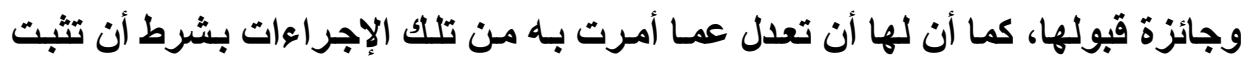

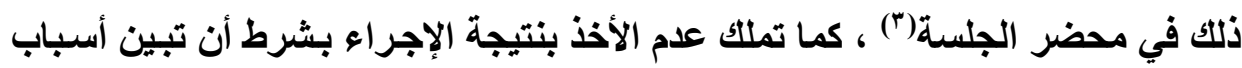

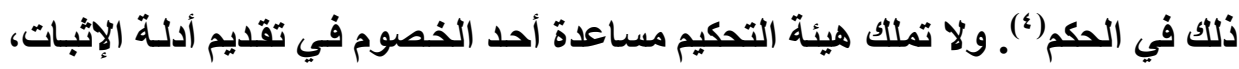

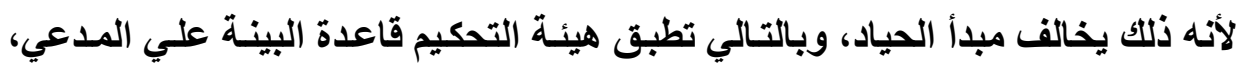
ويقع علي عاتق كل من الطرفين عبء إثبات الوقائع التي يستند إليها لتأييا دعواه.

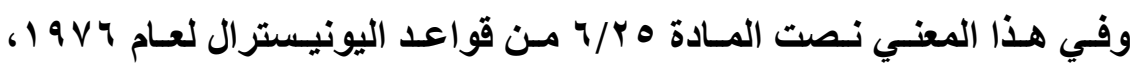
والمطبقة أمام مركز القاهرة الإقليمي للتحكيم التجاري الدولي علي أن " هيئة التحكيم

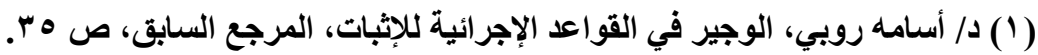

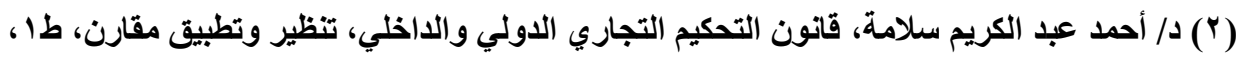

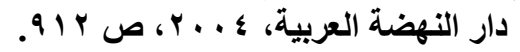

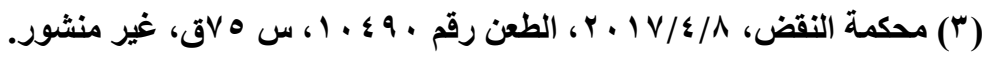

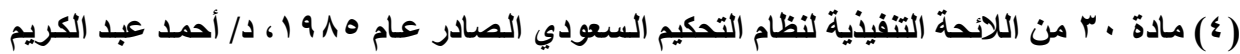

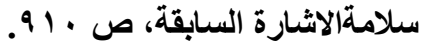


هـي التـي تقرر قبـول الأدلـة المقدمسة أو رفضها، ووجـود صـلة بينها وبيلن موضـوع الاعوي أو انتقاء هذه الصلة، وأهمية الدليل المقدم"('). وهذا مـا نصت عليه لائحة إجراءات التحكيم لمركز التحكيم التجـاري لدول مجلس التعاون الدولي الخليج العريـة

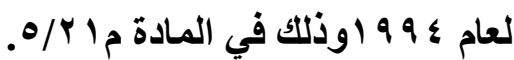

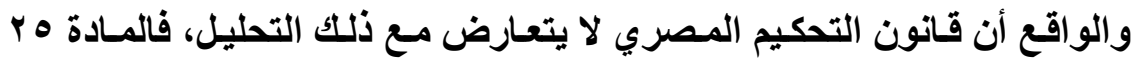
تحكيم تثبر إلى ذلك صراحة بقولها لطرفي التحكيم الاتفاق علي الإجراعات التي تتبعها هيئة التحكيم... فإذا لم يوجد مثل هذا الاتفاق كان لهيئة التحكيم مـع مراعـاة أحكام هذا القانون، أن تختار إجراعات التحكيم التي تراها مناسبة". وبالتالي يكون لهيئة التحكيم مـع احترام اتفاق الأطراف إن وجد، أن تسللك أي طريق إثبات، أو تستعين بـأي دليل مـن الأدلة التي تراهـا ملاعمـة، ومتعلقـة باللدعوي ومنتجة فيها كما لها بالمقابل أن تعدل عما أمرت بـه من إجراءات الإثبات، ويجوز لها ألا تأخذ بنتيجة تلك الإجراعات مع بيان أسباب العدول(؟). ويذهب البعض إلى أنـه إذا رغب المحكم أن يـأمر باتخـاذ إجراء مـن إجراءات

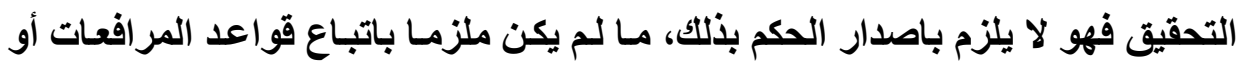
قو اعد قانون الإثبات، وللمحكم أن يـأمر بـالإجراء، حتي لو عـارض أحد الخصوم لأي

(1) CA Paris, 12 juill. 1971, Rev. Arb., 1973, p. 74.

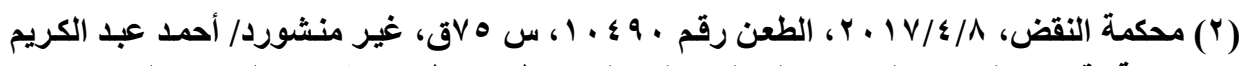

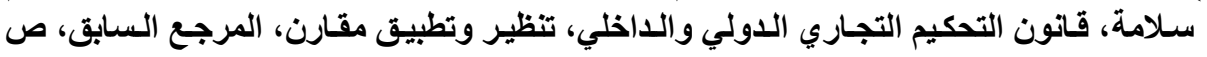
.9r.

CA Paris, 27 fev. 1964, op. cit., p. 49, B. Moreau, A. Beregoi, et autre, arbitrage commercial, op. cit., no 222. 
سبب مـن الأسباب في اتخـاذ ذلك الإجراء كمـا إذا رفض مثثلا أن يستمع إلى شـاهدة

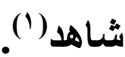

ومن ناحية أخري، لهيئة التحكيم أن تطلب من أحد الطرفين أن يقدم إليها وإلى

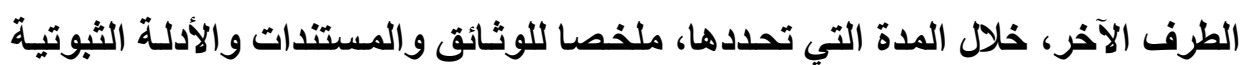
الآخرى التي يعتزم تقديمها لتأييد الوقائع المتنازع حولها، والمحددة في بيان دعواه أو مذكرة دفاعه.

ويثور التساؤل مدي التزام هيئة التحكيم بإجابـه أحد الخصوم إلى طلبه باتخـاذ إجراء من إجراءات الإثبات، مثل سماع شاهد معين.

في الواقع لهيئة التحكيمية سلطة تقديريـة في أتخـاذ أي إجراء من إجراءات

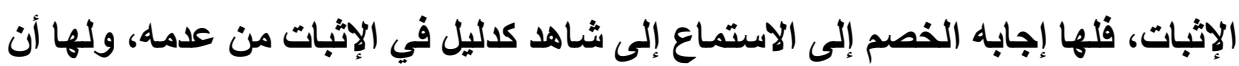
تقرر عدم الحاجة إلى سماع الشهود إذا كانت أوراق الدعوي كافية لتكوين عقيدتهاب(؟). ويجب عليها أن تمسارس سلطتها التقديريـة مـع مراعـاة حقوق الدفاع(")، وإلا تعرض الحكم للبطلان لإخلاله بحقوق الدفاع. فلا يجوز لها أن تستند في رفض الطلب إلى أن

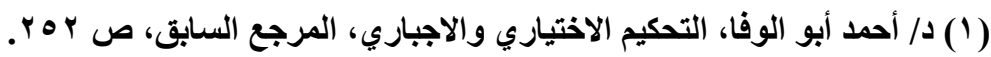

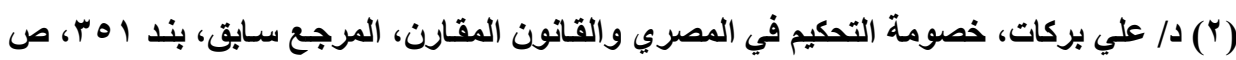
r 4 ¿

René David, l'arbitrage dans le commerce international, Economica, 1982, no 323,p. 413.

(3) CA Paris, 10 nouv. 1989, op. cit., p. 651, obs. Pellerin, CA paris, 11 juill. 1991, op. cit., p. 671, obs. Loquin, CA Paris, 13 mars 1992, op. cit., p. 107, obs. Jarrosson, CA Paris, 13 nouv. 1997, op. cit., p. 719, obs. Derains. 
ميعادالحكم قد قارب علي الانتهاء، وإنمـا يجب أن تبنـي قرارهـا بـالرفض علي أسباب موضوعية، فلا يجوز مخالفة حقوق الدفاع تحت أي مبرر.

وقد ذهبت محكمة استئناف باريس إلى أنـه إذا كاتت سلطة المحكم في قبول أو رفض الاليل لإثبات تقديم به أحد الخصوم سلطة نهائية ولا معقب عليها، فأنها ينبغي مع ذلك أن يبنـي المحكم قراره بـالرفض علي أسس سـائغه كعدم أهميـة الدليل المقدم وكونـه غير منتج في الدعوي، وإذا تبين من ظروف الدعوي وطبيعة الدليل المقدم

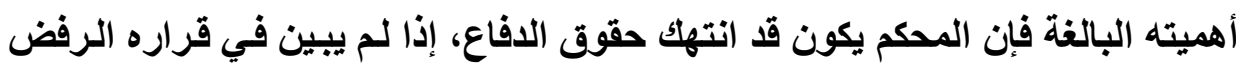
الأسباب الجدية التي بني عليها قراره('). بالتالي يمكن لمن قدم الاليل أن يطعن علي قرار هيئة التحكيم بالرفض بـالبطلان لإخلاله بحقوق الافاع، وهذا ما أكدته المادة به تحكيم مصري، حيث يكون الحكم باطلا في حالة تعذر علي أحد الأطراف تقديم دفاعه بسبب عدم إعلانـه إعلانـا صحيحا بتعيين محكم، أو بإجراعات التحكيم، أو لأي سبب آخر خراج عن إرادته.

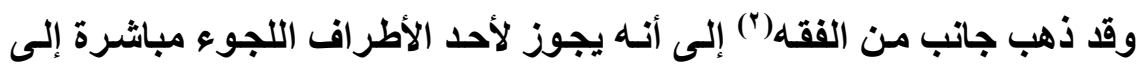

المحكمة المختصة بموجب دعوي أصلية، ودون تلخل من هيئة التحكيم، ويطلب منهـا سماع شاهد كإجراء وقتي تحفظي في حالة خشية وفاته أو سفره. وهذا مـا نصت عليه المادة ؛ ا من قانون التحكيم بقولها يجوز للمحكمة المشار إليها في المادة و تحكيم أن تأمر بناء علي طلب أحد طرفي التحكيم باتخذا تدابير مؤقتة أو تحفظية، سواء قبل البدء

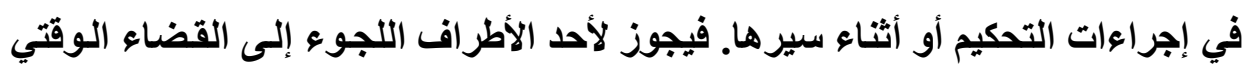

(1) CA Paris, 27 fev. 1964, op. cit., P.49. CA Paris, 4 avr. 1968, Rev. Arb., 1968, p. 19. 
بتقديم مطالبه بسماع شاهد لو توافرت الثروط التي يتطلبها القانون، وذلك لأن الحكم الوقتي لا يتعارض مع اتفاق التحكيم. كما أن سماع الشـاهد أمسام المحكمة القضائية قد يكون له فائدة للخصوم، وتتمثل في تجنب التكلفة الباهظة لانتقال الشهود، فضلا عن تفادي تعطيل النزاع إذا مـا تعذر حضور الشـاهد، كمـا أن سماع الشـاهد أمـام المحكمة يوفر الضمانات القضائية لصحة الشهادة('). ويتقدم الطرف الذي طالب سماع الشهادة إلى هيئة التحكيم كلليل فقط، سواء للنفي أو الإثبات، وللهيئة السلطة في أن تأخذ بها أو

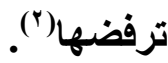

في الواقع نري أنـه إذا رفضت هيئة التحكيم ســاع شـاهد، فأنـه ليس للخصم

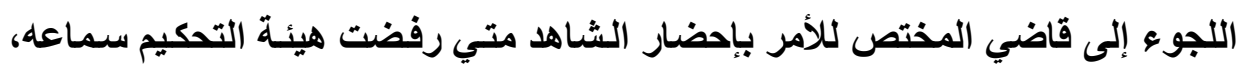
وذلك لأن لهيئة التحكيم السلطة التقديرية في قبول شهادة الشاهد أو رفض الشهادة. ثانيا: أدلة الإثبات أهام هيئة التصكيم: لقد كان النص القيدم في لائحة غرفة تحكيم بـاريس علي أن هيئة التحكيم لا تملك اتخاذ إجراعات الإثبات من تلقاء نفسها إعمالا لمبدأ حياد المحكم، إلا أنه قد عدل عن ذلكـ وأجـازت المـادة rV مـن لائحسة غرفـة تحكيم بـاريس لهيئة التحكيم اتخـاذ إجراءات الإثبات من تلقاء نفسها. كمـا سمحت بهذا المـادة ـ ـ من قـانون المرافعات الفرنسي، وكذلك المادة ب r من قانون التحكيم المصري. في الواقع، كل وسـائل الإثبات التي يجوز تقديمها أمسام القضاء يجوز تقديمها أمسام هيئة التحكيم دون التزام باتبـاع القواعد الإجرائية الواردة في قانون الإثبات أو (1) د/ هدي عبد الرحمن، دور المحكم في خصومة التحكيم وحدود سلطاته، دار النهضة العربيـة،

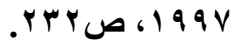

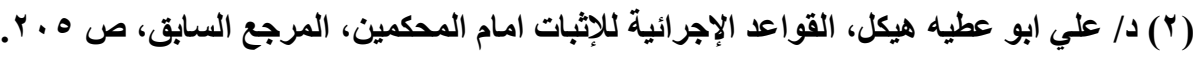


قانون المرافعـات، إلا إذا قيـدها الخصوم باتبـاع هذه القواعد. وبالتـالي، يمكن لهيئة التحكيم أن تشتعين بأدلة الإثبات الآتية: سماع الشهادة والمعأينة والخبرة واستجواب الخصوم أو توجيه اليمين، كما تتولي هيئة التحكيم، بكامل أعضائها، إجراءات الإثبات ويوقع كل منهم علي المحاضر، هذا مـا لـم تكن الهيئة قد نـلبت وأحدا من أعضائها لاتخاذ إجراء معين، وأثبتث ذلك في محضر الجلسة، وإلا كان الإجراء باطلا' (') وسينشير إلى هذه الأدلة علي النحو التالي: |- 1- سماع الشهادة

\section{المقصود بالشهادة}

يقصد بسماع الشهادة، وهي إدلاء الشخص بأقوالهه حول صحة واقعة حدثت،

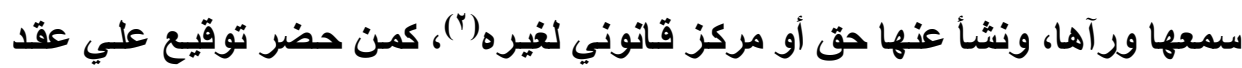
مقأولة أو عقد توريد أو عقد بيع، وتعد الثهادة من اهم طرق الإثبات التي تملك هيئة التحكيم اتخاذهـا سواء من تلقـاء نفسها أو بنـاء علـي طلب أحد الخصوم أو كليهمها، وفي العادة تلجأ هيئة التحكيم إلى سماع الشهود في حالة عدم كفايـة المستندات التي قدمها الخصوم لتكوين عقيدتها، ويستوي في ذلك أن يكون الشهود أشخاصساً عاديين يـلون بـشهادتهم حول الوقائع أم خبراء فنيـين يـدلون بـشهادتهم حول مسـألة فنيـه

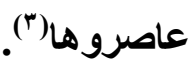

(1) R. DAVID, l'arbitrage dans le commerce international, op. cit., no 328, p. 417.

(Y) د/ أحمد عبد الكريم سلامه، التحكيم في المعاملات المالية الداخلية والدولية، المرجع السابق، ص

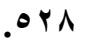

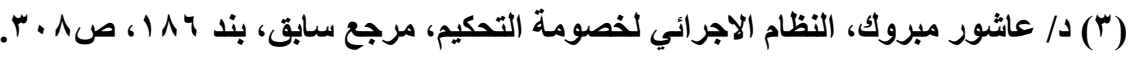


في الواقع، الشهادة ليست مـن الأدلـة القطعيـة ذات القوة المطلقة في الإثبات والتي لا يملك المحكم سوي الأخذ بها وإعمالها مثل الإقرار واليمين الحاسمه، ولكنها وحدها تعد من الأدلة ذات الحجية النسبية، أي أن الأخذ بها وإعمالها يخضع لتقدير الإسراري المحكم، فقد يأخذ بنتيجتها أو يرفضها إذا سأوره شلك حولها، أو إذا وجدها متعارضهـ مع أدله أخري، أو إذا رأي أنها غير مجديه أو غير مؤثره وأن مـا تحت يده من أدلـة ومستندات يكفي للفصل في النزاع(')

\section{- ماططة هيئة التمكيم في الأخذ بالشهادة.}

ولهيئة التحكيم سلطة تقديريه في الاستعانة بشهادة الشهود كدليل في الإثبات من عدمه، كما أنه لا تثريب عليها إن قررت عدم الحاجة إلى شهادة الشهود، إن كانت

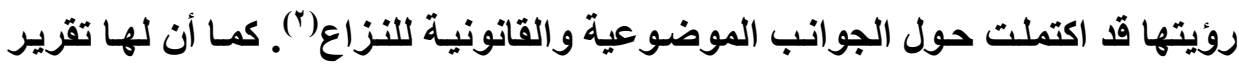

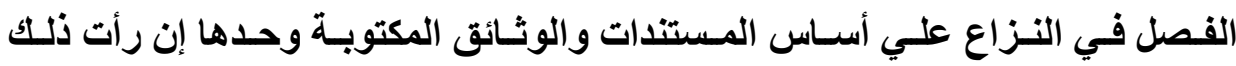
كافيا"). فلا يوجد سوء إداره للإجراءات إذا رفضت هيئة التحكيم سماع أحد الشهود

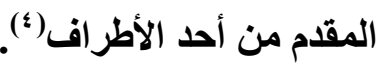

(1) د/ سامي محسن حسين السري، بعض الجوانب في القواعد الإجرائية المنظمـة للتحكيم التجـاري

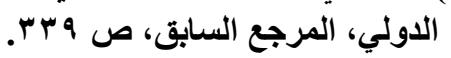

(2) Ph. FOUCHARD, E. GAILLARD et B. GOLDMAN, traite de l'arbitrage commercial international, op. cit., no 1277, p. 713.

(ए) د/ أحمد عبد الكريم سـلامة، قانون التحكيم التجاري الدولي والداخلي، تنظيز وتطبيق مقارن،

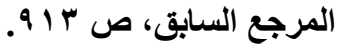
(؛) د/ ياسر عبد الهادي مصلحي سلام، أثر الخطأ في إجراءات التحكيم علي حكم التحكيم، المرجع

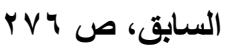


ولكن علي هيئة التحكيم التقيد بما اتفق عليه الأطراف في هذا الشأن(")، بحيث إن كانوا قد اتفقوا علي عدم الحاجة إلى شـهادة الشهود، فلا يجوز لها أن تلجـأ إليها. وعلي العكس تكون هيئة التحكيم ملزمـة بالاستماع إلى الشهود المعينين من الخصوم في عقد التحكيم(؟)، كما أنها تكون ملزمة بالاستماع إلى الشهود في الحالة التي لا يوجد لايها فيها عناصر كافية للفصل في النزاع، وتكون الشهادة جـائزة فيها، ويمكن لهيئة التحكيم أن تلفت نظر أحد الأطراف لتقديم شاهد إذا مار رأت ذلك ضروريا لتوضيح بعض فئ

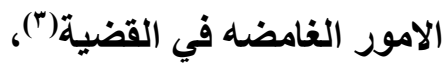

وتخضع أقوال الشهود لتقدير هيئة التحكيم فلها ألا تأخذ بشهاد شاهد لم تطمئن

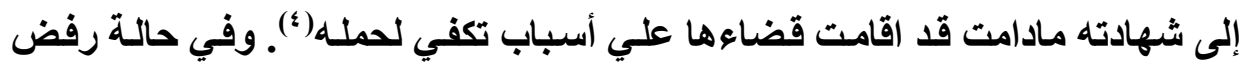
سماع الثاهد، فعليها أن تسبب قراراها الصادر بعدم الاستماع إلى الثهود، ويجوز لها

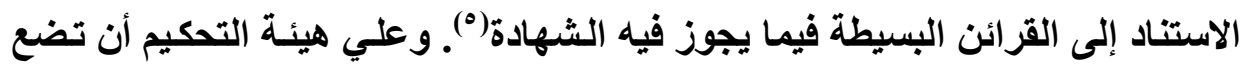
في اعتبارها العلاقة بين الشهود والأطراف(") عند تقييمها شهادة الشهود (v).

(1) د/ أحمد عبد الكريم سلامه، التحكيم في المعاملات المالية الداخلية والدولية، المرجع السابق، ص . 0 r. (r) دا فتحي والي، التحكيم في المناز عات الوطنية والتجاريـة الدولية، علمـاو عملا،المرجع السابق، ص

(3) Ph. FOUCHARD, E. GAILLARD et B. GOLDMAN, traite de l'arbitrage commercial international, op. cit., p. 698.

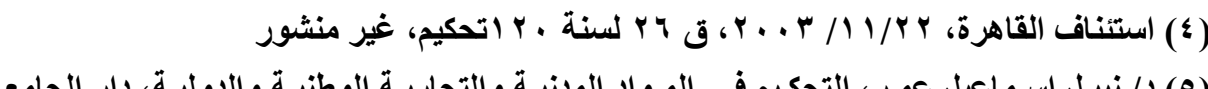

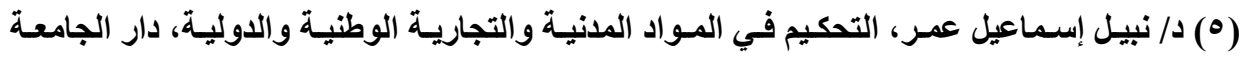

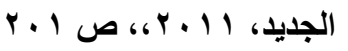

(6) Ph. FOUCHARD, E. GAILLARD et B. GOLDMAN, traite de l'arbitrage commercial international, op. cit.,p .699. (V) داسر عبد الهادي مصلحي سلام، أثر الخطأ في إجراءات التحكيم علي حكم التحكيم، المرجع

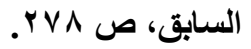




\section{تهليف الشاهد اليسمين}

في الواقع إذا كانت قوانين الإثبات في بعض اللدول تجعل حلف اليمين إجباريـا،

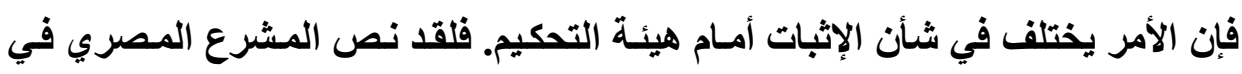
المادة بr من قانون التحكيم صراحة علي أنه يكون سماع الثهود والخبر اءع بلون أداء اليمين، وهو حكم له نظير في بعض القوانين، مثل المـادة VI \ ا من قانون المرافعات الفرنسي، والمـادة بr من قـانون التحكيم العمساني، و القـانون التحكيم السويدي لعسام

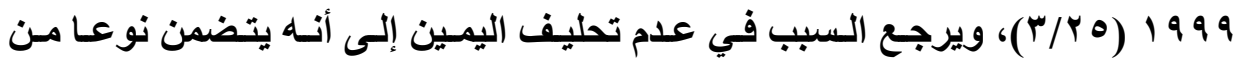
الإجبار ممـا يحتـاج إلى سلطة الأمر (')، وهو ممـا لا تملكك هيئة التحكيم، حيث تسنتمد سلطتها من اتفاق التحكيم المبرم بين الخصوم، وهم لا يملكون هذه السلطة، فلا يمكنهم نقلهـا إلى غيرهم، فقاقـ الشـئ لا يعطيـه، فتحليف اليمسين لا يكون إلا أمسام الجهـات

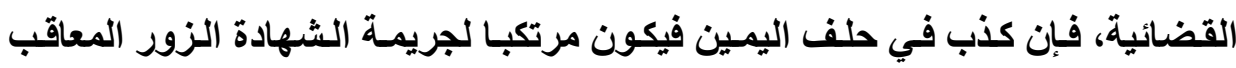
عليها جنائيا، ولا تملك هيئة التحكيم سلطة توقيع عقوبات جنائية عن أفعال إجرامية(؟). كما أن هناك بعض التشريعات أخذت بالحل المعمول به في نظم الإثبات الداخلية،

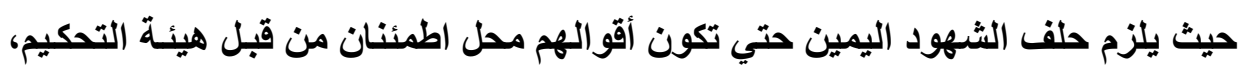

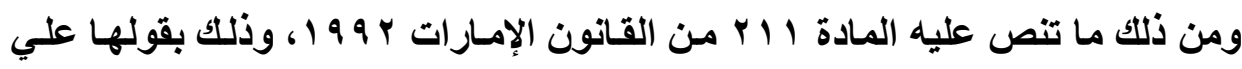
المحكمين أن يحلفوا الشهود اليمين وكل من أدي شـهادة كاذبة أمسام المحكمين يعتبر

(1) Cass. Civ., 2e 25 mars 1999, op. cit., p. 267.

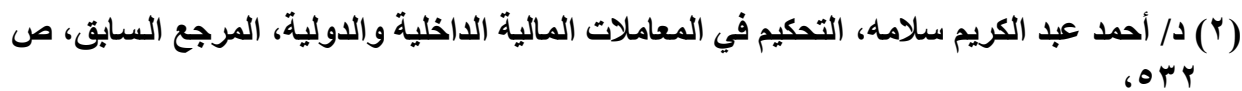

J. ROBERT, l'arbitrage droit interne et droit international privé, Dalloz., 6e éd.1993., p. 178 
مرتكبا لجريمة شهادة زور، وكما تنص علي ذلك م اب من اللانحة التنفيذية لقانون

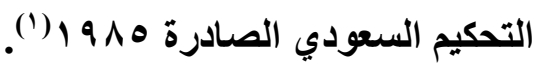

وتذهب بعض الانظمة إلى جعل تحليف اليمين من إطلاقات هيئة التحكيم، بحيث يكون لها أن تطلب منهم حلف اليمين أو أن تعفيهم من ذلك، ويأخذ بهذا الحل قانون

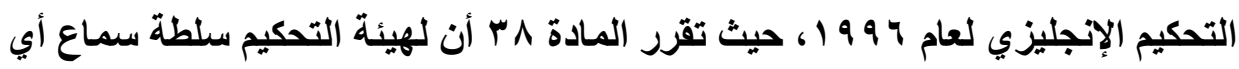
طرف أو شاهد بدون أو بعد حلف اليمين، وهي التي تقوم بتوجيه اليمين وليس الخصم. وهذا ما يثير التساؤل عما إذا كان لهيئة التحكيم أن تطلب إلى رئيس المحكمة المختصة أصلا بنظر النزاع تحليف الثـاهد قبل ادائه للشهادة؟ يذهب البعض(؟) إلى أنها يجور لهيئة التحكيم اللجوء إلى المحكمة المختصة لتحليف اليمين، وهذا مـا نص عليه القانون الليبي، خاصة وأن القانون الليبي قد عالج مسألة الامتناع عن الثهادة أو حلف اليمين.

\section{كيفية أداء الشهادة:}

لم ينص قانون التحكيم المصري علي إجراعات خاصة لسماع الشهود، وبالتالي فقد ترك الأمر لتقدير هيئة التحكيم مـا لـم يتفق الأطراف علـي إجراعات خاصـة لذلك. ولهيئة التحكيم الاستتعانة ببعض إجراعات سـماع الشهود التـي ينص عليهـا قـانون الإثبات، ولكنها لا تثقيد بهذا الإجراءات (").

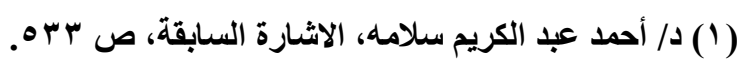

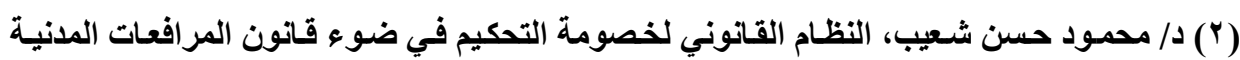

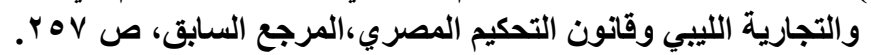

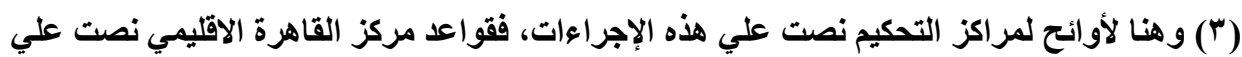

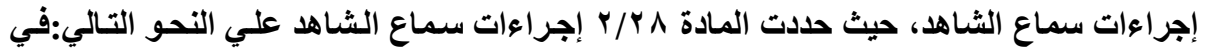
حالة المر افعة الثفوية تخطر هيئة التحكيم الأطراف قبل الجلسة بمدة هـ 1 يوم علي الأقل بتاريخ $=$ 
وقد يقيد الخصوم المحكم بطريق الإثبات التي عينها المشرع في القانون، وبذلك يمكن للقانون حمائة أطر اف النزاع من مخاطر تحكم هيئة التحكيم وأخطائها عند اختيار البينـة، ولا يكفي أن تكون الواقعة جـائزة الإثبـات فحسب، بـل يجب أن تكون جـائزة الإثبات بالاليل المطلوب تقديمه، وفقا لنظام الإثبات الواجب التطبيق، ولهذا فأنه لا يقبل سماع شـاهد لإثبات واقعة لا يجوز إثباتهـا إلا بالكتابـه، ولا يقبل توجيه اليمين المتممـة

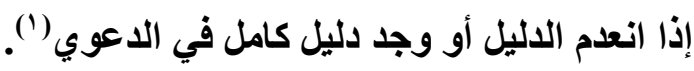
لهيئة التحكيم سلطة تقديرية في سماع الخصوم(؟) والشهود ومناقشتهم في جو

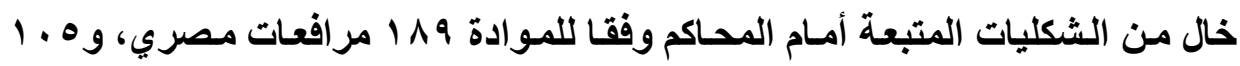
إثبات مصري، وإذا كـان القاضـي هو الذي يوجـه الأسئلة إلى الشهود، أمسا في نظـام التحكيم فـالمحكم أو الخصم هو الذي يوجـه الأسـئلة للشهود أو للخصم الآخر، ولـهـ

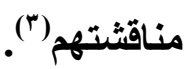

وبالتـالي في النظام المصري هيئة التحكيم لا تكون مقيدة بـاجراءات الشهادة المنصوص عليها في القانون إلا إذا كان الطرفان قد اتفقا علي ذلك، لكنها علي أي حال

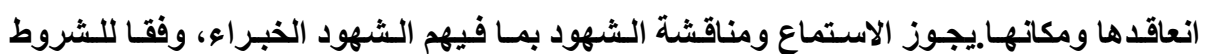

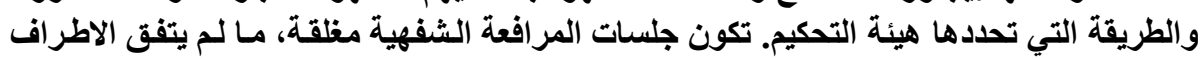

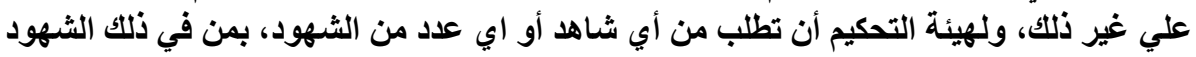

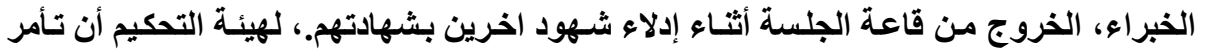

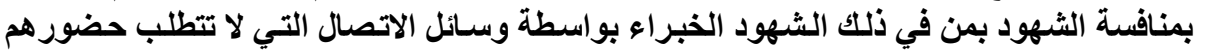

$$
\text { شخصيا في الجلسة. }
$$

(1) د/ منير يوسف حامد المناصير ، سلطة المحكم في الإثبات في خصومة التحكيم التجاري الداولي،

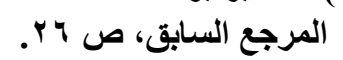

(2) CA Paris, 15 mai 1984, op. cit., p. 287.

(r) د/ نبيل إسماعيل عمر، التحكيم في المواد المدنية والتجارية الوطنية والدولية،المرجع السباق، ص 
مقيـدة بـاحترام المبـادئ الأسـاسية في الإجـراعات('). ولا تلتزم الهيئة بإصـدار حكم

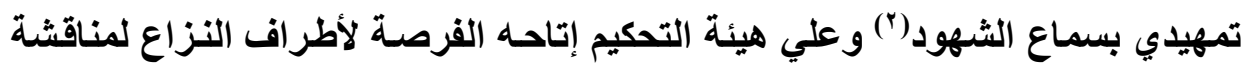
الشهود(")، واستجوابهم من قبل الهيئة ذاتهـا أو من قبل الخصوم وممثليهم("). وفي النظم الانجلو أمريكية للخصم أن يستجوب الشاهد،حتي لو كان الخصم الذي أحضر

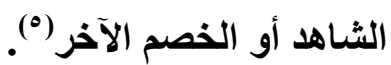

والأصل أن تؤدي الثهادة شفاهة ولا يجوز للشاهد أن يستعين بمذكرات مكتوبة

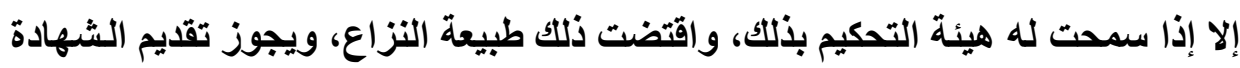

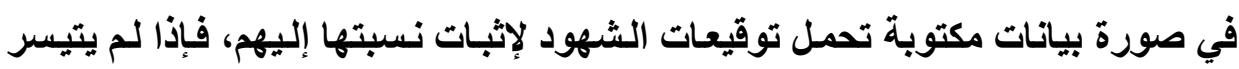

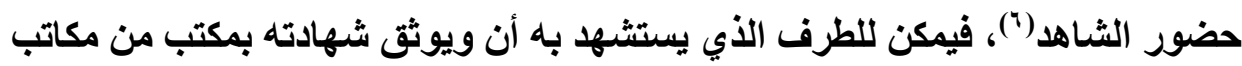

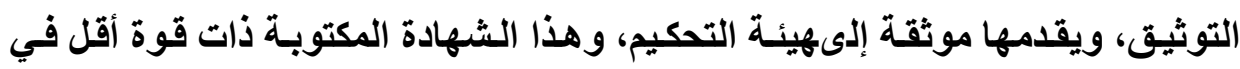

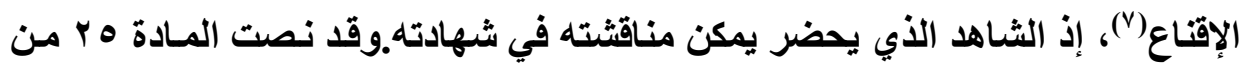

( ) د/ مصطفي الجمال ود/ عكاشة عبد العال، التحكيم في العلاقات الخاصة الدولية والداخلية، المرجع

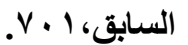

(r) د/ علي بركات، خصومة التحكيم في المصري والقانون المقارن، رسالة، المرجع سـابق الاشـارة،

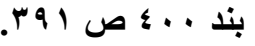

(3) CA Paris, 13 mars 1973, Rev. Arb., 1973, p.176.

(4) Ph. FOUCHARD, E. GAILLARD et B. GOLDMAN, traite de l'arbitrage commercial international, op. cit., p. 701, Cass. Civ., 2e 25 mars 1999, op. cit., p. 267.

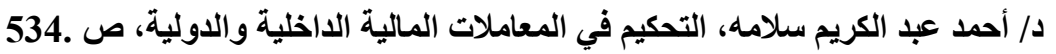

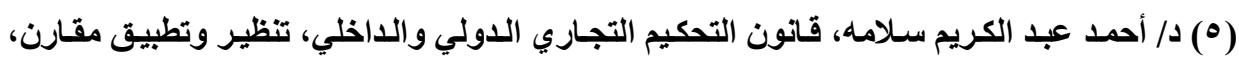

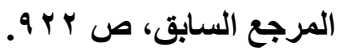
(†) د/ ياسر عبد الهادي مصلحي سلام، أثر الخطأ في إجراءات التحكيم علي حكم التحكيم، المرجع

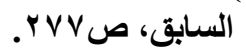
(V) دا فتحي والي، التحكيم في المناز عات الوطنية والتجارية الدولية، علما وعملا، مرجع سابق، ص 
لاتحـة مركز القـاهرة الإقليمي" يجوز أن تكون الشهادة في صورة بياتـات مكتوبـة

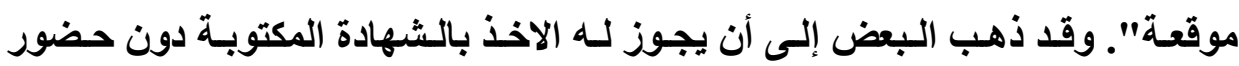

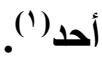

وقد جري العمل في التحكيم التجاري الدولي علي أن تطلب هيئة التحكيم من

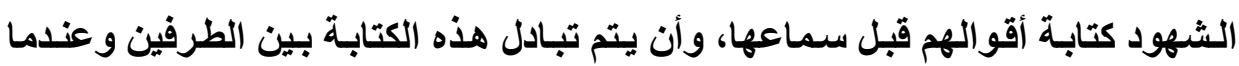

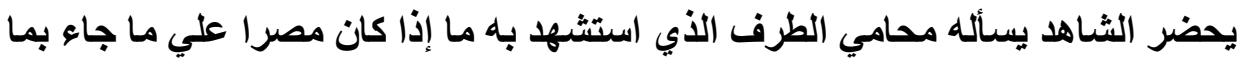

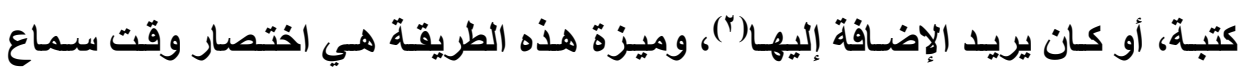

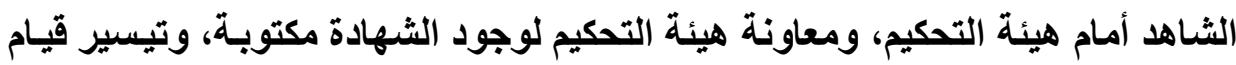

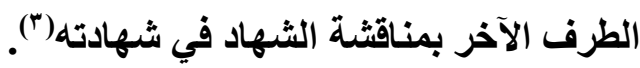

وإذا كان المحكم ملزما باتباع قو اعد القانون فهو لا يملك سماع شهادة الشهود

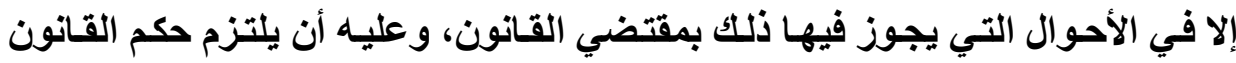

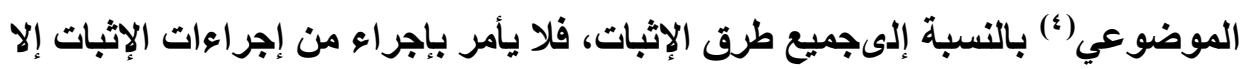

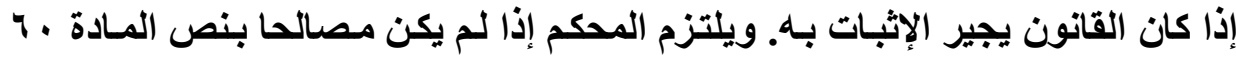

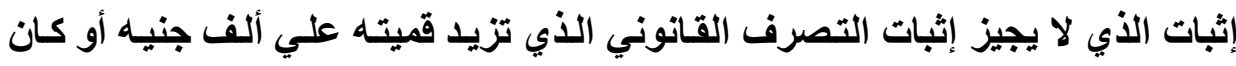

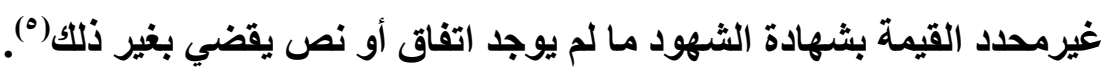

( ) د/ نبيل إسماعيل عمر، التحكيم في المواد المدنية والتجارية الوطنية والدولية،المرجع السبق، ص $r+1$

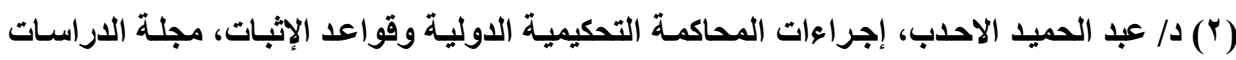

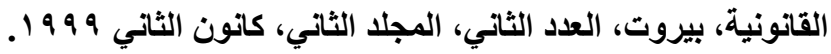

(ए) د/ فتحي والي، التحكيم في المناز عات الوطنية والتجارية الدولية، علمـا وعملا، المرجع السابق،

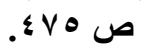

Cass. Civ., 2e 25 mars 1999, op. cit., p. 267

(4) Cass. Civ. 2e, 29 nov. 1995, op. cit., p. 235, note E. Loquin.

(0) د/ أحمد أبو الوفا، التحكيم الاختياري والاجباري، المرجع السابق، ص זه ب.

مجلتّ البحوث القانونيت والإقتصاديت 


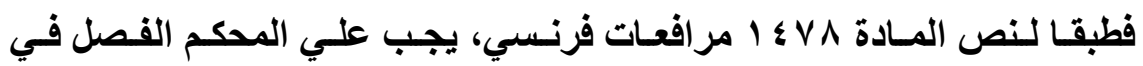

منازعة التحكيم طبقا لأحكام القانون إلا إذا اتفق علي غير ذلك. وفي الواقع إذا أخطأ المحكم في تطبيق القانون لا يمكن إبطال الحكم إلا إذا كان الطعن بالاستئناف جائزاً طبقا للقـانون الفرنسي، وذلك لأن مخالفـة قواعد القـانون ليست سـببا مـن أسباب الطعن

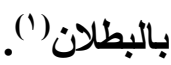

ويجوز للمحكم الإثبات بشهادة الشهود فيمـا كـان يجب إثباتهه بالكتابة إذا وجد مبدأ ثبوت بالكتابة (مץ T إثبات)، ويجوز له الإثبات أيضا بشهادة الشهود إذا وجد مانع مـادي أو ادبي يحول دون الحصول علي دليل كتـابي أو إذا فقد الدائن سنده الكتابي

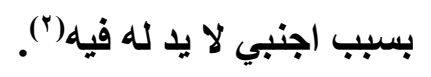

ويجب علي الشهود الحضور في اليوم المحدد لسماع الشهود، إمـا بنـاء علي إخطار من الهيئة أو دعوه من الخصوم أنفسهم، ويجب أن يكون الطرف الذي طالب بسماع الشهود، أن يخبر الهيئة بأسماء الشهود وعنوأينهم، والمسائل التي سيلئي الشهود بشهادتهم بشأنها، واللفة التي تستخدم في أداء الشهادة("). وفي حالة تعدد الشهود، فيؤدي كل شاهد شهادته بمفرده حتي لا يؤثر بعضهم

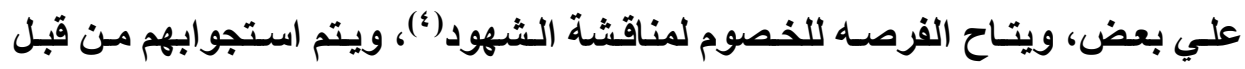
الهيئة ذاتها، أو من قبل الخصوم وممثلوهم(ْ).

(1) B. Moreau, A. Beregoi, et autre, arbitrage commercial, op. cit., no 210.

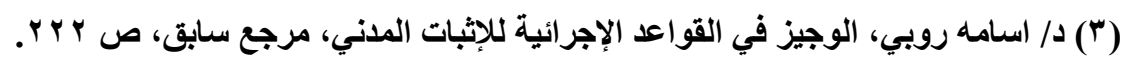

(4) CA Paris, 13 mars 1973, op. cit., p.176.

(5) René David, l'arbitrage dans le commerce international, op. cit. no 324, p. 414. 
ولهيئة التحكيم أن تجتمع بالشهود في أي مكان تراه مناسبا للقيام بذلك، وهذا ما أكدته المادة ^^ تحكيم. وإذا تم أداء الشهادة في حضور الخصوم جميعا، فلهم الحق في الاعتراض عليها،أما إذا تم سماعها في غيابهه جميعا أو بعضهم، فأنها يجب علي هيئة التحكيم في تلكك الحالة أن تحررر محضر المضمونها، حتي يتمكن الخصوم من الاطلاع عليها والاعتراض إن بدا لهم ذلك، تحقيقا لمبدأ المواجهة (').

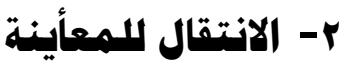

يمكن لهيئة التحكيم من تلقاء نفسها، أن تقرر الاتتقال لمعائية بعض الإمكان والوقائع والبضائع المتنازع عليها أو أي أمر آخر منتج في الدعوي، وتحرر محضرا بإجراءات المعائنة()، ويجوز لأي من الطرفين التقدم بطلب إلى هيئة التحكيم لإثبات

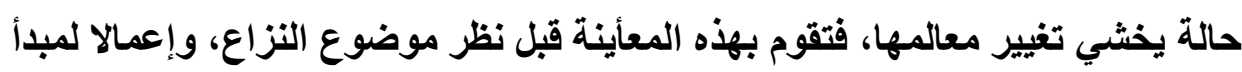
المواجهة(") فأنها يجب علي هيئة التحكيم في تلكت الحالة إخبار جميع الأطراف بمكان إجراء تلكك المعائة، كما تحرر محضرا بما تمت معأينته وانتهت إليه الهيئة من نتائج، خاصة في حالة عدم حضور الخصوم جميعا أو بعضهم(")، ومن حق جميع الأطر اف في

(1) د/ أحمد أبو الوفا، د/ طلعت محمد دويدار،، التعليق علي نصوص قانون الإثبات، مكتبة الوفاء

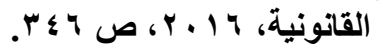

CA Paris, 2 fev. 1988, Rev. Arb., 1989, p. 62, note Couchez, Cass. Civ., 2e, 10 nov. 1998, D., 1999,IR, p. 1.S, CA Paris, 21 nov. 1967, Rev. Arb., 1967, p. 122.

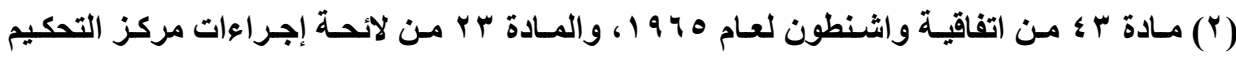

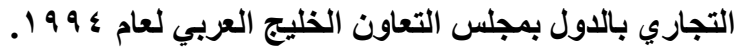

(3) CA Paris, 2 fev. 1988, op. cit., 1989, p. 62, note Couchez, Cass. Civ., 2e, 10 nov. 1998, op. cit.,p. 1.S.

(؛) د/ عاثور مبروك، النظام الإجرائي لخصومة التحكيم، مرجع سابق، بند 19 19، ص ه آم.

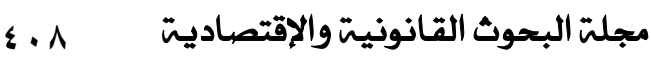


كل الأحوال مناقشة الهيئة فيما انتهت إليه من نتائج(')، كمـا أن الهيئة بإمكانها رفض الانتقال للمعأينة علي الطبيعة مع وجوب بيان أسباب رفضها للطلب المذكور ()، حتي وإن كاتت قد قررت من قبل الانتقال للمعأينة، فهي غير مقيدة بهذا القرار إن وجدت بعد ذلك في أوراق الدعوي ما يكفي لاقتناعها بالفصل فيها، أو تبين لها بعد إعادة دارسـة أوراق الدعوي أن الانتقـال للمعائـة غير منتج أو غير متعلق بهـا، ولكن يجب علـي الهيئة في هذه الحالات أن تبين أسباب العدول في المحضر أو في حكمها (") ، وفي

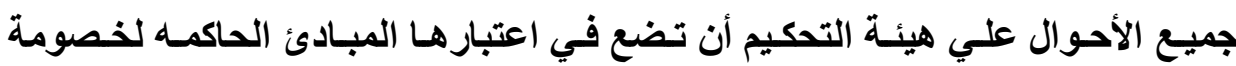
التحكيم، خاصة حقوق الدفاع ومبدأ المواجهة والمساواه بين الأطر اف. وتطبيقا لذلك قضت محكمة استئناف بـاريس، بـأن المحكم إذا قدر أنـه استكمل التحقيق في النزاع وأن القضية أصبحت جاهزة للحكم فيها، فأنه يملك رفض طلب الذي تقلم به أحد الخصوم لإجر اء معأينة دون أن يكون قد أخل بحق الدفاع، خاصـة إذا رأي أن هنالك صعوبات عملية في إجراعت تلك المعأينة، فالمحكم هو الذي يقدر وحده مدي مناسبة أي إجراء من إجراءات التحقيق، وما إذا كان منتجا في الاعوي من عدمـه"(4). كما قضت محكمة استئناف باريس بأنه إذا رفضت الهيئة الانتقال للمعائنة وجب عليها ذكر أسباب الحكم الصادر منها بالرفض(0) وتلجأ هيئة التحكيم إلىالإثبات بالمعائنة عندما يكون من الضروري معائة محل النزاع، وفحص حالته لتتمكن الهيئة من تكوين اعتقـاد صحيح عن حقيقة المنازعة،

(1) CA Paris, 13 mars 1973, op. cit., p.176.

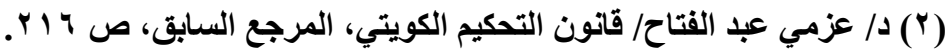

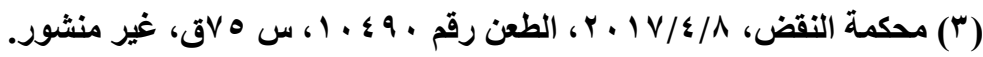

(4) CA Paris,8 Jull. 1982, Rev. Arb., 1983, p. 345.

(5) CA Paris, 15 mars 1984, Rev. Rrb., 1984, p. 285. 
وكيفيـة استخلاص وجـه الحكم فيها، فهـي تعمــ إلـى الانتقـال لتباشـر هذه المعائنـة و الفحص بنفسها ولجوء الهيئة إلى الإثبات بالمعائة مقيد بعدم اتفاق أطراف التحكيم

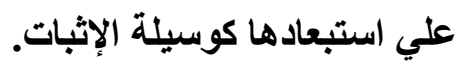

وقد نصت المادة ^^ بحكيم علي أن لهيئة التحكيم أن تجتمع في أي مكان تراه

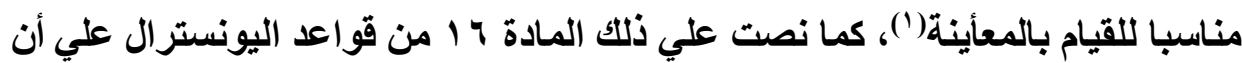

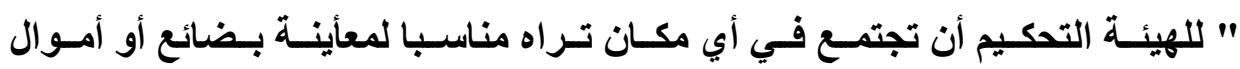
أخري..."، ولم ينص القانون الفرنسي علي حكم هذه الحالة، ولكن ليس هناك مـا يمنع

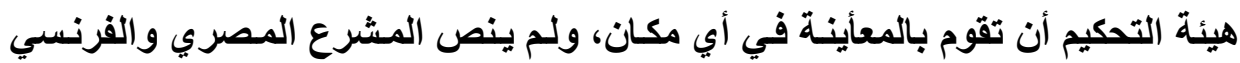

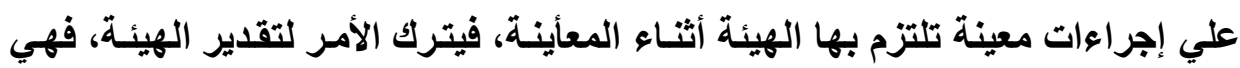
وحدها تقدر جدية الانتقال للمعائة من عدمه.

والأصل أن يتم المعأينة بواسطة جميع المحكمين، ولكن لا يوجد مـا يمنع من

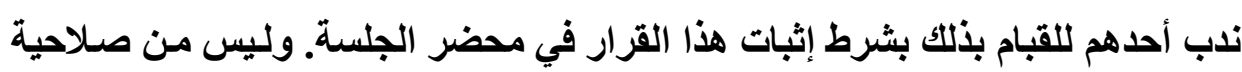

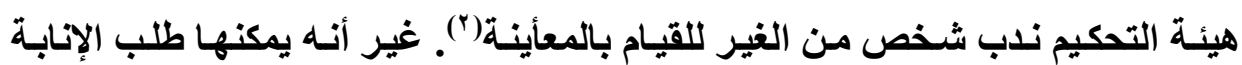
القضائية من المحكمة للقيام بإجراء المعائة(").

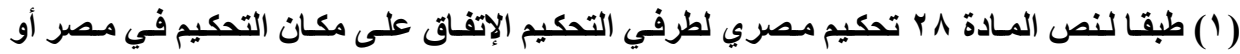

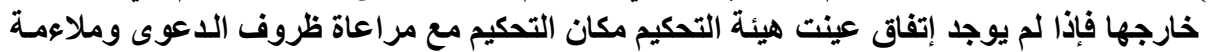

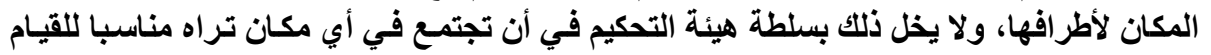

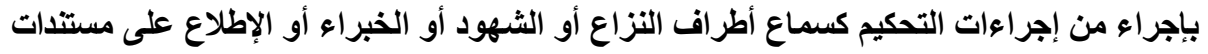

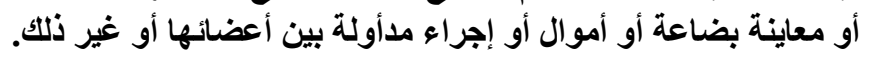

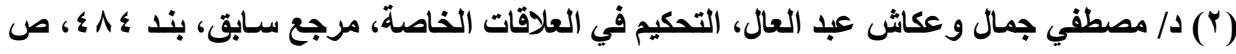
$v \cdot \Lambda$

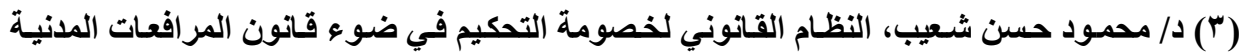
والتجارية الليبي وقانون التحكيم المصري، المرجع السابق، ص البانئ 
وقد يجري المعائة في أثناء جلسة التحكيم إذا تعلق الأمر بمنقول مثل معائنة

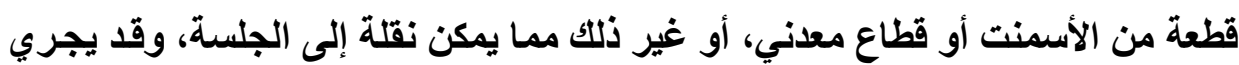

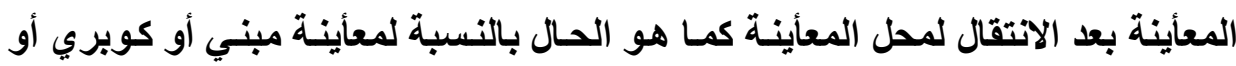

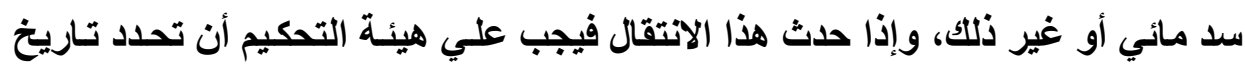

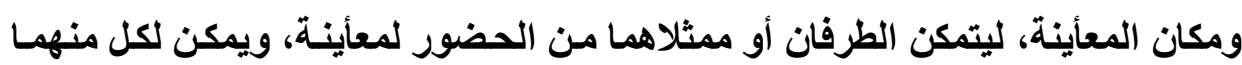
لفت نظر المحكم إلى بعض ما يهم لفت نظر المحكم عند المعائة) (') وقد نصت المادة الب إ من قانون الإثبات علي تحرير محضر تبين فيه جميع

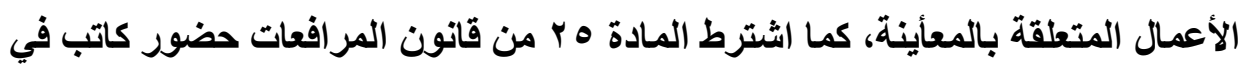

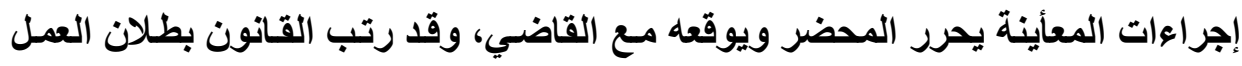

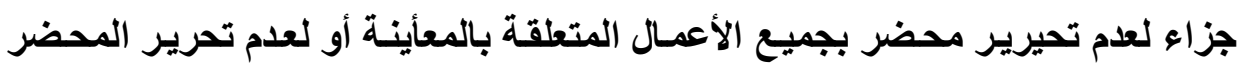

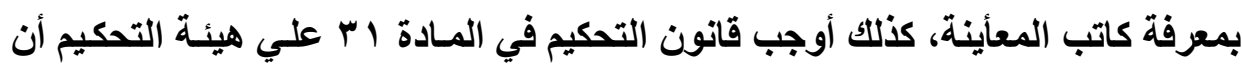

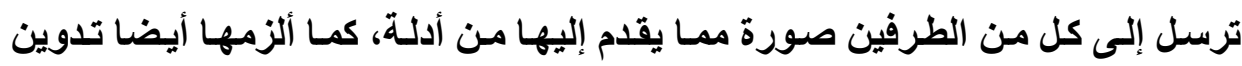

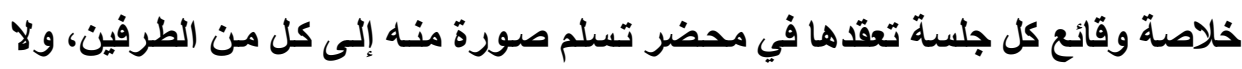

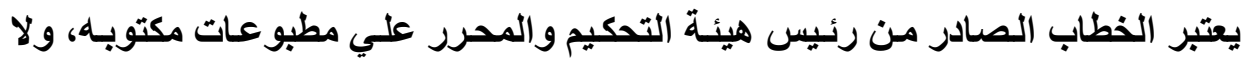

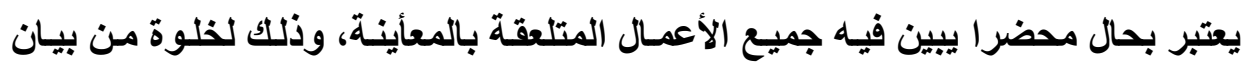

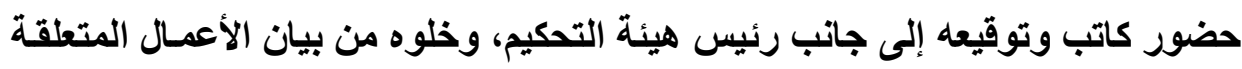

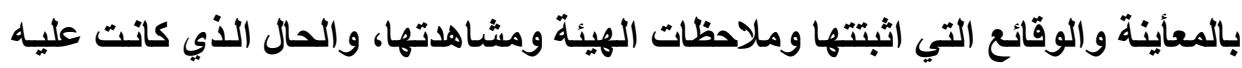

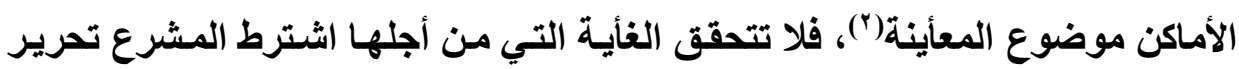

( ) د / فتحي و الي، التحكيم في المنازعات الوطنية والتجارية الدولية، علمـا وعملا، المرجع السابق، ص

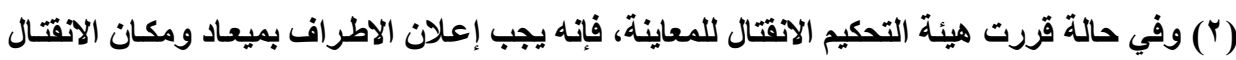

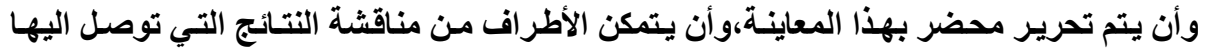

المحكمون من هذا المعاينة. 
محضر تبين فيه جميع الأعمال المتعلقة بالمعائة التي أجرتها هيئة التحكيم عملا بنص

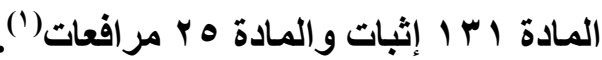
وقد قضت محكمة استئناف القاهرة() بأنه "إذا كان الثابت أن هيئة التحكيم قد قامت بمعأينة الأرض محل النزاع، بل اكتفي رئيسها بإرسـال خطاب إلى مركز القـاهرو الإقليمي للتحكيم التجاري الدولي يشير فيه إلى حصول المعانية وكـان هذا الخطاب لا يعتبر محضر ا تبين فيه جميع الأعمال، وذلك لخلوه من بيان حضور كاتب وتوقيعه إلى

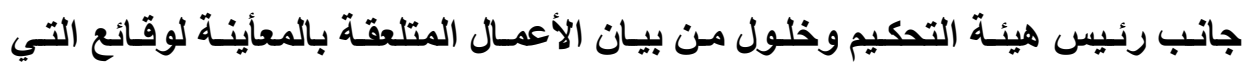
أثبتتها وملاحظات الهيئة ومشاهداتها والحال التي كاتت عليه الأماكن موضوع المعأينة كمـا خـلا مـن بيـان ماهية الأسئلة والاستيضاحات التـي طرحتهـا الهيئة علي الطرفين وإجابتهم علي كل منها، فجاء الخطأ في صياعة عامـة أومجهلة تصلح لأيـة معأينة ولا تحقق الغأيسة التي من أجلها اشترط المشرع تحرير محضر تبين فيه جميع الأعمـال المتعلقـة بالمعائــة ويوقعـة كاتب حضر إجراءاتهـا، فبإن المعائــة تكـون باطلـة عمـلا بالمادتين اس 1 إثبات وه r مرافعات، وحكم التحكيم الذي استتد إلى هذا المعأينة يكون باطلان لوقوع بطلان في الإجراعات اثر في الحكم عملا بالمادة به/ز تحكيم. وقد نقضت محكمة النقض (ז) هذا الحكم مقررة أن "نص المسادة ه مر مرافعـات والمادة اس ا إثبات بثان المعأينة لا ينطبقان علي إجراءات المعائة من هيئة التحكيم لأن قانون التحكيم لم يتضمن نصا بالإحالة إلى أي من القانونين فيما لم يرد بثأنها نص لصد

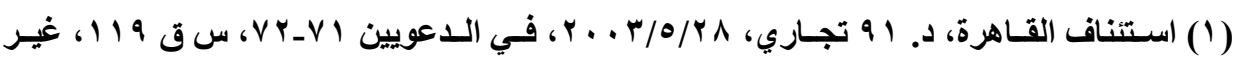
منشور.

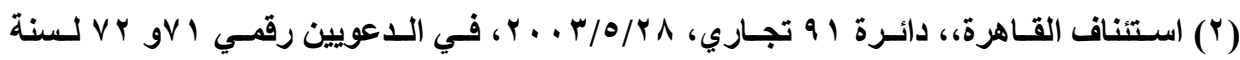
9 ا 1 اتحكيم، غير منشور.

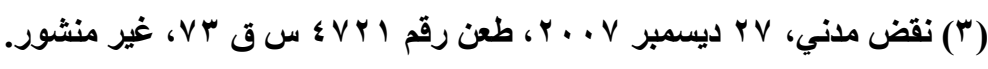


خاص، كما أن نظام التحكيم له طبيعة خاصة تتسم بتبسيط الإجراعات، ومرونتها بمـا لا يجوز التقبد بالإجراءات التي ينص عليها قانون المرافعات أو قاتون الإثبات، فضلا عن أن نص المادة ^^ من قانون الإثبات قد خلا من وجوب التوقيع علـي محضر المعانية

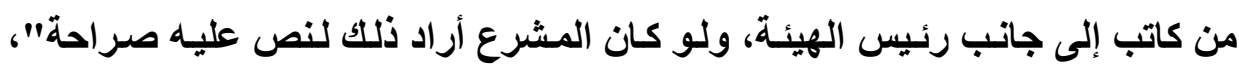
وانتهي حكم النقض إلى أن الحكم المطعون فيها إذ قضي ببطلان حكم التحكيم استنادا إلى المادة ه م مرافعات والمادة اس I إثباتا لبطلان المعانية التي أجرتها هيئة التحكيم بدون حضور كاتب يحرر محضرا بالأعمال المتعلقة بها يكون قد خالف القانون. ويلاحظ علي حكم محكمة النقض أنـه قد ألفي حكم الاستئنـاف الذي أبطل حكم هيئة التحكيم مستتدا في هذا البطلان إلى عدم حضور كاتب وتوقيعه علي محضر المعائة، ولهذا فأنها ليس مؤدي حكم النقض أن المعائية التي تجريها هيئة التحكيم تكون صحيحه ولو لم يحرر محضراً بها يتضمن أعمـال المعائينة ومـا اثبتتهـه الهيئة من وقائع وملاحظات ومشاهداتها والحال التي كان يجب عليهـا الأمـاكن محل المعأينة، مـع تمكين الطرفين مـن حضور المعائـة وإبـاء الملاحظـات عليهـا، إذ بغير هـذا تكـون المعائة قد أخلت بحق الدفاع، مما يبطل حكم التحكيم المستثد إليها'(')

r- استعانة هيئة التمكيم بخبير

الخبرة هي أحدي وسائل الإثبات المتاحة أمام الأطراف والمحكمين، من خلالها يمكن الاستعانة بخبير متخصص في أحدي النقاط التي يثيرها النزاع المعروض ليفحص وقائعها، ثم يبين رأيـة الاستشاري بشأنها. والواقع أن للخبره أهمية كبيرة في مجـال الإثبات، وتبدو أهميتها بصفة خاصـة في تحكيم المنازعات البحريـة، نظر لمـا تنطوي (1) د/ فتحي والي، التحكيم في المنازعات الوطنية والتجارية الاولية، علمـا وعملا، المرجع السابق، ص 
عليه هذه المنازعـات من إثكاليات فنية دقيقة لا يستطيع معرفة أغورهـا سوي خبيز

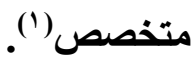

وتثير استعانة هيئة التحكيم بـالخبرة عدة إثكاليات، منها مـا هي نطاق سلطة هيئة التحكيم في الاستعانه بـالخبرة؟ ومـا هي المسائل التي تخضع للخبرة؟ ومـا هي الإجراءات الواجب عليها اتباعها؟ وما مدي إلزامية تقرير الخبير لهيئة التحكيم؟ وذلك

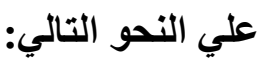

\section{أ. سلطة هيئة التحكيم في الاستعانة بالخبرة}

في الواقع تثير الاستعانه بالخبراء في مجال التحكيم خلافا بين الفقه وحتي بين الأنظمة القانونية فيما يتعلق بسلطة هيئة التحكيم في الاستعانه بخبير، وذلك علي النحو التالي:

حيث يذهب الفكر القانوني في البلاد الأنجلوسكسونية إلى أن الطابع الثخصي

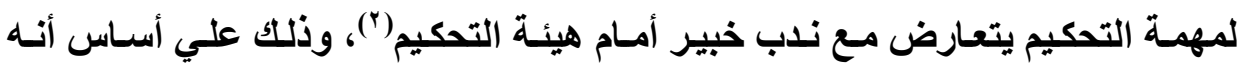
يراعي في تثكيل هيئة التحكيم أن يكون فيها من ذوي الخبرة الفنية في مجال المنازعة المطروحه كأن يكون مهندسا أو محاسبا، كما أن اللجوء إلى الخبراء يجرد التحكيم من أهم صفاته المميزه، وهي السرعة وقلة التكاليف، بالاضافة إلى أن اللجوء إلى الخبراء

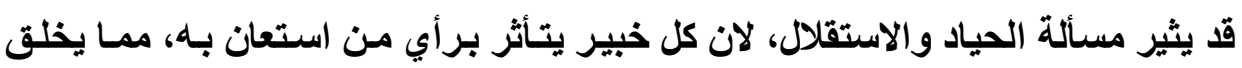
تعارضا بين آراء الخبيرين في نفس الدعوي (").

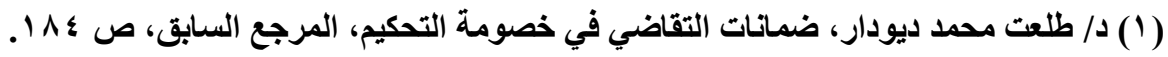

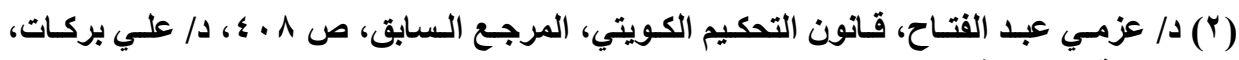

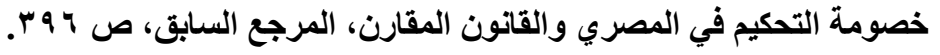

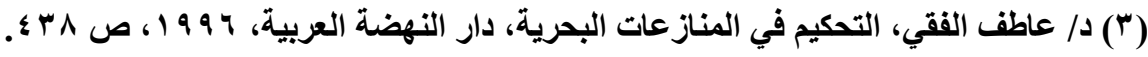


وقد أيد بعض الفقه هذا الاتجاه(')، وإن كان لا يسلم بالنتيجة بـالقول بالاستغناء الكامل والمطلق بالخبراء في مجال التحكيم، وإنما أكل علي ضرورة التدقيق في اختيار

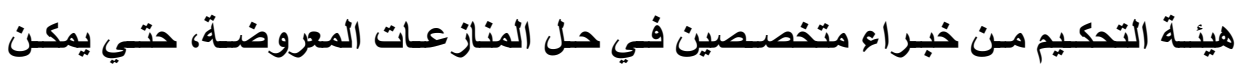
للمحكمين الفصل في النزاع بكفاءة في أسرع وقت ممكن، وبأقّل تكساليف دون الاستعانة بالخبر اء.

وتتجه الأنظمة اللاتتية إلى عكس الاتجاه الأول()، فترى أن اللجوء إلى الخبرة

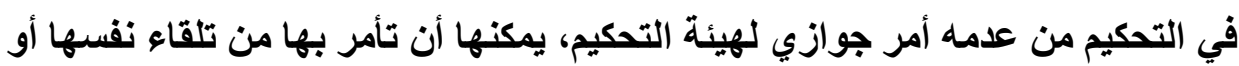
بناء علي طلب من أحد الأطراف أو كلهما، وذلك علي أسـاس أن نـلب خبير أمسام هيئة التحكيم لا يعني تفويض المحكم سلطاته لهذا الخبير، فمهمة الخبير تقتصر علي ابداء الرأي في مسألة معينة غير ملزم للمحكم، كما أن الحاجة تدعوا إلى ندب خبير كمهندس أو محاسب إذا كـان المحكم من رجـال القانون("). ويجو لهيئة التحكيم أن تعرض عن إن ندب الخبير إذا وجدت في أوراق الدعوي مـا يكفي التكوين عقيدتها دون حاجـة إلى خبير ()

ونري أنها من سلطة هيئة التحكيم الاستعانه بخبير، وذلكك علي أسـاس أنها لا يشترط قانونـا في تشكيل هيئة التحكيم أن يكون المحكمن من الخبراء، كمـا أن المحكم وظيفته تختلف عن الخبير، فالخبير يحكم بمقتضي علمـه الشخصي وخبرتـه في مجـال الواقعة محل الخبرة.، كما أن توافر صفة الخبير في عضو هيئة التحكيم يتعارض مـع

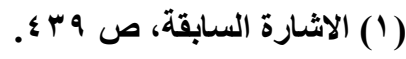

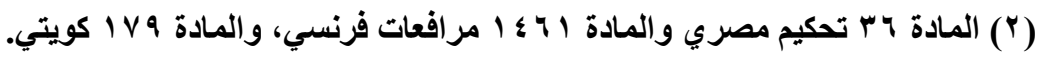

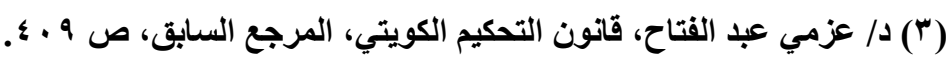

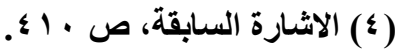


مبدأ القضاء بمقتضي علمه الثخصي. والخبرة طريق من طرق الإثبات المباشر، حيث تتصل ماديـا ومباشرة بالواقعة محل الإثبـات. وتقرير اللجـوء إلـى الخبرة مـن عدمـه

جوازي لهيئة التحكيم

وقد نظم المشرع المصري في قانون التحكيم مبدأ الاستعانه بخبير وكيفية قيامسه.

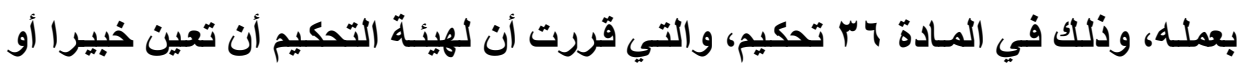

أكثر لتقديم تقريـر مكتوب أو شـفهي يثبت في محضر الجلسة بشـأن مسائل معينـة تحددها، ويتضح من ذلك أن تقرير اللجوء إلى الخبرة من عدمه جوازي لهيئة التحكيم، فيمكنها أن تأمر به من تلقاء نفسها أو بناء علي طلب الأطراف، أحدهم أو كلهم. بل لا

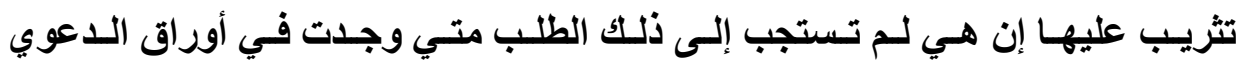
ومرافعات الخصوم وأدلة الإثبات الآخري مـا يكفي لتكوين عقيدتها حول الفصل في النزاع. دون أن يشكل ذلك إخلالا بحق الدفاع('). وقد نصت المادة وج من قواعد مركز القاهرة الإقليمي، علي أنه لهيئة التحكيم بعد التشأور مع الأطراف، تعيين خبير مستقل

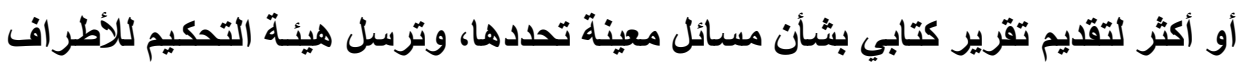

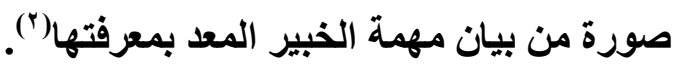

(1) د/ أحمد عبد الكريم سلامه، التحكيم في المعاملات المالية الداخلية والدولية، المرجع السابق، ص

Ph. FOUCHARD, E. GAILLARD et B. GOLDMAN, traite de l'arbitrage commercial international, op. cit., pp. 703.

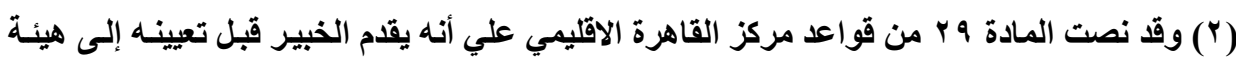

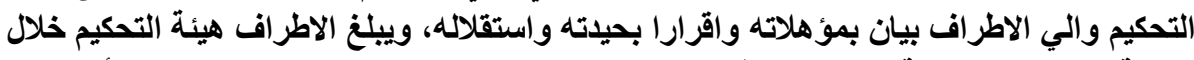

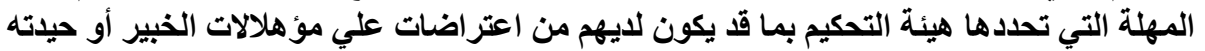

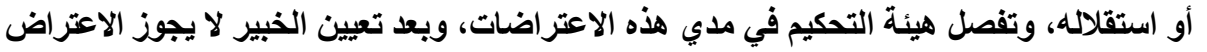
عليه، إلا لاسباب لم يعلم بها الا بعد التعيين. 
وتطبيقا لذلك فقد ذهبت محكمة استتناف القاهرة إلى أن " من المقرر أن وسائل

الإثبات ومنها ندب الخبراء هي من الأمور التي تخضع لتقدير هيئة التحكيم التي لها

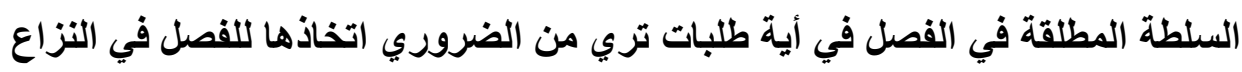
المعروض عليها توصلا لوجه الحق في الدعوي. وذلك طبقا لسلطتها التقديرية الدخوله

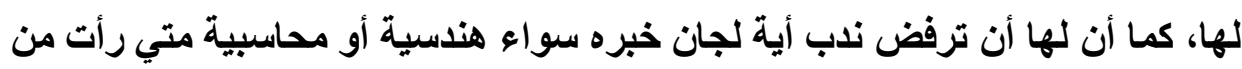

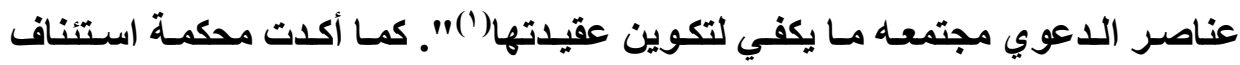

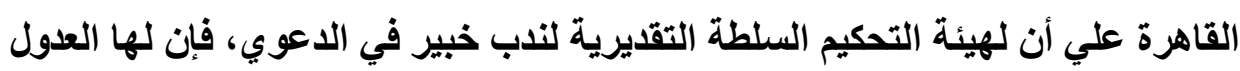
عن هذا الندب متي وجلت في مستندات الدعوي الآخري مـا يكفي لتكوين عقديتها

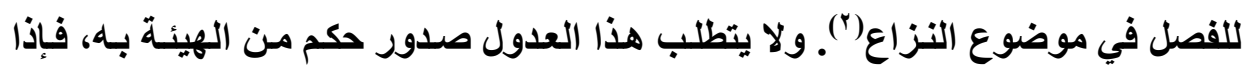

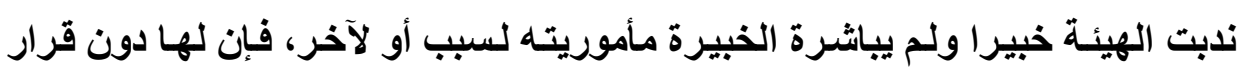

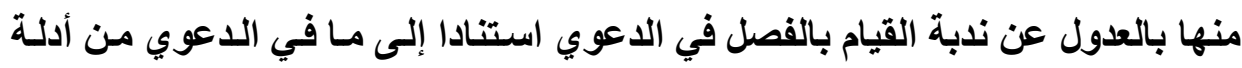

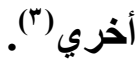

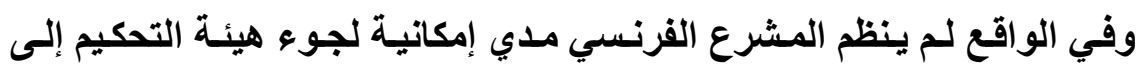

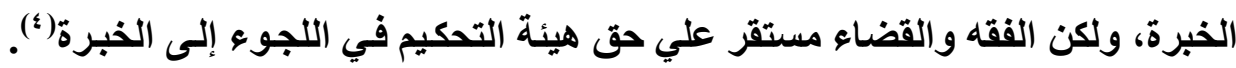

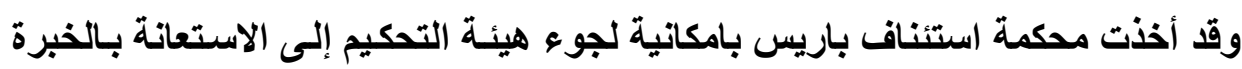

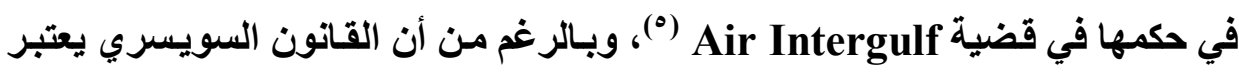
عدم الموافقة علي تعيين خبير سببا لبلطان الحكم، فإن المحكمة الفيدرالية رأت أن أن النيان

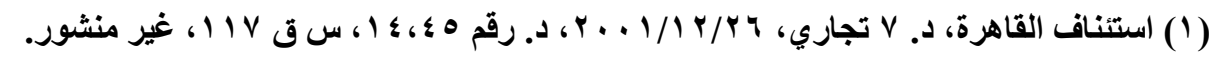

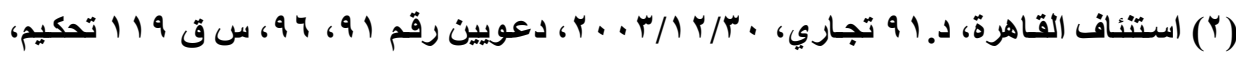

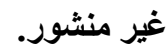

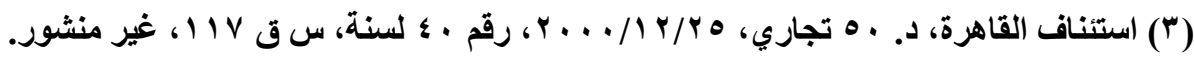

(4) B. Moreau, A. Beregoi, et autre, arbitrage commercial, op. cit., no 222.

(5) CA Paris, 6 sept. 1996, Rev. Arb. 1997, p. 24. 
إلغاء الحكم يجب أن يكون في حالات محددة فقط من حالات تعيين الخبير(')، وفي حالة

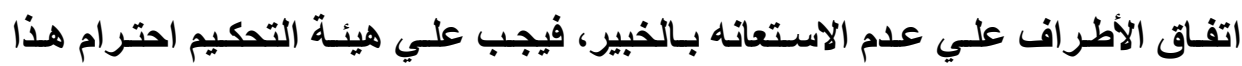

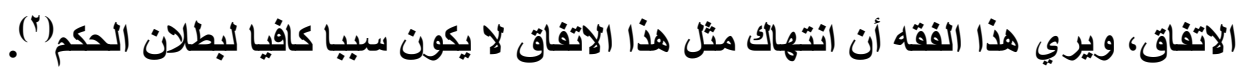
وقد ذهب القضاء المصري إلى تأكيد السلطة التقديريـة لهيئة التحكيم في الاستعانة التهانة

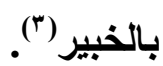

ونري أنه يجوز للأطراف الاتفـاق على إلزام هيئة التحكيم بالاستعانة بأهل

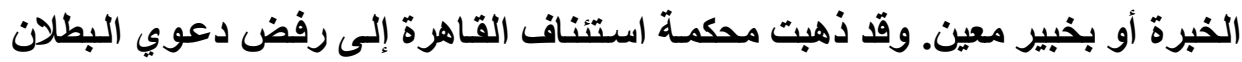

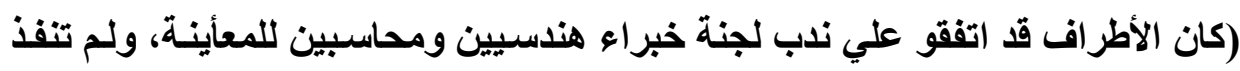

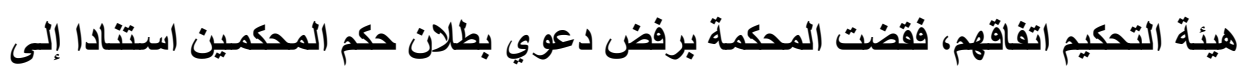

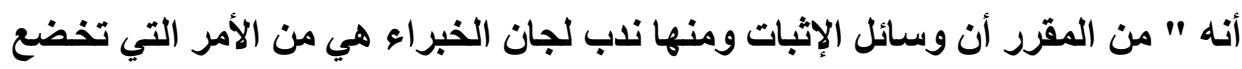

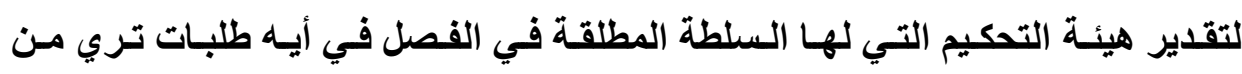

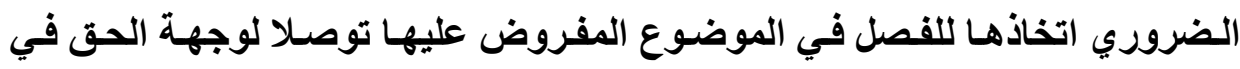

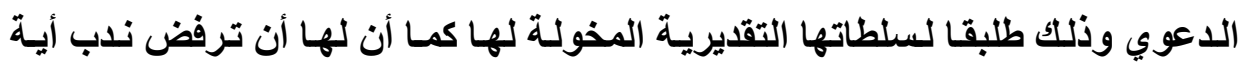

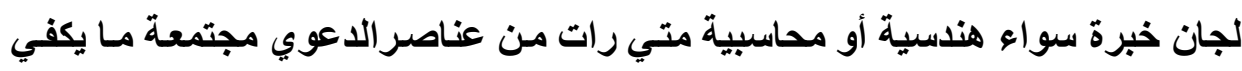

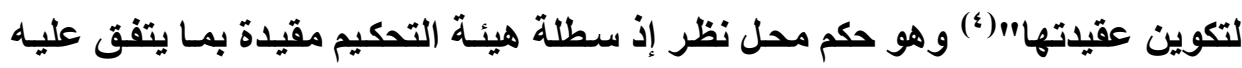

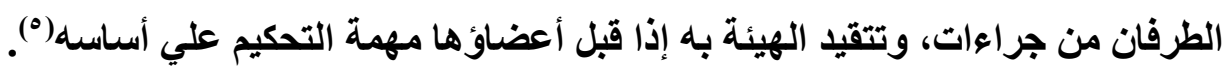

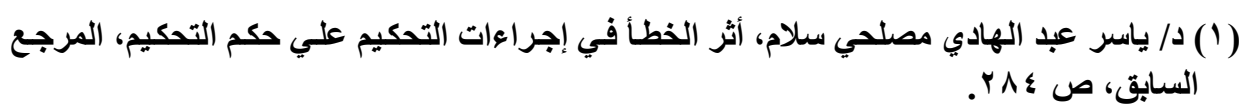

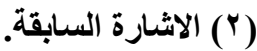

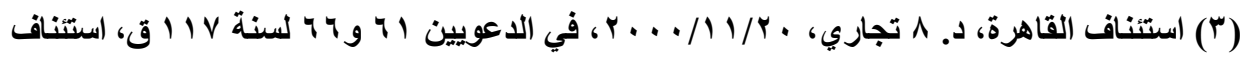

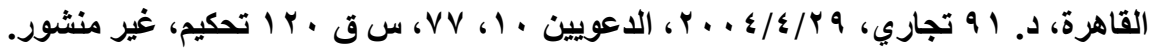

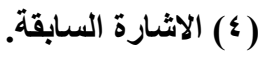
(0) د/ فتحي والي، التحكيم في المنازعات الوطنية والتجارية الدولية، علما وعملا، المرجع السابق، ص ص 
وكمـا نري أن سلطة هيئة التحكيم في الاستعانه بخبير مقيدة بمـا اتفق عليه الخصوم(')، فيمتنع عليها الاستعانه بالخبراء، إذا وجد اتفاق علي ذلك، ولو أثناء سير

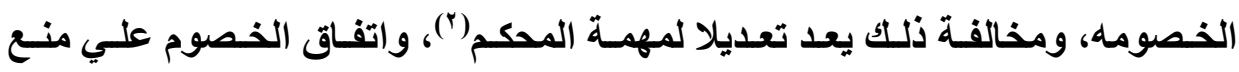
الاستعانة بخبير قد يكون صريحا أو ضمنيا، كمـا لو رعي في تشكيل هيئة التحكيم أن يكون أحد المحكمين خبيرا في مجال النزاع، فهنا يدل علي الاتفـاق الضمني علي عدم الاستعانه بخير طالما اتفق الخصوم علي اسم المحكم الخبير.

\section{ب. المسائل التي تخضع للخبرة}

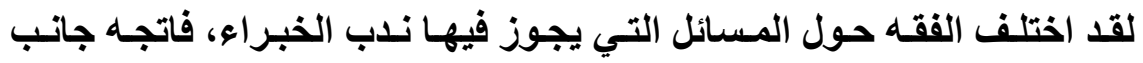
منهم(") إلى مهمة الخبير تنحصر في مسائل الواقع، ولذا لا تسنطيع هيئة التحكيم أن تتدب خبيرا لإبداء رأيه في مسألة قانونية، ولا أن تلجأ إلى القضاء لنفس الغرض، فِّاذا حدث ذلك يكون المحكم قد فوض سلطاته وخرج عن اتفاق التحكيم، وهو مـا يؤدي إلى بطلان حكمهـ. ويري هذا الجانب أن المحكم مثل القاضسي يفترض فيه العلم بالقانون ويلتزم بتطبيقه، أما المسائل القنية فلا يفترض علمه بكل جوانبها. ويمنع القانون علي المحكم كمـا هو الشأن بالنسبة للقاضسي أن يكلف الخبير باعطاء رأي قانوني أو حل

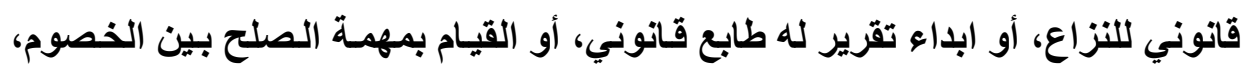
وإذا حدث مثل هذا التكليف، فيكون عمل باطلا لمخالفة اتفاق التحكيم(؛).

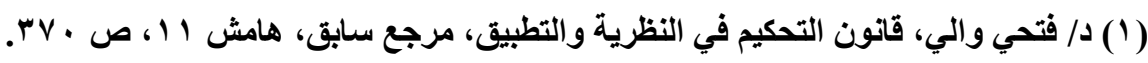

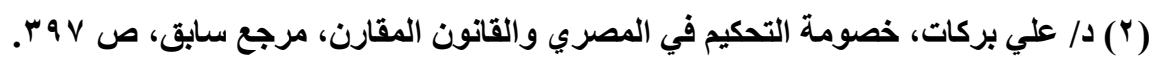

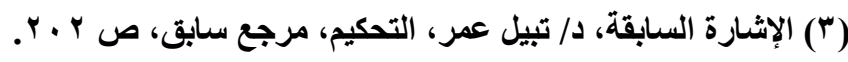

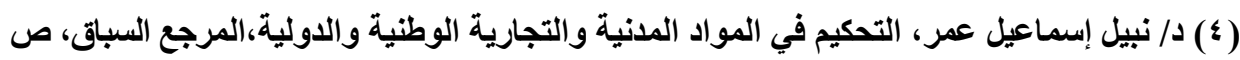


ويري هذا الفقه أنه يقصد بالقانون الأي يفترض علم القاضي به القانون بمعناه الواسع، فيشمل: التشريعات المكتوبة(') مثل الاستور والقانون واللوائح، كذلك يشمل القواعد العرفية، وكذلك القوانين الأجنبية(؟). وبالنسبة للمسائل القنية والواقعية، فهي التي صعب علي المحكم بثقافته معرفة كل جوانبها، لأنها تحتـاج إلى دراسـة متعمقة واسـتعمال أجهـزة دقيقـة وخبـرة عمليـة، كمـضـاهاة الخطـوط والمسسائل الميكانيكيـة، وبراعات الاختراع، ومسائل الطبيعية، والمسائل الزراعية والبحرية. فندب الخبير لعمل بحث فني متعلق ببعض التحاليل الكيميائية أو الزراعيه أو تقدير الاضرار الجسدية، فهذه أعمال فنية لا خلاف عليها في أنها تلاخل في اختصاص القاضي أو المحكم، أما إذا كاتت مهمة الخبير تتصب علي تفسير اتفاق أو تحديد المسئولية في مسألة الحوادث، أو البحث عن النصوص القانونية المطبقة علي النزاع، فهذه تعتبر مسائل قانونية لا يجوز ندب خبير لها"). ويخلص هذا الاتجاه إلى أنه يمكن لهيئة التحكيم أن تعهد بـأي مهمـة للخبير، سـواء حسابية أو هندسية أو طبيـة، أو قانونيـة، وذلك لأيضاح حكم القـانون

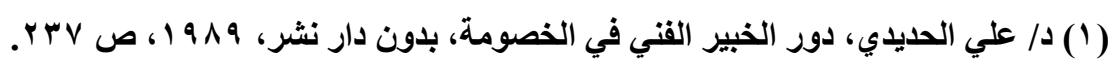

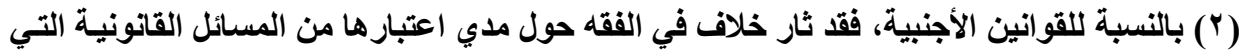

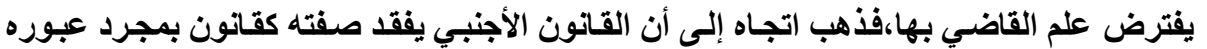

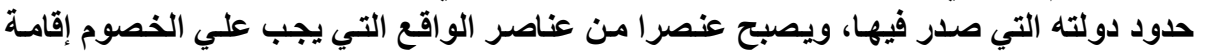

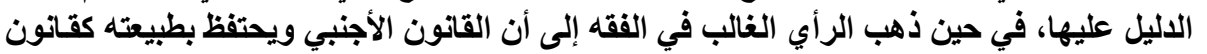

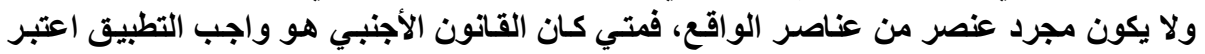

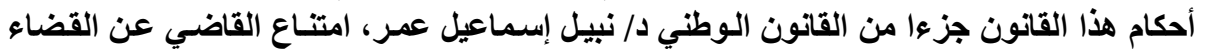

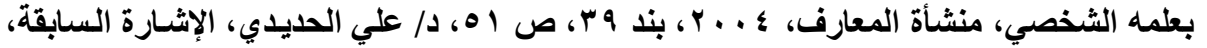

$$
\text { ص إ ب وما بعدها. }
$$

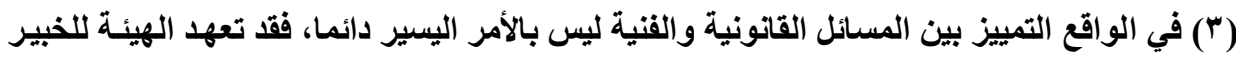

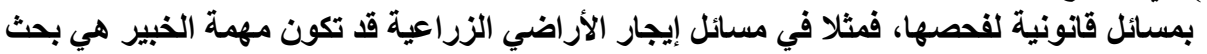

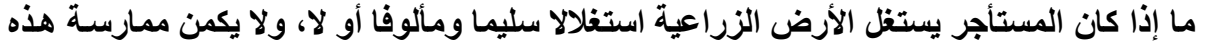

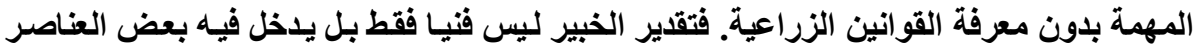

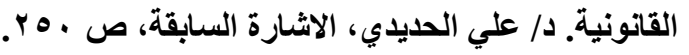


بالنسبة لمسألة معينة(')، وذلك في حالة كون الهيئة مشكلة من غير رجـال القانون، أو القانون الواجب التطبيق اجنبي.

واتجـه رأي اخر إلسى جـواز الاسـتعانة بخبير أمسام المحكمين دون تمييز بـين

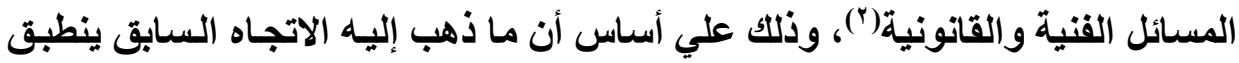

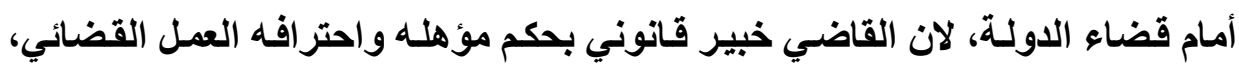

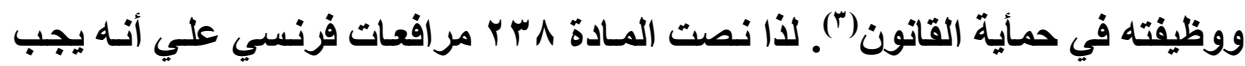
علي الفني ألا يتعرض مطلقا لتقدير مسألة قانونيـة. وهذا الأمر يختلف بالنسبة لهيئة

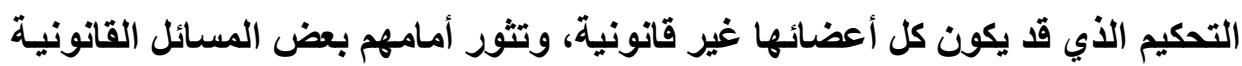

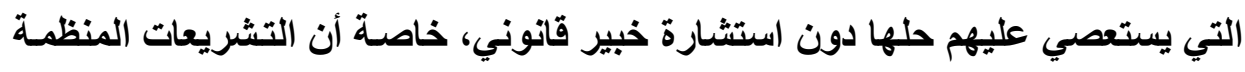

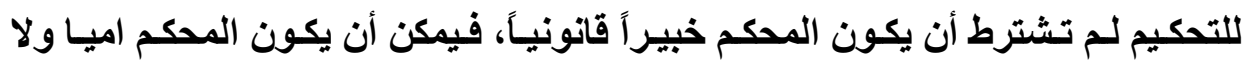

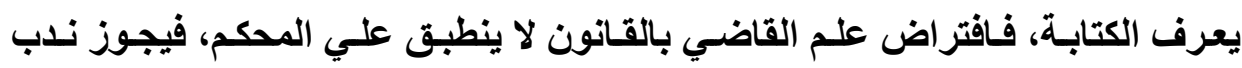
خبراء قانونيين ولا يعد ذلك تخليا عن مهمتهم طالما بقي رأي الخبير استثـاريا.

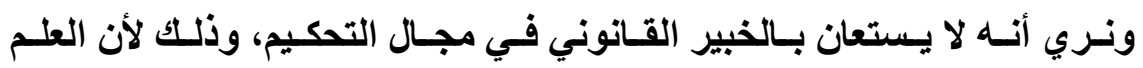
بالقانون هو علم عام ومشهور، وحتي لو كان المحكمون غير قانونين فيجب أن يكونـوا

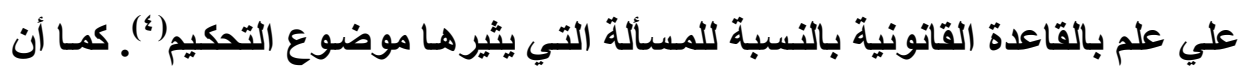

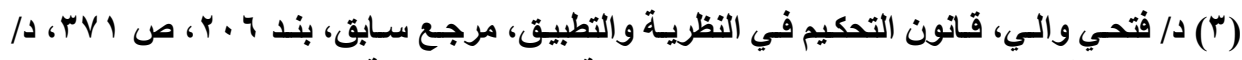

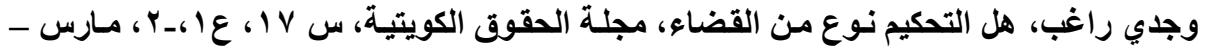

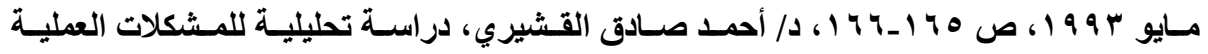

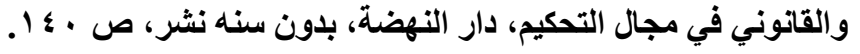

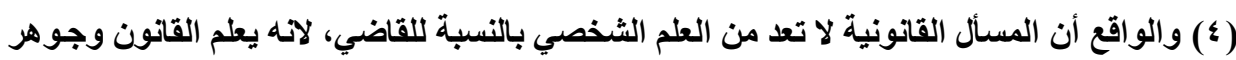

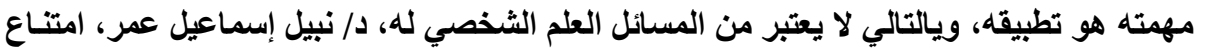

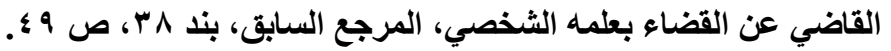




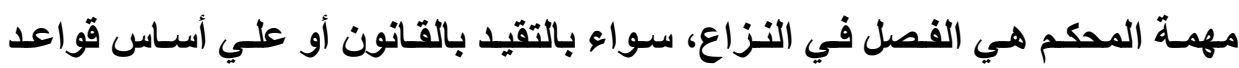
العدالـة والقـانون الطبيعي، وهذا يفترض علمهـه بالقـانون أو قواعد العدالـة والقـانون

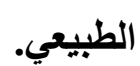

وقد ذهبت محكمـة النقض المسرية إلى أن العلم الثخصي يتعلق بالوقـائع

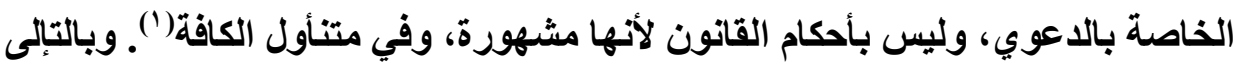

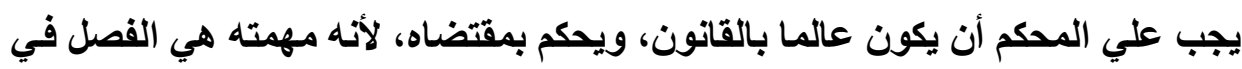

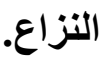

\section{ج. إجراءات الجهوء إلى الخبرة}

ولا تتقيد هيئة التحكيم عند ندب الخبير بالإجراءات المتبعة أمسام القضاء، وقد

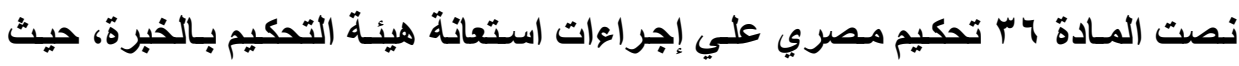

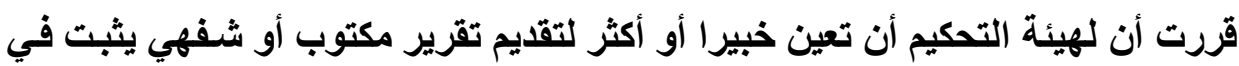

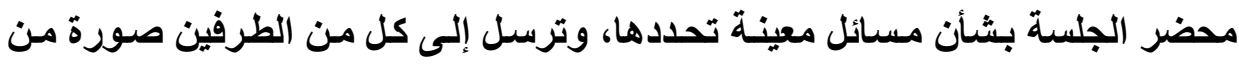

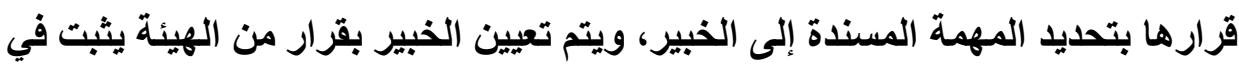

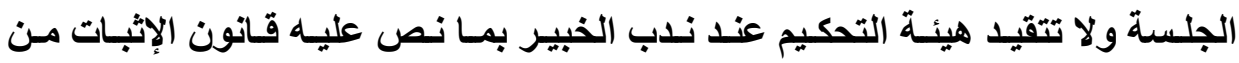
إجراءات، فيمكن أن تعين خبير اتفق عليه الأطراف أو أي خبير آخر. ويتضمن قراراً بالتعيين مهمة الخبير وتقديم تقريره كتابة أو شفويا. ويجب أن تحدد مهمة الخبير علي الترات نحو غير مخالف لاتفاق الأطراف(")، وترسل صورة من القرار إلى الأطراف.

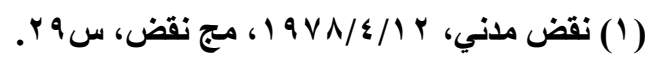

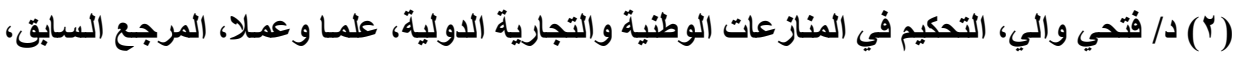
. ص ص

Cass. Civ., 2e 25 mars 1999, op. cit., p. 267 
وقد نصت المادة צ ب/ץ من قانون التحكيم علي أنه يجب علي الخصوم تقديم كل العون للخبير للقيام بمهته، حيث ألزمت هذه المادة الخصوم بتقديم المعلومات المتعلقة بـالنزاع، وتمكين الخبير من معأينـة وفحص مـا يطلبه مـن وثائق أو بضائع أو أموال أخري متعلقة بالنزاع. فجيب علي طرفي اتفـق التحكيم أن يقدم إلى الخبير المعلومـات المتعلقة بالنزاع، وتفصل هيئة التحكيم في كل نزاع يقوم بين الخبير وأحد الطرفين في

وقد يحدث اتفاق الأطراف علي الخبرة في مرحلة لاحقة اثـاء سبر الخصومة أمام المحكمين، وعندئذ يعتبر الاتفـاق تعديلا للمشارطة، ويلزم عندئـذ قبول المحكمين لهذا التعديل صراحة أو ضمنيا إذ أنه يتضمن تعديلا لمهمتهم التي قبلوا مهمـة التحكيم علي أساسها. ولا يؤدي قرار هيئة التحكيم بالاستعانه بالخبراء إلى وقف ميعاد التحكيم، ما لم يتفق الأطراف علي هذا الوقف أو الاتفاق علي مد مهلة التحكيم. لأن مهمة الخبير تستغرق عادة مدة طويلة. لذا يفضل اضافة نص في قانون التحكيم يقضي بعدم احتساب التي مدة مباشرة الخبير لمهمته ضمن ميعاد التحكيم ('). فيجب علي هيئة التحكيم أن تصدر قرارا يحدد فيـه اسـم الخبير والنقـاط أو المسائل التي سيبدي فيها رأيه والمدة اللازمـة لاتمـام المهمة، ولا يحلف الخبير يمينـا

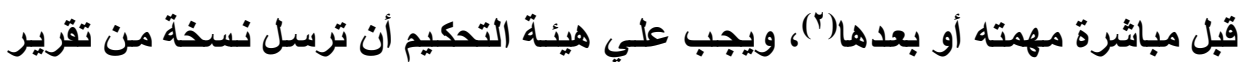
(1) د د فتحي و الي، التحكيم في المنازعات الوطنية والتجارية الدولية، علمـا وعملا، المرجع السابق، ص ص

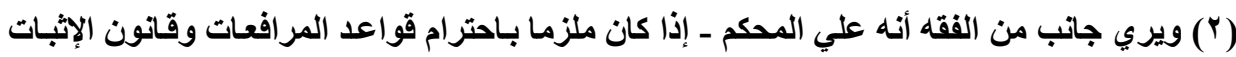

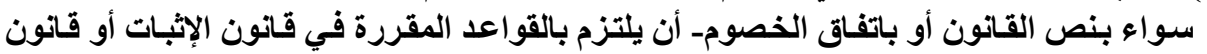

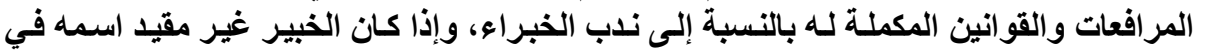

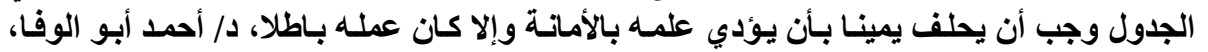

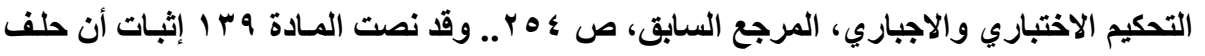
$=$ 
الخبير فور تسليمها أياه إلى الأطراف(')، وتتيح لهم الفرصة لإبداء رأيهم في التقرير كتابةـ ولكل طرف الحق في فحصة أي وثيقة استتد إليها الخبير في تقريره. وتعطي فرصة للأطراف لتكوين رأيهم بشأن التقرير()، ولا تحدد جلة لمناقشة التقرير دون اعطاء فرصـة لتكوين فكرة عن التقرير("). ويجوز بنـاء علي طلب أي طرف، سـاع أقوال الخبير في جلسة تتاح للأطر اف فرصه حضورها واستجواب الخبير. ويجوز لأي طرف أن يقدم في هذه الجلسة شهودا من خبراء ليدلو بثهادتهم، ومخالفة ذلك يترتب عليه البطلان(؛)، لإخلال ذلك بحقوق فئ الدفاع. ونري أنه بشترط للاستعانه بالخبير الأتي:

• تحديد المسألة التي بستعان بـالخبير فيها علي وجـه الدقة، وذلك حفاظـا علي الوقت وحتي لا تتخذ الاستعانه بالخبرة كذريعة للتخلص من عبء الفصل في

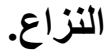
• يجب أن تكون المسألة متعلقة بالواقع، وليس متعلقة بالقانون.

اليمين يكون امام قاضي الامور الوقتية. ويذهب رأي في فرنسا أن يتم حلف اليمين امام المحكم وإذا

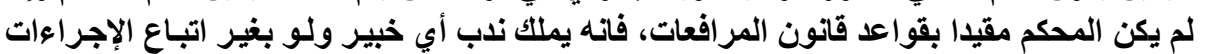
المقررة في القانون.

(1) CA Paris, 7 dec. 1965, JCP, 1966, II, 14625, note Boulbles; Cass. Civ., 2 e 25 mars 1999 op. cit., p. 267.

(2) Cass. Com, 30 juill. 1952, D., 1952, p. 724.

(3) CA Paris, 13 mars 1973, op. cit., p.176. (؛) د/ فتحي والي، التحكيم في المنازعات الوطنية والتجارية الدولية، علمـاو عمـلا، المرجع السابق، . ص ص 
• يجب مراعاة حقوق الدفاع والمساواة بين الخصوم أثنـاء عمل الخبير، وبعد انتهاء الخبير من عمله وتقديمهـ تقريره شفاهة أو كتابـة، يجب علـي الهيئة احترامـا لحقوق الدفاع، أن تطلع الخصوم علي التقرير المقدم من الخبير، وأن تعطي لكل خصم الفرصة الكافية لمناقشة هذا التقرير والرد علي كل مـا جاء

• يجب أن يكون الخبير محأيدا ومستقلا، وإلا طلب رده(؟)

(1) CA Paris, 13 mars 1973, op. cit., p.176. Cass. Com, 30 juill. 1952, op. cit., p. 724.

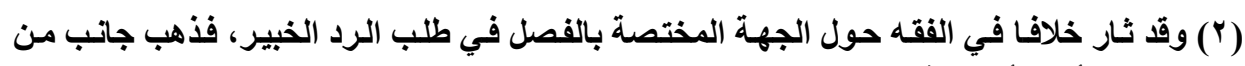

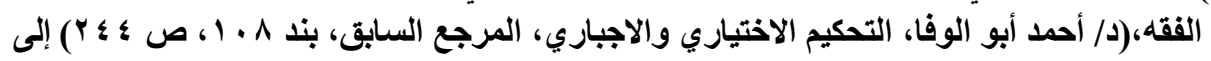

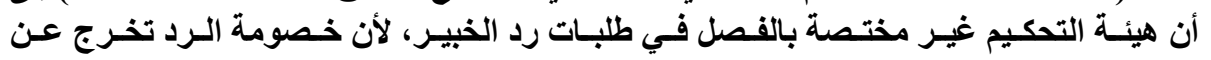

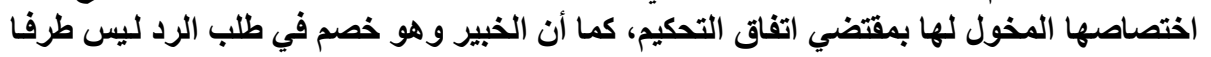

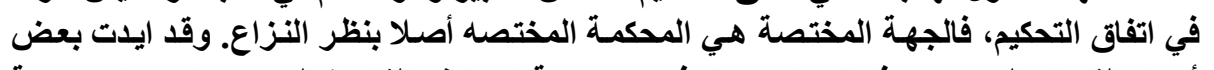

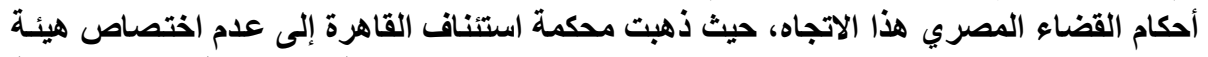

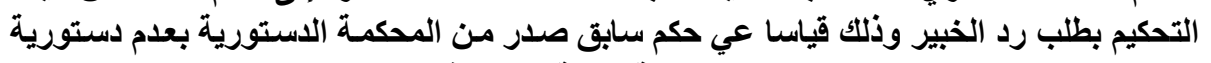

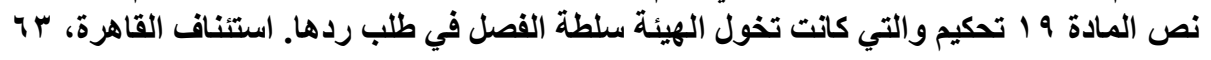

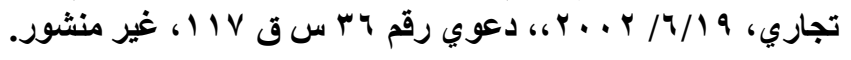

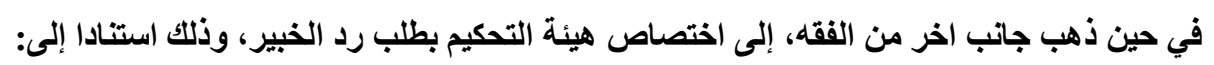

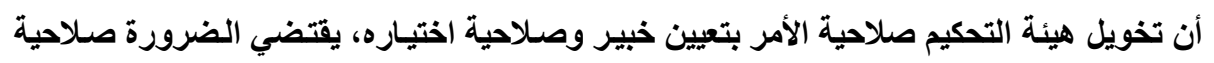

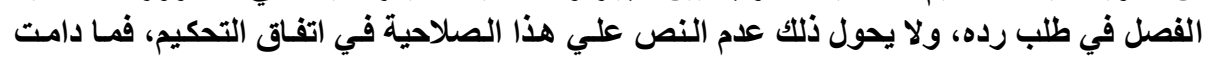

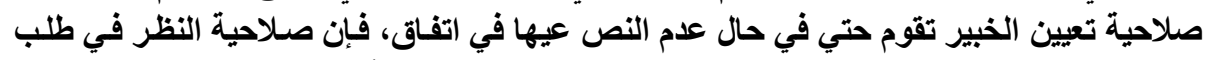

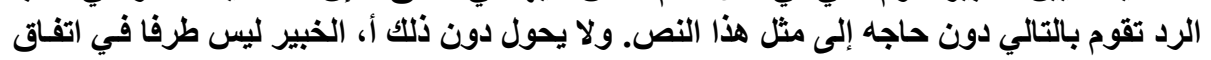
التحكيم.

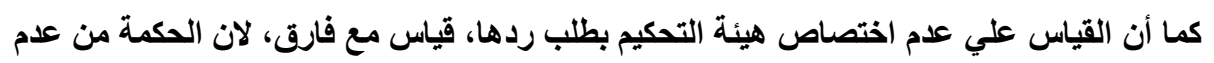

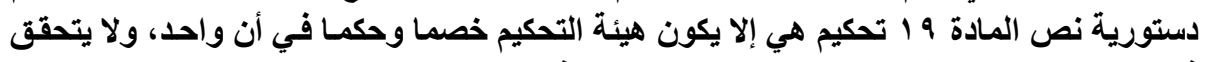

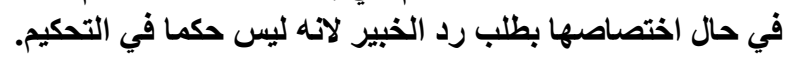

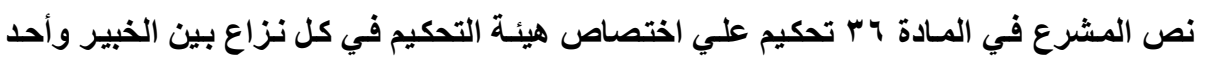

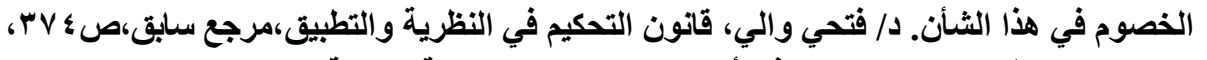

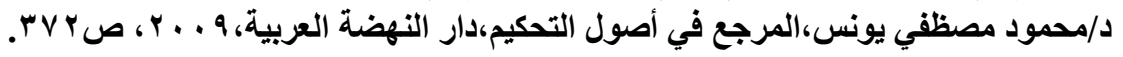




\section{د. خضوع تقرير الخبير السلطة التقديرية لهيئة التمكيم}

ويري جانب من الفقه أن تقرير الخبير يتعلق بمسألة فينة، فيجب الالتزام برأي الخبير في هذه المسألة)(') والواقع أن هذا الرأي لا يمكن الاخذ بهل، وذلك لأن تقرير الخبير من مسائل الإثبات التي تملك هيئة التحكيم سلطة تقديريه بثأنها. والواقع أن هيئة التحكيم لا تتقيد بالرأي الذي انتهي إليه الخبير في تقريره،

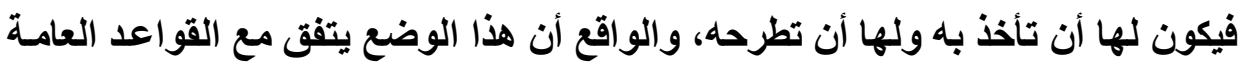

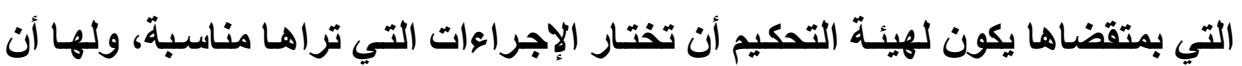

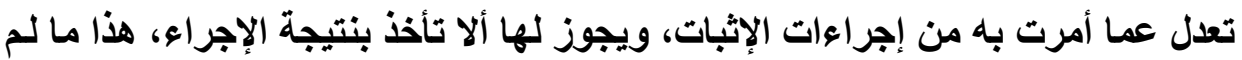
يتفق الأطر اف علي غير ذلك.

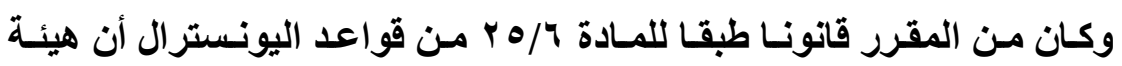

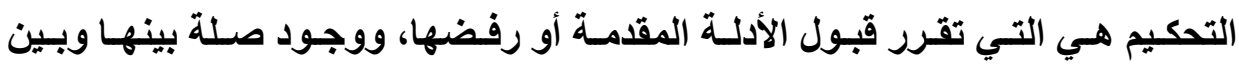
موضوع النزاع أو انتفاء هذه الصلة، وأهمية الاليل المقدم، ومن ثم فإن وسائل الإثبات

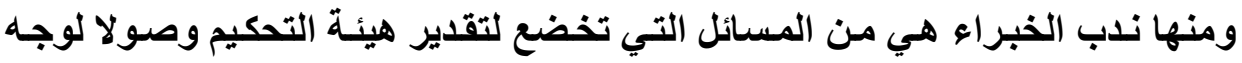
الحقى في الاعوى شأنها شأن المحاكم. هن الديز

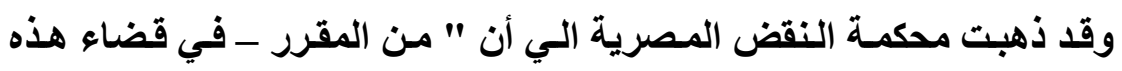

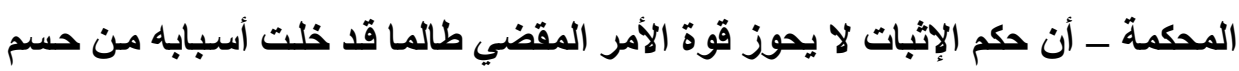

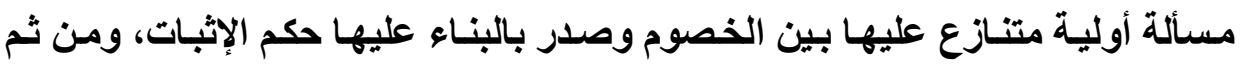

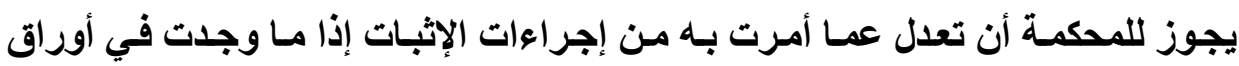

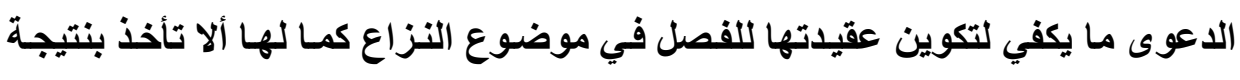
( (1) داسر عبد الهادي مصلحي سلام، أثر الخطأ في إجراءات التحكيم علي حكم التحكيم، المرجع

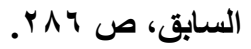


الإجراء بعد تنفيذه، والمشرع وإن تطلب في نص المادة التاسعة من قانون الإثبات بيان أسباب العدول عن إجراء الإثبات في محضر الجلسة، وبيـان أسباب عدم الأخذ بنتيجة

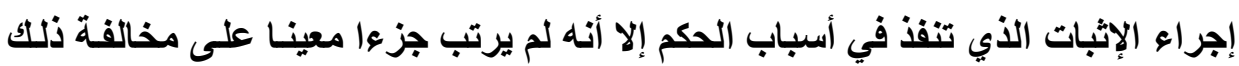
فجاء النص في هذا الثأن تنظيميا، ومن المقرر قانونـا طبقا للمسادة ج/ه ب من قواعد اليونسترال أن هيئة التحكيم هي التي تقرر قبول الأدلة المقدمـة أو رفضها، ووجود صلة بينها وبين موضوع النزاع أو انتفاء هذه الصلة، وأهمية الدليل المقدم، ومن ثم فإن وسائل الإثبات ومنها ندب الخبراء هي من المسائل التي تخضع لتقدير هيئة التحكيم وصولا لوجه الحق في الدعوى شأنها شأن المحاكم. وإذ التزم الحكم المطعون فيه هذا النظر وقضى برفض الدفع المبدي من الطاعنين على سند من أن هيئة التحكيم هي الخبير الأعلى وأنها أفصحت عن سبب عدولها عن حكم ندب الخبير بالاكتفاء بمـا قدم في الدعوى، فضلا عن أن الطاعنين لم يتمسكا ببطلان إجراءات الخصومة لعدم إصدار

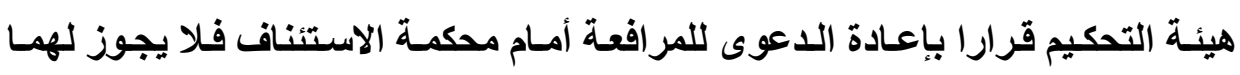
التحدي أمسام محكمة النقض. ومـن ثم فِان النعي عليها بهذا السبب يكون على غير

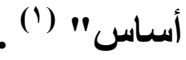

وبالتالي يخضع تقرير الخبير للسلطة التقديرية للمحكم، فعمله لا يعدو أن يكون

عنصرا من عناصر الإثبات الواقعيه في الاعوي، فللمحم سلطة الأخذ بما انتهي إليه الخبير إذا رأي فيه ما يقتعه ويتفق مع وجه الحق في الدعوي، ويقوم علي أسباب لها

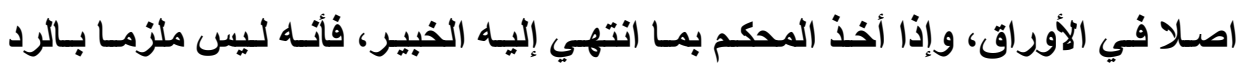
استقلالا علي ما اثير من اعترااضت عليه، إذا في اخذه به محمولا علي أسبابه مـا يفيد 
أنه لم يجد في الاعتراضات الموجهة إليه ما يستحق الرد عليها مما تضمنه التقرير (')

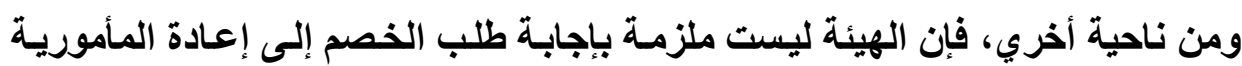

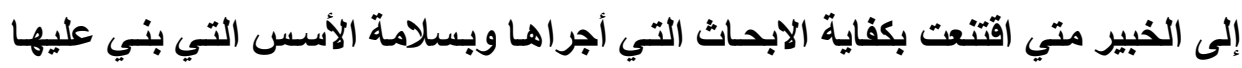
رأية(") يجور لأي من الأطراف أن يستعين برأي خبير استثاري يستند إلى رأيه الفني

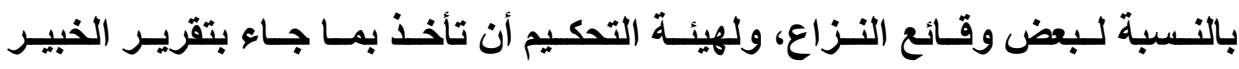

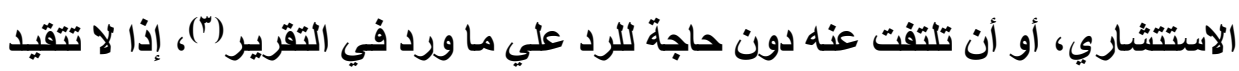

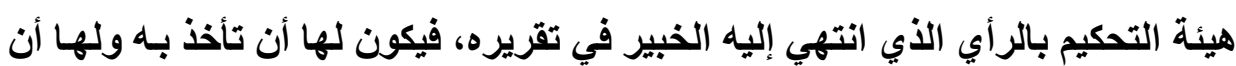

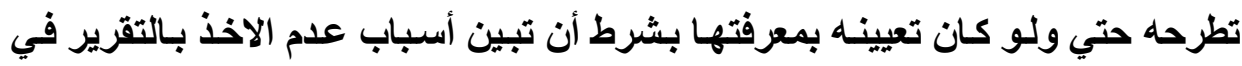

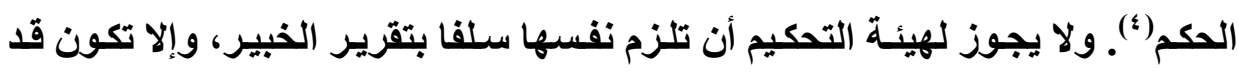

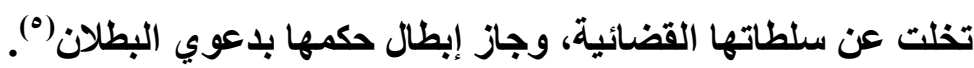

\section{ه. المكم الخبير والعلم الشخصي}

وقد يختار الخصوم المحكم علي أسـاس خبرتهـ في مجال النزاع محل اتفـاق التحكيم(")، وهنا يثور التساؤل عن مدي استعانة المحكم الخبير بطلهـ الثخصي في فئي

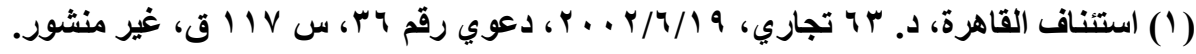

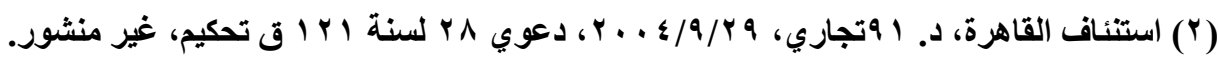

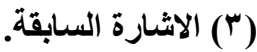

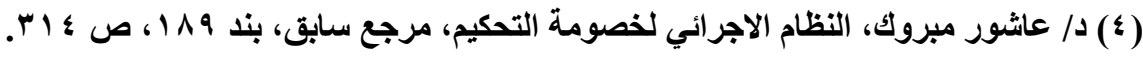

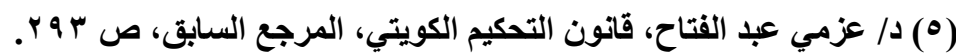

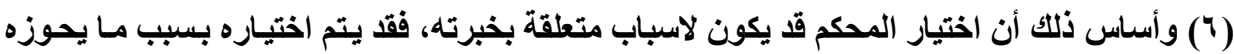

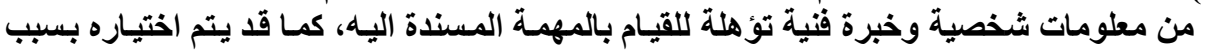

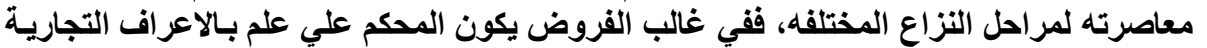

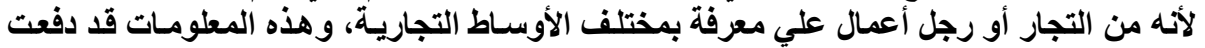

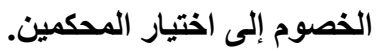


طبقا للقواعد العامة و إعمالا لمبدأ الحياد، فلا يجوز للقاضي أن يحكم بمقضي علمه الثخصي"(')، بل يجب أن يؤسس عمله علي أقوال التي سمعها والمستندات التي قدمت في الخصومة، فهل ينطبق هذا المبدأ علي المحكم كما هو الحال بالنسبة للقاضي؟ أم يجوز للمحكم أن يبدي رأيه الثخصي في مسألة فنية معينة مستعملا معلوماته الفنية لترجيح رأي أحد الطرفين علي الآخر؟

ذهب جانب من الفقـه إلى أنـه لا يجوز للمحكم أن يبنـي حكمـه علـي معلوماتـهـ الخاصة إلا بعد تمكين الخصوم من الإطلاع عليها وإتاحة الفرصه أمسامهم للرد عليها، احتراما لحقوق الدفاع ومبدأ المواجهة(؟). وبالتالي إذا بني المحكم حكمه علي معلومـات فنية تقنية يلم بها المحكم، بحكم بتخصصه القني(")، فإن يكون قد أخل ليس فقط بمبدأ

(1) د/ نبيل عمر، امتتاع القاضي عن القضاء بعلمه الثخصي، المرجع السابق، ص • ؛ وما بعدها.

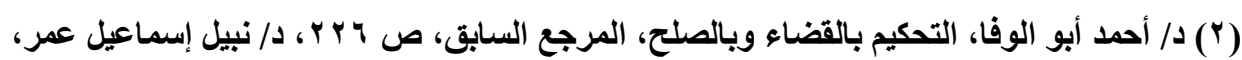

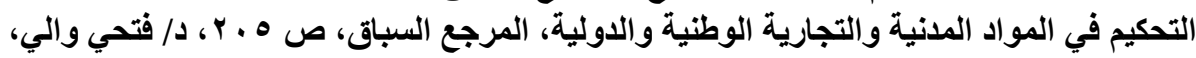

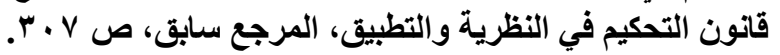

CA Paris, 3 dec. 2002, Rev. arb., 2003, p. 931.

CA Paris, 2 fev. 1988, op. cit., p. 62, note Couchez, Cass. Civ., 2e, 10 nov. 1998, op. cit.,p. 1.S.

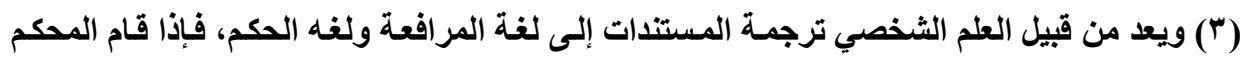

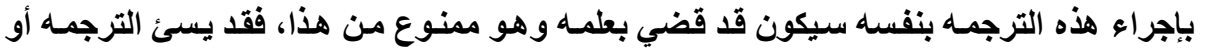

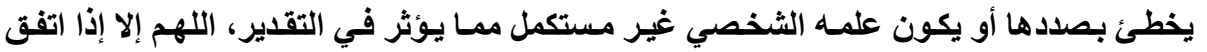

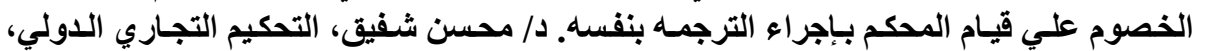

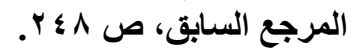

CA Paris, 2 fev. 1988, op. cit., p. 62, note Couchez, Cass. Civ., 2e, 10 nov. 1998, op. cit.,p. 1.S. 
الحيدة، ولكن بحقوق الدفاع ومبدأ المواجهةة(')، وخـالف حدود ولأيته، ممـا يعرض الحكم بالبطلان طبقا لنص المادة به تحكيم.

وإذا كانت هيئة التحكيم هي التي تقدر شـأنها شـأن المحكمة، مدي الحاجة إلى الاستعانة بخبير، فأنه إذا تعلق الأمر بمسائل فنية لا تعتبر من قبيل المعلومـات العامـة

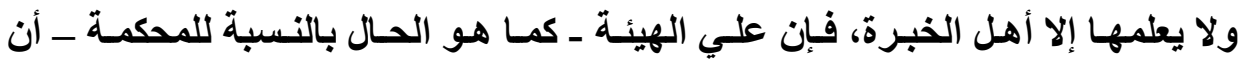
تفصح في حكمها عن مصدر علمها بها من أوراق القضية وإلا اعتبر حكمها قضاء بعلمها الشخصي غبر جائز، ويكون الحكم قد استتد إلى واقعة لم تثبت بطرق الإثبات

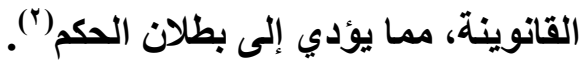

في الواقع نري أنسه لا يجوز أن يستتد المحكم في حكمـه أو يكون عقيدته بنـاء علـي معلومـات خـارج نطـاق الخصومه وصلت إلـى علمـه مـن غير طريتق الخصوم، وبالتالي يجب لاعتبار المحكم الذي قضي بعلمه الشخصي أن تكون المعلومات المتحصل عليهـا لا صـلة للخـصوم بهـا، ولـم تقـــم مـنهم ولـم يقـع عليهـا إثبــات، ولــم تطرح للمناقشة)(")

ولكن هل يعتبر من قبيل العلم الثخصي ما يمارسه المحكم بنفسه من إجراءات الكثف عن الحقيقةٌ ويقصد بذلك ما يجمعه المحكم بنفسه من أدلة إثبات خـارج رقابـة

(1) CA Paris, 10 nouv. 1989, op. cit., p. 651, obs. Pellerin, CA paris, 11 juill. 1991, op. cit., p. 671, obs. Loquin, CA Paris, 13 mars 1992, op. cit., p. 107, obs. Jarrosson, CA Paris, 13 nouv. 1997, op. cit., p. 719, obs. Derains.

(ץ) د/ فتحي والي، التحكيم في المنازعات الوطنية والتجارية الدولية، علمـا وعملا، المرجع السابق، . $\leqslant \wedge \wedge$ ص

CA Paris, 13 mars 1973, op. cit., p.176.

(Y) د/ طلعت محمد دويدار، ضمانات التقاضي في خصومة التحكيم، المرجع السابق، ص ب ا ץ.

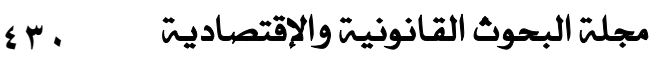


الأطراف، في الواقع لا يجوز للمحكم الحصول علي معلومسات مـن الغير بأسـاليب لا يعلمها الخصوم، كالاستفسار في السوق علي أسباب الخـلاف بينهم، ولكن مـا يقوم بـه المحكم أثناء المعأينة، ويعتمـد علي مـا تحقق منـه بنفسه مـن معلومـات، فإنمـا يمـارس سلطته التي تسمح له بالقيام بمثل هذا الإجراء، وبالتالي فلا يعد ما يحصل عيه إثر هذا الإجراء علما شخصيا، ولكن يجب علي المحكم تمكين الخصوم من العلم بـه، تحقيقا

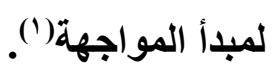

ومع ذلك يمكن للمحمم أن يحكم استندا إلى الوقائع العامة التي تكتسب نوعا من

الثهرة، ومن أمثلة ذلك انخفاض قيمة البترول في فترة معينة، فهذه الوقائع لا تعد من قبيل العلم الثخصي. وهذا ما أكدته محكمة النقض المصرية علي اعتبار أنها معلومـات يفترض في الكافة الالمام بهاب() ويرجع أساس عدم الحكم بمقتضي العلم الشخصي للمحكم إلى الآتي: الأساس الأول: التزام المحكم بالحيـاد إزاء التشييل البنـاء الواقعي للخصومة(")، فهو يقع علي عاتق الخصوم. ولا يجوز للمحم أن يتخذ مبادرة في هذا المجال. وذلك

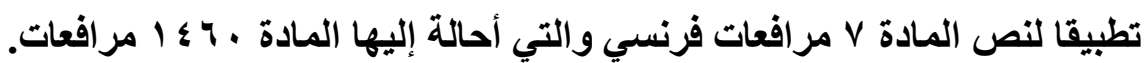

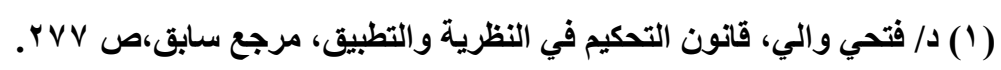

CA Paris, 2 fev. 1988, op. cit., p. 62, note Couchez, Cass. Civ., 2e, 10 nov. 1998 op. cit.,p. 1.S.

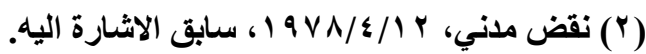

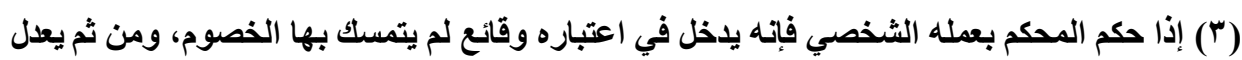

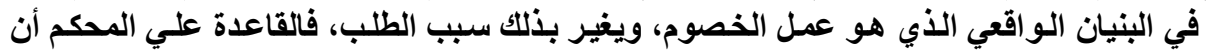

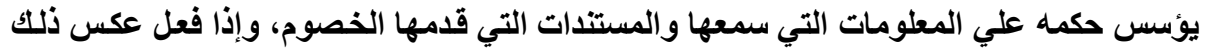
فإنه يكون قد حكم بمقتضي علمه الثخطي. 
الأسساس الثـاني: التزام المحكم بمواجهة الخصوم بالوقـائع وأن يسمح لهم

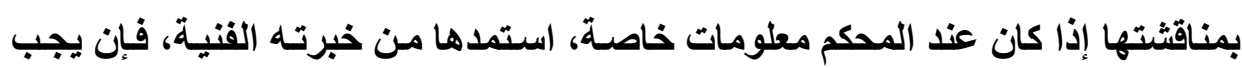

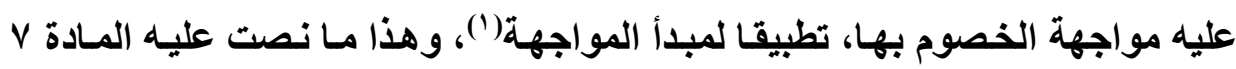
مرافعات فرنسي. والتي نصت علي أنه يجب علي المحكم ألا يؤسس حكمه علي وقائع

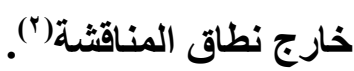

وقد قتضت محكمة استنئاف بـاريس(") ببطلان حم التحكيم لعدم إعمـال مبدأ

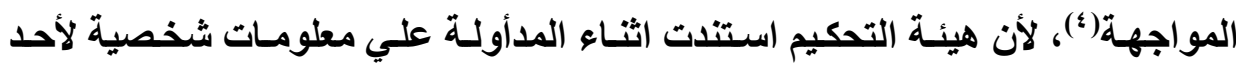
أعضائها تحصل عليها أثناء ممارسته لنثاطة المهني، دون أن تطرح هيئة التحكيم هذه

(1) CA Paris, 2 fev. 1988, op. cit., p. 62, note Couchez, Cass. Civ., 2e, 10 nov. 1998, op. cit.,p. 1.S.

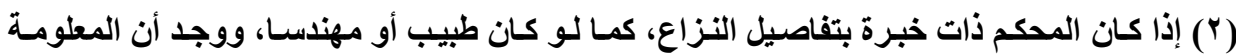

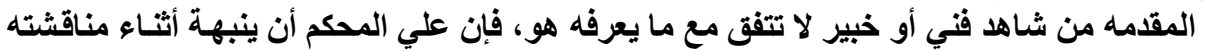

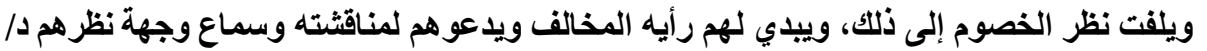

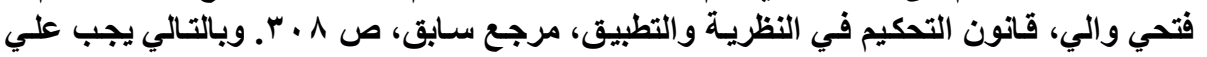

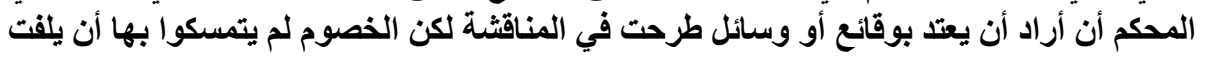

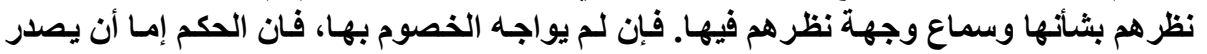

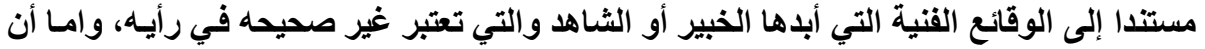

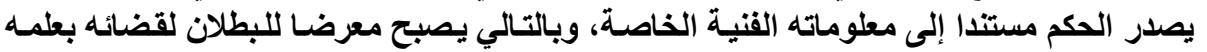
الثخصي الذي لم يكن محل مناقشة.

CA Paris, 13 mars 1973, op. cit., p.176.

(3) CA Paris 12 mars 1963, Rev. Arb., 1963, p. 21; CA Paris, 10 juin 1995, Rev. Arb., 1995, p. 440.

(4) CA Paris, 2 fev. 1988, op. cit., p. 62, note Couchez, Cass. Civ., 2e, 10 nov. 1998, op. cit.,p. 1.S. CA Paris,3 dec. 2002, op. cit., p. 931. 
المطومسات للمناقشة والرد عليها من جانب أطراف الخصومة، بـالرغم من التـأثير الواضح لهذه المعلومات علي القرار الذي أصدرته الهيئة'(') ؟- الاستجواب واليسين

القاعدة أن وسائل الإثبات المقبولة أمسام القضاء تكون مقبولية أمسام المحكم، إلا أن هناك بعض وسائل إثبات أثثار اختلاف الفقه حول سلطة المحكم في استعمال بعضها كتوجيه اليمين. سنثير إلى استجواب الخصوم وتوجيه اليمين، وذلك في النقاط الآتية:

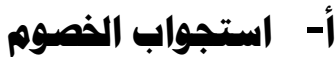

يعتبر الاستجواب من طرق الإثبات التي يمكن لهيئة التحكيم أن تلجأ إليها لحسم بعض نقاط الخلاف عند التحقيق في خصومة التحكيم، ومقتضي الاستجواب أن تقوم

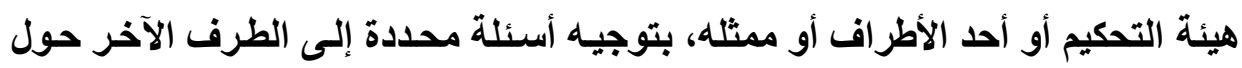

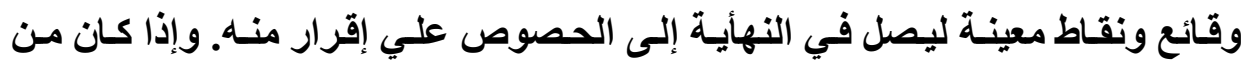
المككن لهيئة التحكيم أن تتصدي لموضوع النزاع وإصدار الحكم الفاصل فيه دون توقف علي حضور الخصوم، وذلك للمرونه والسرعة التي تتسم بها خصومة التهو التحكيم،

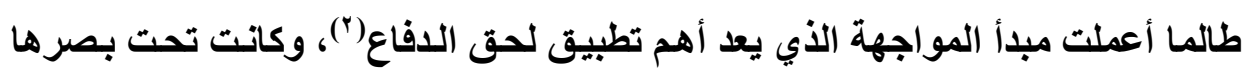
من المستتدات ما يكفي لتكوين عقيدتها وإصدار الحكم الفاصل في النزاع، ويكون ذلك التكات

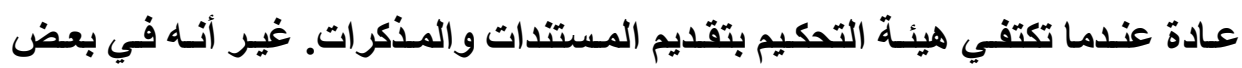

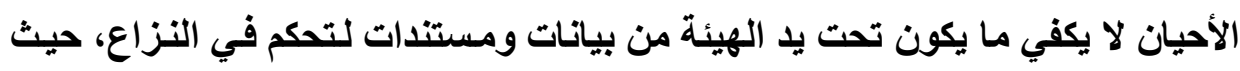

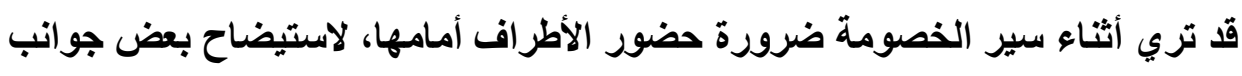

(1) CA Paris, 13 mars 1973, op. cit., p.176.

(ץ) د/ سامي محسن حسين السري، بعض الجوانب في القواعد الإجر ائية المنظمة للتحكيم التجاري

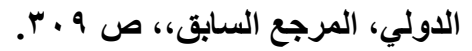


النزاع، بل كذلك لاستكمال تقديم مستندات والأوراق المتعلقة بالخصومة، وبالتالي يجب عليها إخطار الخصوم جميعـا بمواعيد الجلسات كي يتمكنوا مـن المثول أمامهـا في الزمان والمكان المحددين لذلك. وهذا مـا نصت عليه المـادة بr تحكيم. كمـا أن بعض مراكز التحكيم تؤكد علي ضرورة مراعـاة مواعيد المسافة الواجبه كمركز أبو ظبي

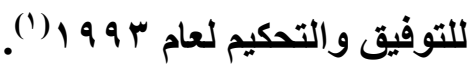

والاسـتجواب أمسر تقـرر إجـراءه هيئة التحكيم مـن تلقـاء نفسها إن رات فيسه ضرورة لإظهار الحقيقة، كمـا يمكن أن يتم بنـاء علـي طلب أحد الأطراف، وفي هذه الحالة الاخيرة يعتين علي طالب الاستجواب أن يعرض علي هيئة التحكيم المسائل التي سيستجوب فيها خصمه لتقدر مدي تعلقها باللدعوي ومدي كونها منتجـة فيها مـن عدمها، وأن يكون الاستجواب صدر في أمور يكون جائزا فيها، أي في أمور يجوز فيها التـــازل أو الـصلح أو إقامـة الــليل عليهـا، وعلـي الوقـائع المنتجـة والجـائز إثباتهـا بخصوصها(؟). ولهيئة التحكيم أن تعدل عن إجراء الاستجواب إذا كان قد توفر لها من

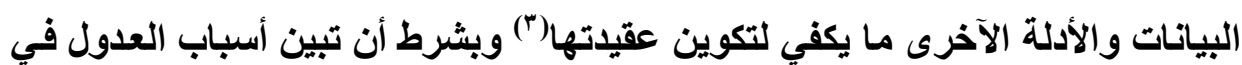

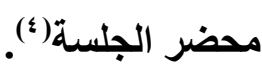

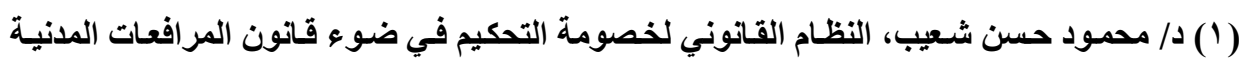

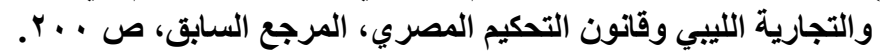

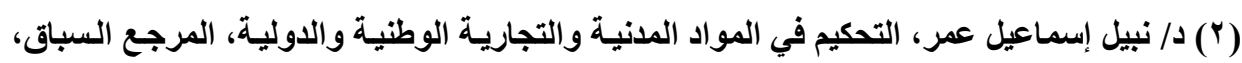

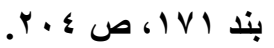

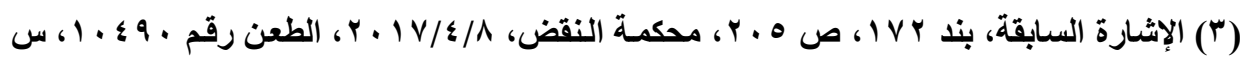

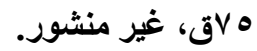

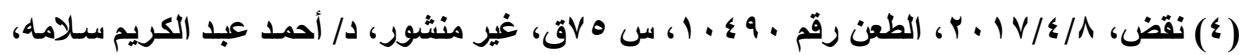

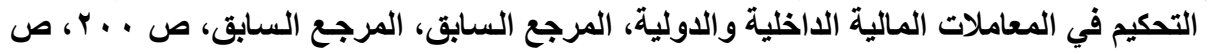

CA Paris, 27 fev. 1964, op. cit., p. 49 
ويشترط للجـوع هيئة التحكيم إلى استجواب الخصوم بالـات أن تـري لـلتك

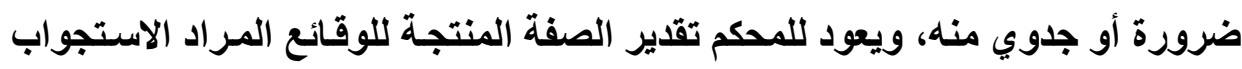

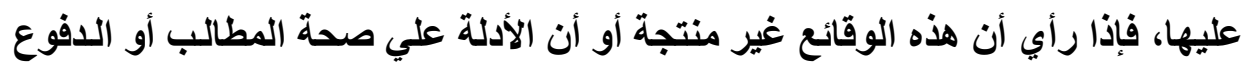

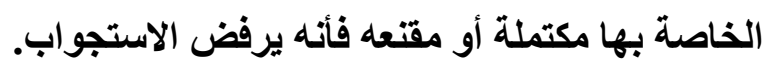

وإذا قرر هيئة التحكيم استجواب الخصوم فـلا تلتـزم بالقواعد المقررة أمسام

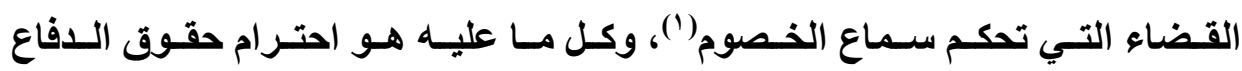

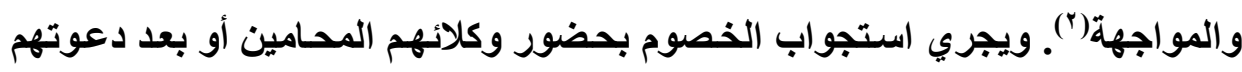

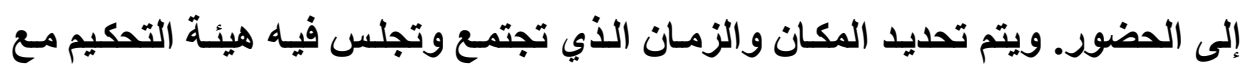
الخصوم أو ممثليهم، وذلك لاستجوابهم، وذلتك في الزمـان والمكان المحدد في اتفـاق الأطراف أو الذي تحدده هيئة التحكيم(").

ويجب أن تتم إجراءات الاستجواب بحضور كل اعضاء هيئة التحكيم، مـا لم أم

يفوض أحدهم في إجراء الاستجواب، وكان ذلك غير مخالف لاتفاق التحكيم واشير إليه

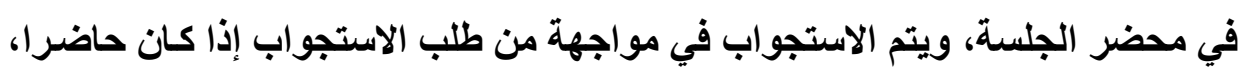

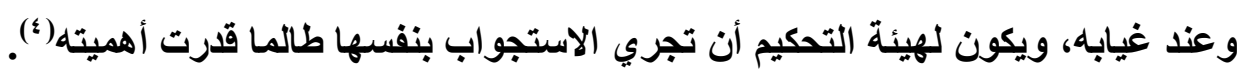

(1) CA Paris, 15 mai 1984, op. cit., p. 287.

(2) CA Paris, 2 fev. 1988, op. cit., p. 62, note Couchez, Cass. Civ., 2e, 10 nov. 1998, op. cit.,p. 1.S.,CA Paris, 10 nouv. 1989, op. cit., p. 651, obs. Pellerin, CA paris, 11 juill. 1991, op. cit., p. 671, obs. Loquin, CA Paris, 13 mars 1992, Rev. Arb. 1993, p. 107, obs. Jarrosson, CA Paris, 13 nouv. 1997, op. cit., p. 719, obs. Derains.

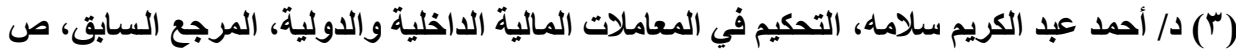

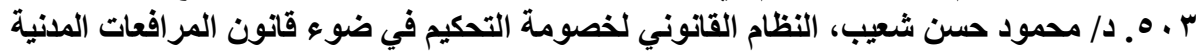

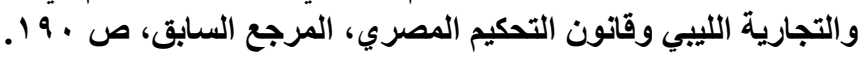

(4) J. ROBERT, l'arbitrage droit interne et droit international privé, op. cit., p. 156. 
ويعـد محضر ا بالاسـئلة المطروحـة عليهم وأجـابتهم معسا، ويوقِع عليـه المحكـون والخصوم الذين تم استجوابهم، وإذا امتتع المستجوب عن الإجابه، أو عن التوقيع، فأنه

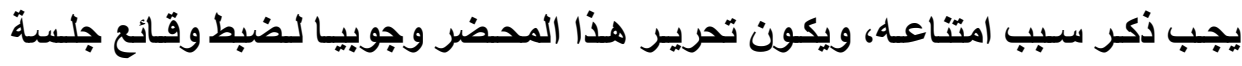
الاستجواب بكاملها، نظر الما يترتب علي بعضها من نتائج هامة للحكم في النزاع. لأن

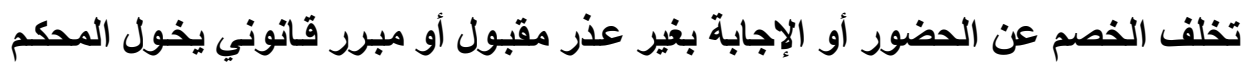

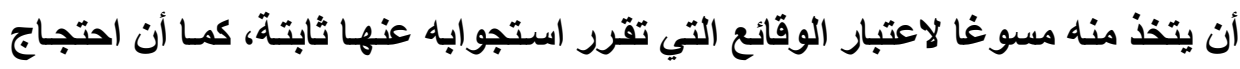

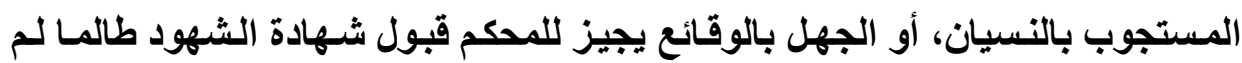
يرفض الخصم الإجابة(').

ونادرا ما يلجأ المحكم إلى استدعاء الخصوم لاستجوابهم، لأن الخصوم عـادة

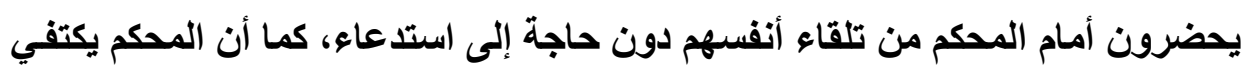

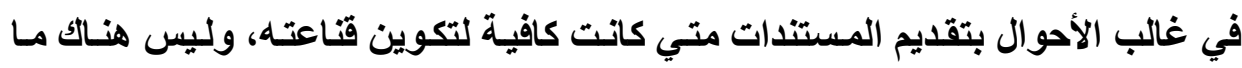

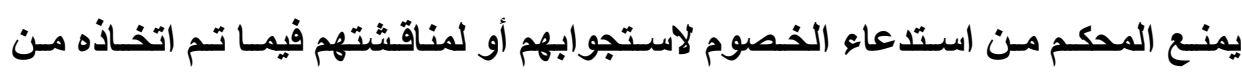

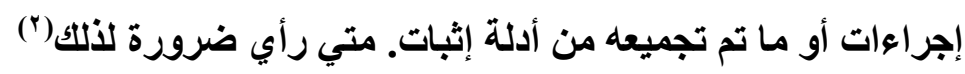

إذا كان الهدف من حضور الخصوم أمسام هيئة التحكيم، هو مساعدتها للوقوف

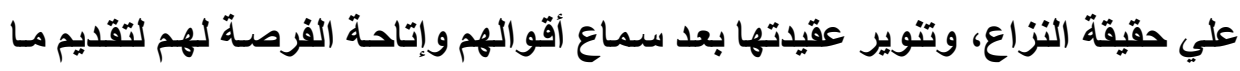
لايهم من ملاحظات أو مستندات تفيد للفصل في الخصومة، فبان تخلفهم جميعا يحول

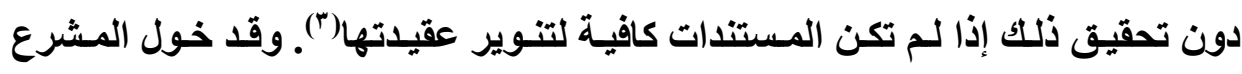
المصري هيئة التحكيم في حالـة غيـاب الخصوم أن تسير في الإجراعت إذا كـان ذلك

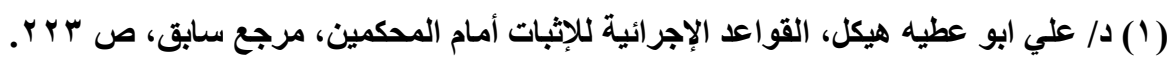

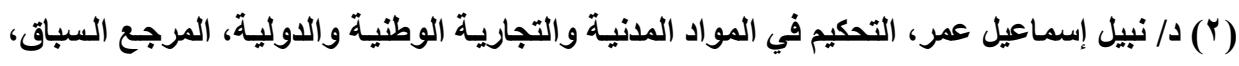

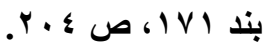

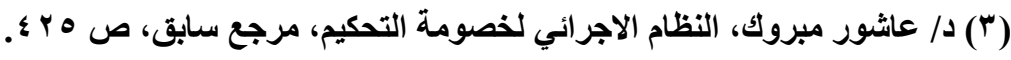


ممكنا أو إنهاء الإجراءات ما لم يتفق الخصوم علي غير ذلك(')، فيمكن للهيئة أن تعتمد

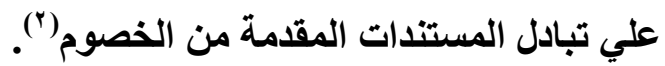

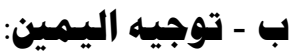

يمكن للقاضي طبقا للقواعد العامـة أن يجـأ الي تحليف أحد الخصوم يمنـا طبقا لديانته، كما يمكن لأحد الخصوم أن يطلب من القاضي تحليف الخصم اليمين، ويسمي

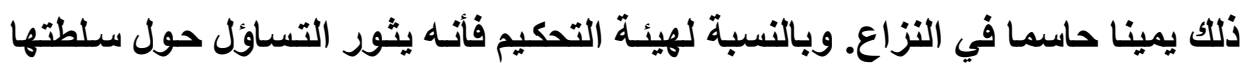
في توجيهها إلى أحد الخصوم اليمين؟ في الواقع لقد اختلف الفقة حول مدي سلطة هيئة التحكيم في توجيهها اليمين إلى أحد الخصوم، وانقسم الفقه إلى اتجاهات الآتية:

\section{الاتجاه الأول("): لا تملك هيئة التمكيم توجيه اليسمين إلى الفموم}

يذهب رأي في الفقه إلى أن هيئة التحكيم لا تملكت سـلطة الأمر التي تخولها

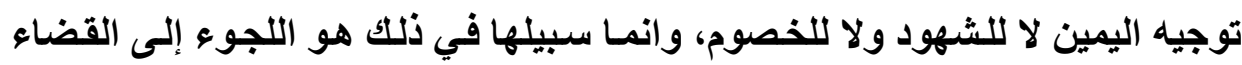

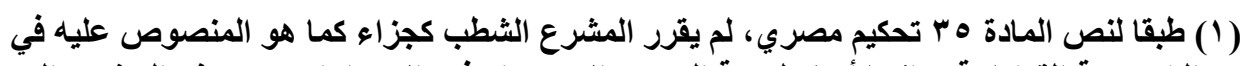

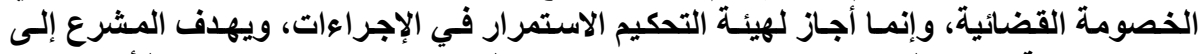

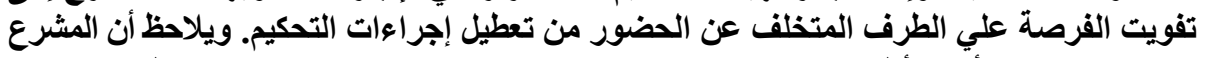

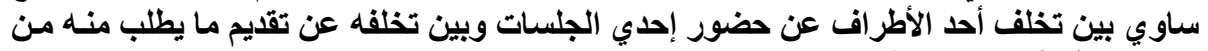

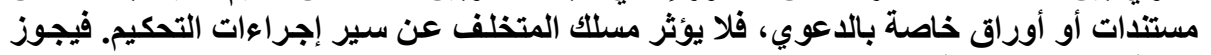

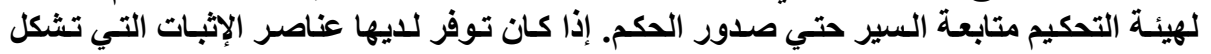

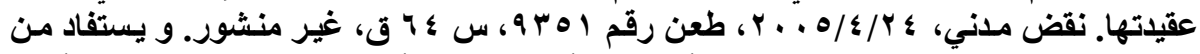

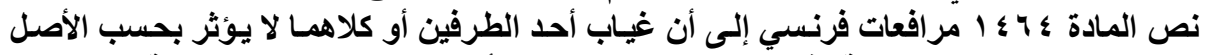

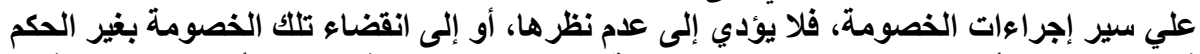

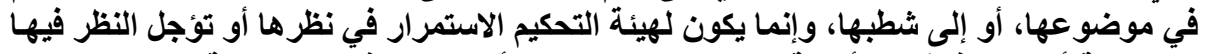

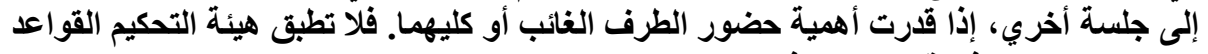

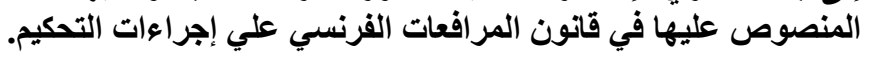

( ( ) CA Paris, 12 juill. 1971, op. cit., p. 74.

(r) د/ نبيل إسماعيل عمر، التحكيم في المواد المدنية والتجارية الوطنية و الدولية،المرجع السباق، بند

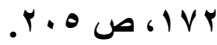


لتوجيهها، ويكون اللجوء إلى القضاء من حق الخصم صاحب المصلحة وحدة في حالة

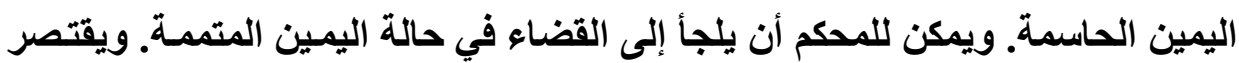

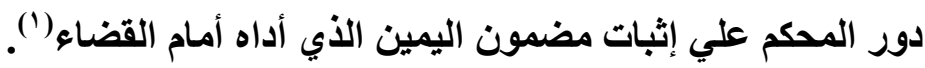

ويستند أنصار هذا الاتجاه إلى المادة بrتحكيم مصري والمادة الج ؛ ا مرافعات

فرنسي، والتي نصت علي أنـه يتم سماع الشهود والخبراء بلدون أداء يمين، وترجع العلة من استبعاد اليمين من مجال التحكيم إلى أنه القانون يحرم شـهادة الزور ويعاقب عليها، في حين أن المحكم لا يملك توقيع عقوبـات علي ذلك. كمـا أن اليمين الحاسمة تؤدي إلى حل النزاع بدلا من حله بطريق التحكيم، وذلك في حالة رفض ادائه أو احالته

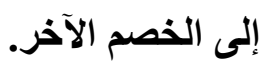

\section{الاتجاه الثاني (ז): يملك المهكم توجيه اليسمين إلى الفموم}

يذهب اتجاه في الفقه إلى أن المحكم يملك من تلقاء نفسه توجيه اليمين المتممـة

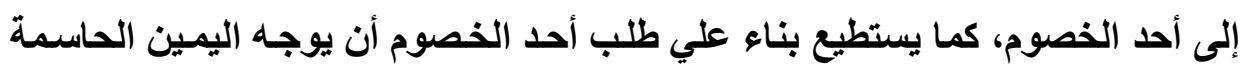
إلى الطرف الآخر(") دون حاجة إلى اللجوء إلى القضاء مـع التزامـه بشروط توجيه اليمين ونتيجة حلفها أو النكول منها أو ردها وكافة القواعد التي تحكمها.

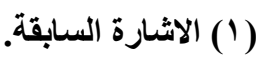

(2) J. ROBERT, l'arbitrage droit interne et droit international privé, op. cit., p. 196, p. 237

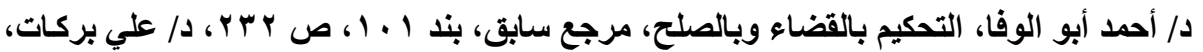

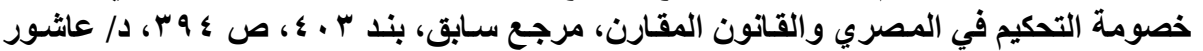

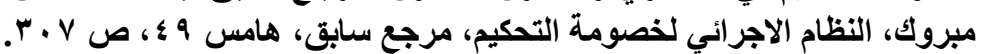

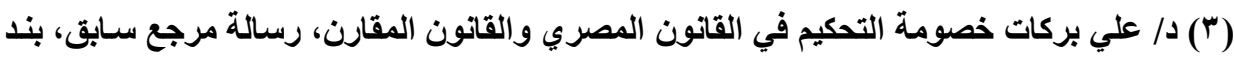


ويرجع ذلك إلى أن اليمين ما هو إلا دليلا من أدلة الإثبات التي ورد النص عليها في القانون ولا يوجد سبب يمنع المحكم من اللجوء إليها، وهو مـا أخذت بـه العديد من المنظمات التحكيمية، حيث أعطت المحكم الحق في اتخـاذ مـا ير اه مناسبا ومنتجا في الاعوي دون تفرقة بين دليل وأخر.

\section{الاتجاه الثالث: تملك هيئة التمكيسمة توجيه اليسمين الحاسمة}

يري جانب من الفقه جواز توجيه اليمين الحاسمة وعدم جواز تقديم اليمسين المتممة(1). وذلك علي أساس أن اليمين الحاسمة مقدمـة من الخصم، ولا يجوز للهيئة من تلقاء نفسها توجية اليمين.

في الواقع نري أنه يجوز لهيئة التحكيم توجيه اليمين إلى أحد الخصوم، وذلك علي أسـاس أن القـانون المـصري و الفرنسـي لـم يمنـع حق هيئة التحكيم في توجيـه اليمين، حيث إن سلطة هيئة التحكيم المقيدة في النص متعلقة بالغير في تحليفة اليمين وليس بـالأطراف، ولو أراد المشرع تقييـ هيئة التحكيم في عدم توجيـه اليمين إلى الخصوم لنص علي ذلك صراحة كما فعل بالنسبة للشهود والخبراء. ونتيجة علي ذلك يتسطيع المحكم أن يوجه اليمين بنوعيها إلى الخصوم بنفس الثروط المطبقة أمام القاضي، دون حاجة إلى اللجوء إلى القضاء، مـا لم يكن المحكم مفوضا بالصلح، فيعفي من تطبيق القواعد المطبقة أمام القضاء.

\section{ه- القرائن والإقرار}

هناك طرق إثبات أخري مثل القرائن والإقرار الذي يمكن لهيئة التحكيم أن تلجـأ إليه، وذلك لما يتمتع به التحكيم من مرونه مصدرها هيمنة إرادة الأطر اف علي مختلف

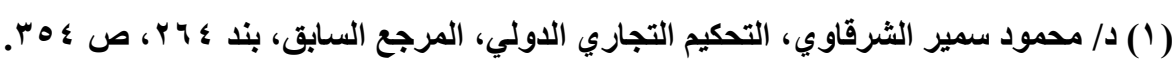


مراحل عملية التحكيم، ولهيئة التحكيم السلطة التقليرية في تقدير مدي اللجوء إلى الدليل وأهيته في إظهار والوصول إلى الحقيقة. سنثير إلى القرائن، ثم الإقرار، وذلك في النقاط الآتية: أ- القرائن تتنوع القرائن إلى قرائن تحكيمية وقرائن قانونية، وذلك علي النحو التالي:

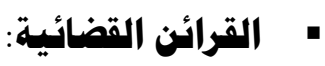

في الواقع من أدلة الإثبات القرائن القضائية، وهي تلكت التي يستتبطها القاضي من ظروف الدعوى وملابستها بمـا له سلطة التقدير، فلـه أن يختار واقعة معلومـة ثم التم يستال بها على الواقعة المراد إثباتها. ونري أن هذه القرائن يمكن للمحكم أن يستند

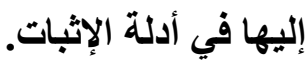

لا شلك أن للمحكم سلطة تقديرية واسعة فى استتباط القرائن التحكيمية، فللمكم سلطة مطلقة في اختيار أية واقعة ثابتة في الدعوى لكى يستنبط منها القرينة، فقد يقتع بقرينة وأحدة قوية الدلالة وقد لا يقتنع بقرائن متعددة ضعيفة الدالالة. ولا يوجد رقابة علي سلطة المحكم في القرائن، وذلك لأن أسباب الطعن بالبطلان منصوص علئهانيا علي سبيل الحصر، وليس منها مـا يتعلق بمراقبة هيئة التحكيم في استتباط القرائن

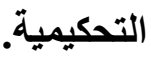

وبالتـالي لهيئسة التحكيم سـلطة واسـعة في تقدير الوقـائع، والاعتمـاد عليها

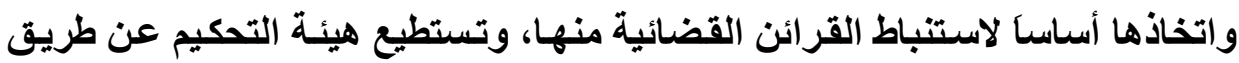
الاستتباط العقلي أن تستلال على الواقعة المطلوب إثباتها. فاستتباط القرينة التحكيمية متروك إلى حكمة هيئة التحكيم، ويصعب حصر القرائن التحكيمية نظرا لاختلاف الوقائع

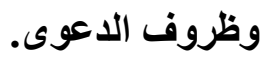




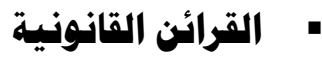

يقصد بالقرينة القانونيـة، افتراض قـانوني يجعل الشيء المحتمل أو المككن

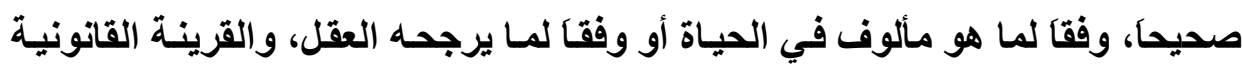
وسيلة من وسائل الصياغة القانونية التي يحاول القانون عن طريقها الإمساك بالواقع بشيء من اليقين والتحديد. فالقرينة القانونية استتباط المشرع لواقعة لم يقم عليها دليل

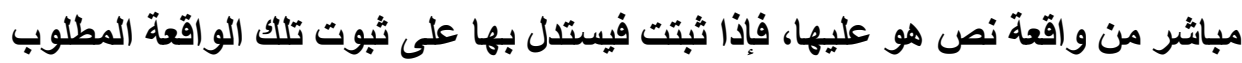

وبالتالي فالقرينة القانونية هى ما يقوم به المشرع نفسه من استخلاص واقعة

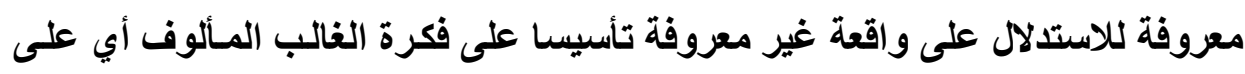

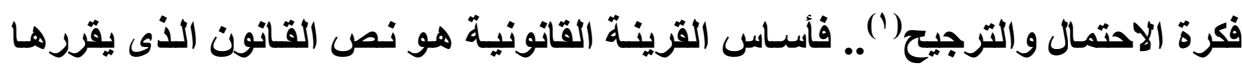

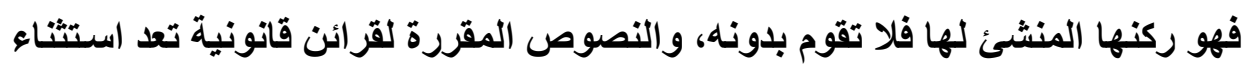

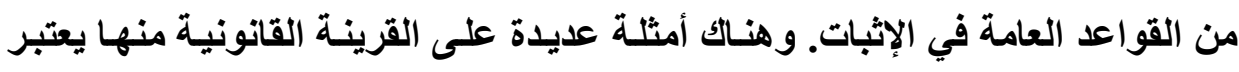

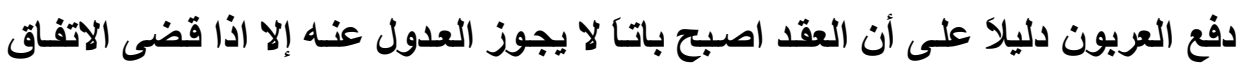

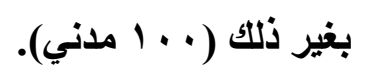

ويجب عدم الخلط بين القرائن واللالائل، فالقرينة هي الصلة الضرورية التي

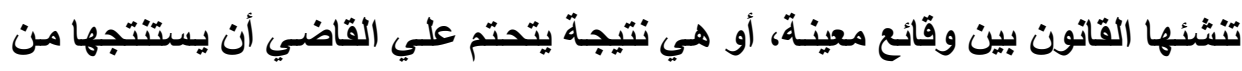

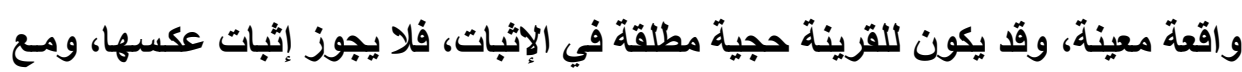
ذلك فيوجد من القرائن مـا يجوز اثبـات عكسها، ويطلق عليها القرائن البسيطة أو

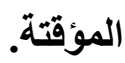


وبالنسبة للدلائل ويطلق عليها أحيانـا القرائن القعلية، تميزا لها عن القرائن

القانونية، وهذه الدلائل لا تـخل تحت حصر ويستتتجها القاضسي من الوقائع الثابتة أمامه. ويوجد فارق أساسي بين القرائن والدلائل، فالأولي تصلح دليلا كاملا، أما الدلائل فلا ترقي إلى مرتبة الاليل. وبالتالي لا يجوز الاستناد عليها وحدها في الإدانه. وقد يقال إن الدلائل تستمد من الوقائع، وإذا جاز أن يكذب الشـاهد فالوقائع لا تكذب، ويرد علي ذلك بأن الوقائع التي تستتتج منها الدلائل قد تكون مُلفقه، كما أن ضعف الدلائل قد يقوم

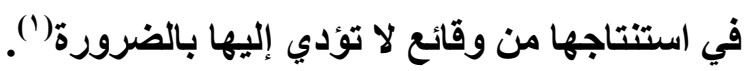

\section{ب-بالإقرار}

يقصد بـالإقرار اعتراف الخصم أمسام هيئة التحكيم بواقعة قانونيـة يـدعى بها

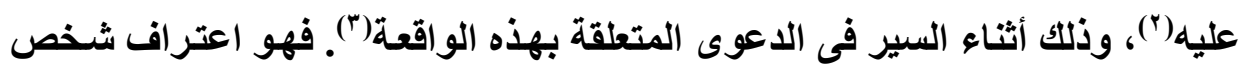
بأمر مدعى عليه به لآخر قصد اعتبار هذا الأمر ثابتا في ذمته واعفاء الآخر من إثباته. والإقرار قد يكون صريحاً عندما ينصب التعبير مباشرة على أمر معين، فيعترف المقر صراحة لصحة الوقائع المنسوبة إليه، وهذا التعبير قد يكون شفهيا أو كتابة، كمـا قد يكون الإقرار ضمنيا، وهذا ما يستدل عليه من موقف الخصم وتصرفاته وأقوالهه من ظروف الاعوى وملابساته. والإقرار الضمني يكون في صورة السكوت. والأصل في

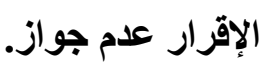

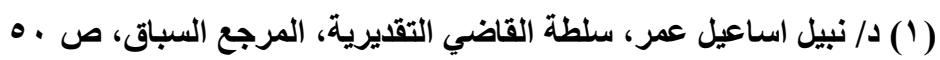

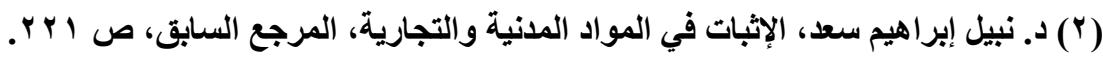
(3) CHEVAILIER J., Cours de droit civil approfondi, la charge de la preuve, Les Cours de droit, 1959, p. 119. 
وقد ذهبت محكمة النقض المصرية إلى أنها يملك المحكم ولو لـم يكن مصالحا، الاعتــاد بـالإقرار القضائي وغيـر القضائي، وفـق الشروط والـضوابط المقررة في القانون. مع مراعاة أن المحكم المصالح يتقيد بـالإقرار القضائي متي توافرت شروطة

القانونية، لأنه يعتبر حجة قاطعة في الاعوي(').

\section{ويشترط لصحة الإقرار:}

$$
\text { أ. أ صدورها عن الخصم. }
$$

ب. أن يصدر الإقرار أمام هيئة التحكيم ج. أن يصدر الإقرار اثثاء سير الدعوى:

الإقرّرار حجـة قاطعـة على المقـر، وقاصـرة عليـه(؟). ولا يتجـزأ الإقـرار على صاحبه، فلا يؤخذ منـه الضار بـه ويترك الصالح لـه بل يؤخذ جملة وأحدة. ومـع ذلك يتجزأ الإقرار إذا انصب على وقائع متعددة، وكان وجود واقعة منهـا لا يستلزم حتمـا وجود الوقائع الآخرى وحدث تـاقض في أقوال المقر، أو إذا تبين للمحكم أن الواقعة الثانية مستحيلة الوقوع أو غير متوقعة الحصول أو الكذب فيها ظاهر (")، ويعد الإقرار حجة بذاته على المقر فلا يكون الخصم الآخر فى حاجة إلى تقديم دليل آخر كما لا يجوز للمقر الرجوع فيه أو العدول عنه الا اذا أثبت الغلط فى الواقع(؛).

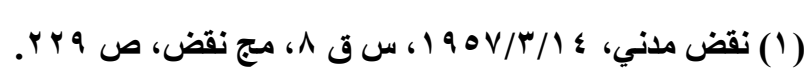

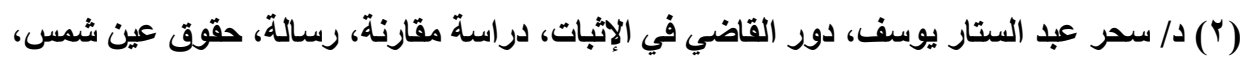


إذا اتخذت إجراعات إثبـات أمسام هيئة التحكيم، وبـلـر مـن جانب الخصوم عنــ

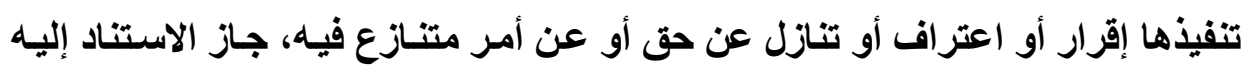
بعدئذ بشرط أن يكون قد ثبت هذا الإقرار في محضر الجلسة ووقع عليه المحكم والمقر

وقد اختلف الرأي في صدد طبيعة الإقرار الذي يتم أمسام هيئة التحكيم، فقيل أنـه يعتر إقرارا قضائيا، استنادا إلى أن المحكم يحل محل القضاء في صدد النزاع المتفق فيـه علـي التحكيم، فيعتبر هو جهة القضاء المقصودة في المـادة ب ـ 1 إثبات مـا دام موضوعه يتصل بذات ما اتفق فيه علي التحكيم ('). ويري جانب من الفقه أن الإقرار لا يعتبر بمثابـة إقرار قضائي، لان المحكم أيـ

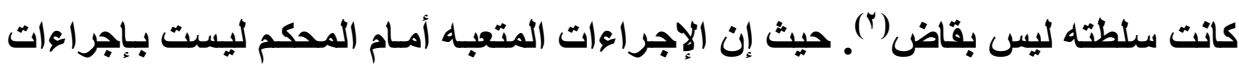

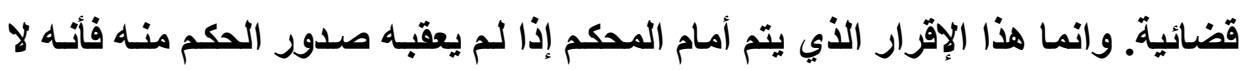
يعتبر إقرارا قضائيا أمام أيه محكمة أو محكم آخر. وإذا نفذت إجراءات إثبات أمر بها المحكم، فأنها لا يعتد بنتيجتها في خصومة أخري أمسام القضاء أو أمسام محكم آخر إلا علي سبيل الاستئناس فقط") ونري أن الإقرار أمسام هيئة التحكيم لـه نفس نتـائج الإقرار أمسام المحكمة، فهو يعد بمثابة إقرار قضائي، فهو يعتبر حجة قاطعة علي المقر عمـلا بالمـادة ؛ ـ أل إثبات، ونري أن الإقرار الذي يصدر من الخصم يمكن الأخذ بـه أمسام أي جهة أخرى سواء

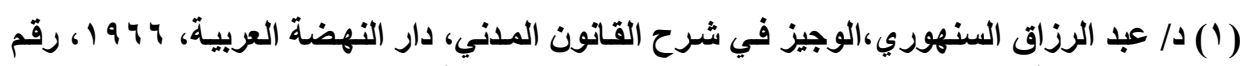

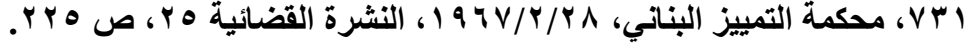

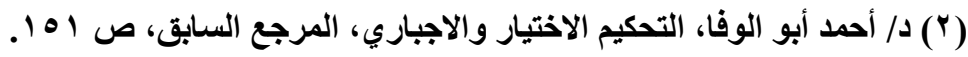

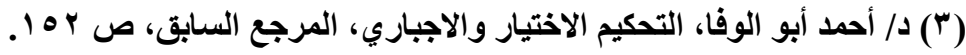


قضائية أو تحكيمية، لأن هيئة التحكيم تعد بمثابة هيئة قضائية، لأن المحكم يقوم بعمل

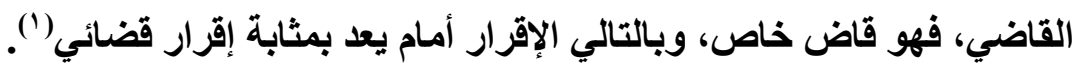

1- سطلة هيئة التمكيم في الفصل في صحة المستندات:

قد يكون مع الخصم دليل كتابي ويقصد بهذا الدليل، المحررات التي يتم بها الإثبات بالكتابة، وهذه الأوراق تتفاوت من حيث حجيتها، وتنقسم إلى أوراق رسمية

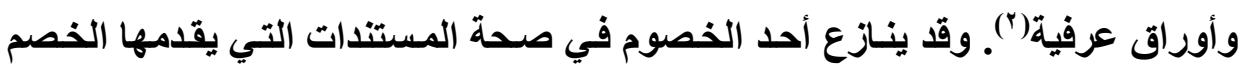

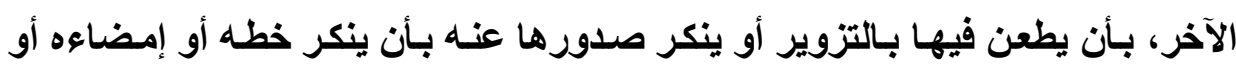

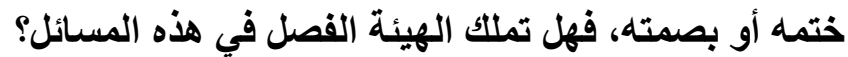
سنثير إلى سلطة هيئة التحكيم في تحقيق الخطوط الأصلية، وسلطتها في الحكم بتزوير الورقة الرسمية، وذلك في النقاط الآتية:

\section{أ- تحقيق الخطوط:}

قد ينكر أحد الأطراف التوقيع علي ورقة عرفية، فهذا الإنكار أو التمسك بجهل التوقيع رخصة مخولة لمن يحتج عليه بورقة عرفية، وذلك لإطراح حجيتها مؤقتا دون

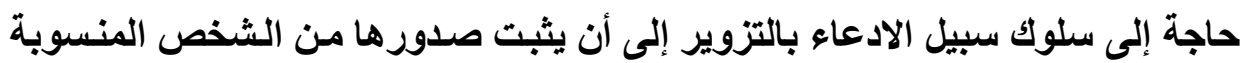

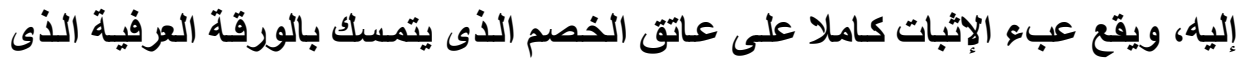

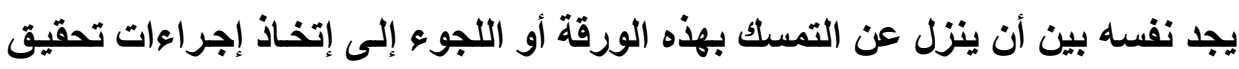

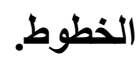

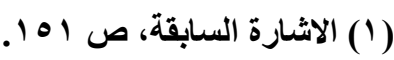

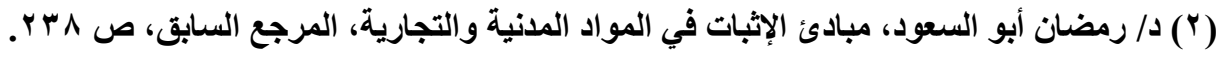


وتحقيق الخطوط قد يبدو في صورة دعوي تسمي دعوي تحقيق الخطوط

الأصلية، وتعد هذه الدعوي من الدعاوي التحفظية الوقائية،يلجأ إليها المستفيل من فن المحرر العرفي ليطمئن إلى إعتراف خصمه بـه مستقبلا أو إلى تحقيق صحة توقيع

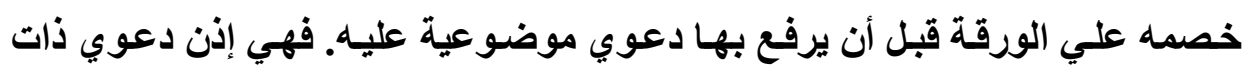
طابع وقائي يلوذ بها المستفيد خشية إنكارها من المنسوب إليه فيمـا بعد، حيث اكتفي المشرع يوجود مصلحة محتملة جديرة بالرعائة. وقد تظهر تحقيق الخطوط في صورة دفع فرعي ينشأ اثنـاء نظر خصومة التحكيم، هي دفع فرعي ينشأ ضمن الدعوي الأصلية بموضوع الحق الذي تشهر عليه الورقة التي حصل الإنكار بشأنها.

ونـري أن اختصاص هيئة التحكيم يكون في حالـة دعوي تحقيـق الخطوط الفرعية، وليس بنظر دعوي تحقيق الخطوط الأصلية، فيمكن اللجوء إلى القضاء لتقديم الـدعوي. وترجـع الحكمـة مـن ذلـك أن دعوي تحقيـق الخطوط الفرعيـة متفرعـة عن الدعوي الأصلية، وهي دفع موضوعي يتصل باتثبات الدعوي ومستثداتها، وبالتـالي فالمحكم يكون مختصا، علي أساس قاعدة قاضي الأصل هو نفسه قاضي الفرع. لقد نصت المادة • إ I من قانون المرافعات الفرنسي علي حق الخصم في أن يطلب من هيئة التحكيم تحقيق الخطوط والفصل في الادعاء بالتزوير محررا عرفيا طبقا

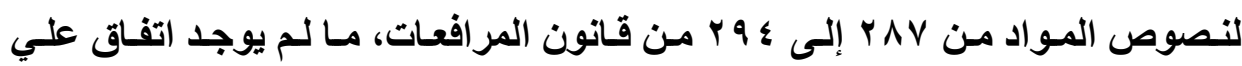
خلاف ذلك. وبالتالي إذا لم يوجد اتفاق علي منع المحكم من الفصل في هذه الدفوع، فإن

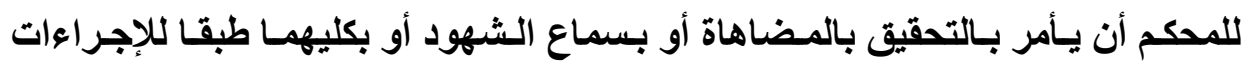
المنصوص عليها في المواد Y IV إلى \& Y مر افعات فرنسي. 
وقد أكلت محكمة النقض الفرنسية هذا المعني بقولها إذا أنكر أحد أطراف التحكيم توقيعه علي أحد الأوراق المقدمه إلى المحكم، فإن المحكم يمكنه الفصل في هذا هذا

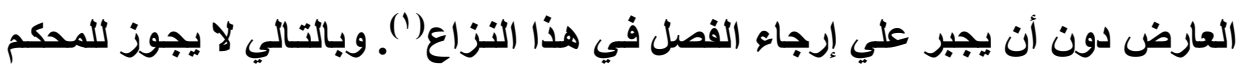

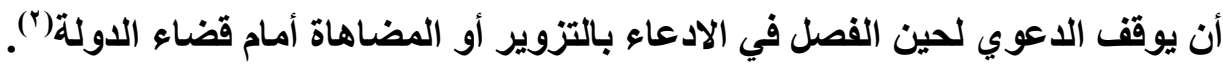
ومن الملاحظ أنه لم يرد نص في قانون التحكيم المصري يعالج هذه المسألة، وهنا يثار التساؤل حول سلطة هيئة التحكيم في الاختصاص بنظر طلب الطعن بالتزوير

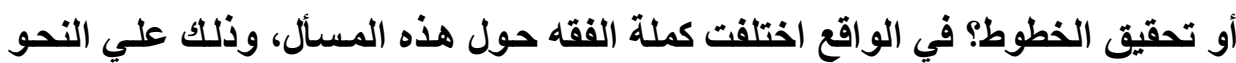

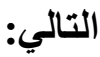

يري جانب من الفقه أن إجراء تحقيق الخطوطو التزوير هو أمر يتصل بأحكام

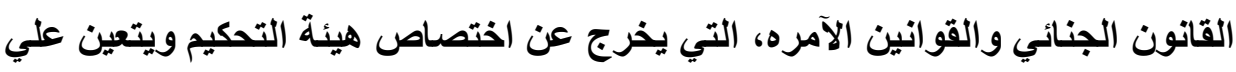

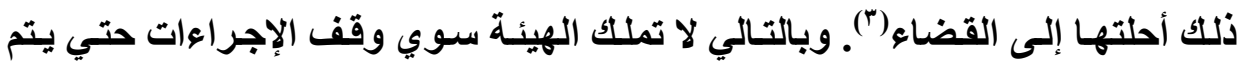

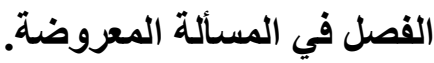
ويذهب جانب آخر من الفقه(") أنه يجب إعطاء المحكم سلطة الآمر بالتحقيق

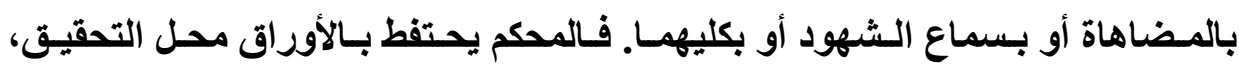

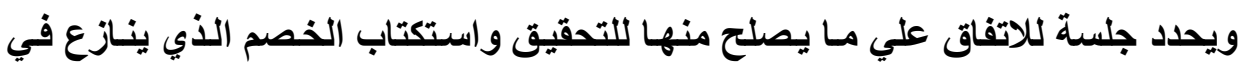

(1) Cass., Req., 5 fév. 1900 , S. 1900 ,1, p. 280

(2) Cass. 1re civ., 27 nov. 1961, Bull. Civ., 1.no 554.

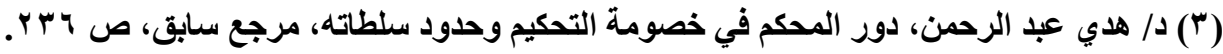

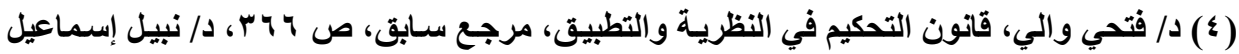

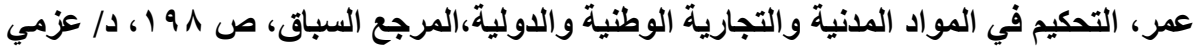

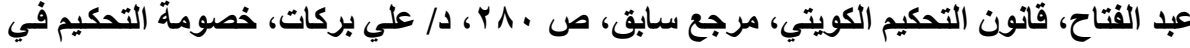

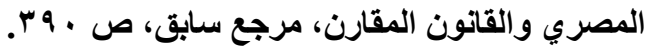


المحرر، فإذا امتتع الخصم عن الحضور بنفسه للاستكتاب بغير عذر مقبول جـاز الحكم

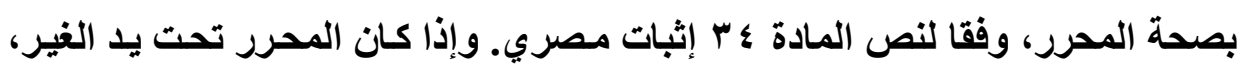
يمكن للمحكم الاستعانة بخبير ليبدي رأيسه في الخطوط محل النزاع، فباذا ثبت صحة المحرر الذي أنكره أحـد الخصوم فـلا يمكن الحكم عليـه بالغرامـة. وإذا كـان المحكم مفوضا بالصلح، فيعفي من اتباع القواعد الورادة في نصوص الإثبات بخصوص هذه

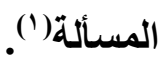

ويري أنصار هذا الاتجاه أن للمحم سلطة مماثلة لقاضي الدولة، بصدد تحقيق الادعاء بصحة الخط المسند إلى الخصم الماثل أمامه، وذلك في السند العرفي الذي أنكر الخصم المنسوب إليه السند خطه أو توقيعه عليه، وله سلطة تقديرية واسعه في إجراء التحقيق أو في النتيجة التي يصل إليها، سواء كاتت نتيجة أيجابية أو سلبية، ولهـ في

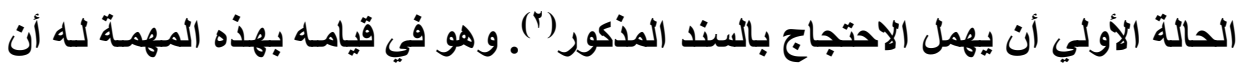

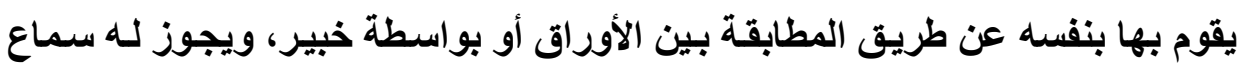

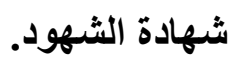
ويري أنصار هذا الاتجـاه أنـه إذا وجد اتفـاق بين الأطراف علي غير ذلك من الإجراءات، كـأن اتفـق الأطراف علـي الفصل في تحقيتق الخطوط مـن قبـل المحكمـة المختصة، ففي هذه الحالة تعبر هذه المسألة أولية يتعين علي المحكم وقف النظر في النزاع حتي الفصل فيها من المحكمة المختصة(").

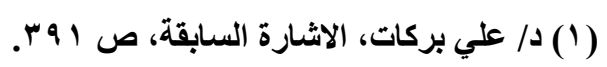

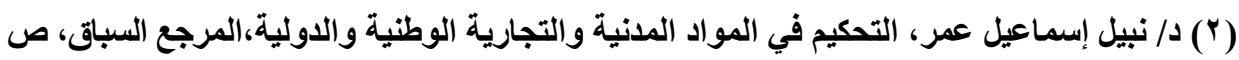
.199

(3) J. ROBERT, l'arbitrage droit interne et droit international privé, op. cit., p. 137, no 161. $=$ 
ومن جانبنا نري أنه يجب التفرفة بين الطعن بالتزوير، وهذا ممنوع علي هيئة التحكيم وذلك طبقا لنص المادة \ ؛ تحكيم، وبين تحقيق الخطوط الأصلية والمضاهاة، فنري أن لهيئة التحكيم سلطة في تحقيق الخطوط الأصلية، وذلك لأن من سلطة المحكم

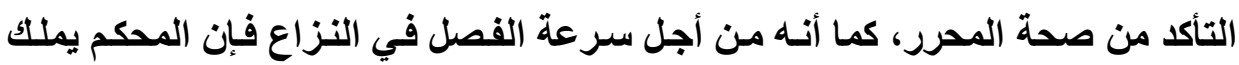
تحقيق الخطوط، وكمـا أنه لا يوجد نص يمنـع من لجوء المحكم إلى تحقيق الخطوط، خاصة بالنسبة للمحرارات العرفية. وبالنسبة للأوراق والمستثات المطلوبة للمضاهاة والموجودة في يد الغير فبان سلطة المحكم في إلزام هذا الأخير بتقديمها إليه لاوجود لها(')، لأنه فاقد لسلطة الأمر، ويمكن لله اللجوء إلى القضاء لتقديم المساعدة في الحصول علي هذه الأوراق، أو يحق لله الانتقال إلى الدوائر الرسمية بنفسه أو بمن يندبه للاطلاع علي الأوراق الموجودة بها، وقد يصطب معه خبيرا إلى هذا المكان للاطلاع دون نقل الأوراق. وبالتالي إذا قدم مستتد عرفي إلى هيئة التحكيم، فجدده الطرف الآخر توقيعه

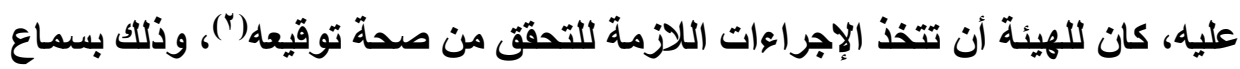
الثهود أو بأن تحيل المستنـ إلى خبير أو أكثر للتحقق من الكتابة أو التوقيع بسماع

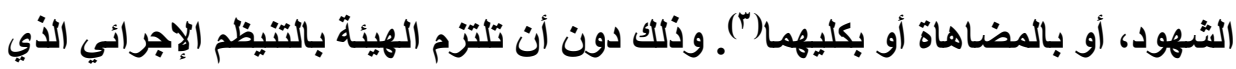

د/ نبيل إسماعيل عمر، التحكيم في المواد المدنية والتجارية الوطنية والدولية،المرجع السباق، ص

B. Moreau, A. Beregoi, et autre, arbitrage commercial, op. cit., no 204.

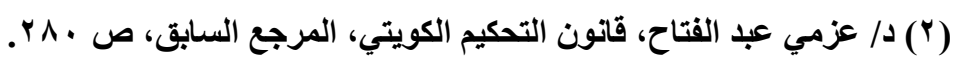

(3) J. ROBERT, l'arbitrage droit interne et droit international privé, op. cit., $\mathbf{p . 1 3 6}$ 
ينص عليه قانون الإثبات وقانون المرافعات بالنسبة لتحقيق الخطوط' ')، مـا لم يوجد اتفاق علي غير ذلك، ويلتزم المحكم بتحدد الأوراق التي تقبل للمضاهاة(؟).

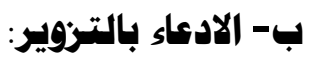

والادعـاء بـالتزوير قد يـرد علـي سـند رسـي ("ا) أو سـند عرفي (؛) مقـدم في

الخصومة ويعمد المحكم أولا إلى الاطلاع علي السند للوقوف علي مدي تأثيره علي

الحكم في الموضـوع المتنـازع عليـهـ وإذا أراد أحـ أطراف الادعـاء بـالتزوير مستنـا

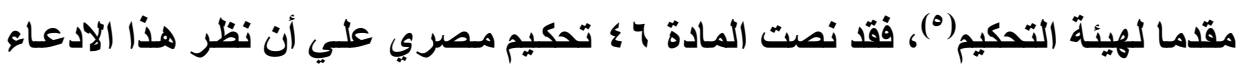
يخرج عن ولأية هيئة التحكيم، وعلي الهيئة إذا وجدت أن المستتد المطعون بتزويره

(1) د/ مصطفي الجمال ود/ عكاشة عبد العال، التحكيم في العلاقات الخاصة الدولية والداخلية، المرجع

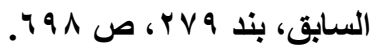

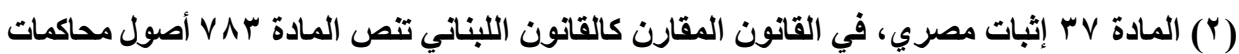

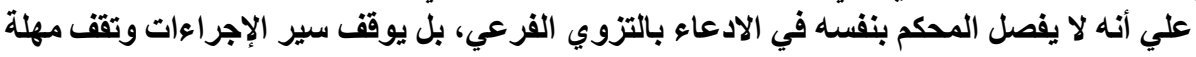

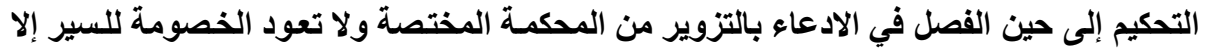
بعد تبليغ المحكمين بالحكم الصادر في التزوين التاءير.

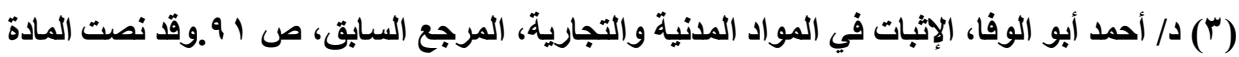

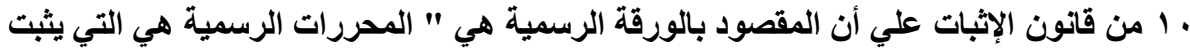

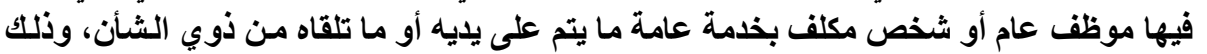

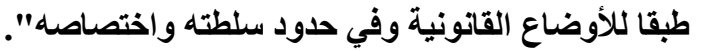

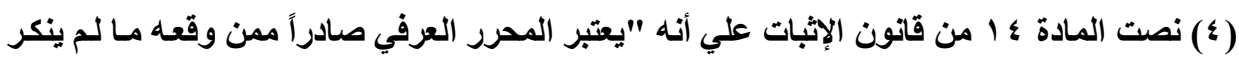

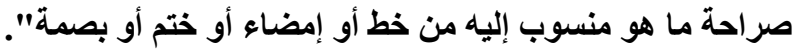

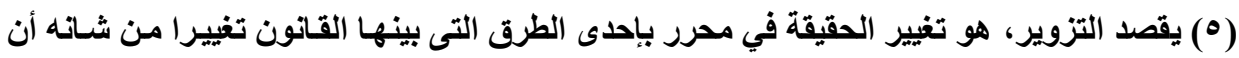

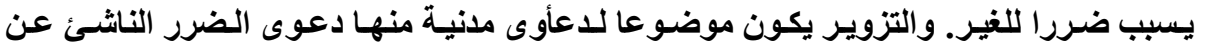

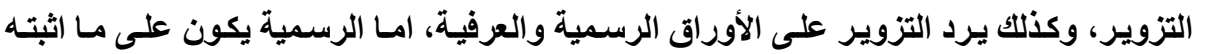

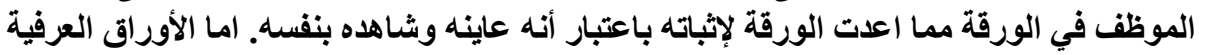

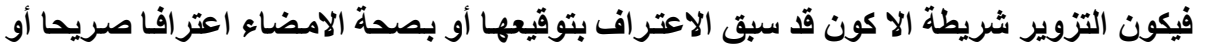
ضمنيا أو الحكم بصحتها بعد تحقيق أو دون تحقيق. 
لازم للفصل في موضوع النزاع، ولهذه المحررات أثر حاسم وهام للفصل في النزاع، يجب عليها أن توقف خصومة التحكيم حتي يصدر حكم نهائي من المحكمة المختصة

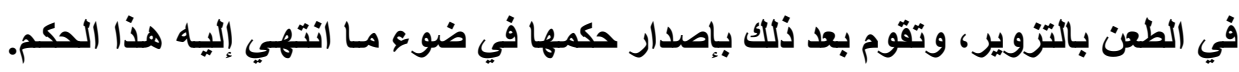

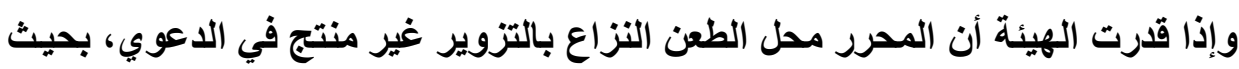

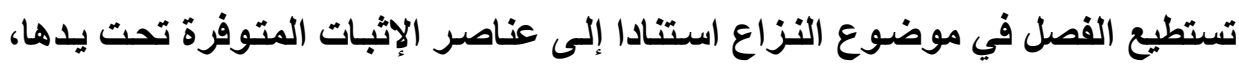

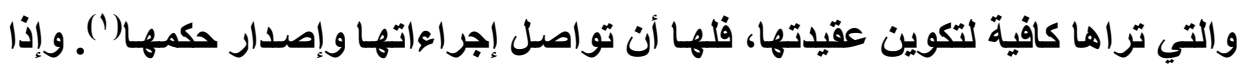

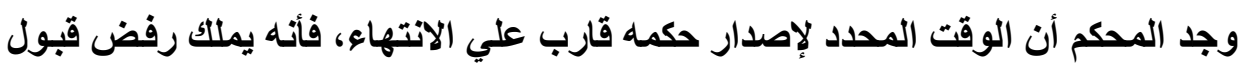

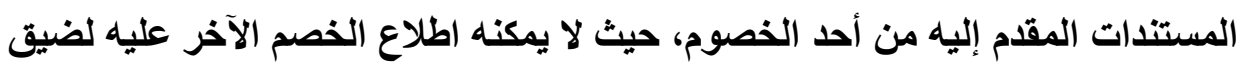

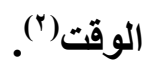

والدفع بالتزوير يكون في شكل طلب عارض أثناء سير خصومة التحكيم، وقد

يتم هذا الاعتراض بصورة مبتدأة أمسام القضاء، وفي الحسالتين تقوم المسئولية التي

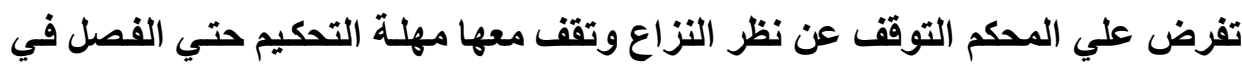
هذا الادعاء، ويشترط طبقا لنص المادة 4 ك تحكيم أن يكون هذا المحرر لازمـا للفصل

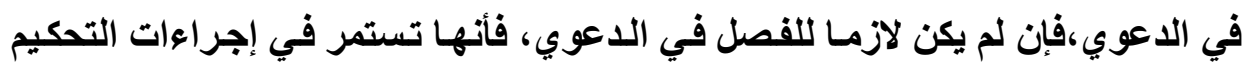

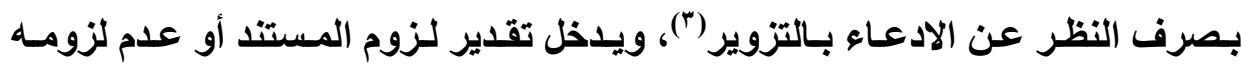
للفصل في الموضوع في السلطة التقديرية لهية التحكيم، علي أن قرار الهيئة لا ليخل بحق الطرف في التمكك بتزوير المستند بدعوي اصلية أمام المحكمة المختصة.

(1)Ph. FOUCHARD, E. GAILLARD et B. GOLDMAN, traite de l'arbitrage commercial international, op. cit., P.703.

(2) Lecuyer, Arbitrage, J. cl., proc. Civ., fasc., 20, no 56.

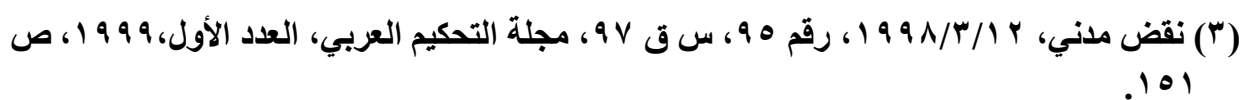


وبالتـالي إذا وجدت هيئة التحكيم أنـه لا تـأثير لهذا السند علـي الحكم المزمـع إصداره في النزاع كان لها أن تهمله، أو تخرجه من إطار المحاكمه، وذلك بعد أن يكون قد ناقثته مع الخصوم، أما في حالة العكسية فأنه يعرض علي الخصم الذي قدم السند بناء علي طلب الخصم الآخر أن يعلن ما إذا كان يصر علي استخدامه أو أنها يعدل عن

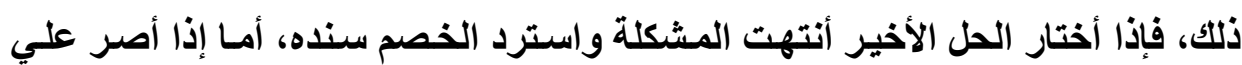
استعماله فيكون للخصم الآخر أن يتقدم بالادعاء بالتزوير أمام المحكمة المختصة بشكل أصلي.

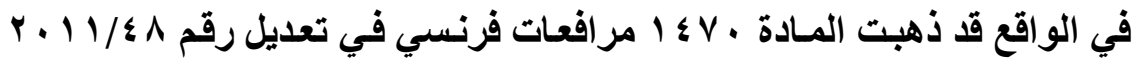
بتخويل المحكم نظر الادعاء بالتزوير إذا تعلق بورقة عرفية أو رسمية، وهذا الحكم لا يمكن الاخذ به في مصر دون نص تشريعي.

وإذا اتخذت الإجراعات الجنائية بالفعل بشأن المحرر الذي قدم للهيئة، فإعمـالا للقاعدة العامة التي تقضي بأن الجنائي يوقف المدني، فعلي الهيئة أن تقضي بـالوقف متي كان المحررلازما للفصل في النزاع. وعادة يكون طلب الوقف بنـاء علي طلب أحد الخصوم، ولهيئة التحكيم سلطة في الاستجابة لهذا الطلب من عدمـه بنـاء علي مدي تأثير الحكم الجنائي علي الخصومة التحكيمية، فإذا استجابت وقف الخصومة فقرارها غير قابل للطعن فيه، فإن رفضت الوقف وصـارت في الإجراءات حتي أصدرت حكمها في الموضوع، فأنسه يكون قـابلا للطعن بـالبطلان متـي كـان الحكم الجنـائي لـه اثر علي الثي

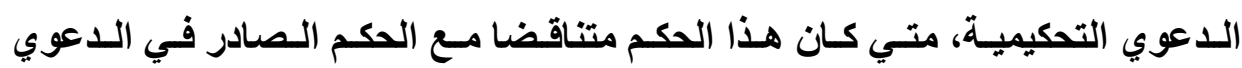

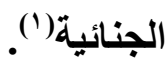


ويتم وقف مدة التحكيم منذ اليوم الذي تم فيه تقرير هذا الوقف من قبل هيئة

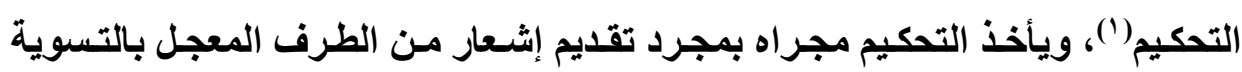

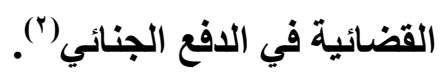

\section{المطالب الثاني \\ سلطة هيئة التمكيم في إلزام الفصوم أو الغير بإجراءات الإثبات}

في حقيقة الأمر، يملك القاضس أمر أطراف النزاع بأي إجراء من إجراءات

الإثبات، كما يملك إلزام الغير بتقديم مستتد تحت يده يفيد في الكثف عن الحقيقة، وهنا

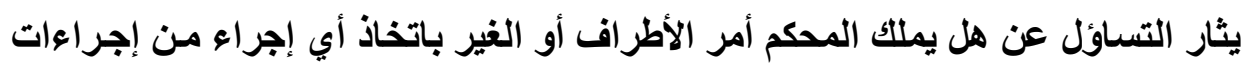
الإثبات؟ وهذا التساؤل سنجيب عليه في هذا المطلب.

سنشير في هذا المطلب إلى مدي سلطة هيئة التحكيم ي في إجبار الخصوم

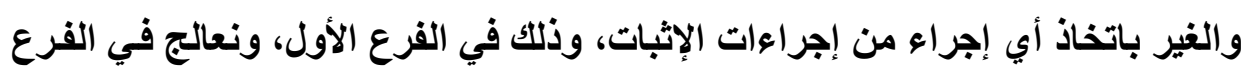

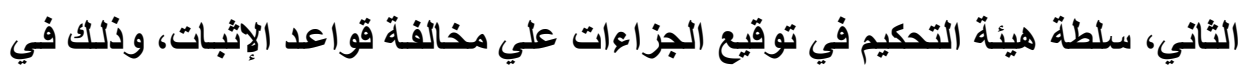

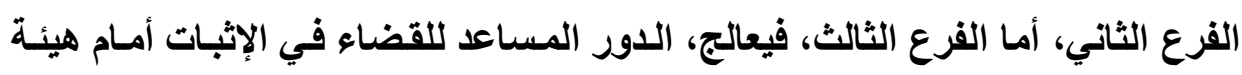

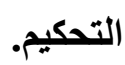

(1) B. Moreau, A. Beregoi, et autre, arbitrage commercial, op. cit., no 220.

(2) J. ROBERT, l'arbitrage droit interne et droit international privé, op. cit., p. 141 


\section{الفرع الأول}

\section{هدي سلطة هيئة التحكيه في إجبار الأطراف والغير علي إجراءات الإثبات}

المحكم ليس مثل القاضي في سلطة الأمر، سواء بالنسبة للأطر اف أو للغير (')،

وذلك نتيجة طبيعيـة للأثر الاتفـاق للتحكيم. حيث إن للقاضـي كامـل السلطة في إلزام أطراف النزاع أو الغير باتخـاذ أي إجراء من إجراعات الإثبات، خاصـة إلزامهم تقديم

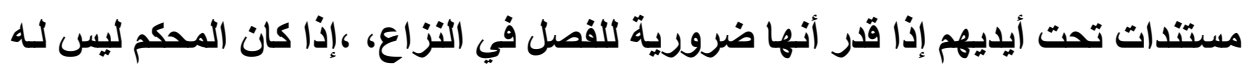
سلطة الإجبار، فهنا يثار التساؤل عن سلطة المحكم في إلزام أطراف التحكيم والغير بتقديم مستند تحت ياهم.

وسنشير إلى سـلطة هيئسة التحكيم في إلـزام الأطراف بـإجراء مـن إجـراءات الإثبات، وسلطتها في ذلك في مواجهة الغير، وذلك في النقاط الآتية:

أولا: سلطة هيئة التحكيم في إلزام أطراف خصومة التحكيم بإجراء من إجراءات

يعد المستتد بما يتضمنه من بيانات ومعلومـات من أهم وسـائل الإثبات الكتابية في الدعوي التحكيمية، ويلجـأ إليه المحكم عـادة لاستخلاص دليل مـا بعينـه، متي كـان ضروريا لإظهار وجه الحق في النزاع المعروض عليه(؟). فقد نص المشرع المصري علي حق هيئة التحكيم الطلب من الخصوم تقديم مـا تحت أيديهم من مستندات، حيث نصت المادة هب تحكيم علي أنه "إذا تخلف أحد الطرفين عن حضور أحدى الجلسات أو

(1) B. Moreau, A. Beregoi, et autre, arbitrage commercial, OP. CIT., no 203.

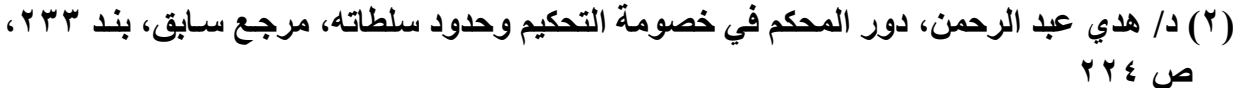


عن تقديم ما طلب منه من مستتدات جاز لهيئة التحكيم الاستمرار في إجراءات التحكيم وإصدار حكم في النزاع استناداً إلى عناصر الإثبات الموجودة أمامها".

والفرض الذي تعالجة هذه المادة أن المستندات التي قدمها الخصوم غير كافية لتكوين عقيدة المحكم، ففي هذه الحالـة يجـوز للمحكم أن يطلب مـن الخصوم تقديم مستتدات أخري، فلهيئة التحكيم طبقا للنظام المصري بناء علي طلب أي من الطرفين، تكليف الطرف الآخر بتقديم مستثد تحت يده، وذلك بمراعاة الشروط التي ينص عليها قانون الإثبات لهذا الإلزام في المادة ـ ب وما بعدها من قانون الإثبات.

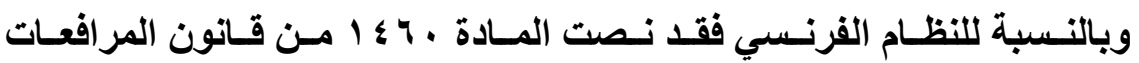

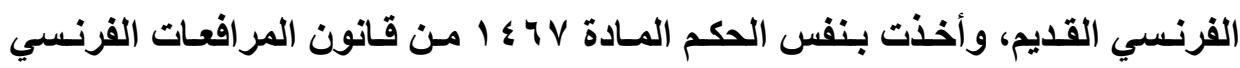
الجديد علي أنـه للمحم السلطة في أن يـأمر أحد الخصوم في تقديم مـاتحت يـده من

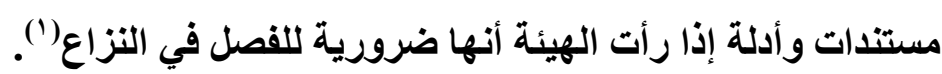
وتتص المادة V من قواعد اليونسترال، والمادة rV من قواعد مركز القاهرة الإقليمسي علـي أن لهيئة التحكيم أن تطلب مـن الأطراف في أي وقت أثنـاء إجراءات التحكيم أن يقدموا خلال المدة التي تحددها وثائق أو مستندات أو أية أدلة أخري. وبالتـالي فبإن لهيئة التحكيم سلطة بالنسبة للأمر للأطراف بـأي دليل من أدلـة الإثبات وهي نفس سلطة المحكة، وإذا أمر المحمم بإجراء من إجراءات الإثبات يتطلب مشاركة أيجابية من الأطراف، فأنه يقع عليهم واجب قانوني في القيام بها، فبان لم يقم الخصم بهذا الواجب، أثبت المحكم تخلفة ولكنه لا يستطيع إجباره علي القيام به(؟).

(1) B. Moreau, A. Beregoi, et autre, arbitrage commercial, OP. CIT., no 203.

(ץ) د/ فتحي والي، التحكيم في المنازعات الوطنية والتجارية الدولية، علمـاو عملا،المرجع السابق، $=$ 
ويلاحظ أنه ليس للمحكم أن يأمر بتحقيق أيها واقعة خـارج الوقائع التي تمسك بها أحد الأطراف مهمـا بـد لـه أهميتها، ذلتك أنها اذا لم يتمسك أحد الأطراف بواقعة معينة، فإن إثارة المحكم لها يعتبر خروجا عن طلبات الخصوم لا يملكه المحكم('). ويثار التساؤل، هل لهيئة التحكيم سلطة إجبار أحد الأطراف أن يحضر شاهده ؟ في الواقع لا تملك هيئة التحكيم سلطة الأمر، وذلك لأنها هيئة قضاء خـاص بعيد

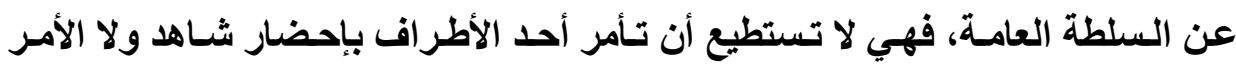
بحضور شاهد، وتوقع جزاء علي ذلك، ولكنها عندما تقدر أهمية وضرورة اللجوء إلى الشهاد لإظهار الحقيقة التي تبحث عنها، أن تطلب ذلك من محاكم الدولة التي يجري التحكيم علي أرضها، أو يوجد فيها الثـاهد المرغوب في سماعه. وهذا مـا نصت عليه المادة V V تحكيم بقولها" يختص رئيس المحكمة المشار إليها في المـادة 9 من هذا القانون بناء علي طلب هيئة التحكيم بما ياتي: الحكم علي من يتخلف من الشهود عن الحضور أو يمتنع عن الإجابة بالجزاءات المنصوص عليها في المـادتين ^ ل و ـ ^ من قانون الإثابت في المواد المدنية والتجارية.

ثانيا: سلطة هيئة التمكيـم في إلزام الغير بإجراء هن إجراءات الإثبات في الواقع، في النظام المصري والفرنسي(r) لا تملكك هيئة التحكيم إلزام الغير الذي ليس طرفـا في خصومة التحكيم بتقديم مستتد تحت يـده ولا بـأي إجراء مـن إجراءات الإثبات مثل الالتزام بتقديم شـاهده أمسام هيئة التحكيم، ذلك لأنه ليس لهيئة

(2) B. Moreau, A. Beregoi, et autre, arbitrage commercial, OP. CIT., no 205. 
التحكيم ولأية علي غير أطراف التحكيم. ففي تلك الحسات وأمثالها لا يملك المحكمة إلا الاستعانة بقضاء الدولة للحصول علي مساعدته مـع توقف الفصل في سير الخصومه إذا كان السير فيها متوقفا علي اتخاذ هذه الإجراعاته('). حيث نصت المـادة 99 \ 19 مرافعات فرنسي جليد علي أن المحكم ليس لله أن يلزم الغير بتقديم ما تحت يده من ادله، ولكن يمكن أن يكلف الخصوم اللجوء إلى قضاء الاولة لإلزام الغير بتقديم مـا تحت يـده من مستندات. والقاضسي لـه سلطة تقديريـة في الأمـر بـإلزام الغير بتقديم المستتند أو رفضه الطلب، أو الحكم عليـه الغيـر بالغرامـة

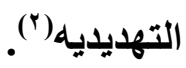

ففي النظـام الفرنسـي القاضــي المختص بـاللجوء إليـه هـو رئسيس المحكمـة

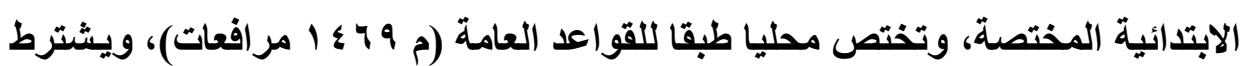
للجوي إلى القضاء موافقة هيئة التحكيم، إذا قدرت أهميـة المستتـد اتحت يــ الغير. ويمكن لرئيس المحكمة الابتدائية أن يحكم علي الغير بالغرامـة التهايدية إذا لم ينصاع لما يطلبه القاضي("). ويكون اللجوء إلى القضاء بطريق الأوامر علي عرائض وليس طريق الدعوي، وينظر القاضي الطلب المقدم إليه، طبقا لنظام الأوامر علي عرائض، وعلي عكس القواعد العامة، لا ينفذ قرار القاضي تنفيذا مجلا، ولكنه يخضع للتظلم منه

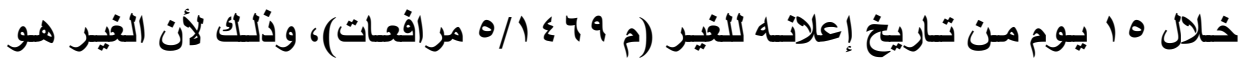
شخص اجنبي عن اتفاق التحكيم، وبالتالي مقتضيات العدالة تستوجب أن يمنح فرصهـ

(1) د/ أحمد أبو الوفا، التحكيم بالقضاء وبالصلح، مرجع سابق، ص بr بr ، د د/ عاثور مبروك، النظام

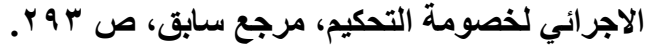

(2) B. Moreau, A. Beregoi, et autre, arbitrage commercial, OP. CIT., no 236.

(3) Id. 206. 
للتظلم من القرار قبل تنفيذه، وهذا يتفق مع روح التحكيم وقواعد العدالة. والتعاون بين

المحكم والقاضي والأطراف('). ويمكن للقاضي أن يحمم بالتنفيذ المعجل لقراره(؟). ولكن إذا قام الغير بعد مطالبته، بتقديم المستتد من تلقاء نفسد، فإن للمحكم بعد إرساله إلى الطرفين، الاعتداد به في التحكيم("). ويري بعض الفقه أنه يجب على هيئة التحكيم أن تـإذن بإدخال الغير لتقديم مستتد تحت يـده إذا وافق الغير وبـاقي أطراف التحكيم علي ذلك("). ويذهب رأي آخر من الفقه إلزام الغير رغم إرادتهه بالتدخل في الخصومة التحكيم(ه). ونري أنه لا يمكن إلزام الغير بالاخول في الخصومة لتقديم مستتد تحت يده. وذللك لأن التحكيم قائم علي أساس اتفاق التحكيم، ويلتزم المحكم بحدود اتفاق التحكيم من حيث الأطراف والموضوع. ولا يمكن للغير التدخل في خصومة التحكيم بدون موافقه الأطراف، لأن هيئة التحكيم تلتزم بحدود اتفاق التحكيم. لذا يلزم موافقة جميع الأطر اف علي تدخل الغير في خصومة التحكيم. الفرع الثاني

سلطة هيئة التمكيه في توقيع الجزاء علي هخالفة ها أهرت به هن إجراءات

\section{الإثبات}

قد يكون هناك مستتد مهم للفصل في الدعوي في يـا أحد الخصوم، أو يرغب المحكم سـماع شـاهد عن طريتق الخصم، فيطلب المحكم بـرورة تقديمسه أو اخطـار

(1) Id., no 208.

(2) Id., no 238.

(َ) د/ فتحي والي، التحكيم في المنازعات الوطنية و التجارية الدولية، علمـا وعملا، المرجع السابق. . ص ص

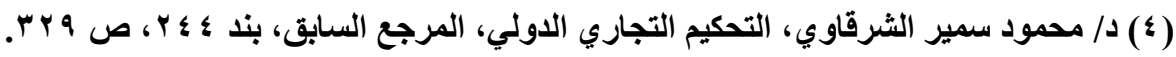

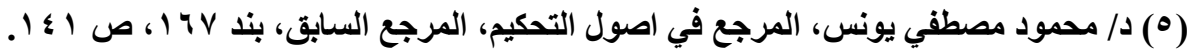

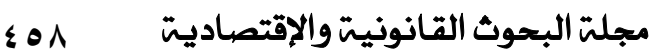


الثـاهد بالحضور، ولا يستجيب الخصم لتقديم ما طلب منـه أو الشـاهد، وإذا كانت هيئة التحكيم لا تملكك سلطة الجبر مثل قضاء الدولة، وبالتـالي لا يمكنها إجبار الشاهد أو

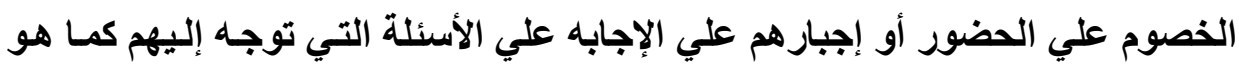

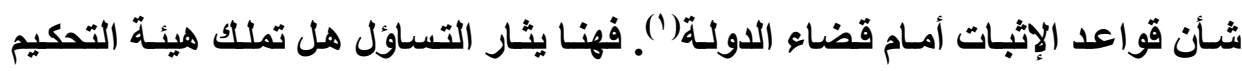
سلطة ترتيب آثار امتناع الخصم أو الشهود عن الحضور أو عن الإجابـة أو تقديم مـا

$$
\text { تحت بده؟ }
$$

سنشير إلى موقف المشرع المصري، المشرع الفرنسي من هذه المسألة، وذلك علي النحو التالي:

\section{أولا: هوقف المشرع المصري}

سنشير إلى موقف المشرع المصري بالنسبة للجزاءات الموقعة علي الخصم، والجزاءات الموقعة علي الشاهد، وذللك علي النحو التالي:

ا- الجزاءات الموقعة علي الخصم

لقد نـصت المـادة هب مـن قـانون التحكيم المصري علـي أنـه "إذا تخلف أحـا

الطرفين عن حضور أحدى الجلسات أو عن تقديم ما طلب منه من مستتدات جـاز لهيئة التحكيم الاستمرار في إجراءات التحكيم وإصدار حكم في النزاع إستناداً إلى عناصر

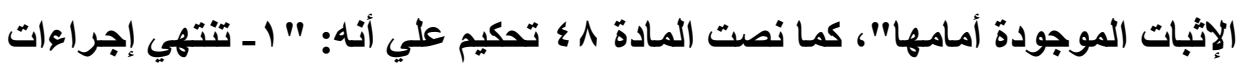
التحكيم... إذا رأت هيئة التحكيم لأي سبب آخر عدم جدوى استمرار إجراءات التحكيم

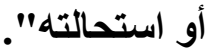

( (1) د/ رضا السيد، مسائل التحكيم، المرجع السابق، ص ^ ^ ؛ ، د/ أحمد عبد الكريم سلامه، التحكيم في

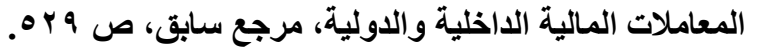


فيستفاد من نص المـادتين هب وم ؛ تحكيم أنسه إذا امرت هيئة التحكيم بإجراء من إجراءات الإثبات، مما ياخل في سلطتها الأمر به من تلقاء نفسها، ولم يستجب أحد الطرفين لما طلب منه، فإن الهيئة تفصل في الدعوي بالنظر إلى الأدلة المتاحة أمامها. وبالتالي لا تملك هيئة التحكيم توقيع جزاء الغرامة التهديديـة ولا جزاء الوقف الجزائسي لخصومة التحكيم كما هو الثأن بالنسبة لما تملكه المحكمة القضائية من جزاعات. وترجع الحكمة في ذلك إلى قوة الأمـر الصـادر من هيئة التحكيم ليس مثل قوة الأمر الصادرة من قاضي الدولة، لأنه هيئة التحكيم لا تمتلك سلطة الأمر الذي تملكها المحكمـة القضائية، وبالتـالي فهـي لا تستطيع إقران قرارهـا بالغرامـة التهديديـه مثـل

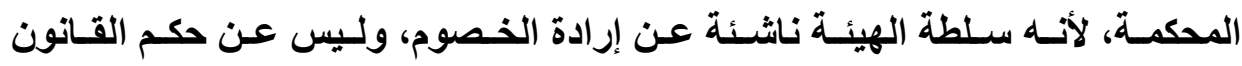
كالمحكمة، وبالتالي لا يستطيع المحكم إرغام أحد الخصوم أو الغير علي تقديم مستند أو دليل في حيازته. وفي حالة رفض الخصم إبراز اللاليل الذي في يده الذي صدر قرار المحكم بتقدميه، جاز للمحكم استخراج النتيجة التي يراها من هذا الامتتاع('). ولا يمكن توقيع جزاء ولا الغرامة التهديدية. وبالتالي إذا لم يمتثل الخصم لتكليف هيئة التحكيم بتقديم مستتـ تحت يـه، فأنـه ليس لهيئة التحكيم أن تلزمه بتقليمه، وفقا للمادة بr ب إثبات إذ ليس لها سلطة الأمر، وليس لهيئة التحكيم أن تلجـأ إلى المحكمـة التـي تنص عليها المـادة 9 تحكيم لإلـزام

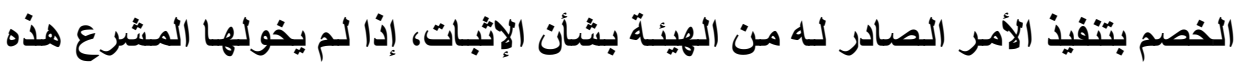
السلطة(؟)، ومن ناحية أخري، فأنه ليس لهيئة التحكيم أن تُعمل ما تنص عليه المادتـان (1) د/ نبيل إسماعيل عمر، التحكيم في المو اد المدنية والتجارية الوطنية والدولية،المرجع السبقى، ص 191 (ץ) د/ فتحي والي، التحكيم في المناز عات الوطنية والتجارية الدولية، علمـاو وعملا، المرجع السابق، 
ب Y ع ץ إثبات(1) فليس لهيية التحكيم أن تطبق نص المـادتين سـالفتي الذكر في حالة إنكـار الخصم وجود السند أو إذا لـم يقم بتقديمـه(؟)، وإنمـا يجـوز لهيئة التحكيم نظر الاعوي بافتراض عدم وجود هذا المستند، وتأكيدا لفقدان صفة الأمر أو الإلزام من قبل

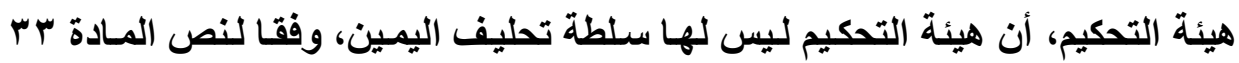
تحكيم، حيث يكون سماع الشهود والخبراء بدون أداء اليمين.

و إذا كانـت المحكمة القضائية تملكت الحكم بـالوقف كجزاء يترتب علي تخلف الخصم القيام بإجراء يكلف بـه من قبل المحكمة، وهنـا يثار التساؤل هل تملتك هيئة التحكيم الوقف الجزائي لخصومة التحكيم،في حالة تخلف الخصم عن القيام بإجراء كُلف به من قبل الهيئة؟

في الواقع الوقف الجزائي في نظام التحكيم، لم يتعرض المشرع المصري، ولكن المتأمل جيدا في نصوص التحكيم المصري يجد المشرع يمنح المحكم سلطة إنهاء

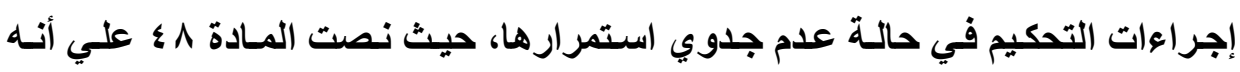
تنتهي إجراءات التحكيم بقرار من هيئة التحكيم إذا رأت لأي سبب آخر عدم جدوي استمرار إجراءات التحكيم أو استحالتها.

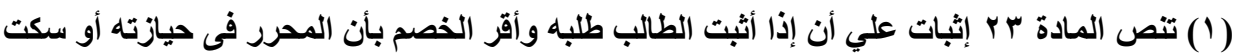

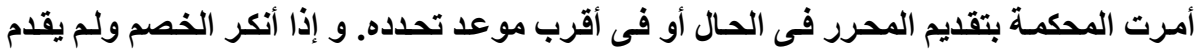

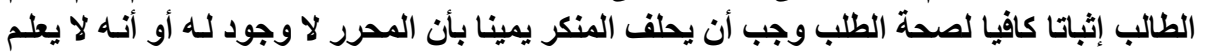

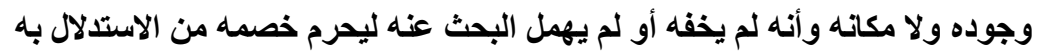

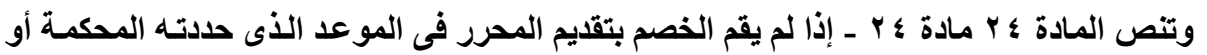

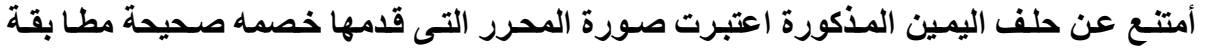

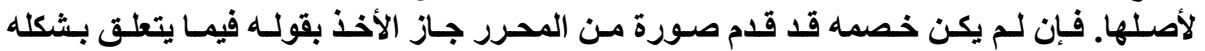

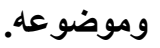
(ץ) د/ فتحي والي، التحكيم في المنازعات الوطنية والتجارية الدولية، علمـا وعملا، المرجع السابق، ص ص 
وبالتـالي، وإذا طالبـت هيئة التحكيم باتخـاذ إجراء مـن إجراءات الإثبـات، ولـم يستجب الخصم الموجه له الطلب، أمام الهيئة أحد أمرين، الأمر الأول، تفصل الهيئة في

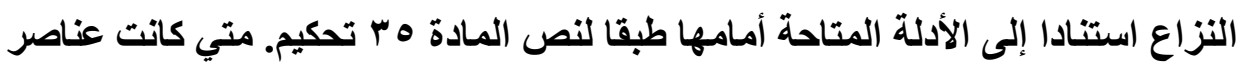
الإثبات الآخرى كافية للفصل في الدعوي. وتملك الههيئة العدول عمـا أمرت بـه من أدلة الإثبات، وذلك إذا وجدت في أوارق الدعوي مـا يكفي لتكوين عقيدتها، أو إذا قدم لها دليلا يغني عما أمرت به، لا تجبر هيئة التحكيم علي تنفيذ إجراء لم تعد تري ضروريته،

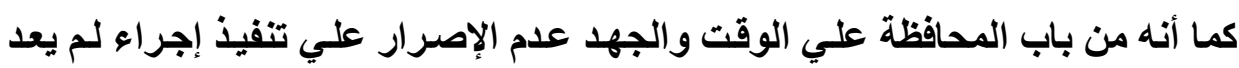

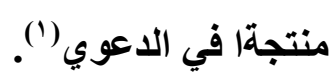

والأمر الثاني، وهو كون عناصر الإثبات غير كافية للفصل في النزاع فلهيئة التحكيم أن تقضي بإنهاء الإجراءات إذا رأت عدم جدوي الاستمرار في التحكيم. وفي الإسي هذه الحالة قد يساعد ذلك المحتكم الممتنع في عدم تقديم ما طلب منه، وذلكك رغبـه منـه في إنهاء الإجراءات، خاصـة إذا رأي أنها في غير صـالحه لـلتك يمتـع عن تقديمها

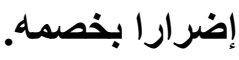

قد يتفق أطر اف التحكيم فيمـا بينهم علي منح المحكم سلطة إلزامهم بتقديم مـا

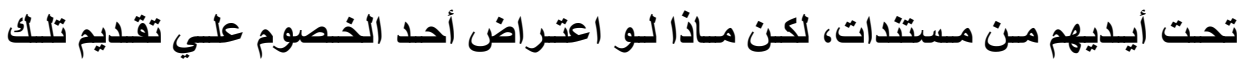
المستتدات رغم اتفاقهم، فهل يستطيع المحكم إجباره علي تقديم ما بحوزته؟ بمعني هل يملكك المحكم سـلطة الحكم بالغرامـة التهديديـة كجزاء علـي تعنتهـه و التي يتمتع بهـا 
نظرا لعدم وجود نص تثريعي، فقد اختلف الفقه في الاجابة علي هذا التساؤل، حيث ذهب بعض الفقه(') إلى أن للمحكم أن يلزم أحد الخصوم بتقديم مـا تحت يده من أدله إثبات، فإن امتنع أصدر المحكم حكما تمهيديا بإلزامه بتقديم هذا المستثد مـع الحكم

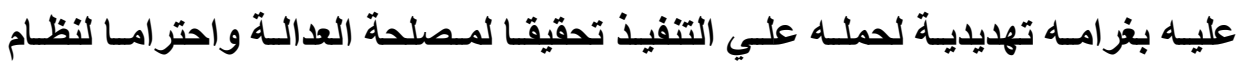
التقاضي.

$$
\text { ويستند أنصار هذا الاتجاه إلى الأتي: }
$$

- يث إن الغرامة التهايدية ليست طريقا من طرق التنفيذ الجبري الذي لا تملك الأمر بـه إلا سـلطات الدولـه التـي تتمتـع بسلطة الجبر، وإنمــا هـي مجرد وسيلة لحمـل وإجبار الخصم الممتتع عن تنفيذ التزامه. - منح المشرع المحكم العديد من السلطات والتي تمكنه من حسن أداء مهمته، ومن هذه السلطات قيامه باتخاذ مـا يراه مناسبا من إجراءات الإثبات أو العدول عنها، ولكن تنفيذ هذه السلطات لابد من أن تكون له سلطة الأمر والجبر، وبهذا القدر يملكك المحكم الأمـر بالغرامـة التهديديـة التي يمكن اعتبارهـا هنـا أحدي الوسـائل الفعاله لحسن أداء المحكم لمهمته القضائية(؟)، والقيد الوحيد الذي يرد علي سطلة المحكم هو عدم تنفيذ ما حكم به بغرامة إلا بعد حصول الحكم الصادر بالغرامة علي أمر التنفيذ من جاتب المحكمة المختصة أصلا بنظر النزاع.

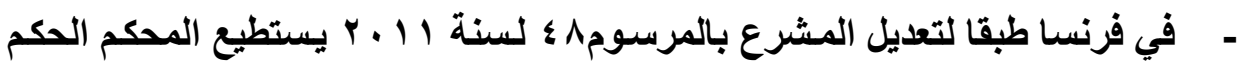

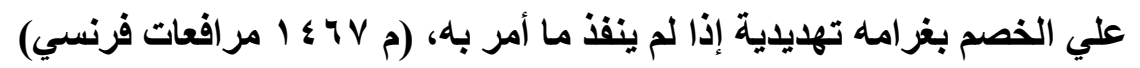

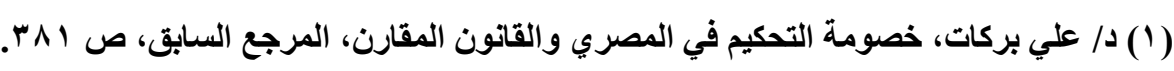
(2) B. Moreau, A. Beregoi, et autre, arbitrage commercial, op. cit., no 202. 
وقد ذهب اتجاه آخر في الفقه(') إلى أنـه إذا امتـع أحد الخصوم عن تقديم مـا طلب منه، فلا يجوز للمحكم إجباره علي تقديمه لكون لا يملك سلطة الإجبار، حيث أنها لا يملكك ما يملكه قاضي الدولة من سلطة توقيع غرامـة تهديديـة علي الخصم الممتنع

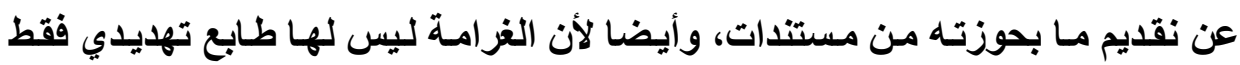
و إنما هي عقوبة لا يملك الأمر بها إلا القاضي، وهذا بعكس المحكم الذي يستمد سلطته من اتفاق التحكيم الأي يبرمه الأطر اف المتخاصمه. والواقع أن هذ الرأي الأخير هو الأقرب إلى الصواب، لأن القانون المصري لم ينص علي سلطة الإجبار والالزام بالنسبة للمحم، ودليل ذلك أن المشرع المصري الزم المحكم بالرجوع إلى القضاء في حالات معينه تقتضي الإلزام مثل الرجوع للمحكمة علي

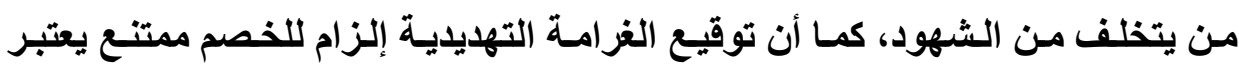
مسألة خارجة عن مهمة هيئة التحكيم ما لم ينص علي ذلك في اتفاق التحكيم(؟). في الواقـع لا تملتك هيئة التحكيم الحكم علـي الخصوم أو الغير بأيسه غرامـات لصلاح الخزانه العامة، كتلك المقررة في المـادة بـ ــ من قانون الإثبات، لأنسه لا يعتبر

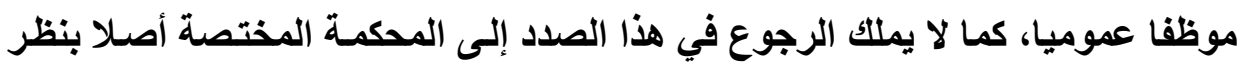
النزاع لأنه لا يملك ذلك إلا في الأحوال المقررة في التشريع علي سبيل الحصر، لان هذا الرجوع بمثابة إنابة للمحكمة عنه في توقيع الجزاء، وهذا ما لا يملكه هو أيضا، أي لا يملكك إحالة الأمر لها في هذا الصدد، فالمخالفة التي يرتب المشرع علي ارتكابها توقيع

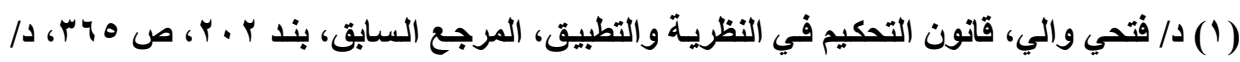

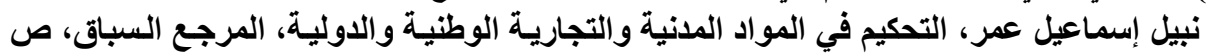

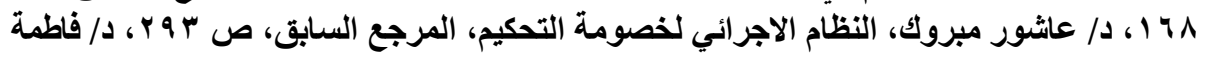

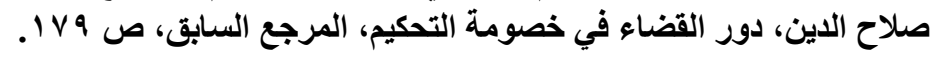

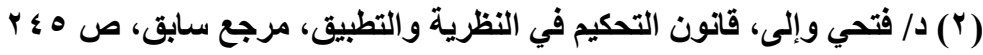


غرامسة لـصالح الخزانـه العامـة هـي تلك التـي تقع مـن الخصم أمسام المحكمة لا أمسام

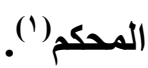

ونري أنه إذا ارتكب أحد الخصوم ما يبرر - بحكم القانون - معاقبته فإن المحكم يملك تطبيق القواعد المقررة في قانون الإثبات في هذا الصدد. ولو كان غير مفوض بالصلح، فمثلا اذا تخلف الخصم عن الحضور للاستجواب بغير عذر مقبول أو امتنع عن الإجابة بغير الإثبات جاز للمحكم - ولو كان مقيداً بقواعد المرافعات ـ أن يقبل الإثبات

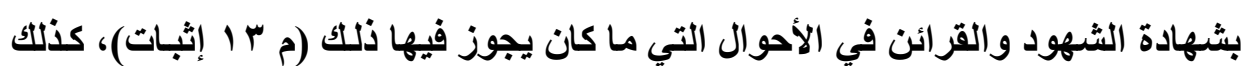
إذا امتنع الخصم عن تقديم ورقة منتجة تحت يده جاز للمحكم أن يعتبر صورة الورقة التي قدمها خصمه صحيحة مطابقة لأصلها عملا بالمادة ؛ r إثبات. علي أنه يجوز للطرفين الاتفـاق في مشارطة التحكيم علي تخويل هيـة التحكيم

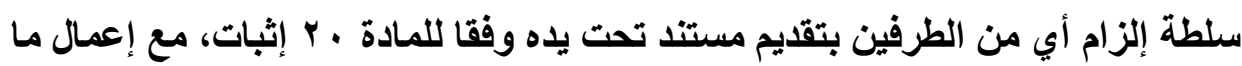

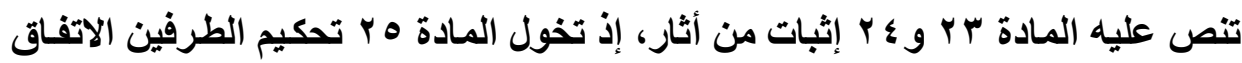
علي ما يرونه من إجراعات الإثبات.

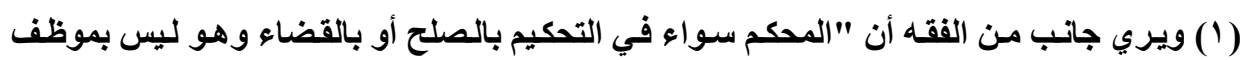

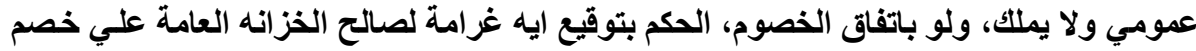

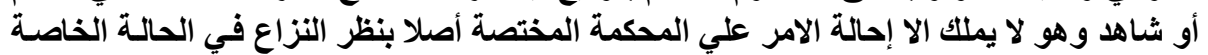

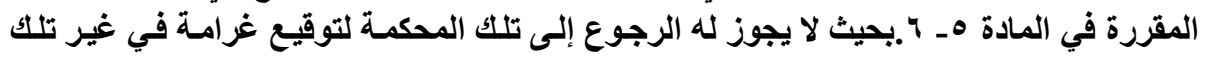

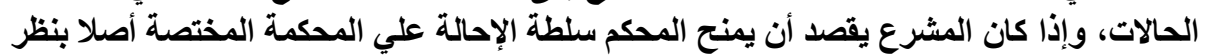

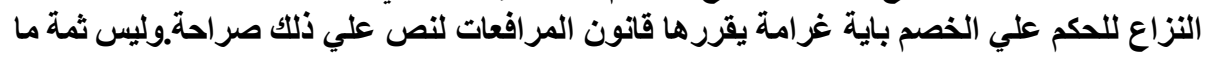

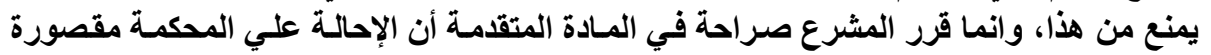

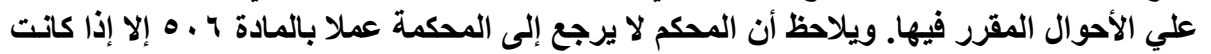

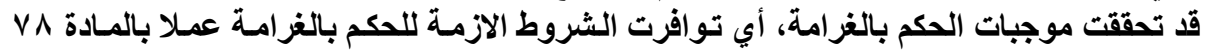

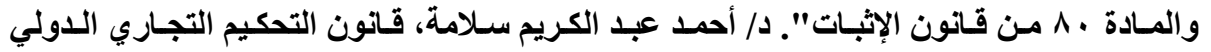

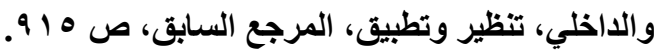


وإذا استعانت هيئة التحكيم بخبير، وامتنع الخصم عن معاونة الخبير في فحص البضائع بحجة عدم تعلقها بالنزاع، أو تعدد إخفاء وثائق في حوزته، فطبقا لنص المادة بس تحكيم تتولي هيئة التحكيم سـلطة الفصل في أي نـزاع يقوم بـين الخبير وأحد الخصوم. ومن هنا يثار تساؤل هل يجوز لهيئة التحكيم إرغام الخصم علي تقايم الوثائق والمطلومات التي يحجبها عن الخبير؟

يري جاتب من الفقه(1)، أن هيئة التحكيم تملك الحكم بحق الخبير في فحص الوثيقة أو البضاعة أو المال الذي طلب من أحد الخصوم، ولكن لا يمكن أن تجبر هذا

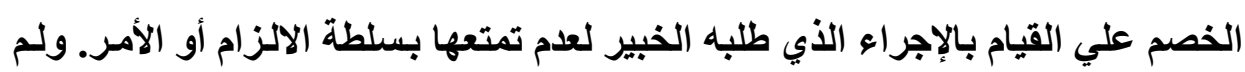
تعط المادة צب تحكيم لهيئة التحكيم حق اللجوء إلى القضاء للاستعانة بـه في إجبار الخصوم علي تقديم مـا يطلبه الخبير منهم، وذلك بتوقيع الجزاعات عليهم في حالة الرفض، كما هو منصوص عليه في المادة ^ \ 1 إثبات. كما لم ترتب المـادة جس تحكيم أي أثر لتخلف الخصم أو امتناعه عن القيام بالإجراء الذي طلبه منـه الخبير، فلم تعتبر

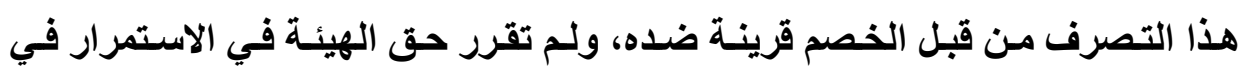
إجراءات التحكيم وإصدار حكم في النزاع استنادا إلى عناصر الإثبات الموجودة أمامها، كما هو الحالة في حالة امتناع عن تقديم المستتد طبقا للمادة هب تحكيم.

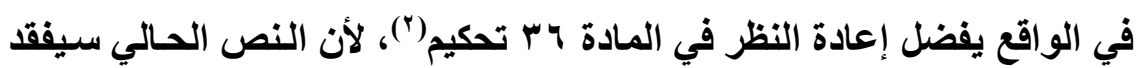
جانبا هامـا من فاعليته في شأن الخبرة، لأن أداء الخبير لمهمته سيتوقف رهنا في نهائة المطاف بمشئية الخصوم الذين كثيرا مـا يختلفون ويلجأون إلى إعاقة عمل الخبير إذا لـان 
شعروا أن تقريره لن يكون في صـالحهم، وهذا مـا يدعوا إلى ضرورة النظر في هذه المادة، بمـا يكفل لهيئة التحكيم الحقى في اللجوء إلى القضاء لإلزام الخصوم بتمكين

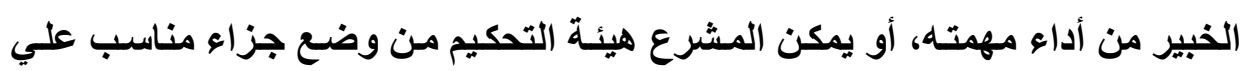
تغنت الخصم في معاونة الخبير. حيث يكون من الأفصل أن ينص المشرع علي أنها إذا تخلف أحل الخصوم عن تقديم مـا طلبه منه من مستتدات، رغم تقديمها خصمه الداليل

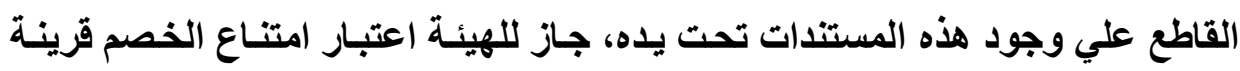
ضده في إثبات ما يدعيه الخصم الآخر (') r- الجزاءات الموقعه علي الشاهد

في حالة قرت الهيئة أهمية وضرورة اللجوء إلى الثهادة لإظهار الحقيقة التي التي تبحث عنها، أن تطلب ذلك من محاكم الدولة التي يجري التحكيم علي أرضها أو يوجد

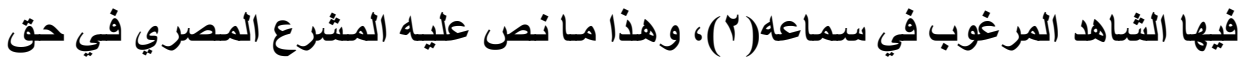

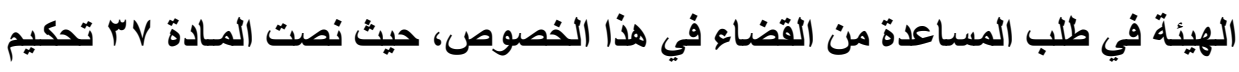

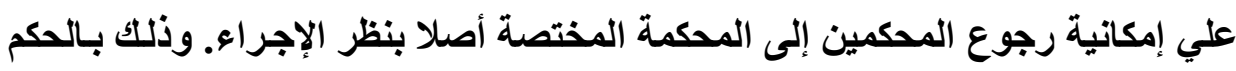
علي من يتخلف عن الثهود عن الحضور بالجزاء المقرر في المـادة V^ إثبات واتخـاذ

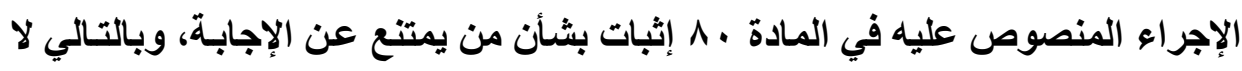

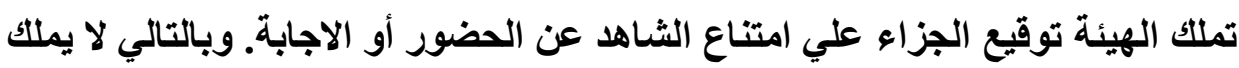

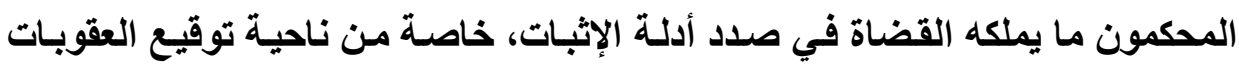

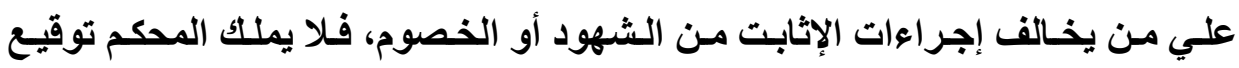
الغرامة ولا الحكم بعقوبة الثهادة الزور، ولا إلزام خصم بتقديم مستتد تحت يداه. فكل (ץ) د/ أحمد عبد الكريم سلامه، قانون التحكيم التجاري الدولي والداخلي، المرجع السابق، ص . بـه 
ما تملكه هيئة التحكيم هو تحرير محضر وأحالة الأمر إلى القضاء(1)، مع توقف الفصل

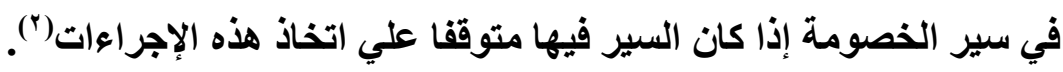

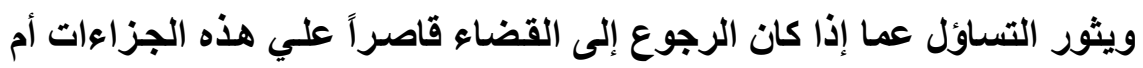

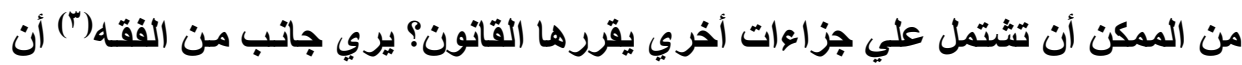

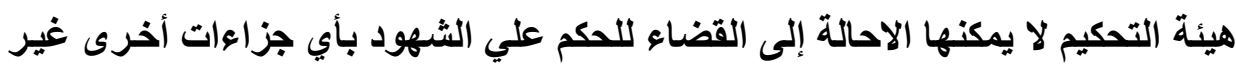

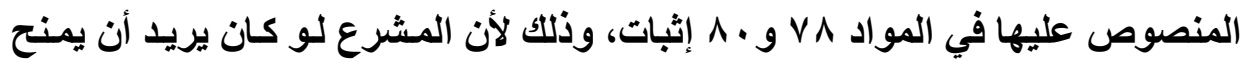
المحكمين سلطة الإحالة إلى القضاء للحكم بأي جزاءات أخري يقررها قانون لنص علي التي ذلك صراحة.

وليس للقاضي المختص أن يسمع الثاهل بل تقتصر سلطته علي أحد أمرين: الأول: توجية الأمر إلى أحد الأطراف بإحضار شـاهده أو تكليف شـاهل بعينه بالحضور لأداء الثهادة والأمر الثاني، الحكم علي الثاهد الذي كلف بالحضور تكليفا صحيحا ولم

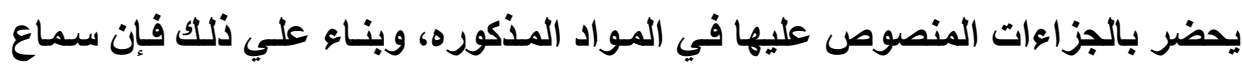
الثاهدا يكون من اختصاص هيئة التحكيم دون أن يحلف اليمين.

\section{ثانيا: موقف المشرع الفرنسي}

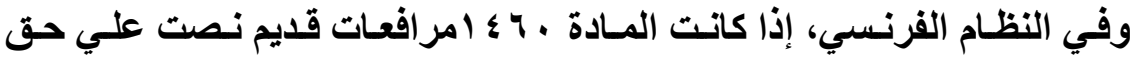

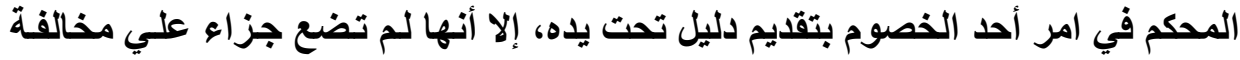
ذلك، ولذا ذهب الفقه أن المحكم لا يملك إلا أن يأخذ في الاعتبار مدي تعنت الخصم في في الخد

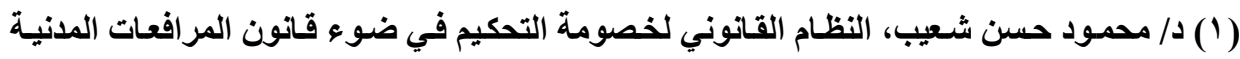

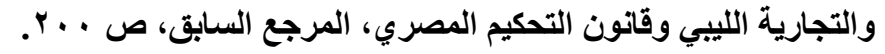

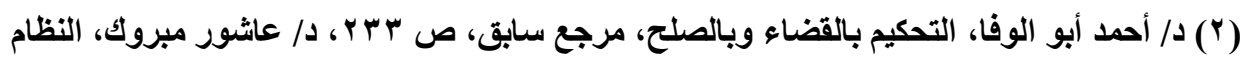

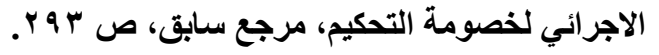

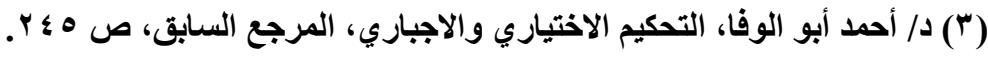


تقديم دليل تحت يده، ومدي أثره في الحكم في الدعوي، ويحكم بناء علي ذلك('). ولكنها

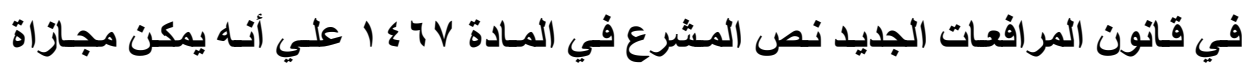
الخصم الممتنع عن تقديم دليل تحت يده بالغرامة التهديدية، ويجب علي المحكم أن يأخذ مأن

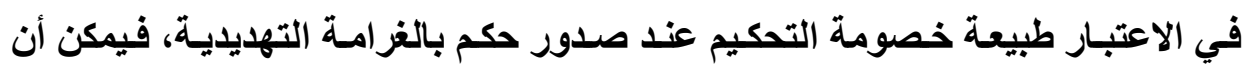
تكون المستتدات الملزم الخصوم بتقديمها تتمتع بالسرية، وعندما يصدر المحكم حكمـه

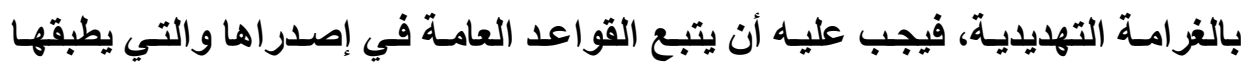

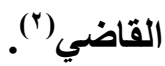

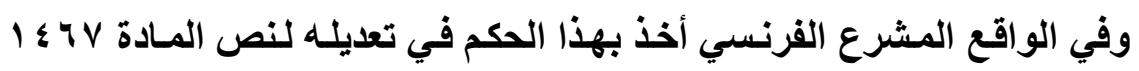

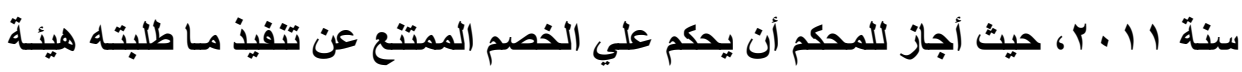

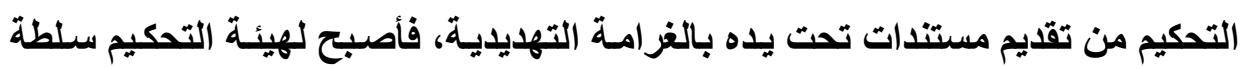

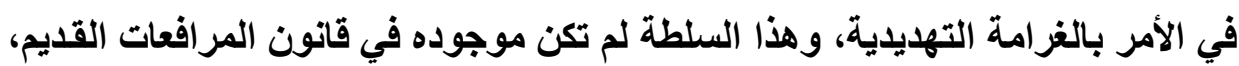

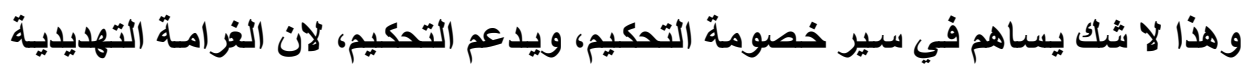

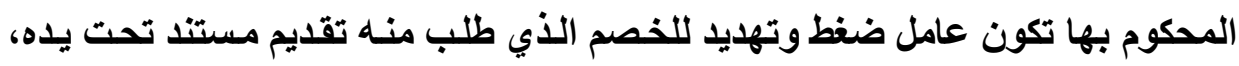

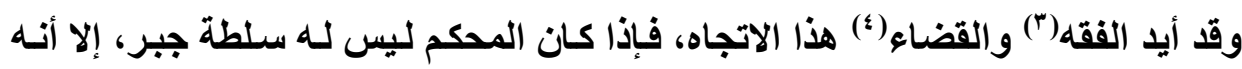
يملك إصدار حكم بالغرامة التهديدية، في جميع الأحوال التي يمكن للقضاء أن يحكم فيها

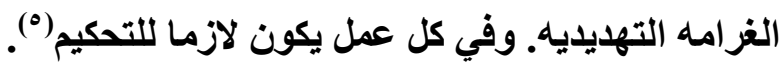

(1) B. Moreau, A. Beregoi, et autre, arbitrage commercial, op. cit., no 204.

(2) Id. no 205.

(3) Id.

(4) CA Paris, 7 oct. 2004, Rev. Arb., 2004, p. 737, note Jeuland, JDI, 2005, p. 341, note Maurre et Prerdone, JCP, 2005, II, 10071, note Jacquet.

(5) CA Paris, 19 mai 1998, Rev. Arb., 1999, p. 601, not. Jarrosson. 
ونري أنه يفضل أن يأخذ المشرع المصري بهذا الاتجاه وهو حق هيئة التحكيم بـالحكم بالغرامـة التهايديـه وبـالجزاءات المنـصوص عليهـا في قـانون الإثبـات، وذلكـ تحقيقا لفاعلية نظام التحكيم. كما أن الاتجاه الحديث يمنح هيئة التحكيم سلطات تعادل سلطات قضاء الاولة.

\section{الفرع الثالث \\ الدور المساعد للقضاء في الإثبات أهام هيئة التحكيم}

سنشير إلى النص على معاونـة القضاء لهيئة التحكيم فيمـا يخرج عن سلطتها في مجال الإثبات، ثم نبين الانابه القضائية، وذلك في النقاط الآتية: أولا: النص علي معاونة القضاء لهيئة التحكيم فيما يخرج عن سلطتها: إذا كان لهيئة التحكيم دور أيجابي في تنظيم إجراعات التحكيم، فلها الأمر بـأي إجراء من إجراءات الإثبات، فيمكن لها أن تطلب من الخصوم تقديم مستندات أخري غير التي قدموها، وشأن الهيئة في ذلك شأن قضاء الدوله بالنسبة لوسائل الإثبات التي يمكن استخدامها للوقوف علي حقيقة النزاع. ونظر الحرمان هيئة التحكيم من سلطة الجبر، فبان ذلك يؤثر علي سلطة هيئة التحكيم عند البحث عن أدلة الإثبات سواء تجاه الخصوم أو تجاه الغير. ويتضح ذللك في الأحوال التي يوجد فيها أحد أدلة الإثبات المنتجة في الدعوي في يد الخصم وامتنع عن تقــيمها، ونظرا لأن القـانون المـصري منـع المحكـم مـن سـلطته في الأمسر بالغزامـة

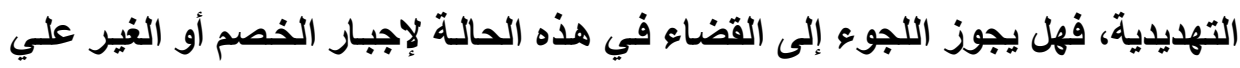
تقديم المستند إذا كان لازما أو الادلاء بالشهادة؟ وقد ثـار الخـلاف حول من الذي يلجـأ إلى القضاء هل هو هيئة التحكيم أم الخصم صاحب المصلحة؟ 
وقد ذهب رأي إلى أن المحكم هو الذي يلجأ إلى القضاء لإلزام الخصم بتقديم مـا لايه(')، انتقد هذا الرأي علي أساس انعلم الصفة والمصلحه، وذهب رأي آخر إلى أن الخصم وحده هو صـاحب الصفة والمصلحة في اللجوء إلى القضاء في مثل هذه

ويـري بعض الفقـهـ أن " التحكيم لا يمكـن أن يقـوم بـدوره الفعـال فـي حسم

المنازعات المنبثقة من المعاملات التجارية الدولية بمنأي عن مساعدة القضاء الوطني، فالعدالة الخاصة تتعم في أحضان العدالة العامة التي تهيمن عليها الدولة، ونظر اللفائدة التي تعود علي السلطة العامة من تحقيق السلام والأمن القانوني في المعاملات الدولية، فقد أصبحت العلاقة بين القضاء والتحكيم علاقة تعأون أو تكامل"("). وبالنسبة للموقف التشريعي مـن معاونـة القضاء لهيئة التحكيم في إجراءات الإثبات، فنجد أنه ذهبت بعض التشريعات إلى جواز اللجوء إلى القضاء لإجبار الخصم المتعنت أو الغير علي تقديم ما تحت يده من مستندات، ومنها علي سبيل المثال، المـادة

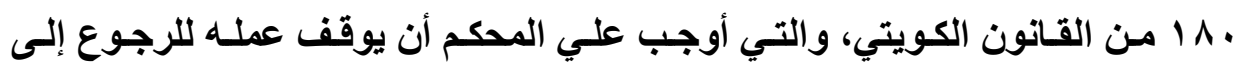

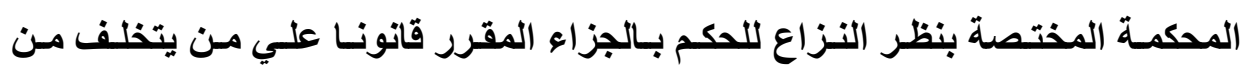
الشهود عن الحضور أو يمتنع عن الإجابة، أو الحكم بتكليف الغير بإبراز مستند في حوزته ضروري للحكم في الدعوي (؛).

(1) B. Moreau, A. Beregoi, et autre, arbitrage commercial, op. cit., no 222. (ץ) دا نبيل إسماعيل عمر، التحكيم في المواد المدنية والتجارية الوطنية والدولية،المرجع السباق، ص . (r) د/ ابو العلا النمر، دراسة تحليلية للمشكلات العملية والقانونية في مجال التحكيم التجاري الدولي،

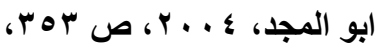

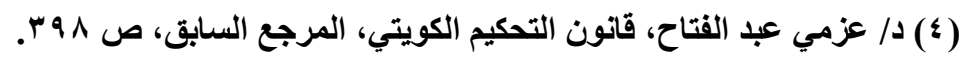


أما بالنسبة للنظام المصري فقد نصت المـادة V تحكيم علي أنه يجوز لهيئة التحكيم أن تطلب من رئيس المحكمة المشار إليها في المـادة 9 تحكيم الحكم علي من يتخلف من الهشود عن الحضور، أو يمتنع عن الاجابه بالجزاءات المنصوص عليها في

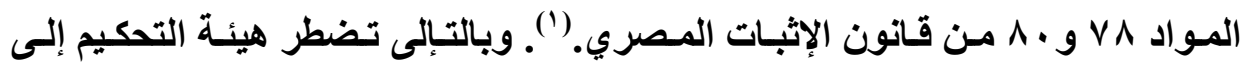
الاستعانة بالقضاء فيما يخرج عن ولأيتها وسلطتها، وذلك في الأحوال التي يكون فيها

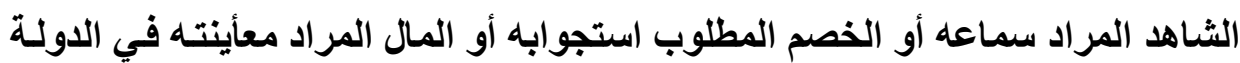
أخري غير الدولة التي توجد فيها المحكمة أو مكان إجراء التحكيم أو غير متيسر لهيئة التحكيم الانتقال إليه إلا بمشقة كبيرة(")

ولم ينص المشرع علي أي آثار لامتناع الخصم عن تقديم مستند تحت يـده، كمـا

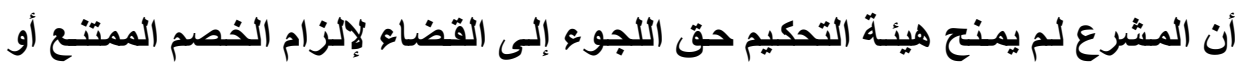
ترتيب أثثار لامتناعه عن تقديم مـا تحت يده، وعلي عكس مـا ذهب إليه بالنسبة لمن يتخلف من الشهود عن الحضور أو يمتتع عن الإجابه حيث أجاز لهيئة التحكيم اللجوء لرهي إلى القضاء في هذه الحالات.

وقد اختلفت كلمـة الفقه حول حق اللجوء إلى القضاء لإلزام الخصم أو الغير بتقديم ما تحت يده من مستندات، فقد ذهب بعض الفقه إلى القول بعدم جواز اللجوء إلى لى لإنى

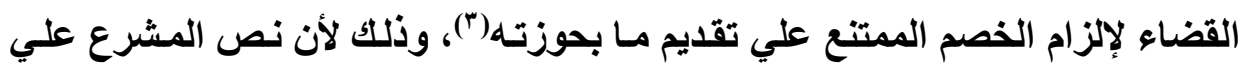
الجوء إلى القضاء قاصر علي حسالتين، وهما في حالـة تخلف الشهود عن الحضور

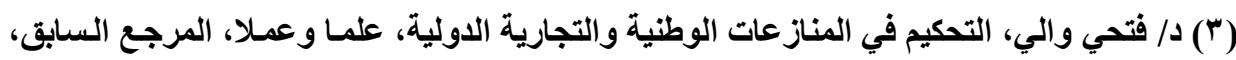


وكذلك الإنابة القضائية، ولم ينص علي إلزام الخصم أو الغير علـي تقديم مـا تحت يده من مستتدات. كما أن المشرع نص علي استمرار الهيئة في الفصل في النزاع دون أن إن يرتب أي جزاء علي تخلف الخصم عن تقديم ما تحت يده، ولم ينص علي إلزام الخصم

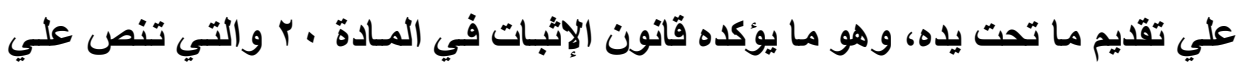
يجوز للخصم في حالات الآتية طلب إلزام خصمه بتقديم أي محرر منتج في الدعوي تحت يده، إذا كان القانون يجيز مطالبته بتقليمه وتسليمه. وهذا لـ ينص عليه قانون التحكيم('). ويجوز للمحكم أن يستتبط النتائج المنطقية التي ترتبت علي الرفض(') ـوقد ذهبت بعض أحكام القضاء المصري إلى أنسه لا يجوز تقديم هذا الطلب إلى المحكمة المختصة بمسائل التحكيم وفقا للمادتين 9 و 1 تحكيم، إذ هذا الطلب ليس طلبا بإجر اء وقتي أو تحفظي (r). وقد ذهب رأي أخر( ) إلى جواز اللجوء للقضاء لإلزام الخصم أو الغير لتقديم مـا بحوزته، وذلك لاعتبار ولب الآتية: • إذا كـان القانون يجيز اللجوء إلى القضاء في حالـة الشهود والإنابة، فيمكن القياس علي ذلك في كل حالة تخرج عن اختصاص هيئة التحكيم، كتكليف من ألزمته الهيئة بتقديم ما يطلب منه.

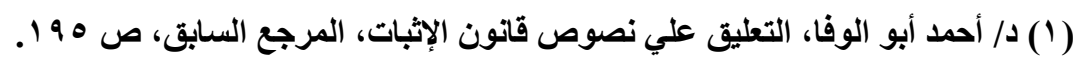

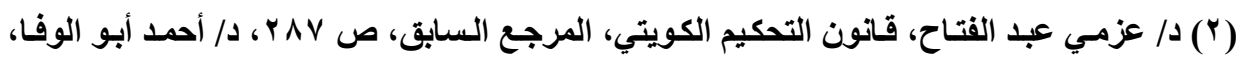

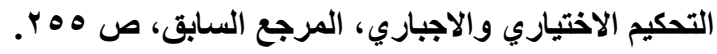

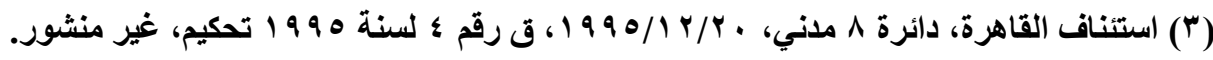

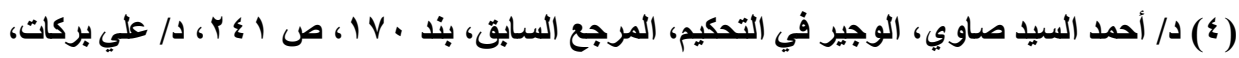

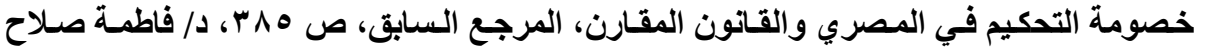

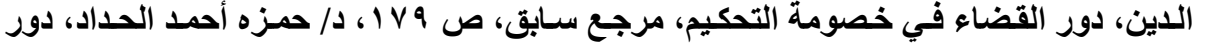

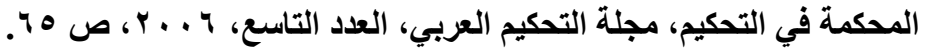


• الاتجاه العام للقانون الذي جعل القضاء سلطة معاونة ومساعدة للتحكيم للتخل في كل حالة تتعرض فيها الخصومة التحكيمية لصعوبات تعوق سيرها طالمـا لا

$$
\text { يمس الموضوع. }
$$

ونري أنه يمكن للمحكم اللجوء إلى القضاء للمساعدة في إلزام الخصم أو الغير

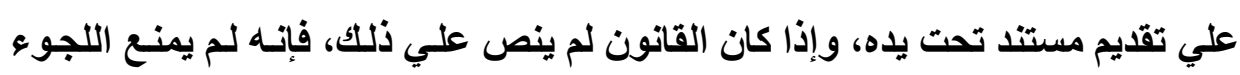
إلى القضاء في مثل هذه الحالات، وفي الواقع لحل هذه الإثكالية، يمكن للأفراد الاتفـاق

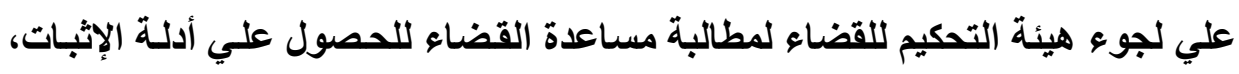
حيث إجازة المادة V r من القانون النموذجي للتحكيم إمكاتية هذا الاتفاق. وبالنسبة للغير الذي يحوز بعض وسـائل الإثبات التي تكون تحت يـده، فِان المحكم لا يملك أيه سلطة في إلزامـه نظرا للطابع الاتفـق للتحكيم. كما أن هذا الأصل يحول دون الغير والتدخل أو إدخاله، إلا بشروط محدده. وبالتالي لا يجوز إجبار الغير علي تقديم مستند تحت يده، كما لا يجوز إجبار شاهد علي الحضور. ويكون اللجوء إلى له القضاء في هذه الحالات هو الوسيلة الوحيده لتقديم هذا الدليل(').

\section{ثانيا: الإنابة القضائية.}

نصت المـادة V T تحكيم علـي أنها " يختص رئسيس المحكمـة المشار إليها في

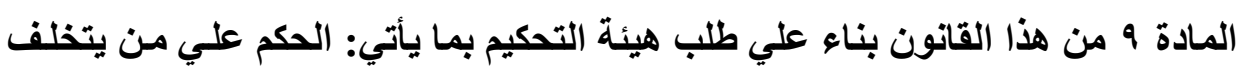

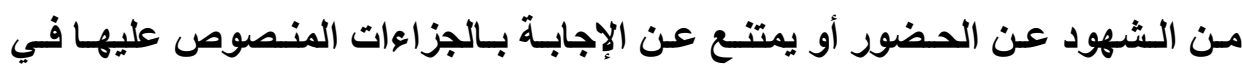

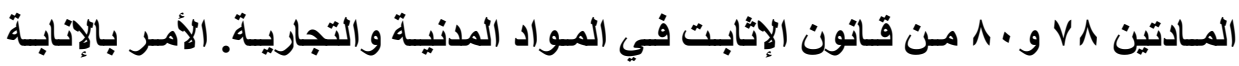


ويقصد بالإنابة القضائية التي نصت عليها المـادة V من قانون التحكيم علي اختصاص رئيس المحكمة المشار إليها في المـادة 9 من هذا القانون بنـاء علي طلب هيئة التحكيم الأمر بالإنابة القضائية. والأصل في هذه الإنابهـ أنها ترد علي أي إجراء من إجراءات التحقيق أو الحصول علي أدلة الإثبات الموجودة في الخارج. أي أن الإنابة القضائية تنصب علـي إجراعات الإثبات أو التحقيق كـالالزام بتقديم مستند، شـهادة الثهودر، معأينة، خبرة، فحص دفتر شركة، استجواب، إجراء تحقيق، استلام كفالـة أو

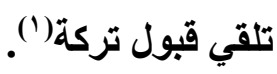
ويتضح من هذا النص الآتي: ا - وإذا كان الأمر يقتضي القيام بإجراء من إجراءات الإثبات في الخـارج، فليس

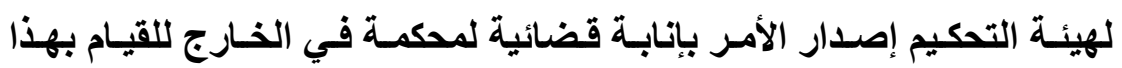
الإجراء. إذ تنص المادة vr تحكيم علي أن " تختص رئيس المحكمة المشار إليها في المادة 9 من هذا القانون بناء علي طلب هيئة التحكيم بمـا يأتي:.....

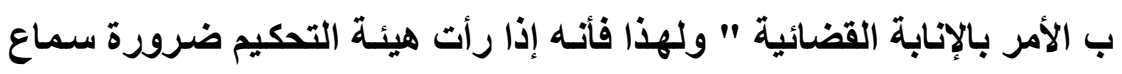
شاهد مقيم في الخارج تمنعه ظروفه من الحضور أمامها، أو معأينة عقار أو منقول أو مكان معين بالخارج يلزم معائته للفصل في النزاع، فأنها تطلب من

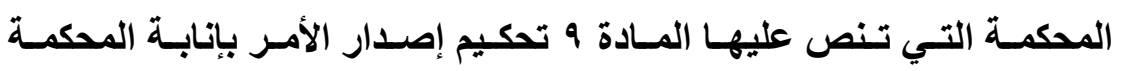

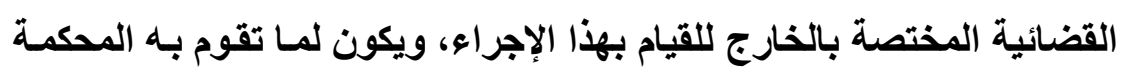
الأجنبية في هذا الشأن قوته في الإثبات أمام هيئة التحكيم(؟).

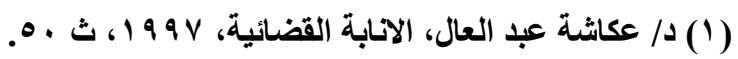

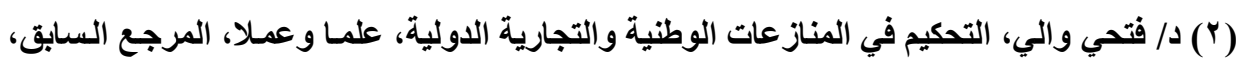

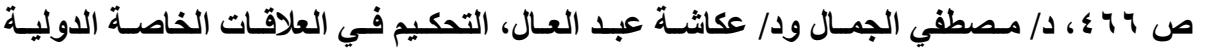

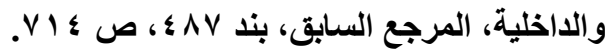




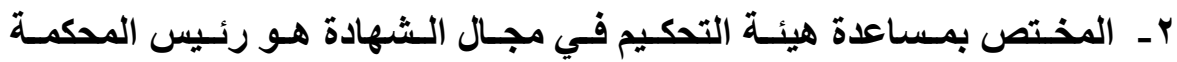

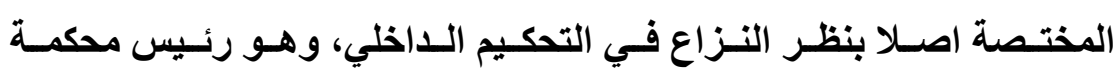
الاستئناف بالقاهرة إذا كان التحكيم تجاريا دوليا سواء جري التحكيم في مصر أو في خارج مصر، أو رئيس أية محكمة استنئاف يتفق أطراف التحكيم علي اختصاصها. r- وليس للقاضي المختص أن يسمع الثاهد بـل تقتصر سلطة علي أحد أمرين: الأول: توجيه الأمر إلى أحد الأطراف باحضار شـاهده أو تكليف شـاهد بعينه بالحضور لآداء الشهادة والأمر الثاني، الحكم علي الثـاهد الأي كلف بالحضور

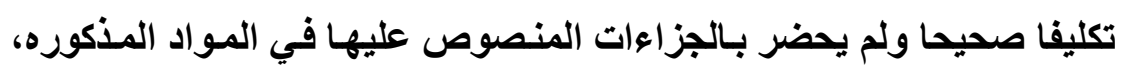
ويناء علي ذلك فإن سماع الشـاهد يكون من اختصاص هيئة التحكيم دون أن يحلف اليمين. ويثبت الحكم في المحضر ولا يكون قابلا للطعن، وفي غير أحوال الاستعجال إذا تخلف الشاهد عن الحضور رغم إعادة تكليفة الحضور حكم عليه بضعف الغزامة المذكورة. ء - أن المحكمة المختصة لا تتلخل علي النحو المشار إليه إلا بناء علي طلب هيئة

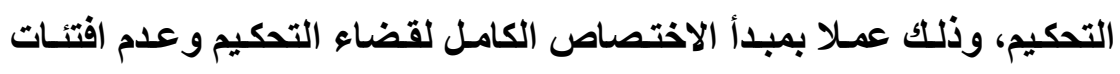

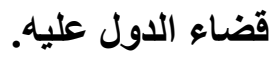
ويلاحظ أن هذا ما نص عليه القانون النموذجي للتحكيم الصادر عن لجنة الأمم المتحدة للقانون التجاري الدولي لعام هـ9 1 ـ كما أن له نظيرا في تثريعات التحكيمية المقارنـة منها القانون التحكيم الإنجليزي لعام 999 19، في المسادة بـ ؛، وفي القانون الهولندي

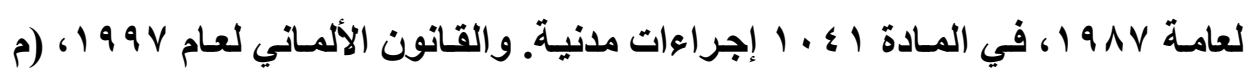

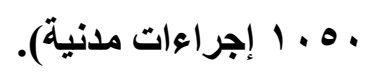




\section{المبحث الثاني \\ ساطة هيئة التمكيم في تقدير أدلة الإثبات}

سنشير في هذا المبحث إلى ماهية السلطة التقديرية لهيئة التحكيم في الإثبات،

وذلك في المطلب الأول، ونعـالج نطـاق السلطة التقديريـة لهيئة التحكيم، وذلـك في المطلب الثاني.

\section{الاطباب الأول \\ هاهية السطبة التقديرية لهيئة التمكيم في الإثبات}

سـنعالج في هـا المطلب، المقصود بالسلطة التقديريـة لهيئسة التحكيم في

الإثبات، وخصائص السلطة التقديرية لهيئة التحكيم، وذلك في الفروع الآتية:

\section{الفرع الأول}

المقصود بالساطة التقديرية لهيئة التمكيم في الإثبات

في الواقع تعترف الدولة للمحكمين بسلطة الفصل في بعض المنازعات التي

تحددها القوانين، فالتحكيم يعد صوره خاصة من صور القضاء، أو أحد الأنظمـة البديلـة للحمائة القضائية(')، يتفق فيه الأطراف علي منح المحكم سلطة في الفصل في النزاع. ولقد سعي المشرع المصري إلى تحقيق الفاعلية والأيجابية لهيئة التحكيم عن طريق تزويده بمزيد من حرية الحركة في الخصومة، وذلك حتي لا يترك كشف الحقيقة رهنـا

( ) د/ سحر عبد الستار يوسف، دور القاضي في الإثبات، دراسة مقارنة، المرجع السابق، ص 9 ؛. 
بمبادرة الخصوم وحدهم، وحرص علي سد باب الحيل والكيد. وكمـا منح هيئة التحكيم سلطة أوسع من سلطة المحكمة القضائية، حيث منع الطعن علي قرار هيئة التحكيم بأي طريق من طرق الطعن(')، ولم يُجيز مراجعة حكم التحكيم إلا بطريق دعوي البطلان وحدد أسبابها علـي سبيل الحصر، وليس منهـا مـا يتعلق بالرقابـة علي سلطة هيئة التحكيم في تقدير وتفسير أدلة الإثبات. وذلكك علي عكس بعض الأنظمـة التي أخذت بنظام الطعن بالاستئناف ضد حكم التحكيم كالنظام الفرنسي. فنلاحظ أن السلطة التقديرية لهيئة التحكيم واسعة المجال فهي تمتد إلى إسباغ التكييف القانوني الصحيح علي الادعاء، إمـا بتكييفهـ بـاعة أو بإعادة التكييف للوقائع

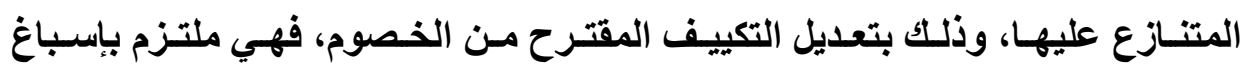
الوصف القانوني الصحيح علي ادعاءات الخصوم، دون التقيد بتكييف الخصوم لها في حدود سبب الدعوي، فـالعبرة بحقيقة المقصود مـن الطلبـات لا بالألفـاظ التي صيغت

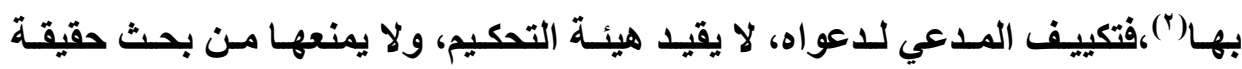

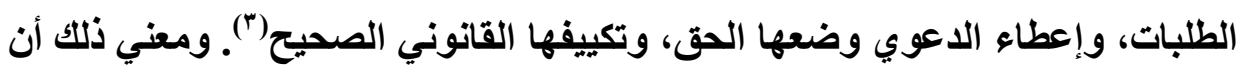
عملية المقارنة التي يقوم بها المحكم، وهو بصدد التكييف القانوني للنزاع قد لا تكون صحيحة نتيجة لخطأ المحكم في عمليـة القيـاس التحكيمي التي تتم بنـي الواقع وبين القانون. لأن المحكم اذ يمارس سلطتة التقديرية في هذا المجـال قد لا يجاتبه التوفيق، فيقدر الوقائع بفهم مغلوط، وبالتـالي يخطئ في اعمـال التكييف، وبالتالي يخطئ في تطبيق القانون. فالمحكم يقدر الوقائع، وهو يقدر مدي تطابقها مع المفترض الكامن في

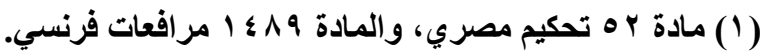

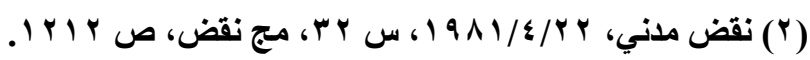

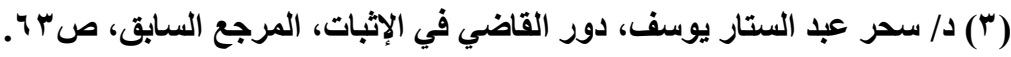


القاعدة القانونية، وأخيرا يقدر أن أثر معينا لقاعدة قانونية معينة هو الذي ينطبق علي واقع معين متنازع عليه، وبالتالي ينحسم النزاع علي هذا الواقع نتيجة لأعمال القانون.

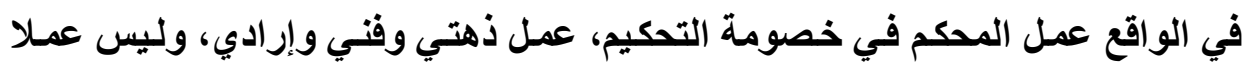

وإذا كان الخصوم أحراراً في اختيار الأدلة التي يرون أنها تؤدي إلى إقناع هيئة

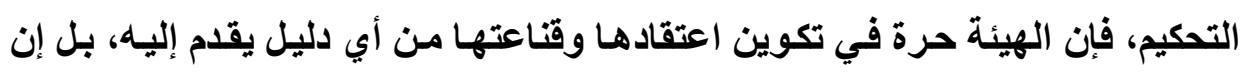
المحكم يستطيع أن يقوم بدور أيجابي في تحري الحقيقة بجميع الطرق التي يراهيا

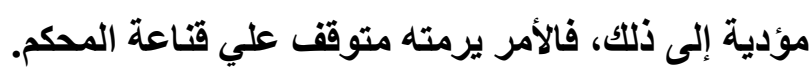

ويعتمد المحكم علي فهمة الثخصي لأدلة الإثبات وللقواعد الواجب التطبيق

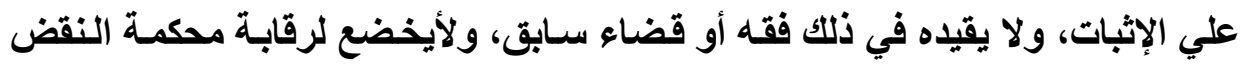
في ذللك، لأنه الحكم غير قابل للطعن، وتتلخص ماهية السلطة التقديرية الممنوحه لهيئة

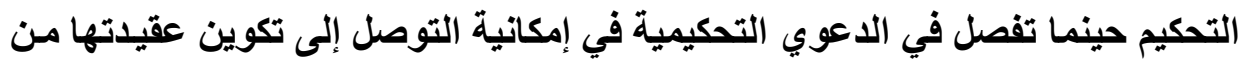
خلال ما يطرح عليه من وقائع وأدله وما يقوم بـه من عملية تدليل، وفيما ينتهي إليه من إعمالها النص القانوني أو قواعد العدالة التي تراهـا صـاحة للإعمال علي وقائع

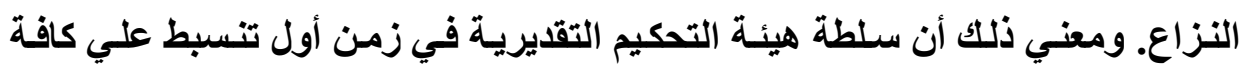
عناصر الدعوي. وعلي كل ما يلحق بها وما يتبعها. ومعني انبساط هذه السلطة يقصد به أن نثاط المحكم الذهني ينصب علي الواقع وعلي القانون في عملية مركبة شديدة

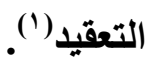


متي توافرت أدلة الإثبات التي أمرت هيئة التحكيم باتخاذهـا، سواء من تلقاء نفسها أو نباء علي طلب الخصوم، كان لها مطلق الحرية في تقديرها، وسلطتها في ذلك

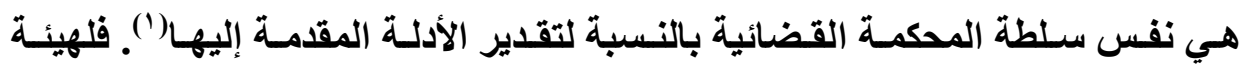
التحكيم السلطة التقديرية في أن تأخذ بنتيجة مـا أمرت بـه من إجراءات الإثبات أو ألا تأخذ به، وفي أن تكون عقيدتها مما أمرت به من إجراء أو من غيره ممـا في الدعوي من القرائن والمستندات، غير أنها إذا لم تأخذ بنتيجة ما أمرت به، وجب عليها أن تبين

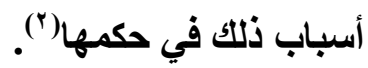

ويقوم المحكم باستخلاص ثبوت الواقعة عن طريق الاستنتاج مما يتكثف له من

الظروف والقرائن وترتيب النتائح علي المقدمات. ومعني ذلك أن الجهد الاستنباطي الأي يقوم به المحكم، لفرز الحقيقة عن الاليل المقدم إليه يجب أن يتم في اطار ذات هذا الاليل وليس في معزل عنـه، ويقوم المحكم عند بحث الأدلة بنشاط ذهني معين، وله حدود تتمثل فيما هو مطروح علي المحكم من عناصر واقعية ومـا هو منصوص عليه قي اتفاق التحكيم. وخلاصة النشاط الذهي تتمثل في تقدير كفاية وقوة الدليل من أجل حسم النزاع، وسلطة المحكم التقديريـة هي مجرد نشاط يرمسي إلى التوصل إلى أيجاد حدث معين،هذا الحدث هو تطبيق القانون أو القواعد المتفق عليها. ونري أنه يقصد بالسلطة التقديرية لهيئة التحكيم في الإثبات، هي حريـة ومكنة هيئة التحكيم في القيـام بعمليـة نشاط ذهنـي تعتمــ علـي استتباط من الدليل المقبول 
الاحتجاج به، والاقتناع الذي يدفع الهيئة إلى الحكم علي نحو معين، بعد تقديرها كفاية الاليل وقوة الاليل في الوصول إلى حقيقة النزاع.

ويقوم المحكم اثناء ممارسة سلطته التقديرية، بحصر إطار الدعوي التحكيمية، ثم بعد ذلك يقوم بفحص الأدلة المطروحه عليه، ويزن حقيقتها وقيمتها في الإثبات وكفايتها. فالقاعدة أنه حر في تكوين عقيدته. هذه الحرية مقيدة بأن هذه العقيدة يجب العاب أن تولد من العناصر المطروحة عليه. بمغني أن سلطته مطلقة في تكوين عقيدتهـ. بشرط أن تستخلص هذه العقيدة من عناصر طرحت أمامسه. أي أنه حريته في تكوين

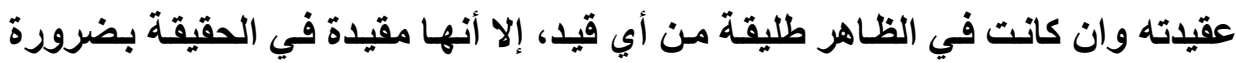
ميلادها من عناصر الخصومة التحكيمية.

ونري أن الهدف الأساسي من ممارسـة المحكم لسلطة التقيرية هو الوصول

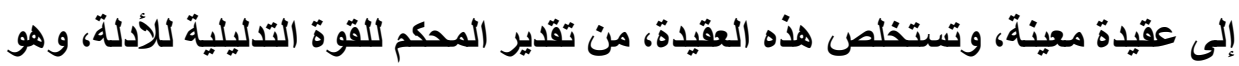

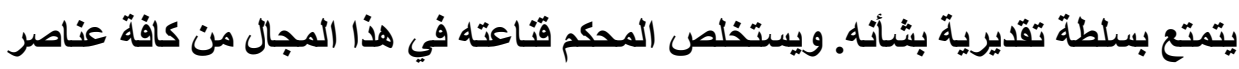

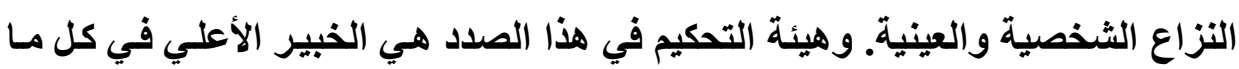
تسنطيع أن تثثق طريقها فيه بنفسها.

و يذهب رأي إلى أن أساس تقدير القاضي أو المحكم في نطاق الأدلة مستوحاة

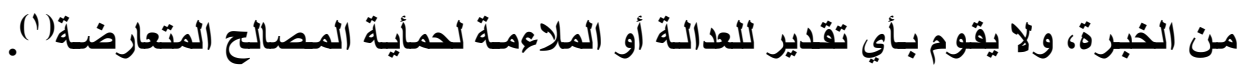
ومعني ذلك أن القاضي أو المحكم بصدد تقدير الأدلة ليس أمامسه متي اقتنع بحقيقة

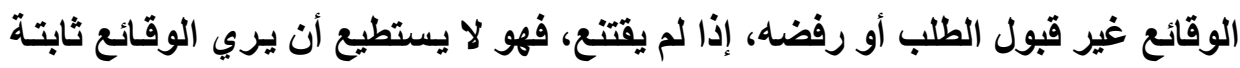
حسبما يبدوا له الطلب عادلا أو غير عادل وإنما هو يؤسس حكمه علي مطابقة الحقيقة. 
ويري البعض الآخر من الفقه أن هذا المنطق يجافي الطبيعة التقديريـة لعملية الإقتــاع، فالاقتــاع ذاتـه هـو عمل تقديري، يرجـع فيـه القاضـي أو المحكم للضميره ليستخلص الانطباعات التي تركتها الأدلة، المقدمة في القضيه في نفسه، وهذا المسلك من جانبه

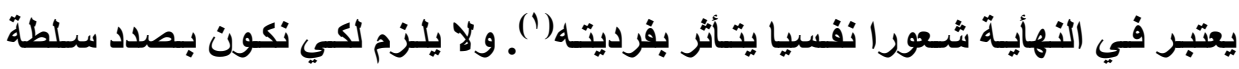

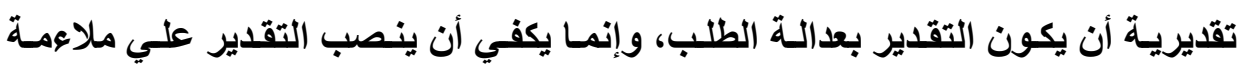

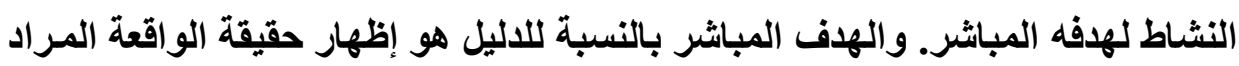
إثباتها. وهذا الهذف بالذات هو محل تقدير القاضي أو المحكم، وهذا التقدير لا يخضع لرقابة محكمة الطعن، كما أن القاضي غير ملزم ببيـان أسباب اقتناع بالدليل(؟). ويميز جانب آخر من الفقه بين تسبيب الاقتناع بمعني إعطاء تفاصيل تقدير المحكم للأدلة، وتحديد مدي نفوذ كل منها في ضميره وتحليل طريقة تكوين اقتناعه، فكل هذا يعفي منه المحكم، أما تسبيب الحكم بالأدلة فيلزم به المحكم، لأن الأدلة هي العناصر أو المصادر التي يستمد منها المحكم اقتناعه وليست أسباب هذا الاقتناع(").

\section{الفنرع الثثاني \\ خصائص السلطة التقديرية لهيئة التمكيم في الإثبات}

في الواقع تجد السلطة التقديرية للقاضي أساسها الشكلي في جميع الحالات التي

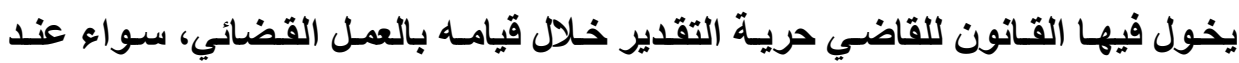
مباشـرة نـشاطه الإجرائسي أو عند اقتناعـه بـالواقع أو تقدير للحل الموضـوعي. حيث

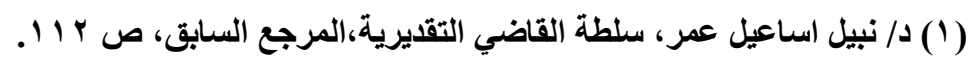

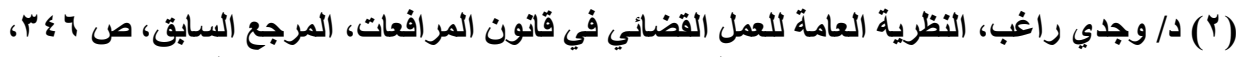

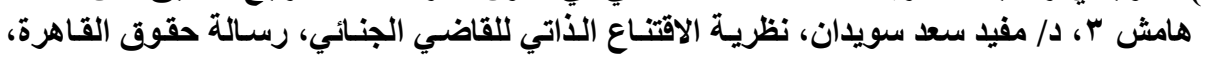


يتنازل المشرع عن إرداتـه في التحديد، وترك القاضـي ليقوم بذلكك بدلا منـه. وجوهر فكرة السلطة التقديرية يتمثل في أن يكون للقاضي حرية تقدير نشاطه في كل حالة علي لهي حدة وفقا لملابساتها الخاصة مما يتلاعم مع أهداف وظيفته('). في الواقع السلطة التقديرية لهيئة التحكيم تتمثل لها خصائص مميزة، وتتمثل في الآتي:

\section{أولا: حرية الهيئة في تقدير كفاية الأدلة:}

للمحم الحرية المطلقة في تكوين عقيلته كقاعدة عامـة. ومعني ذلك أن المحكم

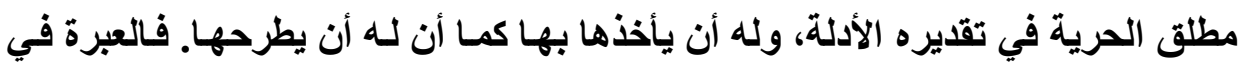

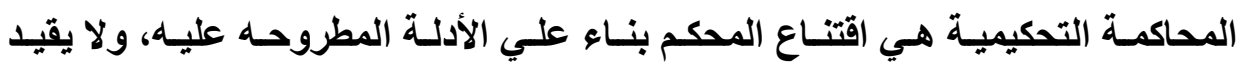
المحكم إلا اتفاق الأطراف والنظام العام، فيمكن للأطر اف الاتفاق علي علي تقييد المحكم بالأخذ باليل بعينه.

ولا يلزم في الأدلة التي اعتمد عليها الحكم أن يقطع كل دليل منها في كل جزء

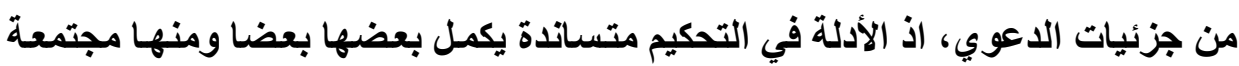
تنكون عقيدة المحكم.

\section{ثانيا: حرية الهيئة في تقدير قوة الداليل:}

تقوم الأدلة في التحكيم علي الاقتناع، للمكم أن يلتفت عن دليل نفي ولو حملته أوراق رسميه ما دام يصح في العقل أن يكون غير ملتئم مع الحقيقة التي أطمانت إليها

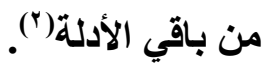

( (1) ولا تتنفي السلطة التقديريـة للقاضسي بمجرد تقييدها بالغايـة الموضوعية من النشاط، لأن ارادة

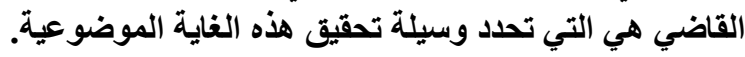

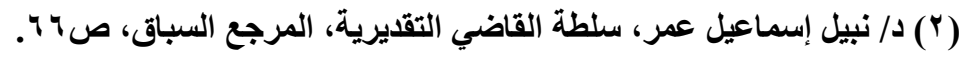


ومن الملاحظ في التحكيم، أن من سلطة هيئة التحكيم أن تزن قوة الإثبات وأن

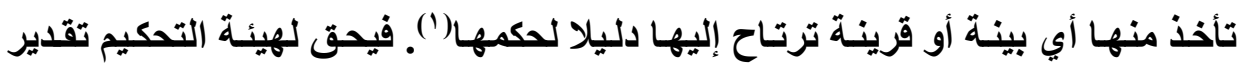
القوة التدليلة لكل دليل يعرض عليها، كتقرير الخبير المقام إليها. ويجب أن تبني حكمها

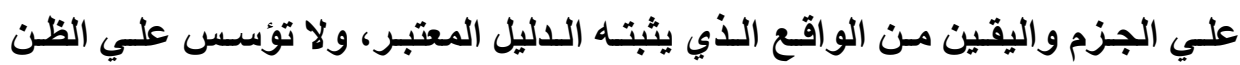
والاحتمال، ولا يقوم حكمها علي الفروض والاعتبارات المجردة. وتقدير القوة التدليلية وإن كاتت سلطة مخولة للمحكم، إلا أنها ليست سلطة مطلقة، بل مقيدة ومنحصرة في نطاق العنصر أو العناصر التي استمد منها المحكم هذا

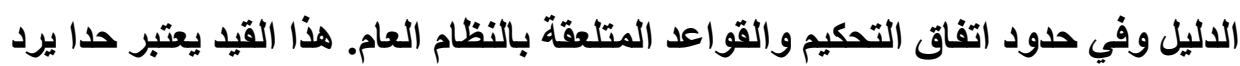
علي الاطلاق الذي قد يتصور البعض تركه لسلطة المحكم. ويجب أن يكون استخلاص هيئة التحكيم سـائغا وأن يكون دليلها قائمسة في الأوراق. وسلطة هيئة التحكيم في هذا المقام مقيدة بقدين: 1 - ما طرح عليها وكان ثابتا في الأوراق وتم تحصليه بإجراءات صحيحة.

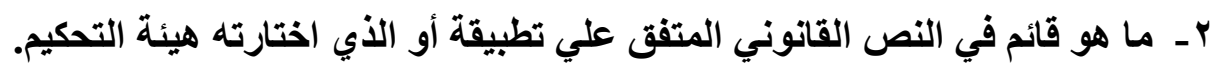
وسلطة المحكم التقديرية تنثط بين هذين الحدين. ولا يمكن تجاوزهما. وتختلف

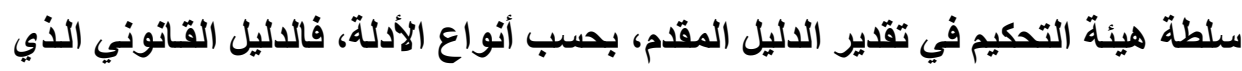

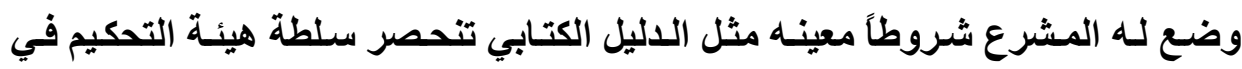
التأكد من توافره من عدمه فليس لـه تقدير قوة اللاليل إذا حددها المشرع مسبقا، ومـا علي المحكم إلا مراقبة توافر الثروط المطلوبه قانونا في الإجراء أو الدليل الذي استتد

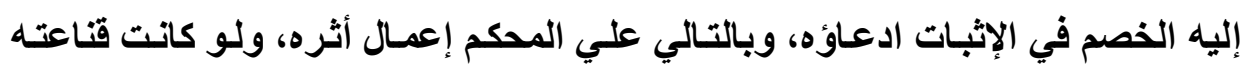


الاخلية متناقضة مع الحكم الذي أصدره، فمثلا الأدلة الكتابية أو المحررات المكتوبـة بنوعيها تقليدية أو إلكترونيـة لها حجية ملزمـة للمحكم كدليل إثبـات للواقعه المتــازع عليهـا، متــي كانـت مستوفية لشروط المطلـوب توافرهـا قانونـا ودور المحكم إزاءهـا يقتصر علي مراقبة المحررات من حيث مظهرهـا وصحتها. أمسا بالنسبة لأدلة الإثبات

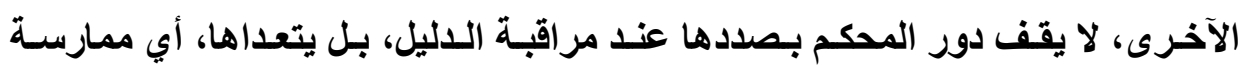
السلطة المطلقة في تقدير قوة كل دليل، ويبنـي حكمـه علـي مـا يطمسئن إليسه وجدانـه وشـوره، ويـوزان بين تلك الأدلـة مفضلا بعضها علـي بعض، فيأخذ بمـا اطمسان إليه ويطرح ماعداه ممـا لـم يطمسئن إليه،، مراعيـا في ذلك عدم الإخـلال بحقوق الدفاع '". ومراعاة دفوع الخصوم والتي من شأنها لو صحت لتغير به وجه الرأي في الدعوي وتطبيقا لذلك، فلهيئة التحكيم سلطة تقدير قيمـة الشهادة للأخذ بها من عدمـه، وله الأخذ بتقرير الخبير للأسباب الورادة بـه متي اطمسئن إليه، ولـه استتباط القرائن التحكيمية التي يعتمد عليها في حكمه، ولا يلتزم بإبداء أسباب ترجيحه دليلا علي آخر، مادام حكمه يقوم علي أسباب تكفي لحمله وتسوغ النتيجة التي انتهي إليهاب(؟). ومـن تطبيقـات ذلك ذهبت محكمة استئناف القـاهرة إلى أنـه إذا أتفق أطراف التحكيم علي نلب لجنه خبراء هندسيين ومحاسبين للمعأينة، فإن هذا الاتفاق غير ملزم لهيئة التحكيم، لأن وسائل الإثبات ومن بينها لجان الخبراء هي من الأمور التي تخضع هئ

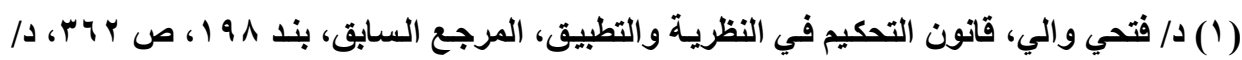

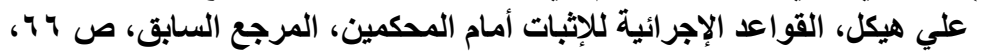

CA Paris, 10 nouv. 1989, op. cit., p. 651, obs. Pellerin, CA paris, 11 juill. 1991, op. cit., p. 671, obs. Loquin, CA Paris, 13 mars 1992, op. cit., p. 107, obs. Jarrosson, CA Paris, 13 nouv. 1997, op. cit., p. 719, obs. Derains.

(2) Id. 
لتقدير هيئة التحكيم التي لهـا السلطة المطلقة في الفـصل في أي طلبـات تـري مـن الضروري اتخاذهـا للفصل في الموضـوع المعروض عليهـا توصـلا لوجـه الحتق في الاعوي، وذلك طبقا لسلطتها التقديرية المخولة لهاب(').

\section{ثالثا: عدم الرقابة علي السلطة التقديرية لهيئة التمكيم:}

في الواقع،ازاء تعذر الرقابـة الحقيقيـة المطلقة للوقـائع، يقتـع المشرع بـاليقين الثخصي الذي يتحقق باقتناع القاضي. وليس معني ذلك أن رأي القاضي في الوقائع متروك لمطلق حريته وتحكمه دون ضابط أو رقيب. فالاقتناع هو اتجاه نفسي لشخص،

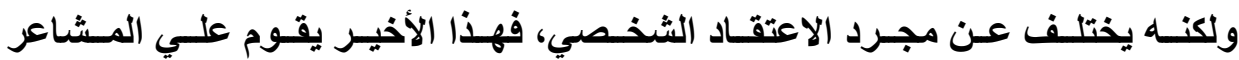
والانطباعات العابرة. والاقتناع يبدأ من مقدمات موضوعية يفترض بحثها وتمحيصها وتقديرها لاستخلاص نتائجـه المنطقيـة، أي أن القاضـي يقوم لتكـوين اقتناعـه بتفكير منطقي، وذلك لأيجـاز رابطة عقلية بين وقائع معلومـة وأخري غير معلومـة. وأسباب الحكم يجب أن تلل علي رأي القاضي، وتتضمن نتيجة منطقية لمقدمات تؤدي إليه وفقا للمنطق العادي المقبول، وتتحقق الرقابة علي القاضي من خلال التسبيب. يثار تساؤل هل المحكم، يخضع لرقابـة القضاء فيمـا يتعلق بالسلطة التقديريـة،

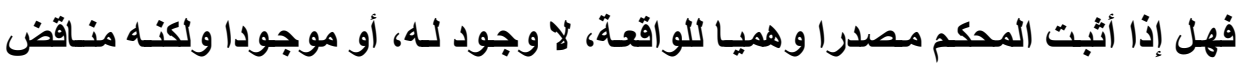
لوقائع أخري ثابتة، أو غير مناقض ولكن يستحيل عقلا استخلاص الواقعة منه كما فعل هو، فهل يكون حكمه مخالفا للقانون وواجبا نقضه. هذه الأعمال تؤدي إلى بطلان حكم 
يري بعض الفقهـ أنـه لا يمكن مراقبة خطأ المحكم في تطبيق القانون إذا كـان ملتزما به إلا إذا كان هنالك طعن بالاستئناف، أما الطعن بالبطلان فلا يمكن مراقبة عمل المحكم إذا أخطا في تطبيق القانون علي الوقائع ('). وذلك لأن أسباب الطعن البطلان محددة علي سبيل الحصر، وليس من ضمنها مراقبة المحكم في الخطأ في فهم أو تفسير القانون. ومن جانبنا نري أنه يمكن الاعتراض علي حكم التحكيم بطريق البطلان، وذلك علي أساس وجود خطأ أثر في الحكم. في الواقع يجب علي قاضسي الموضوع القيام بتسبيب الحكم موضوحا وقائع اللاعوي، ومـا استتـا إليسه من أسباب لقضائة هذا، ويخضع في هذه المسألة لرقابـة

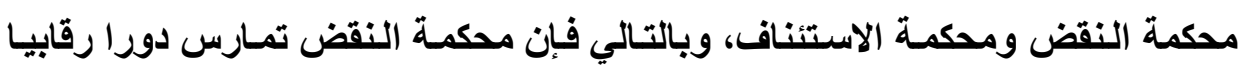
علي وقائع الحكم برقابتها علي التسبيب(`).

وبالنسبة للتحكيم، فلقد نصت المـادة بـ ــن قانون التحكيم علي أنها يجب أن يكون حكم التحكيم مسببا إلا إذا اتفق طرفـا التحكيم علـي غير ذلتك أو كـان القـانون الواجب التطبيق علي إجراءات التحكيم لا يشترط ذكر أسباب المكم، كمـا أن المـادة ب ه تحكيم نصت علي أن حكم التحكيم لا يقبل الطعن عليهه بـأي طريق من طرق الطعن، سواء كانت طرق عادية أو طرق غير عادية، ويترتب علي ذلك عدم جواز إعادة نظر موضوع النزاع من جديد أمام محكمة الطعن، وبالتالي لا يمكن مراقبة حكم التحكيم من ناحيـة كفايـة الأسـباب والقـصور فـي الأسـباب، خاصـة وأن أسـباب دعـوي البطلان

(1) B. Moreau, A. Beregoi, et autre, arbitrage commercial, op. cit., no 239.

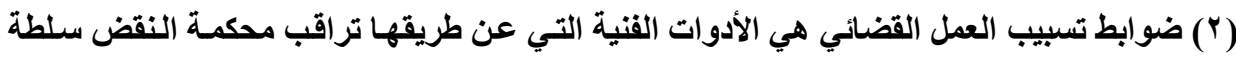

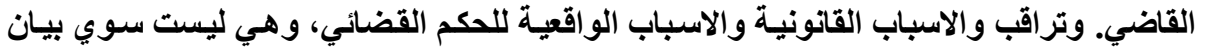

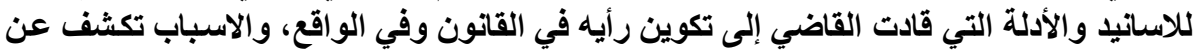
الطريق المنطقي الأي اتبعه القاضي في تكوين رأيه. 
منصوص عليها علي سبيل الحصر، ولا تتضمن الإثـارة إلى مقاربة أسباب التي بنى عليها المحكم حكمه. سواء من حيث القصور أو عدم كفاية التسبيب، أو عدم منطقية الإندانية

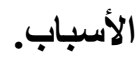

وترجيع الحكمة في منـع الطعن علـي حكم التحكيم بالاستتناف، إلى أن نظـام التحكيم يهذف إلى الابتعاد عن الإجراءات المعقدة في نظام التقاضي، وتعدده درجاته، بالإضافة، إلى اللجوء السماح باللجوء إلى محكمة الاستئناف يجعل هيئة التحكيم كأنها

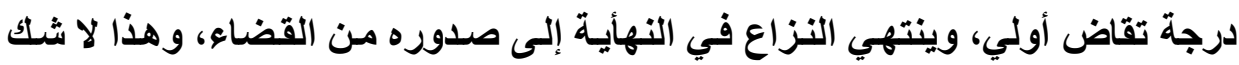
يقضي علي مميزات التحكيم، باعتباره طريقا سريعا وسريا للفصل في المنازعات. ونري أن مبدأ عدم مراقبة هيئة التحكيم في سلطتها التقديرية، وإن كان يحمل في طياته بعض مخاطر التحكم أو الخطأ في التقدير، إلا أن هذا المبدأ يتفق مع طبيعه فئه التحكيم، وكما أن الخصوم علي علم مسبقا بهذا الأمر، وقد قبلوه، وذلكت لمـا يحققه التحكيم من مميزات كثيره ومن أهمها السرعة والسرية وبساطة الإجراءات، وكما يخفق من هذه المخاطر أن التحكيم لا يكون في المسائل التي تتعلق بالنظام العام. ونري أنه لتحقيق العدالة، ومنح الخصوم مكنة مراجعة تقدير هيئة التحكيم، أن

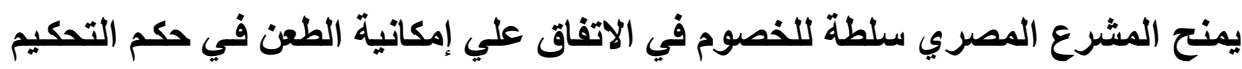

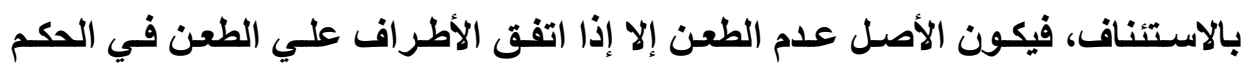

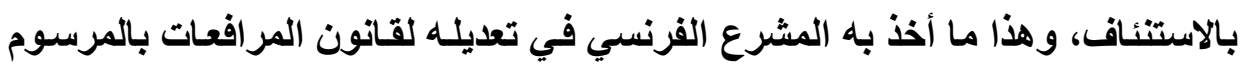

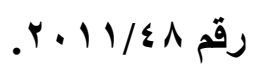

وقد ذهبت محكمة النقض الفرنسية إلى أنه حكم المحكم المخالف لقواعد القانون

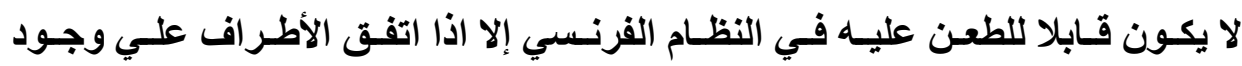


الاستئناف، وذلك لأن دعوي البطلان حالاتها علي سبيل الحصر وليس من ضمنها

حالات الخطأ في تطبيق أو تفسير القانون (')

خلاصة ما تقلم، في الواقع السلطة التقديريـة للمحكم تؤثر في مضمون عمله، فقد تجعله ملائما أو غير ملائم، وبالتالي عادلا أو غير عادل، كمـا في حالة إذا رفض المحكم الأمر بإجراء تحقيق، حيث يكون في هذا التحقيق فائدة لإظهار الحقيقة. ممـا يؤثر ذلك في تحقيق أو عدم تحقيق العدالـة. ورغم ذلك لا رقابة علي سلطة المحكم بصدد تقدير الأدلة فإن القانون يترك له حرية التقدير، حيث يقدر حالة بحالة قوة الدليل وكفأيته.

\section{الامطاب الثاني \\ نطاق السلطة التقديرية لهيئة التمكيم في الإثبات}

إذا كان الخصم مكلفا بعبء الإثبات، فلا يعني ذلك أن يقف المحكم مكتوف اليد منحسرا دوره في تلقي الأدلة دون أن يمارس دورا فعالا إزاءها، إذ اتجهت التشريعات الحالية نحو العمل علي زيادة فاعلية دور المحكم في إدارة الدليل متخذة خطوات جليـة. ولبيان نطاق السلطة التقديرية لهيئة التحكيم بوجه عام، يجب علينا أن نهتم ببيان كيف يسلك المحكم عند إصداره للعمل التحكيمي، وكيف يكييف المحكم الواقع المجرد بهدف إعـادة مطابقته للقانون أو للعدالـة، وكيف يقدر المحكم هذه الوقائع؟ ومـا هو مقدار التقدير الموضوعي المجرد في العمل التحكيمي، ومـا هو مقدار التقدير الثخصي في هذا العمل؟ وما الذي يخضع والذي لا يخضع لرقابة علي عمل هيئة التحكيم؟ (1) Cass. Civ., 2e, 29 nov. 1995, op. cit., note. E. loquin. 
في الواقع هذا التحديد ليس سـهلا، وانمـا يحتـاج لفحص أعمال هيئة التحكيم المختلفه اثنـاء سير خصومة التحكيم لمعرفة ماهية السلطة التقديريـة للمحكم، ولكن سيكون بحثنا قاصراً علي سلطة هيئة التحكيم في مجال الإثبات. ومقارنـة هذه السلطة بسلطة قاضي الاولة، وهذه الأخيرة تختلف باختلاف الموضوعات التي ينظمها القانون

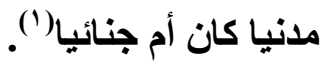

ويلاحظ أن السلطة الممنوحة للمحم تكون مقيدة عندما توجد شـروط معينة لمباشـرتها، وتكون تقديريـة حينمـا يترك المشرع أو اتفـاق الأطر اف لهـا مجـالا حرا للتقدير. ويترتب علي ذلك أن المحكم المقيد بقواعد القـانون لـه سلطة تقديريـة، تختلف عن السلطة التقديرية للمحكم الطليق أو الحر أو المصالح. وعلي ذلك يمكن القول بـأن

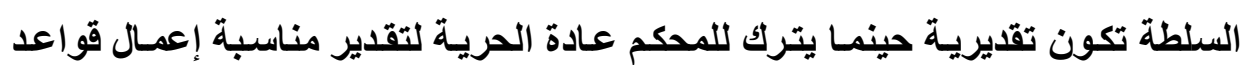

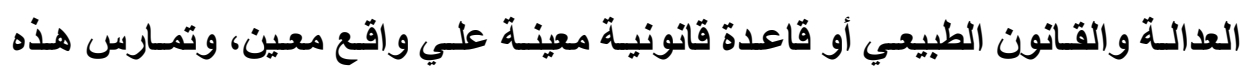
السلطة في مجال الواقع وليس في مجال القـانون في حالـة المحكم المقيـ بالقانون، والسلطة التقليرية لهيئة التحكيم في هذه الحالـة تؤدي بنفس الوظيفة التي تؤدي بها أمام القضاء. وسنقتصر دراستنا في هذ الموضوع علي نطاق السلطة التقديرية لهيئة التحكيم في الإثبات. سواء بالنسبة للمحم المقيد أو بالنسبة للمحم الطليق أو الحر، والمحكم المعفي من القواعد الإجرائية، وذلك في الفروع الآتية: 


\section{الفرع الأول \\ نطاق الساطة التقديرية للامكم المقيد}

سنشير إلى المقصد بالمحكم المقيد، وأنواع السلطة التقديرية للمحمم، وتطبيقات السلطة التقديرية للمكم، وحدود سلطته التقديرية في الإثبات، وذلك في النقاط الآتية:

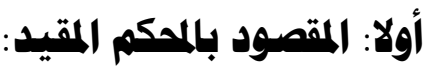

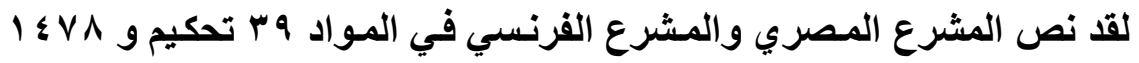
مرافعات علي أن المحكم يلتزم بالحكم طبقا لقواعد القانون ما لم يخوله الأطراف سلطة المحكم الحر أو المصالح'(")، ويستفاد من هذه النصوص بأن الأصل هو التزام المحكم بتطبيق قواعد القانون المختارة من قبل أطراف التحكيم. ويلتزم المحكم بتطبيق قواعد القانون كما هو الشأن بالنسبة للقاضي. ويقصد بالمحكم المقيد، هو ذلك الذي يتقيد فيـه المحكم بتطبيق قواعد القانون الموضوعي والإجرائي عدا تلك القواعد التي لا تتفق مـع أصول التحكيم، وهذا النوع

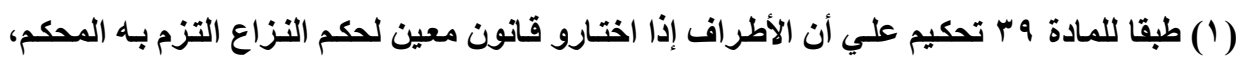

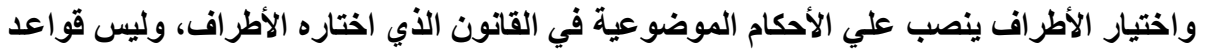

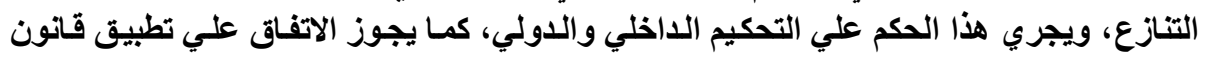

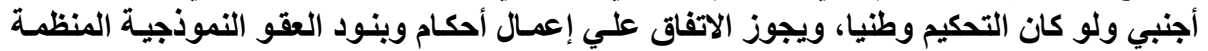

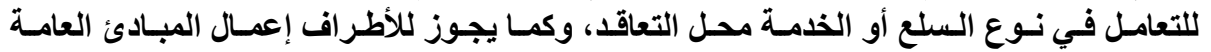

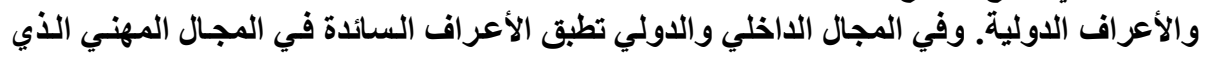

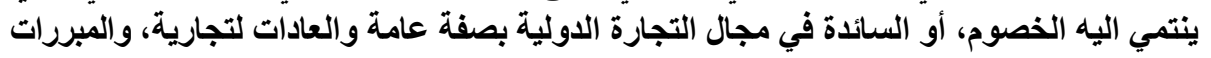

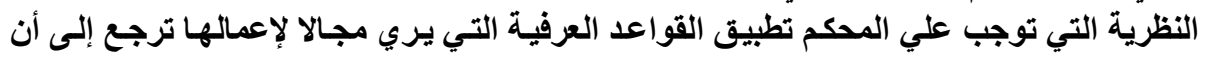

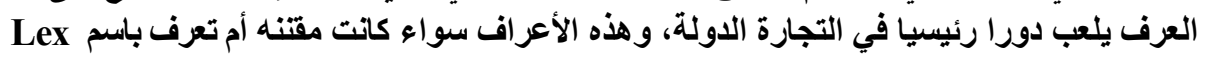
Mercatoria

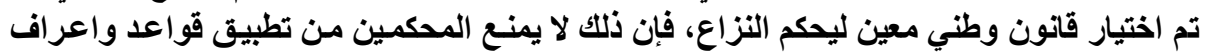
التجارة الدولية علي سبيل الاحتياط. 
هو الأصل في التحكيم، ولا يحتاج في الأخذ به إلى نص صريح علي ذلك في اتفـق التحكيم، وتقوم قرينة التحكيم العادي أو المقيد في حالـة عدم وصف نـوع التحكيم في التي الاتفاق علي التحكيم بأي وصف، وتستتد هذه القرينة إلى إرادة الأطراف في التمسك بالضمانة الناتجة عن تطبيق القانون. أما التحكيم المطلق فلا بـ من النص عليه، لأنها يشكل عدولا اتفاقيا لا لبس فيه عن حق التمسك بتطبيق القانون('). ويقوم المحكم بتطبيق قواعد القانون علي النزاع المطروح عليه، ويرجع بشأنه إلى إرادة الأطراف إذا كانوا قد اختاروا قانونا للانطباق علي النزاع، والقاعدة في هذا الثأن هي حريـة الإرادة في اختيـار القواعد الموضوعية والإجرائية التي تطبق علي

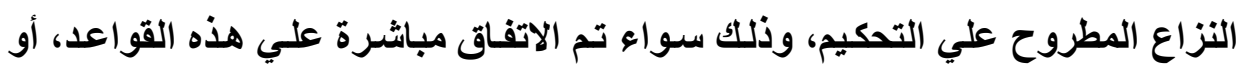
بطريق غير مباشر، أي تفويض هيئة التحكيم أو مركز تحكيم أو الغير علي تحديد هذه القواعد القانونية، وهناك اتجاه عام نحو إلزام المحكم بإعمال القانون الذي يتفق عليه الطرفـان أو يتبين من الظروف أنه هو المراد تطبيقة(؟). وحريـة الطرفين في اختيـار القانون الواجب التطبيق أمسام المحكم أوسع من حريتهم أمسام القاضسي، وأسـاس هذه الحرية يرجع إلى قاعدة دولية موضوعية أو مادية مضمونها أن لطرفي التحكيم إختيار

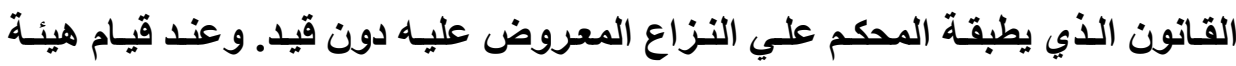
التحكيم بتطبيق القـانون الذي اختـاره الطرفـان فأنـه يطبقة باعتبارهـا قواعد قانونية تتتمي لنظام قانوني معين إختاره الطرفان، وليس بصفته امتدادا لنصوص عقد التحكيم

(1) Cass. 30 sept. 1981, Rev. Arb., 1982, p. 431.

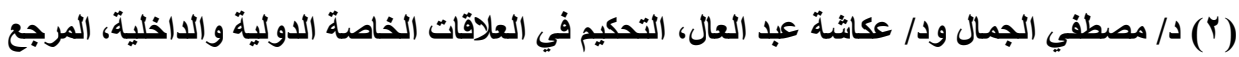

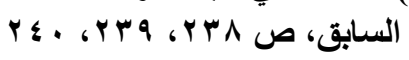

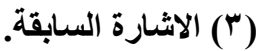


القواعد القانونية التي يتعين علي المحكم تطبيقها إمـا أن تكون قواعد قانونية

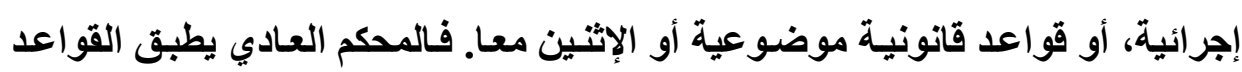

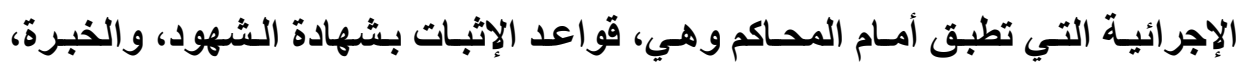

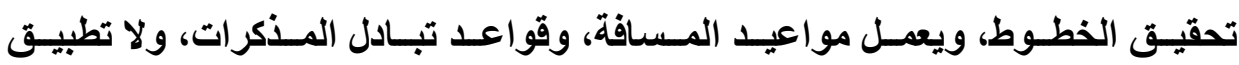
الإجراءات التي لا تتلاعم مـع أصسول التحكيم والقوعد الإجرائيسة التـي أوجد القـانون ل التحكيم قو اد بديلة عنها. وتتلذص سلطة المحكم العـادي في خصومة التحكيم في أنسه يتبع إجراءات

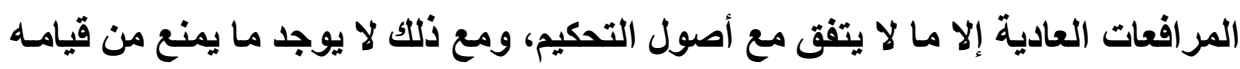

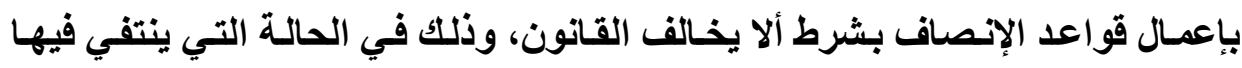
وجود نص قانوني يحكم النزاع، وواجب المحكم في إعمال قواعد القانون يستمد من فئن إرادة الطرفين الصريحة أو الضمنية أو المفترضه في قيام قرينة التحكيم العادي. ويري البعض أن سلطة المحكم في تطبيق القاعدة القانونية يترتب عليها فقدان

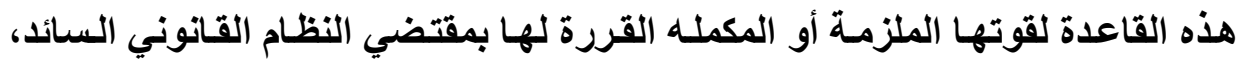

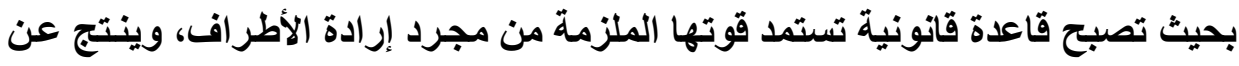

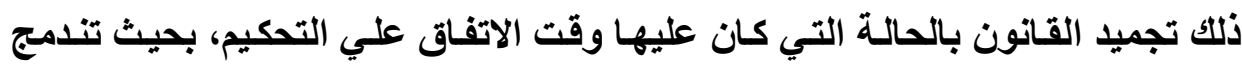
القاعدة القانونية في هذا الاتفاق، وتصبح مماثلة للشروط التعاقدية وملزمـة للمحكم علي هذا الأساس، وذلك رغم التطور الذي قد يلحق بهذه القواعد فيما بعد (').

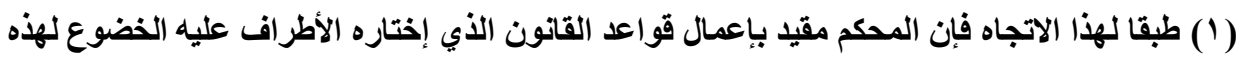

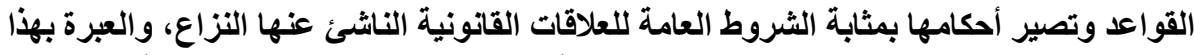

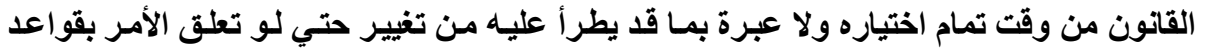


ويجوز للأطراف إعمال المبادئ العامة والأعراف الدولية. وفي المجال الداخلي واللدولي تطبق الأعراف السائدة في المجـال المهني الذي ينتمسي إليسه الخصوم، أو السائدة في مجال التجارة الدولية بصفة عامة والعادات التجارية، وجوهر هذه القواعد هو نظام مستمد من العادات والمماراسات السائدة في التجارة الدولية والمبـادئ العامـة المسلمة بين الدول وتعرف بقانون التجـارة الدولية. وهي عبـارة عن مجموعة قواعد

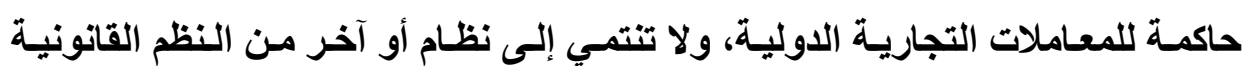
الوطنية، وإنما تقف إلى جاتبها مستقلة عنها(')

ويلاحظ في نطـاق قيـام المحكم بإعمـال القواعد العرفيـة أنسه لا يصح افتراض

أقتران التحكيم بالأعراف كطريق لحل النزاع إلا إذا انتمي كل الخصوم إلى نفس الوسط المهنـي أو المجـال التجـاري الذي يـدور فيـه النزاع، ولا يصح للمحكم أن يطبق هذه النه الأعراف إلا إذا انتمي هو شخصيا إلى نفس الوسط أو المجـال، أمسا إذا كـان المحكم من خارج الوسط الذي يدور فيه النزاع، فينبغي عليه أن يتأكد من الخصوم أو من غيرهم عن وجود القاعدة العرفية التي ينوي تطبيقها ومن مدي قوتها الملزمـة(؟)، وينبغي القـول بأنـه يمتــع علـي المحكم تطبيق الأعراف مهمــا كانت قوتهـا الملزمـة إذا أدرج الخصوم بنــا صـريحا بـذلك في اتفـاق التحكيم، وإلا تعرض حكمسه للإبطـال لاستبعاده تطبيق القانون الذي تم الاتفاق علي تطبيقة كما تنص علي ذلك المادة به تحكيم، ولكن نري أن اتفاق الخصوم ليس شرطا لتطبيقها ويسنطيع المحكم إعمالها من تلقاء نفسه،

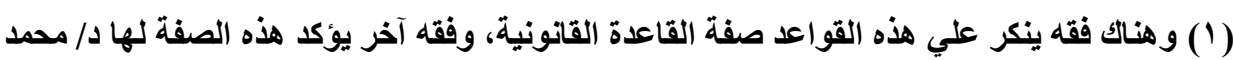

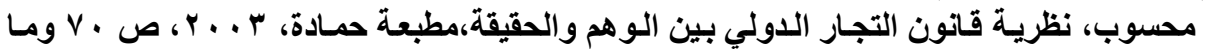

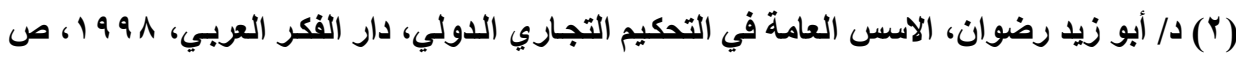


وهذه الأعراف لا تطبق إلا في أوسـاطها المهنية. ويجب علي المحكم الالتزام بـاحترام مبدأ المواجهة وعدم مخالفة النظام العام حينما يتصدي لإعمال القواعد العرفية.

\section{ثانيا: أنواع السلطة التقديرية للامصكم المقيد:}

ينقسيم نطاق السلطة التقديريـة التي يتمتـع بها المحكم إلى نـوعين: النـوع

الأول: التقدير الموضوعي الذي يتمتع بـه المحكم، والنوع الثاني: التقدير الثخصي

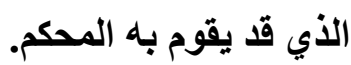

ويقصد بالتقدير الموضوعي، هو بحث النشاط الذي يقوم بـه المحكم بهدف

إعمال القانون علي المركز المتنازع عليه، والذي طرحه الخصوم علي المحكم، حيث يكون المحكم إزاء واقع يتطلب حلا قانونيا، وعلي المحكم أن يعطيه هذا الحل وإلا عد مخالفا لقبول مهمة التحكيم، ويلتزم بالتـالي بـالتعويض، والمحكم المقيد بالقانون ازاء هذا المركز المتنازع عليه يملك ترسانة من أدوات الفن القانوني، ونشاطه كلها ينحصر في إصدار عمل قضائي يعمل بمقتضاه حكم القانون علي هذا الواقع، ولكي يتم إعمـال

القانون، يجب علي المحكم أن يقوم بعمل تقديري، وهذا التقدير يكون موضوعيا' (').

ويقصد بالتقدير الشخصي للمحكم، هو الذي يراعي فيه عناصر شخصية في النزاع، ومن الناحية العملية فبان سيادة أي تقدير علي الآخر تتوقف علي مـا إذا كـان الأخذ في الاعتبار عناصر شخصية سوف يؤثر ام لا علي مضمون الواجب أو الالتزام الأي حصل الإخلال به. ففي أحوال الخطأ مثّلا، هل من الملائم ترك الاعتبـارات الأاتية جانبا لتحديد مضمون الالتزام الأي ترتب علي مخالفته وقوع الخطأ، وهذا هو المعيار الموضوعي، أم أنها يجب أن تؤخذ في الاعتبارات الشخصية في الحسبان عند تقدير 
مضمون الالتزام الذي أخل الخطأ به، وكذلك الأمر، تقدير قيمـة الشهادة، ومدي قبولها قوتها في الإقناع، فهذا تقدير شخصي من المحكم. ثالثا: تطبيقات للسططة التقديرية للمصكم المقيد

وإذا كانـت سـلطة المحكم المقيد تتحـد بنطـاق القـانون أو النظـام الذذي اتفـق

الأطراف علي تطبيقة، فإن هذا التقيد لا يلغي سلطة المحكم التقديرية، فالمحكم هو الذي

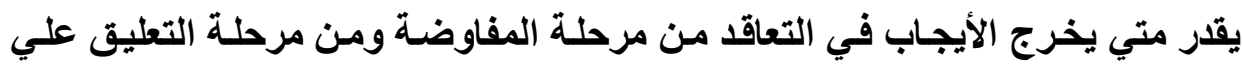
شرط إلى مرحلة الأيجاب البات، وفقا لإرداة المتعاقدين، ووفقا لظروف كل حالة، حيث إن ذلك من مسائل الواقع لا من مسائل القانون، وذلك وفقا للأدلة التي يقتنع بها. والمحكم المقيد لا يقتصر سلطته علي تفسير العقد بل يساهم في صنعته من خلال الأدلة المقدمة إليه، ولا شك في أن تقدير جوهرية المسائل المختلف فيها جوهرية أم لا، وبالتالي يبرم العقد أم لا من المسائل التي تلدخل في السلطة التقديريـة للمحكم، ويقوم المحكم أيضا بتقدير الظروف الملابسة في السكوت لبيـان دلالتهه علي الرضساء، وإذا تم العقد بطريق الإذعان، وكان قد تضمن شروطا تعسفبه، جاز لمحكم أن يعدل هذه الثروط أو أن يعفي الطرف المذعن منها، وذلك وفقا لما تقضي به العدالة، وهنـا أيضا يقوم المحكم بإعــال سـلطته التقديريـة لبيـان مقـدار التعسف في الـشروط، وبيـان مقتضيات العدالة.

والمحكم هو الذي يقدر قيام الغلط الجوهري من عدمـه ذلك الذي يعيب الرضسا ويجعل العقد قابلا للبطلان، وقد ذهبت محكمة النقض إلى أن تقدير ثبوت أو عدم ثبوت التدليس الذي يجيز إبطال العقد هو من المسائل التـي تستقل بها محكمة الموضوع)'. 
وير اعي المحكم في تقديره للإكر اه طبقا لنص المـادة V I مدني جنس من وقع عليه هذا الإكر اه وسنه وحالته الاجتماعية والصحية، وكل ظروف آخري من شـأنها أن تؤثر

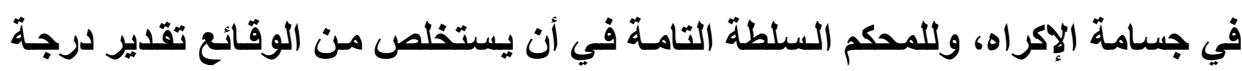
الإكراه، وهل هو مؤثر أو غير مؤثر، مسترشدا في ذلك بالمعيار الذاتي للشخص الواقع عليه الإكراه(') وللمحكم سلطة تقديريـة في نطاق إثباب الخطأ في نطاق المسئولية المدنية الذي هو أنحراف في السلوك، ويقع هذا الانحراف إذا تعمد الشخص الإضرار

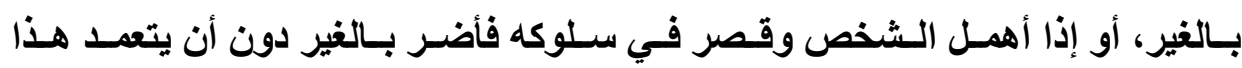
الإضرار(") ويحكم بالتعويض والذي هو جزاء مدني ينظر فيه إلى التعدي، وليس جزاء جنائيا ينظر فيه إلى شخص المعتدي. وفي نطاق فكرة النظام العام والآداب يظهر دور المحكم بسلطته التقديريـة، فهو يقر مدي اعتبار المسالة متعلقة بالنظام العام أم لا، ويقدر مدي تطبيق هذه القواعد المتلعقة بالنظام العام، ويعتبر مشرعا في هذه الدائرة المرنة فهو يتحري آداب المجتمـع ومصالحه.

وتلعب السلطة التقدير للمحكم دورا بـارزا في تفسير اتفـاق التحكيم والعقد الأصلي ما لم تكن العبارات واضحه، مثثله في ذلك مثل القاضي المدني (َ). وقد نصت المادة ـ 10 مدني مصري علي أنه اذا كان هناك محل لتفسير العقد، فيجب البحث عن النية المشتركة للمتعاقدين، دون الوقوف عند المعني الحرفي للألفاظ، مع الاستهداء في ذلك بطبيعة التعامل، وبما ينبغي أن يتوافر من أمانة وثقة بين المتعاقدين، وفقا للعرف

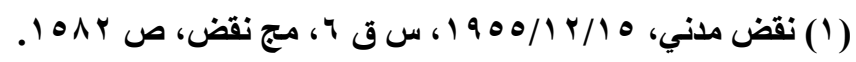

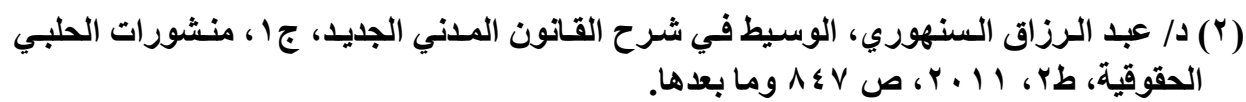

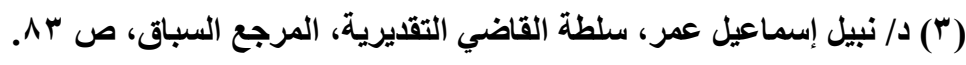


الجاري في المعاملات، ويعمل المحكم المقيد مثل القاضسي المدني سلطته التقديريـة في تحديد نطاق العقد، وذلك طبقا لنص المـادة ^ \ ا مدني، التي تنص علي أن " يقتصر العقد علي إلزام المتعاقد بما ورد فيه، ولكنه يتــاول أيضا مـا هو من مستلزماته، وفقا للقانون والعرف والعدالة بحسب طبيعة الالتزام". وبالتالي يمكن للمحم اللجوء إلى قواعد العدالة في استكمال شروط العقد لتحديد نطاقه('). ونري أن للمحكم سلطة تقديرية في نظرية الظروف الطارئة مثل القاضي، فيقوم بتقدير توافر أو عدم توافر شروط الواجب توافرها لقيام هذه النظريـة، وهو يقدر علي وجـه الخصوص نطاق الإرهـاق الذي يصيب المـدين من تنفيذ الالتزام عندما يتوافر الظروف الطارئة(؟) ويعمل المحكم سلطته التقديريـة في نطاق المسئولية التقصيرية، فيقر كفأيتها وقيام أركانها ويستخلص كافة النتائج المترتب عليها. وبالتالي فلكي يقوم المحكم بسلطته التقديريـة، يجب عليه القيام بنشاط الذهني في فهم الواقع المطروح عليه، واستتباط العناصر التي تلخل هذا الواقع في نطاق قاعدة قانونية معنية، ويقدر أنها هي التي تحكم النزاع المطروح عليه، ويملك المحكم سلطة تفسير أحكام القـانوني، فهو المنوط بـه تفسير القانون وتطبيقة تطبيقا صحيحا علي الواقع الذي يثبت أمامـه، وقدم يقوم الخصم بتفسير القاعدة القانونيـة، قاصـا حمل المحكم علـي أن يفهم القـانون الفهم الذي يتفق مـع مصلحته، وهـي لا تعدو مجرد محاولة، للمحم القول الفصل فيها، مستعينا في تحصيل هذا العلم بمراجعة نصوص 
القانون، وما وضعه الفقه من شرح لهذه النصوص، ومـا قرره القضاء من مبـادئ في

تطبيقهاب (1)

ويقوم المحكم بدور كبير في تقدير الأدلة وبيـان حجيتها، و إثبات الواقع الذي

يطبق عليها القانون، ولا نبالغ في القول بـأن عمـاد تطبيق القانون يرجع أسـاسـا إلى سلطة المحم التقديرية. فنلاحظ أن للمحم سلطة كاملـة في بحث الدلائل والمستندات المقدمة له(؟)، وفي عدم الأخذ بما لم يقتنع به ويطمسئن إليهه وجدانـه منها، ويحسبه أن يقيم قضاءه علي أسباب تحمله، وتؤدي إلى النتيجة التي انتهي إليها، وكذلك استخلاص المحكم علاقة السببية بين الخطأو الضرر، هو مما ياخل في تقديره(").

\section{رابعا: هدود السلطة التقديرية للمصكم}

ولا شك في أن سلطة المحكم في تقدير الأدلة تثبه سلطة القاضي المدني، وقد

قضت محكمة النقض بأن" لمحكمة الموضوع سلطة مطلقة في تقدير الأدلة المطروحة عليها، وفي استخلاص القرائن لما تحت يدها من أوراق وظروف الدعوي، وأنه لقاضي الموضوع السلطة التامة في فحص المستتدات المقدمة في الدعوي لاستتنتاج مـا يمكن استتتاجه عقلا من وقائعها"("). وقد ذهبت محكمـة اسـتئناف القـاهرة إلى أن " مـن المقرر أن وسائل الإثبات ومنها ندب الخبراء هي من الأمور التي تخضع لتقدير هيئة التحكيم التي لها السلطة المطلقة في الفصل في أية طلبات تري من الضروري التخاذهـا

(1) Ph. BERTIN, $L^{\prime}$ indication du fondement juridique de la demande, Gaz pal, 1987, 2 oct., p. 839.

(2) CA Paris, 12 juill. 1971, op. cit., p. 74.

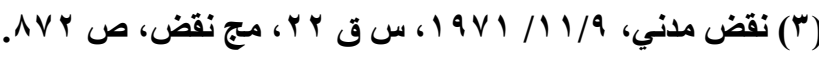

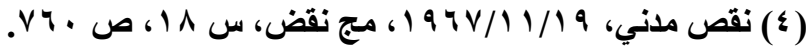


للفصل في النزاع المعروض عليها توصلا لوجه الحق في الدعوي. وذلك طبقا لسلطتها التقديرية المخولة لها"(1). وقد ذهبت محكمة النقض المصرية إلى أنها إذا اعتد حكم التحكيم بصورة ضوئية لمستندات جدها الخصم، فزالت حجيتها في الإثبات، فإن النعي عليه هو نعي علـي سلطة هيئة التحكيم في تقدير الأدلة، ولا يتسع لـه نطاق دعوي

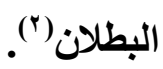

ويتقيد المحكم العادي في ممارسة سلطاته في الخصومة القائمسة أمامسه وأعمـال

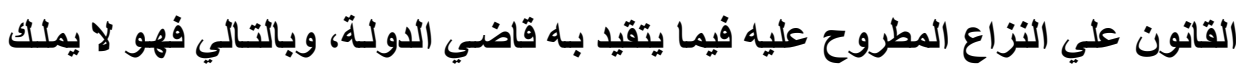
في أعمال القانون إلا بالقيـام بتفسيره وتطبيقه علي ضور التفسير المعتمد في العمل

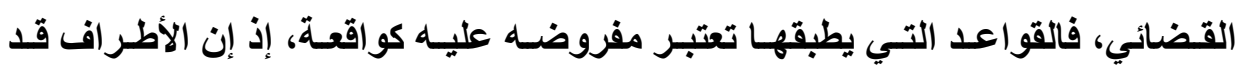
اعتمدوا قواعد تطبيق القانون الوضعي بحالته وقت توقيع اتفاق التحكيم، وهذه القواعد هي التي تلقي المحكم مهمة تطبيقها. في الواقع للسلطة التقديرية للمحكم حدود تثمثل في الآتي: - بالنسبة لبعض الأدلـة كـالإقرار والأدلـة الكتابية مثل المحررات، ليس من سلطة المحكم تقدير قوة الاليل إذ هذه حددها المشرع مقدما، ولهذا تتحصر سلطته في

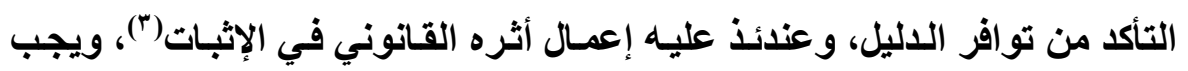
علي المحكم احترام مـا ينص عليه قانون الإثبات إذا كـان واجب التطبيق خاصـة القواعد التي تتعلق بقوة الدليل، ولهذا فإذا كان قانون الإثبات المصري هو الواجب الاجب إب 
التطبيق، فلا يجوز لهيئة التحكيم الاستناد إلى صورة ضوئية لورقة عرفية إذا كلان الطرف الآخر قد جدها أو جد توقيعه عليها' (') - بالنسبة لألة الإثبات الآخري، للمحكم السلطان المطلق في تقاير الاليل المقدم إليه

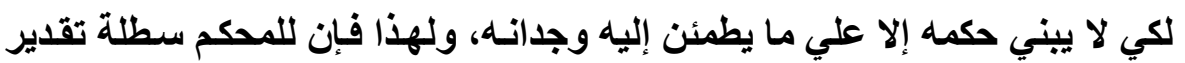
قيمة الثهادة للأخذ بها من عدمـه، ولهه الأخذ بتقرير الخبير للأسباب الورادة بـه

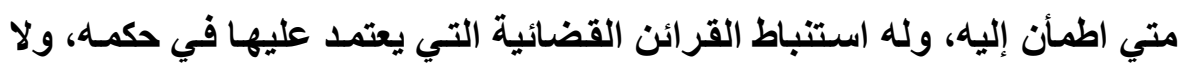
رقابة عليه في ذلك. - -

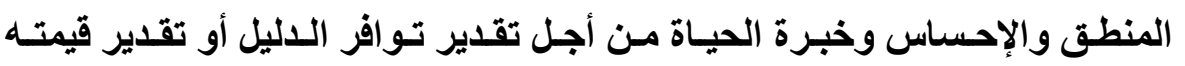

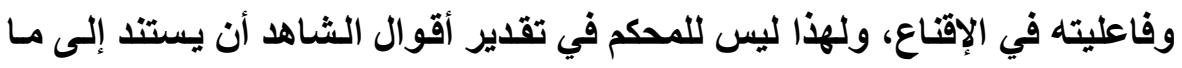

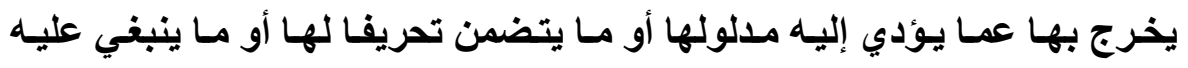
مخالفة للثابت من الأوراق.

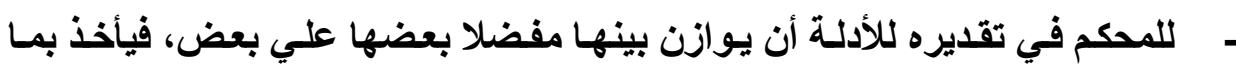
اطمأن إليه ويطرح ما عداه ممـا لم يطمئن إليه، ولا يلتزم بأيداء أسباب ترجيحه

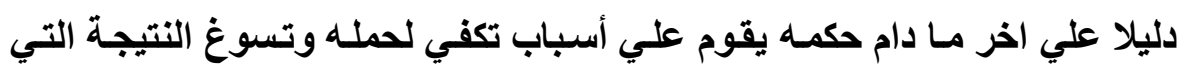

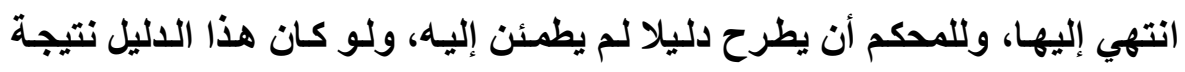
إجراء أمر به دون حاجة إلى إبداء سبب لذلكت. 
- والواقع أن سريان سـلطات القاضـي علي المحكم لا يأخذ بها علـي إطلاقهـا فيمـا يتعلق بأدلة الإثبات، ذلك أن هنائك بعض الأدلة التي يملك القاضي الأمر باتخاذها لما لهه من سـلطة جبر، والتي سـيتمدها من صفتته كعضو في السلطة القضائية)('). ويرجع ذلك إلى أن هيئة التحكيم تستمد سلطتها من اتفاق الأطراف، وبالتالي فهي لا تملك سلطة الجبر التي تملكها المحكمة باعتبار ها سلطة عامة. - أن لهيئة التحكيم السلطة الكاملة في الأمر بأدلة الإثبات التي تراها مناسبة للتحقيق في النزاع وتكوين عقيدتها، وسلطتها في ذلك نفس سلطة المحكمة، فلها من تلقاء نفسها أن تسمع الـشهود وتعـأين الأمكنـهـ أو تستعين بخبيـر أو توجيـه اليمسين

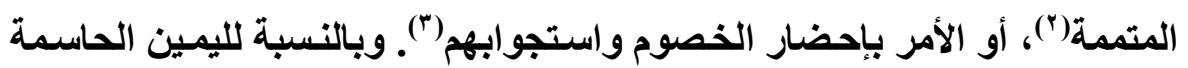
فيري البعض عدم جواز توجيهها في التحكيم(؛). - وفي الواقع، الجزاء علي مخالفة التزام المحكم بإعمـال القواعد المتفق عليها هو بطلان الحكم الصادر بنـاء علي هذه المخالفهه، ويؤسس هذا البطلان علي فكرة إاتصاب المحكم المقيد بقواعد القانون لسلطات المحكم المفوض بالصلح، علي أساس أن المحكم في مثل هذه الحالة يكون قد تعمد عدم احترام القانون، ويتحقق ذلك بتعمده أن يؤسس حكمسه علي أسباب أخري غير تلكك الأسبباب المستمدة من نصوص القانون.

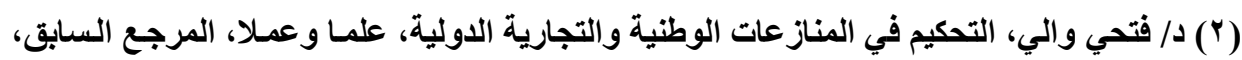
ص • ب

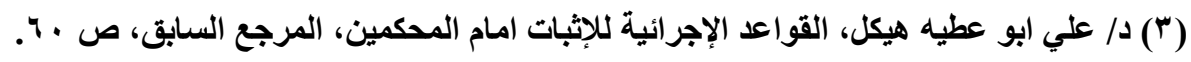

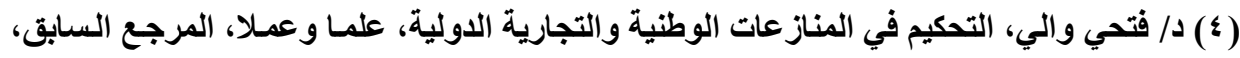




\begin{abstract}
الفرع الثاني
نطاق السلطة التقديرية للمشكم الفوض بالصلح أو الحر

سنشير إلـى المقصود بـالمحكم المفوض بالـصلح أو الحر، وحدود سـلطاته، والقيود التي ترد علي سلطته، وذلك في النقاط الآتية:

أولا: المقصود بالمككم الففوض بالصلح أو الحر:

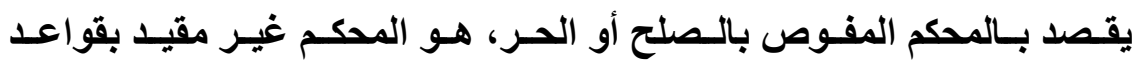
القانون(")، وذلك بنـاء علي تفويض أطراف التحكيم لله، فهو يحكم بنـاء علي قواعد هو

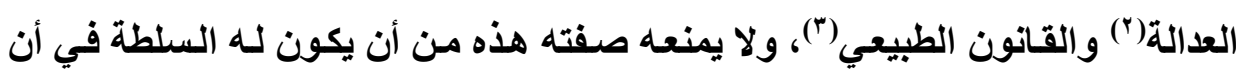
يحكم طبقا لقواعد أي قانون يراه مناسبا، باعتبارها تمثل قواعد العدالة. ويقصد بمبادئ

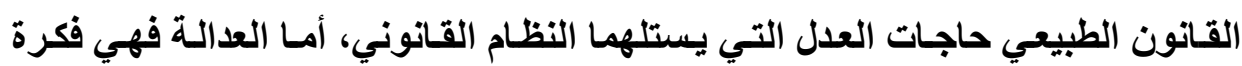

(1) B. Moreau, A. Beregoi, et autre, arbitrage commercial, op. cit., no 210

(2) Cass. Civ., 2e, 25 juin 1981, D., 1998, R., 185; Cass. Civ., 2e , 13 mai 1991, D., 1991, IR, 153, CA Paris, 28 nov. 1996, Rev. Arb., 1997, p. 380, note loquin.

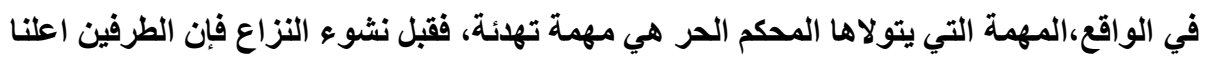

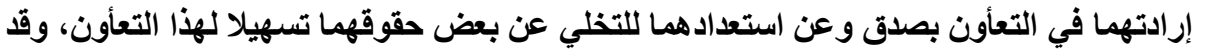

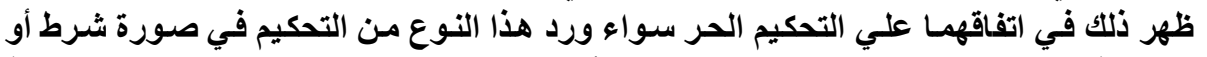

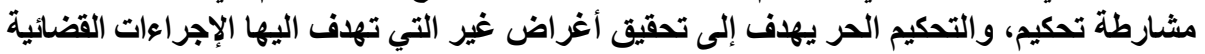

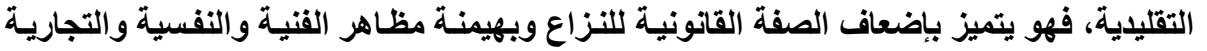

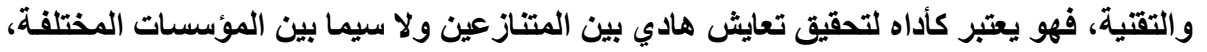

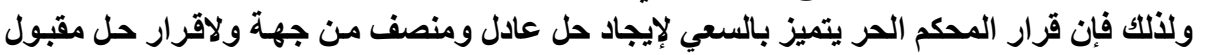
لكأطراف من جهة أخري.

(3) E. Lquin, l'amiable composition en droit compare et international, 1981, litec, p. 10. 
أغريقيـة الأصـل، تنسب إلى أرسـو الذّي حددها بأنها عدل الحالـة الفرديـة(') أي

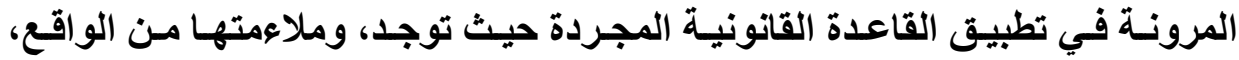
وبحيث يتفق هذا التطبيق مـع مهمة القاعدة وغائها، لا مـع حرفيتها. ومعنـي ذلك أن المحكم حينما يحكم في القضية، فأنه يستلهم مباثرة حاجـات العدل بالنسبة لملابسات القضية التي يفصل فيها، دون أن تكون قاعدة قانونية مسبقة. وقد أجاز المشرع المصري في المسادة و ب من قانون التحكيم كلا من التحكيم طبقا لقواعد القانون والتحكيم مع التفويض بالصلح()، وأتي بقرينة في صـالح التحكيم طبقا لقواعد القـانون، حيث ينبغي علـي الخصوم إذا أرادوا إعفـاء المحكم مـن أعمـال القانون أن ينصوا علي ذلك صراحة بتفويضه بالصلح (")، واستبعاد تطبيق القانون يتت بنـاء علي هذه الإرادة، بمعني يتــازل الأطراف في التحكيم عن الاستفادة من تطبيق القانون بواسطة المحكم،والواقع أنه من الصعب وضع تحديد منضبط ودقيق لمصطلح التفويض بالصلح، ويجب الرجـوع إلى إرادة أطراف التحكيم لتحديـ طبيعـة ونطـاق شروط التفويض بالصلح لأنها تلعب دورا رئيسيا في تحديد نظامه القانوني( (؛).

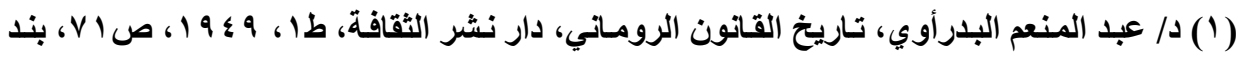

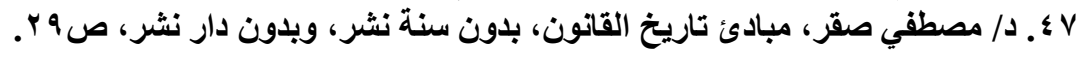

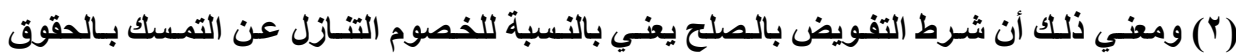

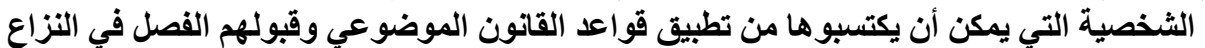

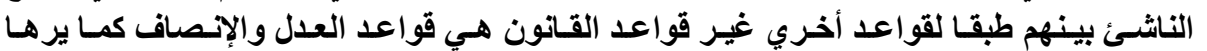

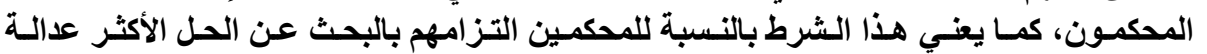
لموضوع النزاع المعروض عليهم دون التقيد بتطبيق أحكام القانون الواجب التطبيق أو بنود العقد التئ

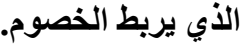

(3) B. Moreau, A. Beregoi, et autre, arbitrage commercial, D. 2014, no 212.

(4) E. Loquin, l'amiable composition en droit copmparé et international, Litec, 1981, p. 40 et s. 
ونري أن شرط التفويض بالصلح يفهم بصورة إجمالية علي أنسه تنـازل عن التهر

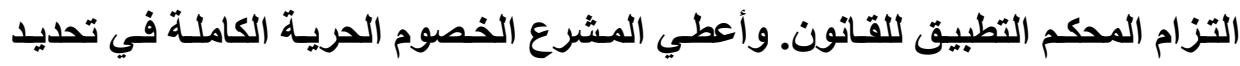

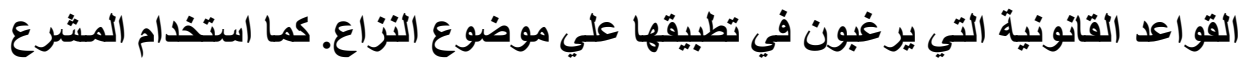

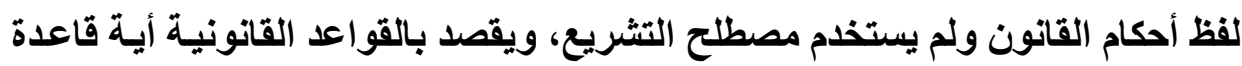
قانونية تحكم موضوع النزاع في القانون وطني معين، أو في أعراف التجارة الدولية،

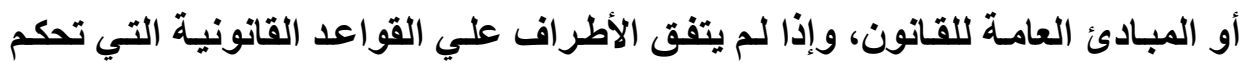

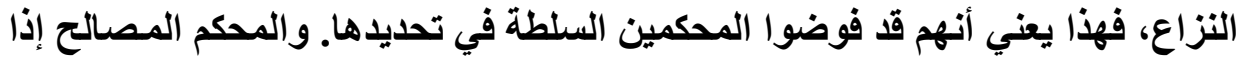
يقضي وفقا لما يراه من مقتضيات العدل والإنصاف، أيا كاتت طبيعة التحكيم وطنيا كان فئان

وقد نصت المـادة V \& ا مرافعات فرنسي علي أن المحكم يلتزم بالحكم طبقا

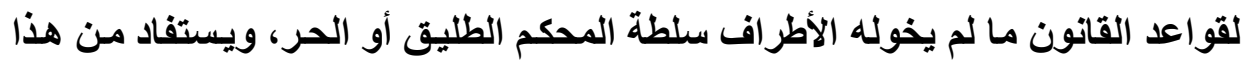

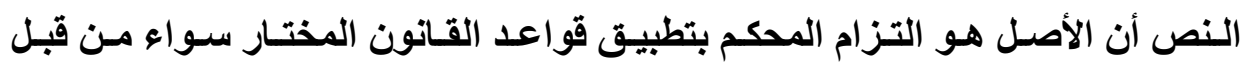
الأطراف أو الغير أو هيئة التحكيم نفسها، ولكن المحكم الطليق لا يتقيد بهذه القواعدا

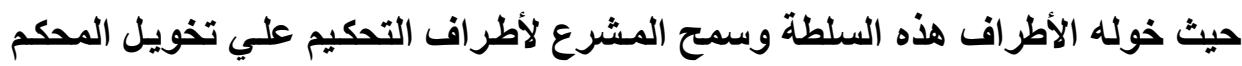
سلطة عدم التقيد بقواعد القانون، ولكن يجب عليه أحترام القواعد المتعلقة بالنظام

ويلاحظ المحكم المفوض بالصلح وإن كان معفيا من التقيد بأحكام القانون التي

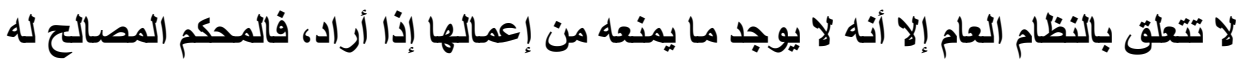

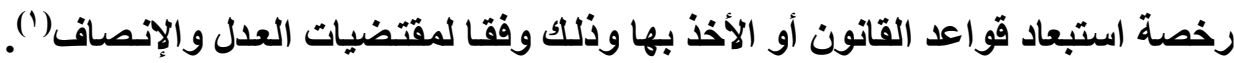

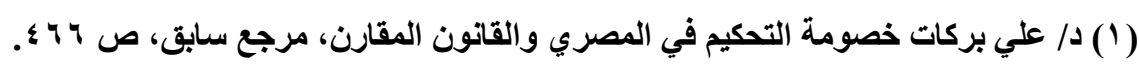
E. Loquin, l'amiable composition en droit copmparé et international, op. cit., p. 60 et s. 
والمحكم المفـوض بالـصلح لا يقضي طبقـا لقواعد العدالـة كمـصدر مستقل للقواعد القانونية، وإنما بالنظر إلى العدالة كغائة يجب البحث عنها في كل مصادر القانون من تشريع وعرف ومبادئ عامة، والتفويض بالصلح يشمل في وقت وأحد رخصة تطبيق قواعد القانون، وواجب استبعاد أي حل يتعارض مع مبادئ العدل والإنصاف، وبالتـالي ينبغي علي المحكم المفاوض أن يمتنع عن تطبيق القواعد القانونية إذا أدي تطبيقها في

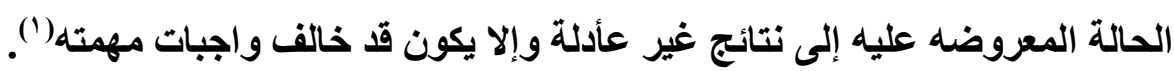
من المعروف أن التحكيم الحر يظهر في المجال التجـاري، ويعتمـد المحكم في عمله علي ما يجب اعطاءه لمعني العدالة في محيط الأعمال، ويلاحظ أن شرط التحكيم الحر أو مـع التفويض بالصلح يلدرج في معظم اتفاقـات التحكيم سواء كانت دولية أو وطنية، وأسباب ذللك ترجع إلى معـاداة اللجوء إلى القضاء التابع للاول بصفة عامـة، وذلك اقتناعا بعدم توافق نصوص القانون الوطنية لحكم الروابط التعاقدية نظرا لطابعها الدولي، أو للمسائل الفنية التي تثيرها هذه المنازعات، أو لتوجس الأطراف من إعمـال قانون وطني تقليدي علي علاقات تجارية حديثة متقدمة(؟). وفي هذا النوع من التحكيم نجد أن المحكم يبحث عن حل للتزاع وفقـا لقواعد العدالة، وذلك باستلهام ضمير العدل والجماعه للتوصل إلى حل لهذا النزاع، أي أن المحكم يتصور قاعدة قانونية تصلح للتطبيق علي النزاع، وهو في بحثه هذا يملك سلطة تقديرية في البحث والتقدير والملاعمـة، فهو يخلق قاعدة قانونية لها مفترضسا ولها حكما صالحا للإعمال علي الواقع المطروح عليه.

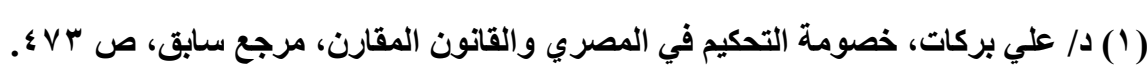
(2) E. Loquin, l'amiable composition en droit copmparé et international, op. cit., p. 40 et $s$. 


\section{ثانيا: حدود سلطات المككم الفوض بالصلح}

في الواقع هناك مبادئ قانونية مشتركة بين مختلف أنواع التحكيم سواء كان

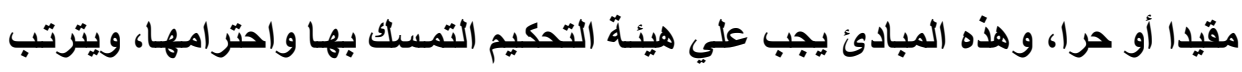
علي مخالفتها بطلان حكم التحكيم، مثال ذلك المبادئ المتعلقة بالنظام العام والمبادئ

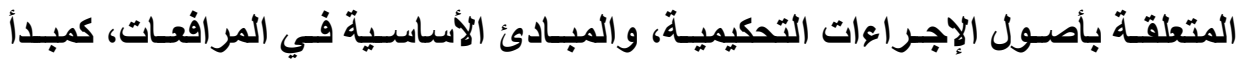

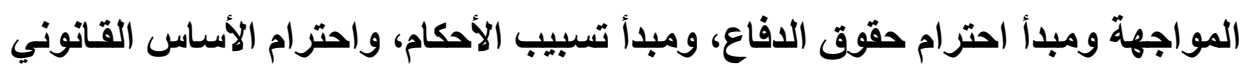
لخصومة التحكيم المحدد بواسطة الخصوم. وغنــ طرح نزاع علـي المحكم المفوض بالصلح، فأنسه يبحث مسائلة نطـاق

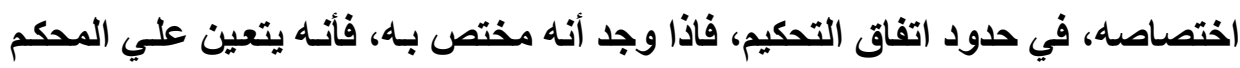

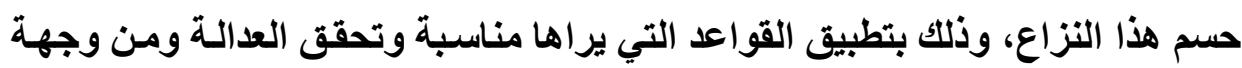

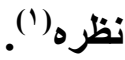

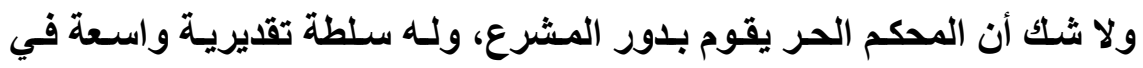
الرجوع إلى النصوص القانونيـة المكتوبـة أو القواعد العرفيـة، أو يرجع إلى مبـادئ

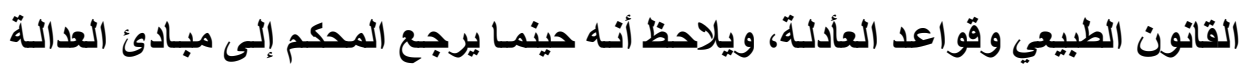
وقواعد القانون الطبيعي، فأنه لا يخلق فقط المعيار في فرض القاعدة التي يتوصل

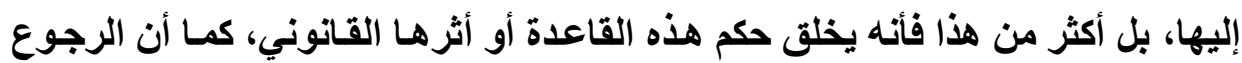
إلى قواعد القانون الطبيعي، لا يرجع المحكم إلى فراغ ليستمد منه هباء، وإنما يرجع لا شعوريا إلى المبادئ العامـة في القـانون الوطني، أو المقارن، وقد يرجع إلى أحكام

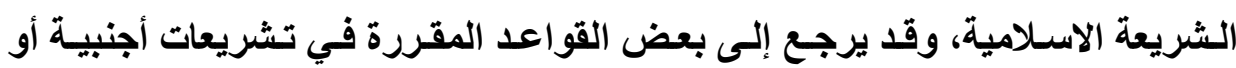

(1) Id., p. 20 et s 
معاهدات دوليـة، وقد يستخلم أحكامـا استوجبتها طبيعة الروابط الاجتماعية، دون أن يكون لها سند في سوابق التشريع أو العرف('). والواقع أن ثقافة المحكم تؤثر عليه في هذه المسألة.

والمحمم المفوض بالصلح في نطاق عمله، يجب الاعتمـاد علي مجموع واقعي مطروح عليه بهدف حسم النزاع الناشئ بصدده، وفي ضوء قيام المحكم باختيار قواعد العدالة التي يراها هو بحسب سلطته في التقدير أنها محتملة التطبيق علي هذا النزاع، ثم بعد ذلك يعمل المحكم نشاطه في فهم المعيار المجرد والوارد في هذه الأحكام، لكي يقوم بإعماله بعد ذلك علي مجموع الوقائع التي تستجيب موضوعيا لهذا المعيار، فدور السلطة التقديرية للمحم في هذا النطاق أوسع من دور المحكم المقيد(؟). في مرحلة نظر النزاع، فالمحكم المفوض بالصلح يتمتع بسلطة تقديريه واسعة النطـاق(")، تتمثل في النشاط الذهني الذي يقوم بـه، وهذا النشاط يمر بالعديــ مـن المراحل التي يستطيع المنطق رسم حدودها، ففي المراحلة الأولي يبحث المحكم في مدي تعلق وقائع النزاع بالدعوي، أي مدي قدرة وكفاءه هذه الوقائع في إثبات الواقعة الأصلية، ثم يبحث مدي إنتاج الواقعة في الإثبات أي دورها في إثبات الواقعة الأصلية. حيث يتعاصر في ذهن المحكم مجموعة من الوقائع تتعلق بالإثبات أو بالموضوع أو الو الو

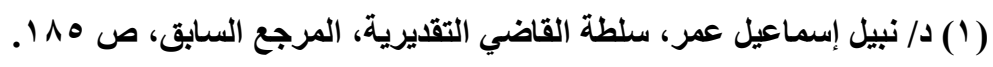

(2) E. Loquin, l'amiable composition en droit copmparé et international, op. cit., p. 40 et s; M. Maurin, le rôle reateur du juge dans les jurisprudances canadienne et francaise comparées, paros Rousseau, 1938, p. 13.Et s.

(3) E. Loquin, id., CA Paris,2 fev. 1988, op. cit., p. 68, note Couchez, CA Paris, 5 fev. 1976, Rev. Arb., 1976,p. 255. 
بالإجر اءات، كما يقوم في ذهن المحكم مجموعة من المبادئ تتعلق بالعدالة. كل ذلك يبحث مدي تعلق وإنتاجية الواقعة بالدعوي المطروحة علي المحكم.

ونخلص من ذلك أن نطاق سلطة المحكم الحر أكثر اتساعا من المحكم المقيد بقواعد القانون، حيث يملك المحكم تطبيق ما تراه مطابقا للعدالة والإنصاف دون التقيد بأحكام القانون، فالمحكم المفوض بالصلح غير ملزم بتطبيق قواعد المرافعات العادية، فيجوز للححم الأخذ بالقواعد الإجرائية التي يراها أكثر ملاعمة للفصل في النزاع بشرط

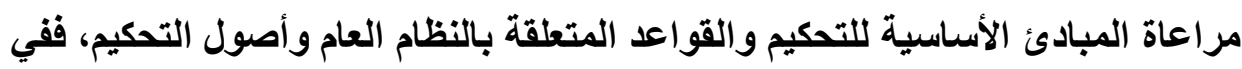
التحكيم المطلق تنحسر القيود علي سلطة المحكم إلى حدها الأدني إذ يتحرر في نظر النزاع والفصل فيه من تطبيق قواعد القانون الموضوعية والإجرائية ويحكم بمقتضي العدل والإتصاف بشرط أن يراعي القواعد المتعلقة بالنظام العام والمبادئ الأساسية في الخصومة والمر افعات والقواعد الخاصة بالتحكيم.

وفي هذا الصدد يجب ملاحظة أن التحكيم المطلق ليس صلحا، بـل هو عمل قضائي، إذ أنه يتم عن طريق فحص مـا إذا كـان مطلب الفريق الذي يتمسك بالإجحاف الظـاهري الـذي يلحق بـه الشرط المتــازع عليـه هـو مبـرر أم غيـر مبـرر إلا بـالنظر

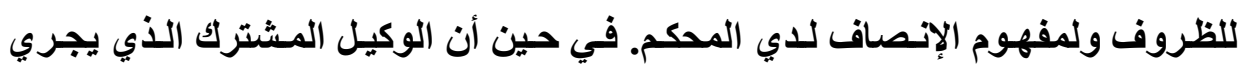
الصلح بين الأطراف لا يقوم بهذا الفحص، بل يحاول فقط التوفيق بينهما وإجراء تسوية بين مطالبهما المتعارضة. ويجير البعض للمحكم الطليق سلطة تعديل أثثار العقد المبرم بين الأطراف، فقد اعتبرت بعض أحكام القضاء الفرنسي أن مبدأ عدم تعديل العقد أو المساس به ليس من النظام العام، وهو لا يفرض علي المحكم المطلق، كما أن الأطر اف بالاتفاق علي التحكيم 
المطلق يكونون قد قبلو التنازل والذي يمنح حرية التصرف فيها(')، وعلي ذلك يستوي أن يحصل هذا التنازل عن حق يكون ناشئا عن القانون أم ناشئا عن العقد، إذ لا محل

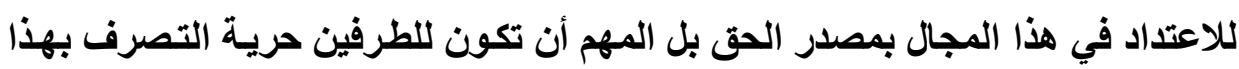

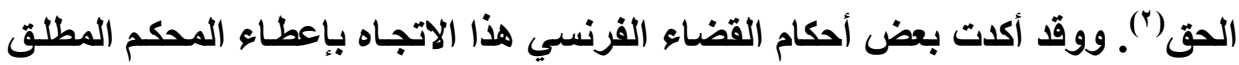
سلطة تعديل الحقوق الناشئة عن العقد (")، فقد أقرت سلطة المحكم المطلق في تعديل

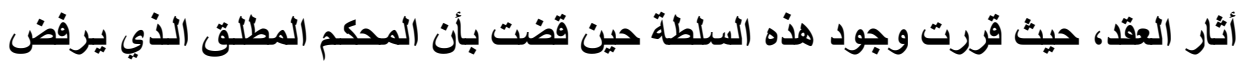
تقرير دين لأسباب بينها في حكمه، وهي تستتد إلى مفهومة للإنصاف لا يعد متجـاوزا لسلطاته كمكم مطلق، وكاتت القضية الصادر فيها هذا القضاء تتطلق بعقد توزيع أفلام

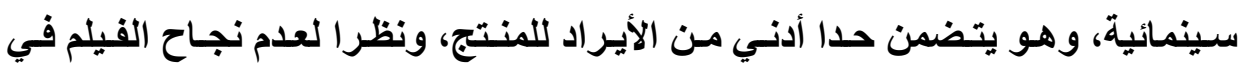

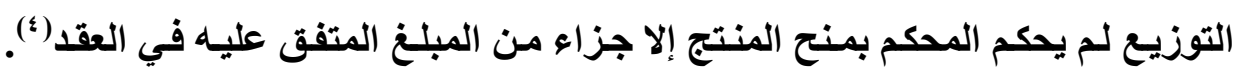
ويتضح من القرارات القضائية الصادرة في هذا المجال أن المحكم المطلق له سلطة في

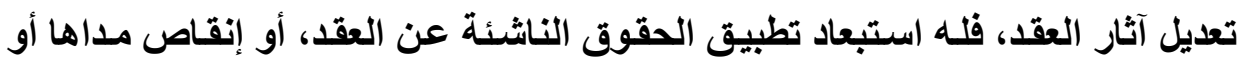
توسيع هذا المدي، وذلك تحقيقا للعدل والإنصاف، وتثبه سلطته في ذلك سلطة قاضي الدولـة في تعديل الشرط الجزائسي المنصوص عليهل في العقود، وذلكت تحقيقـا للعدل

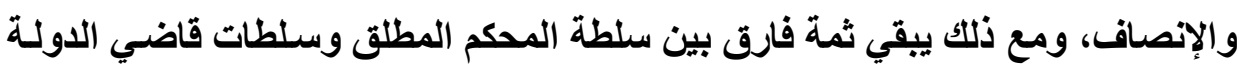
في تعديل آثار العقد، إذ إن المحكم المطلق يمارس سلطته تلك في نطاق شـامل وكمبدأ

(1) CA Paris, 12 mars 1985, Rev arb., 1985, p. 299, CA Paris, 6 janv. 1984, Rev. Arb., 1984, p. 279

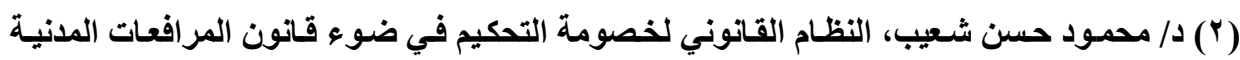

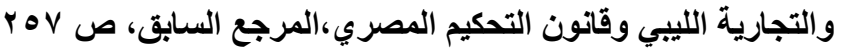

(3) CA Paris, 12 mars 1985, Id., p. 299, CA Paris, 6 janv. 1984, id., p. 279

(4) CA Paris, 10 mars 1981, Rev. Arb., 1982, p. 214.

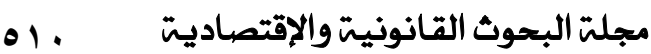


عـام، بينمـا قاضـي الدولـة الملتزم بتطبيق القانون يملكك هذه السلطة بشكل استثنائي محصور في الحالات التي يسمح لله بها القانون.

بينما يري جانب آخر من الفقه أن الاتفاق علي التحكيم المطلق لا يمكن أن يخول المحكم الخروج عن الإرادة المعلنة في العقد، ولا يتصور أن يعطي الأطراف مثل هذا المدي لتنازلهم، ويؤكد بعض الفقه في هذا المجال علي أن التحكيم الحر يفترض احترام العقد علي المحكم احتراما وثيقا، ومع ذلك يمكن اعتبار أن الاتفاق علي التحكيم الحر يخول المحكم استعمال سلطاته لمجرد أن يكون تطبيقة القانون بدقة علي العقد مؤديا إلى نتيجة غير عأدلة، وبالتالي يملك أطراف العقد أن يقصروا التحكيم المطلق علي الحقوق الذاتية الناشئة لهم عن القانون، دون تلك الناشئة عن العقد المتنازع عليه.

\section{ثالثا: القيدود التي ترد علي سلطة المككم الافهوض بالصاح}

سلطة المحكم المفوض بالصلح ليست مطلقة، ولكن يرد عليها بعض القيود (1)

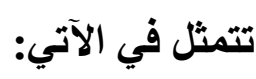

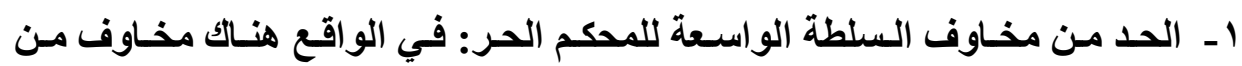
السلطة الواسعة التي يمارسها المحمم المفوض بالصلح، ولكن يتخفف من مخـاطر التعسف الذي قـ يـلازم هذا التحكيم بالقدر الذي يعتمده المحكم كحل متوافق مـع

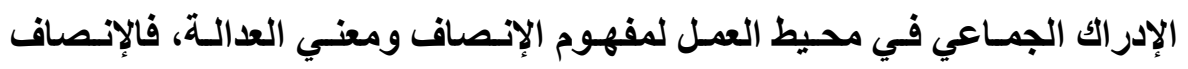
يعتمد علي قيام المحكم بإعادة التوازن الاقتصادي للعقد عندما يظهر أن هذا الأخير

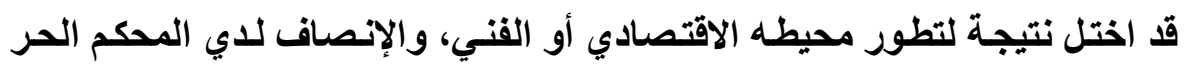
يرمي إلى المحافظة علي التوازن الأصلي للعقد، وفي نظر الأطراف يقوم الإنصاف 
بالتوازن العقدي كما كان متحققا عند إجراء المفاوضـات وابرام العقد، ويختل هذا التوازن مثُلا عندما تتغير الظروف التي تعاقد الطرفـان تعت حكمها ممـا أدي إلى زيادة الأعباء على أحدهما زيـادة بالغة بالنسبة إلى الفائدة التي توخاهـا الأصل،

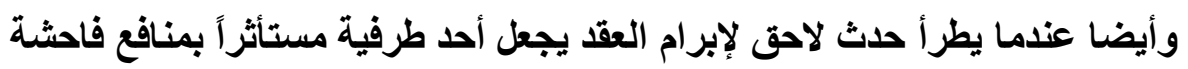

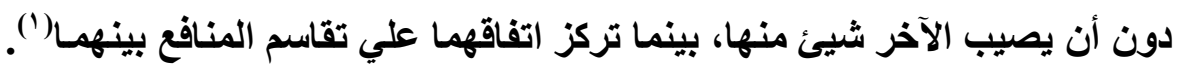

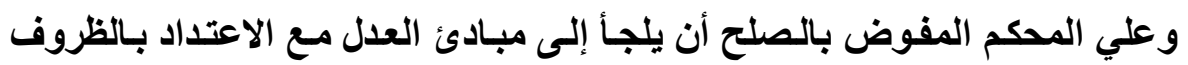
والملابسات الخاصة بالقضية المطروحة عليه(؟). وعلي المحكم أن يجتهد علي أن لا يصدر ذلـك عن معتقداتـه الذاتيـة، بـل بنـاء علـي اعتبـارات موضسوعية، وهـا المسلك يتطلب أن يجته المحكم في تقييم ادعاءات الخصوم، وفقـا للشعور العدل في ضمير الجماعة، آخذ في اعتباره الملابسات الخاصـة لهذه الادعاءات، ومعنسي ذلك أن المحكم يمارس سلطة تقديرية لتحديد مضمون نشاطه، وذلك علي النحو الأي يراه أكثر ملاعمة للغائة النهائية لهذا النشاط

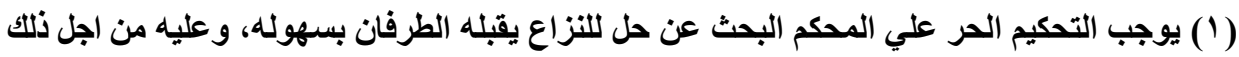

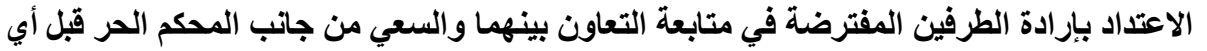

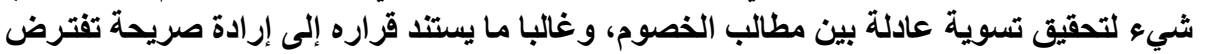

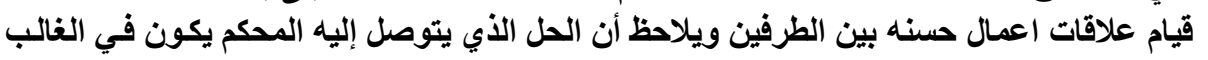

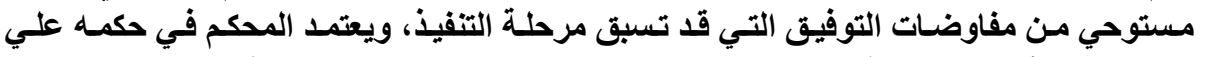

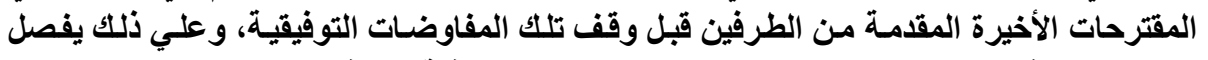

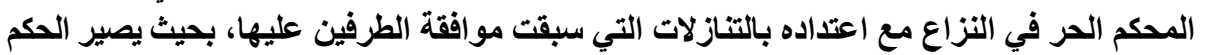

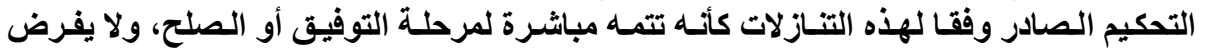

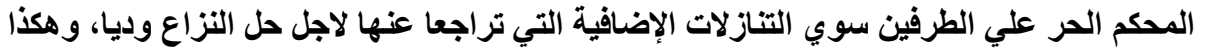

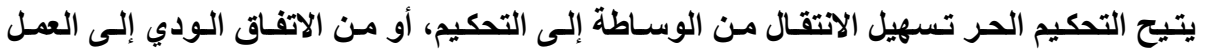
القضائي، وقد اعتمد العمل التحكيمي هذه الحلول.

(2) E. Loquin, l'amiable composition en droit copmparé et international, op. cit., p. 40 et s. CA Paris, 2 fev. 1988, op. cit., p. 68, note Couchez, CA Paris, 5 fev. 1976, op. cit., p. 255. 
r ــ الرقابـة علـي أعمـال المحكم المفوض بالـصلح: في الواقع عنـدما يكـون المحكم مفوضا بالصلح، فأنه يحال إلى قواعد العدالة والإنصاف، ويقصد بها القواعد التي تستنبط من الأعراف والأحكام الدولية، وقواعد الفقيه في مجـال التحكيم، وهذه المسألة لو اخطأ فيها المحكم فأنه يترتب علي ذلك بطلان حكم التحكيم علي أسـاس بطلان الإجراءات التي لها أثرت في الحكم، وبالتـالي تخضع لرقابة محكمة الطعن بالبطلان. r- تقيد المحكم بحدود الطلب: إذ يجب ألا يحكم في غير ما طلب منهم، وألا يخرج عن حدود الاتفاق علي التحكيم. فلا يجوز للمحكم أن يعدل الوصف أو الأساس القانوني عندما يكون هناك اتفاق صريح بين الخصوم بشأن الحقوق التي يملكون حرية التصرف بها، فقد قيدوه بوصف ونقاط قاتونية أرادوا حصر المناقشة فيها، وهذا الوضع يطبق أمام المحكم نظرا لارتكاز التحكيم علي أسـاس عقدي، وعلي ذلك لا يجوز للمحكم أن يعدل الوصف الأي أعطاه الأطراف للعقد، كمـا لا يجوز لله تعديل الأساس القانوني الذي اتفق الطرفان علي إسناد الحق المتنازع عليه إليه، كمـا لو حدد هذا الأسـاس بأنه مسئولية تعاقدية، فلا يمكنه اعتباره مسئولية تقصيرية أو العكس، أمسا إذا قـام نـزاع بين الأطرف علـي وصـف العملـل أو التصرف القـانوني واتفقا علي عرضـه علي التحكيم، فيكون للمحكم أن يفصل في هذا النزاع مقررا الوصف الحقيقي للعمل أو التصرف والذي قـ يطابق الوصف الذي يتمسكك بـه الخصوم. ـ ـ لا يجـوز للمحكم القضاء بحقوق لا تستتد إلى الوقائع التي ظهرت في القضية

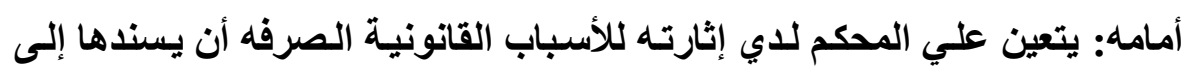
الوقائع المؤسس عليها النزاع المعروض عليه، إذ لا يجوز لـه الاستتناد إلى وقائع خارجه عن إطار الخصومة عند الفصل في النزاع، وعليه في مثل هذه الحالة دعوة 
الطرفين للمناقشة وتقديم الملاحظات بشأن هذه الأسباب('). والأسباب القانونية الصرفة يمكن أن تكون مستمدة من قواعد قانونية مكملة أو متعلقة بالنظام العام أو قواعد العدالة والقانوني الطبيعي. هـ لا يجـوز للمحكم الحر مخالفـة النظــام العـام: يجب مراعـاة حقوق الـدفاع ومبــأ المواجهة والمساواة بين الخصوم(؟)، وقد ذهبت محكمة النقض إلى وجوب التزام المحكمين المفوضين بالصلح بالمبـادئ الأساسية في التقاضسي، وأهمهـا احترام حقوق الدفاع("). ويجب علي المحكم القيام اخطار جميع الخصوم باتخاذ ما يأمر بـه من إجراءات الإثبات، فلا يأمر بها في غقلة من البعض، ولا ينفذ إجراء التحقيق في حضور البعض دون تمكين البعض الآخر من الحضور(؛). ويترتب علي مخالفة هذه القيود بطلان حكم التحكيم(0). وذلك لأن سلطة المحكم مستمدة مـن سـلطة الأطر اف، وهي بالتالي تقف عند حدودها في التصرف في الحقوق الخاصة بها، وبالتالي يكون للمحكم المطلق حريـة التصرف كاملة في نطاق القواعد القانونية المكملـة التي للطرفين حريـة التصرف فيها، وبالتـالي يكون لـه استبعاد القواعد

(1) CA Paris, 13 mars 1973, op. cit., p.176.

(2) CA Paris, 10 nouv. 1989, op. cit., p. 651, obs. Pellerin, CA paris, 11 juill. 1991, op. cit., p. 671, obs. Loquin, CA Paris, 13 mars 1992, op. cit., p. 107, obs. Jarrosson, CA Paris, 13 nouv. 1997, op. cit., p. 719, obs. Derains.

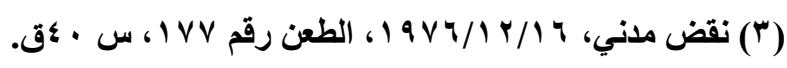

(4) CA Paris, 3 dec. 1965, Rev. Arb., 1966, p. 22, JCP, 1966, II, 14625, note Boulbes. Cass. 2e, 16 dec. 1985, Rev. Arb., 1987, p. 390, CA Paris, 2 fev. 1988, op. cit., p. 62, note Couchez.

(5) CA Paris, 3 dec. 1965, id.; Cass. 2e, 16 dec. 1985, id., CA Paris, 2 fev. 1988, id. 
المكملـة. ويلاحظ من جهة اخري أن سلطات المحكم المطلق لا تتقيــ في جميع الحالات بقواعد النظام العام، لأنه في نطاق هذه القواعد يميز بين القواعد المتعلقة

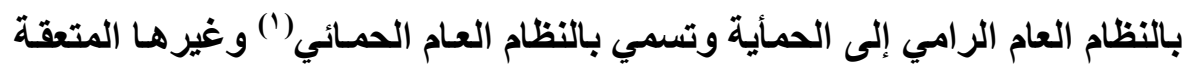
بالنظام العام الأساسي، فالنسبة للأولي يجوز التــازل عن الحقوق الناشئة عنها عندما تكون الحقوق التي يحميها القانون قد اكتسبت فعلا، وبالتالي يجب علي هيئة

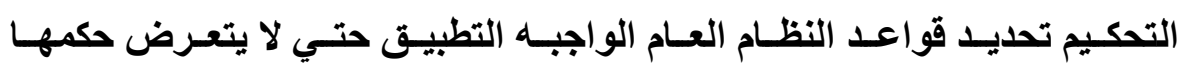
للبطلان (r)

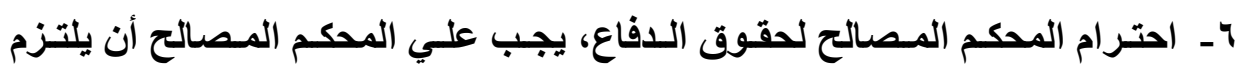
باحترام حقوق الدفاع، وذلك لتعلقها بالنظام العام.

\section{الفرع الثالث}

\section{نطاق الساطة التقديرية للمحكم المهفي هن القواعد الإجرائية فقط}

سنشير إلى المقصود بالمحكم المعفي من القواعد الإجرائية، وضوابط سلطته وذلك في

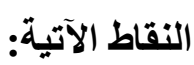

\section{أولا: المقصود بالمكمم المعفي هن القواعد الإجرائية}

في الواقع إذا كان يوجد نظام التحكيم المقيّ والتحكيم الطليق أو الحر، فإن هناك نوعا آخر من التحكيم يندرج في مرحلة تتوسط التحكيم المقيد والمطلق، ففي هذا النظام تبقي سلطة هيئة التحكيم مقيدة بقواعد القـانون الموضوعية كالتحكيم المقيد، ولكنه هـيه يعفي من إعمـال قواعد المرافعات، وقد جري العـل كثيرا إلى الاخذ بهذا النوع من من من

(1) CA paris, 25 mars 1982,Rev. Arb., 1982, p. 467. E. Loquin, l'amiable composition en droit copmparé et international, op. cit., p. 279 et $\mathrm{s}$.

(2) CA paris, 25 mars 1982, id., E. Loquin,id. 
التحكيم، لأنه يبقي علي ضمانة إعمال القانون الموضوعي والتحرير من إعمال القواعد الإجرائية، ويترك للهيئة إعتماد القواعد الإجرائية التي تراها مناسبة للتواصل إلى حل

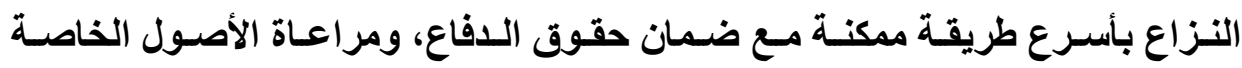
بالتحكيم، وهذا النوع من التحكيم يحتاج وجوده لنص صريح في اتفاق التحكيم. وفي التحكيم المعفي من تطبيق قواعد المرافعات العادية يجوز للمحكم الأخذ بالقواعد الإجرائية التي يراهـا أكثر ملاعمـة للفصل في النزاع بشرط مراعـاة المبادئ

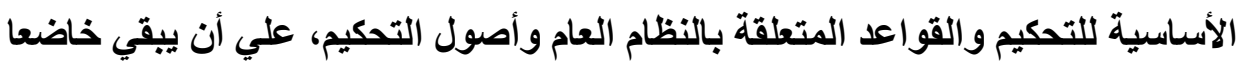
في إصداره لقراراه لقواعد القانون الموضوعي. أما في التحكيم المطلق فتحسر القيود علي سلطة المحكم إلى حدها الأدني إذ يتحرر في نظر النزاع والفصل فيه من تطبيق

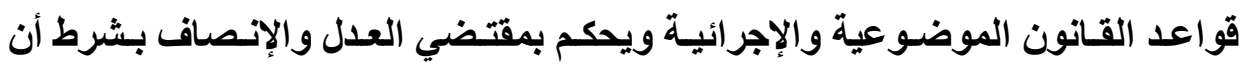

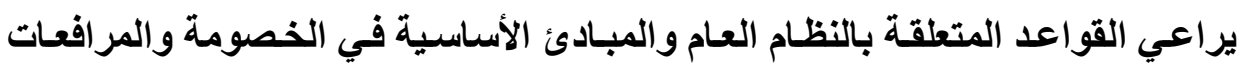
والقواعد الخاصة بالتحكيم.

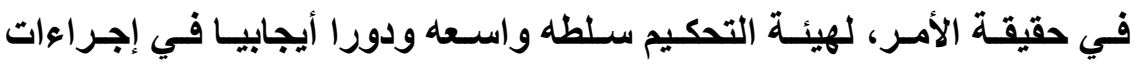
الإثبات، فيمكن لهيئة التحكيم أن تأمر بأي إجراء من إجراءات الإثبات، فلها أن تطلب من الخصوم تقديم مستندات أخري غير التي قدموها، أو دعوة شهود آخرين للإدلاء بشهادتهم إذا كاتت الأقول التي أدلـي بها الشهود السابقون غير كافية، كذلك للهيئة الاستعانة بخبير أو أكثر لإبداء رأيه حول نقطة محددة في النزاع، وتملك هيئة التحكيم أن تعدل عن قرارها باستجواب أحد الخصوم، متي رأت في عناصر الدعوي مـا يغتيها عن ذلك، وهو أمر خاضـع لتقديرها، كمـا لها أن تعدل عن إلزام خصم بتقديم وروقهـ تحت يـه، كمـا لها أن تعدل عن اتتداب خبير أو أي إجراء من إجراءات الإثبات ('). 
وكما يملك المحكم استجواب الخصوم فأنسه يملك العدول عنـه، إذا كانت الأدلة مقنعـه. وتطبيقا لذلك فقد نص المشرع المصري إلى ذلك بشكل صريح، عندما نص في المسادة r r تحكيم علي أنه: لهيئة التحكيم أن تجتمع في أي مكان تراه مناسبا للقيام بإجراء من

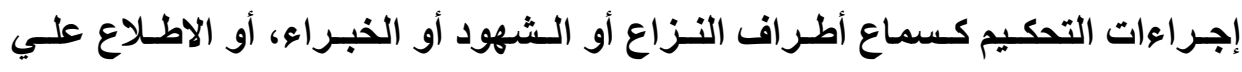
مستندات أو معأينة بضاعة أو أموال أو إجراء مدأولة بين أعضائها أو غير ذلك.

\section{ثانيا: القيود التي ترد علي سلطة هيئة التحكيم}

ونلاحظ علي سلطة هيئة التحكيم في هذا النوع من التحكيم ما يلي:

ا- وفي الحالة التي تقوم فيها هيئة التحكيم بخلق قواعد إجرائية مخصوصة لخصومة التحكيم المنظورة أمامها، فأنها لن تستطيع أن تضع نظامـا إجرائيا مكتملا خاصـا بالنزاع المعروض عليها، وإنما هي فقط تقوم بتكملة النظام الإجرائس، الوارد في قانون التحكيم(')، حيث نصت المادة الأولي من قانون التحكيم علي ضرورة مراعاة

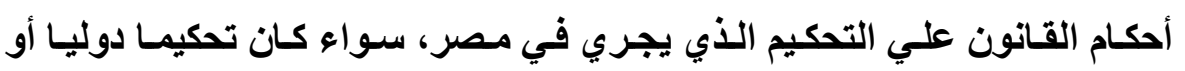
داخليا، وكذلك التحكيم الذي يجري في الخـارج إذا كـان الأطراف قد اتفقوا علي إخضاعه لهذا القانون، وقد أكدت ذلك المـادة هب من قانون التحكيم، حيث قيدت حرية هيئة التحكيم بمراعاة أحكام هذا القانون. r- لهيئة التحكيم سلطة في اعتماد القواعد التي تراهـا أكثر تماثيا مع طبيعة النزاع وظروف المنازعة والوصول إلى الحل النهائي بأسرع وقت ممكن، فقد يميل إلى استبعاد مبدأ شفاهية المرافعات، عندما تبعد المسافات بين الخصوم، ويستبللها بالكتابة نظر الصعوبة تتيظم الاجتماعات وكلفتها العاليه. كمـا قد يستبعد المذكرات (1) د/ نبيل إسماعيل عمر، التحكيم في المواد المدنية والتجارية الوطنية والدولية،المرجع السباق، ص 
المكتوبـة وتبادلهـا إذا كـان محل النزاع مـواداً قابلـة للتـف وتحتـاج إلى قرارات سريعة.

r- ويلاحظ أن المشرع المصري، وإن كـان قد اعتل بمعيـار شخصي بحت في اختيـار هيئة التحكيم للتنظيم الإجرائسي لخصومة التحكيم، حيث جعل لها حريـة اختيـار الإجراءات، التي تراهـا مناسبة، فهي ليست حريـة مطلقة، فهي تثقيد بمضانات التقاضسي الأساسية، ولذلك فقط حرصت المـادة ؟ب تحكيم النص علـي أن يعامـل طرفا التحكيم علي قدم المساواة وتهيـأ لكل منهمـا فرصـة متكافئة وكاملة لعرض دعواه، كما تتقيد الهيئة بالنظام العـام('). وبالتـالي يظل المحكم في هذا النوع من التحكيم مقيدا بالإجراءات التالية: الإجراعات المتعلقة بالنظام العام: ومنها المبادئ الأسـاسية للخصومة وحقوق الدفاع وتسبيب الأحكـام وسـائر البيانـات الالزاميـة

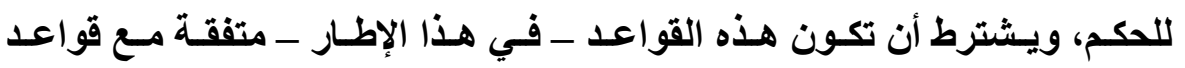
الإجراعات المتصلة بنظـام التحكيم التي لا يمكن إعفـاء المحكم منهـا، مثـال ذلك قواعد رفع النزاع أمام المحكم، وقواعد التدخل ومهلة إصدار حكم المحكم وطرق الطعن في حكم المحكم. والواقع أن الإعفـاء من قواعد المرافعات لا يشمل الإعفـاء من القواعد المتعلقة بقبول الطلبات الموضوعية والتي تظل خاصعة للمبادئ التي يخضع لها موضوع النزاع. ع- كما يتقد المحكم بالقواعد التي تتفق الأطراف علي استمرار إعمالها رغم إعفـاء

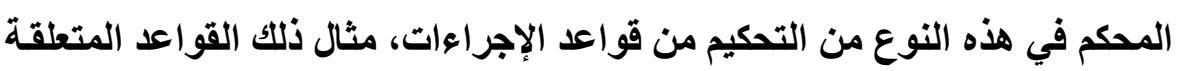

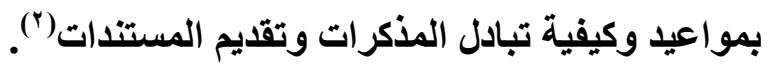

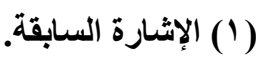

( ${ }^{\curlyvee}$ Ca Paris, 21 fev. 1966, Som. Jurid, 1966, 2, 14828; CA Paris, 12 juill. 1971 op. cit., p. 74. 
هـ يترتب علي مخالفة هيئة التحكيم لإجراعات التي تتعلق بالنظام العام بطلان حكم التحكيم، فقد نصت المادة به تحكيم علي أن مخالفة النظام العام سبب في بطلانـه، تقضي المحكمة بـالبطلان من تلقـاء نفسها، ويفهم النظـام العـام بـالمعني الواسـع،

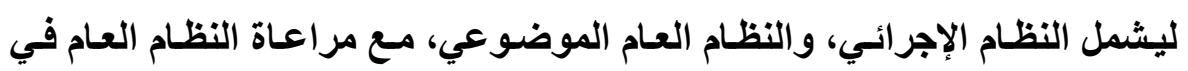
الدولة المطلوب تنفيذ حكم التحكيم فيها. حيث نصت المـادة ^ه تحكيم علي عدم تنفيذ الحكم في حالة مخالفته للنظام العام.

\section{خلاصة الفصل الأول}

لقد خلصنا إلى أن نشاط المكم التقديري يرمسي إلى ازالة التجهيل الذي أحساط بـالمركز القانوني للخصوم، والوصول إلى العدالة_ومـا يعرض علي المحكم ليس هو المراكز القانونية الموضوعية، وانما هو آراء الخصوم عن هذه المراكز الموضوعية، وذلك في صورة ادعاءات. ويقوم المحكم من خلال الإجراعات بنشاط ذهني وتقديري الهذف منه تقييم ادعاءات الخصوم مقيدا في هذا بقواعد القانون الموضوعي واتفـق

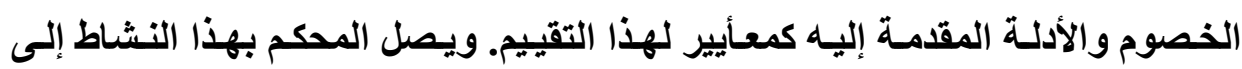
تكوين رأي قانوني في ادعاءات الخصوم، وهذا هو الرأي التحكيمي.

لقد خلصنا إلى أن يستفاد من المادة هب تحكيم علـي أنسه مـع مراعـاة مـا يتطلبه

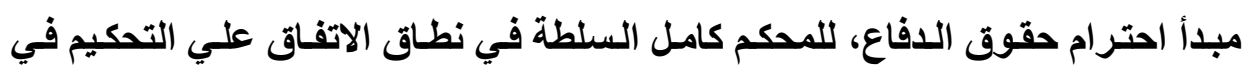
استخدام كافة طرق الإثبات كالكتابة، القرائن،شهادة الشهود، الخبرة، المعائة نخلص مما سبق إلى أن لهيئة التحكيم سلطة واسعة ودور أيجابي في إجراعات

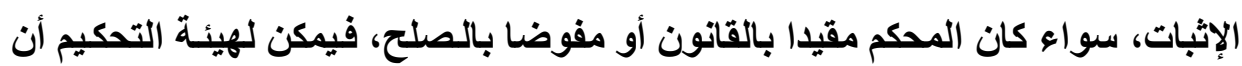
تأمر بأي إجراء من إجراءات الإثبات، فيمكن لها أن تطلب من الخصوم تقديم مستثدات أخري غيـر التـي قدموها، أو دعوة شـهود آخـرين لـلإدلاء بشهـادتهم، كـللك للهيئة 
الاستعانه بخبير أو أكثر لإبداء رأيه حول نقطة محددة في النزاع، وشأن الهيئة في ذلك شأن قضاء الدولة بالنسبة لوسـائل الإثبات التي يمكن استخذامها للوقف علي حقيقة

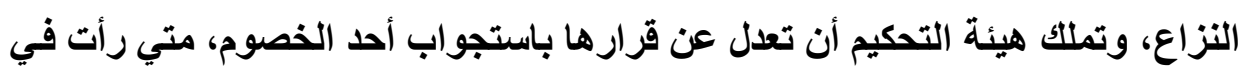

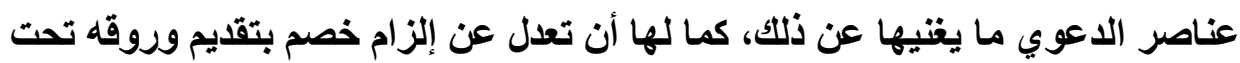

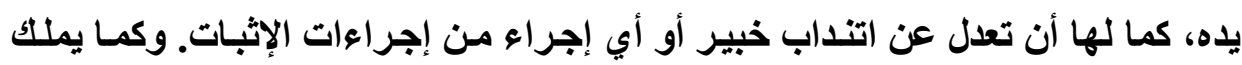
المحكم استجواب الخصوم فأنه يملك العدول عنه، إذا كانت الأدلة مقنعه. ولهيئة التحكيم السلطة التقديريـة الكاملـة في اتخـاذ إجراءات الإثبات وتقدير الأدلة، سواء من تلقاء نفسها أو بناء علي طلب أحد الخصوم، ولها نفس سلطات قضاء

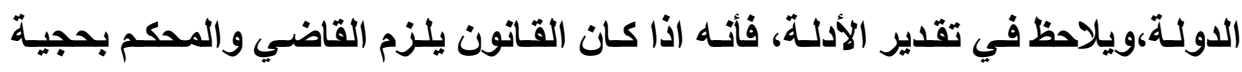

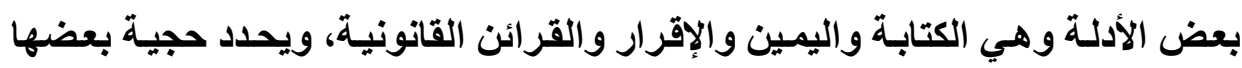
الآخر كالبينه و القرائن القضائية، فينع من قبولها في إثبات بعض الوقائع، فأنسه يترك

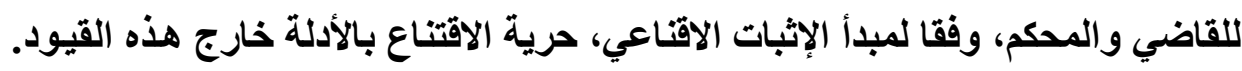

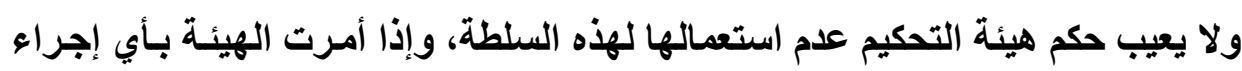

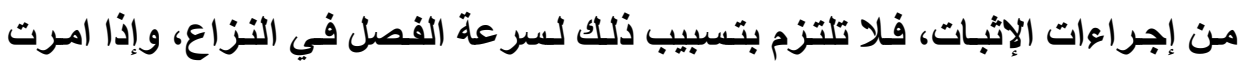

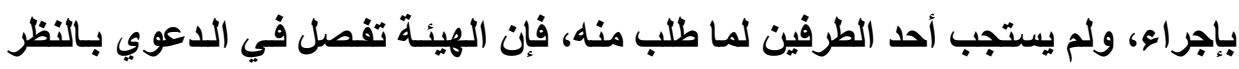

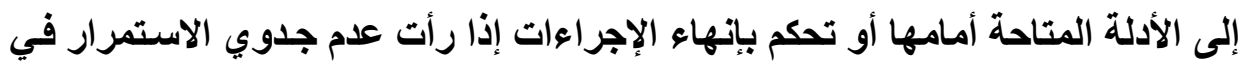

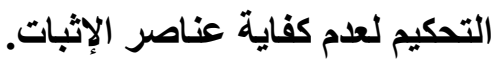

أيا كانت سلطة هيئة التحكيم بالنسبة لإجراءات الإثبات، فإن سلطتها هذه تحدها

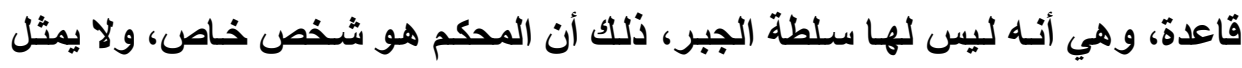

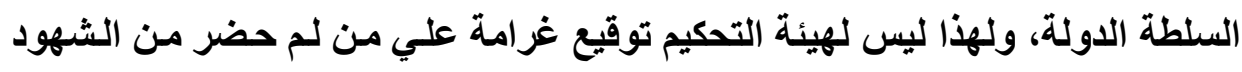

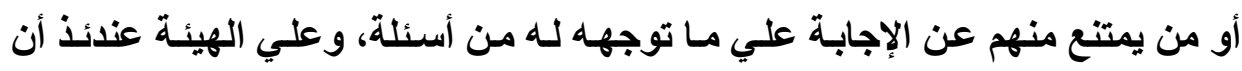

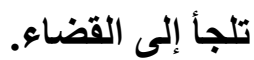


ولقد خلصنا مما سبق إلى أنها في غير الحـالات التي يحل فيها المحكم النزاع باللجوء إلى قواعد القانون الطبيعي ومبادئ العدالة، فأنـه يلتزم بتطبيق القانون، وهو في هذا العمل ليس مجرد آله، بل هو صاحب نشاط هذا النشاط يوجد بـه جانب تقديري دائما، هذا التقدير يظهر في كافة مراحل تكوين العمل التحكيمي، ففي مجال الوقائع يقوم المحكم بعمل تقديري في بحثه الذهني لما اذا كاتت وقائع النزاع المتعلقة بالدعوي

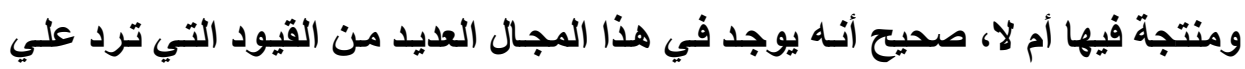
سلطة المحكم في التقدير، ولكن هذه القيود لا تنفي السلطة التقديرية بل تؤكدها. ولقد خلصنا إلى أن سـريان سـلطات القاضـي علـي المحكم لا يأخذ بهـا علي إطلاقها فيما يتعلق بأدلة الإثبات، ذلك أن هنالك بعض الأدلة التي يملك القاضي الأمر باتخاذهـا لمسا لـه مـن سـلطة جبر ، والتـي سيستمدها مسن صـفته كعضو في السلطة القضائية. ويرجع ذلك إلى أن هيئة التحكيم تستمد سلطتها من اتفاق الأطراف، وبالتالي

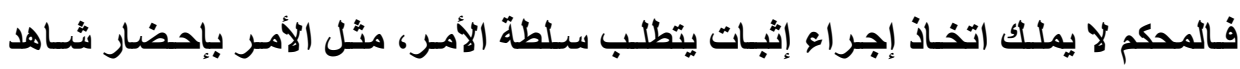
لسماعه، أو إجبار الغير الذي ليس طرفا في الخصومة بتقديم مستند تحت يده، ففي تلك الحالات وأمثالها لا يملك المحكمة إلا الاستعانة بقضاء الدولة للحصول علي مساعدته مـع توقف الفصل في سـير الخصومة إذا كـان السير فيهـا متوقفـا علـي اتخـاذ هذه الإجراءات. 


\section{الفئسل الثاني \\ ضوابط السلطة التقديرية لهيئة التمكيمي في الإثبات}

و إذا كان المشرع لم يتلخل فيما يتعلق بكيفية ممارسة القاضي لنشاطة العقلي،

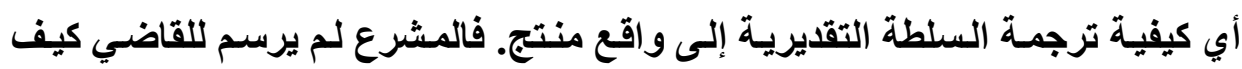

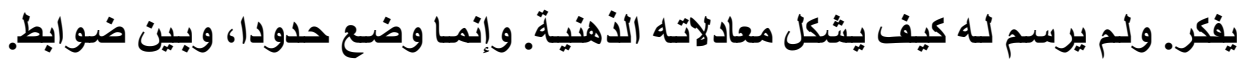

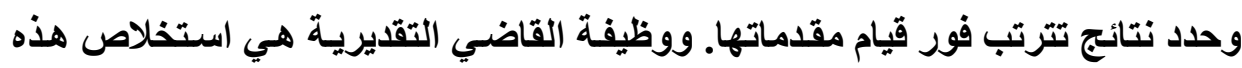

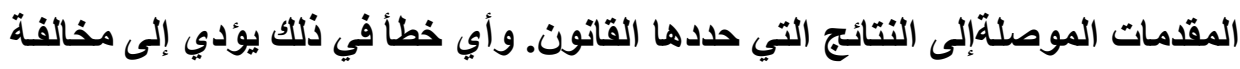
القانون. فأنه من باب أولي تطبيق ذلكت علي نظام التحكيم، حيث يكون لهيئة التحكيم

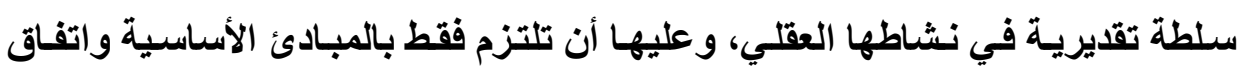

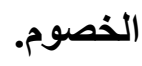

ولهيئة التحكيم أن تأمر باتخاذ مـا تراه ملائمسا، سواء من تلقاء نفسها أو بنـاء

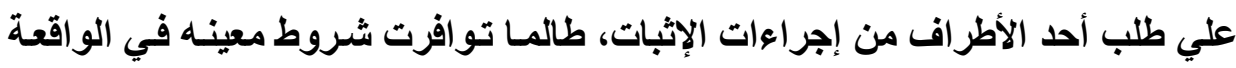

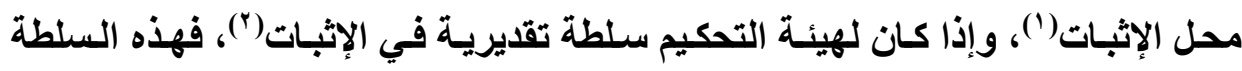

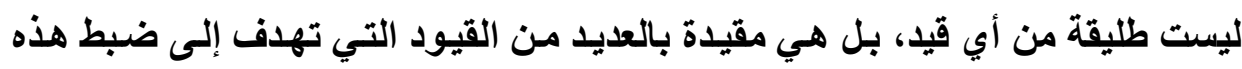

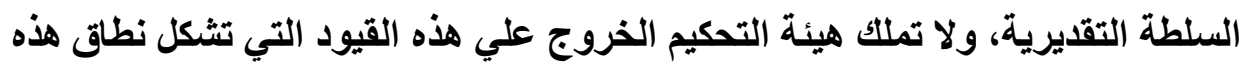

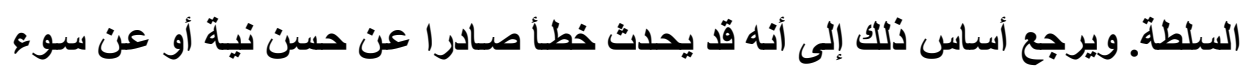
قصد أو عن أهمال من جانب المحكم، وقد يكون نتيجة القصور العلمي أو الثقافي أو أو أو أونائ

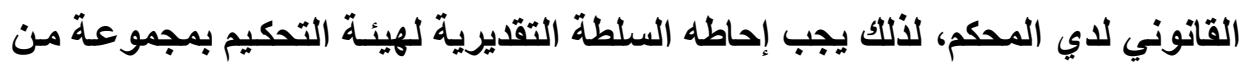

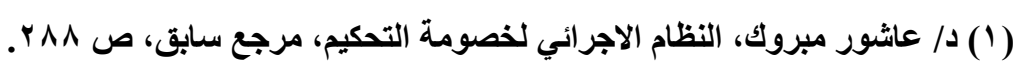
(2) CA Paris, 12 juill. 1971, op. cit., p. 74. 
الضمانات والقيود التي تمثل سياجا ضد التعسف أو الغلو في استخدامها والاعتمـاد عليها.

في الواقع هذه الضوابط الواجب مراعاتها أثنـاء اتخـاذ إجراءات الإثبات تتمثل في الآتي: وجودب مراعات المبادئ الأسساسية للتقاضي، مثل حقوق الدفاع والمساواة والمواجهة، كما يجب اشتراك جميع المحكمين في إجراعات الإثبات، كمـا يجب مراعاة

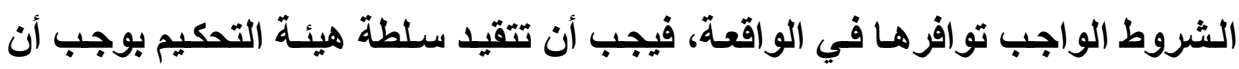

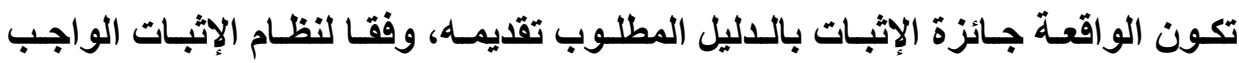

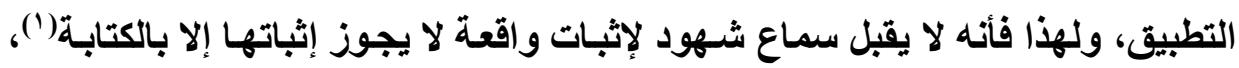
ويجب لقبول إثبات الواقعة أن يكون من الجائز إثباتها، فلا يجوز إثبات واقعه مستحيلة

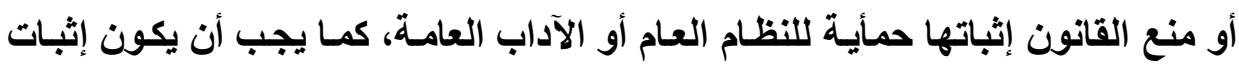

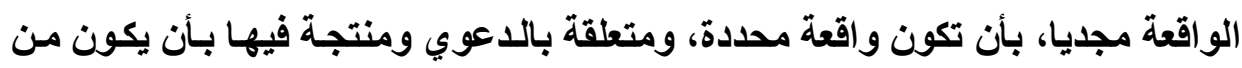

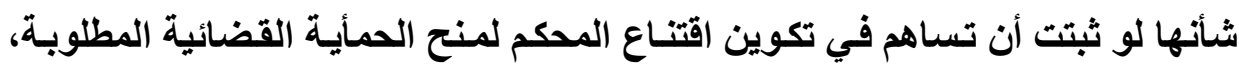

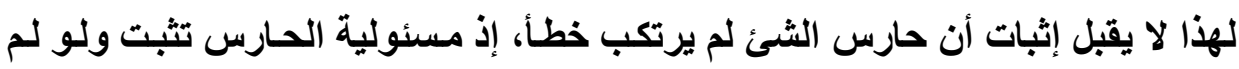

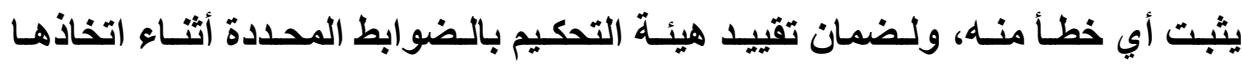

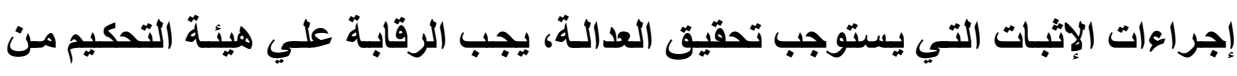

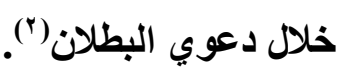

سنشير في هذا الفصل إلى التزام هيئة التحكيم بمبـادئ التقاضـي في الإثبات، وذلك في المبحث الأول، أما المبحث الثاني، فيخصص لبيـان الرقابـة علي سلطة هيئة التحكيم في الإثبات، وذلك علي النحو التالي:

(1) د/ فتحي والي، التحكيم في المنازعات الوطنية والتجارية الدولية، علمـا وعملا، المرجع السابق،

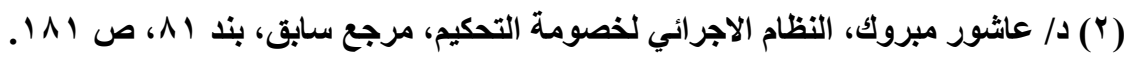




\section{المبحث الأول \\ التزام هيئة التمكيم بمبادئ التقاضي في الإثبات}

إذا كان الثابت أن هيئة التحكيم تتمتع بدور أيجابي في البحث عن الحقيقة، مما

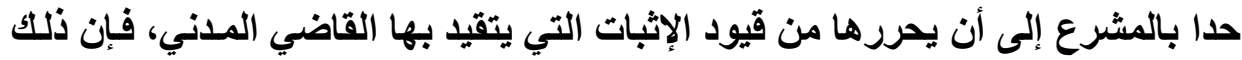
يرجع بصفه أساسية إلى أن الخصومة التحكيمية تتصل بمصلحة الأفراد وأن التحكيم

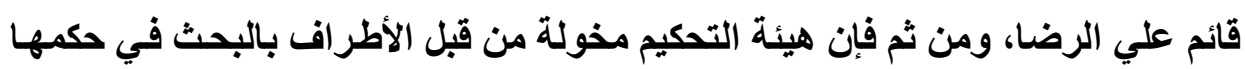
عن الحقيقة، وذلك بالأللة التي تسوقهاإلى ذلك. ولمـا كان الاعتر افت بسلطة واسعة لهيئة التحكيم قد يؤدي إلى إساءة استخام هذه السلطة، مما يدفع إلى حدوث مشكلات

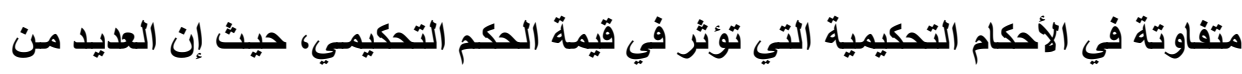

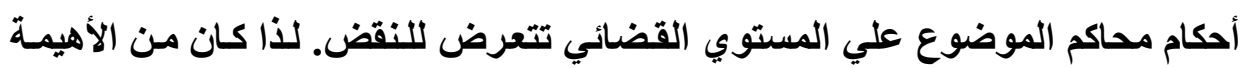
بمكان وضع ضو ابط لسلطة هيئة التحكيم' (1) .

ولضمان عدم تعسف هيئة التحكيم أو تجنب أخطائها، يجب علي هيئة التحكيم أن تلتزم بمجموعة من المبادئ والقو اعد الإجرائية اثناء تصديها لإجراءات الإثبات،

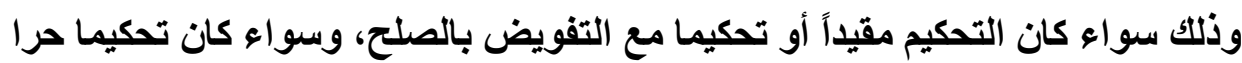

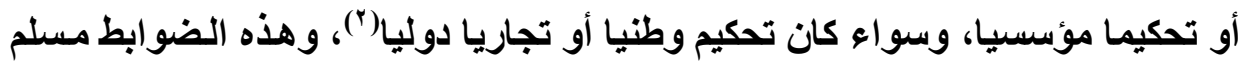

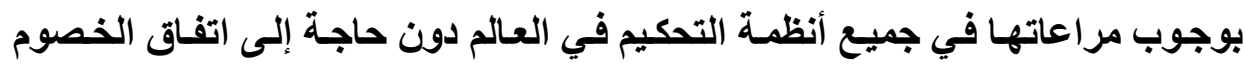
(1) حسين علي محمد علي الناعور النقبي، سلطة القاضي الجناني في تقدير الادلة، دار النهضة

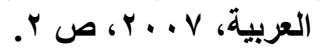

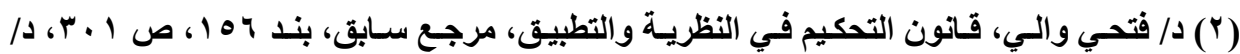

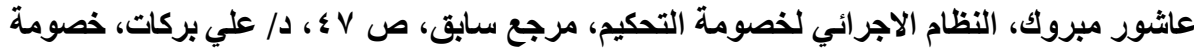

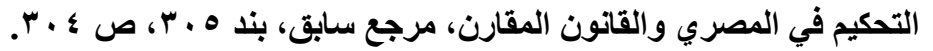


عليها أو النص الصريح عليها، باعتبارها ضرورية لتحقيق العدالة'(') وميع ذلك نجد

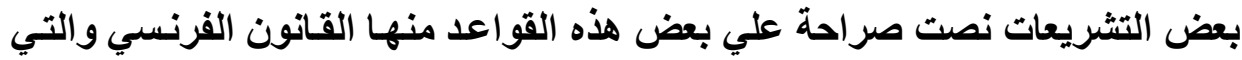

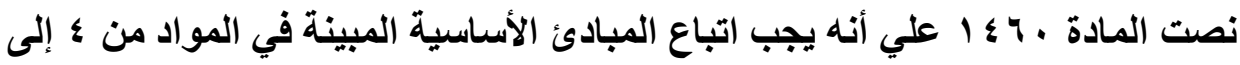

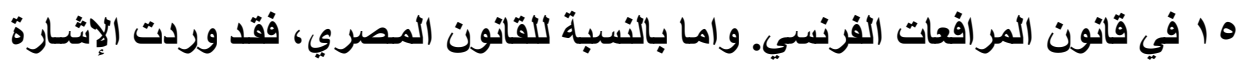

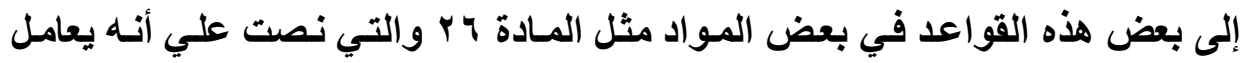

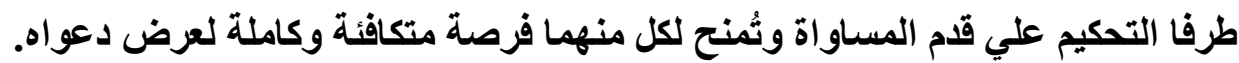
وإذا كانت القاعدة الذهبية في المواد التحكيمية هي حريـة المحكم في تكوين

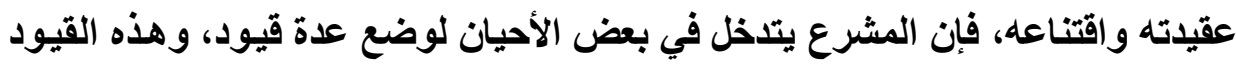

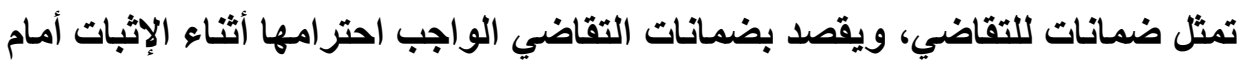

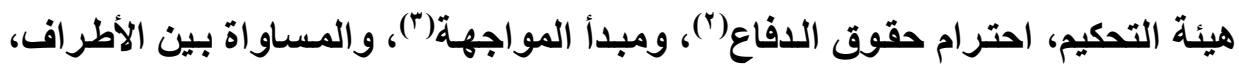

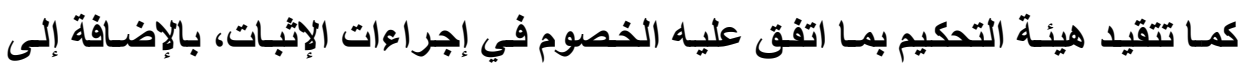

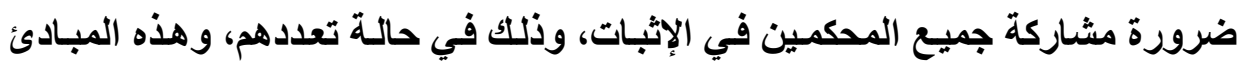

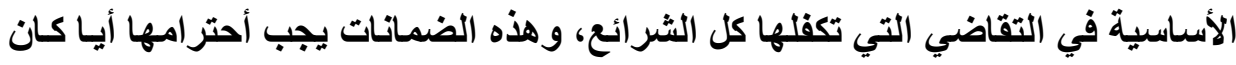

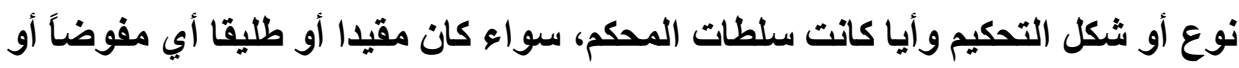

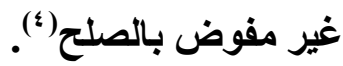

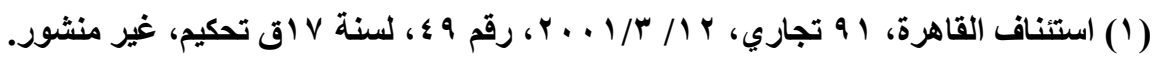

(2) CA Paris, 27 fev. 1964, op. cit., p. 49. CA Paris, 10 nouv. 1989, op. cit., p. 651, obs. Pellerin, CA paris, 11 juill. 1991 op. cit., p. 671, obs. Loquin, CA Paris, 13 mars 1992, op. cit., p. 107, obs. Jarrosson, CA Paris, 13 nouv. 1997, op. cit., p. 719, obs. Derains.

(3) CA Paris, 3 dec. 2002, op. cit., p. 931.

(4) E. Loquin, l'amiable composition en droit copmparé et international, op. cit., p. 40 et s. CA Paris, 2 fev. 1988, op. cit., p. 68, note Couchez, CA Paris, 5 fev. 1976, op. cit., p. 255. 
سنشير إلى التزام هيئة التحكيم بمبدأ المواجهة وحقوق الدفاع والمساواة في الإثبات، وذلك في المطلب الأول، أمسا المطلب الثـاني، فيعـالج التزام هيئة التحكيم بإجراءات الإثبات التي اتفق عليها الخصوم، ويعالج المطلب الثالث، التزام هيئة التحكيم بالإثبـات الجمـاعي. أمسا المطلب الرابـع، فيخصص لالتزام هيئة التحكيم بالحيـاد في مي هي الإثبات، وذلك علي النحو التالي:

\section{المطاب الأول \\ التزام باحترام هبدأ المواجهة وحقوق الدفاع والمساواة في الإثبات}

يقوم المحكم بإدارة الخصومة والتحقيق فيها، ولـه مـا للقاضـي في هذا الشأن

من سلطات ومكنات، فيمكنه من تلقاء نفسه ودون طلب أن يأمر بإجر اء تحقيق، كما لـه

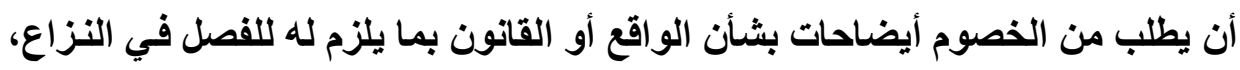
كما أنه يستطيع الأمر باتخاذ تدابير تحقيق حتي بدون طلب من الخصوم، ومع ذلك يجب احترام مبدأ المواجهة، ويجب تبليغ الخصوم بنتيجة التحقيق أو الخبرة حتي يمكنهم مناقشة كل ذلك وجاهياً (')

وتخضع خصومة التحكيم لمبـادئ لا يمكن مخالقتهـا(") مثل مبدأ المواجهة،

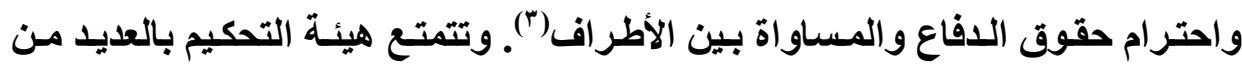

(1) Cass., 3 nouv. 1978, Rev. Arb., 1979, p. 343

(2) B. Moreau, A. Beregoi, et autre, arbitrage commercial, op. cit., no 212

(3) CA Paris, 10 nouv. 1989, op. cit., p. 651, obs. Pellerin, CA paris, 11 juill. 1991, op. cit., p. 671, obs. Loquin, CA Paris, 13 mars 1992, op. cit., p. 107, obs. Jarrosson, CA Paris, 13 nouv. 1997, op. cit., p. 719, obs. Derains. 
السلطات ويقع عليها بعض الواجبات في مجال الإثبات، ويرجع ذلك إلى أن التحكيم يعد نوعا من القضاء، لذا يجب علي هيئة التحكيم في جميع الأحوال سواء أكان التحكيم بالصلح أو التحكيم المقيد، أن تكون ملزمة باتخـاذ إجراعات الإثبات في مواجهة جميع

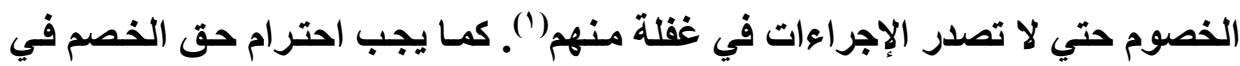
تقديم كل وسائل الإثبات، ويجب مراعاة المساواة بين الخصوم في تقديم أدلة الإثبات.

$$
\text { وسنشير إلى ذلك في الفروع الآتية: }
$$

الفرع الأول: التزام هيئة التحكيم بمراعاة مبدأ المواجهة بين أطراف التحكيم الفرع الثاني: التزام هيئة التحكيم بمراعاة حقوق الدفاع أثناء إجراعات الإثبات الفرع الثالث: التزام هيئة التحكيم بمبدأ المساواة بين الخصوم أثناء إجراءات الإثبات

\section{الفرع الأول \\ التزام هيئة التهكيم بمبدأ المهاجهة}

سنشير إلى تعريف مبدأ المواجهة، ومقتضبات المبدأ، وذلك في النقاط الآتية: أولا: تعريف هبدأ المواجهة: يقـصد بمبـدأ المواجهـة أن لكـل خصم الحـق في أن يبــنغ بـالأوراق والطلبـات والدفوع التي يقدمها الخصم الآخر لهيئة التحكيم. ويعتبر هذا المبدأ من النظام العام(")، يترتب علي مخالفته بطلان الحكم، وقـ عرف مبدأ المواجهة بأنسه التزام علي هيئة

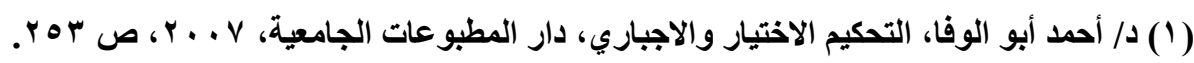
(2) B. Moreau, A. Beregoi, et autre, arbitrage commercial, op. cit., no 211. 
التحكيم بـإعلام(') كل طرف بمـا يقدم في الخصومة من مزاعم وطلبـات ودفوع وأدلة إثبات(؟) فهو يهدف إلى إعلام الخصم الآخر بكل المبادرات التي يتخذها المحكم للفصل في النزاع، سواء تلكك المتعلقة بـالواقع وتحصيلها وفهمها وتقديره، وسواء المتعلقة

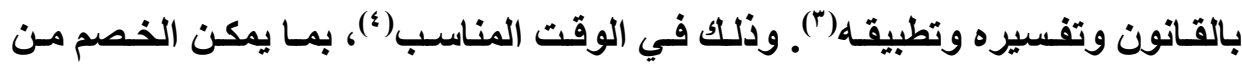
الاعتراض والرد عليها ومناقشتها()، كذلك عرف البعض مبدأ المواجهة ببين الخصوم

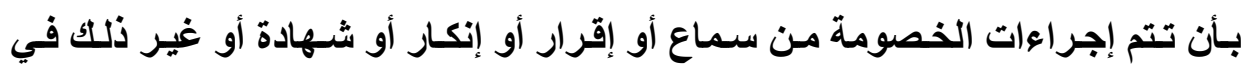
حضور الخصم الآخر أو وكيله("). ويؤدي هذا الحق إلى تمكين الخصم من الرد علي كل ادعاء موجه من الخصم الآخر، كما يفيد في إعطاء الخصم الحق في مناقشة دفاعـات

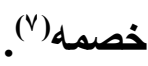
ونظرا لأهمية مبدأ المواجهة فقد افردت له العديد من التشريعات فرعا مستقلا في قانون الإجراءات المدنيـة، وذلك مـا فعلـه المشرع الفرنسي في البـاب التمهيدي، وأفرد له عنوان (المواجهة)، وقد خصص قانون المرافعات الفرنسي في المواد 7 الـ

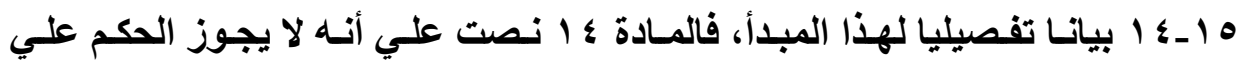

(1) CA Paris, 18 sept. 2012, Rev. Arb., 2012, p. 867.

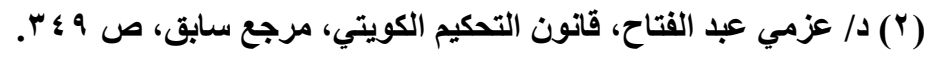

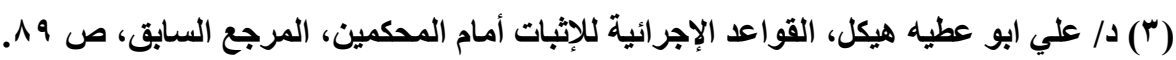

CA Paris, 18 sept. 2012, op. cit., p. 867.

(4) R PERROT, Principe de la contradiction et les faits dans le débat, RTD civ. 2011.590

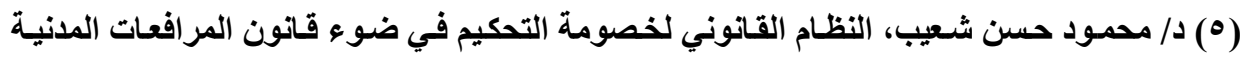

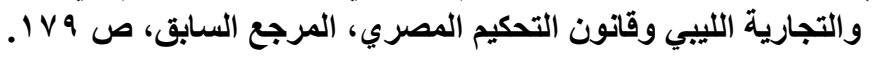

(6) CA Paris, 7 janv. 1963, Gaz. Pal., 1963, 1, p. 435, CA Paris, 14 fevr. 1985, Rev. Arb., 1987, p. 325, note level.

(7) CA Paris, 18 sept. 2012, rev. arb., 2012, p. 867. 
الخصوم دون أن يستدعي ويسمع له، ونصت المادة ها 1 علي أن من حق كل خصم أن يعلم في وقت مناسب بالوقائع التي يستند إليها خصمه ووسـائل الإثبات التي يقدمها ومواد القانون التي يثيرهـا حتي يتمكن كل منهم مـن إعداد دفاعه، ثم نصت المـادة 7 اعلي أن يحترم القاضي - والمحكم ـ دائما مبدأ المواجهة، فلا يستند في حكمـه إلى وقائع وأدلة إثبات ومستتدات قدمها أحد الخصوم ولم تكن محلا للاطلاع، ويجب دعوة

الخصوم إلى إبداء ملاحظاتهم (').

وقد نص المشرع المصري في المواد من اب إلى هب تحكيم علي أحكام تتضمن احترام مبدأ المواجهة، حيث نصت المادة بس علي إلزام هيئة التحكيم بعقد هيئة التحكيم جلسات مرافعة لتمكين كل من الطرفين من شرح موضوع الدعوي وعرض حججه وادلته، كما يجب إخطار طرفي التحكيم بمواعيد الجلسات والاجتماعات التي تقرر هيئة

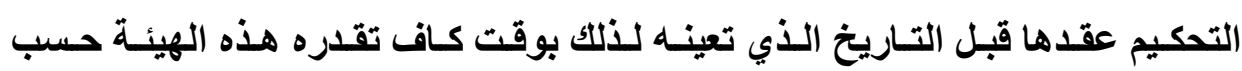
الظروف، ويقتضي مبدأ المواجهة أن تسمع هيئة التحكيم الشهود والخبير في مواجهة جميع الخصوم، وتدون إجابـات الشهود في محضر الجلسة، ثم تثلي عليهم وتسلم صورة منها إلى كل من الطرفين.

ويكيف مبدأ المواجهة علـي أنسه من المبادي الأساسية في الخصومة المدنية وسواء تمت أمسام قضاء الدولة أو أمسام التحكيم، وسبب أهمية هذا المبدأ أنها تحقق مئق العدالة(؟) وبالتالي تهيمن علي جميع الأعمال في الخصومة منذ رفع الدعوي وحتي

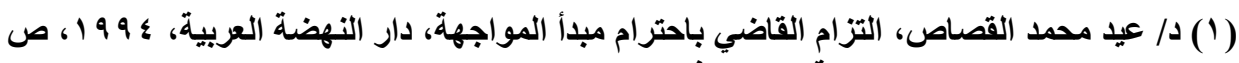

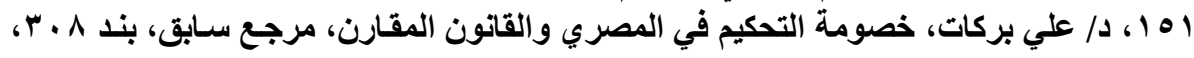
ص س +r. (ץ) د/ سيد تمام، مبأ المواجهة في التحكيم، دار النهضة العربية، بدون سنة نشر، ص بr.

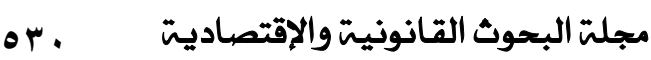


تاريخ قفل باب المرافعة(')، كما يعد مبدأ المواجهة من أهم تطبيقات حق الدفاع("). ويعد ضمانة أساسية في الإجراءات، فإذا لم يحترم مبدأ المواجهة فلن تكون هناك عدالة. وتطبيـق مبــأ المواجهـة فـي مجـال التحكـيم يــلازم مــع الطبيعـة القـضائية

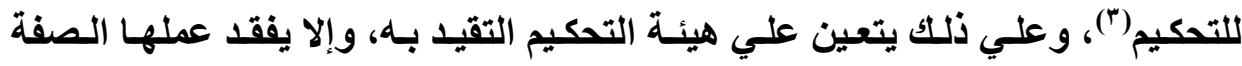
القضائية، ويتعين علي الطرف الذي يزعم عدم احترام هذا المبدأ إثبات ذلكت.

\section{ثانيا: هقتضيات هبددأ المواجهة:}

فحتي لا تخرج هيئة التحكيم علي مبدأ المواجهة يجب عليها عندما يقدم أحد

الأطراف مستندات ووثائق أن تطلع الطرف الآخر عليها، وتمنحسه الوقت الكافي للرد

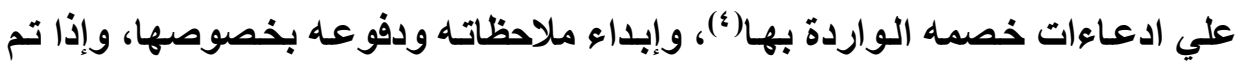
قبول مستند أو وثيقة في وقت متأخر، فيجب مد الموعد حتي يتمكن الطرف الآخر من

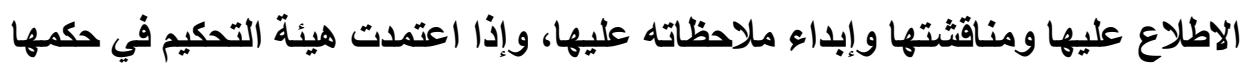

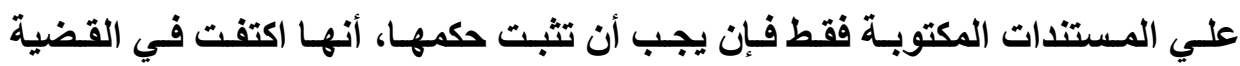
بالمستتدات المكتوبة، وأنه قد تم تبادلها بالنحو الصحيح بين الأطراف(ث)، وتم تمكينهم من الاطلاع عليها ومناقشتها والرد علي مـا جـاء بها، حتي لا يتعرض الحكم للبطلان

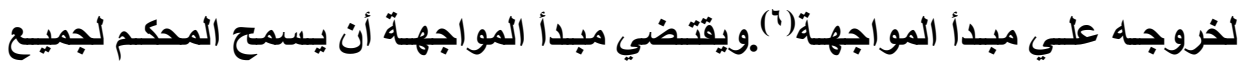

(1) B. Moreau, A. Beregoi, et autre, arbitrage commercial, op. cit., no 285.

(2) CA Paris, 18 sept. 2012, op. cit., p. 867.

(3) CA Paris, 3 dec. 2002, op. cit., p. 931.

(4) CA Paris, 3 dec. 2002, op. cit., p. 931. CA Paris, 12 juill. 1971, op. cit., p. 71, CA paris, 20 mai 1983, Rev. Arb., 1984, p. 389.

(5) CA Paris, 12 juill. 1971, id.

(†) د/ ياسر عبد الهادي مصلحي سلام، أثر الخطأ في إجراءات التحكيم علي حكم التحكيم، المرجع

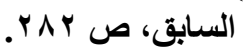

CA Paris, 24 mai 1974, Rev. Arb., 1975, p. 246. 
الخصوم إبـاء مـا لديهم من دفوع ودفاع، ويكفي تمكين الخصم من استخدام هذا

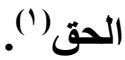
يتضمن مبدأ المواجهة العديد من الأحكام تتمثل في الآتي: ا. حق الفصم في العلم والاطلاع ("): يقتضي مبأ المواجهة أن يكون هناك علم بـالإجراءات(")، وهذا العلم ضروري لمباشرة حق الافاع، فالخصم لا يمكن أن يباشر حقه في دحض أدلة الإثبات التي قدمها خصمه إلا إذا علم بها. ولا يمكن له تقديم أي دفع إلا إذا علم بالإجراءات التي يتخذها خصمه أو تتذذها الهيئة، ولا يمكن مباشرة حقه في المرافعة (شفوية أو كتابية) إلا إذا لإنا علم بما قدم خصمه من وسائل دفاع واقعية أو قانونية أو حجج أو أوراق ومستتدات. وقد نصت المادة V تحكيم علي قواعد أكثر تحررا من القيود المتبعة في الإعلان القضائي. ويجب لتحقيق الإعلان غأيته أن يحقى العلم باعتباره أهم تطبيقات حق الافاع

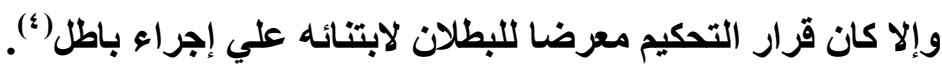
ويقتضي العلم أن يبلـغ الخصم بـالأوراق التـي يقدمها الخصم الآخر، فليس للمحكمة أن تستتد إلى ما يقام إليها من خصم دون سماع أقو ال الخصم الآخر، وتمكينه

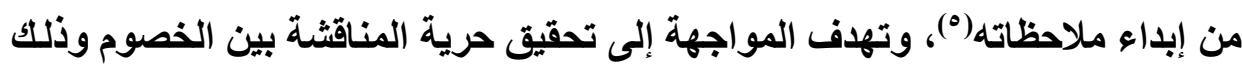

CA Paris, id. CA Paris, 3 dec. 2002, op. cit., p. 931. (')

(2) CA Paris, 18 sept. 2012, op. cit., p. 867.

(3) CA Paris, 3 dec. 2002, op. cit., p. 931.

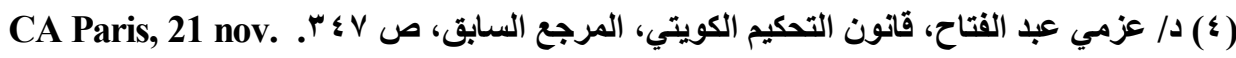
1967, op. cit., p. 122.

(0) د/ فتحي والي، قانون التحكيم في النظرية والتطبيق، المرجع السابق، بند ـ ؟r. 
بسماع القول والقول الآخر (')، وحتي تتحقق المناقشة يجب أن يكون كل خصم علي علم بما قدمه الخصم الآخر حتي يمكنه مناقثتّه، فإعطاء المحكم الفرصة لكل خصم كي يعبر عن وجهة نظرة وأن يعلم بذلك الخصم الآخر. والاعلام يمتا إلى المدعي والمدعي

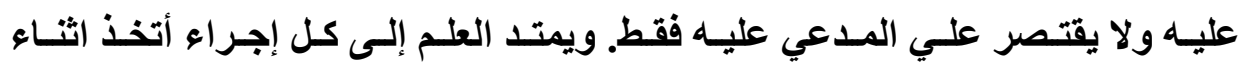
الخصومة(؟). والأصل أن يكون العلم فعليـا، إلا أن هنـاك بعض الحـالات يكتفي باتخـاذ الوسائل التي تكفل العلم(") وأن لم يتم العلم بشكل فعلي، كما في حالة العلم في الموطن لأحد الأشخاص الموجودين في الموطن.

ويعد من أهم مقتضيات مبأ المواجهة تمكين الخصم من الاطلاع علي مـا قدمـه

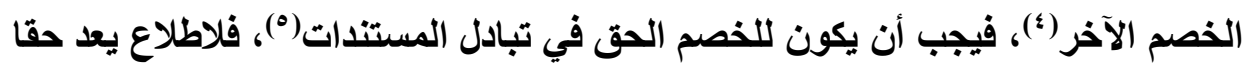

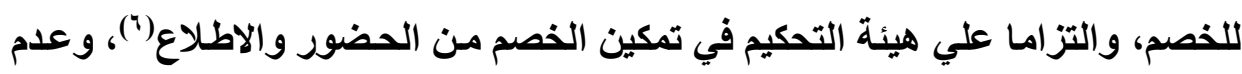
مراعاة ذلك الالتزام يترتب البطلان علي مخالفته(V). وقد نصت المـادة به هن من قانون

(1) CA Paris, 13 mars 1973, op. cit., p.176.

(2) CA Paris, 18 sept. 2012, op. cit., p. 867.

(3) CA Paris, 12 juill. 1971, op. cit., p. 71, CA paris, 20 mai 1983, op. cit., p. 389.

(4) CA Paris, 2 fev. 1988, op. cit., p. 62, note Couchez, Cass. Civ., 2e, 10 nov. 1998, op. cit.,p. 1.S.

(0) د/ عزمي عبد الفتاح، واجب القاضي في تحقيق مبدأ المواجهة باعتباره اهم تطبيق لحق الدفاع،

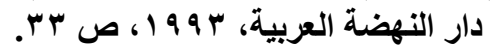

CA Paris, 13 nouv. 1980, Rev. Arb., 1984, p. 12, CA Paris, 24 oct. 1991, Rev. Arb., 1994, p.110.

(6) CA Paris, 24 mai 1874, op. cit., p. 246. CA Paris, 1995, Rev. Arb., 1996, p. 530, obs. L.K. CA Paris, 12 juill. 1971, op. cit., p. 74.

(7) CA Paris, 24 oct. 1980, Rev. Arb., 1982, p. 54, note fouchard. 
المحاماة علي التزام الخصم بتمكين الخصم الآخر أو وكيله من الاطلاع علي مـا تحت يده من مستندات لم يعلن بها أو لم يبدها شفويا في حضوره.

وحق الاطلاع يكون علي كافة المستتدات مثُل مذكرات الدفاع وتقرير الخبراء

وإجراءات الإثبـات ومحاضر التحقيق (سمـاع الشهود والمعائنة) وهذا الحق واجب

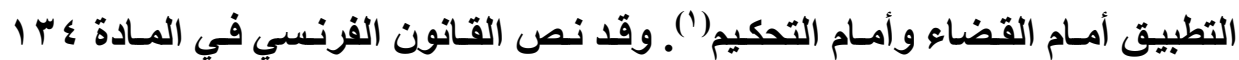
مرافعـات ونص القـانون المصري في المـادة V و مرافعـات علي حق الخصم في طلب الاطلاع من القاضي، وعلي القاضي أن يمكنه من هذا الاطلاع. وهذه الأحكام تطبق علي التحكيم. وإذا كـان المشرع اعطي سلطة لهيئة التحكيم في اتخـاذ مـا تراه مناسبا من إجراعات الإثبات للفصل في النزاع، فإن ذلك يستوجب بالضرورة علي كل خصم من

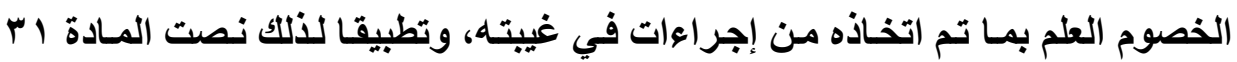
تحكيم مصري علي أن ترسل إلى الطرفين صورة من كل ما يقدم إلى هيئة التحكيم من

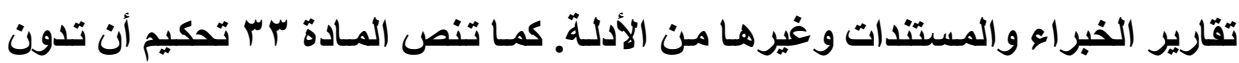
خلاصة وقائع كل جلسة تعقدها هيئة التحكيم في محضر تسلم صورة منـه إلى كل من الطرفين ما لم يتفقا علي غير ذلك. وقد أكدت علي حق العلم أيضا المـادة بس تحكيم

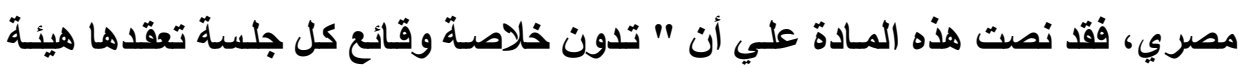
التحكيم في محضر تسلم صورة منه إلى كل من الطرفين ما لم يتفقا علي غير ذلك(؟). ويلاحظ أن المواجهة لن تحقق هدفها إلا إذا كـان العلم في وقت نـافع، ويقصد بذلك الوقت الذي يمكن الخصم من تنظيم دفاعه للرد علي مـا علمهه، فالمواجهة تهدف

(1) CA Paris, 13 nouv. 1980, op. cit., p. 12, CA Paris, 24 oct. 1991, op. cit., p.110.

(Y) د/ علي بركات، خصومة التحكيم في المصري والقانون المقارن، المرجع السابق، ص ^ ـ بـ. 
إلى تمكين الخصم من العلم توصلا للرد عليه('). وقد نصت المادة ه 1 مرافعات فرنسي علي ضرورة العلم في وقت نـافع()، فيجب منح الخصم فرصة من الوقت ليتمكن من تدبر أمره مع محاميه وأن يجري بعض الأبحاث القانونيـة اللازمـة وأن يفكر ويتروى. وإذا تقاعس الخصم عن الاطلاع، فيمكن للمحم أن يأخذ بالمستند الذي قدم ولم يطلع عليه لخطأ منه. ولا يمثل ذلك اخلالا بحق الدفاع أو المواجهة("). وقد تضمن قانون المرافعات المصري بعض الأحكام التي تحث علي العلم في وقت نـافع، مثثل المـادة ه و والتي توجب علـي المدعي عليه في جميع الدعاوي عدا المستعجلة والتي أنقص ميعاد العضور فيها أن يودع قلم الكتاب مذكرة بدفاعه يرفق ليقي بها مستنداته قبل الجلسة المحددة لنظر الدعوي بثُلاثة أيسام علي الأقل، وهذا الميعاد تنظيمي. إذن يستوجب مبأ المواجهة أن يكون كل خصم علي علم بما قدمه الخصم الآخر

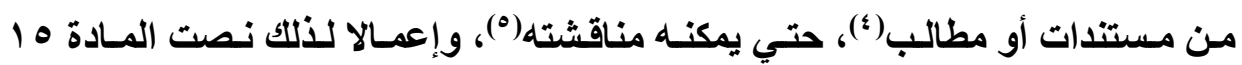
مرافعات فرنسي علي أن يعلن الخصم بشكل تبادلي وفي وقت مناسب بجميع الأسباب

(1) CA Paris, 2 fev. 1988, op. cit., p. 62, note Couchez, Cass. Civ., 2e, 10 nov. 1998, op. cit.,p. 1.S.

(2) CA Paris, 12 juill. 1971, op. cit., p. 71, CA paris, 20 mai 1983, op. cit., p. 389.

(ए) د/ عزمي عبد القتاح، واجب القاضي في تحقيق مبذأ المواجهة باعتباره اهم تطبيق لحق الدفاع،

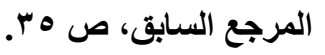

CA Paris, 24 mai 1874, op. cit., p. 246.

(4) CA Paris, 18 sept. 2012, op. cit., p. 867.

(5) CA Paris, 3 dec. 2002, op. cit., p. 931. 
الواقعية التي يؤسس كل منهم عليها ادعاءاته، وكذلك جميع أدلة الإثبات التي يقدمونها والأسباب القانونية التي يثيرونها في الدعوي حتي يتمكن كل منهم من تجهيز دفاعه('). ولا يوجد شكل معين يجب اتباعه للاطلاع والعلم علي ما يقدمه الخصم في نظام التحكيم علي عكس الأمر بالنسبة للنظام القضائي(؟)، وإنمـا كل مـا ينبغي مر اعاتهـه هو احترام مبـدأ مواجهـة الأدلـة تحت أي شـكل كـان، والأصـل أن يـتم تبـادل الاطـلاع بـين

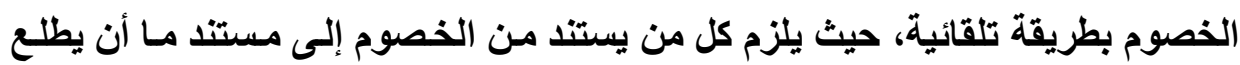

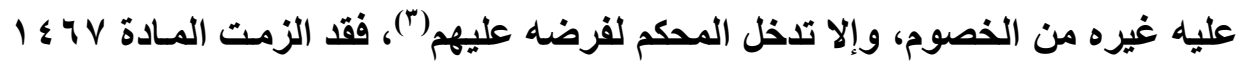
مرافعـات فرنسي الأطراف بتبـادل المستثدات وإلا تـخلت هيئة التحكيم بتنظيم عملية الاطلاع، ومع الأخذ في الاعتبار طبيعة بعض الوثائق ـ أثنـاء الاطلاع والتبـادلـ التي

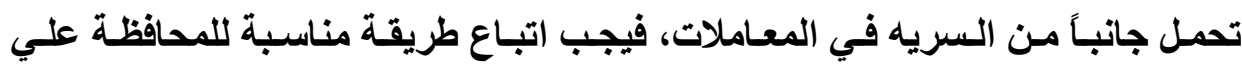
السرية"(؛)، وإذا رفض الخصم تقديم المستتـل المطلوب الاطلاع عليـه، فيمكن لهيئة التحكيم أن تحكم عليـه بالغرامـة التهديديـة، و إذا لـم ينـصاع الخـصم للحكـم بالغرامـة التهديديـة، فعلـي هيئة التحكيم أن تحكم في النـزاع، وأن تراعـي تعنـت الخصم أثنـاء

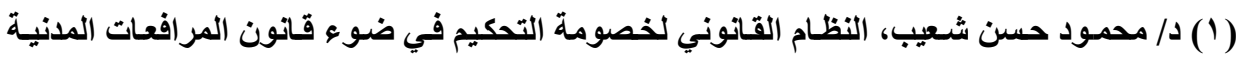

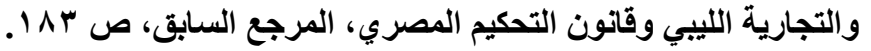

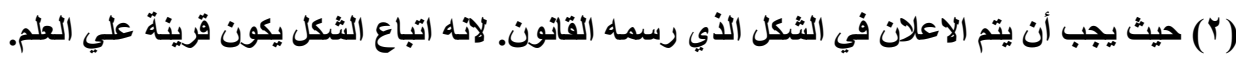

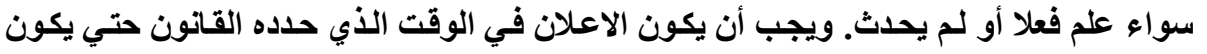

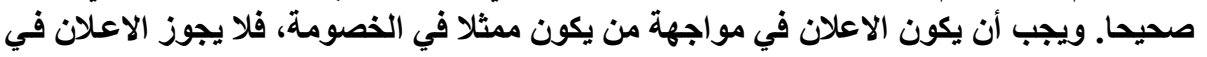

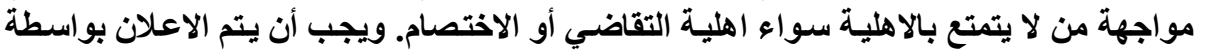
المختص وهو المحضر. وقد نظم المشرع المصري الاعلان في الموادة هـ ــ الأي مرافعات.

(3) CA Paris, 1995, Rev. Arb., 1996, p. 530, obs. L.K.

(4) B. Moreau, A. Beregoi, et autre, arbitrage commercial, op. cit., no 235. 
وتحـد هيئة التحكيم موعدا للخصوم لتقديم مستنداتهم ومـذكراتهم وأوجـه دفاعهم، ويحدد هذا المواعد حسب ظروف سير الدعوي. ويجب تمكين كل خصم من الاطلاع علـي المستتدات المقدمة(')، ويمكن أن يحدث دون إعلان الخصم الآخر عن طريق مندوب الإعلان، حيث يكفي أن يدعو المحكم الخصوم لايهه، ويقدم لهم المستندات المقدمة ليطلع كل خصم علي مـا قدمـه الخصم الآخر ويبدي ملاحظاتـه بشأنها. ويمكن لكل خصم في جلسة التحكيم تقديم المستتدات التي تدعم وجهة نظره بحيث يتحقى العلم ويحترم مبدأ المواجهة(؟). وإذا أقام المحمم قضاءه علي مستتد قدم من أحد الخصوم

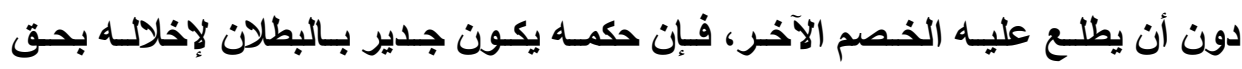
الدفاع.فإذا لم يتم إعلام الخصم بالدليل أو المستتد المقدم، فعلي المحكم أن يمتنع عن

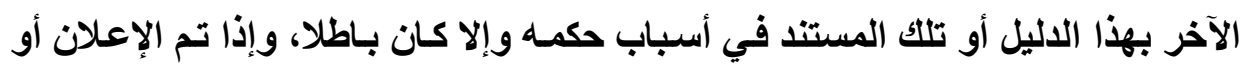
الاطلاع علي الاليل أو المستتد قبل عدة ساعات من قفل بـاب المرافعة لا شكل مخالفة

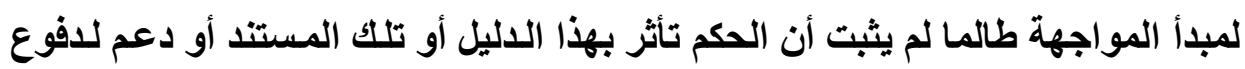

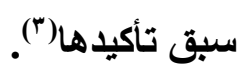
تلتزم الهيئة احتراما لمبدأ المواجهة بين الخصوم(؛) بأن ترسل لكل طرف صورة

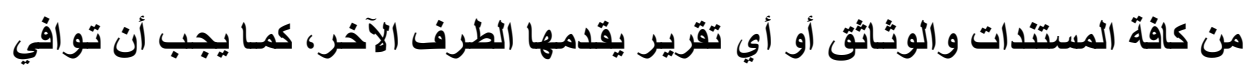
الأطراف بكل المستندات التي قد تحصل عليها الهيئة مباشرة عن غير طريق الأطراف،

(1) CA Paris, 13 nouv. 1980, op. cit., p. 12, CA Paris, 24 oct. 1991, op. cit., p.110.

(2) R. David, I arbitrage dans le commerce international, op. cit., no 320, p. 410.

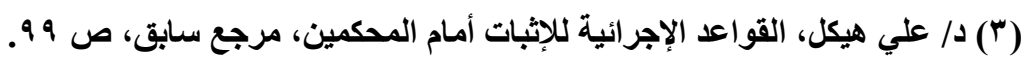

(4) CA Paris, 3 dec. 2002, op. cit., p. 931. 
كما لو ندبت خبيرا فقدم لها تقريره بشأن ما طلب منه، أو استعملت من إحدي الجهات المتصلة بالنزاع عن معلومات أو طلبت منها بيانات معينة، كطلب صورة من خطابـات أو مستتدات بنكيـة متعلقة بموضـوع النزاع أو ســدات شــن أو تقـارير مـن شـركات الشحن والتفريغ، ففي هذه الحالات يجب إرسـال صور من كافة مـا تحصل عليه إلى بـ الأطراف حتي يكونوا علي درأيه بما تحت يد الهيئة من مستندات تستتد إليها وتؤثر في اتخاذ قراراها، ويجب علي الهيئة التأكد من استيفاء هذا المبدأ الأساسي، حيت يترتب علي انتهاكه بطلان الحكم أو رفض التنفيذ(').

ويجب أن ينصب العلم علي كل عناصر الخصومة من ادعاء و مـا قدمـه الخصم

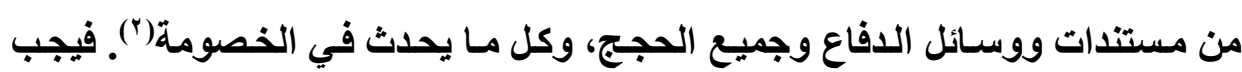
العلم بسبب الطلب، ويمتد هذا الالتزام في جميع مراحل الخصومة، سواء كاتت هذه الوسـائل قدمت وقت رفع الـدعوي أو اثنـاء الخصومة، ويجب العلـم بوسـائل الـفاع القانونية التي يقدم الخصم بهدف تأسيس طلب قضائي أو لإفشال ادعاء تقدم به الخصم الآخر. فهذه الوسائل تتعلق بالإجراءات. كما ينصب العلم بـالحجج التي يقدمها الخصم،

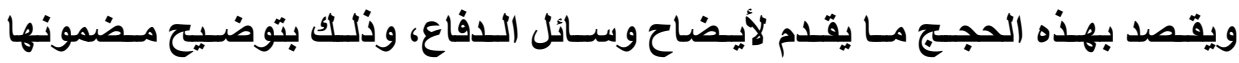
وتفسيرها، وذلك لإقناع المحكم بها. ومن أمثلة الحجج الأحكام القضائية غير المنشورة التي يستدل بها الخصم. ويجب أن يتضمن العلم وسـائل الإثبات التي يقدمها الخصم الآخر فإذا كانت وسيلة الإثبات دليل كتـابي تعين أيداعـه حتـي يمكن للخصم الآخر 
الاطلاع عليه('). وإذا اتخذ القاضي دليلا للإثبات من تلقاء نفسه، فيجب عليه أن يعلم به كافة الخصوم، ويجب إعلانهم بالنتيجة التي أدت إليه.

ويشترط أن تكون المستندات التي يجب أن تبادل الاطلاع عليها مؤثره ومفيدة

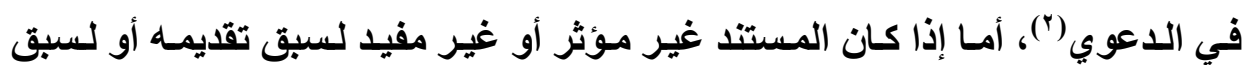
الاطلاع عليه، حتي لو عاد طرحه من جديد، فإن لا يتطلب الاطلاع عليه. ويلتزم المحكم بألا يعتمد في تكوين اقتناعه علي ما لم يتم الاطلاع عليه من مستتدات بمعني أن بستبعد مـن الأسسس التـي يؤسسس عليها قراعة هذه المستتدات التـي لـم يطلـع عليها الخصم

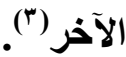

\section{r. مق الخصم في الهضور}

لتحقيق مبدأ المواجهة يجب تمكين الخصم من الحضور، ويهرف حضور الخصم إلى وجود صله مباشرة في الجلسة بين الخصوم وهيئة التحكيم، لمحاولة تفهم حق هق الخصم وإقناع الهيئة بادلته، كما يعمل الحضور إلى اعمـال بعض وسـائل التحقيق كان يتيح للخصوم مثلا أثناء إدلاء الشاهد بمناقشته عن طريق توجيه من أسئلة للشاهد، كمـا يمكنه الحضور من تقديم معلومـات أو إبداء ملاحظـات ومناقشة تقرير الخبير أو المعائةة(؛).ومن أجل احترام مبلأ المواجهة، يجب علي هيئة التحكيم ألا تسمع الشاهد

(1) CA Paris, 13 nouv. 1980, op. cit., p. 12, CA Paris, 24 oct. 1991, op. cit., p.110.

(2) CA Paris, 13 nouv. 1980, id.; CA Paris, 24 oct. 1991, id.

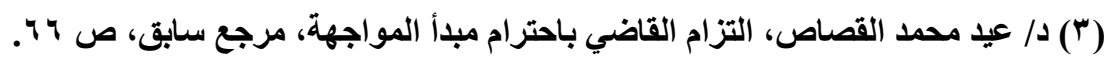

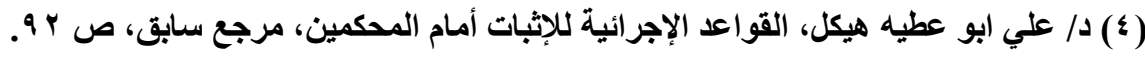


إلا بحضور جميع الأطر اف وفي مواجهتهم، وهذا ييسر إمكانيـة قيام الحضور بمناقشة

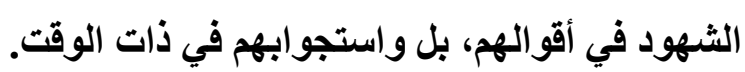

للتلك حق الخصم في الحضور ضمانة أساسية لتحقيق العدالة(')، ويجب عدم التثدد والمبالغة في وجوب دعوة الخصوم للحضور باعتباره كأحد مظاهر احترام مبدأ المواجهة(؟)، حيث يذهب بعض الفقه إلى أن هذا الالتزام يجب ألا يحمل علي مفهوم ضيق، وإنمـا ينبغي التعويل علي النتيجة التي يمكن أن تترتب علي عدم استدعائهم للقول بمدي احترام مبدأ الحضورية كأوجه من وجوه مبدأ المواجهة مـن عدمـه، لذلك فعدم استدعاء الخصم يمكن أن يثكل مخالفة لمبدأ المواجهة، إذا كـان يؤدي إلى عدم تمكين الخصم من الاطلاع علي ما قدمه الخصم الآخر من أدلة (َ)، وعدم معرفـة كيفية سير الخصومة أمام المحكمين، وعلي ذلك فإن وجود تكليف بالحضور لا يكفي لضمان احترام مبدأ الحضورية إذا تم ذلك في وقت متـأخر، ولم يترك الفرصة للخصوم لإعداد أدلتهم ودفاعهم (؛)، وعدم حصول دعوة الخصوم علـي الاطلاق يرتب بطلان الحكم الصادر، كما لا يلزم دعوة الخصوم إلى حضور جميع الجلسات، طالما كانوا قد حضروا بعضا من الاجتمـاعـات فقط، وكسان في إمكانهم إبـاء مـا يشاؤون مـن أقوال. ويمكن إصدار القرار في غيابهم بشكل صحيح(ه).

(1) CA Paris, 7 janv 1963, Rev. Arb., 1963, p. 75.

(2) CA Paris, 7 janv. 1963, op. cit., p. 435, CA Paris, 14 fevr. 1985, op. cit., p. 325 , note level.

(3) CA Paris, 24 mai 1874, op. cit., p. 246.

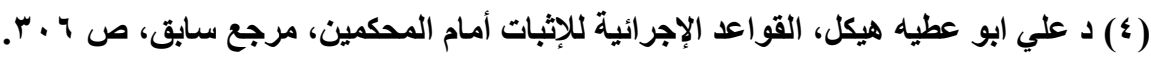

(5) Cass., civ., 12 Janv. 1968, Bull. Civ., n03, 15, CA, Paris, 5 juill. 1963, Rv. Arb., 1965, p. 152. 
ولا يشترط صدور الحكم إلا بعد سماع أقوالهم ودفاعهم، وإنما يقصد بذلك إتاحة الفرصة لكل خصم لتقديم دفاعه، فإذا لم يشأ استعمال هذا الحق أو أصر علي الامتـاع عن الحضور دون عذر مقبول، فيمكن للمحم إصدار قراره دون سماع أقوال الخصم أو في غيتـه، ويجب علي المحكم أن يكون حريصا علي صحة الإعلان وتفاهة الأعذار

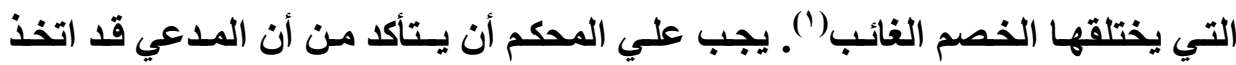
الإجراءات التي من شأنها إعلام المدعي عليه بالإجراءات المتخذة ضده(؟). r. حق كل خصم في أن يسسمعه المحكم:

يقتضي مبدأ المواجهة دعوة كل خصم لسماع أقواله(")، وهذه اللاعوة ضمانة أساسية لتحقيق العدالة، ويعتبر من أهم حقوق الخصم هو العلم واستدعاء الخصوم للحضور، وإتاحة الفرصة لهم لتقديم أدلتهم وحججهم، ويقتضي احترام مبدأ المواجهة أن يسمع المحكمون الخصوم إذا ما تم دعوتهم(4)، وهذا ما نص عليه القانون الفرنسي في المادة ؛ 1 مرافعات، ويجب أن يسمح لكل خصم علي قدم المسـاواه من تقديم أدلته

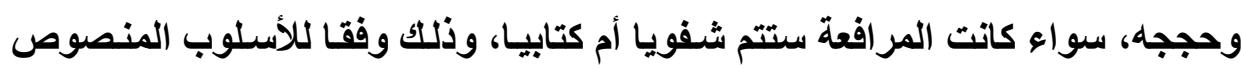
عليه في اتفاق التحكيم، أو المحدد من قبل هيئة التحكيم(0). وهذا مـا نصت علية المـادة rr من قانون التحكيم المصري. وحتي لو حصلت دعوه للخصوم، فِان مبدأ المواجهة

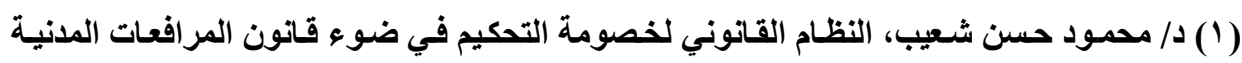

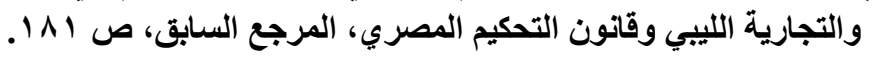

(2) CA Paris, 3 dec. 2002, op. cit., p. 931.

(3) id.

(4) id.

(0) د/ نبيل إسماعيل عمر، التحكيم في المواد المدنية والتجاريـة الوطنية والدولية، المرجع السابق، 
لا يكون قد تم احترامه إذا حصلت هذه الدعوة في وقت متأخر، ولم يكن لاعوة الخصوم مهلـة كافيـة لتحضير دفـاعهم. وإذا تمــت الـدعوة في وقـت مناسـب فـلا عبرة بعـدم حضورهم. ونظـرا لأن المواجهـة تقـوم علـي أســاس حريـة النقــاش، وهـذا الأمـر يتطلب أولا:منح الخصم الحق في تقديم ما يدعم وجهة نظرة، والأمر الثاني: أن يعلم كل طرف

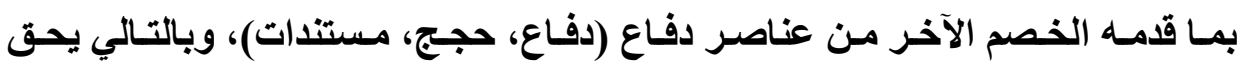

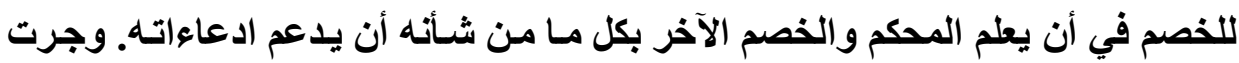
العادة في التحكيم علي أن الملاحظات والمستتدات المقدمة من أحد الخصوم يتم بتبادلها للطرف الآخر بمجرد وصولها من أحد الخصوم إلى هيئة التحكيم('). ويمكن تحقيق مبدأ المواجهة أمام المحكمين بأي شكل كان(汭 ويجب أن يمكنوا وفقا للأسـلوب المنصوص عليـه في الاتفـاق علـي التحكيم، أو المحدد مـن قبـل هيئة

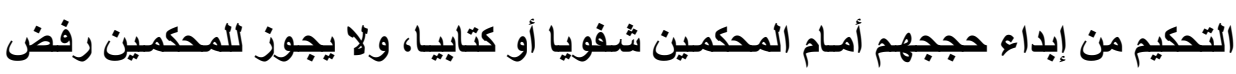

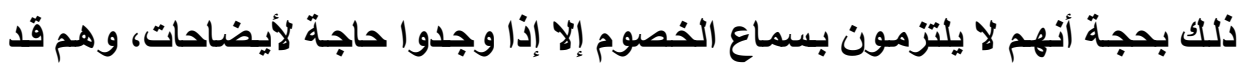

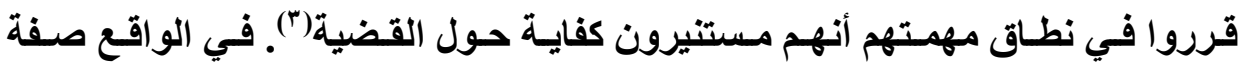
المواجهة أمام التحكيم لا تفرض بالضرورة حضور الخصوم ووكلائهم أمسام المحكمين، بل يكفي تقديم أوجه الافاع كتابيا، لأن مبدأ المواجهة يكون قد احترم في الحالات فقط

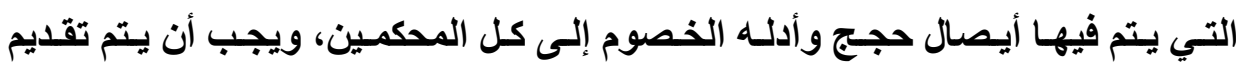
المذكرات قبل ختام المحاكمة وإلا جاز لهيئة التحكيم صرف النظر عنها، ويجب سماع الخصوم من كامل هيئة التحكيم إذا كانت متعددة، إذ لا يكتمل ولا يتحقق مبدأ المواجهة

(1) CA Paris, 12 juill. 1971, op. cit., p. 74.

(2) CA Paris, 3 dec. 2002, op. cit., p. 931.

(3) CA Paris, 22 mars 1965, Rev. Arb., 1966, p. 107. 
إلا إذا وصلت حجج الخصوم إلى جميع المحكمين. وهذه القاعدة لا تلزم إشراك جميع المحكمين في التحقيق، وإنما يجب تمكين جميع المحكمين بأي طريقة كانت من الوقوف

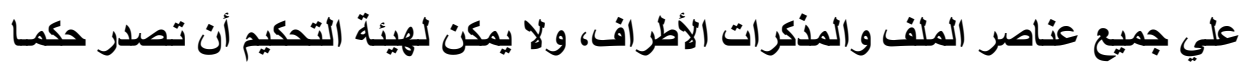
صحيحا إذا بقي أحد أطرافها علي جهل بعناصر علم بها المحكمون الآخرون(') كمـا

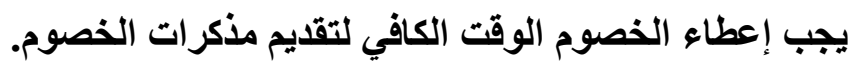

ويجب عنــ مخالفـة مبـا المواجهة أن يـدفع الخصم بـذلك، فقــ ذهب القضاء

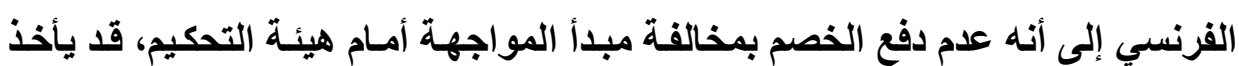
منه علي أنه قرينة علي التنازل عن هذا الدفع في دعوي البطلان().

\section{ع.حق الخصم في هناقشة الأدلة}

يقتضي مبدأ المواجهة التزام علي المحكم هو ألا يؤسس حكمه علي وقائع

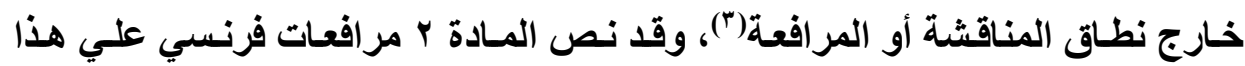
الالتزام ليس فقط بالنسبة للوقائع، ولكن بالنسبة لكافة الوسـائل، سواء التي أثثارهـا الخصوم أو أثارها المحكم، وبشرط أن تكون قد نوقثت حضوريا وفي المواجهة( نصت هذه المادة علي أنه علي المحكم أن يطرح علي الخصوم كل مـا جمعه من أدلة

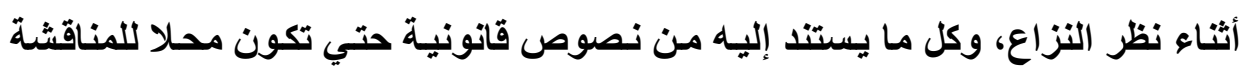

(1) Cass., 31 janv. 1979, Rev. Arb., 1979, p. 366.

(2) B. Moreau, A. Beregoi, et autre, arbitrage commercial, op. cit., no 213.

(3) CA Paris, 13 mars 1973, op. cit., p.176. CA Paris, 3 dec. 2002, op. cit., p. 931.

( ) د/ طلعت محمد دويار، ضمانات التقاضي في خصومة التحكيم، مرجع سابق، ص II Y.

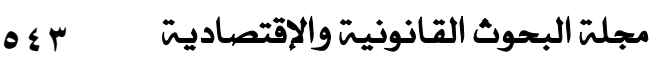


وإذا كان مبدأ المواجهة يستوجب أن يخضع كل مـا يجمعه المحكم من مسائل واقع وقانون للمناقشة من ذوي الشأن كأول مراحل الخصومة، فالمبدأ يفرض نفسه وبصورة واضحة في مرحلة الإثبات لخطورة هذه المرحلة، فمثلا لو أمر المحكم بندب خبير تعين منح الخصوم فرصة العلم بمضمون التقرير لمناقشة نتائجة، والا يكون قد خالف مبدأ المواجهة لاعتداده بعناصر وقائع لـم يمنح الخصوم فرصة لمناقشتها ('). ويجب علي المحكم أن يمنح الخصوم مناقشة وسـائل القانون، خاصـة تلك التي يثيرهـا من تلقاء نفسه، سواء تعلقت بالنظام العام أو لا تتعلق بـه، بل ولو كانت وسيلة واقع آثار ها الخصوم ولكنهم لم يتمسكو ابها صراحة، فيجب أن يخضع كل ذلك للمناقشة قبل

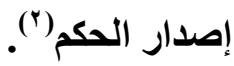
ويجب علي المحكمة أن يحترم مبدأ المواجهة إذا استند في حكمه إلى معلوماتـه الثخصية، فلا يقضي بعلمه الثخصي عن وقائع تتعلق بالنزاع الذي ينظره، إلا إذا كان

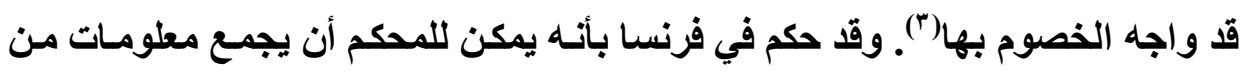

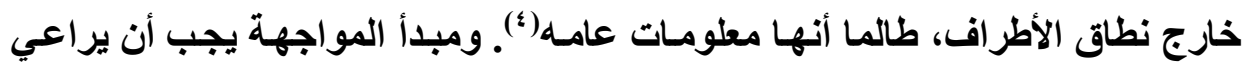
حتـي في اسـتعمال المحكـم معلوماتـهـ العامـة بـصورة مجـردة لأجلـل تقــير الموضـوع المتنـازع عليه، وقد حكم بأنـه إذا كـان مـن حق المحكم استيفاء معلوماتـه مـن رجل

(1) CA Paris, 18/1/1983, Rev. Arb., 1984, p.87.

(r) د/ علي بركات، خصومة التحكيم في المصري والقانون المقارن، مرجع سـابق، بند ؛ اب، ص (1)

(4) CA Paris, 24 oct. 1980, op. cit., p. 54, note fouchard. 
متخصص بـون علـم الخصوم حلـول الأثر الذي يترتب علـي طريقـة حساب مؤشـر الأسعار، قذلك بشرط أن يكون الخصوم قد مكنوا من مناقشة هذه المعلومات(').

$$
\text { ويقتضي هذا الحق الاتي: }
$$

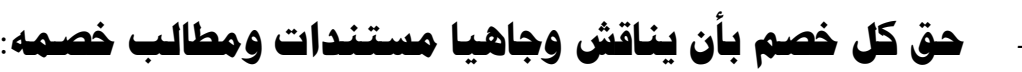

مبدأ المواجهة يستلزم أن يتقيد المحكم به ويفرض علي الخصوم التقيد به()،

وهو يستلزم إبراز المستندات حتـي يمكن للخصم الآخر مناقشتها وإبداء ملاحظاتـه

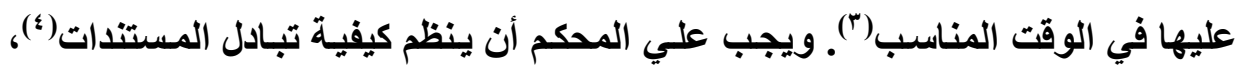
وأن يرفض أي مستتـ لا يتم إعلانسه للخصم الآخر، وكل إخـلال بهذا الالتزام يعرض

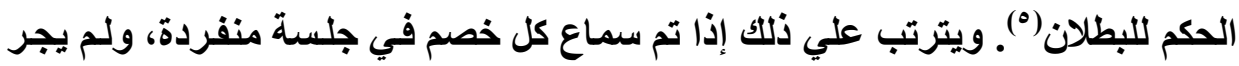
أي إعلان لباقي الخصوم بأقواله يخالف مبأ المواجه ويؤدي إلى بطلان الحكم، والواقع أن إقامه الاليل علي عدم إبلاغ المستند المقدم قد يكون صعبا، خاصة وأن القضاء يقرر قرينة في هذا المعني تقضي بأن كل مستتد أثبير إليهه في القرار يفترض أنه قد جري (إبلاغه (7) (1)

(1) Id.

(2) CA Paris, 3 dec. 2002, op. cit., p. 931.

(3) CA Paris,24avril 1980, Rev. Arb., 1981, p. 177.

(4) CA Paris, 13 nouv. 1980, op. cit., p. 12, CA Paris, 24 oct. 1991, op. cit., p.110. CA Pris, 1995, op. cit., , p. 530, obs. L.K.

(5) CA Paris, 13 nouv. 1980, id., CA Paris, 24 oct. 1991, id.

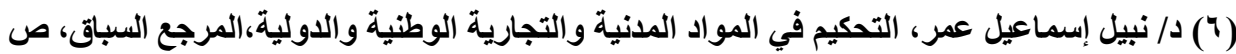




\section{حق كل خصم في هناقـشة عناصـر الواقـع والقـانون التـي تلقاهـا وأثارهـا}

يجب تطبيق مبدأ المواجهة في كل مراحل الخصومة، لأنه من المبادئ الأساسية في كل أنواع الخصومات، وتشكل أسـاس لمبدأ احترام حقوق الدفاع، ويترتب عليها ضرورة حضور الخصمين لمناقشة جميع عناصر الخصومة، ويطبق ذلك على كل أعمال الخصومة، سواء كان تحقيقا أو خبره أو معأينة، ويكفي أن تضع هيئة التحكيم الخصوم في موضوع يمكنهم من مناقثة ذلك. ويجب احترام مبدأ المواجهة والمساواة في خصوص ما يقوم به الخبير من أعمال، يجب أن يحضر الأطراف أو ممثلوهم، كل إجراء يتخذه أو اجتماع يعقده، وأي اتصال بين الخبير وهيئة التحكيم يجب أن يحساط بـه الأطر اف، كما أن لهم مناقشة الخبير في أعماله وإبداء ملاحظاتهم عليها، كمـا أن لهيئة التحكيم استـاعاء الخبير لجلسة تحددها وتقوم هي والأطراف بمناقشة الخبير في تقريره. وهذا ما اخذ به القانون المصري للتحكيم في المادة وس تحكيم، وقد تبنت ذلك

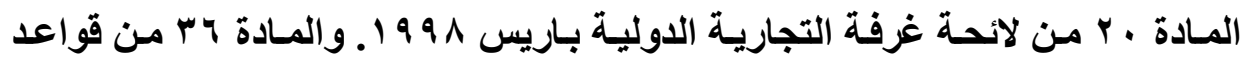

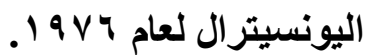

ويلاحظ أن المبادئ العامة للخصومة تفرض علي المحكم والقاضي أن لا يستند في حكمه إلى اسباب قانونية أثثارها من تلقـاء نفسه دون أن يـدعو الخصوم مقدما إلى تقديم ملاحظاتهم بشأنها، ويطبق هذا المبدأ عندما تكون القاعدة المثارة هي عرف اعتبرها القرار عينه معادلا لقاعدة قانونية(؟).

(1) CA Paris, 21 mars 1963, Rev, Arb., 1963, p. 21

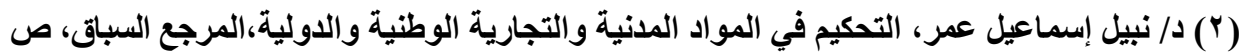


وهناك خلاف في الفقه(') حول ضرورة تبادل وسـائل الدفاع القانونيـة ومصادر القانون كالعرف والعادة وهل يجب علي المحكم اطلاع كل خصم علي مـا استتد إليه. خصمه؟ هناك رأي يري أن هذه الوسائل غير ملزمـة للمحكم، وبالتـالي فهو غير ملزم بتبادلها مـع الخصوم، لأنها يفترض علم الكافة بها. وهنـاك رأي آخر يلزم المحكمين بتبادلها لأن مجرد إبدائها قد يؤثر في رأي المحكم. وهنـاك رأي آخر يلزم المحكمين بتبادلها لأن مجرد إبدائها قد يؤثر في رأي المحكم.

وخلاصـة القول، تحقيقـا لمبـأ المواجهة يجب إخطسار الخصوم بميعـاد ومكسان الانتقال للمعائة، ليتمكن الطرفان أو من يمثلهمـا من الحضور وقت المعائنة، ويكون

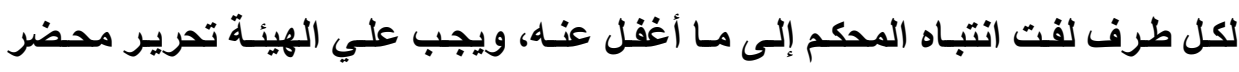
بالمعائنة، وتمكن الأطر اف من مناقشة النتائج التي توصل إليها المحكمون من هذه المعائـة. وذلك حتـي لا يتعرض الحكم الصـادر للبطلان. وهذا مـا قضت بـه محكمـة استثناف القاهرة، بقولها بأن المعأينة التي استندت إليها هيئة التحكيم في حكمها لن يتم تحريـر محضر بشأنها، وإنمـا اكتفت الهيئة بإرسـال خطساب يشير فيها إلى حصول المعائة وما تم فيها، غير أن الخطاب جاء في صياغة عامـة ومجهولة لا تحقق الغائة التي من أجلها اشترط المشرع تحرير محضر تبين فيه جميع الأعمال المتعلقة بالمعأينة ويوقعه كاتب حضر إجراءاتها، وحكم التحكيم الذي استتد إلى هذه المعأينة يكون بـاطلا لوقوع بطلان في الإجراءات أثر في الحكم عملا بالمادة ؛ ه تحكيم(؟).

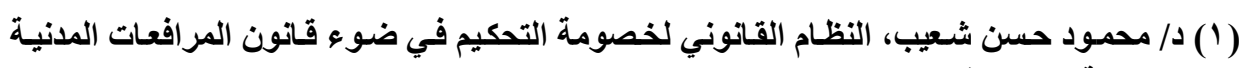

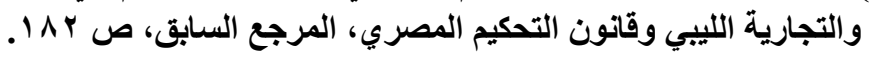

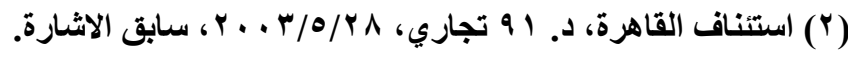




\section{الفرع الثاني \\ التزام هيئة التمكيم بمراعاة حقوق الدفاع}

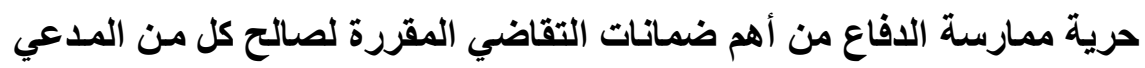

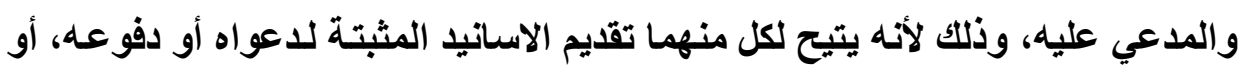

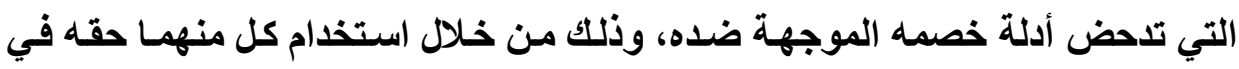
الدفع والإثبات و المرافعة الثفوية أو الكتابة(') وقد نصت المادة بr تحكيم علي إلزام هيئة التحكيم بعقد جلسات مرافعة لتمكين

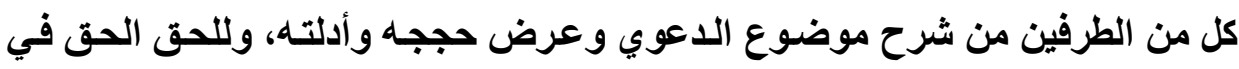
طلب عقد جلسة مرافعة ولهيئة التحكيم أن تستجيب لهذا الطلب إن كان هنـاك مـا يبرر ذلك،، وله الحق في أن يستعين بمن يراه أقدر علي أيصال ما يريده إلى هيئة التحكيم("). ويري الفقه أن حق الدفاع صـابر يعبر عنه بحرية الدفاع، وليس مجرد حق، وذلك لأهميته البالغة(")، فهو حق عام يجب احترامه في جميع الحالات التي يفصل فيها

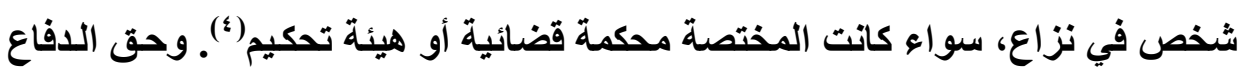
يجب أن يكون مكفولا مـن جانب هيئة التحكيم، فحق الدفاع يعد التزامـا علـي هيئة

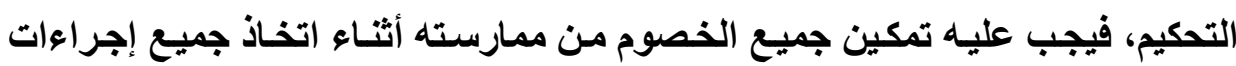

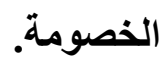

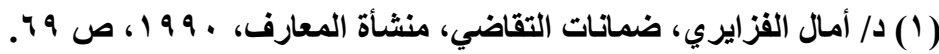

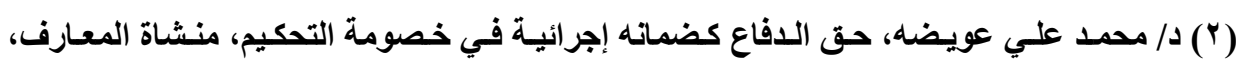

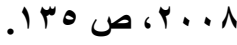

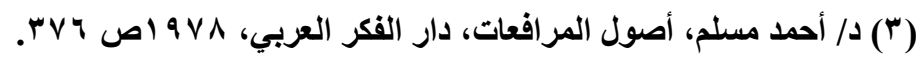

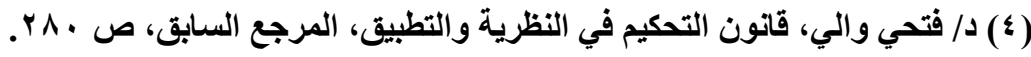


سنشير إلى ماهية حقوق الدفاع، وأنواع حقوق الدفاع، ومقتضياته، وتطبيقات حقوق الدفاع، وذلك في النقاط الآتية:

أولا: هاهية حقوق الدفاع

سنشير إلى تعريف حقوق الدفاع، والأسساس القانوني لحقوق الدفاع، والتمييز بين حقوق الدفاع وبعض الحقوق الإجر ائية الآخرى، وذلك في النقاط الآتية:

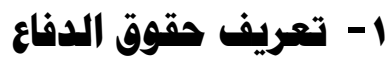

ليس من السهل وضع تعريف محدد ودقيق لمفهوم حق الدفاع، ولكن المفهوم التقليدي له ينصرف إلى حق الخصم في أن يسمع المحكم وجهة نظره(')، و إلى تمكين

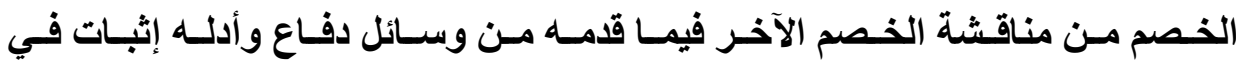

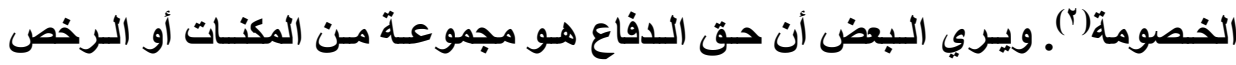

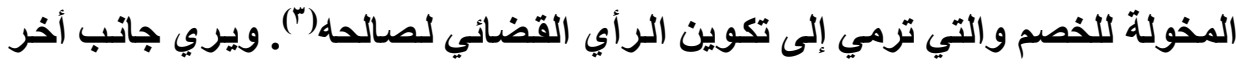

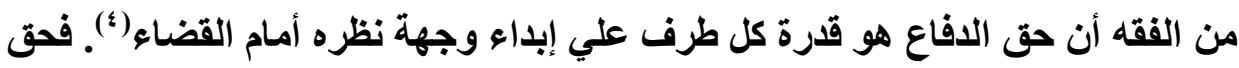

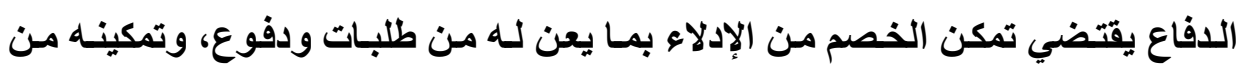

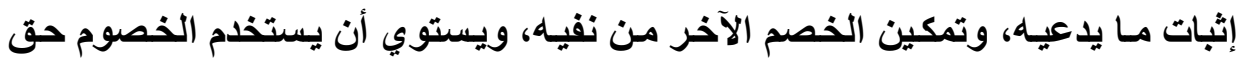

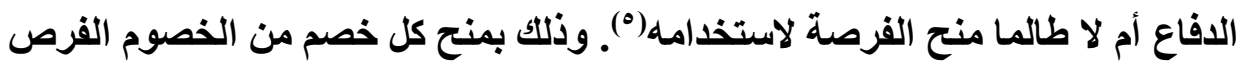

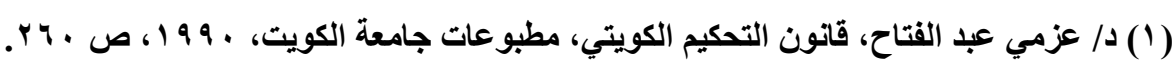

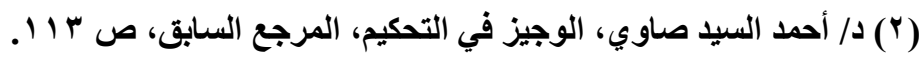

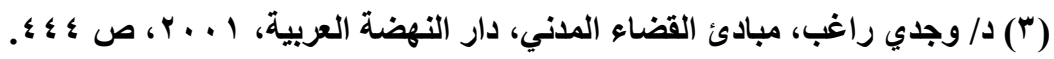

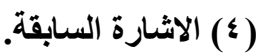

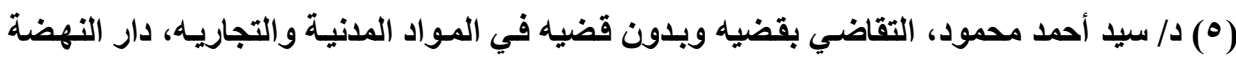

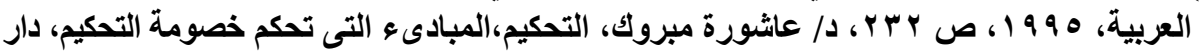

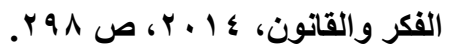


والمهل اللازمة أو المناسبة لعرض ادعاءاته أو دفاعه وما لايه من أدله(') فهذا الحق

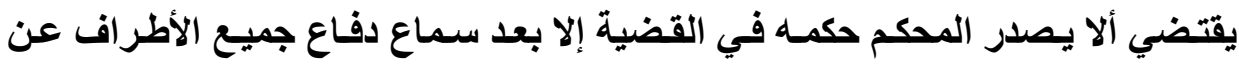

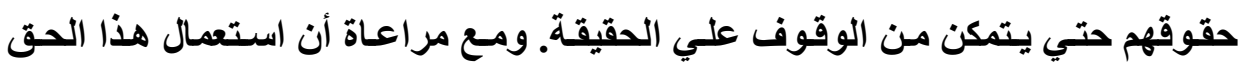

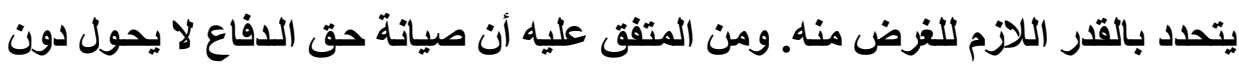

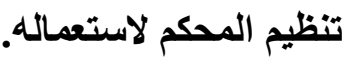

وحقوق اللفاع تقتضي إتاحة الفرصة الكاملة لكلا الخصمين في المثول أمسام هيئة التحكيم لشرح ادعاءاتهم وتفنيد مزاعم الخصم الآخر، وهذا يقتضي الاطلاع علي التئي

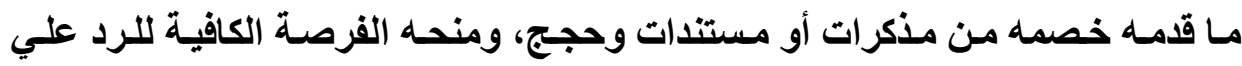
المذكرات أو المستندات والطلبات المقدمة من خصمه(")

الواقع أن جميع التعريفات تدور حقوق تمكين كل خصم من الإدلاء بمـا يعن لهـ

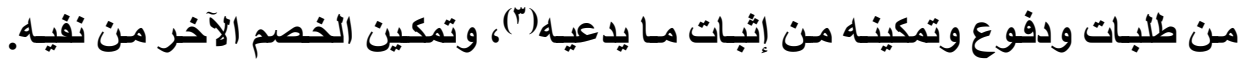

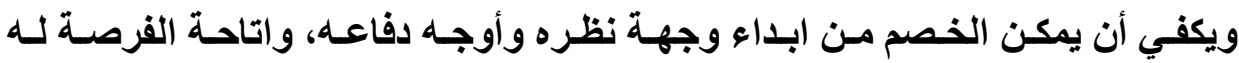
لاستخام كل حقوق دفاعل. ويقتضي ممارسة حقوق الدفاع(')، أن يعلن الخصم بقيام

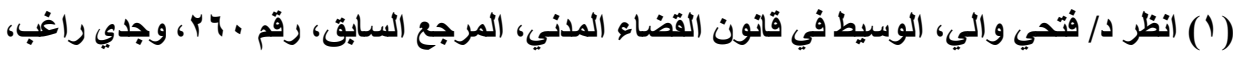

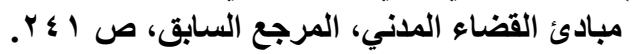

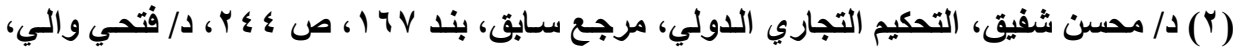

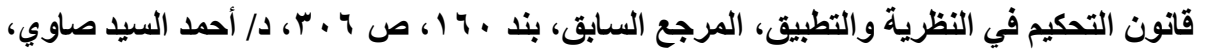

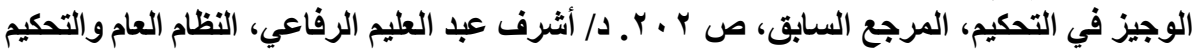

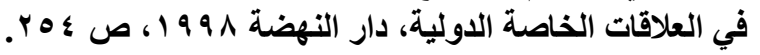

(3) CA Paris, 24 mai 1874, op. cit., p. 246. CA Paris, 10 nouv. 1989, op. cit., p. 651, obs. Pellerin, CA paris, 11 juill. 1991, op. cit., p. 671, obs. Loquin, CA Paris, 13 mars 1992, op. cit., p. 107, obs. Jarrosson, CA Paris, 13 nouv. 1997, op. cit., p. 719, obs. Derains.

(4) CA Paris, 10 nouv. 1989 op. cit., p. 651, obs. Pellerin, CA paris, 11 juill. 1991, op. cit., p. 671, obs. Loquin, CA Paris, 13 mars 1992, op. cit., p. $=$ 
خصومة التحكيم، وأن يمنح فرصة للحضور لتمكينه من تحضير دفاعه، كذلك لا يجوز

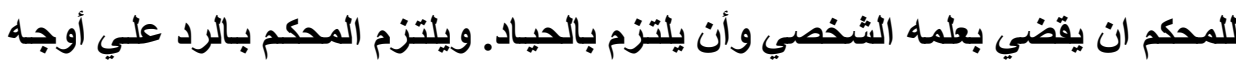
دفاع الخصم أثناء التسبيب، وذلك احترام لحق الدفاع'"). في القانون المصري يعد حق الدفاع حق من الحقوق المتعلقة بالنظام العام،

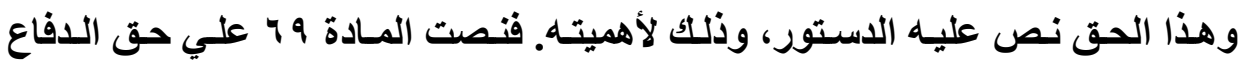
أصالة أو بالوكالة مكفول، وقد نظم قانون المرافعات المصري ضمانات هذا الحق منذ التهات بدء الخصومة حتي انتهائها. وفي فرنسا يعد مبدأ احترام حقوق الدفاع من المبادئ الجوهرية في النظام القضائي(")، فهذا الحق يعد حقا طبيعيا، وقد أكلت ذلك محكمة فئس النقض الفرنسية هذه النظرة منذو القرن التاسع عشر ("). وقد نظم قانون المرافعات الفرنسي إجراءات الخصومة علي أساس احترام مبدأ المواجهة بين الخصوم واحترام

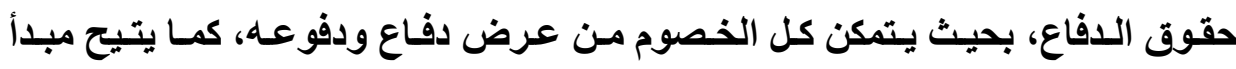
المواجهة بين الخصوم للقاضي الوقوف علي وجه الحق في الدعوي، وذلك من خلال مقارنة الأدلة المقدمة من كل خصم، وقد تتضمن قانون المرافعات الفرنسي العديد من

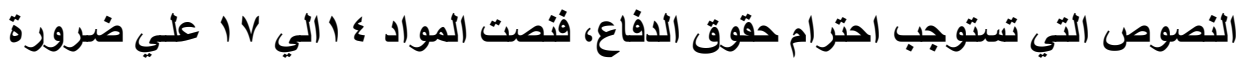

107, obs. Jarrosson, CA Paris, 13 nouv. 1997, op. cit., p. 719, obs. Derains.

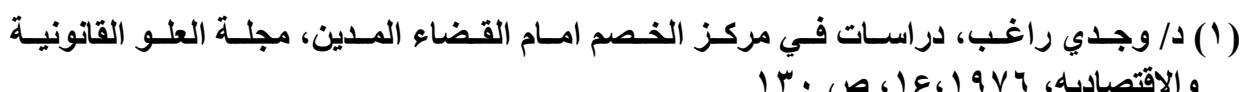

(2) CA Paris, 10 nouv. 1989, op. cit., p. 651, obs. Pellerin, CA paris, 11 juill. 1991, op. cit., p. 671, obs. Loquin, CA Paris, 13 mars 1992, op. cit., p. 107, obs. Jarrosson, CA Paris, 13 nouv. 1997, op. cit., p. 719, obs. Derains.

(3) Cass. Civ., 7 mai 1828, S. 1828, I, 93. cité par, Gerard couchez, procédure civil, 12e éd., Armand colin,p. 239. 
حقوق الدفاع، وذلك في جميع مراحل الخصومة، سواء مرحلة البدء أو مرحلة التحقيق أو مرحلة المرافعة الثفوية أو مرحلة إعداد الحكم(').

ويتميز حق الدفاع بأنه حق عام وشامل، فهو حق عام لأنه يطبق علي جميع

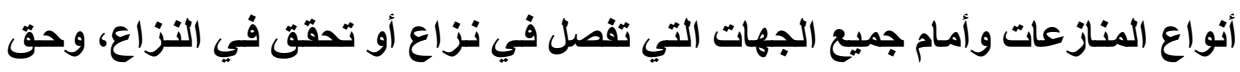

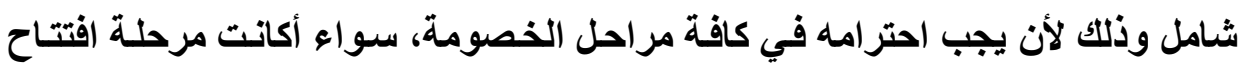
الخصومة أو مرحلة سيرها أو المرحلة الختامية.

ويقوم حق الدفاع علي أساس عملية الاستنباط الفعلي والمنطقي التي يمارسها

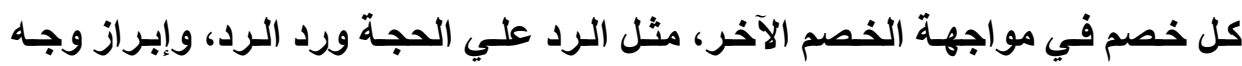

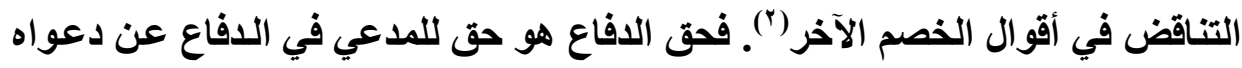

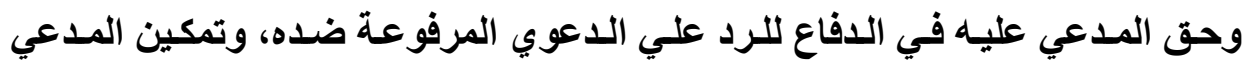

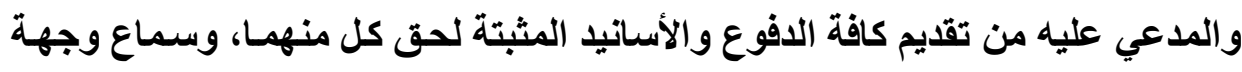
نظر الخصوم في الطلبات والدفاع، ومنحهم الوقت الكاف للاطلاع وسماع ردهم وتحقيق الكأيق دفاعهم (").

\section{r- الأساس القانوني لهق الدفاع}

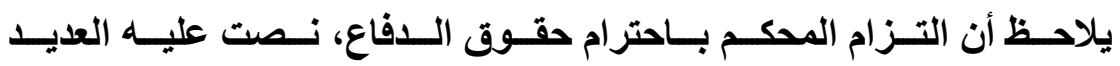

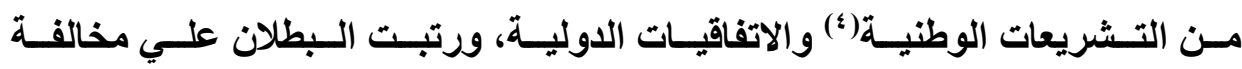

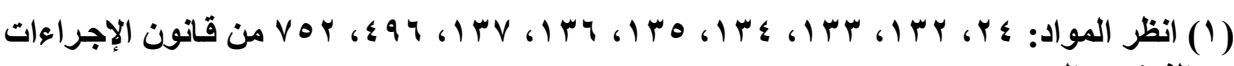

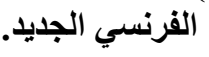

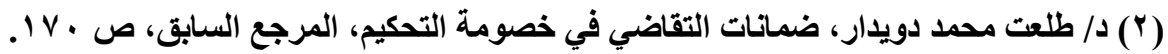

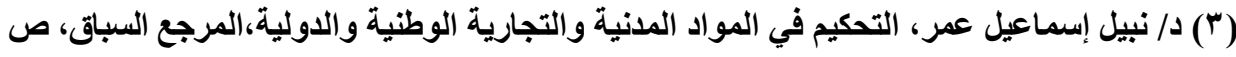

(4) CA Paris, 10 nouv. 1989, op. cit., p. 651, obs. Pellerin, CA paris, 11 juill. 1991, op. cit., p. 671, obs. Loquin, CA Paris, 13 mars 1992, op. cit., p. 107, obs. Jarrosson, CA Paris, 13 nouv. 1997, op. cit., p. 719, obs. Derains. 
ذلك الحق، وذلك لأنه يعد أهم أسس التقاضي، فهو من الحقوق الأساسية التي لا يمكن

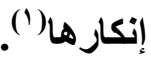

ولقد تعددت النظريات في تحديد الأساس القانوني لحق الدفاع، فالبعض أسس حق الدفاع علي أساس المبادئ العامة، والبعض الآخر اسس حق الدفاع علي أسساس القانون الطبيعي، ويري البعض أن أساس حق الافاع هو النص عليه في الاستور.

\section{ـ حق الدفاع تقرره المبادئ القانونية العاهة}

هنايك مبادئ عامة تحكم القواعد القانونية، وتعد أصول عامـة للتقاضس، وهذه المبادئ تتعلق بالعدالة، وظهرت نتيجة لما جري عليه الواقع العملي، فالقضاء والفقهـ كان لهما الدور في تحديد هذه القواعد بناء علي ما يستشعر القضاء والفقه من حاسـة الشعور بالقانون ومتطلبات العدالة.

ويقتضي المبادئ العامة التي تحكم نظام العدالة، تمكين كل شخص من الدفاع علي حقوقه أمام القاضي أو المحكم، واتاحه الفرصـة لـه لمناقشة دفاع ودفوع الخصم

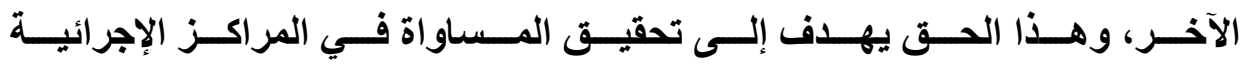

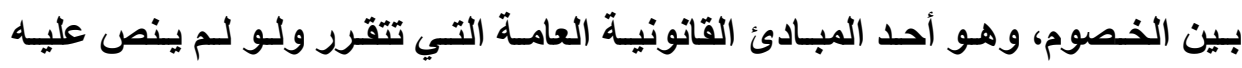

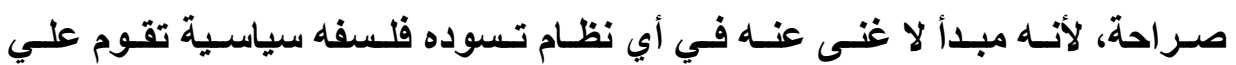
الايمقر اطية)(r).

(1) د/ منير يوسف حامد المناصير، سلطة المحكم في الإثبات في خصومة التحكيم التجاري الدولي،

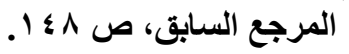
(r) د/ عزمي عبد الفتاح، واجب القاضي في تحقيق مبذأ المواجهة باعتباره اهم تطبيق لحق الدفاع،

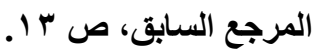




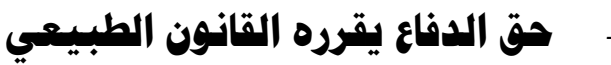

يذهب البعض إلى أن أسـاس حق الدفاع هو القانون الطبيعي")، وتقوم فكرة

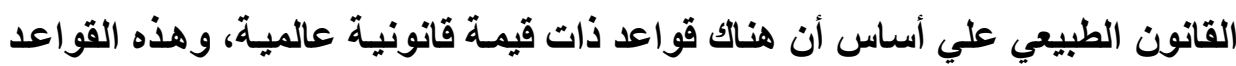
ترتكز علي الضمير الإنساني. وأن فكرة العادلة تتجاوز مفهوم القانون، وأن مهمة رجل القانون هي السعي إلى تحقيق العدالة. وقواعد القـانون الطبيعي ثابته لا تتغير في الزمان ولا المكان وتعلو علي القواعد الموضوعية. وذهب البعض إلى أطلاق مسمي آخر علي هذه القواعد هو القواعد العامة، بحيث يترادف الاصطلاحان. بينما فرق بينهم

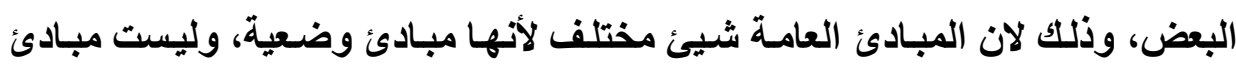

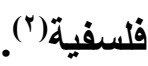

ويلاحظ أن هنـاك قواعد نتجبت عن القـانون الطبيعي، منها قاعدة ألا يكون القاضي خصما وحكما، ومنها عدم الحكم علي شخص دون أن يسمع دفاعه، فمثل هذه الحقوق التي تثبت للإنسان لمجرد كونه انسانا وهي تسمي بحق الدفاع الذي الذي يعد أصلا

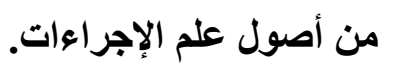

\section{الأساس الدستوري لحق الدفاع}

يعد حق الافاع من المبادئ الدستورية، وتنظيم القانون لهذا المبدأ يعد تكملة

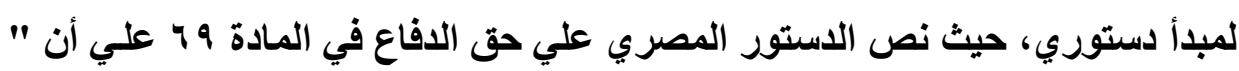

(1) Charmont, La reconnaissance du droit naturel, 2 éd., Paris, 1927, p. 80, BARRET-KRIEGEL B. Les droits de l'homme et le droit natural, Paris, PUF, 1989, p. 41.

(r) د/ عزمي عبد الفتاح، واجب القاضي في تحقيق مبلأ المواجهة باعتباره أهم تطييق لحق الدفاع، المرجع السابق، ص ؟ ؟ أ. 


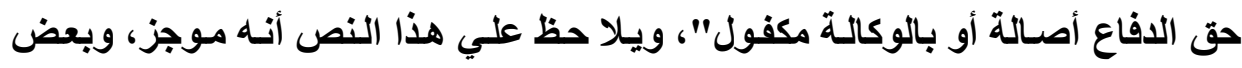

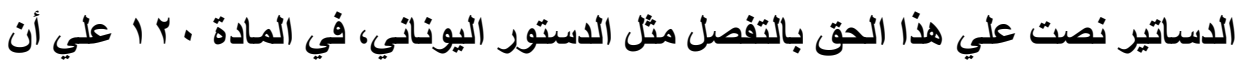

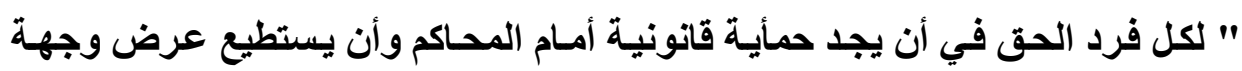
نظره التي تدعم حقوقه أمامها وأن يعرض مصالحه التي تتو افق ميع نصوص القانون،

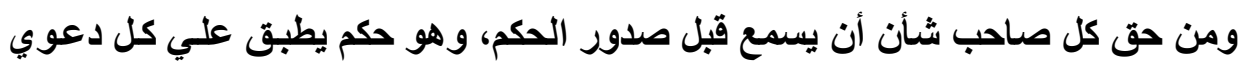
أو إجراء إداري يكون من شأن التأثير علي حقوقه أو مصالحة. وقد اتجهت بعض التشريعات إلى النص علي هذا الحق في الاستور أو في التشريع، والبعض نص علي تطبيقا لهذا الحق في اماكن متفرقة من التشريع. و هناك إجماع في الفقه الإجرائي علي أن مبدأ احترام حق الافاع مبدأ أساسي

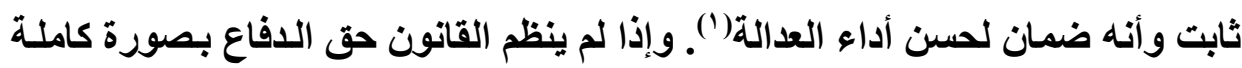

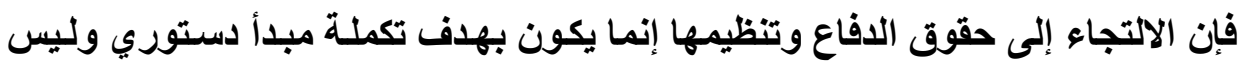
مجرد سند نقص في التثريع، فكل ما يضمن حقوق الدفاع هو مبأ ذو قيمة دستورية.

\section{r- التمييز بين حقوق الدفاع وبعض الهقوق الإجرائية الآخرى:}

سنشير إلى حق الدفاع ومبدأ المواجهة، وحق الدفاع ومبدأ المساواة.

\section{حق الدفاع وهبدأ المواجهة.}

من مقتضيات مفهوم حق الدفاع أن يناقش الخصم مـا يقلمه الخصم الآخر من

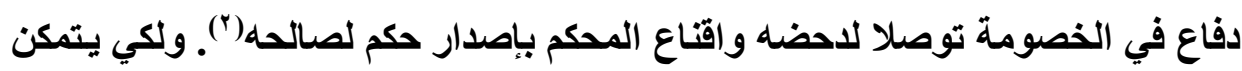

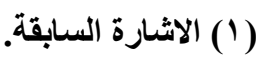

(Y) د/ عزمي عبد الفتاح، واجب القاضي في تحقيق مبلأ المواجهة باعتباره أهم تطييق لحق الدفاع،

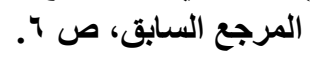


الخصم من الدفاع فيجب أن يمنح الحق في العلم (') بما لاي الخصم الآخر من ادعاءات ووسائل دفاع قانونية وحجج ومستندات، وهذا ما يطلق عليه مبدأ المواجهة.

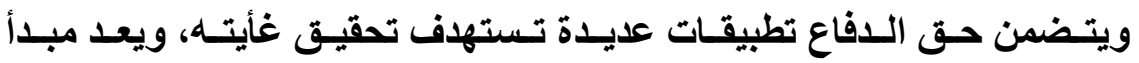

المواجهة من أهم تطبيقاته(). ويقصد بمبدأ المواجهة العلم بمـا لدي الخصم الآخر من وسائل دفاع وغيرها(")، وأن يكون هذا العلم في وقت نافع يسمح للخصم الآخر بتنظيم

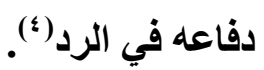

ولقد خط البعض بين مبدأ المواجهة وحق الدفاع(0)، وذلك لأنـه يقصد بحق

الدفاع، حق كل خصم في أن يسمع أمسام القاضسي كي يعرض ادعاعته ووسـائل دفاعه

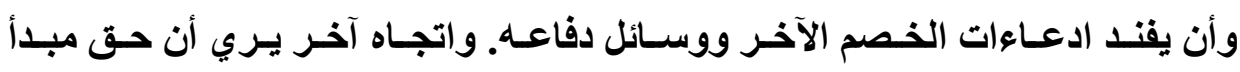

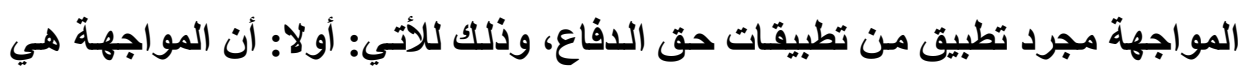
أداة فنية إجرائية تهدف إلى تحقيق مبدأ أكثر عمومية وهو احترام حق الدفاع، وثانيا: أن احترام المواجهـة لا يكفي وحده لاحترام حق الـفاع فهذا الحق لا يحترم إلا إذا احترمت كافـة تطبيقاتـه("). ولا شـك في أن المواجهة بين الخصوم تمكن الخصم مـن

(1) CA Paris, 21 nov. 1967, op. cit.,p. 122.

(r) د/ عزمي عبد الفتاح، واجب القاضي في تحقيق مبدأ المواجهة باعتباره أهم تطبيق لحق الدفاع،

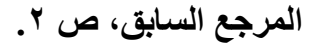

(3) CA Paris, 21 nov. 1967, op. cit., p. 122.

(؛) د/ عزمي عبد الفتاح، واجب القاضي في تحقيق مبأ المواجهة باعتباره أهم تطبيق لحق الدفاع،

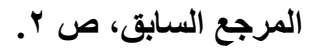

CA Paris, 21 nov. 1967, op. cit., p. 122.

(5) Emmanuel Blanc, principes generaux de la nouvelle procedure civile, JCP, 1973, 2559.

(†) د/ عزمي عبد الفتاح، واجب القاضي في تحقيق مبأ المواجهة باعتباره اهم تطبيق لحق الدفاع،

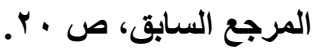


الوقوف علي طلبات ودفاع خصمه وبالتالي تتاح له فرصة الرد عليه('). مـع ذلك فإنـه حق المواجهة مختلف عن حق الدفاع، كل من المبدأين لا يغتي أحدهما عن الآخر،

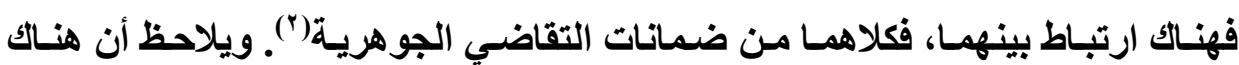
ارتباطا بين المبلأين من حيث الوسيلة، بمعني أن المواجهة بين الخصوم هي الوسيلة المباشرة لاحترام مبدأ حق الدفاع(").

وقد ربط المشرع المصري ممارسة حق الدفاع بمبدأ المواجهة، وتطبيقا لذلك؛، لا يجوز الحكم علي شخص إلا بعد سماع دفاعه أو علي الأقل منــه الفرصـة للازمـة أو

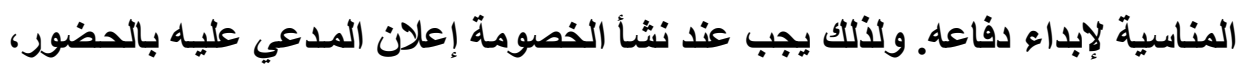
لإبداء دفاعه، ويكون المـدعي عليه أخر من يتكلم(مسادة ب ـ 1 مرافعـات). ويتم تمكن

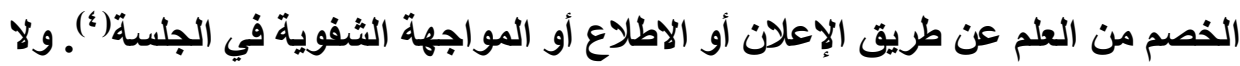
يجو للهيئة التحكيم أن تسمع الخصم أو دفاعهـ إلا بعد حضور خصمه أو علي الاقل دعوتـه للحضور، وبالتـالي لا يجوز للمـدعي أن يبدي في الجلسة التي تخلف فيها المدعي عليها طلبات جديده أو أن يعدل أو يزيد أو ينقص في طلباته الأولي، ومن ناحية أخري لا يجوز للمدعي عليه أن يطلب في غيبة المدعي المكم عليه بطلب ما (مسادة بر

(1) CA Paris, 2 fev. 1988, op. cit., p. 62, note Couchez, Cass. Civ., 2e, 10 nov. 1998, op. cit.,p. 1.S.

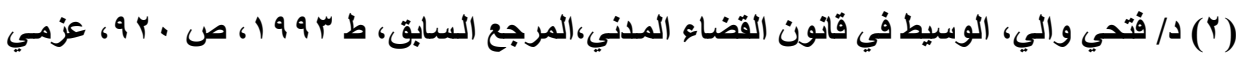

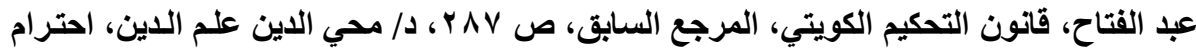

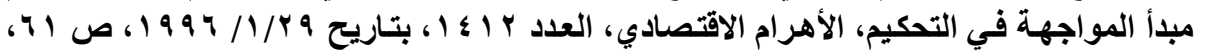

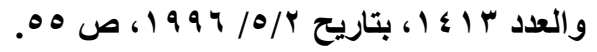

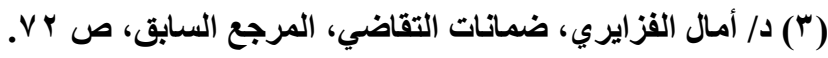

(4) CA Paris, 13 nouv. 1980, op. cit., p. 12, CA Paris, 24 oct. 1991, op. cit., p.110. CA Paris, 21 nov. 1967,op. cit.,p. 122. 
مرافعات). ولا يجوز للمحكم في مرحلة المدأولة أن تسمع خصم بدون حضور الخصم الآخر أو تسمح بقبول أوراق أو مذكرات دون اطلاع الخصم الآخر وتمكنيه من الرد عليها، وإلا كان العمل باطلا (ماد ی17 17 مرافعات).

\section{ـ .}

يعد حق الافاع من أهم الضمانات التي يجب توافرهـا لتحقيق المحاكمـة العأدلة. وتحقيق حق الدفاع يؤدي إلى تحقيق المساواة في المراكز الإجرائية للخصوم أمسام

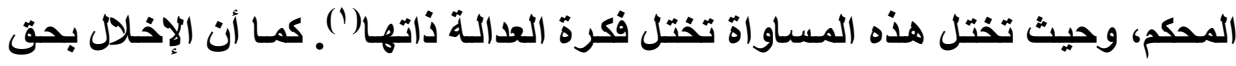

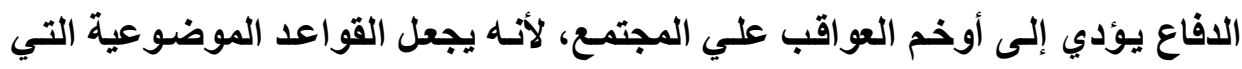

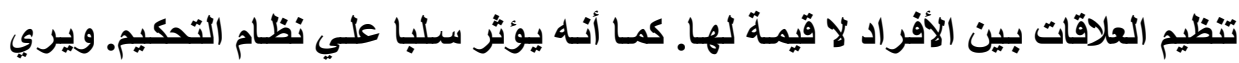

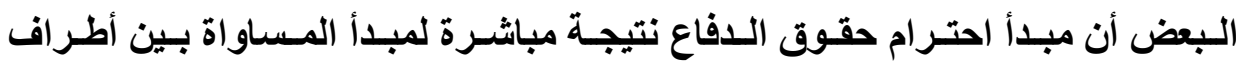

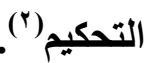

ويقتضي مبدأ المساواة بين الخصوم أمام هيئة التحكيم، أن تعامل طرفي التحكيم علي قدم المساواة دون تفريق بينهما أو تمييز ("). والمساواة بين الأطر اف أمر بديهي لا

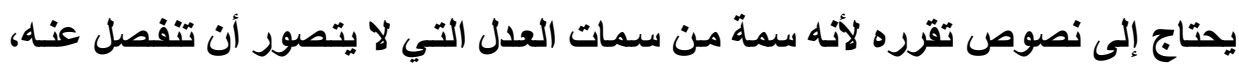

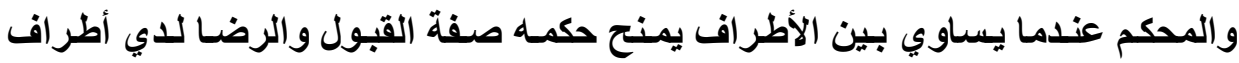
التحكيم (؛) (1) د/ عزمي عبد الفتاح، واجب القاضي في تحقيق مبدأ المواجهة باعتباره اهم تطبيق لحق الدفاع،

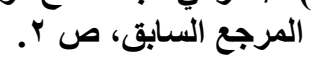

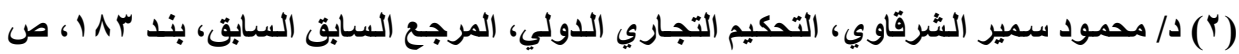

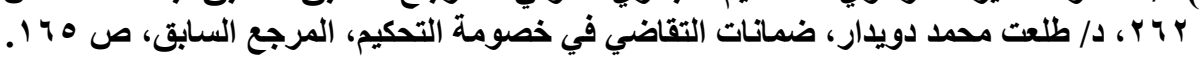

(3) Ph. Pinsolle et R. Kreindler, les limites du role de la volonte des parties dans la conduit de l'instance arbitrale, Rev. Arb., 2003, p. 60.

(4) S. Guinchard, L'arbitrage et le respect du principe du contradictoire, Rev. Arb., 1997, p.1. 


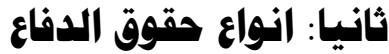

تتميز حقوق الدفاع بأن مضمونها تمكين الخصم من تقديم مـادة دفاعه إلى الى

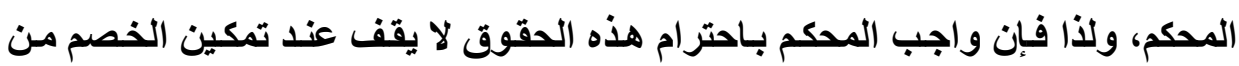
مباشرة هذه الحقوق أثناء الخصومة، وإنما يمتد إلى وجوب الاعتداد بها لهان في الحكر.

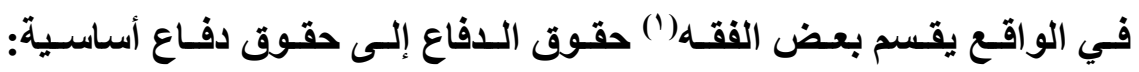

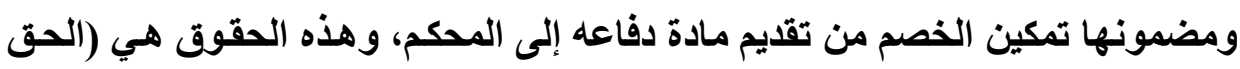

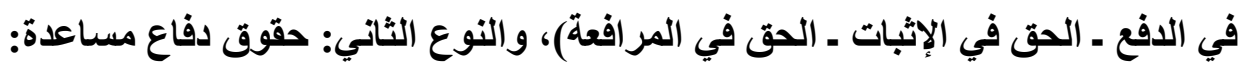

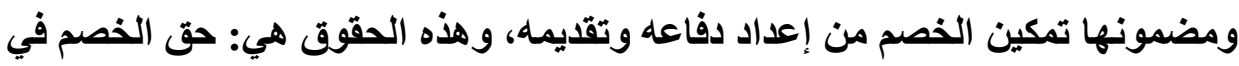

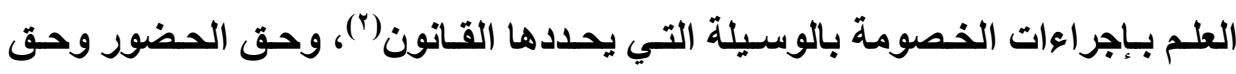

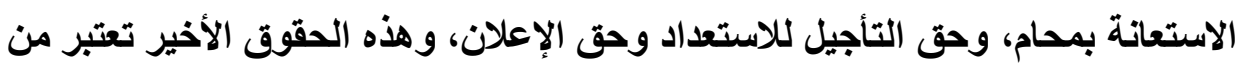

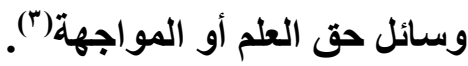
سنشير إلى حقوق الدفاع الأساسية، وحقوق الدافع المساعدة، وذلك في النقاط الآتية:

\section{أ- حقوق الدفاع الأساسية}

وتتنوع هذه الحقوق إلى: الحق في الدفع والحق في الإثبات، والحق المرافعة.

الدفوع

وتتنـوع الدفوع إلى الآتـي: دفوع الإجرائيسة أو الشكلية، ودفوع موضسوعيه،

$$
\text { ودفوع بعدم القبول }
$$

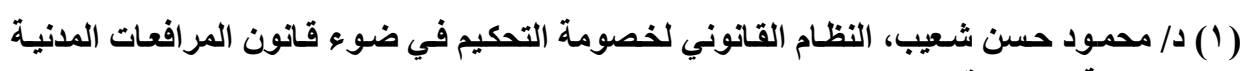

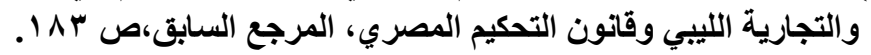

(2) CA Paris, 21 nov. 1967, op. cit., p. 122.

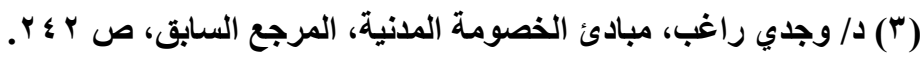




\section{الدفوع الشكلية أو الإجرائية:}

هي التي تتعلق باعتراض الخصم علي الإجراءات عن طريق تأكيد واقعة تؤُثر

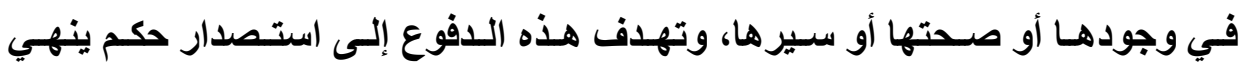

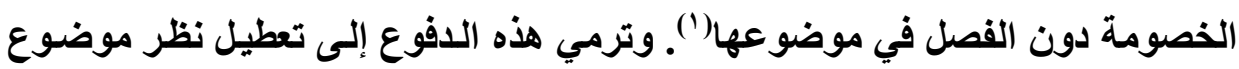
القضية أو منعه لسبب يتعلق باختصاص هيئة التحكيم أو بإجراءات الخصومة (ب).

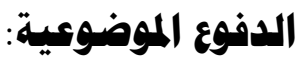

ويقصد بالدفوع الموضوعية كل ما يعترض به المدعي عليه علي الحق المطلوب حمايته من المدعي، أو هو سلطة المدعي عليه في تأكيد واقعة مانعة أو منهية

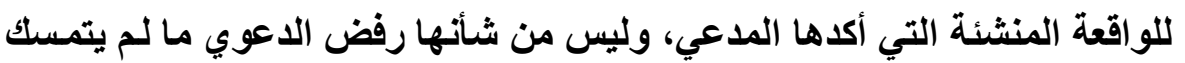

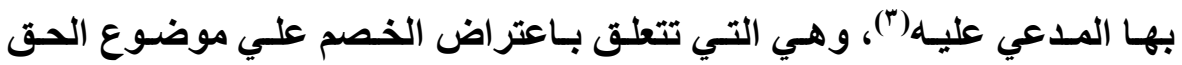

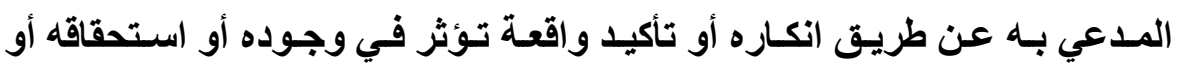

$$
\text { مقداره. }
$$

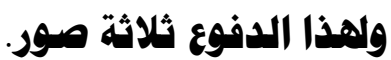

الصورة الأولي: أن ينكر المدعي عليه الوقائع التي يتمسك بها المدعي، كمـا لو أنكر المدعي عليه العقد مصدر الالتزام، أو إنكر أنه يلتزم بشئ وفقا لهذا العقد.

(1) دا وجدي راغب، دراسـات في مركز الخصم امسام القضاء المـني، مجلـة العـوم القانونيـة

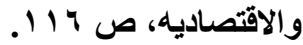

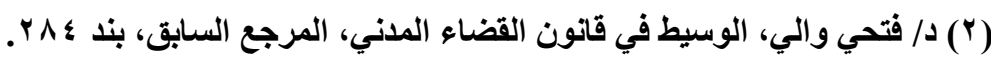

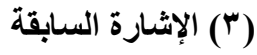

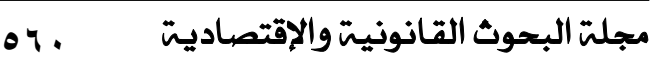


الصورة الثانية: أن يتمسك المدعي عليه بواقعة معاصرة لنشأة الواقعة التي يتمسك بها المدعي من شأنها منـع هذه الواقعة الأخيرة من إنتـاج كل أو بعض آثارهـا القانونية. كما لو تمسك المدعي عليه بصورية العقد أو بإبطاله للغلط. الصورة الثالثة: أن يتمسك المدعي عليه بواقعة من شـأنها إنهاء آثار الواقعة التي يتمسك بها المدعي. كما لو تمسك المدعي عليه بالوفاء بالالتزام. ويجب علي المدعي عليه أن يثبت إنكاره للوقائع التي يتمسك بها المدعي حتي يكون محل نظر من المحكم، ولكن مجرد الإنكار بدون إثبات لا يعتبر من قبيل الدفاع في

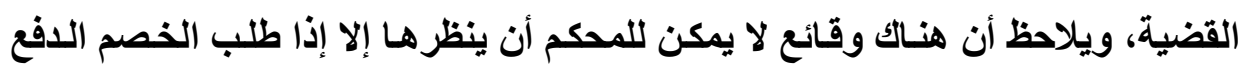
بـقص الأهليـة أو التدليس أو الغلط. وتتميز وسـائل الدفاع الموضـوعي بأنها ليست واردة علي سبيل الحصر، حيث لم ينص القانون علي ترتيب معين بينها أو علي وجوب إبدائها في وقت معين. حيث لا يؤدي تأخير أحدها إلى سقوط الحق فيها. كمـا يمكن التمسك بها في أية حالة كانت عليها الخصومة ولو لأول مرة أمام محكمة الاستئناف.

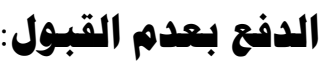

وهو عبارة عن اعتراض الخصم علي ما يسمي بحث اللاعوي، وتتضمن تأكيد

$$
\text { بعدم توافر شرط من الشروط الدعوي. }
$$

المق في الإثبات:

وهو حق الخصم في تقديم الأدلة المثبتة للدعواه أو دفوعه وفي دحض أدلة خصمه(')، ويقتضي حق الإثبات حق الخصم في إقامـة الـليل أمسام القضاء علي وجود (1) د/ عبد الباسط جميعي، نظام الإثبات في القانون المدني المصري، طץ، به 9 19، بدون دار نشر، 
واقعة قانونية مطروحة أمامه، وحق الخصم في الإثبات يقابله واجب يلقي علي عاتق الخصم الآخر، في ألا يعطل هذا الحق بعنت منه أو سوء نيه. و لا يجوز مساس المحكم بسبب الطلب أو محل الطلب، لان في هذا المساس إخلالا بحق الدفاع(')

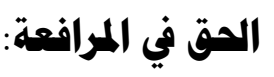

ويقصد به حق الخصم في مخاطبة المحكمة موضـحا وقائع أو القـانون، ويمكن أن تكون شفاهه أو كتابة، ويعد الحق في المرافعة حقا أساسيا من حقوق الدفاع التي يعترف بها القـانون للخصم، فـالحق في الإثبات والحق في المرافعة والحق في الدفع

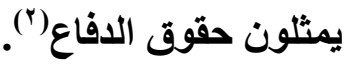

\section{ب- حقوق الدفاع الثانوية:}

ومضمون هذه الحقوق هو تمكين الخصم من حسن إعداد دفاعه وتقايمسه أثناء الخصومة، وهذه الحقوق هي:

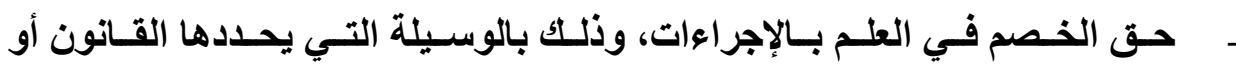
اتفاق الأطر اف أو هيئة التحكيم. ويتم الإعلان طبقا للقواعد التي تفرضهها الأحكام العامة. - حق الخصم في طلب مدة لإعداد دفاعه: لا يجوز مفاجسأة الخصم بطلب، فيجب إعطاء الخصم مهله لتحضير دفاعه، ومنحه اجلا وذلك احتراما لحقوق الدفاع.

( (1) د/ عزمي عبد الفتاح، واجب القاضي في تحقيق مبدأ المواجهة باعتباره اهم تطبيق لحق الدفاع،

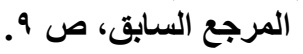
(Y) د/ وجدي راغب، تأصيل الجاتب الإجر ائي في هيئة التحكيم، بحث منشور في مجلة حقوق الكويث،

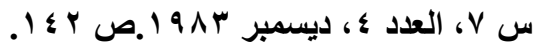


حق الخصم في الحضور، وهذا يقتضي تكليف الخصم بالحضور أمام هيئة التحكيم، وتبدو أهميـة الحضور في أيجـاد صـلة مباشـرة بني الخصم وهيئة التحكيم

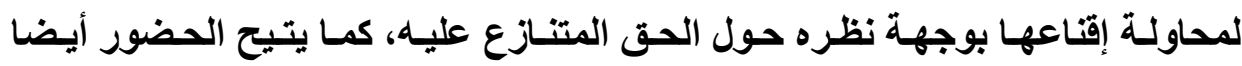
الإسـهام في إعمـال بعض وسـائل الإثبات مثثل الخبرة والمعأينـة، لتقديم معلومـات إلى الخبير أو المعأينة وإبداء ملاحظات، ولذلك كان لابد من النص عليه. وإذا لم يحضر أحد

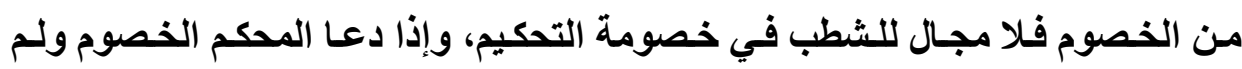
يحضر فلا يفترض نفسه معزولا عنهما، بل عليه متابعة مهمته حتي النهائة تحت طائلة المسئولية الواقعة علي امتناعه، كما أن له أن يلعو الأطراف بكتاب موصسي عليه إلى

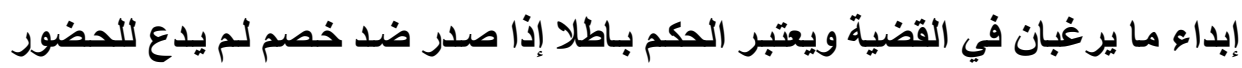
وفقا للأصول أو لعدم علمه بالخصومة (')

حق الخصم في المناقشة، وهذا الحق يقتضي تمكين الخصم من مناقشة الشهود وتقارير الخبير. ولا شك في أن تمكن الخصم من الدفاع يؤدي إلى إصدار حكم عادل، ولهذا فإن حق الدفاع يلزم المحكم بالعديد من الواجبات، من أهمها تحقيق المساواة في

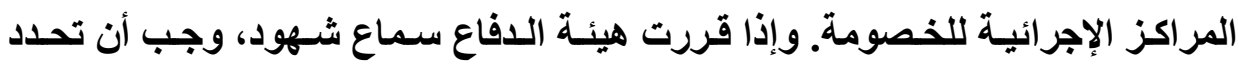
الوقائع التي تري سماع الشهود بشأنها، وإذا لم تحدد هذه الوقائع، فبإن لهيئة التحكيم أن ترفض طلب سماع الشاهد()، وأن تعين أشخاص الثهود، ويجب أن يمكن الأطر اف لت مسن مناقشة الشهود ومسن تقديم شـهود نفي، وأن تثبت أقوال الشهود في محضر الجلسة، وإذا سمعت الهيئة الثهود، وجب أن تسمعهم في حضور جميع أعضاء هيئة

(1) CA Paris, 7 janv. 1963, op. cit., p. 435, CA Paris, 14 fevr. 1985, op. cit., p. 325, note level.

(ץ) د/ فتحي والي، التحكيم في المناز عات الوطنية والتجارية الدولية، علمـا وعملا، المرجع السابق، 
التحكيم وجميع لأطراف، ولا يجـوز للهيئة سـماع الشهود دون حضور الأطراف أو دعواتهم للحضور، فـإن دعت الهيــة الأطراف لحضور جلـسة ســاع الشهود ولـم يحضروا، فيجب ارسـالة صورة من المحضر المثبت لاقوال الشهود إليهم واعطائهم الفرصة لمناقشتها، وإلا كان الحكم المبني علي هذه الاقوال بـاطلا'". وإن كانت بعض أن أن

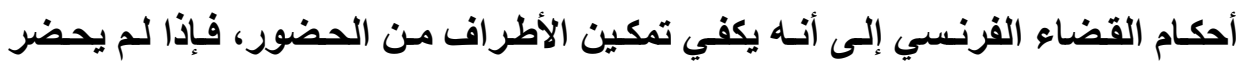
أحدهم فلا يترتب علي ذلك مخالفة لمبدأ المواجهة أو حقوق الدفاع(؟)

حق الخصم في تقديم الطلبات، سواء كانت طلبات جديده أو متقابلة أو تعديل الطلبات السابقة أو استكمالها، وذلك في حدد اتفاق التحكيم. وقد هذا مـا نصت عليه المادة I و Y Y من مركز القاهرة الإقليمي، فالمبدأ إذن علي حريه الخصوم في الدفاع عن وجهة نظر هم بالطريقة التي يرونها مناسبة، وأن سلطة المحكم التقديرية ويجب أن يتمتع به من سرعة ومرونة يجب أن لا يؤدي إلى الإخلال بحق الأطراف في خصومة عأدلة.

\section{ثالثا: هقتضيات حقوق الدفاع}

يقتضي حقوق الدفاع، أن تمكن هيئة التحكيم جميع الخصوم من سماع وجهة

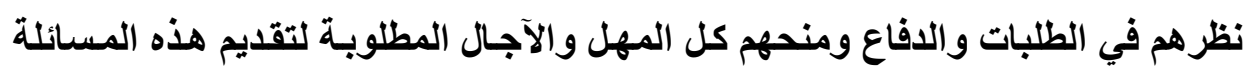

(1) د/ علي بركات، خصومة التحكيم في المصري والقانون المقارن الرسالة، مرجع سابق، بند ا ــ؛ ،

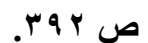

(2) CA Paris, 24 mai 1874, op. cit., p. 246. CA Paris, 10 nouv. 1989, op. cit., p. 651, obs. Pellerin, CA paris, 11 juill. 1991, op. cit., p. 671, obs. Loquin, CA Paris, 13 mars 1992, op. cit., p. 107, obs. Jarrosson, CA Paris, 13 nouv. 1997, op. cit., p. 719, obs. Derains. 
ومنحهم الوقت الكافي للاراسة والاطلاع وسماع ردهم وتحقيق دفاعهم (1)، فبإذا أصدر المحكم حكمه دون سماع الخصم أو تمكينه من اسماع المحكم دفاعه كان الحكم بـاطلا

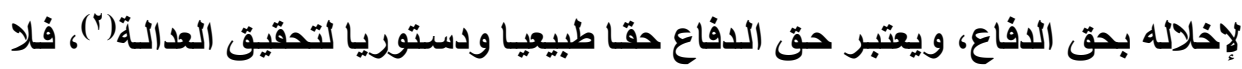
عدالة بلا دفاع(")، وهو من أهم الوسائل التي تمكن الخصم من توضيح موقفه للمحكم وتكوين رأيه لصاحه، وبالتالي لا يجوز الإخلال به بأي حال من الأحوال("). يقتضي حق الدفاع أن تمكن هيئة التحكيم كل الذصوم من الآتي:

\section{1- جق الخصم في ابداء ها لدية هن دفوع:}

يجب علي هيئة التحكيم تمكين كل طرف من إبداء ما لايه من طلبات والرد علي طلبات خصمه، والاطلاع علي مـا قدمه خصمه من مستنذات ومذكرات، وكذلك منحسه

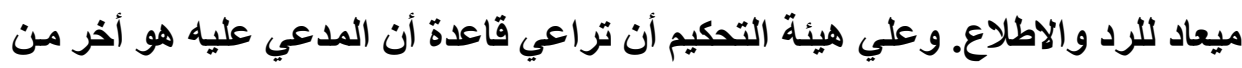

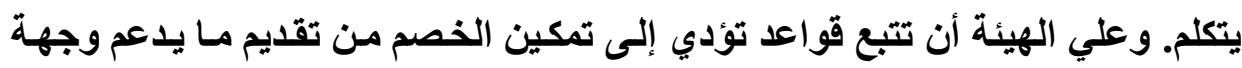
نظره، وأن يطلم الخصم الآخر بشكل كتابي، وذلك بإعلان كل خصم بمستندات خصمه التي تتضمن ادعاءاته ووسـائل دفاعه الواقعية والقانونية والحجج التي يستند إليها،

(1) د/ نبيل إسماعيل عمر، سلطة القاضي التقديرية، المرجع السابق ص ه ؛ 1.

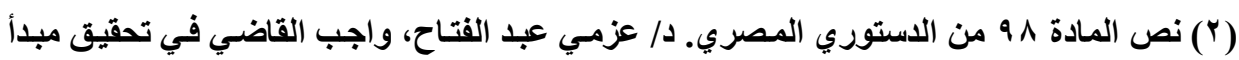

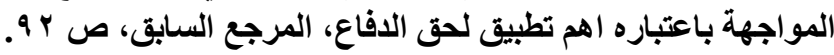

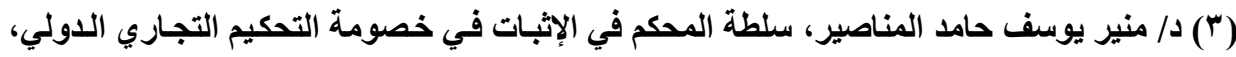

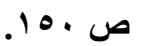
(؛) د/ سـامي محسن حسين السري، القو اعد الإجرائية المنظمة للتحكيم التجاري الدولي، المرجع

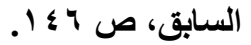


ومـا يطرأ عليها من تغيرات أو تعديلات وتمكينه من ذلك في وقت يمكنه من الرد ('). وهذا ما نصت عليه المواد اس و ب و وسم من قانون التحكيم المصري. ويقتضي ممارسة حق الدفاع اخطار الخصم بمواعيد الجلسات، وقد نص قانون التحكيم المصري في المـادة سب علـي حق الخصم في الحضور أمسام هيئة التحكيم في الجلسات المحددة لنظر النـزاع، سـواء في ذلـك جلسـات المرافعـة أو فـي إجـراءات التحقيق، ولم تقيد التشريعات من حيث المبدأ باتباع وسيلة معينة أو باتباع ترتيب معين

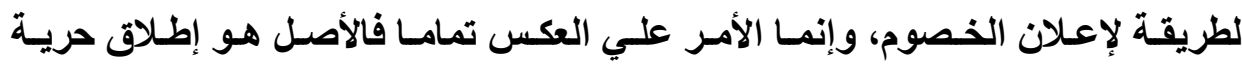
الاختيار في سـلوك الوسيلة الأكثر ملاعمـة لطرفي التحكيم أو للطرف الذي يقع عليه. عبء مباشرة الاعلان، اللهم إلا إذا اتفق الأطراف علي تطبيق قانون إجرائي معين، حيث يلزم في تلك الحالة سلوك الوسيلة التي يتعين اتباعها في القانون الإجرائي المتفق التقي عليه، وذلك إعمالا لإرادة الأطراف.

\section{r- اتاحة الفرصة للخصم في إثبات دعواه:}

يقتضي احترام حق الـدفاع أمسام هيئة التحكيم، تمكين كل خصم علـي قدم المساواة من إبداء مـا لايـه من أدله، وإعطائهـ الحق في إثبات مـا يدعيهه بكافة طرق الإثبات(؟). فكل خصم أن يقيم الاليل علـي واقعة معينه وخصمه الآخر الحق في نفيها باللدليل، فبإذا اثبت خصم الدليل بطريق الشهود فللخصم الآخر نفيهه بنفس الطريقة، ولهيئة التحكيم سلطة تقديرية في ترجيح أي من أدلة الخصمين.

(1) E. Loquin, l'instance de l'arbitrage, J. CL, Proc. Civ., facs, no 36.

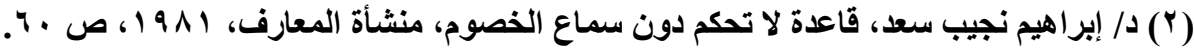




\section{r- يكفي لإعمال الحق في الدفاع أن يمكن الخصم هن إبدائه (1).}

حيث إن للخصم الحريـة في إبداء دفاعه علـي الوجها الذي يريده، لأن الدفاع

حق للخصم وليس واجبـا عليه. ويجب لقبول دفاع الخصم أن يقيم الدليل عليه، وألا يجب علي هيئة التحكيم إغفاله(؟) كما أنه ما دامت الهيئة منحت الخصم فرصة لتقديمـه

دفاعه، فهي ليست ملزمة بإجابته إلى طلب التأجيل لإبداء دفاع أو تقديم مذكرة به.

\section{ع- للهيئة التمكيميهة أن تنظم كيفية استفدام الفصم لهقه في الدفاع}

إن احترام حق الدفاع ووجوب كفالته للخصوم لا يحول دون تنظيمه من أجل

ضـمان الممارسـة السليمة وتحقيق الأهداف المرجوة مـن ورائسه(")، لـللك فبإن لهيئة التحكيم أن تحدد المواعيد لتقديم الدفاع أو الادعاءات وكذلك المستتدات والمذكرات، ولها حق الرفض إذا تم الإخلال أو عدم الالتزام بهذه المواعيد، وبالتـالي يمكن للهيئة عدم قبول الطلبات والمستتدات المقدمة بعد الميعاد المحدد للخصوم، واعتبار الوارد بها غير مطروح عليها، دون أن يعد ذلك إخلال بحق الدفاع، وللهيئة سلطة في ذلك حتي ولو كانت قد حددت تواريخ أيداع مذكرات دون مراعـاة الاتفـق المبرم بين الطرفين، طالما كفلت لكل من الأطراف الرد علي المذكرات التي تقدم بها الطرف الآخر خلال مدة معقولة") ـ. ومن هذا المنطلق فعلي المحكم أن يراعي حسن سير الخصومة التحكيمية وفق القواعد الإجرائية التي تضمن حقوق الخصومة الرئيسية.

(1) CA Paris, 24 mai 1874, op. cit., p. 246.

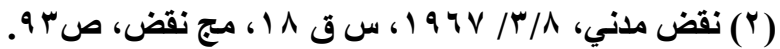

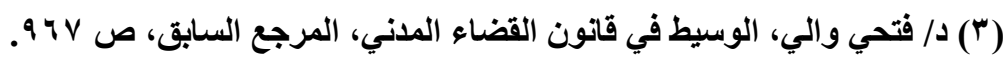

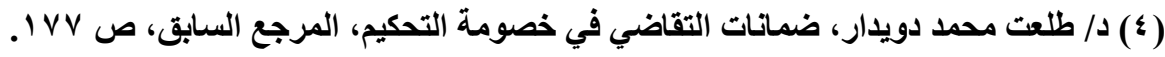


ويجوز لهيئة التحكيم أن تقبل مستندات جديدة أو تعيد فتح باب المرافعة بشرط

علم الطرف الآخر بها، وتمكينه من مناقشة أي ادعاءات أو دفوع جديدة، ويجب أن أن

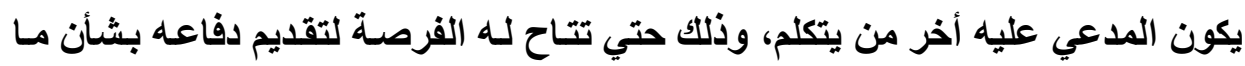
يقدمه المدعي.

ويشترط في تنظيم الهيئة للإجراءات أن تمكن الخصم من ممارسة هذا الحق،

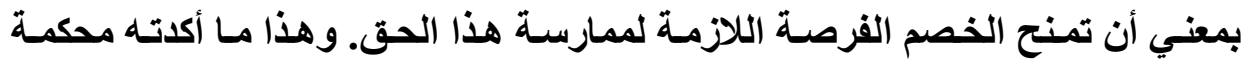

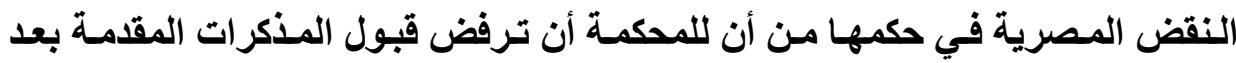
الميعاد (') ولكن يمكن للمحكم قبول المذكرات بعد الميعاد الذي حددته، لأن هذا الميعاد يلزم الخصم وليس المحكم. ونظرا لأن بعض الخصوم قد يستخدم حق الدفاع لإطالة أمد

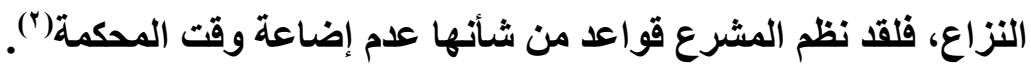
وبالتـالي فحريـة ممارسـة حقوق الدفاع تستوجب أن يعطي المحكم الفرصـة

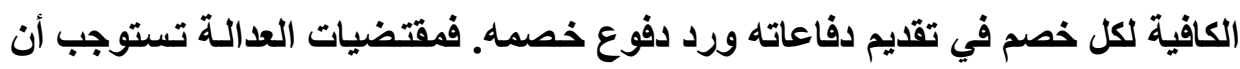
يستمع المحكم إلى أقوال الخصوم جيدا، وأن يططي كل خصم الفرصة الكافية للحصول

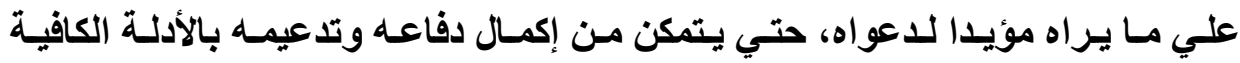

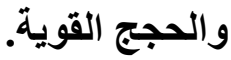

ويلاحظ أن حق الدفاع مقيد بقيد أساسي وهو احترام قيمة الوقت في خصومة

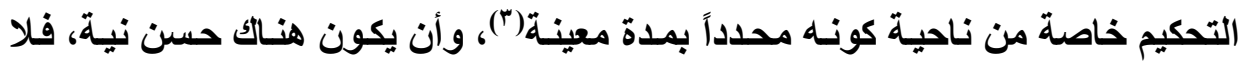
يتذذ هذا الحق بهدف تعطيل الفصل في الخصومة بحجة استعمال الخصم لحقه.

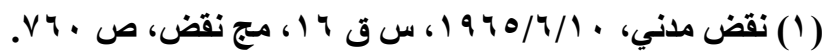

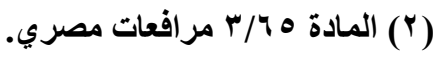

(3) B. Moreau, A. Beregoi, et autre, arbitrage commercial, op. cit., no 220. 
وبالتالي يتقيد حق الخصم في الدفاع بضرورة تقديم وسائل الدفاع قبل قفل بـاب

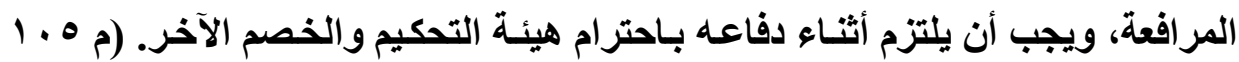

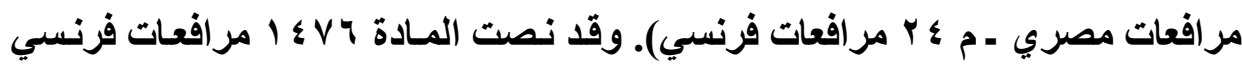

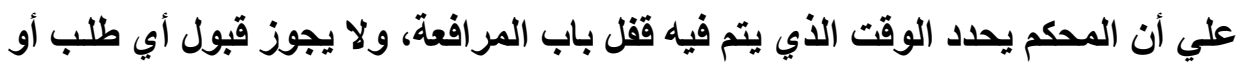
مستند أو أي دليل في الخصوم، ويمكن للمحكم أن يسمح بتقديم مستندات أو مذكرات

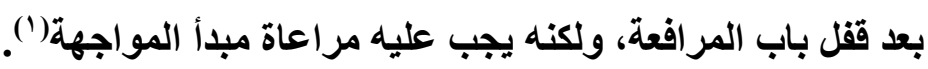
ويري بعض الفقه(ז)، أن اتفـاق الأطراف علي تقديم المستندات فقط إلى هيئة

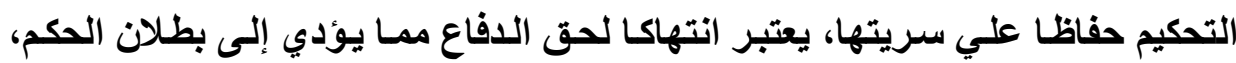

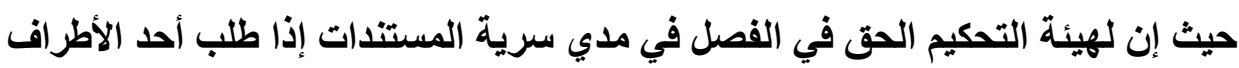
تقديمها، ورفض الطرق الآخر ذلك بحجة سريتها(").

\section{ه- حرية الفصم في إبداء دفاعه في شكل هرافعة شـفاهة أو في شـكل مهذكرات}

\section{هكتوبة.}

في الواقع، حق الدفاع هو حق للخصوم وليس التزامـا عليه، ويمكن لهيئة

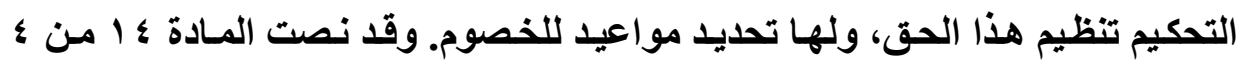
قانون المرافعات الفرنسي علي أنه لا يجوز محاكمة أي شخص من دون استدعائه أو

(1) Id., no 285.

(2)Ph. FOUCHARD, E. GAILLARD et B. GOLDMAN, traite de l'arbitrage commercial international, op. cit.,p. 703. د/ ياسر عبد الهادي مصلحي سلام، أثر الخطأ في إجراعات التحكيم علي حكم التحكيم، المرجع

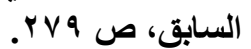

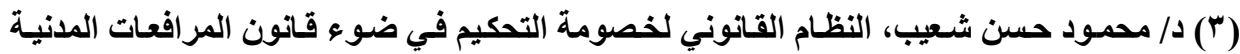

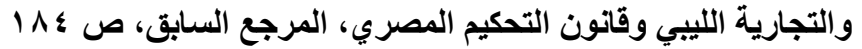


الاستماع إلى دفاعه، ويعد هذا المبدأ من النظام العام الذي تبطل به إجراءات المحاكمة

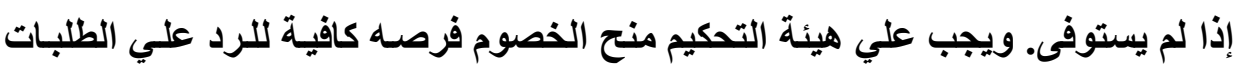
وأوجه الدفاع والدفوع التي يقدمها الخصم الآخر ('). ويلاحظ أن الدفاع أمام هيئة التحكيم شـأنه شـأن الدفاع أمسام القضاء، فهو حق

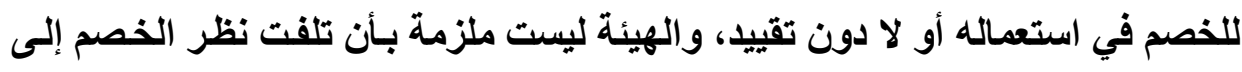

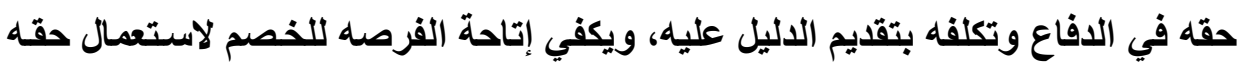
في الدفاع دون تقييد (")

وعلي أن ممارسة هذا الحقى مقيد بالقدر اللازم للغرض منه، فإذا تجاوزه الخصم

بنسبة أمور شائنة لخصمه مما يمس شرفه أو كرامتهه، فأنـه يكون مسئولا عما ينشأ عن هذا من أضرار ومسئولية قانونية.

ويفضل البعض وسيلة المناقثة المكتوبة، وذلك لأن المناقثة الثفوية قد تفاجاً

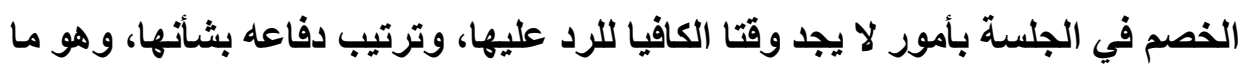
يخل بحق الدفاع(") \- حق الخصم في الاطلاع علـي جميع المـكرات والمستتدات التي يقوم بأيداعها الخصم الآخر

وذلك حتي يتمكن من ممارسة حقه في الافاع بصددها. ولهذا لا يجوز لهيئة التحكيم قبول أي مذكرة دون إطلاع الخصم الآخر عليها أو إعلانه بها. وإذا قبلت الهيئة

(1) د/ عزمي عبد القتاح، إجراءات خصومة التحكيم، بحث مقدم في الدوره العامـة لإعداد المحكم،

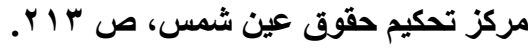

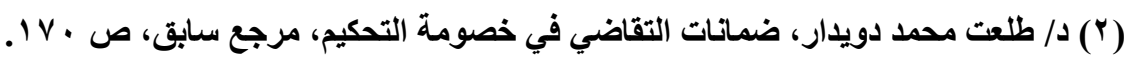

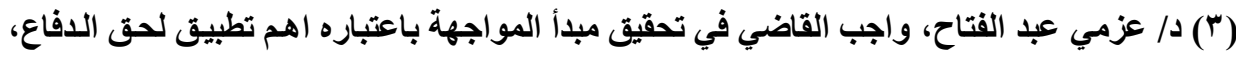

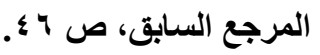


هذه المذكرة يجب ألا تعول عليها أو تثتأثر بها وإلا كان حكمها باطلاً إلا إذا كاتت المذكرة لا تلتضمن دفاعا جدياً.

في الواقع خصومة التحكيم مستقله بذاتها وتنظيمها وأدواتها عن الخصومة القضائية، ولذلك فِإن إعمال كافة وسـائل الدفاع في خصومة التحكيم لا يكون بنفس الألية الإجرائية الثكلية في الخصومة القضائية أمسام المحاكم، وذلك نظرا لمـا تفتضيه خصومة التحكيم من مرونة وسرعة وسرية(')

\section{رابعا: تطبيقا حقوق الدفاع}

إذا كان حق الدفاع يقتضي إبداء الخصم لوجهة نظره أمسام هيئة التحكيم فيمـا

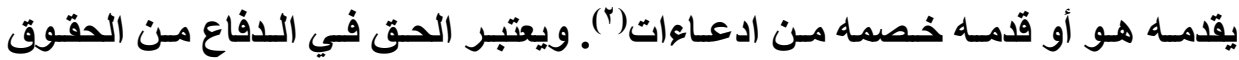
الأساسية التي يقوم عليها أي نظام قضائي، ويترتب علي مخالفة هذا المبدأ بطلان الحكم الصادر. وهذا الحق مكفول للخصم في أية حالة تكون عليها الإجراءات. وبالتـالي أن تمكن هيئة التحكمي جميع الخصوم من إبداء وجهة نظرهم، فليس لها القيام بـأي إجراء من شأنه انتهاك هذا الحق.

ولا يمكن أن تتحقق المناقشة الحرة وحقوق الدفاع إلا إذا ســح للخصم بـإعلام المحكم بكل ما من شـأنه أن يساعده علي حسن تأسيس ادعاعتـه، فهذا الإعلام شرط أولي لكل ممارسة حق الدفاع(")، وقد أكد القضاء في مصر وفرنسا علي أن عدم جواز منـع الخصم مسن تقديم مـا لايـه مسن مستتـات. ويتمتع الخصم بحصانة قضائية في

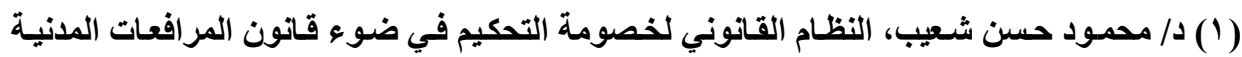

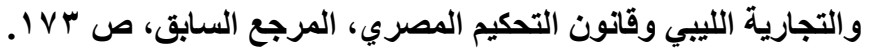

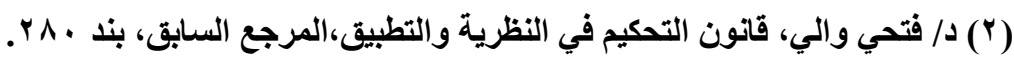
(3) CA Paris, 13 mars 1973, op. cit., p.176. 
استعماله لحريته تقديم دفاعـه، بحيث لا تكون حريتهـ في هذا الشأن سببا لمجازاتـه بجريمة قذف أو سب، وتتصرف هذه الحصانة إلى ممثل الخصم، ولذلك نصت المـادة V V Vحامـاة علي أنه لا يجوز مساعلة المحامي عما أورده في مرافعته كتابية أو شفويا مما يستلزمه حق الدفاع. ويقتضي حق الدفاع أنه لا يجوز رفض طلب أحد الخصوم بتحقيق أمر يعد

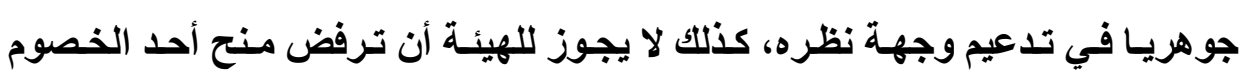
المهل اللازمة أو المناسبة لتأييد ادعاءاته أو دفوعه بالأدلة المختلفة. وقد نصت المادة 9 أمن الاتفاقية الأوربية للتحكيم التجاري الدولي الموقعة

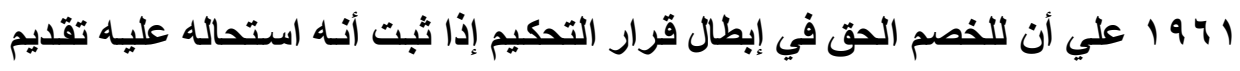
دفاعه في المنازعة الصادر فيها الحكم. وقد نصت المادة ه من اتفاقية نيويورك لسنة 19 19 علـي جـواز إبطـال قرار التحكيم إذا اسـتحاله علـي أي مسن الخصوم أن يقدم دفاعه، أو كـان القرار قد فصل في نـزاع غير وارد في مشارطة التحكيم. وقد رتب إنب المشرع المصري والفرنسي البطلان علي الإخلال بحقو ق الدفاع بكل أنواعها. في الواقع هناك بعض الحالات لا تعد اخلالا بحقوق الدفاع، وتتمثل في الآتي: - الحكم علي الخصم في غيبته ودون سماع دفاعه، وذلك في حال ما إذا كان امتناعاً عن الحضور بسبب غير مقتع وبغرض المماطلة وعرقلة سير إجراعات التحكيم، أو بسبب عدم رغبته بممارسة هذا الحق (') 
- رفض هيئة التحكيم للمستتدات أو المـكرات التي يقدمها الأطراف إذا قدمت بعد فوات هذه المواعيد التي حددها الأطراف مسبقا، حيث إن وجوب احترام حق الدفاع لا يحول دون تنظيمه، وإلا فتح الباب للمماطلة وعرقلة الإجراعات(') لا يعد اخلال بحق الدفاع، الاكتفاء بتقديم المذكرات المكتوبة والوثثائق دون الحاجة

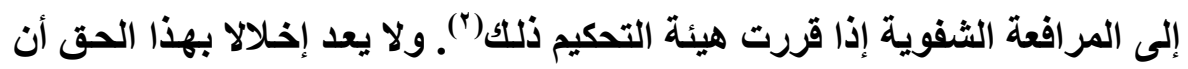
ترفض الهيئة طلب الخصم بالمرافعة الثفوية ما لم يتفق الخصوم علي غير ذلك، (م بr تحكيم). كما لا يعد اخلال بحق الدفاع أن تفصل الهيئة في موضوع النزاع دون تحديد جلسة للمر افعة بعد استئناف الخصوم لسيرها بالفصل في طلب الرد، إذا كانت الهيئة قد سمعت دفاع الخصم قبل الوقف وكانت المستندات المقدمة كافية، كما لا يعد إخلالاً بحقوق الدفاع، أن ترفض الهيئة سماع الثهود بما لها من سلطة تقديرية. لا يعد إخـلالا بحق الــفاع، قضاء المحكم بعلمـهـ الثخصـي في حالـه مـا إذا كـان اختياره بسبب علمه وخبرته بالموضوع محل النزاع، وذلك من أجل تسخيرها في الفصل فيـه، بـشرط أن يطرح مـا عنــه مـن معلومـات علـي الطرفين ومناقشتهم

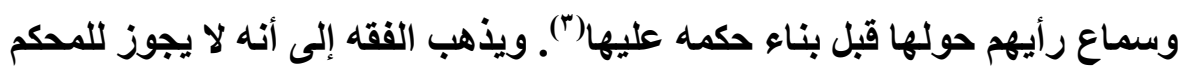
بأي حال من الأحوال أن يبني حكمه علي معلومات أيا كان مصدرها إلا بعد تمكين

( (1) د/ فتحي والي، التحكيم في المنازعات الوطنية والتجارية الدولية، علمـا وعملا، المرجع السابق، ص ص 97 (1)

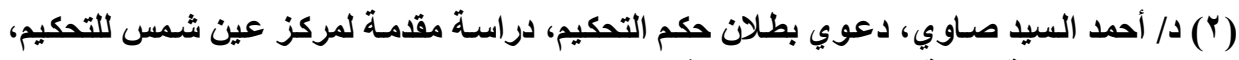

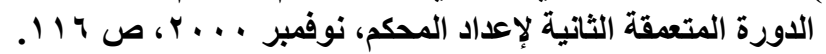

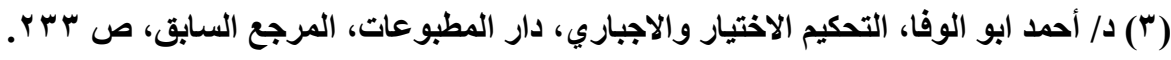


الخصوم من الاطلاع عليها وإتاحة الفرصـة أمامسه للرد عليها، وهو مـا يعبر عنه بأعمال مبدأ المواجهة('). ويستوي في ذلك المعلومـات العامـة أو الخاصـة، طالمـا وضعت تحت نظر الخصوم ومكنوا من الوقوف عليها والاعتر اض عليها إذا ما عن لهم ذلك، وبالتالي فلا حرج علي المحكم من استخدام معلوماتـه الشخصية طالمـا أعمل مبذأ المواجهة(؟). وبالتالي يجب علي المحكم ألا يؤسس حكمه علي وقائع لـ تكن محل مناقشة من الخصوم، ويجب علي المحكم تأجيل الدعوي في الحالات التي يتطلب فيها القانون التأجيل، وإلا عد ذلك إخلالا بحقوق الدفاع. لا يعد إخلالا بحق الدفاع إعطاء الخبير فرصة للخصوم ليقدم مستتداته وأوراقه لتصحيح أخطاء وتنظيم دفاتزه، ولم يمتثل الخصم للتلك، بـالرغم من قيسام الخبير بارسال خطاب موصي عليه بعلم الوصول(َ). وقد ذهبت محكمة النقض الفرنسية إلى أنه لا يعتبر التحقيق الخبير غير قانوني في حالة عدم دعوة الخصوم إليه وعدم اشتراكهم في أعمال، طالما أنهم قد استطاعوا فيما بعد مناقشة تقرير الخبير الذي وضع نتيجة هذا التحقيق. ولا يلزم مناقشة تقرير الخبير بين الخصم أمسام المحكم طالما أنهم اطلعوا علي نتيجته ولم يعترض عليه(؛).

(1) CA Paris, 10 nouv. 1989 op. cit., p. 651, obs. Pellerin, CA paris, 11 juill. 1991, op. cit., p. 671, obs. Loquin, CA Paris, 13 mars 1992, op. cit., p. 107, obs. Jarrosson, CA Paris, 13 nouv. 1997, op. cit., p. 719, obs. Derains.

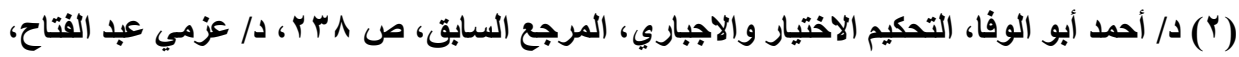

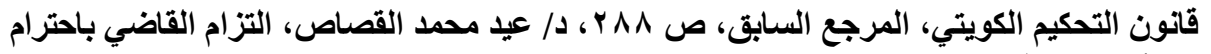

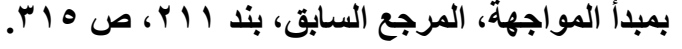

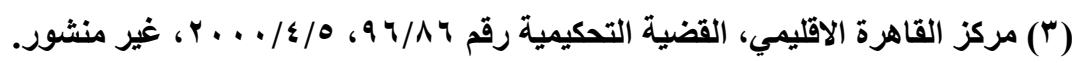

(4) Cass. Civ., 31nouv. 1978, Rev. Arb., 1978, p. 343. 
ـ ـ ـلا يعد إخلالا بحق الدفاع رفض هيئة التحكيم سـماع جميع الشهود المطلوبين، حيث يظل من حقها رفض سماع الشهود الذين تهدف شـهادتهم إلى إثبات وقائع غير منتجة في الاعوي، ويمارس المحكمون حقهم في هذا بحرص شديد حتي لا

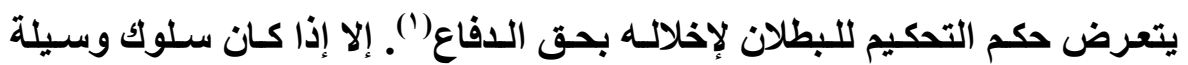
معينة أمرا وجوبيا أو محظورا علي هيئة التحكيم وفقا لاتفـق التحكيم، حيث تلتزم

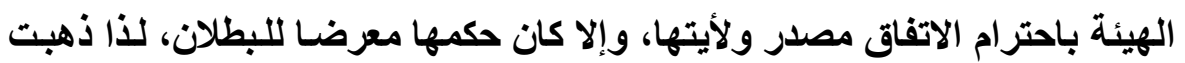
بعض الأحكام إلى أن محكمة الموضوع غير ملزمة بإجابة الخصوم إلى مـا يطلبونـهـ من إحالة النزاع إلى التحقيق لإثبات دعواهم، إلا أنها ملزمـة إذا رفضت الاستجابة

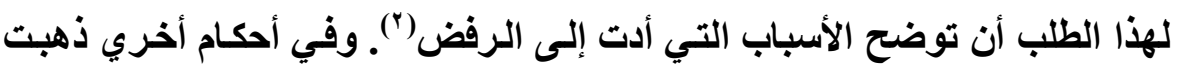
إلى أن طلب إجراء التحقيق ليس حقا للخصوم وإنمـا هو من الرخص التي تملك محكمة الموضوع عدم الاستجابة إليها متي وجلت في أوراق اللاعوي ومستنداتها ما يكفي لتكوين عقيدتها دون أن تلتزم بتسبيب الرفض (َّ) ويري جانب من الفقهـ أن هيئـة التحكيم يجـب عليهـا أن تلتـزم بالتـسبيب لأن فيـهـ درعاً للـشبهات عـن

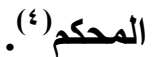

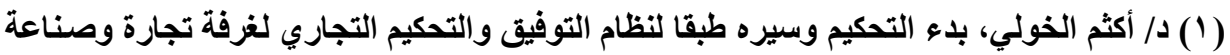

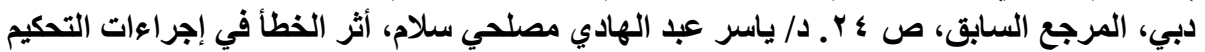

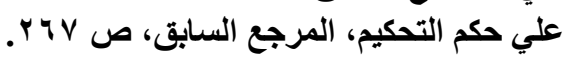

M. de BOISSESON, le droit français de l'arbitrage interne, droit international, préface de P. BELLET, GLN Joly, 1990, n. 292, p. 249.

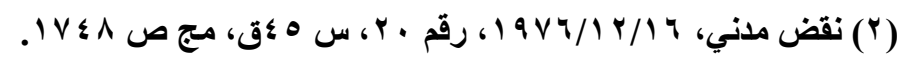

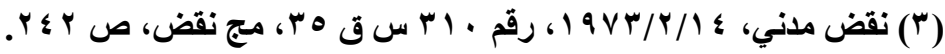

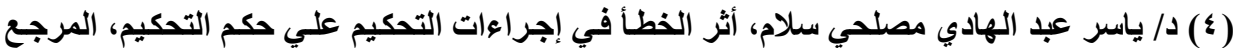

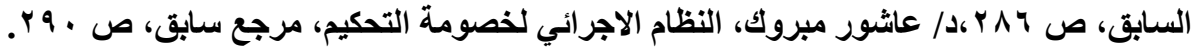




\section{الفرع الثالث}

\section{التزام هيئة التمكيم بمراعاة هبدأ المساواة بين الأطراف في الإثبات}

سنشير إلـى المقـصود بمبــأ المسساواة، و أهميـة المسـاواة، ومقتضيات مبــأ المساواة، وتطبيقات مبدأ المساواة، وذلك في النقاط الآتية:

\section{أولا: المقصود بمبدأ المساواة:}

يقصد بالمساواة أمام هيئة التحكيم أن يكون لكل خصم الحق في عرض دعواه،

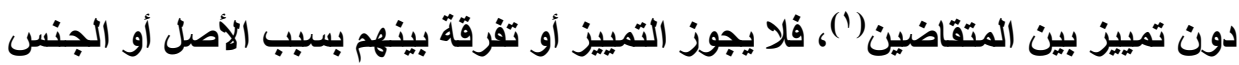

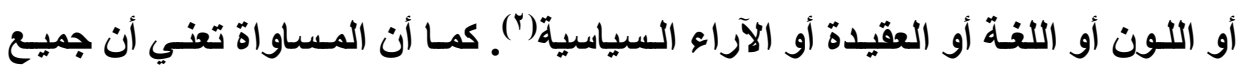
الخصوم تستفيد بنفس الحقوق وتتحمل نفس الواجبات("). والمساواة هنـا تنصب علي المساواة الإجرائية بين الخصوم، أي منحهم فرصـا متساوية لإبـاء طالبتهم ودفاعهم، ولا يجوز التمييز بين الأطراف، سواء في المعاملة أو في مجلس التحكيم، أو حتي في

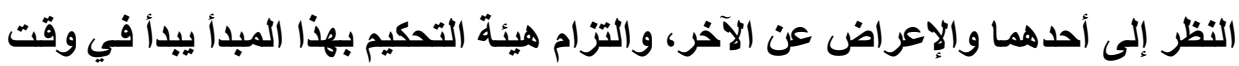

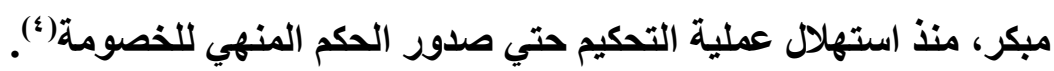

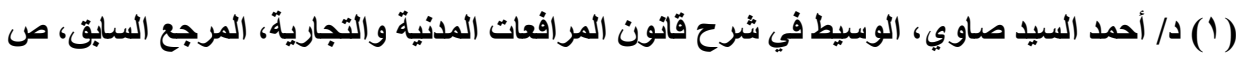

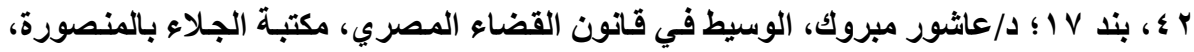

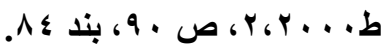

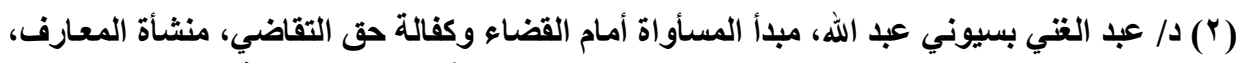

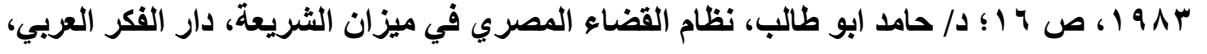

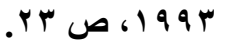

CA Paris, 5 juin 1998, GP, 1999, Com, n², note Mvereon.

(ए) د/ سيد أحمد محمود، التقاضي بقضية ويدون قضية في المواد المدنية والتجارية، المرجع السابق، PrA ص

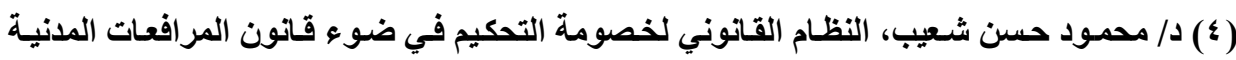

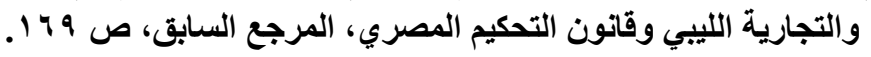


فالمساواة تقتضي عدم التفرقة بين الأفراد ذوي المراكز القانونية المتماثلـة('). والمساواة بين الخصوم تقتضي منح الخصوم فرصا متساوية لإبداء دفاعهم وطلباتهم

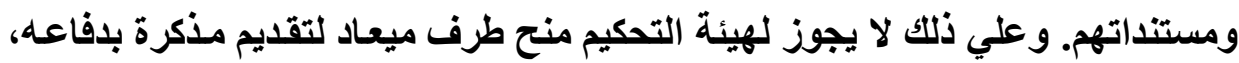
وتمنح الطرف الآخر ميعاد أطول أو أقصر، أو أن يفسح المجال لأحد المحتكمين لشرح

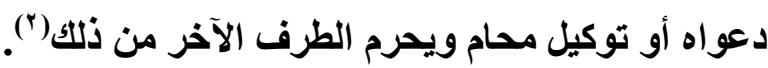
وبالتالي بحق كل طرف في المساواة مع الطرف الآخر في الاستماع إلى قضيته

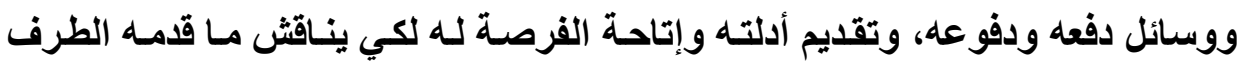

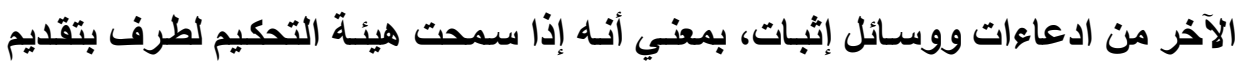

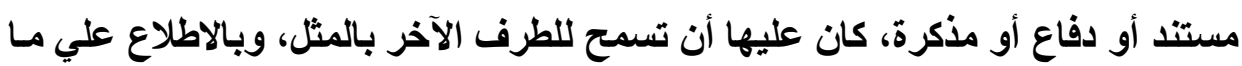

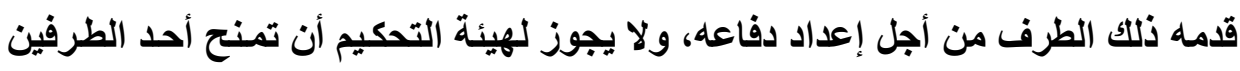

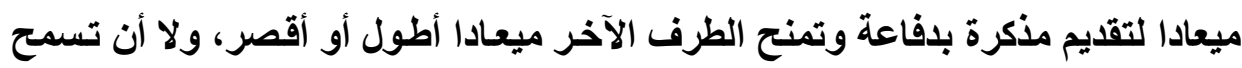
لممثل أحد الطرفين بالمرافعة الشفوية أمامها ولا تمنح هذا الحق للطرف الآخر مكتفية مدية

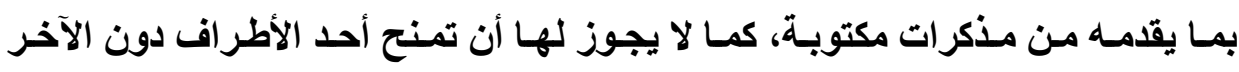
بالاطلاع علي تقرير الخبير أو المستثات، وليس لهاتها أن تتصل بأحد الطرفين أو تقابله

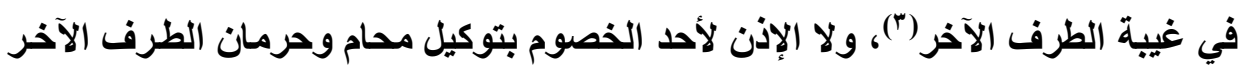

من هذا الحق، أو حضور ذي خبره لمساعدة أحد الأطراف ولا تإذن للطرف الآخر (؛).

(1) د/ أحمد قطب عبساس، إسـاءة أستعمال الحق في التقاضسي، دار الجامعة الجديدة، 7 . . Y، ص .111

(ץ) د/ منير يوسف حامد المناصير، سلطة المحكم في الإثبات في خصومة التحكيم التجاري الدولي،

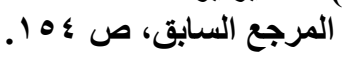

(3) CA Paris, 3 dec. 1965, op. cit., p. 22, op. cit., 14625, note Boulbes. Cass. 2e, 16 dec. 1985, op. cit., p. 390, CA Paris, 2 fev. 1988, op. cit., p. 62, note Couchez.

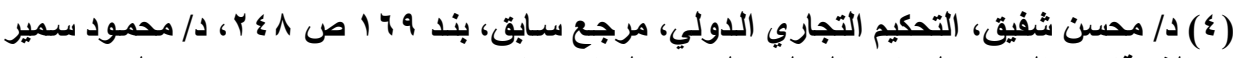

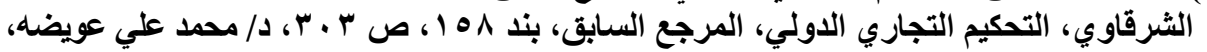

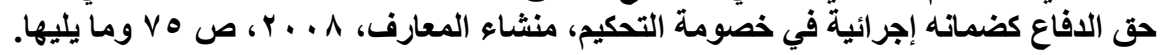


ولا يقصد بالمساواة هنا المساواة المطلقة، وإنما المقصود منها أن تنظيم مركز

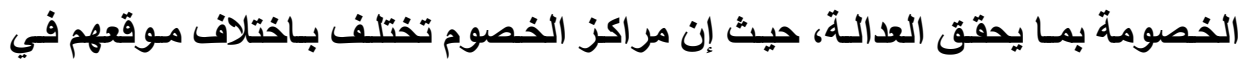
الخصومة، فمثلا عندما لا يقدم المحتكم بيانا بلعواه دون عذر مقبول يجب علي المحكم أن ينهي إجراءات التحكيم، مـا لـم يتفق الطرفان علي غير ذلك، في حين عدم تقديم

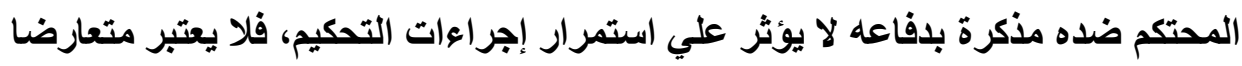
مع مبدأ المساواة رفض طلب لأحد الطرفين باعتبار أن نظره يعطل الفصل في النزاع

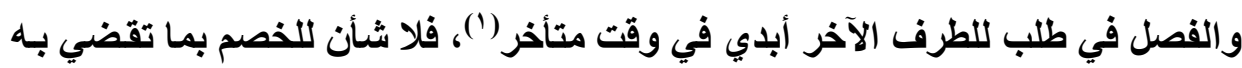

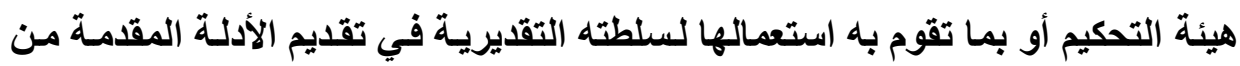

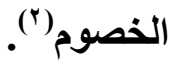

\section{ثانيا: أهميهية هبدأ المساواة}

فـي الواقع المسـاواة في معاملـة طرفي التحكيم، وتهيئة الفرصـة المتكافئة

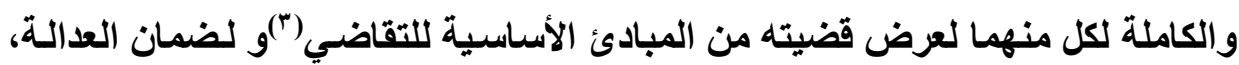

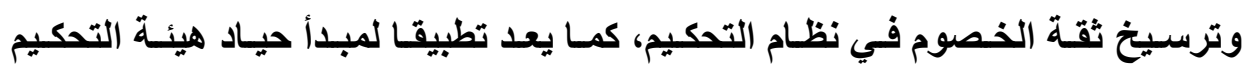

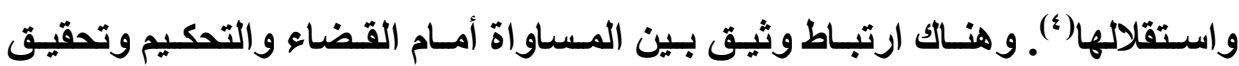
العدالة(•)، لأنه لا عدالة بدون مسأواة حيث إن المساواة تقتضي أن يطبق علي الخصوم

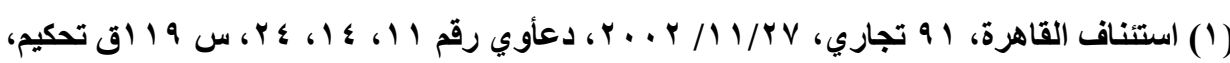

$$
\begin{aligned}
& \text { غير منشور. }
\end{aligned}
$$

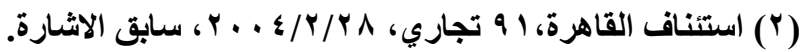

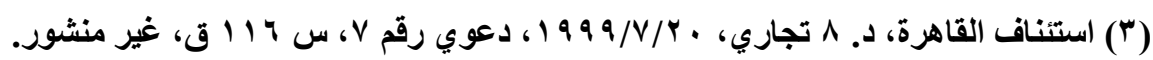

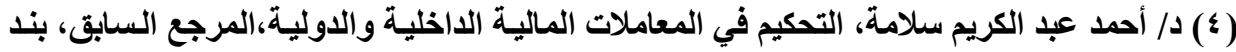

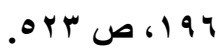

(0) د/ أحمد فتحي سرور، الثرعية الاستورية وحقوق الانسان في الإجراءات الجنائية، دار النهضة

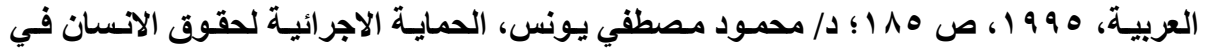

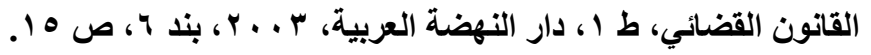




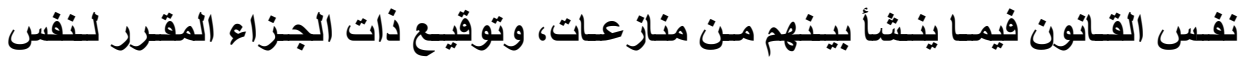

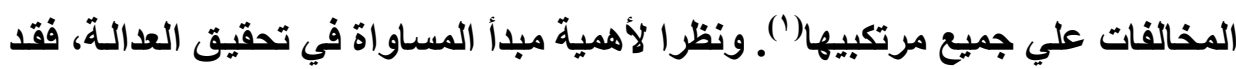

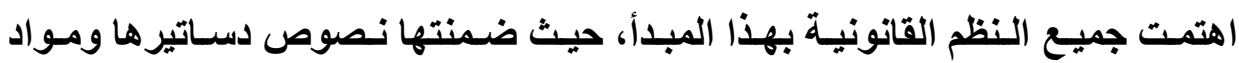

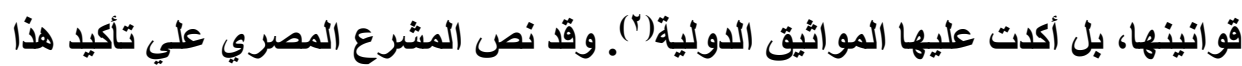

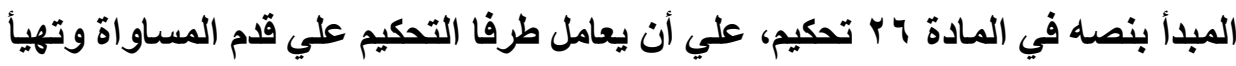

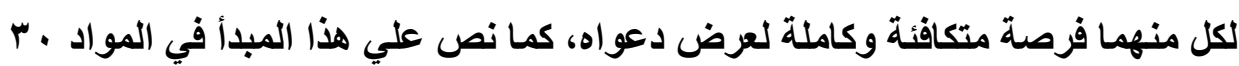

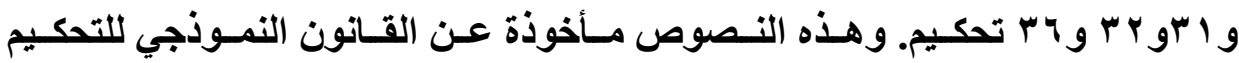

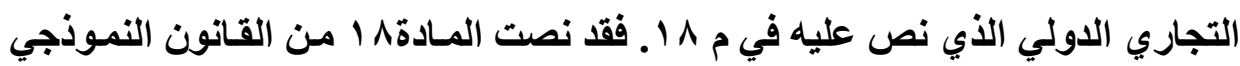

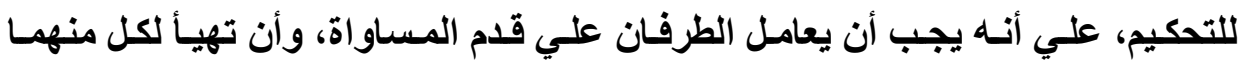
فرصة الكاملة لعرض دعواه.

والواقع أن مبدأ المساواة أمام القضاء الدولة أو قضاء التحكيم من أهم المبادئ

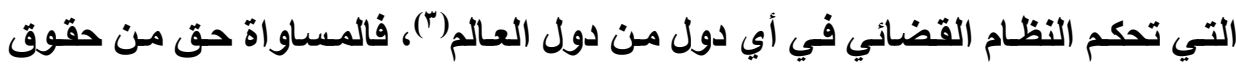

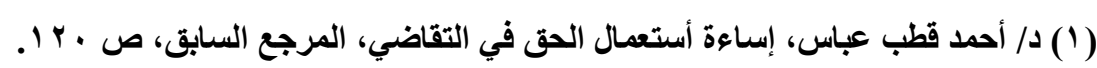

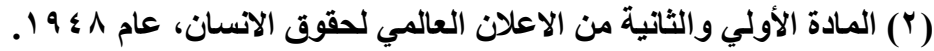

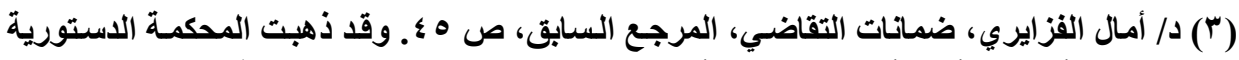

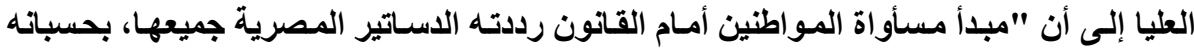

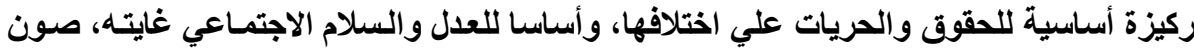

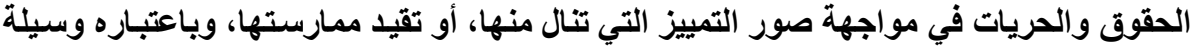

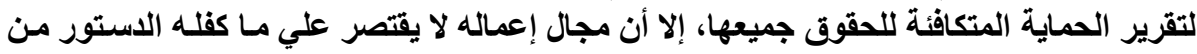

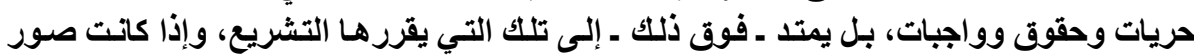

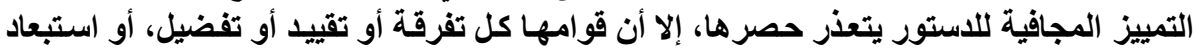

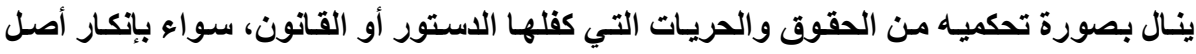

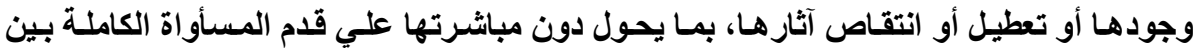

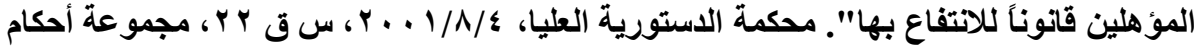

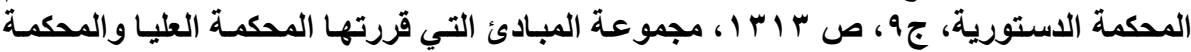

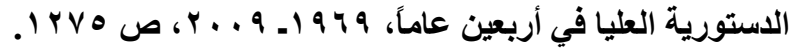


الإنسان الطبيعية، والقضاء بصفة عامة سواء قضاء الدولة أو قضاء التحكيم اكتسب شرعيته مسن مراعـاة حقوق الانسان(") كمـا أن المساواة تؤدي إلى اطمئنـان نفوس المتقاضين في التحكيم، فالمساواة حق مقدس في جميع الأنظمة القانونية في العالم. فقد قررت المواثيق الدولية الخاصة بحقوق الإنسان مبدأ المساواة أمام القضاء، ومنع كل أشكال التمبيز، وهذه المواثيق الدولية لها قوة تعلو علي القانون في مصر بعد الت التصديق عليها()، ومن هذه المواثيق ما نصت عليه المادة الأولي من الإعلان العالمي

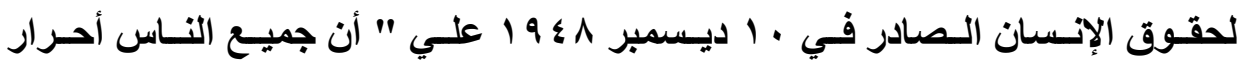
ومتسأوون في الكرامة والحقوق"، ونصت المـادة الثامنة من هذا الإعلان علي أن " لكل إنسان حق التمتع بجميع الحقوق الحريات المذكورة في هذا الإعلان، دونمـا تمييز

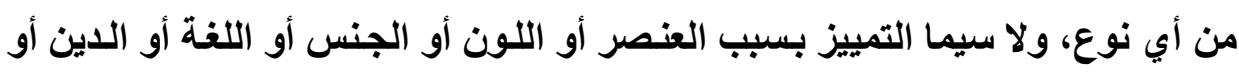

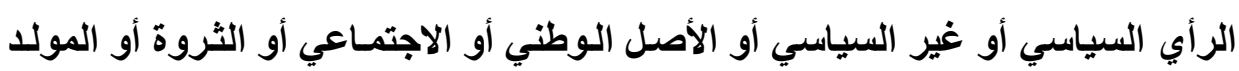
أو أي وضع آخر". وكما نصت المادة العاشرة من نفس المصدر السابق علي أن " لكل الكل

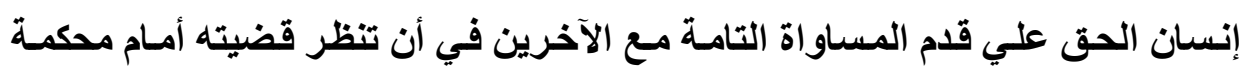
نزيهة نظرا عادلا علنيا للفصل في حقوقه والتزاماتهـ وأيـة تهمـة جنائية توجها إليهه". وقد أكدت هذا المعني المـادة ؛ ا من العهد الدولي للحقوق المدنيـة والسياسية لسنة צ 97 ــوقد جاء في المادة السابعة من إعلان الأمم المتحدة للقضاء علي جميع أشكال التمييز العنصري أن " لكل انسان حق في المساواة أمام القانون وفي العدالة المتساوية

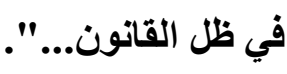
(1) د/ أحمد فتحِي سـرور، الشرعية الدستورية وحقوق الانسان في الإجراءات الجنائية، المرجع

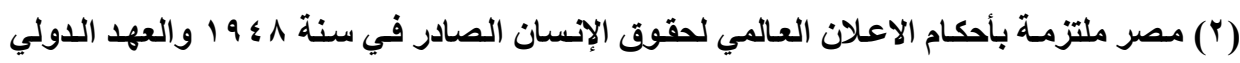
للحقوق المدنية والسياسية، والاتفاقية الدولية للقضاء علي جميع أثنكال التمييز العنصري. 
وقد نـصت المـادة الخامسة مـن الاتفاقيـة الدوليـة للقضاء علـي أوجـه التمييز

العنصري علي الحق في المعاملـة علـي قدم المسـاواة أمسام المحساكم وجميع الهيئات الآخرى التي تتولي إقامـة العدل. وقد نصت علـي هذا المعني أيضا الاتفاقيـة الأوربية

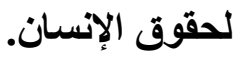

كما أن المادة 11 من ميثاق حقوق الإنسان والثعب في الوطن العربي الصادر

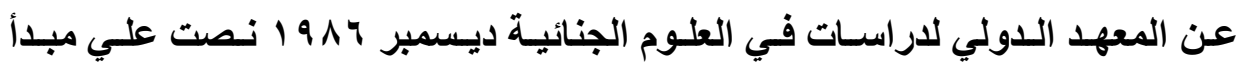
المساواة أمام القضاء والقانون، حيث نصت علي أن النـاس متسأوون أمسام القانون، والناس متسأوون أمام القضاء، وتكفل الدولة استقلال القضاء وحيـاده، وتكفل الدولة

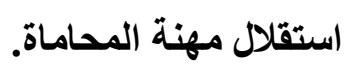

\section{ثالثا: هقتضيات هبدأ المساواة أهاه هيئة التحكيه في الإثبات: يقضضى مبدأ المساواة أمام هيئة التحكيم الآتي:} 1 - تهيئة هيئة التحكيم فرصة متكافئة وكاملة لكل خصم لعرض دعواه وتحقيق دفاعه، ولا يمنح أحد الخصوم حقا دون منح الآخر نفس الحق.

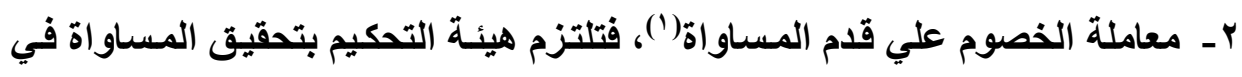
المر اكز الإجرائية للخصوم أثناء إدارتها لوسـائل الإثبات، بحيث لا تفضل خصما

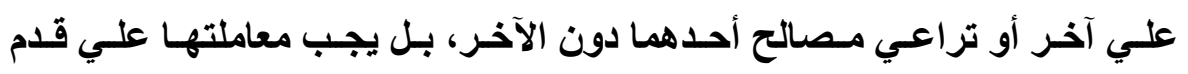
المساواة. فيستلزم مبدأ المساواة أمسام التحكيم أن تكون معاملة المتقاضين وأحدة بـلا محابـاة أو تمييز، وهـا يقتضي أن يطبق عليهم نفس الإجـراعات بالنسبة 
لاستدعاء الخصوم أو في الاستماع إليهم والتحقيق معهم، وذلك سواء من جانب المدعي ببيان دعواه وبينته، أم من المدعي عليه برد الاتهام وشرح أوجه الدفاع عن نفسه. إذا فشرط المساواة أمام هيئة التحكيم أن يكون لجميع الخصوم علي السواء حق في الإثبات، ولا فرق في مباشرة هذا الحق بين الأطراف مهمـا تفأوتت منـازلهم، ويلاحظ أنـه لا يتــافى مـع مبـأ المساواة، إعطاء حريـة لهيئة التحكيم لكي تحكم بالعقوبة الملاعمة تبعا لاختلاف ظروف كل مركز للخصوم. r- يجب علي هيئة التحكيم مراعـاة المساواة بين الخصوم في تحديد الوقت الكـافي والمفيد، وذلك بأن تمنح كل خصم الميعـاد الذي يتناسب معه، ومسأواة كل خصم بالآخر حتي يتمكن كل منهمـا من تنظيم دفاعـه وحمأيـة مصالحه، حسبما نصت المـادة ج ب تحكيم، وهذه المسـاواة نوعيـة، وعليهـا أيضا أن تأخذ في الاعتبـار ظروف كل خصم علي حدة فيما يتعلق باللغة أو المسافة('). ويجب تحقيق المساواة بين الأطراف بالنسبة للقوانين الإجرائية، أي أن تكون الإجراءات المنصوص عليها فـي القـانون عــي جميـع الأطر اف بشكل موحـد، ويجب أن تطبق علـي جميـع المتقاضين نفس الضمانات من حيث حقوق الدفاع وعلانية المحاكمة(؟)، والمواعيد هي هوني وإجراءات، حيث يكون للجميع الحق في استخدام هذه الإجراءات دون تمييز.

(1) Kessed J. principe de la contradiction et arbitrage, Rev. arb., 1995, p. 393.

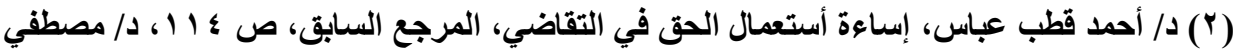

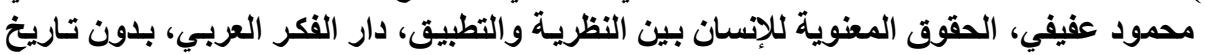

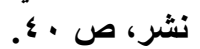

CA Paris, 10 nouv. 1989, op. cit., p. 651, obs. Pellerin, CA paris, 11 juill. 1991, op. cit., p. 671, obs. Loquin, CA Paris, 13 mars 1992, op. cit., p. 107, $=$ 
ع - ويجب لضمان المساواة بين الخصوم أمام المحكم أثناء إجراعات الإثبات، تمكين كل خصم من معرفة تطور المحاكمة، ومتابعة مـا تم فيها وأبداء أقواله، ودفاعـه فيها و إلا كان حكم المحكم الذي لم يراع كل ذلك بـاطلا' '). ويقتضي مبدأ المساواة أن يشترك جميع الأطراف في اختيار إجراعات الإثبات سواء بشكل مباشر أو بتفويض مبر الغير.

\section{رابعا: تطبيقات هبدأ المساواة}

يعتبر مبدا المساواة من المبادئ المتعلقة بالنظـام العـام(؟)، وبالتـالي لا يجوز التنازل عنه إلا بعد بدء الخصومة، ويعتبر الحكم باطلا إذا أخلت الهيئة بهذا المبدأ في حكمها، وتطبيقا لذلك يجب احترام مبدأ المساواة في خصوص مـا يقوم بـه مـن أعمـال الخبرة(")، فيجب أن يحضر الأطراف، أو ممثلوهم(")، كل إجراء يتخذ الخبير أو اجتمـاع

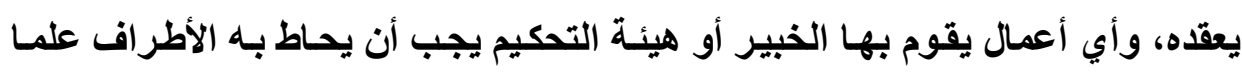

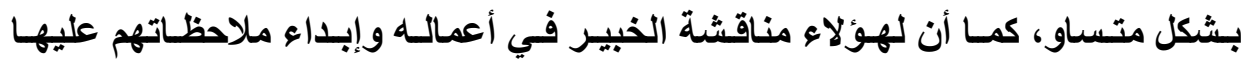
بالمساواة بينهم، كما أن لهيئة التحكيم أن تأمر باستدعاء الخبير في جلسة تحددها كي obs. Jarrosson, CA Paris, 13 nouv. 1997, op. cit., p. 719, obs. Derains.

(1) CA Paris,24fev. 1984, Rev. Arb., 1985, p. 175.

(2) Cass. Civ. 7 janv. 1992, Rev. Arb., 1992, p. 470; B. Moreau, A. Beregoi, et autre, arbitrage commercial, op. cit., no 211.

(3) CA Paris, 10 nouv. 1989, op. cit., p. 651, obs. Pellerin, CA paris, 11 juill. 1991, op. cit., p. 671, obs. Loquin, CA Paris, 13 mars 1992, op. cit., p. 107, obs. Jarrosson, CA Paris, 13 nouv. 1997, op. cit., p. 719, obs. Derains.

(4) CA Paris, 2 fev. 1988,rev. arb., 1989, p. 62, note Couchez, Cass. Civ., 2e, 10 nov. 1998, op. cit.,p. 1.S. 
تقوم هي والأطراف بمناقثة في التقرير الذي يضعه في نهائة أعماله، إن رأت حاجة في ذلك، ويبدي الخبير رأيه وردوده مؤيدة و أسبابها، ولكل من الطرفين أن يقدم في جلسة خبيرا أو أكثر من طرفه لإبداء الرأي في المسائل التي تناولها تقرير الخبير الذي واني

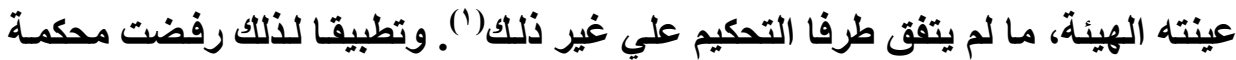
استئناف باريس إلغاء حكم التحكيم عندما رفضت هيئة التحكيم أن تضع في اعتبارها حقيقة أن الخبير اتخذ بعض الخطوات في غياب أحدا الأطراف، حيث اعتبرت هيئة الخئة

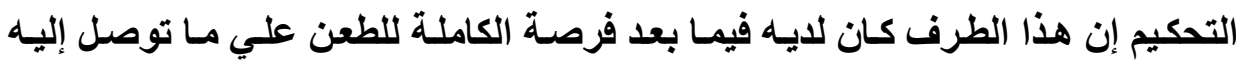

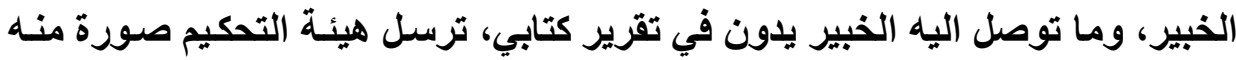

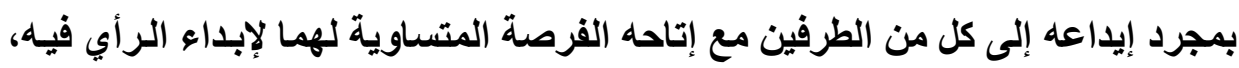

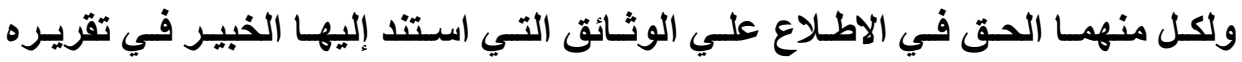

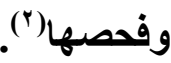

وإذا كانت هيئة التحكيم تملكك إدارة إجراءات الخصومة، إلا أنها ملزمـة بتهيئة

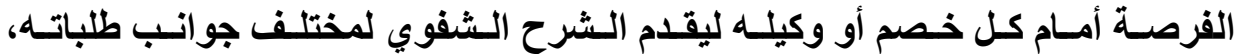
وادعاءاته في حضور الطرف الآخر. فيمكن للخصوم تقديم طلباتهم ودفاعهم ودفوعهم

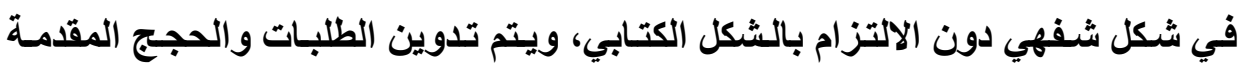
شفويا في محاضر، وهذا مـا نصت عليه المسادة بس تحكيم. ويجب علي هيئة التحكيم مراعاة الأمور الآتية عند تنظيمها لإجراءات الخصومة، إعطاء كل طرف نفس المساحة الزمنية لعرض حججه وأدلته دون زيادة أو نقصان، وكنلك مراعاة أن يكون المحتكم

(1) Ph. FOUCHARD, E. GAILLARD et B. GOLDMAN, traite de l'arbitrage commercial international, op. cit.,p. 705.

(2) CA Paris, 13 mars 1973, op. cit., P. 176, CA PARIS, 12 fev. 1993, Rev. Arb., 1993, p. 255. 
أول من يتر افع ويتكلم، والمحتكم ضده التالي لله، يعقبه ويقدم دفاعه وردوده وطلباته المقابلة"(') ولكل طرف الحق في تقديم ما يوضح موقفه وروئيته في الرد علي ادعاءات

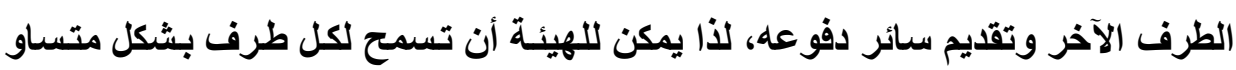
بتقديم الطلبـات والمستندات المكتوبـة دون استلزام حضور الخصوم بأنفسهم أو مـن يمثلهم ودون إجراء مناقشة شفهية(؟). ويلجأ إلى ذلك عادة في تحكيم الصنف أو النوع في البضائع والمعدات، عندما يثور الخلاف حول مدي مطابقتها للمواصفات في تجاره تلكك البضائع والمعدات ولما اتفق عليه الطرفان.

ويجب علي هيئة التحكيم أن تحترم مبدأ المواجهة أثناء الإجراءات بشكل متساو

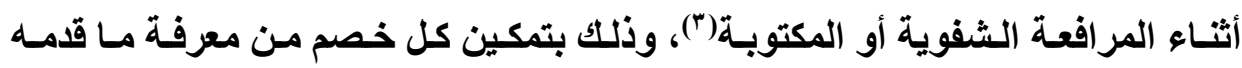

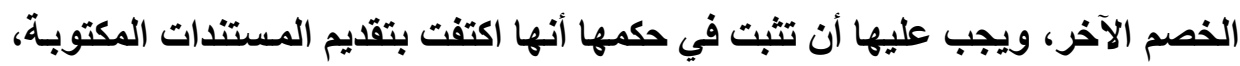
وأنه تم تبادلها بـالنحو الصحيح بين الأطراف، وتم تمكينهم من الاطلاع عليها بشكل متساو( () ومناقشة والرد علي ما جاء بها، كل ذلك حتي لا يتعرض الحكم للطعن عليه بالبطلان لخروجه عي مبدأ المساواة.

(1) د/ أحمد عبد الكريم سلامه، التحكيم في المعاملات المالية الاخلية والدولية، مرجع سـابق، ص

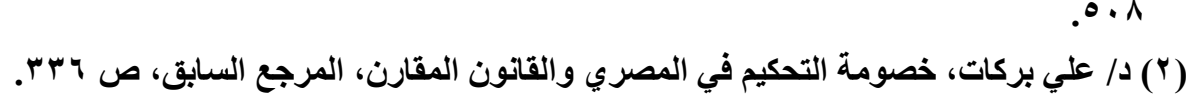

(3) CA Paris, 10 nouv. 1989, op. cit., p. 651, obs. Pellerin, CA paris, 11 juill. 1991, op. cit., p. 671, obs. Loquin, CA Paris, 13 mars 1992, op. cit., p. 107, obs. Jarrosson, CA Paris, 13 nouv. 1997, op. cit., p. 719, obs. Derains.

(4) CA Paris, 24 mai 1874, op. cit., p. 246. 


\section{المطاب الثاني \\ الترام هيئة التمكيم باتفاقات النصوم في الإثبات}

سنشير إلى الأساس القانوني لالتزام هيئة التحكيم باتفاق الخصوم في وقواعد

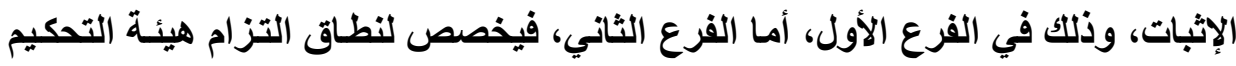

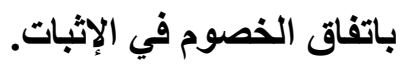

\section{الفرع الأول}

\section{الأساس القانوني لالتزام هيئة التمكيم باتفاق الفصوم في قواعد الإثبات}

في حقيقة الأمر، من المستقر عليه في كافة أنواع التحكيم إعمال مبدأ " سلطات

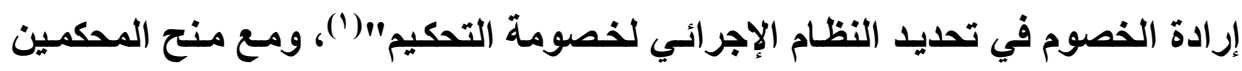

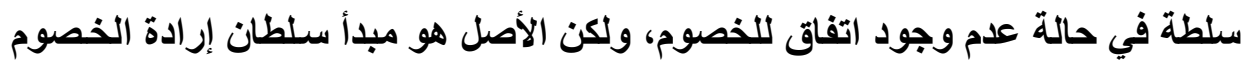

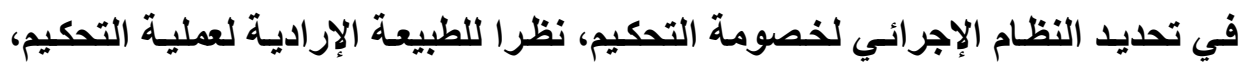
وباعتبار أن التحكيم اتفاقي النشأة قضائي الأثر (†).

(1) Ph FOUCHARD, L'arbitrage commercial international, op. cit., no 471 et s; J. ROBERT, l'arbitrage droit interne et droit international privé, op. cit., p. 54 et $s$.

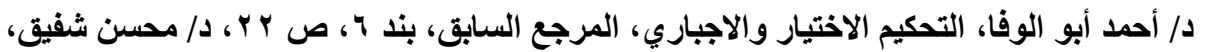

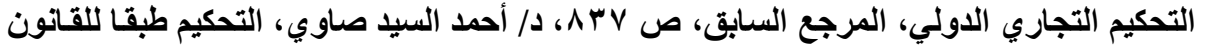

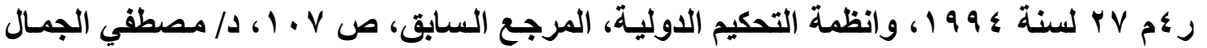

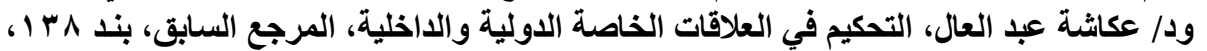

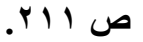
(Y) د/ محمـود السيد التحيوي، الاتجاهـات النظريـة والحلـول الوضعية في تحديد التظظيم الاجرائسي

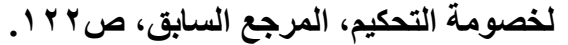


في الواقع يتميز التحكيم عن القضاء بأساسه الاتفاقي، فالقضاء أساسـه القانون وولأيته عامه، ونظرا لأن الإجراءات هي الوسـائل الفتيـة التي حددها القـانون لحمائية الحق الموضوعي وفض المنازعات التي تثار بثأنه، والقاعدة أنه تغاضي المشرع عن الإنه تنظيمه لإجراعات أمام هيئة التحكيم('). وقد ترك المشرع للأطر اف الحريـة في اختيار النظام الإجرائسي المحقق لهذه الأهداف، وإذا اختـارت الخصوم إجراعات الإثبات أمسام هيئة التحكيم فيجب الالتزام بها، بشرط أن لا يكون هذا الاتفـاق مخالفا لقواعد النظام

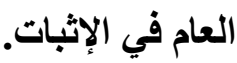

ويرجع أسـاس التزام هيئة التحكيم بتطبيق اتفـاق الأطراف في تحديد إجراءات الإثبات إلى الأتي:

\section{الأساس الأول: إرادة المشرع:}

في الواقع مصدر التحكيم إرادة المشرع، حيث إن الأفراد لا يستطيعون اللجوء

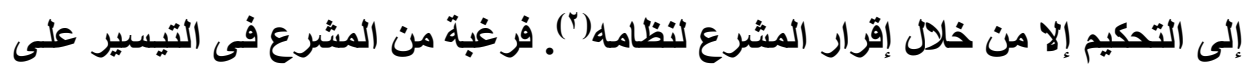
الأطر اف ولتحقيق مصالحهم، اعترف بقضاء التحكيم ونظمـه تنظيمـا دقيقـا وترك فيه فيه مساحة كبيرة لإرادة الأطراف. وقـد أسـند المشرع لهيئة التحكيم اختصاصا قضائيا بالفصل فى المنازعـات التى يتفق الأطراف على اللجوء فيها إلى التحكيم. كمـا أن

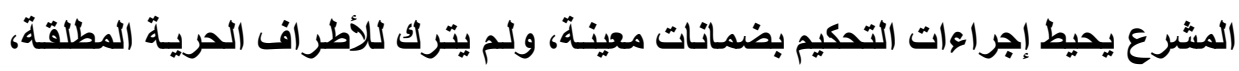

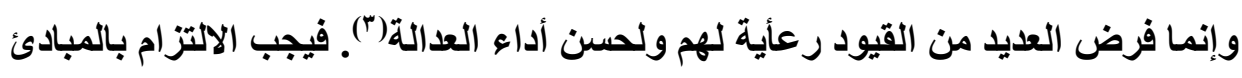

(1) د/ نبيل إسماعيل عمر، التحكيم في المواد المدنية والتجارية الوطنية والدولية،المرجع السباق، ص 10 .

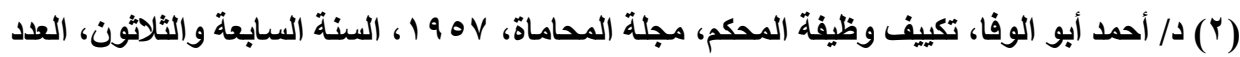

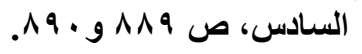

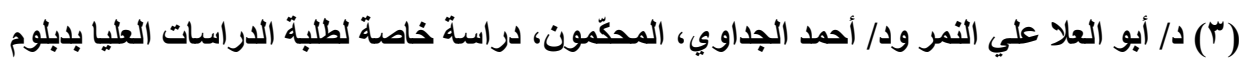

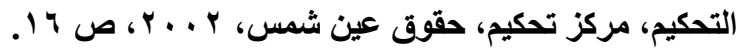


الأساسية للتقاضي مثل حقوق الدفاع والمواجهة والمساواة، ويجب أن يكون المحَّم محأيدا ومستقلا مثل القاضي.

وتطبيقـا لـلك نـصت المـادة هب تحكيم مـصري، علـي أن للأطراف في اتفـاق

التحكيم اختيار الإجراعات مباشر أو إخضاع التحكيم للإجراعات النافذة في منظمة تحكيم أو مركز مـن مراكزه(')، وإذا لـم يوجـ اتفـاق علـي ذلـك فتنص المـادة علـي أن هيئة التحكيم تختـار الإجراءات. إذا سـلطة هيئة التحكيم في تحديد إجراءات الإثبـات تتقيد باتفاق الأطراف علي هذه الإجراءات، فطبقـا لنص المـادة هب لهيئة التحكيم في حالة عدم وجود الاتفاق أن تضع بنفسها القواعد الإجرائية المناسبة لكل مسألة من مسائل التحكيم الإجرائية، ولها صياغة هذه القواعد جملة عند اتصالها بالموضوع، كما لها أن تضع مـا تحتـاج إليسه مـن هذه القواعد أولا بـأول، ويجوز لها اتبـاع النظـام الإجرائسي المعمول به في هيئة تحكيم أو منظمة تحكيم دولية، ويجو لها اتباع الإجراعات النافذة في دولة معنية تختار ها هي.

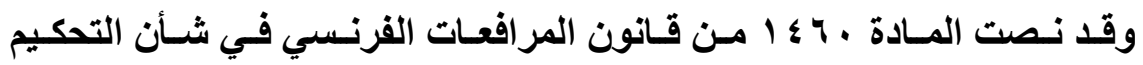
الــاخلي، إجـراءات خـصومة التحكيم، وذلــك بقولهـا" يـنظم المحكـون الإجـراءات التحكيمية دون أن يكونوا ملزمين باتباع القواعد المعتمدة من قبل المحاكم، إلا إذا كـان

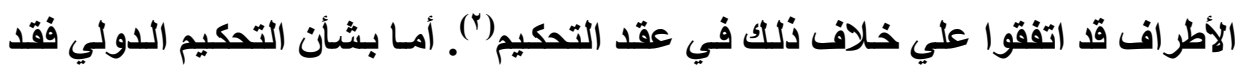
نصت المادة ب9 \ ا مرافعات فرنسي علي أنه يجوز أن يحدد اتفاق التحكيم مباشرة أو

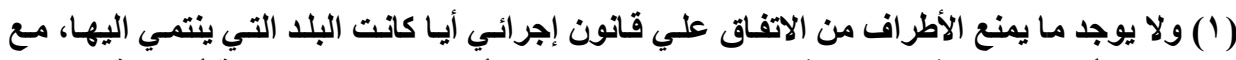

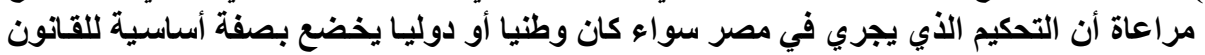
المصري ما لم يوجد اتفاق علي خلاف ذلتك.

(2) R. PERROT, l'application a l'arbitrage des regles de nouveua code de procedure civile, op. cit., p. 643 
بالإحالة إلى نظام تحكيم الإجراءات التي يجب اتباعها في خصومة التحكيم، ويجوز أيضا إخضاع هذه الدعوي إلى قانون إجراءات معين يحدده اتفـق التحكيم، وفي حالة

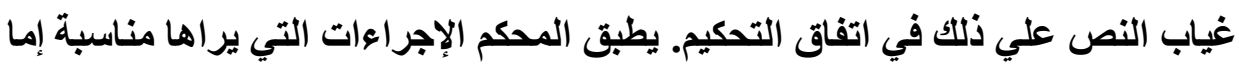
مباشرة أو بالإثارة إلى قانون معين أو إلى نظام تحكيمي معين". فيلاحظ أن المشرع الفرنسي طبق القاعدة العامـة وهي مبدأ سلطان إرادة الأطراف المحتكمين في تحديد التنظيم الإجرائي لخصومة التحكيم في شـأن التحكيم الدولي، وقد منح لهاعل لهيئة التحكيم

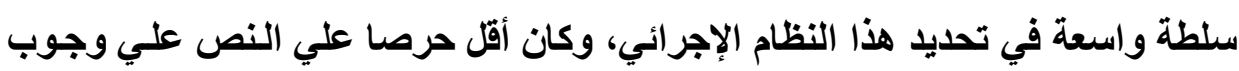
احترام ضمانات التقاضي الأساسية و التي حصر علي الإنشارة إليها في التحكيم الداخلي. في الواقع يضبط المشرع إعمـال إرادة الأفراد وشـروط اللجوء إلى التحكيم

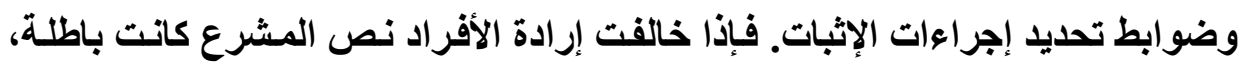

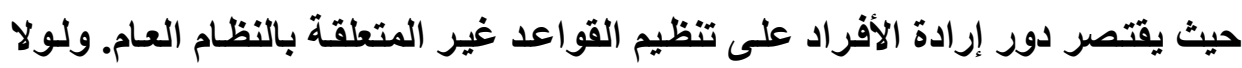

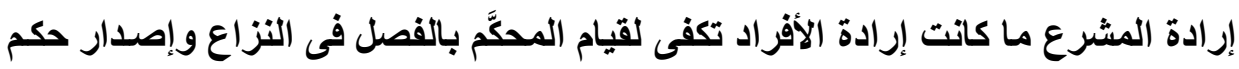

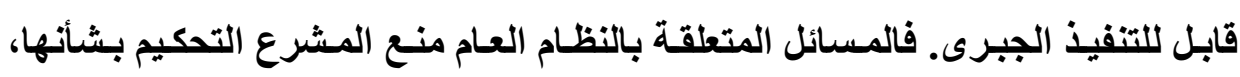
وإرادة الأفراد لا يمكنها الاتفاق على التحكيم بثأن هذه المسائل.

\section{الأساس الثاني: إرادة الأطراف}

في الواقع سلطة المحكَّم مستمدة من إرادة الخصوم. فالخصوم هم الذين منحوا

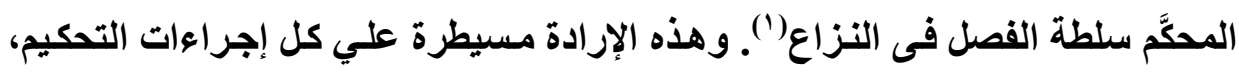

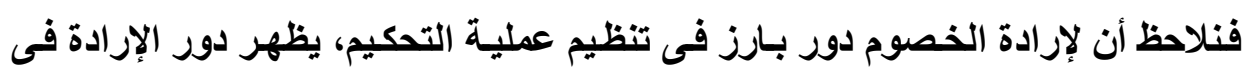

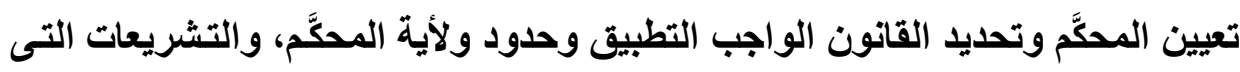

(1) F.E. KLEIN, "autonomie de la volonté et arbitrage", Rev. crit. DIP, 1958, p. 280. 
تسنها الدولـة في شـأن التحكيم لا تضع أحكامـا آمرة إلا فـى أضيق الحدود، وأكثرهـا قواعد مكملة لإرادة الأطر اف. أما بـء التحكيم وسيره وصدور الحكم، فيجد أساسـه فى

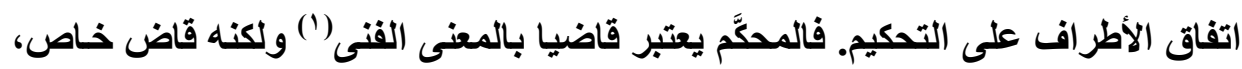

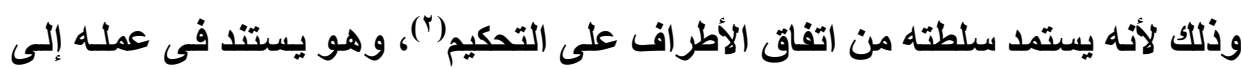
اتفاق التحكيم وإرادة المشرع التى تعترف به وتجعل حكمه قابلا للتنفيذ الجبرى.

والأسساس الاتفـاقي لهيئة التحكيم لا ينفي عنها صـفة الهيئة القضائية ذات الطبيعة الخاصة، حيث ذهب البعض إلى القول بأنه "من الصعب اعتبـار هيئة التحكيم جهة قضائية بالمعنى الفنى الدقيق لتمتعها بطبيعة خاصـة تلـخلها فى مصاف الهيئات ذات الاختصاص القضائى ممـا يقتضى تمييزهـا عن أيسة جهة قضائية"("). وقد تبيّت المحكمة الاستورية العليا وجهة النظر هذه باعترافها لهيئة التحكيم بالطبيعة القضائية

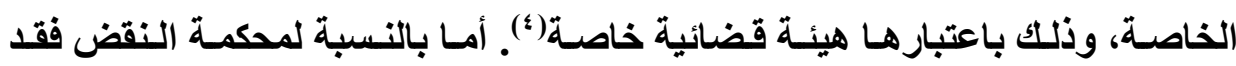
اعتبرتها طريقا استثنائيا للفصل فى النزاع(ه).

(1) VINCENT et GUINCHARD, procedure civile, 26 éd. Dalloz, p. 1108, no 1667 ; P. LEVEL, " Brèves réflexions sur l'office de l'arbitre", Mélanges Perrot, Dalloz, 1995, p. 259.

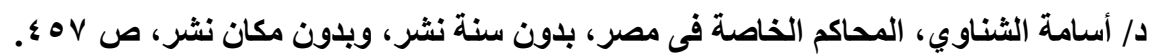

(2) VINCENT et GUINCHARD; Ibid.

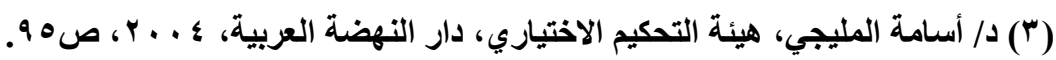

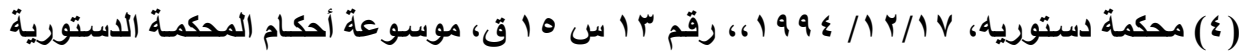

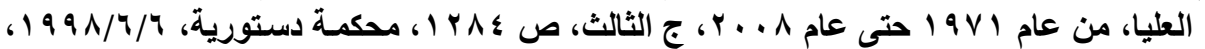

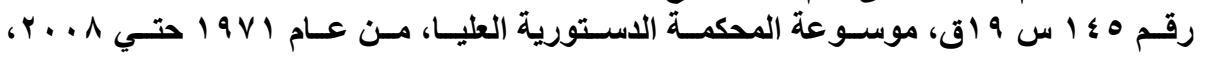

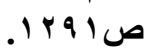

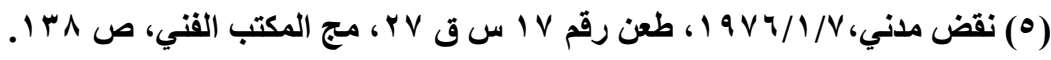

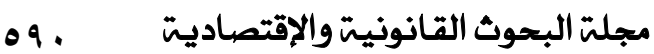


وبالتالي نخلص إلى أن أسساس التزام هيئة التحكيم باتفاقات الأطراف إلى أن

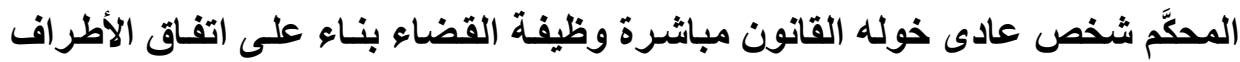

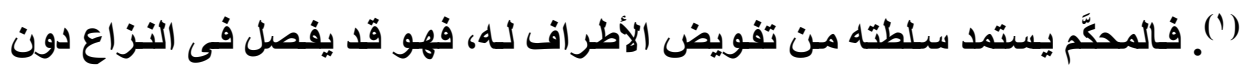

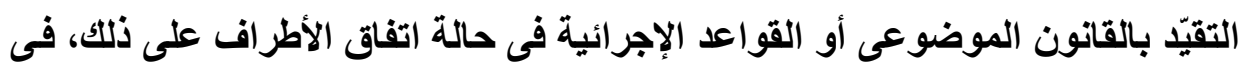

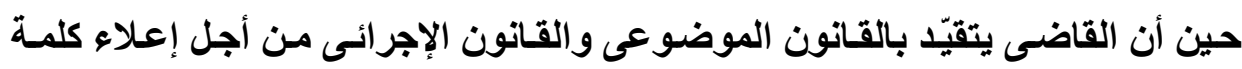

\section{الفرع الثاني \\ نطاق التزام هيئة التحكيه باتفاق الأطراف في تهديد إجراءات الإثبات}

يحكم اختيار إجراءات الإثبات بواسطة الأطراف في الاتفاق التحكيم مجموعة من الضوابط الفنية، الأصل فيها ترك الحرية في تحديد الإجراءات لإرادة الأطراف، ويتم هذا التحديد بالاتفاق المباشر بين الأطراف علي هذه الإجراءات في ذات الاتفاق علي لإني

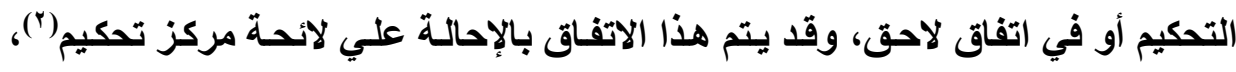

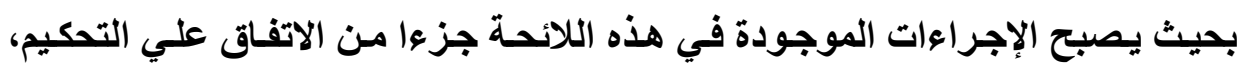

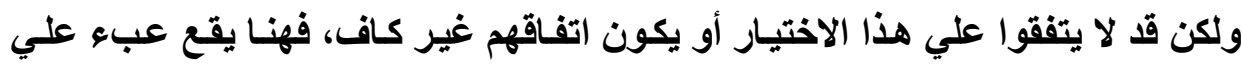

$$
\text { هيئة التحكيم في تحديد هذه الإجراءات("). }
$$

وبصفة عامـة تتقيد سلطات هيئة التحكيم بـاحترام الشروط الواردة في اتفـق

التحكيم وقانون التحكيم فيما يتطلق بالقو اعد الإجرائية، سواء مـا تطلق منها بإجراءاء التهات

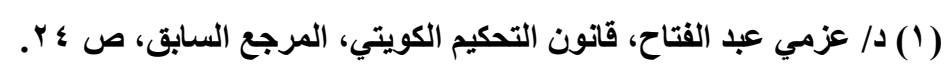

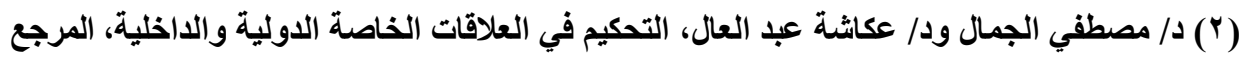

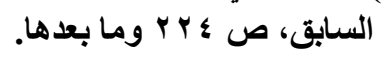

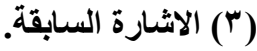


الإثبات، أو ضمانات التقاضـي أمسام هيئة التحكيم. وإذا لـم يوجد اتفـاق للخصوم علـي تحديد إجراعات الإثبات التي يجب علي الهيئة اتباعها، فقد نصت المسادة ه ب تحكيم مسري علـي أن هيئة التحكيم تختــار الإجـراعات، ويكـون لهـا الحريـة فـي اختيـار الإجراعات غير مقيدة بأي قانون('). ويلاحظ أن قانون التحكيم المصري يتميز بطابع تحرري واضـح حيث يسمح بحريـة الطرفين في إخضاع التحكيم للقواعد الإجرائيـة السائدة في قانون وطني يختار سواء كان التحكيم يجري في مصر أو في الخارج. واذا كانـت هيئة التحكيم مقيدة باتفـاق الخصوم في تطبيق إجراعات الإثبـات، فليس معني ذلك أنها ليس لها سـلطة تقديريـة في الإثبات. فالهيئة التحكيم في نظرهـا للـدعوي ملزمـة بتطبيق القـانون علـي الوقـائع التـي تفصل فيهـا تطبيقـا صـحيحا بعد التهـ تمحيصها لجميع كيفياتها وأوصـافها، وهي غير مقيدة بالوصف الذي تسبغه عليها أطراف التحكيم، لأن الهيئة من اختصاصها إظهـار الحقيقة مـن خـلال الإثبات، وهذا يتطلب تكييف الوقائع المراد إثباته، وتقدير النتيجة التي تترتب علي وسائل الإثبات، فقد تطمئن إلى دليل، وترفض الأخذ بنتيجة دليل آخر، وحق هيئة التحكيم في التكييف وتغير الوصف هو حق أصيل لها، ويثبت لها حق دون طلب الخصوم، فلها استبعاد بعض الوقائع من الإثبات إذا لم يكن لها ضرورة في الإثبات أو خارجه عن اتفاق التحكيم. ولهيئة التحكيم تملك تغيير الوصف بناء علي الوقائع التي استخلصتها. ويشترط لذلك: 1ـ أن تكون العناصر التي استندت إليها الهيئة في إعطاء الوصف الصحيح للواقعة قد استخلصتها من التحقيقات التي أجرتها بمعرفتها أو من المرافعة في الجلسة. (1) د/ نبيل إسماعيل عمر، التحكيم في المواد المدنية والتجارية الوطنية والدولية،المرجع السباق، ص 
r- ألا يتضمن تغيير الوصف إضافة وقائع جديدة.

وهنا قيود ترد علي سلطة هيئة التحكيم في تحديد إجراعات الإثبات المتبعة(1)

$$
\text { وتثمثل في الآتي: }
$$

ا. إذا كان التحكيم يجري في مصر وطنيـا كـان أم دوليـا ستكون هيئة التحكيم ملزمـة باتباع الإجراءات المنصوص عليها في القانون المصري وفقـا للمـادة الأولي منـه، وكذلك يسري هذا القانون علي التحكيم التجاري الدولي الذي يجري في الخارج ويتفق الأطراف علي إخضاعه للقانون المصري.

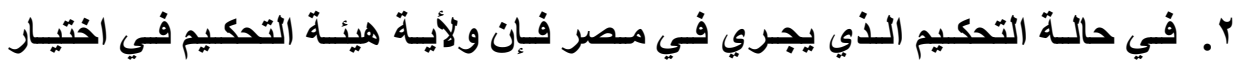
الإجراءات تقتصر علي الحالات التي لا يواجهها قانون التحكيم المصري أو لم يشر

r. امسا التحكيم الذي يجري في الخـارج ولا يتفق الأطراف علـي إخضاعه لقـانون

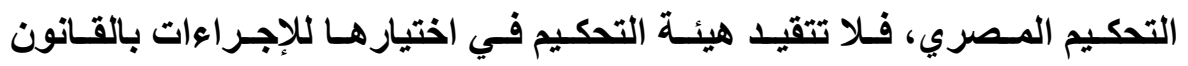
المصري.

؛. لهيئة التحكيم سلطة واسعة في الحساتات التي تعدد فيها إلى وضع قواعد إجرائية مادية بطريقة مباشرة حسب طبيعة النزاع، ولا قيد عليها إلا النظام العـام. ولكن إذا لم تضع هيئة التحكيم قواعد إجرائية مباشرة واختـارت نظامـا إجرائيا تنتسب إلى هـ دولـة مـن الـدول، فعليهـا أن تختـار نظامـا إجرائيـا لـه صـله بالموضـوع المطروح عليها، ولا يجوز لها أن تختار نظامـا إجرائيا لا صلة لـه بموضوع النزاع، وعند 
تعدد القوانين ذات الصلة بموضوع النزاع فعليها اختيار القانون الأكثر صلة بهذا الموضوع.

هـ وفكرة النظام العام تشكل مبدأ يقيد سلطة هيئة التحكيم في اختيـار الإجراءات في الأحسوال التـي يكون لها فيهـا سـلطة الاختيـار، فيجب احترام الأصـول العامـة في الإجراءات والتي تتعلق بالنظام العام الإجرائي. وهذه الأصول العامة تجد مكانها في كافة النظم الإجرائية بصفة عامـة، وتشكل نوعا من النظام العام الدولي الذي لا لأل يجوز المساس به بالاتفاق بين الأطراف، وتلكزم بـه هيئة التحكيم ولو وجد اتفـاق مغأير، وقد يضع المشرع الوطني قواعد إجرائية داخلية مغايرة ويجعها قواعد

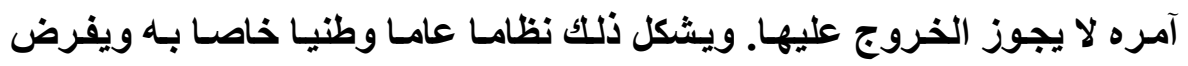
إعمالها علي التحكيم الخاضع له.

ويجب التمييز بين التحكيم في العلاقات التجارية الدولية وفيه يتعين علي هيئة التحكيم في اختيارها للإجراعات أن تتقيد بالنظام العام الدولي وحده، أما في التحكيم في العلاقات الداخلية فيجب علي هيئة التحكيم التقيد بالنظام العام الداخلي. وبالتـالي يجب استبعاد الإجراعات التـي يختارهـا الطرفـان أو تقررهـا هيئة التحكيم كلمـا كانت مخالفهـ للنظام العام واحلالا القواعد التي يفرضها هذا النظام. ويترتب علي مخالفة النظام العام بنوعية الدولي والداخلي ما يلي: - إذا صلدرت المخالفـة من طرفي النزاع عند الاتفـق علـي القواعد الإجرائية فعلي هيئة التحكيم استبعاد الحكم المخالف وإحلال مقتضي النظـام العام مخلفه و إلا كـان حكمها باطلا. 
- إذا خالفت هيئة التحكيم النظام العام بنوعية الدولي والداخلي عند تصديها لاختيار الإجراءات بنفسها، فهنـا يتقرر بطلان حكمهـا بنـاء علـي إجراءات رفـع دعوي

البطلان.

\section{الإطبا الثالث \\ الترام هيئة التمكيم بالإثبات البماعي}

من المبـادئ العامـة في التقاضسي ضرورة اشتراك جميع المحمين في اتخـاذ إجراءات الإثبات، وذلك في الأحوال التي يتعددون فيها، وبالتالي لا يجوز الانفراد من جانب أحدهم في اتخاذ إجراءات الإثبات دون علم الآخرين. سنشير إلى الأسناس القانوني لالتزام هيئة التحكيم بالإثبات الجماعي، وذللك في الفرع الأول، أما الفرع الثاني، فنعالج فيه الاستثناعات علي مبدأ الإثبات الجماعي.

\section{الفرع الأول}

\section{الأساس القانوني لالترام هيئة التمكيم بالإثبات البماعي}

الأصل أن يقوم بالتحقيق المحكمون مجتمعين ما لم ينص الاتفاق علي التحكيم علي تفويض أحدهم بهذه المهمة(')، وبالتالي يجب في حالة تعدد المحكمين أن يشتركوا جميعـا في التحقيق(†)، وكذلك يجب أن يشترك جميع المحكمين في جلسات التحكيم والمناقشات التي تتم، ولا يشذ عن ذلك إلا في الحالة إلى يرد بالاتفاق علي التحكيم نص مغأير، كأن يجيز تفويض أحدهم فقط بإجراء التحقيق في النزاع.

(1) B. Moreau, A. Beregoi, et autre, Arbitrage commercial, D., 2014, no, 204. 


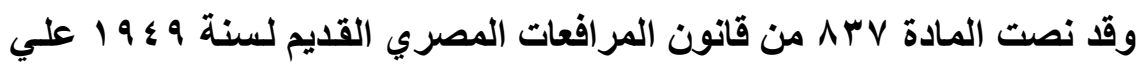
أنه يتولى المحكمون مجتمعين إجراءات التحقيق، ويوقع كل منهم علي المحاضر مـالم يكونـوا قد ندب أحدهم لإجراء معين، وأثبتوا ندبـه في محضر الجلسة. غير أن هذه

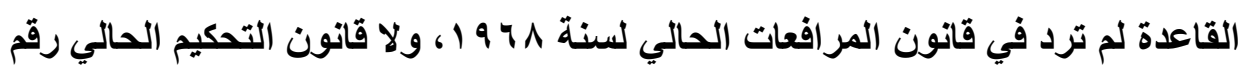
و 99 1 1، غير أن الفقه المصري ذهب إلى أن هذه القاعدة يعمل بها ولو بدون نصا"(

وقد نصت علي هذه القاعدة قـانون المرافعات الفرنسي الجديد في المـادة مـادة VT \ ا ا يتولى المحكمن مجتمعين إجراعات التحقيق ويوقع كل منهم علي المحاضر ما لم يخولهم عقد التحكيم ندب أحدهم. وبالتالي يجب علي هيئة التحكيم أن تقوم بنفسها بإجراءات الإثبات، فليس لها

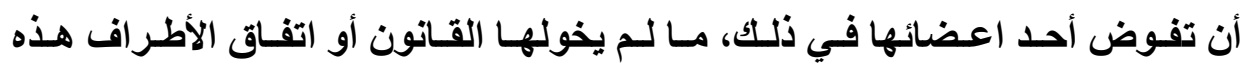

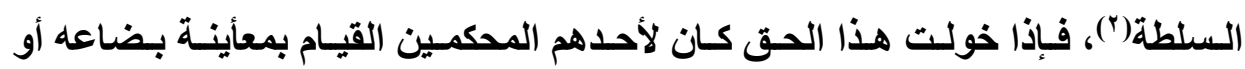
مناقشة خبير، فيجب إذن أن يتولى ا لمحكمون لو تعددوا بأنفسهم إجراعات التحكيم، ولا يجـوز نـــب الغيـر للقيـام بـالتحقيق أو أن يتــأول معسه ولـو كـان خبيـرا معينـا في في الاعوي، وبالتالي لا يجوز لهيئة التحكيم في حالة التعدد أن تجتمع بعضوين فقط في أي جلسة أو عضو فقط.

وقد ذهبت محكمة استئناف القـاهرة إلى أنـه إذا كـان الثابت أن بعض محاضر جلسات هيئة التحكيم قد تضمنت اسـم رئيس الهيئة فقط دون بـاقي الأعضاء الهيئة

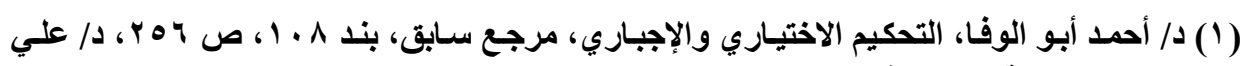

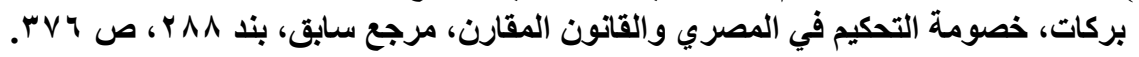

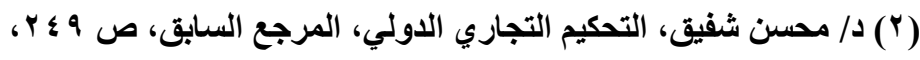


وبعض الآخر تضمنت حضور رئيس الهيئة وأحد المحكمين دون المحكم الآخر، فِان إجراءات التحكيم تكون باطلة، ويتعين القضاء ببطلان الحكم. ويجب أن تلتزم الهيئة بهذا المبدأ حتي ولو كاتت الهيئة مفوضة بالصلح، وذلك لأهمية وسائل التحقيق والدور الحاسم لها في بيان وجه الحقيقة في موضوع النزاع. فإذا كان التفويض بالصلح يعفي هيئة التحكيم من اتباع الإجراعات والمواعيد المطبقة أمسام المحاكم وحريـة الهيئة في تطبيق قواعد العدالة علي موضوع النزاع إلا أنه لا يعفيها من اتباع القواعد التي تقرر

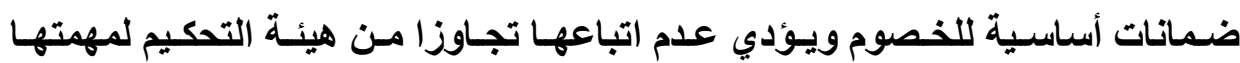
المعهود بها إليها، ويترتب عليه بطلان الحكم التحكيم(') ويرجع الأساس القانوني لقاعدة التحقيق الجماعي إلى الآتي: أولا: أن إثبات الإجراءات يجب أن يشارك فيه كل المحكين حتي يتسني لهم نظر النزاع باعتبارهم هيئة تحكيم(؟) فالأسـاس في ذلتك يرجع إلى اشتراكهم جميعا في نظر

$$
\text { النزاع باعتبار هم هيئة وأحده. }
$$

ثانيا: لا يجوز توزيع المهام بين المحكمين، لأن ذلك سوف يضر الخصوم ويعد انتهاكا لحقوق الدفاع (باع. ثالثا: الالتزام بـالتحقيق الجمـاعي ضمان ضد التمييز والتحيز المحتمل لو انفرد أحد المحكمين باتخاذ إجراء ما أو بنظر جزء من النزاع('). فقد يحتمل أن يتحيز المحكم

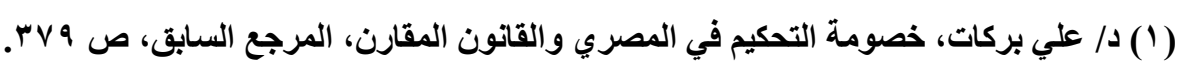

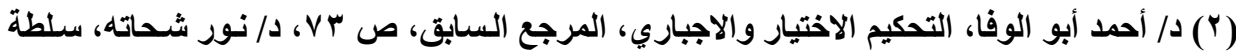

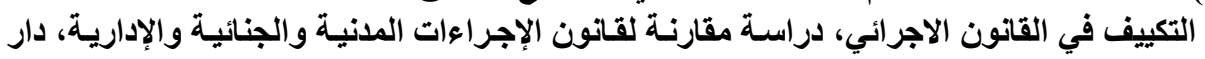

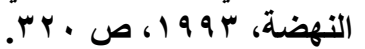

(3) J. ROBERT, l'arbitrage droit interne et droit international privé, op. cit., p. 153. 
للخصم الذي اختـاره بتفسير التحقيق لصالحة إذا مـاسمح بجواز التحقيق أمسام

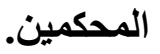

رابعا: وقد ذهب رأي إلى أن ذلك يعد تطبيقا لمبدأ المواجهة، علي اعتبار أنه في حالة تعدد المحكمين يكون اثنان منهم معينا من كل من الطرفين في الاتفاق علي التحكيم بغيـة إعطاء هؤلاء الأطر اف ضمانـا خاصسا، فبإذا مـا توزع العمل بين المحكمين، فيخثي وقوع ضرر للطرفين ومساس بحقوق الدفاع فيما إذا انفرد أحد المحكمين

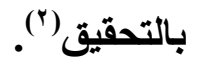

فهذه القاعدة لا تتأسس علـي أسـاس احترام حقوق الدوف، إذا احترام حقوق الافاع لا يفرض مباشرة التحقيق بصورة جماعية، إذا يجب أن يحصل التحقيق بدون تحيز وأن يطلع المحكمون جميعا علي النتيجة التي توصل إليها، فيتحقق بذلك احترام حقوق الدفاع(") - مقان ونري أن هذه القاعدة يرجع أساسـها القانوني إلى أنـه لصحة الحكم يجب أن يصدر من المحكمين الذين شاركوا بأنفسهم في نظر جميع أوجـه النزاع، وخاصـة أدلة الإثبات التي بني عليها الحكم. وهناك قاعدة أصولية مقتضاها وجوب سماع كل أعضاء المحكمة لموضوع الدعوي، وتكتسب هذه القاعدة ميزه خاصة في موضوع التحكيم في

(1) E. Loquin, l'instance de l'arbitrage, op. cit.., NO 97.

(ץ) نبيل إسماعيل عمر، التحكيم في المواد المدنية والتجارية الوطنية والدولية، المرجع السباق، ص r. $r$

(3) CA Paris, 10 nouv. 1989, op. cit., p. 651, obs. Pellerin, CA paris, 11 juill. 1991, op. cit., p. 671, obs. Loquin, CA Paris, 13 mars 1992, op. cit., p. 107, obs. Jarrosson, CA Paris, 13 nouv. 1997, op. cit., p. 719, obs. Derains. 
حالة تعدد المحكمين('). ويترتب علي مخالفة ذلك البطلان، ويمكن إثبات هذه المخالفة بكافة طرق الإثبات لأنها واقعه مادية(؟).

كمـا يلاحظ أن عدم التقيد بالقاعدة التحقيق الجمـاعي يخـالف المهــة الموكلـة للمحكمـين، ذلـك أنـه عندم وجـود اتفـاق علـي السماح بـإجراء التحقيق مـن قبـل أحـا المحكمين، فأنه يفترض أن الطرفين قد أراد إجراء التحقيق بصورة جماعية، إذ تعتبر هذه القاعدة قاعدة مكملة للإرادة ولا يجوز استبعاد تطبيقها إلا بنص مخـالف. وبالتـالي

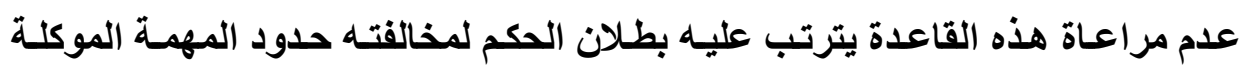

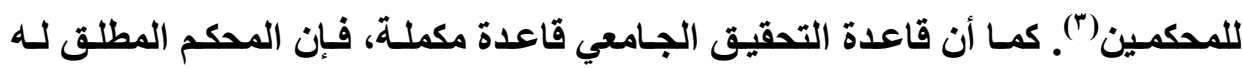
سلطة استبعادها، ذلك أنه مـا دام الطرفـان لهما حق العدول عن تطبيقها، فبإن المحكم المطلق الأي يستطيع عدم التقيا بجميع قواعد القانون المكملة في إجراعات التقاضي العادية، ويمكنه استبعاد القواعد المكملة في إجراءات وأصول التحكيم. والتزام هيئة التحكيم بأعمـال قواعد الإثبات يختلف تبعـا لكونهـا موضوعية أو

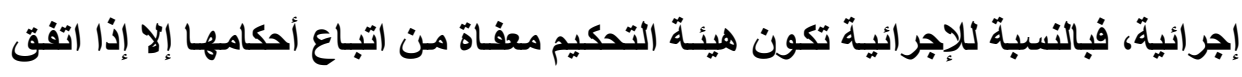
علي وجوب مراعاتها أو كاتت تتعلق بالنظام العام(؛)، أما القواعد الموضوعية فـالمحمى مئه

(1) R. David ; L'arbitrage dans le commerce international, op. cit. no 328 p. 418,

(2) CA Paris, 18 nov. 1952, D., 1952, p. 804. B. Moreau, A. Beregoi, et autre, arbitrage commercial, op. cit.,no 204.

(r) د/ نبيل إسماعيل عمر، التحكيم في المواد المدنية والتجارية الوطنية والدولية،المرجع السباق، ص r. 1

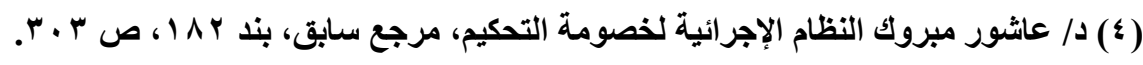


يكـون مقيــا مـن حيـث الأصـل باتبــاع أحكـام القـانون الموضـوعي ومنهــا القواعـــ الموضوعية في الإثبات(')

وبالتالي يمكن القول بأن التحقيق الجماعي هي قاعدة يمكن أن تضمن واقعيا احترام حقوق الدفاع، غير أن عدم احترام هذه القاعدة لا يشكل بذاته وبصورة حتمية

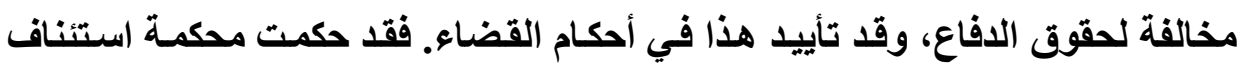
باريس بأنـه إذا تم بعض إجراءات التحقيق من قبل محكم وأحد مفوض بالصلح من المحكمة التحكيمية لا يخالف مبدأ المواجهة والدفاع الذي يفرض تمكين كل خصم من مناقثة مطالب وأدلة وحجج خصمه(؟).

\section{الفرع الثاني \\ الاستثناءات من الالتزام بالإثبات البماءي}

إذا كـان مـن الضروري اشـتراك جميع المحكمين في اتخـاذ إجراعات الإثبـات، وذلك في الأحوال التي يتعددون فيها، وبالتالي لا يجوز الانفراد من جاتب أحدهم في اتخاذ إجراءات الإثبات دون علم الآخرين، ومـع ذلك فهذا الالتزام ليس مطلقا، حيث يوجد استثناءات أجاز فيها القانون علي هيئة التحكيم الخروج علي هذا المبدأ. فإذا كان الأصل أن تتخذ هذه الإجراعات من هيئة التحكيم مجتمعة في حالة تعدد المحكمين، إلا أنها قد لا يكون ميسرا في جميع الأحوال لكون المكـان الواجب إجراء الإثبات فيه بعيدا عن مقر الهيئة، لهذا يمكن لهيئة التحكيم للسماح باتتاب أحدهم للقيام بأحدى إجراءات الإثبات بشرط إثبات ذلك في محضر الجلسة. كما هو منصوص عليه

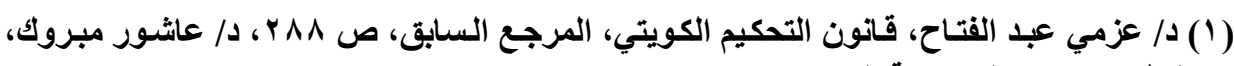

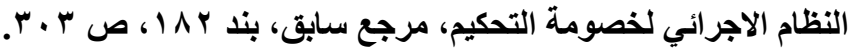

(2) CA Paris, 29 avril 1985, Rev. Arb., 1985, p. 311.

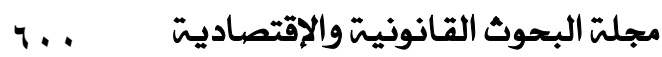


في المادة إ؟ أ مرافعات فرنسي، ولم ينص قانون التحكيم المصري علي هذا الأمر، إلا أن الفقه لا يمانع من قيام الهيئة بانتـاب أحدهم بالقيـام بـالإجراء. المحكم المنتدي

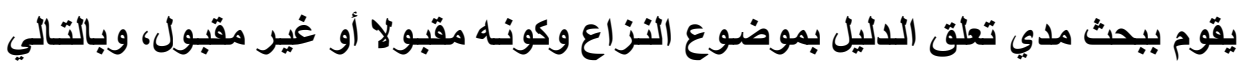
سقوط الحق في عرضه علي هيئة التحكيم بعد ذلك (مV V تحكيم) ويجوز له اصدار قرار مؤقت يمكنه من السير في إجراءات الإثبات إذا لم ير جديـة المنازعـة العارضـة، ويكون قراره واجب النفاذ، ويحق للخصم إعادة عرض هذه المسائل علي هيئة التحكيم بكامل

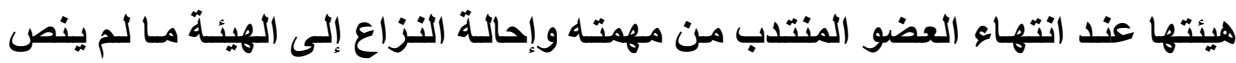
القانون علي غير ذلك (مV إثبات مصري).

ويحب علي العضو المنتدب بعد أن يتخذ الإجراء المطلوب أن يعرض علي بقية أعضاء هيئة التحكمي نتيجة عمله قبل إصدار قراره('). ويجب اطلاع الخصم الآخر علي ما تم من إجراءات وتمكينه من الرد، وإلا تعرض الحكم الصادر للبطلان. لإخلالهه بحقوق الدفاع.

وقد حكم بأنه لا تثريب علي المحكمين إذا انفرد أحد المحكمين ببعض إجراءات التحقيق بناء علي تفويض ضمني من هيئة التحكيم المشارك فيها، لأن مـا يسفر عنـه

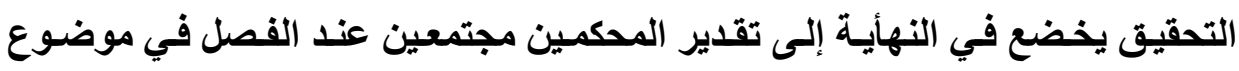

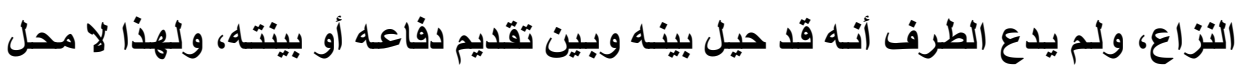
للقول ببطلان حكم التحكيم لهذا السبب(r). 
ويمكن لأحد أعضاء هيئة التحكيم القيـام ببعض إجراءات الإثبات منفردا في

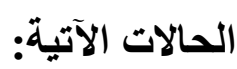

ا- إذا كان عقد التحكيم يجيز لأحد أعضاء الهيئة القيام بالإجراء بمفرده، وهذا مـا

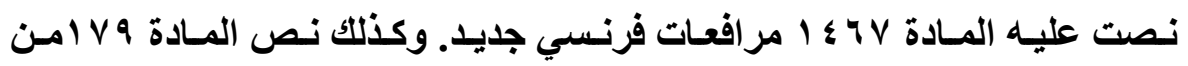
قانون المرافعات الكويتي. ولم ينص القانون المصري علي مثل هذه القاعدة. إلا أن

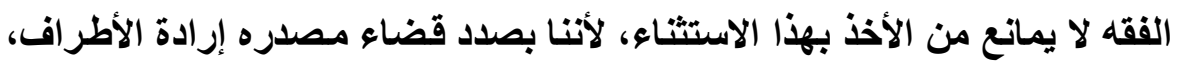

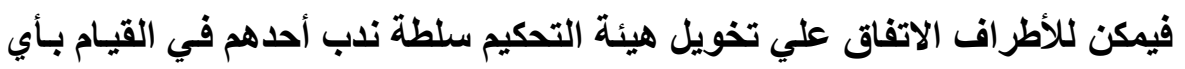

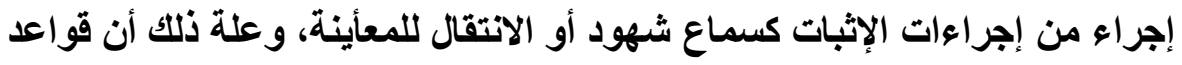

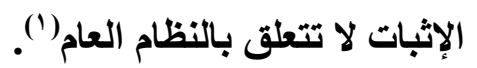
r- - إذا أجمع المحكمون علي ندب أحدهم لاتخاذ إجراء معين، وإثبات ندبه في محضر

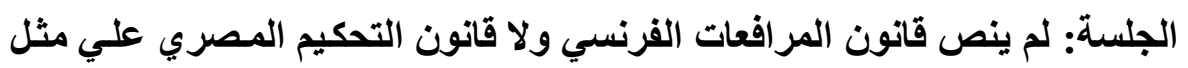

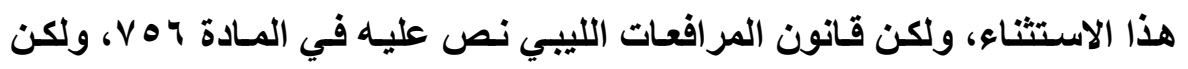

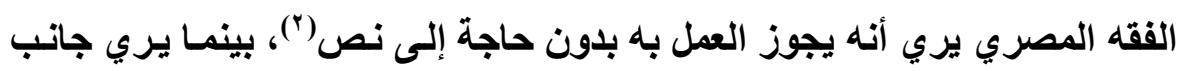

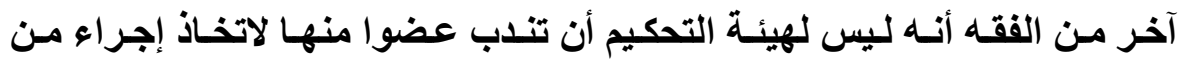

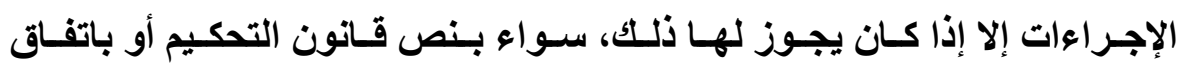

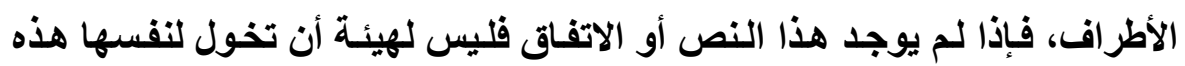

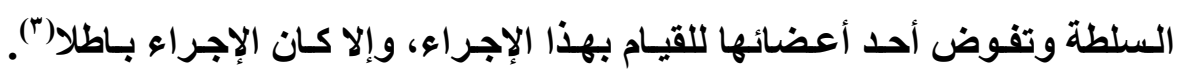

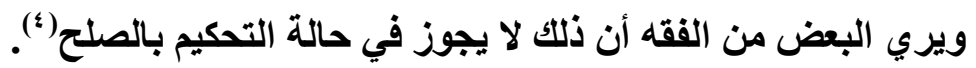

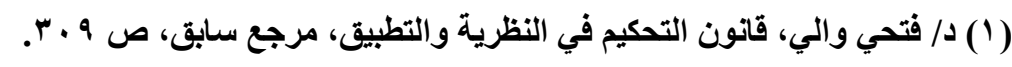

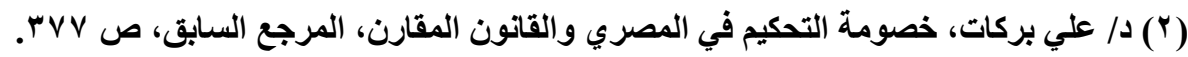

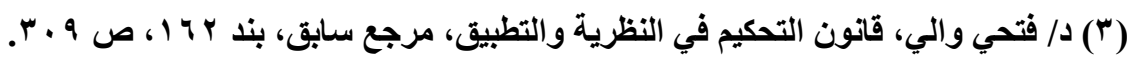

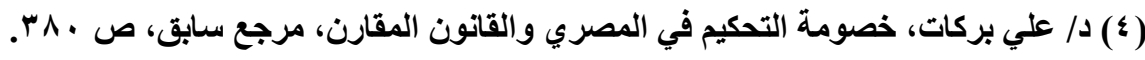


وبالنسبة للنظام الفرنسي فإذا لم يسمح اتفاق التحكيم بهذه الرخصة، وقامت

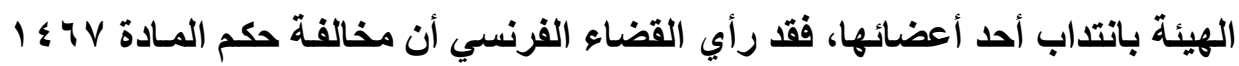

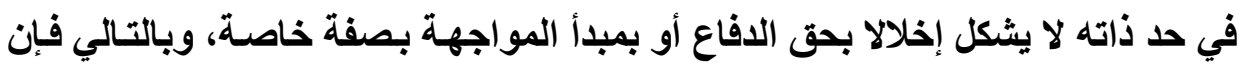

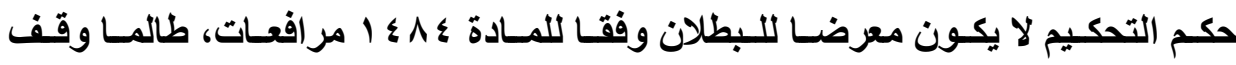

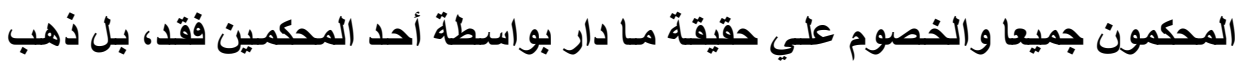

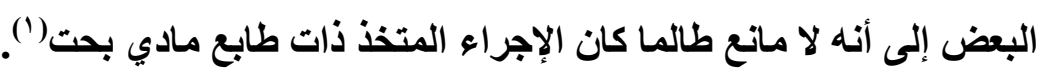

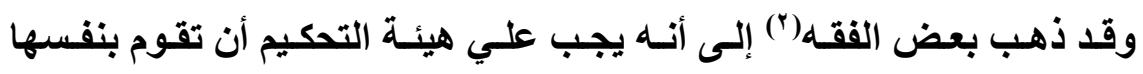

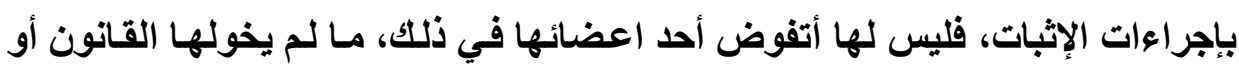

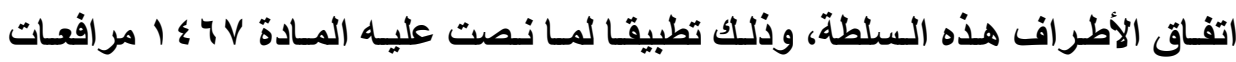

$$
\text { فرنسي. }
$$

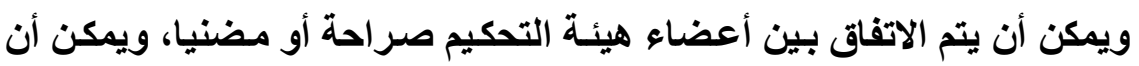

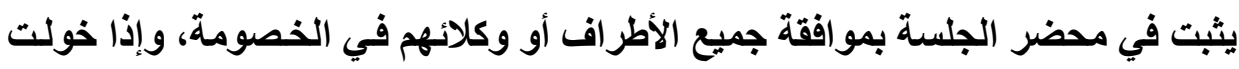

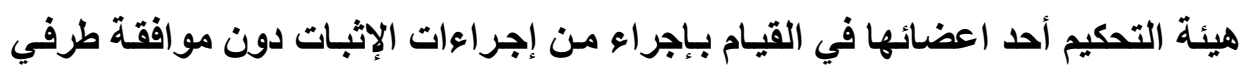

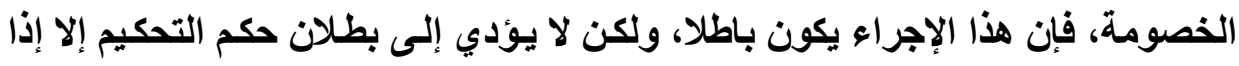

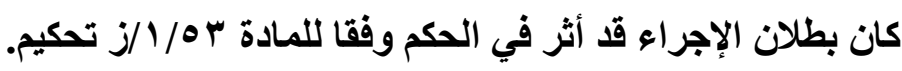
ويلاحظ أن عدم إطلاع المحكم المفوض بـالتحقيق لسائر المحكمين علي نتائج

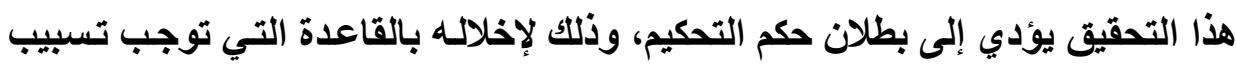
هذا القرار نظرا لأن هذا التسبيب لم يشر إلى نتائج هذا التحقيق الذي لم تطلـع عليه هيئة التحكيم.

(1) CA Paris, 26 avril 1985, Rev. Arb., 1985, p. 311. Note Mezger. (ץ) د/ فتحي والي، التحكيم في المنازعات الوطنية والتجارية الدولية، علمـا وعملا، المرجع السابق،

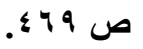




\section{الاطباب الرابع \\ التزام هيئة التهكيم بالهياد}

لا يجوز للمحكم كما هو الحال بالنسبة للقاضي التابع للاول أن يحكم بنـاء علي

معلوماته الشخصية في القضية، وهذه القاعدة هي تطبيق لمبدأ المواجهة(')، ويجب أن تراعي بالتـالي في كافة صورة وأشكال التحكيم. غير أنـه يجوز للمحكم الاستناد إلى مي معلوماته الشخصية المستقاة من خبرتـه في الشئون العامـة المفروض إلمامـه الكـافي بها (ن)

سنـشير إلـى المقصود بالحيـاد، وذلـك فـي الفـرع الأول، أمسام الفـرع الثـــي،

فيخصص للحياد الأيجابي لهيئة التحكيم، وذلك علي النحو التالي:

\section{الفرع الأول \\ المقصود بمياد هيئة التمكيم الهوليم}

فى الواقع ليس من السهل تعريف حياد المحكَّم(")، فحياد المحكَّم يتميز بالمرونـة كما أن صفة الحياد صفة متغيرة"(')، لكونها حاله ذهنية ونفسية لها طابع ذاتي شخصي أكثر مما هو موضوعي (r)

(1) CA Paris, 3 dec. 2002, op. cit., p. 931.

(ץ) د/ نبيل إسماعيل عمر، التحكيم في المواد المدنية والتجارية الوطنية والدولية،المرجع السباق، ص . r.

CA Paris, 3 dec. 2002, op. cit., p. 931. CA Paris, 24 oct. 1980, op. cit., p. 54, note fouchard.

(3) Ch. JARROSSON, la notion d'arbitrage, préface de B. OPPETIT, LGDJ, 1987, $n^{\circ}$ 451-477. 
وقد عبر البعض عن العياد بكونه التجرد فى العمل عن أى مصلحة ذاتية لـه أو

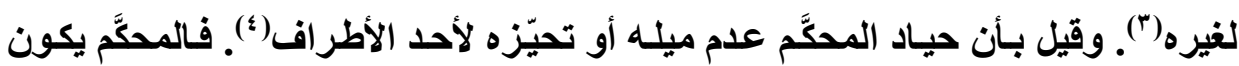
محأيدا إذا بحث النزاع دون تصور سابق تجاه موضوع النزاع(ه)، بل يبحث الموضوع

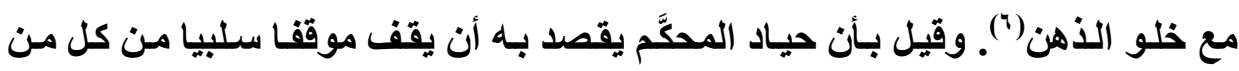
الخصوم على حـ سـواء(V)، وقيل إنـه التزام المحكَّم نطـاق الادعـاء سـبباً وموضوعاً وإثباتا كما قدّمسه الخصوم، وذهب البعض إلى أنسه مباشرة المحكَّم إجراعات التقاضسي ويصدر حكمه دون تحيز لخصم أو ضد خصم تأثرا باعتبارات غير موضوعية(^). فعدم الحيدة هى حالة نفسية تتعلق بالعاطقة (مصلحة شخصية أو صلة مودة أو عدأوة بأحد

(1) J. VIATTE, «la récusation des arbitres», Gaz. pal, 1973, 2, doctr., 719; T. Clay, L'arbitre, op. cit., p 234.

(2) CA Paris, 20 novembre 1997,op. cit., p. 329 ; M. HENRY, «les obligations d'indépendance et l'information de l'arbitre à la lumière de la jusprudence récente», op. cit., p.193 spéc. P. 195.

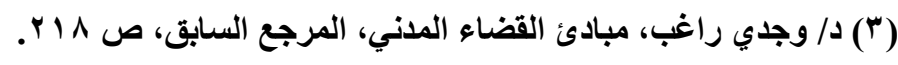

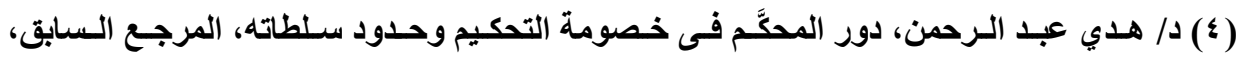

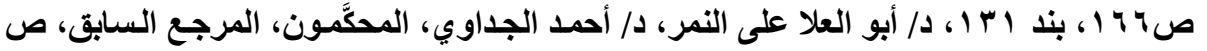

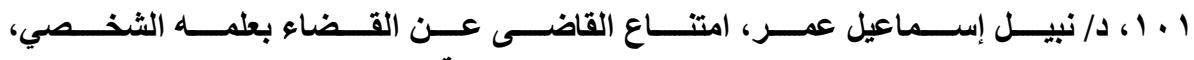

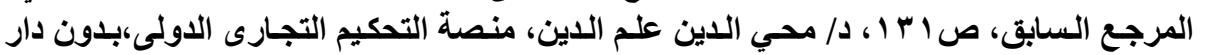

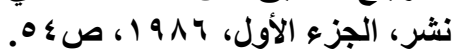

(5) T. Clay, L'arbitre, op. cit., p. 241.

(6) P. LALIVE " sur l'impartialité de l'arbitre international en suisse' semaine judiciaire, 1990, p. 3- 64.

(7) P. AZARD, l'immutabilité de la demande en droit judiciaire français, thèse, Paris, 1936, p. 148.

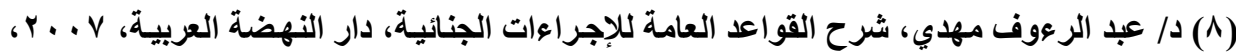


الخصوم) يرجح معها عدم استطاعة المحكَّم الحكم بغير تحيز (')، وقيل إنـه ألا تكون لـه عند مباشرته وظيفته مصلحة ذاتية قد يميل إليها وتؤثر فى تقديره على نحو أو على آخر على حساب التطبيق الموضوعى المتجرد لإرادة القانون(؟).

ونري أن الحياد يعنى تجرد المحكَّم من أية ضغوط خارجية تمليها عليه مشاعره الخاصة (ضغوط معنوية) أو المصلحة المادية الذاتية (ضغوط مادية) التي تحيد بـه عن التطبيق القانونى الصحيح. فالحيدة هى عدم انحياز المحكَّم إلى أى من طرفى التحكيم أو ضـده لأسـباب شخصية أو أسباب خاصـة، وإنمـا يلتزم أن يكون عـادلاً بـين الطرفين متجردا عن كل ما ينأى عن اعتبارات العدالة("). وقد ذهبت محكمة استئناف القاهرة إلى أن عدم الحيدة عبارة عن "ميل نفس أو ذهنى للمحكَّم يكون لصالح أو ضد أحد أطراف النزاع أو الغير أو الدولـة، بحيث يرجح معه عدم استطاعته الحكم بغير ميل لأحد ممن ذكروا ضده"(؛). والواقـع أن الحيـاد يـرتبط باسـتقلال المحكَّم، وهـو ألا توجـــ للمحكَّم صــلة أو مصلحة بموضوع النزاع أو ارتباطات بأحد الأطراف أو ممثليهم(*)، وأن مـا ينتهى إليه

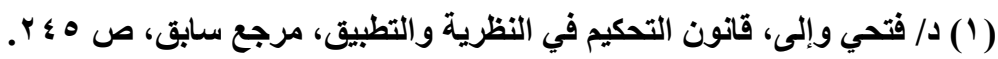

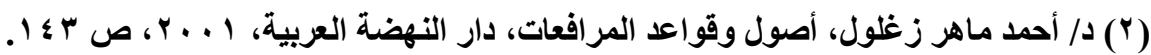

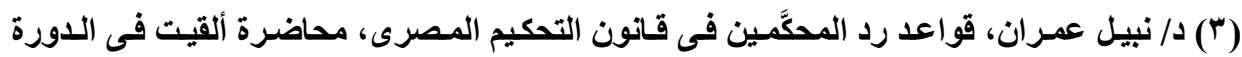

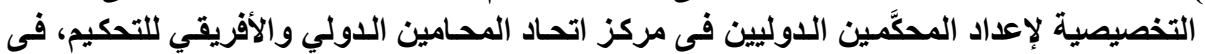

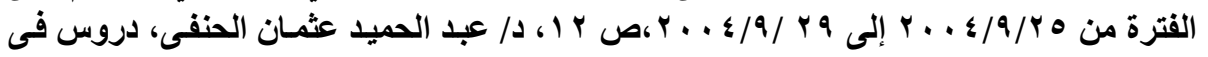

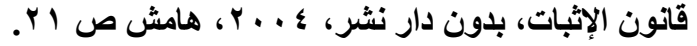

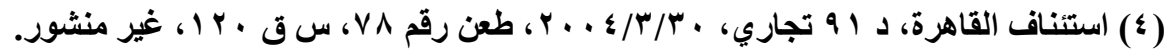

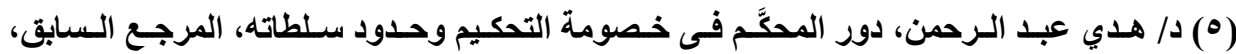


من رأى فهو غير متأثر فيه بعلاقة تربطه بأحد الطرفين(') سواء أكانت علاقة مالية أم

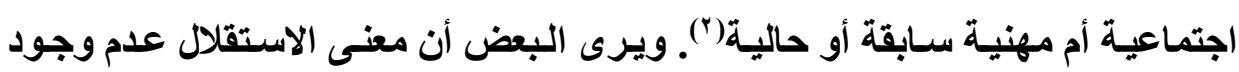
مصلحة أو ارتباط أو تبعية من جاتب المحكَّم بـأى من طرفى التحكيم("). وحتى يكون

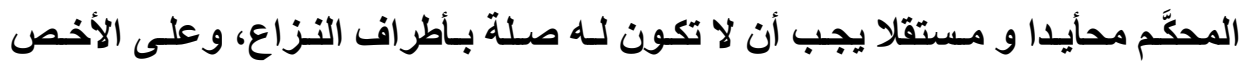
الطرف الأى شارك فى تعيينه(؛)، فلا يكون تابعا لأحدهم(0).

في الواقـع حيـاد واسـتقلال هيــة التحكيم يعــ روح التحكيم وجـوهر العدالـة

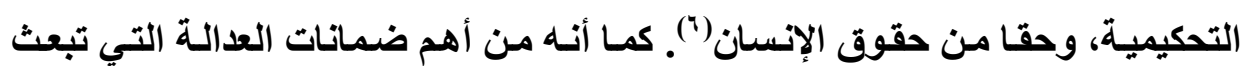
الاطمئنـان في نفوس المتقاضين(v)، لأن المحكم لـن يصدر حكمـه متـأثرًا باعتبـارات شخصية أو ضغوط خارجية، ولهذا يعد مبدأ حياد المحكم في النظم الحديثة من المبادئ

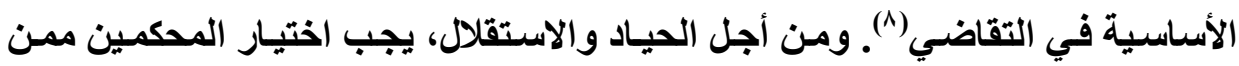
تتوافر فيهم صفات الوعي والثجاعة والموضوعية والإنسانية والمعرفة والتعالي علي

(1) CA Paris, 28 octobre 1999, Rev. Arb., 2000, p. 299, note ph. GRADJEAU; CA Paris, 20 novembre 1997, op. cit., p. 329.

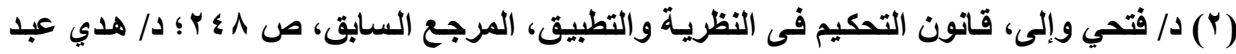

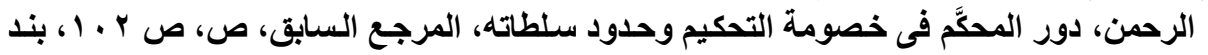

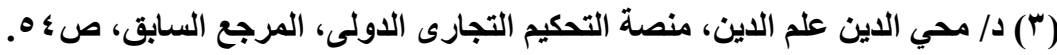

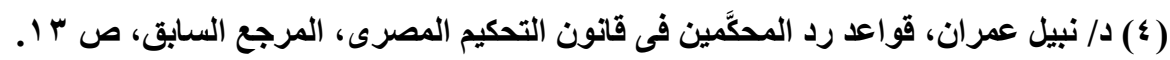

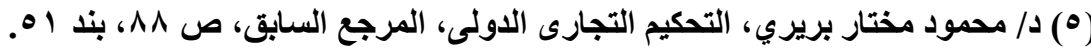

(6) Cass., 2e civ., 27 mai 2004, Recueil Dalloz, 2004 p. 1863.

(7) R. De GOUTTES, "L'impartialité du juge", Revue de science criminelle, 2003, p. 63.

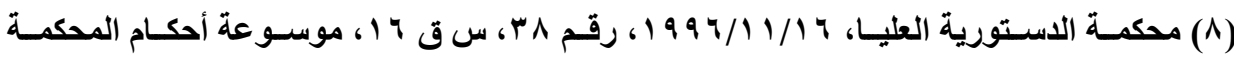

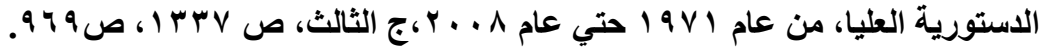


الأهواء والذات، لأن هذه الصفات هي المستلزمات الأساسية للححكم العادل الجدير بالثقة والحكم وفقا لمقتضيات العدالة.

ويري البعض أن حياد المحكم وإن كان أمرا مرغوبـا فيه، إلا أنه يجب التسليم

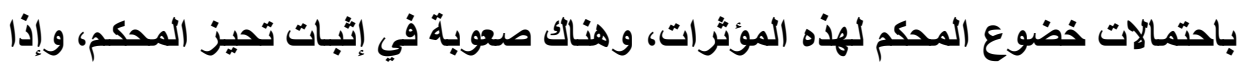

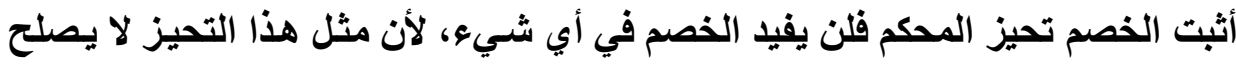

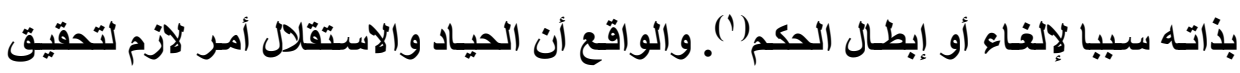

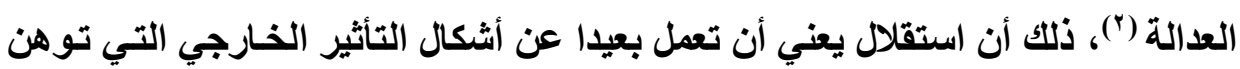
عزائم رجالها، فيميلون معا عن الحق إغواءو وإرغامسا، ترغيبا أو ترهيبا، فِإذا كـان

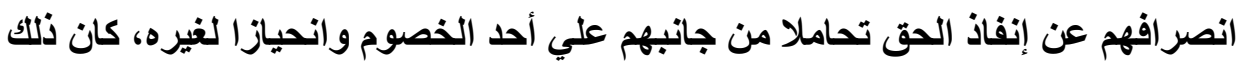
منافيًا لضمانة الحياد أثناء الفصل في الخصومة.

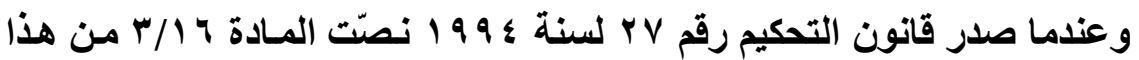

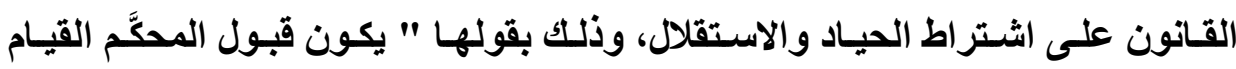
بمهيته كتابة، ويجب عليه أن يفصح عند قبوله عن أية ظروف من شأنها إثارة شكوك

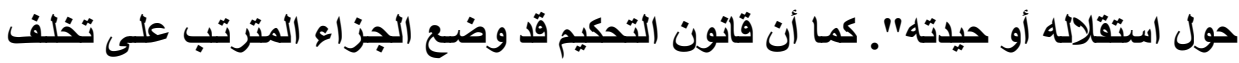

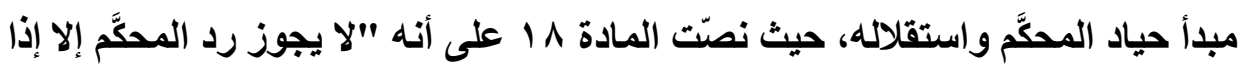
قامت ظروف تثير شكوكا جدية حول حيدته أو استقلاله.

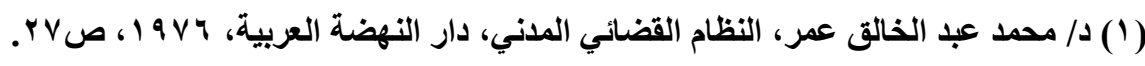

(2) S. JOSSERAND, L'impartialité du magistrat en procédure pénale, préface de J. FRANCILLON, L.G.D.J., 1998, n $^{\circ}$ 128, p. 133 ; M-A. FRISON-ROCHE, «l'impartialité du juge», Recueil Dalloz, 1999, chronique p. 53, ${ }^{\circ} 12$. 
وقد ذهبت محكمة استئناف القاهرة إلى أن "الحيدة التى هى جوهر الاستقلال ليست حكرا على العمل القضائى بل هى لازمة كذلك فى العمل التحكيمى لأن المحكَّم وإن

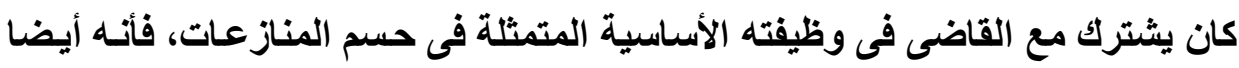
يتبع المنهج القضائى فى مراعاة الضمانات الأساسية للتقاضى عند تحقيق الادّعاءات ونظر الطلبات وأسلوب فض المنازعة سواء بهذف إنزال حكم القانون عليها أو إجراء تسوية وفقا لقواعد العدالة والإنصاف. فطبيعة مهمة المحكَّم ذات طابع موضوعى غير

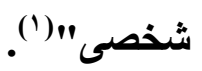
وفـى حكـم آخـر ذهبـت محكمـة اسـتئناف القـاهرة إلـى أن "اشـتراط الحيـدة والاستقلال باعتبار هما ضمانتين أساسيتين للتقاضىـ قاعدة مجمـع عليها، بل وتنص عليهـا غالبيـة النظم القانونيـة للدول والاتفاقيـات الدوليـة للتحكيم فضلا عن اللـوائح

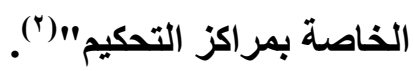
وقد ذهبت المحكمة الدستورية العليا إلى أن استقلال السلطة القضائية، وحيدة قضاتها ضمانتان تنصبان معًا علي إدارة العدالة بمـا يكفل فعاليتها، وهمـا بـذلك أمران متلازمان، والواقع أن الخصومة القضائية لا يستقيم الفصل فيها حقًا وعدلا إذا خالطتها عوامل تؤثر في موضوعية القرار الصادر بشأنها، فقد صسار أمرًا مقضيًا أن تتعادل

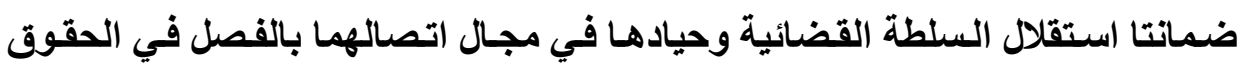
انتصافا، لتكون لهما معًا القيمة الاستورية ذاتها، فلا تعلو أحداهما علـي الآخرى أو تجبها، بل تتضامان تكاملاً، وتتكافآن قدرًا"(")

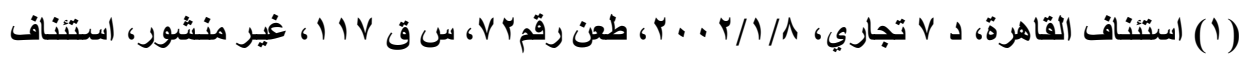

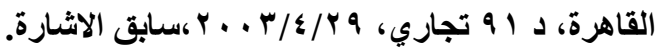

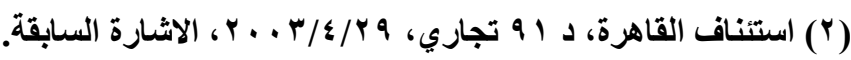

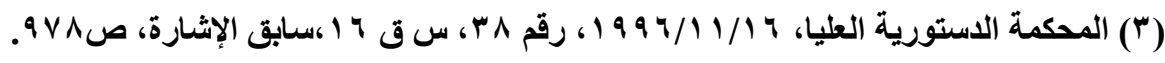


في الواقع تنص معظم التشريعات الوطنية والاتفاقيـات الدولية ولوائح هيئات ومراكز التحكيم على ضرورة تـوافر حيـاد المحكَّم واستقلاله، وإن كسان الملاحظ فى

قوانين التحكيم الدولية مرور المشرع بجاتب هذا الموضوع دون تأكيا وإشـارة واضحة إليه، بينما فى قوانين التحكيم الاخلية هناك تأكيد صريح على أن المحكَّم يجب أن يكون مستقلا وحياديا"') فقد نصت المادة به ؛ ا من قانون المرافعات الفرنسى الجديد على إلزام المحكَّم بـأن يفصح عنــ قبولـه عن أيـة ظروف مـن شــأنها إثـارة شـكوك حول استقلاله أو حيدته. وأكََّّ القضاء الفرنسى على وجوب حياد واستقلال جميع المحكَّمين، بل اعتبرها صفة أساسية لكل من يمارس مهنة القضاء سواء كان قاضيا أو محكما"(َ) علي الرغم من أن المشرع الفرنسى لم يشر إلى استقلال وحيـاد المحكَّم فى التحكيم الدولى، فقد حرص القضاء(") الفرنسى على ضرورة توافر الحياد والاستقلال، سواء

(1) J. L. DELVOLVE, " devoirs et responsabilités de l'avocat exerçant la fanction d arbitres", Rev. arb., 1984, p. 435; Ph. FOUCHARD, E. GAILLARD et B. GOLDMAN, traite de l'arbitrage commercial international, op. cit., p. 592, no 1045.

(2) La Cour de cassation a dispose que "l'independence d'esprit est indispensable à l'exercice du pouvoir jurisdictionel quelle qu'en soit la source, qu elle est l'une des qualité essentielle des arbitres." Cass. 2 civ., 13 avril 1972, Bull. civ., 11, $\mathrm{n}^{\circ} 91$, Rev. arb., 1975, p. 235, note $\mathrm{E}$. LOQUIN ; D. com, 1973, 2, note J. ROBERT ; JCP, 1971, II, 17189, note P. LEVEL ; RTD civ., 1973, p. 769, obs. Y. LOUSSIUAR; CA Paris, 2 juin 1990, Rev. Arb., 1991, p. 87, obs. Cl. REYMOND; CA Paris, 28 juin 1991, Rev. arb., 1992, p. 568, note P. BELLET; CA Paris, 12 décembre 1996, Rev. arb., 1998, p. 699, note D. B.

(3) CA Paris, 8 juin 1972, Rev. arb., 1973, p. 38, note J. RUBELLINDEVICHI; Cass. 2e civ. 20 février 1974, Rev. arb., 1975, p. 238; TGI Paris, 28 octobre 1988 et 29 juin 1989, Rev. arb., 1990, p. 497, obs. M. de BOISSESON; TGI Paris, ref., 22 mars 1983 Rev. arb, 1983, p. 479, note $=$ 
كـان التحكيم داخليا أم دوليا. وقد استقر القضاء الفرنسى على وجوب حياد المحكَّم واستقلاله فى التحكيم الدولى (')

وقد استوجب القانون الإتجليزى للتحكيم الصادر فى V مأيو 99 و ا ضرورة

تــوافر شـرط الحيـاد والاســقلال بالنسبسة للمحكمسين باعتبـاره مسن المبـادئ العامـة

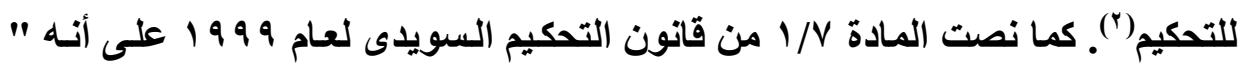
يجب أن يكون المحكَّم محأيدا". وذهبت العديد من القوانين فى هذا الاتجـاه، مثل قانون التحكيم الدولى فى البحرين. أمسا قانون الإمـارات العربية المتحدة فاشترط فئ المحكَّم الثروط المستوجبة فى القاضى("). كما اشترط القانون التونسى فى المحكَّم الاستقلالية والحياد(؛). ونص القانون الفيار إلى فى الولأيـات المتحدة على أن يكون كل المحكَّمين مستقلين وحياديين، وأن المحكَّمين الذين يختارهم كل طرف يجب ألا يعتبروا أنفسهم ممثلين لهذا الطرف أو محامين له، وبمجرد تسميتهم يجب أن ينهوا أى ارتباط مع الذى لى سمّاهم إذا كان ثمة ارتباط سابق.

B. MOREAU; TGI Paris, ref., 21 septembre 1989, Rev. arb., 1990, p. 176, note Ph. KAHN; M. HENRY, " Les obligations d'indépendance et d'information de l'arbitre a la lumière de la jurisprudence récente", op. cit., p. 194, spec. p. 196.

(1) CA Paris, 8 juin 1982, Rev. arb., 1983, p. 38; TGL Paris, ref, 22 mars 1983, op. cit., p. 479, note B. MOREAU.

(2) Loi anglaise sur l'arbitrage du 17 juin 1996 (1re art.), sur cette question v. V. VEEDER «la nouvelle loi anglaise sur l'arbitrage de 1996, la naissance d'un magnifique éléphant», Rev. arb. 1997, p. 3, sép. 9et 15.

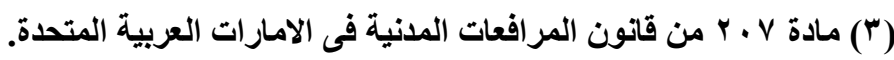

$$
\begin{aligned}
& \text { (\&) مادة Vo من قانون التحكيم التونسي. }
\end{aligned}
$$


وقد نص القانون النموذجى للتحكيم التجارى اللدولى على اشتراط تمتع جميع

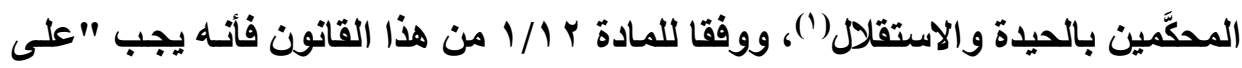
الشخص حين يطالب بتعيينه محكَّمـا أن يصرّح بكل الظروف التى من شـأنها أن تثير شكوكا لها ما يبررها حول حيدته واستقلاله، و على المحكَّم منذ تعيينه وطوال إجراءات التحكيم، أن يفضى بلا إبطاء إلى طرفى النزاع بوجود أى ظروف من هذا القبيل، إلا إذا

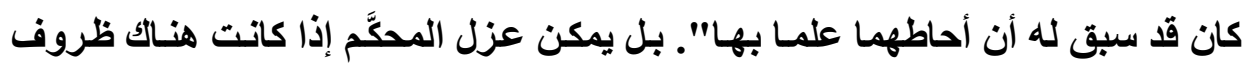
تثير شكا حول حياده واستقلاله. وبالنسبة للاتفاقيات الدولية نجد أن اتفاقية واشنطن

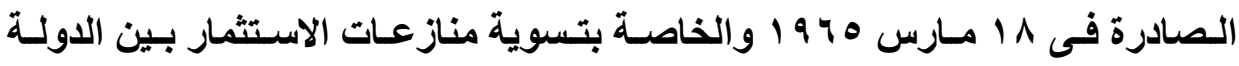
ومواطنى الاول الآخرى والتى اعتمدت نظـام اللانحسة لاختيـار المحكَّمين قد نصّت فى لى

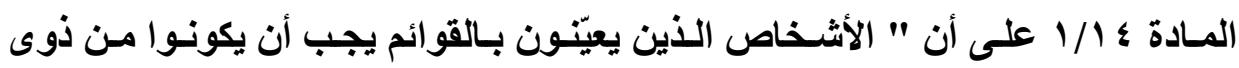
الأخلاق العالية ويكون مسلما بمقدرتهم فى ميادين القانون أو التجارة أو الصناعة أو لون

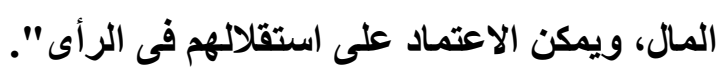

بل إن بعض الاتفاقيات تجعل مبدأ الاستقلال مبدأ مقدسا يتعين الحلف بـالاكتزام

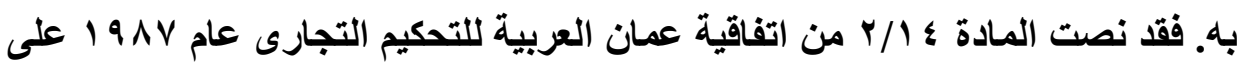
أن " يـؤدى المحكَّمون قبـل مباشـرة مهامهم اليمين أمسام رئيس المركز أو مـن ينيبـه (اقسم بالله العظيم أن أحكم بالعدل وأن أرعى القانون الواجب التطبيق، وأؤدى مهمتى

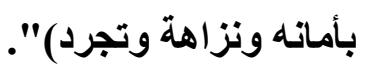

وقد حرصت لـوائح هيئسات ومراكز التحكيم على اشتراط ضرورة توافر حياد

واستقلال المحكَّمين، نذكر منها على الأخص، نظام التحكيم والمصالحة لغرفة التجارة

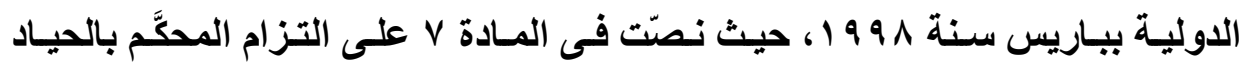


والاستقلال وأن يؤكد استقلاله قبل تعيينه. وبل تذهب إلى أبعد من ذلك إلى إجازة عزل

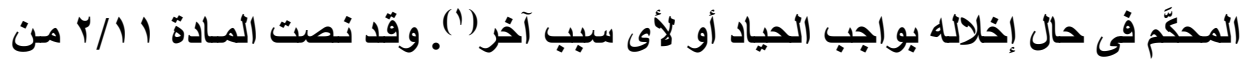

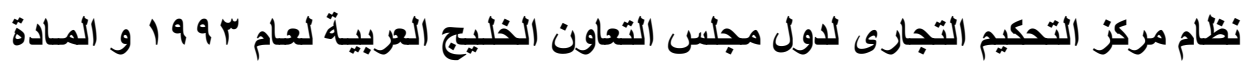

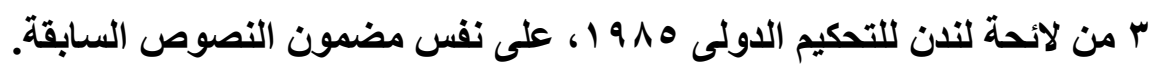

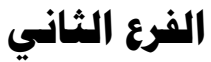 \\ الحياد الأيجابي اهيئة التمكيم في الإثبات}

اذا كان حياد القاضي لم يعد يملي عليه ضرورة الالتزام بالسلبية المطلقة(') إزاء

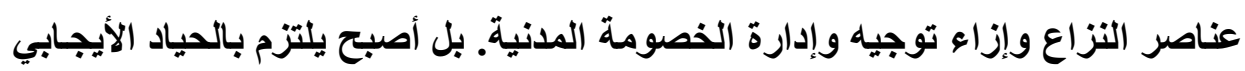

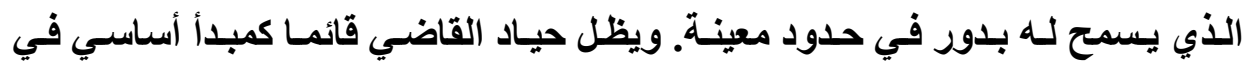

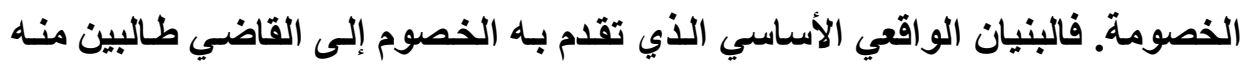

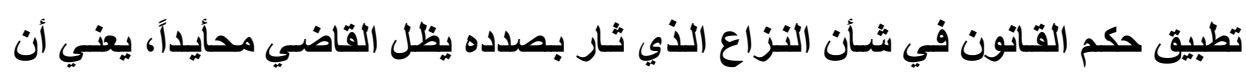
عبء الادعاء والإثبات يقعان علي الخصوم بشكل مباثر، وفي الحدود التي رسمها

(1) مادة r من نظام غرفة التجارة الدولية بباريس.

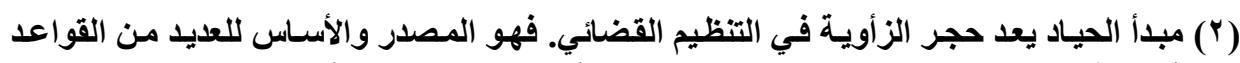

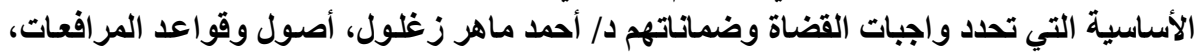

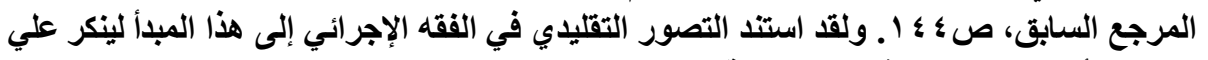

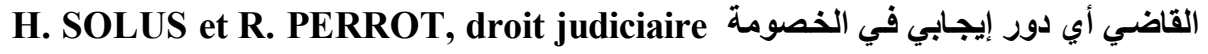
prive, t1, 1961, p. 286.

فالقاعدة وفقا لهذا التصور هي أن السيادة علي الخصومة للخصوم أنفسهم، فنشأتها ومباثرتها

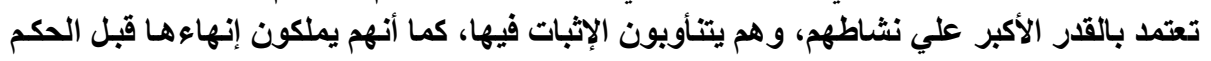

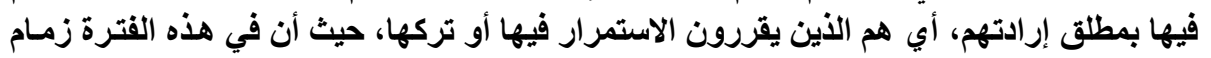

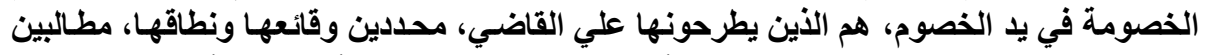
بما يرغبون من حقوق، وبالتالي سـاد مبدأ المذهب الفردي وعلي الفي الأخص مبدأ سيادة الخصوم

.NORMAND, le juge et le litige; thèse, lille, 1965, p. 30. 
القـانون. ويقع علـي القاضـي عبء تقـدير الأدلـة، وإعطـاء الوصف القـانوني للنـزاع وتطبيق القانون عليه. ويرجع ذلك إلى أنه في ظل النظم القانونية الحديثة تتسع فكرة النظام العـام، وتؤدي إلى الاعتر اف للقاضـي بسلطات واسعة في الخصومة التصة المدنيـة، سواء في مجال الإثبات وإجراءات التحقيق وطلب تكملة وقائع النزاع. وفي الواقع حياد

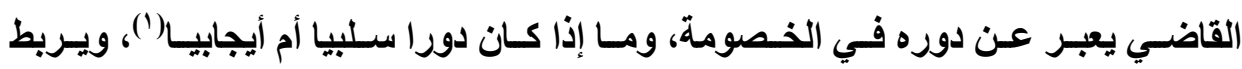
بمجموعة الأفكار القانونية التي تسود بلدًا مـا في زمـان مـا. فقد ظهر اتجاه يساند العيـاد المطلق للقاضي، ودوره السلبي في الخصومة المدنية، واتجـاه ثـان يري الحيـاد الأيجابي للقاضـي في الخصومة المدنية، وقد اتبع المشرع الفرنسي والمصري موقفـا وسطا من هذه الاتجاهات. وقد انتقد الققه الحديث نظريـة الحيـاد المطلق للقاضـي(r)، حيث بـأت الأفكار القانونية والاقتصادية تبتعد في فترات معينة عن المذهب الفردي وتميل إلى المذهب الاشتر اكي، وقد انعكس كل ذلك علي فكرة الحقوق الخاصـة، حيث نظر إليها علي أنها محملـة بوظيفـة اجتماعيـة يتعين أن تؤديهـا ليس لـصالح صـاحبها فقط و إنمـا لصالح المجتمع. ومن هنا تظهر الوظيفة الاجتماعية للحقوق والمراكز القانونية("). وأخذ مبدأ الحياد الأيجابي للقاضـي في الظهور، وذلك لأنها يؤدي إلى تحقيق العدالة)(؛)، حيث إن وظيفة شاغلي القضاء في المقام الأول هي إقامة العدل الاجتمـاعي،

(1) د/ طلعت محمد دويدار، تطور الحمايـة التشريعية لمبدأ حيدة القضاة،، دار الجامعة الجديدة،

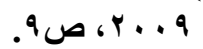

(2) SOLUS H. et PERROT R., droit judiciaire prive, , op.cit., p. 285.

(3) ANDRE, Du principe de la neutralité du juge dans l'instruction des affaires civiles, Paris, 1910, p. 14.

(4) SOLUS H. et PERROT R., droit judiciaire prive, op.cit., p. 285 
ولا يقتصر فقط علي تحقيق العدل الفردي، وهذه الأفكار أثرت علي مضمون الحياد

(التقليدي للقاضي( ')

ونري أن حياد هيئة التحكيم كما هو الثأن بالنسبة للقاضي، حياد إيجابي، فهي

التي تتولي مسائل الإثبات، وتقدر الأدلة، وتعطي الوصف القانوني للنزاع. ويتمتع المحكَّم فى ظل نظام التحكيم المصرى والفرنسى بسلطات قضائية، تبدأ من الفصل فى الافع بعدم الاختصاص أو الدفوع المتعلقة بموضوع النزاع، واتخاذ إجراءات الإثبات، وتنتهى بإصدار حكم التحكيم وتفسيره وتصحيحه. وكان لابل من تطلب بعض الضمانات

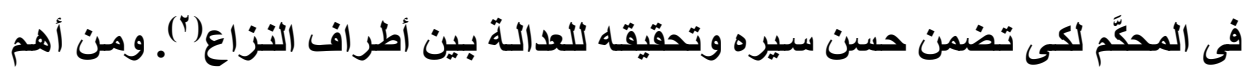
الضمانات الواجب توافرهـا فى المحكَّم الحيدة والاستقلال عن أطراف النزاع. وهذه الحيدة لا تقتضتي أن يكون سلبيا، ولكن حياد إيجابي للبحث عن العدالة.

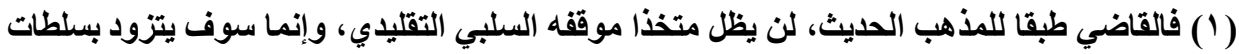

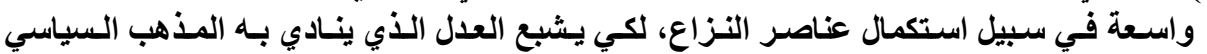

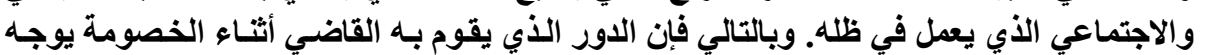

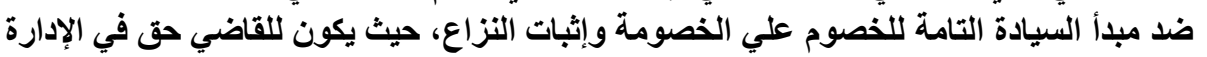

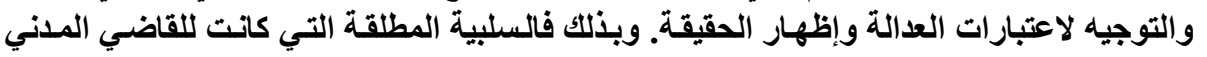

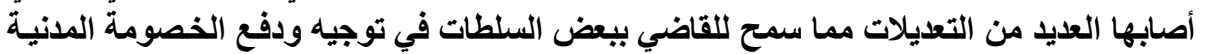

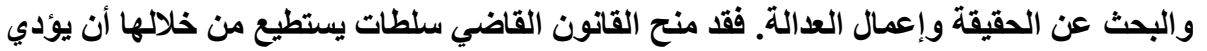

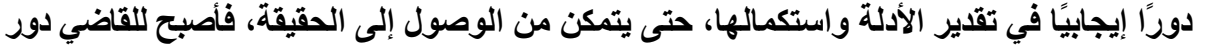

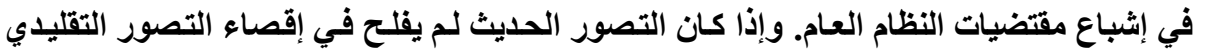

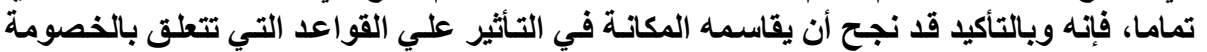

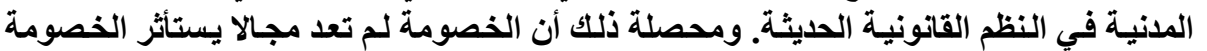

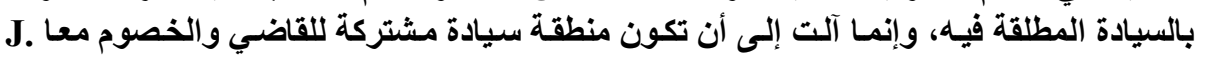

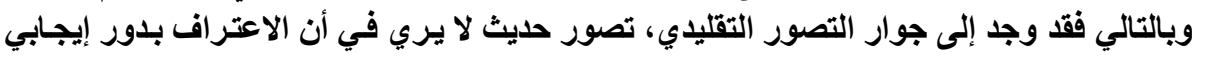
للقاضي في تسيير الخصومة وتوجيهها ما يخل بحياده.

VINCENT S. GUINCHARD, procédure civile, op. cit., $n^{\circ} 378$.

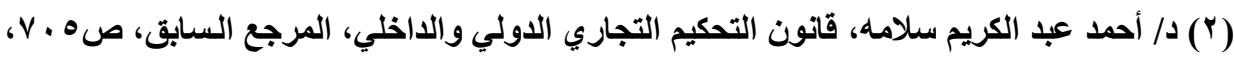


ومـع ذلـك تلتزم هيئة التحكيم الحيـاد اتجـاه صـفة أطراف التحكيم وطلبـات الخصوم، فلا يجوز لها أن تقضي للخصم بغير ما طلبه. كما لا يجوز لها أن تقضي بمـا طلبه في مواجهة شخص آخر لـم يختصم في اللاعوي. ويعبر عن ذلك بـأن للاعوي التحكيمية قيدين يقيدان سلطة هيئة التحكيم، أحدهما شخصي، والآخر عينـي. ويلاحظ أنه تلتزم هيئة التحكيم بالإضافة إلى تقيدها بالوقائع تتقيد بالأشخاص المرفوعة عليهم الاعوي. فلا يجوز لها إدخال أشخاص آخرين حتي ولو استبان من التحقيقات والمرافعة أن هناتك أشخاص آخرين يجب إدخالهم في الدعوي. وكل ما تملكه المحكمة في مثل هذه الفروض هو أن تلفت نظر الخصوم إلى ضرورة ادخـال اشخاص اخرين وذلك لتعديل اتفاق التحكيم. ويلاحظ أن الإثبات في موضوع الدعوي لابد وأن يكون مرتبطا بالطلبات التي رفعت بها والتي يتضمنها اتفاق التحكيم، ولا يجاوزها إلى غيرها، وهذه الطلبات تتحدد بالوقائع المرفوعة عنها الدعوي. فيجب التزام هيئة التحكيم بالوقائع ولا تتجأوزهـا إلى غيرها حيث تتحدد بما هو ثابت باتفاق التحكيم. بـان وإذا تجاوزت هيئة التحكيم هذا القيد وحكمت في واقعة لـم ترد باتفـاق التحكيم أو طلبات الخصوم، فأنها تكون قد اخطأث القانون في أمرين: 1 ـ أنها أضافت علي نفسها سلطة مخولة لأطر اف اتفاق التحكيم في تحديد الوقائع التي يتضمنها الاتفاق. r- أنها فصلت في غير ما طلبة الخصم رافع الدعوي. ولا يؤثر في ذلك أن تكون الوقائع الجديدة واضحة من الأوراق ولم تسع إليها

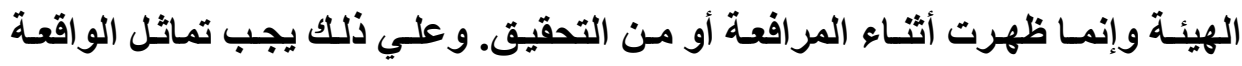

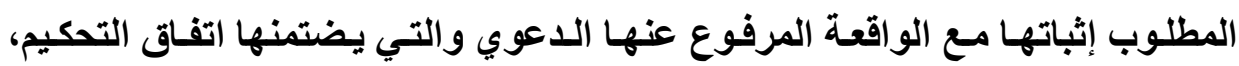


ويتحقق هذا التماثل اذا كاتت الواقعة التي أثبتتها الهيئة تملك ذات المقومـات المادية و المعنوية التي يتكون منها الو اقعة محل اتفاق الأطراف في اتفاق التحكير.

ويثور التساؤل حول مدي سلطة هيئة التحكيم في استبعاد عنصر من عناصر

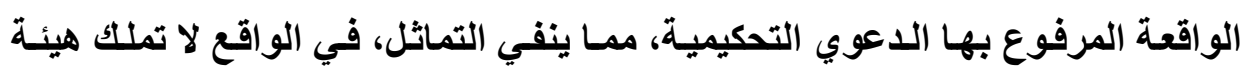

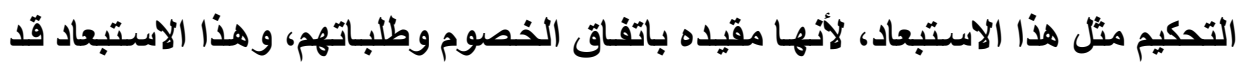

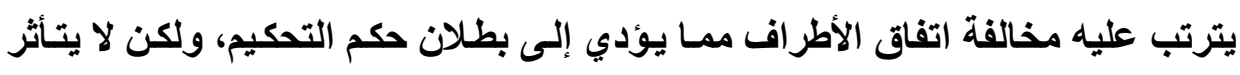

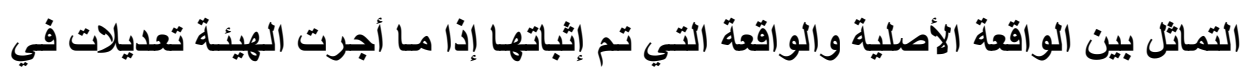

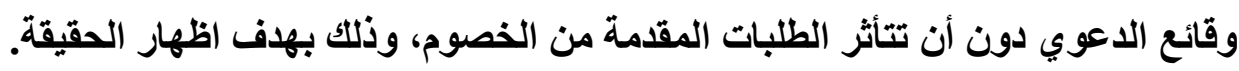
والواقع أن للحكم دوراً أيجابياً في الخصومه التحكيمية، ويتمثل ذلك في الآتي:

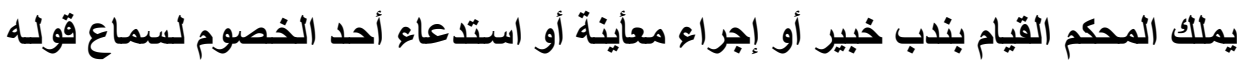

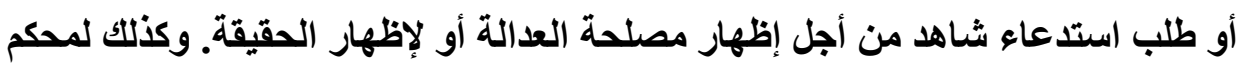

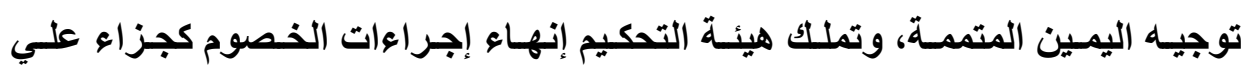

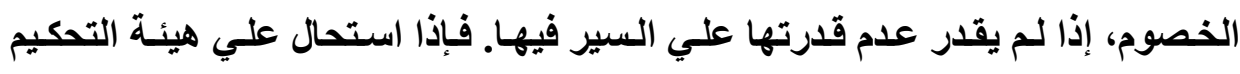

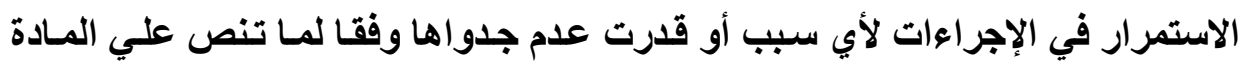

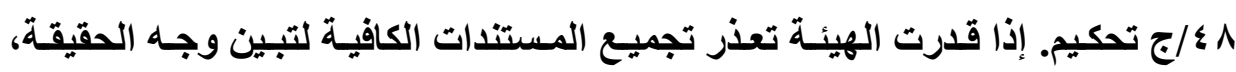

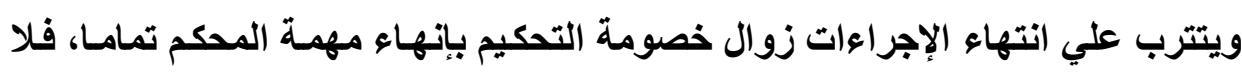

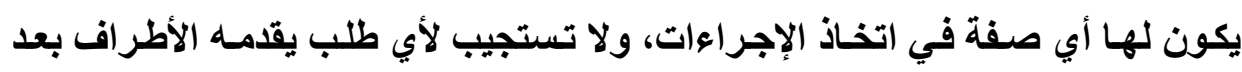
صدوره قرارها باتتهاء الإجراءات.

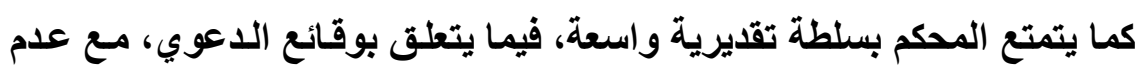

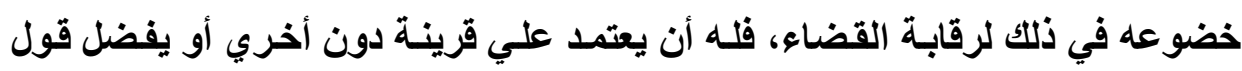

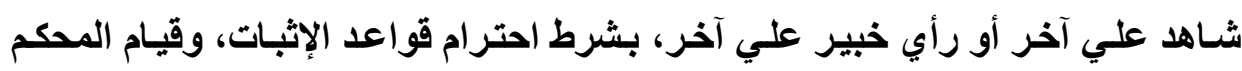

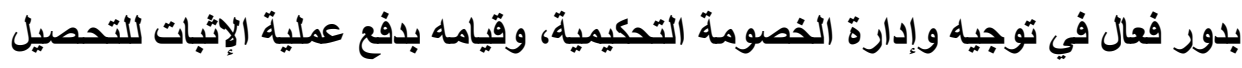

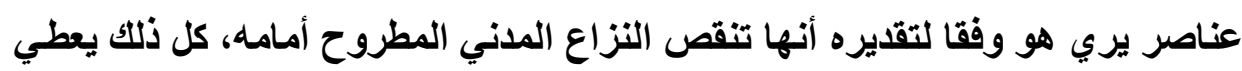
لمبدأ حياد المحكم لونا جليدا ينحو به نحو الفاعلية بلا من السلبية الكاملة. 


\section{المبحث الثاني \\ الرقابة علي سلطة هيئة التمكيم في الإثبات}

إذا كانت لهيئة التحكيم سلطة تقديرية في الإثبات، إلا أن هذه السلطة يرد عليها

بعض القيود التي تتعلق بحقوق الدفاع ومبدأ المواجهة والمساواة بين الخصوم، وكذلك التزام الهيئة بالحياد والتحقيق الجماعي.

والواقع أن وجود سلطة بلا رقابة يؤدي إلى التحكيم والتعسف في استخدام هذه

السلطة، ومن هذا المنطلق نظم المشرع رقابة للقضاء علي سلطة هيئة التحكيم، وذلك إنك عن طريق دعوي البطلان، وقد أخذت بعض الأنظمـة بنظام الطعن بالاستئناف ودعوي البطلان كما هو الثأن في النظام الفرنسي. وسنشير في هذا المبحث إلى سلطة القضاء في الرقابة علي هيئة التحكيم، وذلك

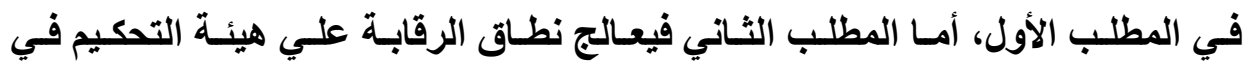
الإثبات، وذلك علي النحو التالي:

\section{المطلب الأول \\ سلطة القضاء في الرقابة علي هيئة التمكيم}

سنشير إلى طرق الرقابة علي حكم التحكيم، وذلك في الفرع الأول، أمـا الفرع الثاني، فيخصص لبيان إجراعات الرقابة علي هيئة التحكيم. 


\section{الفرع الأول \\ طرق الرقابة علي حكم التمكيم}

تقتضي العدالة أن يمنح المحكوم عليه الفرصة لإعادة النظر في الحكم الصادر

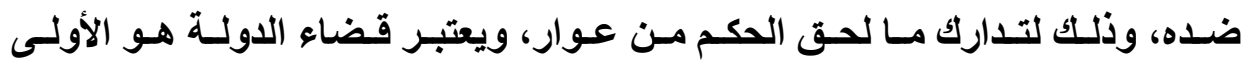

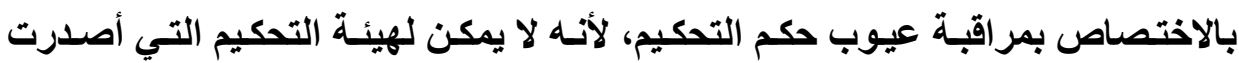
الحكم أن تراقب عيوب الحكم الصادر منها، ولا يمكن عمل هيئة تحكيم عليا للطعن أمامها فى الحكم الصادر، لأن في ذلك تكلقة للخصوم، وبالإضافة إلى أن قضاء الدولة لا يراقب عدالة الحكم إنما يراجع حالات في أغلبها شكلية أو متعلقة بالنظام العام. ونظرا لطبيعة التحكيم التي لا تتفق مع طرق الطعن المنصوص عليها ضد أحكام القضاء، فقد نص قانون التحكيم المصري فى المادة به على أن لا تقبل أحكام التحكيم

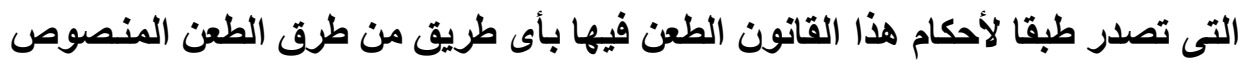

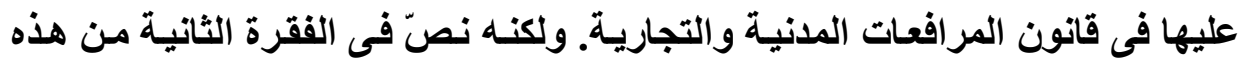
المادة على أنه يجوز رفع دعوى بطلان حكم التحكيم وفقـا للأحكام المبينـة فى المـادتين التاليتين (به و ع ه من قانون التحكيم).

وتعتبر دعوى البطلان طريقا خاصسا للاعتر اض على أحكام التحكيم ولا يمكن استخدامها ضد الأحكام القضائية(') بصفة عامـة. فالهـف من الاعتر اض على أحكى أحكام المحكَّمين بطريق البطلان الوصول إلى تقرير بطلان الدكم(؟). وطريق البطلان ضد حكم

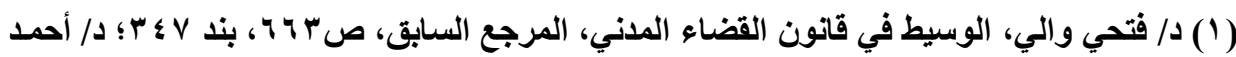

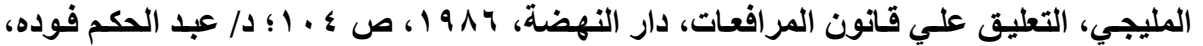

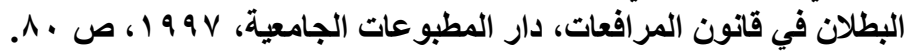

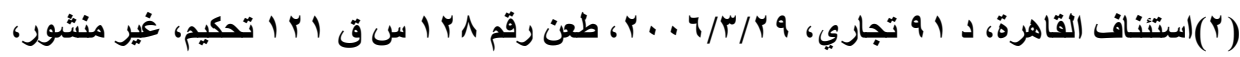

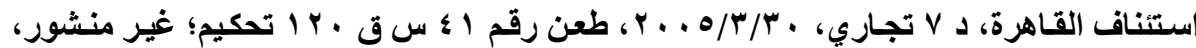

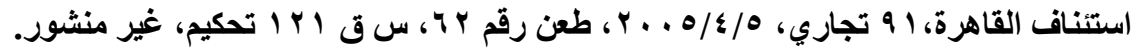


التحكيم تأخذ بـه معظم أنظمـة العـالم. ويترتب على حكم المحكمة ببطلان حكم التحكيم

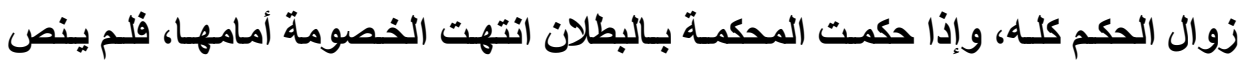
قانون التحكيم المصرى على قيـام المحكمة بنظر موضسوع التحكيم كمـا فعل المشرع

الفرنسى، وذلك لأن دعوى البطلان فى القانون المصرى ليست طريقا للاستئناف(') وبالنسبة للنظام الفرنسي فقد كان الاتجـاه في القانون الفرنسي قبل تعديل رقم

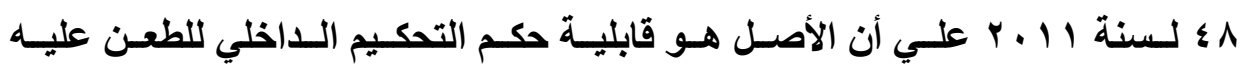
بالاستئناف، وطريق الطعن بالبطلان هو الاستثناء، فجيب أن يتفق الأطراف علي جواز الطعن علي الحكم الصادر بالبطلان.

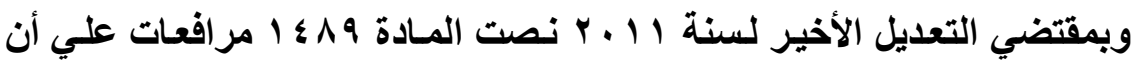
حكم التحكيم لا يكون قابلا للطعن عليه بالاستتئاف إلا إذا أتفق الأطراف علي الطعن

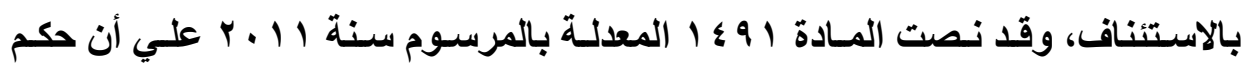
التحكيم يكون قابلا للطعن عليه بالبطلان إلا إذا كان قابلا للطعن بالاستنئاف طبقا لاتفـق بات الخصوم، فأصبح طبقا للتعديل الأخير أن الأصل هو الطعن بـالبطلان والاستنئاف هو بالهون الطريق الاسنتثنائي.

ونـري أن مـا ذهب إليـه المشرع الفرنسي في تعديلـه الأخير يتفق مـع طبيعة

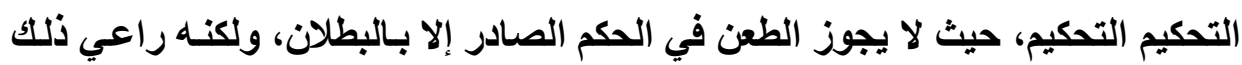
سلطة الأطراف في التحكيم، فنص استثناء جواز الطعن بالاستنئاف، ونري أنسه يفضل أن ياخذ المشرع المصري بهذا الاتجاه. 
وبالنسبة للتحكيم الدولي فقد نصت المادة 1 ه 101 مرافعات علي أن حكم التحكيم

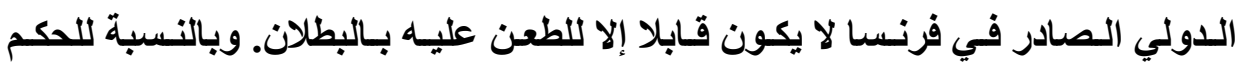
الصادر خارج فرنسا لا يكون قابلا للطعن عليه بأي طريق من طرق الطابل الطعن.

\section{الفنرع الثثاني \\ إجراءات الرقابة علي هيئة التصكيم}

سنشير إلى المحكمة المختصة بـالاعتراض علي حكم التحكيم، وإجراءات رفع الاعتراض علي حكم التحكيم، وذلك في النقاط الآتية:

\section{أولا: المكمة المفتصة بالاعتراض علي هكم التمكيم}

وقـد نـصت المـادة ــ مـن قـانون التحكيم المـصري علـى تحديــ المحكمـة المختصة بـدعوى البطلان وفرقت بـين التحكيم التجـاري الدولي والتحكيم الـداخلي:

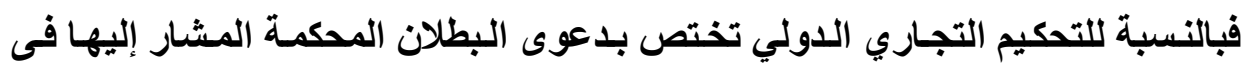

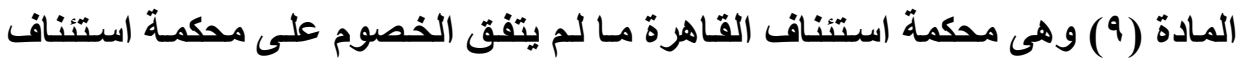

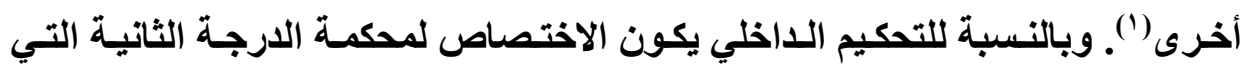

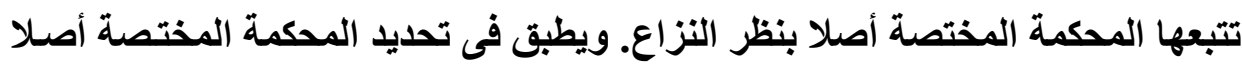

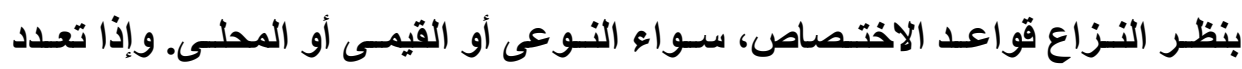

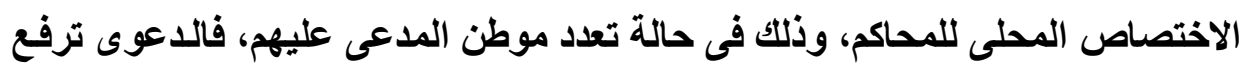

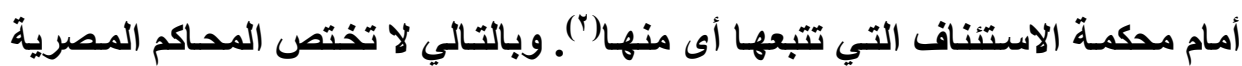
ولائيا بنظر دعوى بطلان حكم التحكيم الأجنبي (").

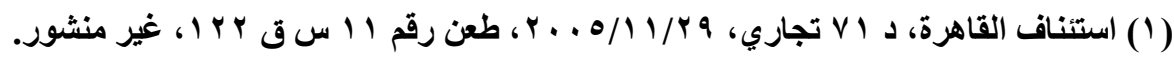

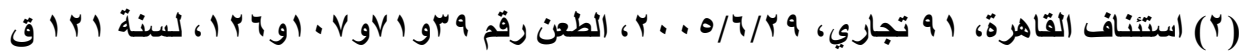
تحكيم، غير منشور.

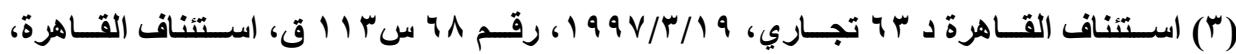

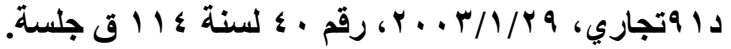


ويرى البعض أن المشرع خـالف القاعدة العامـة فى الاختصاص الذي تقضى

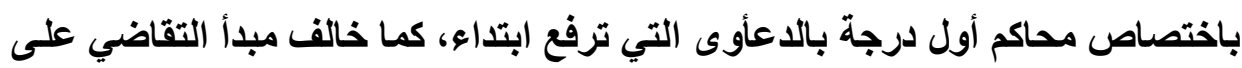
درجتين. ويرى أنصار هذا الرأي أن الباعث هو سرعة الفصل فى دعوى البطلان('). وفى حقيقة الأمر فإنـا نرى أن المشرع لم يخـالف مبدأ التقاضسي على درجتين، وذلـك لأن هذه الـدعوى هـي طريـق طعن خـاص للطعن ضــ حكم التحكيم، وبالتـالي فالاعتر اض على حكم التحكيم الأى يثبه حكم قاضسى أول درجـة يطعن عليه أمسام ثاني درجة، ولا يطعن عليه أمام أول درجة.

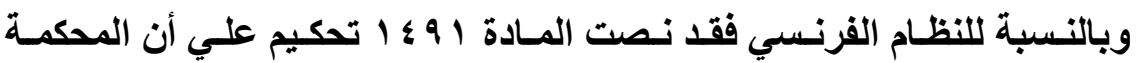
المختصـة بـالطعن بـالبطلان أو الاسـتئناف ضـــ حكم التحكيم الــاخلمي هـي محكمـة الاستئناف التي صدر حكم التحكيم في دائرتها، ويرجع في ذلك إلى الاختصاص المحلي

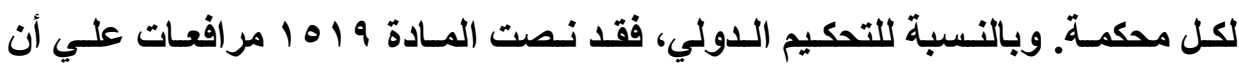
المحكمـة المختصة هـي محكمة الاستئناف التي صسر في حدود اختصاصها الحكم المطعون عليه بالبطلان. وفي الواقع هذا الاتجاه في النظام الفرنسي قد يواجه ببعض العقبـات في تعديد اختصاص المحكمـة، وذلك في حالـة صدور حكم التحكيم من هيئة مشكلة مـن ثلاثة

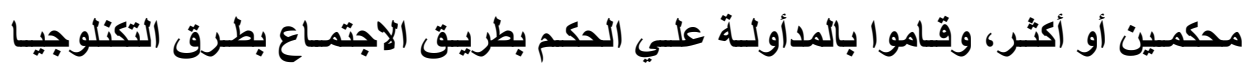
الحديثه أي الاجتماع بطريق الإنترنت، وأصدروا الحكم بهذا الطريق، وكـان كل وأحد منهم في مكان بعيد عن الآخر، ففي أي مكان يكون الحكم قد صدر في هذه الحالة. لذا 
نفضل أن يأخذ المشرع الفرنسي بطريق محكمة الدرجة الثانية للمحكمة المختصة أصلا بنظر موضوع النزاع كما فعل المشرع المصري. ثانيا: إجراءات الاعتزاض علي هكم التمكيم

ترفع دعوى البطلان في النظام المصري أمسام المحكمة المختصة، وذلك طبقا للإجراءات العادية لرفع الطعون، وذلك بأيداع صحيفة دعوى البطلان قلم كتـاب محكمة الاستئناف المختصة، حيث نصت المادة ب آ مرافعات على أن ترفع الدعوى إلى القضاء

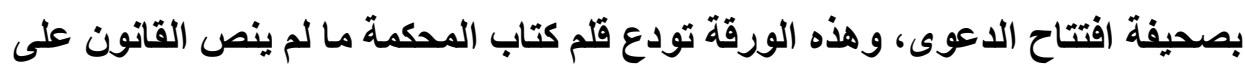
غير ذلك، حيث يقوم المدعى بتحرير صحيفة ثم يودعها قلم كتاب المحكمة ويطلب قيدها فى السجل المعد لذلك. وتتتج الدعوى آثارها بمجرد أيداع الصحيفة قلم الكتاب بعد أداء الرسم كاملاً. ولكن لا يترتب أي بطلان لصحيفة الدعوى لعدم أداء الرسم المستحق على الاعوى ('). وتخضع خصومة الطعن بـالبطلان للقواعد الإجرائية التي نص عليها قـانون

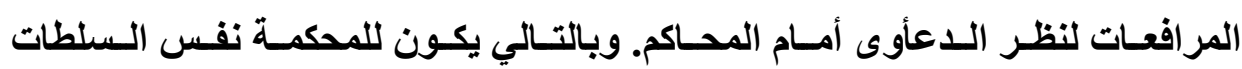
الإجرائيـة التـي تكون لها عنــ نظر أى خصومة(؟) فيجب عليهـا احترام الضمانات الأساسية للتقاضي، ويجوز التدخل فى الخصومة تلخلا انضماميًا ممن له مصلحة طبقا

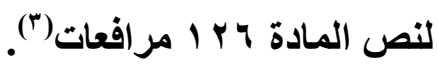

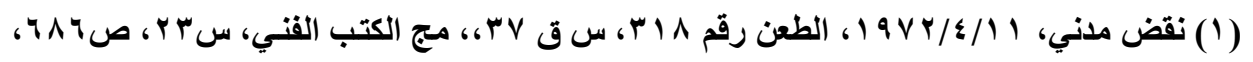
نقض مدني، 1 (

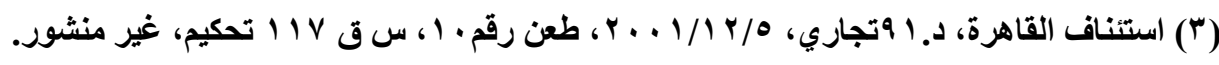


وقد نصّت المسادة ؛ ه تحكيم على ميعاد رفع دعوى البطلان، فيجب أن ترفع دعوى بطـلان حكم التحكيم خـلال التسعين يومـا التاليـة لتـاريخ إعـلان حكم التحكيم للمحكوم عليه، ويجب أن يتم الإعلان بواسطة قلم المحضرين طبقا للقواعد التي نص إنص عليها قانون المرافعات فى هذا الشأن، ولا يغيّر من ذلك علم المحكوم عليه به ولا عبرة بتحقق الغأيـة من الإعلان(')، وذلك لأن قـانون التحكيم أوجب الإعلان، وهذا قـانون خاص يقيد قانون المرافعات، وبالتبالى فلا عبرة بتسليم صورة من حكم التحكيم للمحكوم

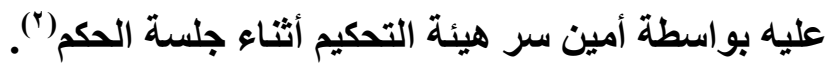

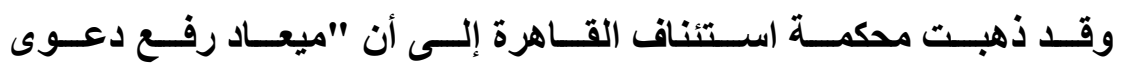
البطلان لا ينفتح إلا من تـاريخ إعلان هذا الحكم للمحكوم عليـه إعلانـا صحيحا وفقا للقواعد المتبعة فى إعلان أوراق المحضرين وتسليمها وأنها لا يغنى عن هذا الإعلان أى إجراء آخر، كما لا يغتى عنه كذلك علم المحكوم عليه بأيسة طريقة أخرى ولو كاتت

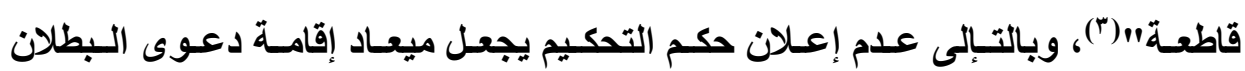

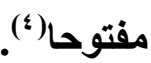
وينتقد البعض هذا الميعاد، وذلك لأنه من الضروري أن يبدأ ميعاد الدعوى من وقت صدور الحكم، وذلك حتى لا يكون هنـاك مزيــ من تضييع الوقت بسبب تعقيـ

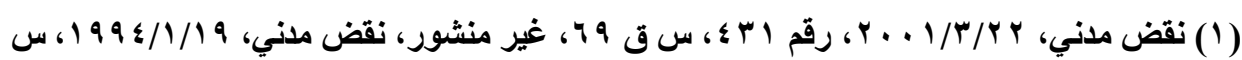

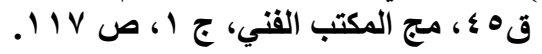

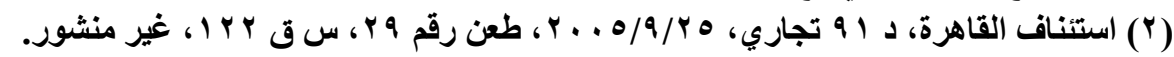

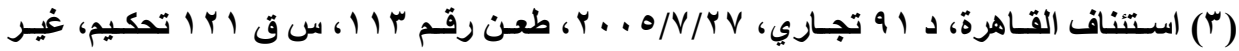

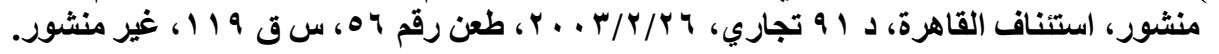

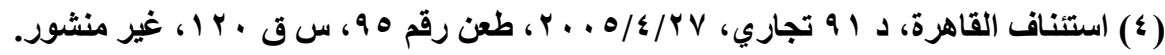


إجراعات إعلان الحكم للمحكوم عليه فى موطنه، وخاصـة إذا كـان المحكوم عليه مقيمـا فى الخارج(')، وينتقد البعض هذا الميعاد لأنه يتميز بالطول النسبى(") ونرى أنه من الأفضل أن ينص المشرع على أن يبدأ ميعاد التسعين يومـا من صدور الحكم بالنسبة للأحكام الحضورية ومن إعلان الحكم بالنسبة للأحكام الغيابية. ويلاحظ أن هذا الأجل الذى حدده المشرع لاتخـاذ إجراءات رفع الدعوى يترتب على فواتـه سـقوط الحق فى رفع الدعوى، وجزاء السقوط يتعلق بالنظـام العـام(")، وبالتبالى لا يجوز للأفراد الاتفاق على مخالفة ميعاد رفع الدعوى. وعلى القاضى أن يقضى من تلقاء نفسه. ولا يحول دون قبول دعوى البطلان نزول الخصم عن حقه فى رفع الدعوى قبل صدور حكم التحكيم. أما إذا كان النزول عن الدعوى بعد صدور الحكم، فيؤدى ذلك إلى عدم قبول الدعوى. وبالنسبة للقـانون الفرنسى، فقد نـصت المـادة ه 9 ؛ أ مرافعـات علـي أن تتبع

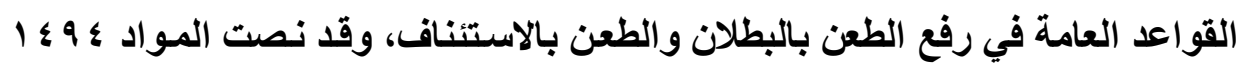

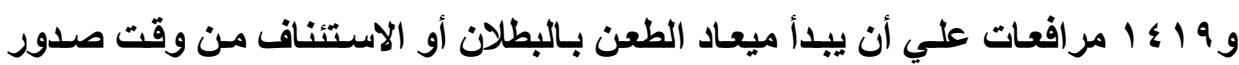
الحكم، وينتهي بمرور شهر من إعلان المحكم، وبالتالي يترتب علي انتهاء مدة الشهر من اعلان الحكم سقوط الحق في الطعن.

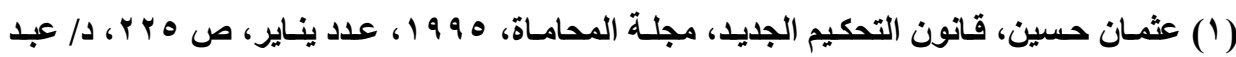

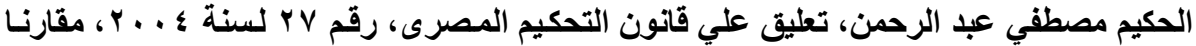

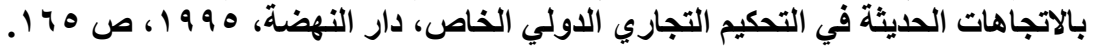

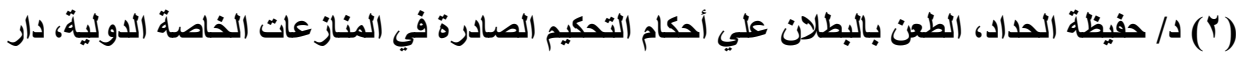

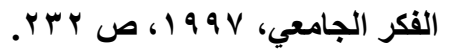

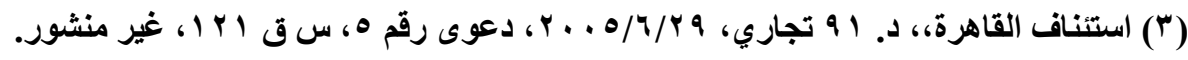


وفى حقيقة الأمر المشرع الفرنسى جعل انتهاء ميعاد الطعن مرتبطاً ببارادة من صدر الحكم لصالحه، وذلك حتى يسرع فى طلب استصدار أمر بالتنفيذ وينتظر مدة شهر لاتتهاء ميعاد الطعن. وبالتّالى في ميعاد الشهر مدة مناسبة لنظام التحكيم. وميعـاد إقامـة دعوى بطلان حكم التحكيم لا يوقف إقامتهـا أمسام محكمة غير مختصة، حيث يسقط الحق فى دعوى البطلان لإقامتها بعد الميعاد ولا يغير من ذلك

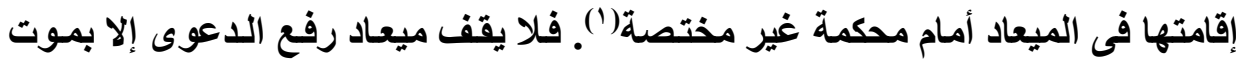
المحكوم عليه أو بفقده أهليته للتقاضى أو بزوال صفة من كان يباشر الخصوم عنه(؟).

\section{المطلب الثاني \\ نطاق الرقابة علي سلطة هيئة التحكيم في الإثبات}

سنشير إلى حالات الرقابـة علي سلطة هيئة التحكيم في الإثبات، وذلك في

الفرع الأول، أما الفرع الثاني، فيخصص لاثر مخالفة قواعد الإثبات علي حكم التحكيم. وذلك علي النحو التالي.

\section{الفرع الأول}

\section{حالات الرقابة علي سلطة هيئة التحكيم في الإثبات}

سنشير إلى حصرية حالات الرقابة علي سلطة هيئة التحكيم، وأسباب الرقابـة

علي سلطة هيئة التحكيم في الإثبات، وذلك في النقاط الآتية:

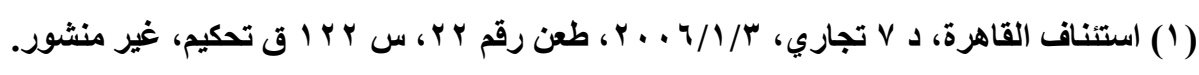

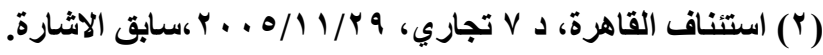




\section{أولا: هصرية حالات الرقابة علي اسلطة هيئة التمكيم}

في الواقع لم يسمح المشرع المصري إلى فتح باب الطعن بالاستئناف ضد حكم

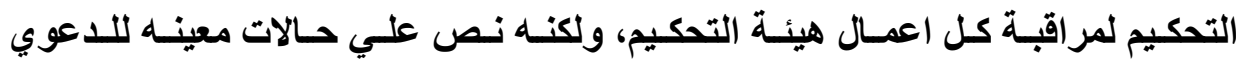
البطلان، علي عكس القانون الفرنسي الأي نص علي أن الأصل هو الطعن بـالبطلان إلا إذا اتفق الأطر اف علي الطعن بالاستنئاف.

والحالات منصوص عليها في دعوي البطلان علي سبيل الحصر في المـادةهه تحكيم، حيث نصت المادة به تحكيم علي أنه، لا تقبل دعوى بطلان حكم التحكيم إلا في

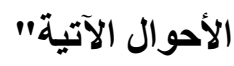

أــ إذا لـم يوجد اتفـاق تحكيم أو كـان هذا الاتفـاق بـاطلا أو قـابلا للإبطـال أو سـط

$$
\text { بانتهاء مدتهه. }
$$

بـ إذا كـان أحـد طرفى اتفـاق التحكيم وقت إبرامـه فاقد الأهليـة أو ناقصها وفقـا

$$
\text { للقانون الذى يحكم أهليته. }
$$

ج- إذا تعذر على أحد طرفى التحكيم تقديم دفاعه بسبب عدم إعلانـهـ إعلانـا صحيحا بتعيين محكَّم أو إجراعات التحكيم أو لأى سبب آخر خارج عن إرادته.

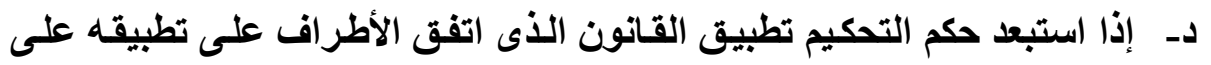

$$
\text { موضوع النزاع. }
$$

هـ إذا تم تشكيل هيئة التحكيم أو تعيين المحكَّمين على وجـه مخـالف للقـانون أو

لاتفاق الطرفين.

و- إذا فصل حكم التحكيم فى مسائل لا يشملها اتفـق التحكيم أو جاوز حدود هذا الاتفـاق. ومـع ذلـك إذا أمكن فصل أجـزاء الحكم الخاصـة بالمســائل الخاضـعة للتحكيم عن أجزائه الخاصة بالمسائل غير الخاضعة له، فلا يقع البطلان إلا على النى

$$
\text { الأجزاء الأخيرة وحدها. }
$$


ز- - إذا وقع بطلان فى حكم التحكيم أو كاتت إجراءات التحكيم باطلة بطلانـا أثر فى الحكم". ويستفاد من هذه المادة أن المحكمة المختصة بنظر دعوى البطلان لا تنظر حكم التحكيم كانها محكمة طعن، فلا تنظر موضوع الحكم من حيث الواقع

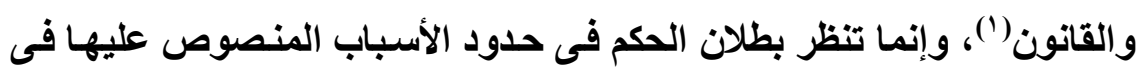
المـادة به تحكيم. ويمكن للمحكـة أن تقضى بوقف تنفيذ حكم التحكيم خـلال

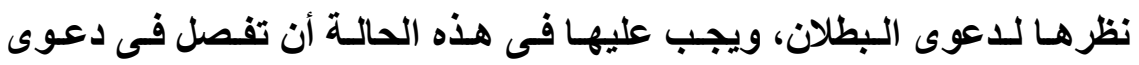

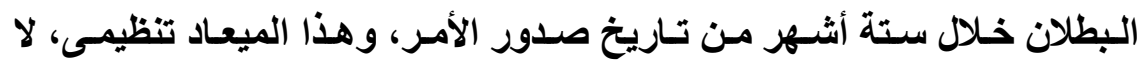
يترتب عليه سقوط أو بطلان.

وبالنسبة للقانون الفرنسي فقد نص على الأسباب التي تؤدى إلى بطلان حكم

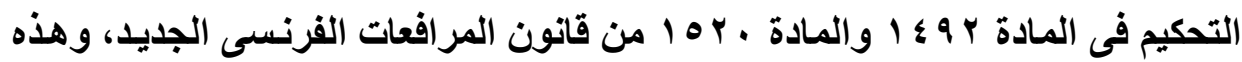
الأسـباب منـصوص عليهـا على سـبيل الـصر، وهـى تتشـابه مـع أسـباب البطلان المنـصوص عليهـا فـى القـانون المـصرى، ولكن المـشرع الفرنسـي قد سـمح للطعن

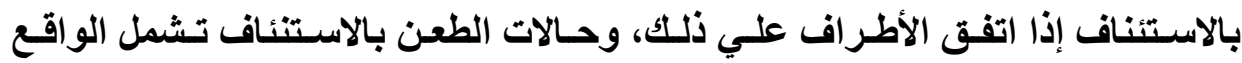
والقـانون، وبالتـالي سيكون هنـاك رقابـة عامـة وشـامله علـي سلطة هيئة التحكيم في

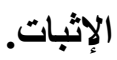

ونري أن يفضل أن يأخذ المشرع المصري بهذا الاتجاه، وهو أن يسمح بالاتفاق علي الاستنئاف في اتفاق التحكيم. لأن قاضي الاستنناف سيراقب ما انتهي إليه المحكم في تكوين عقيدته هو أمر يمكن الوصول إليه من الثابت بـالأوراق ومـاطرح من أدله

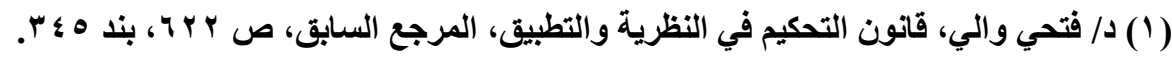
Cass. Civ., 2e, 17nov. 1976, D. 1977, p. 577 note Boré, Rev. Arb., 1977,p. 281, note Robert, Cass. Civ., 2e, 28 avr. 1980, op. cit., CA paris, 1re dec. 1995, op. cit., p. 529, obs. Fouchard. 
بالجلسة، وذلك وفقا لمقتضيات العقل والمنطق، بمعني أن تكون الأدلة في مجموعها مؤدية إلى ما قصده الحكم منها في إثبات اقتناع المحكم مادام تخلص إليهه لا يخرج عن الاقتضاء العقلي والمنطقي. ونظرا لأن حكم التحكيم فى أغلب نظم التحكيم غير قابل لطعن عليه إلا بدعوى البطلان ولأسباب محدة على سبيل الحصر، فالحكمة تقتضى أن يتجه قضاء الدولة إلى إعطاء مفاهيم مرنة لأسباب الطعن بالبطلان حتى تستوعب كافة احتمـالات الخطأ التى يمكن أن تصيب الحكم. فإذا صدر الحكم فلا سبيل للنعى على مسلك المحكَّم إلا من خلال طلب إبطال الحكم استناداً إلى أحد الأسباب التى أوردهـا القانون على سبيل الحصر. ويجب أن تتسع هذه الأسباب لتشمل حالة الخطأ في إجراءات الإثبات، لأنه لا يمكن قبول حكم من محكَّم غير عـادل ولـم يتمكن الخصوم من ممارسـة حقوقه في الإثبات لسبب خارج عن إرادته اثناء خصومة التحكيم.

\section{ثانيا: أثر هذالفة قواعد الإثبات علي هكم التمكيم}

ويلاحظ أن المادة به تحكيم لـم تشر صراحة إلى أن الرقابـة على سلطة هيئة

التحكيم فـي الإثبـات ضـمن حسالات البطلان، ولكـن هـذه الحسالات تتسع لتشمل هــا السبب(')، حيث يلخل هذا السبب ضمن حالة " إذا تعذر على أحد طرفي التحكيم تقديم دفاعه بسبب عدم إعلانه إعلانا صحيحا بتعيين محكَّم أو إجراعات التحكيم أو لأى سبب آخر خارج عن إرادته. إذا تعذر على أحد طرفى التحكيم تقديم دفاعه بسبب عدم إعلاتهـ

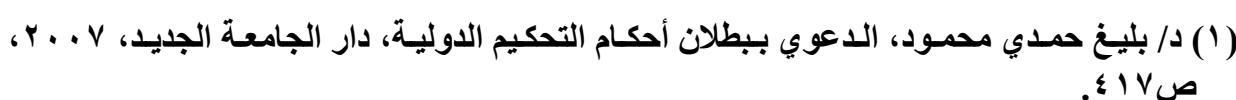
Charles JARROSSON, note sous Cass. 2e civ., 19 avril 1985, , Rev. Arb., 1986, p. 57, spec. p. 62. 
إعلانا صحيحا بتعيين محكَّم أو إجراعات التحكيم أو لأى سبب آخر خارج عن إرادته. "، حيث لو خالفت هيئة التحكيم حقوق الدفاع أو المواجهة أو المساواة بين الأطراف أثناء اتخاذ إجراءات الإثبات، فيمكن اللجوء إلى هذا السبب للطعن علي حكم التحكيم بالبطلان، وكذلك يمكن في حالة " إذا استبعد حكم التحكيم تطبيق القانون الذى اتفق الأطراف على تطبيقهـ" فلو اتفق الأطر اف علـي تطبيق قـانون إثبـات معين وخالفت أحكامه هيئة التحكيم، ففي هذه الحالة يمكن الطعن علي قرار هيئة التحكيم بـالبطلان.

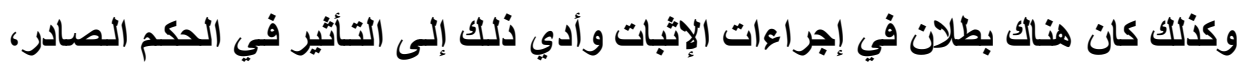
فيمكن طلب بطلان حكم التحكيم، بالاضافة إلى أنه إذا كاتت بعض قواعد الإثبات متعلقة بالنظام العام وخالفت ذلك هيئة التحكيم، فيمكن للمحكمة المختصة بـالبطلان أن تحكم بالبطلان من تلقاء نفسها.

وبالنسبة للنظام الفرنسي فلم يُشر صراحة في الطعن بالبطلان إلى الرقابـة علي

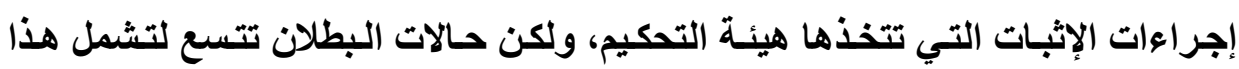
السبب. فقد أسس البعض بطلان إجراءات الإثبات يؤثر على حقوق دفاع الخصم ممـا يبرر بطلان الحكم(')، حيث إن المحكَّم إذا خالف المبادئ الأساسية في الإثبات يعتبر ذلك

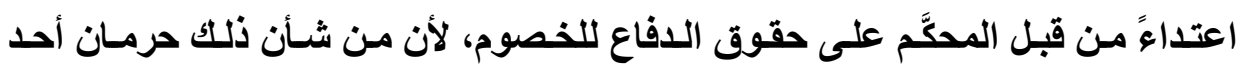
الخصوم من بعض حقوقه(r). وهذه الحالة تلخل ضمن حالات البطلان التى نص عليها قانون التحكيم المصرى وقانون المرافعات الفرنسى، حيث نصّت المادة به/ / - ج تحكيم والمادة ؟ 9 ـ أمن قانون المرافعات الفرنسى الجديد على جواز إبطال حكم التحكيم إذا تعذر على أحد طرفى التحكيم تقديم دفاعه لأى سبب آخر خارج عن إرادته. بل يمكن أن

(1) CA Paris, 13 mars 1981, Rev. arb, 1983, p. 63, note B. MOREAU; CA Paris, 28 octobre 1999, op. cit., p. 299, note ph. GRADJEAU.

(2) CA Paris, 12 décembre 1996, op. cit., p. 699, note D. B. 
يؤدى الإخلال بقواعد الإثبات إلى الإخلال بمبدأ المساواة بين الخصوم(') الذي يعد من النظام العام الإجرائى التى تؤدى إلى بطلان حكم التحكيم. (). وقد ذهب اتجـاه في الفقه والقضاء الفرنسي إلى أنسه إذا أخطأ المحكم في تطبيق قانون الإثبات لا يمكن إبطال الحكم إلا إذا كـان الطعن بالاستئناف جائزاً طبقا للقانون الفرنسي، وذلك لأن مخالفـة قواعد القانون ليست سببا من أسباب الطعن بالبطلان(").

ويالتالي إذا كانت المادة به تحكيم لم تشر صراحة إلى أن خطأ هيئة التحكيم في تطبيق قواعد الإثبات يترتب عليها البطلان، إلا أنه يمكن القول بأن مخالفة بعض قواعد إلى إند الإثبات يترتب عليها بطلان حكم التحكيم، ويمكن أن يؤسس ذلك علي الآتي:

\section{ا- تعذر تقديم الدفاع للخالفة قواعد الإثبات}

نظر الأهمية حقوق الدفاع في الخصومة، فـلا يمكن أن تتحقق العدالة بدون

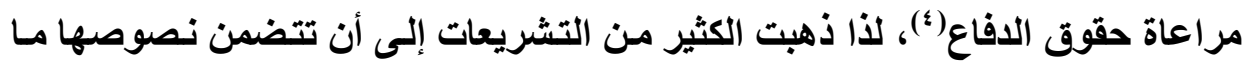

$$
\text { (1) د/ أبو العلا علي النمر، د/ أحمد الجداوي، المحكَمون، المرجع السابق، ص ؛ ـ 1. }
$$

CA Paris, 20 novembre 1997,op. cit., p. 329.

Charles JARROSSON, note sous Cass. 2e civ., 19 avril 1985, op. cit., p. 57, spec. p. 62.

(2) ID.; M. HENRY, «les obligations d'indépendance et l'information de l'arbitre à la lumière de la jurisprudence récente», op. cit., p.193 spéc. $P$. 215.

(3) B. Moreau, A. Beregoi, et autre, arbitrage commercial, op. cit., no 210. Cass. Civ., 2e 17nov. 1976, op. cit., p. 577 note Boré, Rev. Arb. Op. cit,p. 281, note Robert, Cass. Civ., 2 e, 28 avr. 1980, op. cit., CA paris, 1re dec. 1995, op. cit., p. 529, obs. Fouchard.

(4) CA Paris, 10 nouv. 1989, op. cit., p. 651, obs. Pellerin, CA paris, 11 juill. 1991, op. cit., p. 671, obs. Loquin, CA Paris, 13 mars 1992, op. cit., p. 107, obs. Jarrosson, CA Paris, 13 nouv. 1997, op. cit., p. 719, obs. $=$ 
يفيد إلزام المحكم باحترام حقوق الدفاع ويفرض رقابـة علي أحكامـه، حيث إن الأحكام

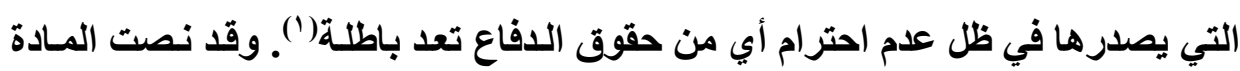
به تحكيم علي أن يبطل حكم التحكمي إذا تعذر علي أي من طرفي التحكيم تقديم دفاعه

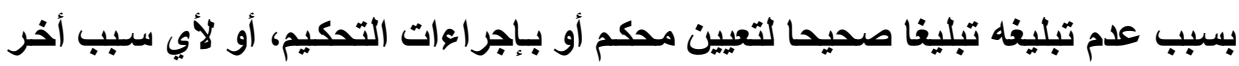

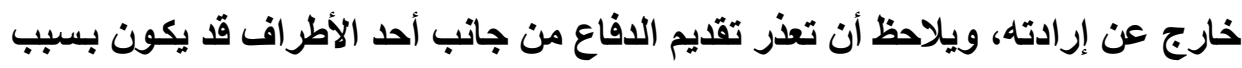

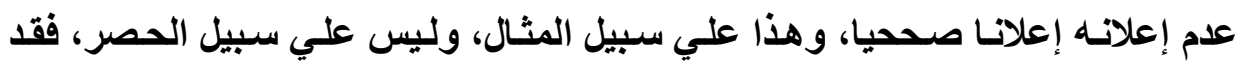
تكون هنـاك أسباب اخري ريمـا تبطل حكم التحكيم لأنها اثر علـي حقوق الدفاع. أمسا

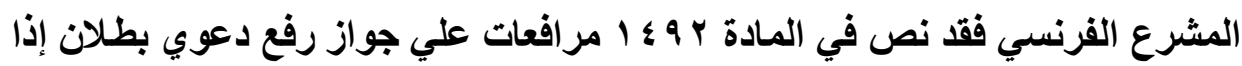
كان حكم التحكمي قد صدر مخالقا لمبدأ المواجهة. وبالتالي إذا أدت مخالفة قواعد الإثبات إلى عدم تمكين الخصم من الدفاع يكون

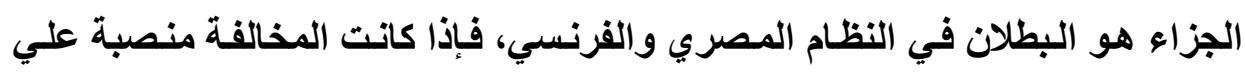
تبادل بعض المستندات، أو لأنها قدمت بعد قفل باب المرافعة(؟)، وثبت أن المحكمين قد فـ

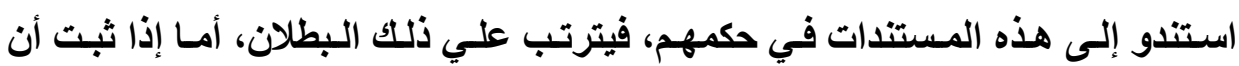
المحكمين لم يستندوا إلى هذه المستندات في حكمهم، فإن هذه المخالفة لا يترتب عليها البطلان("). ولكن إذا كانت لهذه المستندات قيمة في الخصومة ولو اعتمد عليها وراعي حقوق الدفاع بشأنها لأدي ذلك إلى تغير وجه الحكم في الدعوي، فنري أن يكون لها أثر

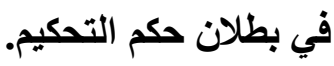

Derains.

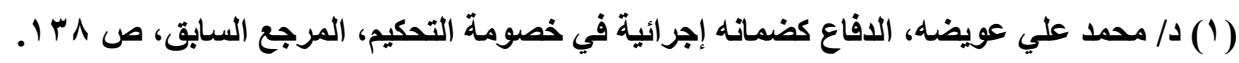
(2) B. Moreau, A. Beregoi, et autre, arbitrage commercial, op. cit., no 285.

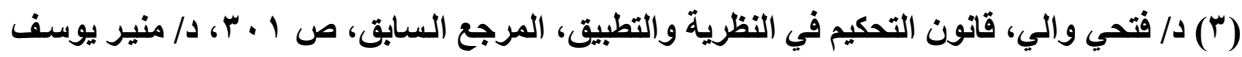

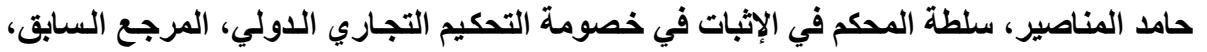


ونظرا لأهميـة حقوق اللدفاع فقد نصت اتفاقيـه نيويـورك المتعلقة بـالاعتراف وتنفيذ أحكام التحكيم الأجنبية في المادة الخامسة علي أن يرفض الاعتر اف وتنفيذ حكم التحكيم في حالة عدم قدرة الخصم علي تقديم دفاعه أو عدم إعلانسه إعلانـا صحيحا باجراءات التحكيم أو تعيين المحكم. ويلاحظ من خلال استقرار هذا النص أن احترام حقوق الدفاع مطلب أساسي في مجال إجراءات التحكيم ('). وقد ذهبت محكمة النقض المصرية إلى أن تمكين المدعي عليه من إبداء دفاعه وتقديم مستتداته يؤدي إلى بطلان حكم التحكيم(؟). وفي أحكام اخري ذهبت محكمـة النقض إلى بطلان حكم التحكيم، وذلك بسبب الإخلال بحقوق الدفاع("). وتثثور اشكاليه كيفية إثبات أن هيئة التحكيم قد تجاوزت حقوق الدفاع، وذلك في ظل عدم التزام هيئة التحكيم بالأشكال والإجراعات المتبعة أمسام محاكم القضاء، والتي تفرض علي القاضي التقيا بها لضمان مراعاة حقوق الدفاع؟ في الواقع، يلتزم الخصم الذي يـدعي عدم مراعـاة حقوق دفاعـه، عند نظر القضية أن يثبت باللدليل أن هذه الحقوق قد انتهك بالفعل، ولا يكفي أن يتمسك بعدم التزام المحكم بتطبيق الإجراءات والإثكالات، لأن طبيعة نظام التحكيم تقتضي عدم الالتزام بكافة الإجراءات المتبعه في

CA Paris, 10 nouv. 1989, op. cit., p. 651, obs. Pellerin, CA paris, 11 juill. 1991, op. cit., p. 671, obs. Loquin, CA Paris, 13 mars 1992, op. cit., p. 107, obs. Jarrosson, CA Paris, 13 nouv. 1997, op. cit., p. 719, obs. Derains.

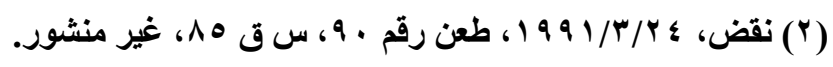

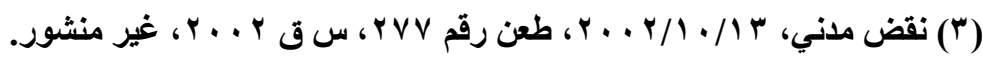


وبالتالي إذا أقام المحكم قضاءه علي مستند قدم من أحد الخصوم دون أن يطلع عليه الخصم الآخر، فِإن حكمه يكون جديراً بـالبطلان لإخلاله بحق الدفاع(') ـوتحدد

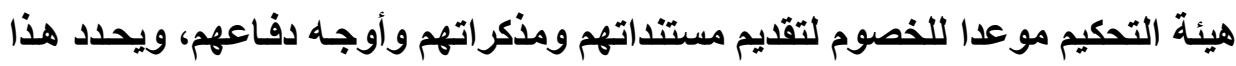
المواعد حسب ظـروف سـير الـدعوي. ويجب تمكين كل خصم مسن الاطـلاع علـي المستندات المقدمة(؟)، ويمكن أن يحدث دون إعلان الخصم الآخر عن طريق مندوب الإعلان، حيث يكفي أن يـاعو المحكم الخصوم لايسه، ويقدم لهم المستتدات المقدمـة ليطلع كل خصم علي ما قدمه الخصم الآخر ويبدي ملاحظاته بشأنها. ويمكن لكل خصم في جلسة التحكيم تقديم المستندات التي تدعم وجهة نظره بحيث يتحقق العلم(") ويحترم

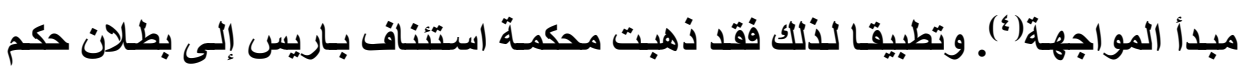
التحكيم على أساس مخالفة حقوق الدفاع (•).

\section{r- بطلان في إجراءات الإثبات أثر ت في الهكم:}

لقد نصت المادة به تحكيم علي أنه يترتب البطلان إذا كانت إجراءات التحكيم باطلة بطلانـاً أثر في الحكم، فإذا وقع بطلان في إجراءات الإثبات وأثر ذلك في حكم

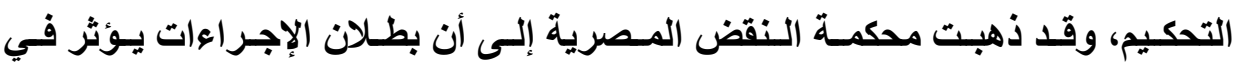

(1) Chainis, l'arbiter, le droit et la contradiction, Rev. Arb., 2010, p. 3.

(2) CA Paris, 13 nouv. 1980, op. cit., p. 12, CA Paris, 24 oct. 1991, op. cit., p.110.

(3) CA Paris, 21 nov. 1967, op. cit., p. 122.

(4) R. David, I arbitrage dans le commerce international, op. cit., n- 320, p. 410.

(5) CA Paris, 20 novembre 1997, op. cit., p. 329. 
وهذا البطلان يأخذ العديد من الصور، ويمكن تصور ذلك في الفروض الآتية: هخالفة قاعدة الإثبات البماعي:

الأصل أن يتم التحقيق الجامعي لخصومة التحكيم، ولكن استثناء من ذللك سـح

اتفاق التحكيم أو إذا أجمع المحكمن علي ندب وأحد منهم لإجراء معين وأثبتوا ندبـه في محضر الجلسة، فيجب عرض نتيجة عمله علي هيئة التحكيم قبل إصدار الحكم('). وعدم مراعاة ذللك يترتب عليه البطلان، و إذا اشترط اتفاق التحكيم اتخاذ كل الإجراءات الإثبات بمعرفة كل المحكمين فبان حكم التحكيم يقع بـاطلان إذا قـام أحدهم فقط بـإجراء الإثبات(؟). وتجدر الإشـارة إلى أنـه لا يكفي للحكم بـالبطلان أن يثبت صـاحب المصلحة

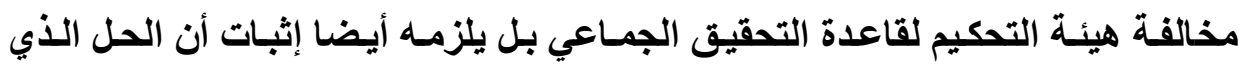
انتهت إليه هيئة التحكيم كان سيتغير لو لم ترتكب هذه المخالفة(")، وهذا ما اكدته المادة به تحكيم بأنه لا يحكم بالبطلان إلا إذا كان من شأن بطلان إجراءات التحكيم التأثير في الحكم الصادر في الدعوي. ولا يلزم لإثبات أن الإجراء قد تم بواسطة بعض المحكمين دون تفويض إتباع طريق الادعاء بـالتزوير، إذ يتعلق الأمر بإثبات واقعة ماديـة يجوز

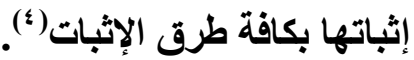

وقد ذهبت محكمـة استئناف القـاهرة إلى أنـها إذا كـان الثابت أن بعض محاضر جلسات هيئة التحكيم قد تضمنت اسم رئيس الهيئة فقط دون باقي أعضاء الهيئة بحيث

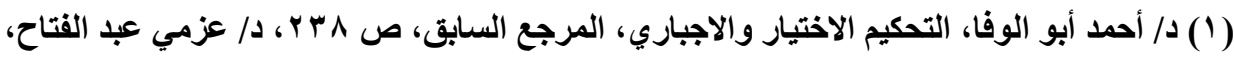

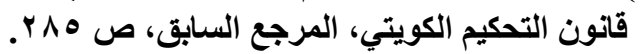

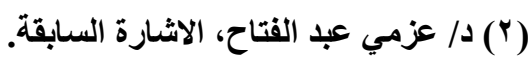

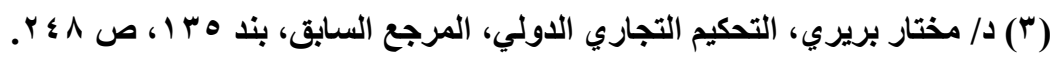
(4) J. ROBERT, l'arbitrage droit interne et droit international privé, op. cit., p.154, no 177. 
تضمنت حضور رئيس الهيئة وأحد المحكمين دون المحكم الآخر، فإن إجراعات التحكيم تكون باطله، ويتعين القضاء ببطلان الحكم. ويجب أن تلتزم الهيئة بهذا المبدأ حتي ولو كانت الهيئة مفوضه بالصلح، وذلك لأهمية وسائل التحقيق والدور الحاسم لها في بيـان وجه الحقيقة في موضوع النزاع. فبإذا كان التفويض بالصلح يعفي هيئة التحكيم من ونس

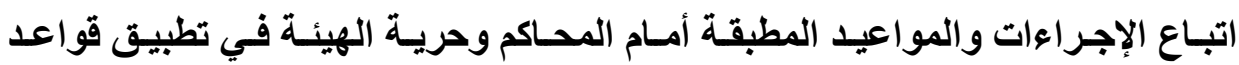
العدالـة علي موضوع النزاع إلا أنسه لا يعفيها من ابتـاع القواعد التي تقرر ضـمانـات

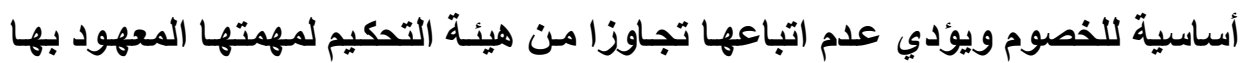
إليها، ويترتب عليه بطلان الحكم التحكيم(')

\section{هخالفة الإجراءات المتعلقة بمبدأ المواجهة والمساواة بين الأطراف.}

وتحقيقا لمبدأ المواجهة يجب إخطار الخصوم بميعاد ومكان الانتقال للمعاينةة(؟)،

ليتمكن الطرفان أو مثثلاهما من الحضور وقت المعائنة، ويكون لكل طرف لفت انتباه المحكم إلى ما أغقل عنه، ويجب علي الهيئة تحرير محضر بالمعائنة، وتمكن الأطراف

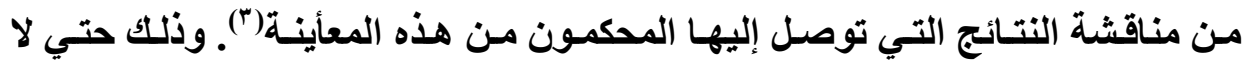
يتعرض الحكم الصادر للبطلان. وهذا ما قضت به محكمة استئناف القاهرة، بقولها بـأن المعأينة التي استندت إليها هيئة التحكيم في حكمها لن يتم تحرير محضر بشأنها، وإنمـا

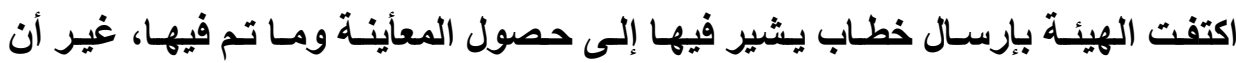
الخطاب جاء في صياغة عامة ومجهولة لا تحقق الغأية التي من أجلها اشترط المشرع تحرير محضر تبين فيه جميع الأعمال المتعلقة بالمعأينة ويوقعه كاتب حضر إجراءاتها،

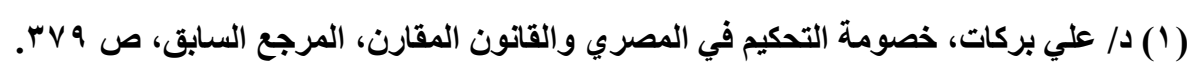

(2) Cass. Civ., 2e 25 mars 1999, op. cit., p. 267

(3) CA Paris, 13 mars 1973, op. cit., p.176. 
وحكم التحكيم الذي استند إلى هذه المعأينة يكون باطلا لوقوع بطلان في الإجراعات أثر في الحكم عملا بالمادة ؛ ه تحكيم (').

وقد نـصت المـادة هـ 1 مرافعـات فرنسي علـي ضرورة العلم في وقت نـافع ().

فيجب منح الخصم فرصة من الوقت ليتمكن من تدبر أمره مع محاميه وأن يجري بعض الأبحـاث القانونيـة اللازمـة وأن يفكر ويتـروي. وقـ ذهب القضاء الفرنسـي بأنـه يعد مخالفة لحقوق الدفاع، وبالتالي بطلان حكم التحكيم إذا سمحت هيئة التحكيم بسماع أحد الأطر اف في غيبة الطرف الآخر ولم تدع للحضور("). وعلي المحكم أن يحدد الوقت الكافي، فإذا وجد المحكم أن الخصم لم يتمكن من العلم في وقت نـافع، فعليه أن يستبعد المستتد (مادة هـ ا مرافعات فرنسي)، ويترتب البطلان علي اتخاذ الإجراء في وقت لا يسمح بالعلم والرد في وقت كاف. وذلك لأن العلم في وقت غير كاف يؤدي إلى الإخلال بحقوق الدفاع مما يؤدي إلى البطلان( ()، وعدم الاعتراض علـي مخالفة مبدأ المواجهة

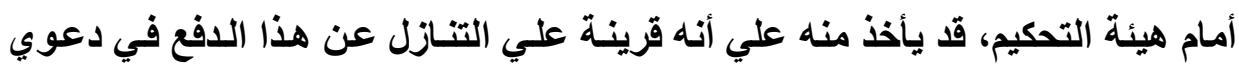

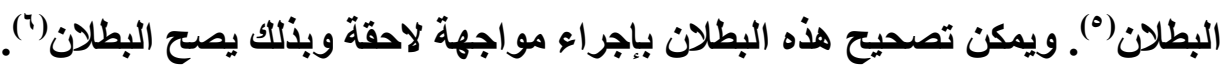

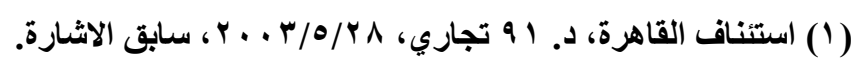

(2) CA Paris, 21 nov. 1967, op. cit., p. 122.

(3) CA Paris, 3 dec. 1965, op. cit., p. 22, op. cit., 14625, note Boulbes. Cass. 2e, 16 dec. 1985, op. cit., p. 390, CA Paris, 2 fev. 1988, op. cit., p. 62, note Couchez.

(4) CA Paris, 21 nov. 1967, op. cit.,p. 122.

(5) B. Moreau, A. Beregoi, et autre, arbitrage commercial, op. cit., no 213. (†) د/ عزمي عبد الفتاح، واجب القاضي في تحقيق مبأ المواجهة باعتباره اهم تطبيق لحق الدفاع،

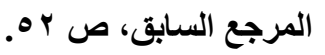


ويجب علي هيئة التحكيم مراعاة القواعد والإجراعات التي تحقق المساواة بين أطراف التحكيم، ومخالفة ذلك يترتب عليه البطلان، وقد ذهبت محكمة النقض الفرنسية

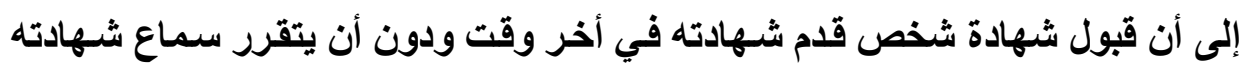

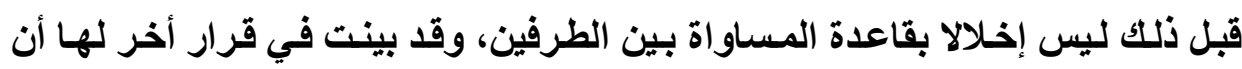

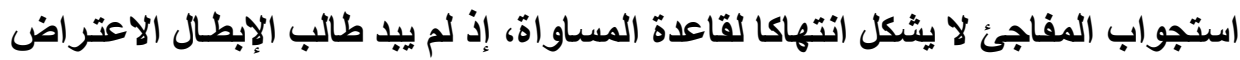

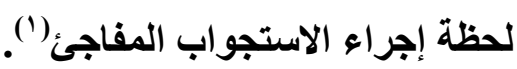

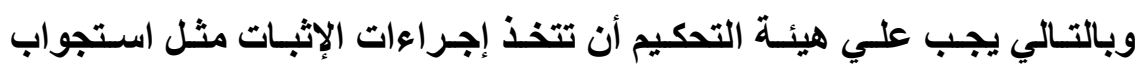
الخصوم، أو توجيه اليمين أو المعائنة أو سماع الشهود في مواجهة كل الخصوم، وكمـا

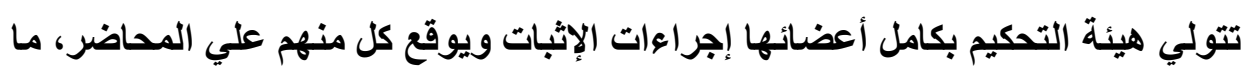

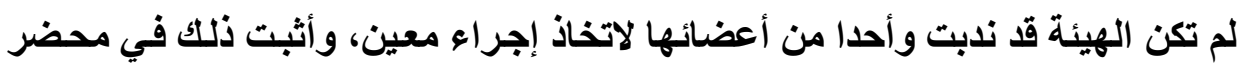
الجلسة و إلا كان الإجراء باطلا(). وهذا ما يطلق عليه واجبـات هيئة التحكيم في مجـال

\section{هفالفة قواعد التسبيبب.}

لقد نص القانون المصري في المـادة بـ تحكيم علي أنسه يجب أن يكون حكم

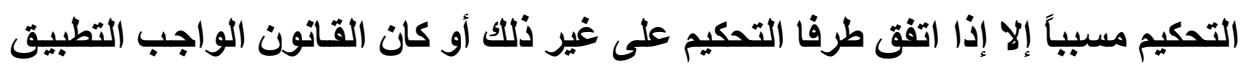

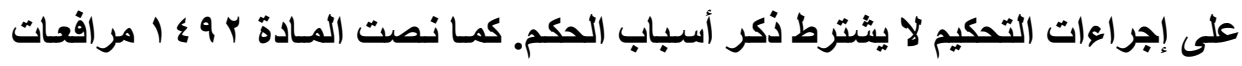

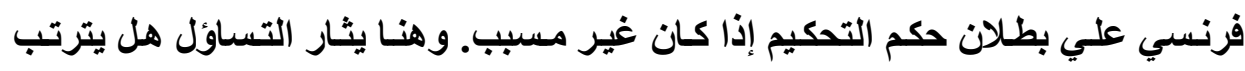

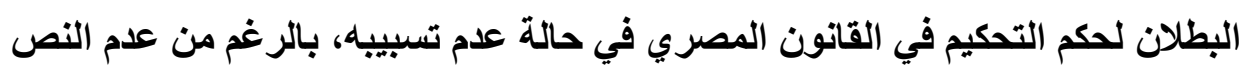

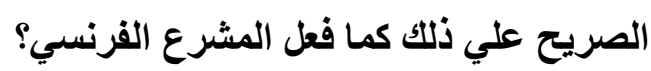

(1) CA Paris, 13 juill. 1987, Rev. Arb., 1988, p. 50.

(ץ) د/ أحمد عبد الكريم سلامة، التحكيم في المعاملات المالية الداخلية والدولية، المرجع السابق، ص 
في الواقع نري أنها يترتب البطلان علي عدم تسبيب حكم التحكيم في القانون المـصري إذا كـان واجب التسبيب ولـم تقـم هيئسة التحكيم بالتسبيب، وذلـك لأن هيئة التحكيم تلتزم بأحكام القانون التحكيم، كما أن المشرع امر الهيئة بالتسبيب، وإذا خالفت الهيئة نص المادة بـ تحكيم، ولم يوجد جزاء البطلان، فيترتب علي ذلك اعتبار كل نصوص قانون التحكيم مكملة لهيئة التحكيم وغير ملزمـة لها، وهذا مـا لم يشر إليه

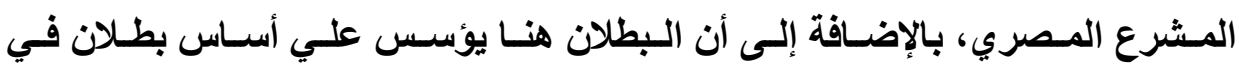
الإجراءات أثراً في حكم التحكيم.

وللتسبيب أهميـة عظيمـة في شـأن التحكيم، لا يمكن التغافل عنهـا، حيث إن التسبيب يؤدي إلى إقناع الخصوم والرأي العام بعدالة الحكم مما يكسب الثقة في عدالته ويدفع عنه مظنة الريبة الثك(') كما أنـه ضمان ضـد تعسف الذي قد يصدر من هيئة التحكيم، وضمان لسلامة العمل الصادر منهم من حيث الواقع ومن حيث القانون، كمـا أنه ضمان للخصوم بتعريفهم كيف فصل المحكم في نزاعهم وعلي أي أسساس(") كمـا أنها تساعد الخصوم في بناء الطعن علي الأحكام، كما أن الأسباب تمكن محكمة الطعن من مراقبة عمل المحكم. كمـا أن تسبيب الاحكام يؤدي إلى بيـان مدي احترام حقوق

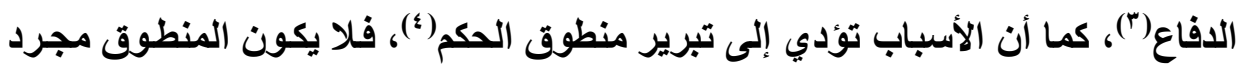
عبارات ليس لها أسـاس منطقي من خلاله وصل المحكم إلى المنطوق. لذلك نري أنـه

$$
\begin{aligned}
& \text { (1) د/ عزمي عبد الفتاح، تسبيب الأحكام وأعمال القضاة، المرجع السابق، ص بّاب. }
\end{aligned}
$$

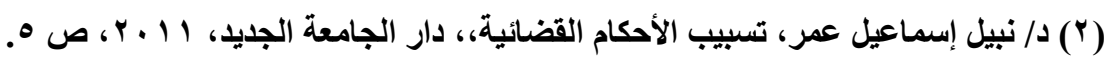

(3) CA Paris, 10 nouv. 1989, op. cit., p. 651, obs. Pellerin, CA paris, 11 juill. 1991, op. cit., p. 671, obs. Loquin, CA Paris, 13 mars 1992, op. cit., p. 107, obs. Jarrosson, CA Paris, 13 nouv. 1997, op. cit., p. 719, obs. Derains. 
يفضل أن ينص المشرع علي اعتبار تسبيب الدكم سببا من أسباب البطلان بشكل صريح. فالوقائع ترتبط بالحكم الأي يتوصل إليه المحكم، فيجب أن يصدر حكمـا تؤول

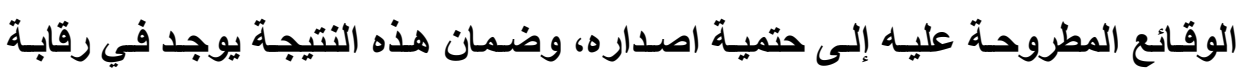
محكمة النقض علي التسبيب في النظام القضائي ('). ومسن وجهـة نظرنـا، محكمة البطلان لا تراقب هيئة التحكيم مـن حيث كفايـة التسبيب ومنطقية التسبيب، ولكن تراقب الوجود الثكلي للأسباب وعدم انعدامها. وذلك لأن محكمة البطلان ليس طريقا للاستئناف ضد حكم التحكيم، فلا يجوز لها أن تقوم باور محكمة الاستئناف، لأن ذلك يخالف اتجاه المشرع المصري والفرنسي في شـأن تنظيمه لاعوي البطلان، حيث إنها رقابه شكليه وحالاتها محدده علي سبيل الحصر. ومن جاتبا نري أنـه لا تلتزم الهيئة بتسبيب مـا تـأمر بـه مـن إجراعات الإثبـات، وذلك علي أساس أن لها في هذا الثأن سلطة تقديرية، فلا يعيب حكمها عدم استعمالها هذه السلطة، ولكن نري أنه إذا رفضت اتخاذ إجراء من إجراءات الإثبات أو عدلت عن اتخاذ إجراء معين، فإنه يجب عليها تسبيب قرارها علي أساس احترام حقوق الدفاع. ويجب أن تكون أسباب الحكم تثنتمل علي الأسباب الواقعية والأسباب القانونية، ويجب أن يكون استخلاص هيئة التحكيم للنتائج المستفادة من الأدلـة استخلاصسا سـائغا وفقا لمقتضيات العقل والمنطق(). ويجب ألا يكون هناك انعدام للأسباب، وهذا الانعدام قد يكون كليا أو جزئيا، ويقصد بانعدام الأسباب خلو الحكم من أي سبب يحمل منطوقه، اما إذا وجد ولو سبب وأحد، حتي لو كان غير كاف، فإن عيب الانعدام لا يتوافر. وذلك

(1) CH. PERELMAN et P. FORIERS, la motivation des decisions de jusitice, D., 1978,p. 6 et s.

(ץ) د/ نبيل اساعيل عمر، سلطة القاضي التقديرية، المرجع السابق، ص ا V. 
لأن عدم الكفاية يتعلق بالقصور أو عجز في الأسباب ولا تبطل حكم التحكيم، أما الانعدام

فيتعلق بعدم الوجود. والجزاء الذي يترتب علي انعدام الأسباب هو بطلان الحكم(').

ويجب أن توجد الأسباب في ذات ورقة الحكم، وذلك لأن السند يجب أن يجتمع

فيه شروط صحته دون حاجة إلى دليل آخر(). ولا يجوز للمحم أن يعتمد في الأسباب علي علمه الثخصي، ويقصد بذلك عدم الاعتماد علي الوقائع حصل عليها بغير طريق الوقائع المطروحة عليه من الخصوم، والتي تم إثباتها بمعرفته، وهذا الحظر متعلق بمسائل الواقع دون مسائل القانون.

ويثور التساؤل عن التزام المحكم بتسبيب كل أعمالـه؟ في الواقع لإرادة المحكم دور في إصدار الأحكام، وهذه السلطة قد تتسع وقد تضيق، فقد يكون له سلطة مطلقة لا

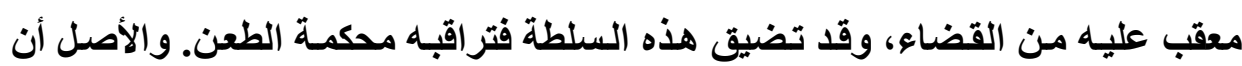
سلطة المحكم غير مطلقة، ويجب أن نفرق بين فرضين: الفـرض الأول: في الأحوال التي تنعدم فيها سلطة المحكم التقديريـة لا يكون هناك أي التزام عليه بالتسبيب. وذلك لان عمل المحكم يكون تقريريـاً يهدف إلى إعلان إرادة المشرع أو إرادة الخصوم فقط، ولا دخل لإرادته في هذا العمل. فمثلا يقوم المحكم بإعلان إرادة المشرع في حالة انقطاع الخصومة قانونـا طبقا لنص المسادة ^ب تحكيم، ففي هذه الأحوال لا يشترط التسبيب. الفرض الثاني: في حالة تمتع المحكم بسلطة تقديريـة غير كاملة فإنـه يلتزم بالتسبيب("). وهذا يرجع إلى أنـه من المتصور أن يسئ المحكم في استعمال سلطته،

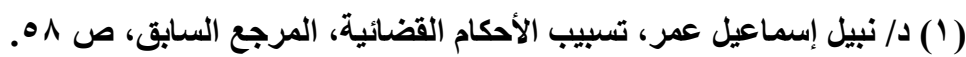

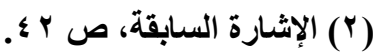

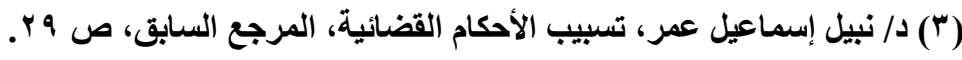


فيجب التسبيب لمراقبة المحكم في عمله. وهذه الرقابة تهدف إلى معرفة مـا إذا كان

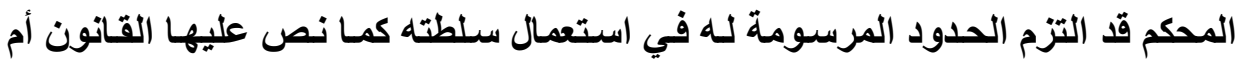

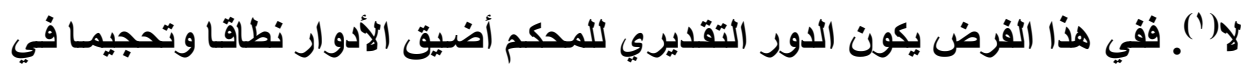

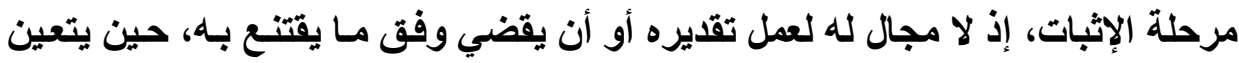
عليه إعمال لهذا الدور المحدود أن يراقب توافر الثروط المطلوبة قانونا في الإجراء أو الو التهائ

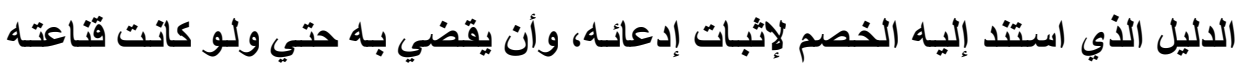
الداخلية متناقضة مع الحكم الذي أصدره. لذا فالأصل أن يقوم المحكم بتسبيب حكمه. ويترتب علي مخالفة ذلك بطلان حكم

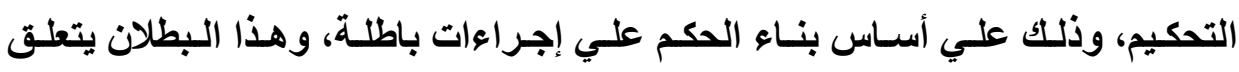

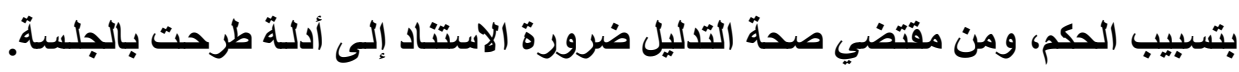

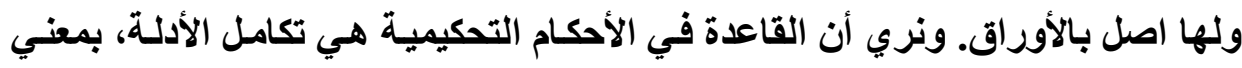

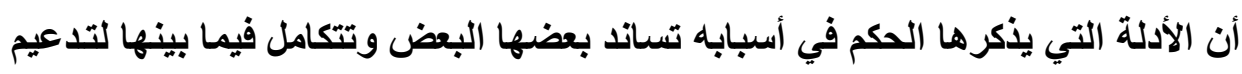

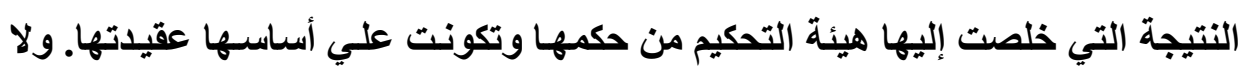

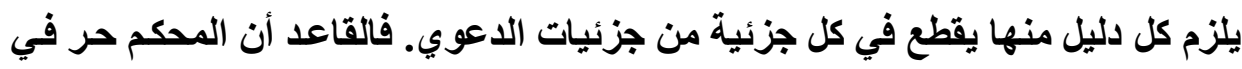

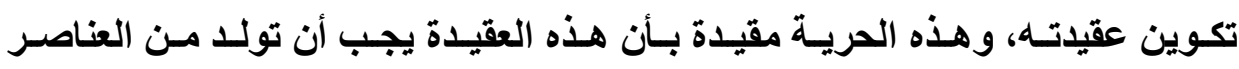

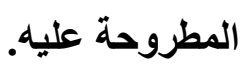
غير أن هذا المبدأ لا يحول دون القول بأن العيب الذي يشوب التدليل بالنسبة

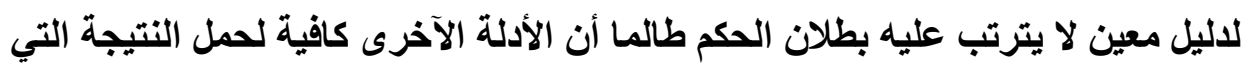

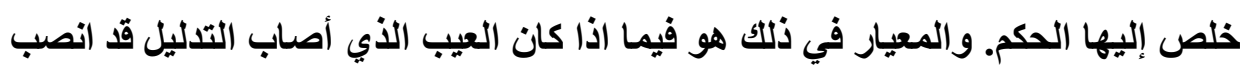
علي دليل لو استبعد لتغير رأي المحكم أم لا.

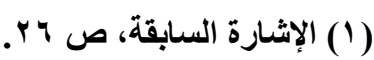




\section{r- هخالفة إجراءات الإثبات التي اتفق عليها الخصوم يترتب عليها البطلان:}

لقد نصت المادة به تحكيم علي أنه كون الحكم باطلا إذا فصلت هيئة التحكيم في

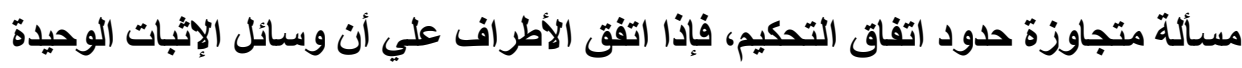

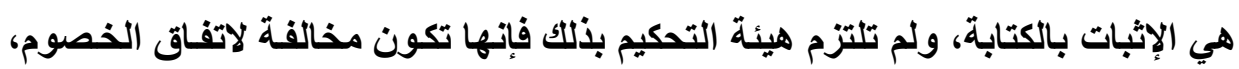
ويترتب علي ذلك البطلان.

ويجب لصحة الدليل أن يكون التلاليل واضحا، وأن يكون التدليل مستساغا. ،وأن يكون التدليل مستندا إلى أدلة طرحت في الجلسة واستندت إلى إجراءات صحيحة. وأن يذكر مضمون الأدلة دون غموض أو إبهام. بمعني أنه لا يكفي الإثـارة فقط إلى الأدلة

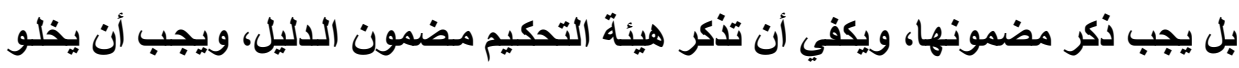
التدليل من التناقض، بين عناصر الحكم ذاته.

وبالتـالي يجب علي المحكم مراعاة اتفـاق الخصوم، وعدم مراعاة الإجراءات

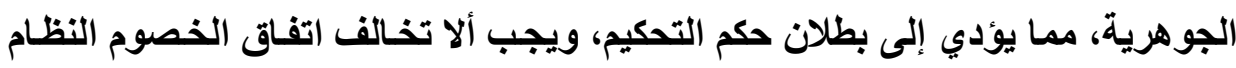

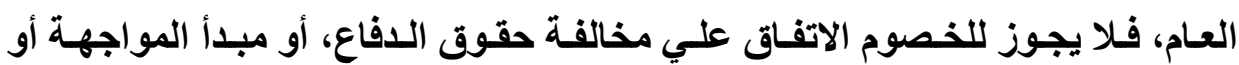

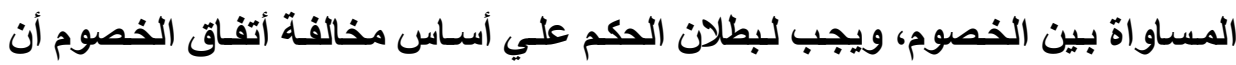

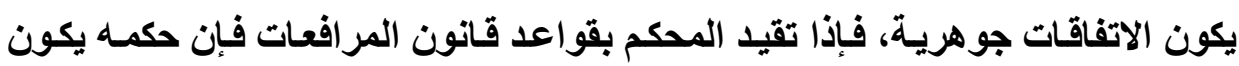

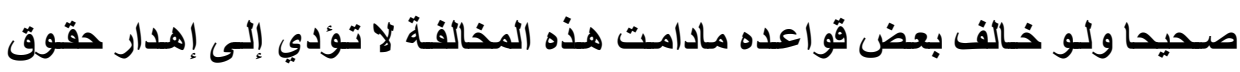
الدفاع، ولا تخل بما جاء في قانون التحكيم (') وإذا اشتترط الخصوم تسبيب الأحكام الصادرة بالتسبيب أو إحالـة إلى قانون

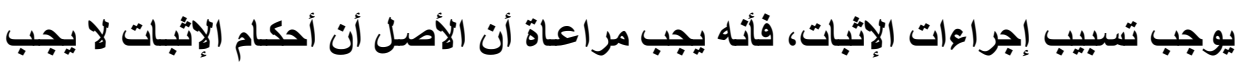

$$
\text { (1) أحمد ابو الوفا، التحكيم الاختيار والاجباري، المرجع السابق، ص ه ـ r. }
$$


تسبيبها، فقد نصت المادة ه من قانون الإثبات علي عدم تسبيب الأحكام التي تصدر باتخاذ إجراء من إجراءات الإثبات. مثل الحكم بالإحالة لخبير أو باجراء معاينة أو بتخاذ إجراء أو تقديم ورقة. ولكن مع ذلك قد ينص المشرع علي وجوب تسبيب بعض الأحكام

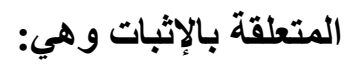
- أحكام الإثبات التي تتضمن قضاء قطعيا، حيث نصت المـادة ه من قانون الإثبات علي ضـرورة تسبيب الحكم القطعي، مثل الحكم بإجـازة الإثبـات بطريـق معين، والحكم الصادر في ذات الوقت في الموضوع وفي الإجراءات كـالحكم بالمسئولية وندب خبير لتقدير التعويض. الحكم الصادر بالعدول عن إجراءات الإثبات، فإذا عدلت هيئة التحكيم عن إجراعت

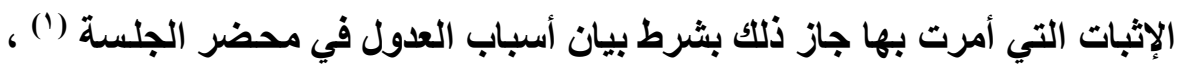
ولا يشترط أن يذكر الأسباب في ذات الحكم الصادر بالعدول، وذلك لعدم مساس هذا الحكم بمـصالح الخصوم(؟). ولا يشترط هذا التسبيب في حالة مـا إذا كانت هيئة التحكيم من تلقاء نفسها هي التي أمرث بالإجراء الذي عدلت عنه. تسبيب الأحكام التي ترفض اتخـاذ إجراء مـن إجراءات الإثبـات، فبإذا طلب أحد

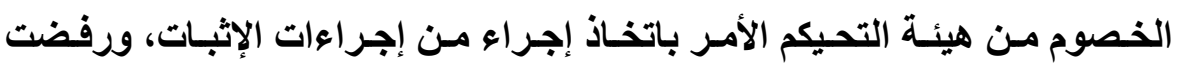
المحكمة إجابـة طلبـه، ففي هذه الحالـة طبقـا لنص المـادة هـ مـن قـانون الإثبـات المصري يجب علي المحكم تسبيب حكمها. 
- ـ تسبيب الحكم الصادر بعدم الأخذ بنتيجة إجراء الإثبات، لقد نص المشرع علي عدم

إلزام المحكم بالأخذ بنتيجة إجراء الإثبات، ولكنـه نص في المـادة 9 من قـانون

الإثبات علي إلزام المحكم بـللك الأسباب التي أدت إلى عدم الاخذ بنتيجة إجراء الإماء الإثبات، ويكفي ذكرها في محضر الجلسة.

ويترتب علي مخالفة ذلك بطلان حكم التحكيم، وذلك بشرط أن يكون الأطراف قد اتفقوا علي التسبيب أو أحالوا إلى قانون الإثبات المصري. ع- هخالفة قواعد الإثبات التب تقعلق بالنظام العام

لقد نصت المادة به تحكيم علي أن تقضي المحكمة التي تنظر دعوى البطلان من تلقاء نفسها ببطلان حكم التحكيم إذا تضمن مـا يخالف النظام العام في جمهوريـة

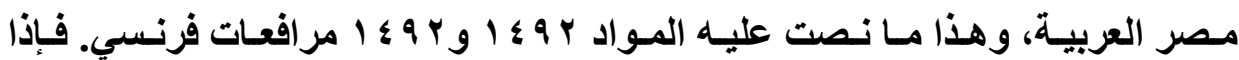

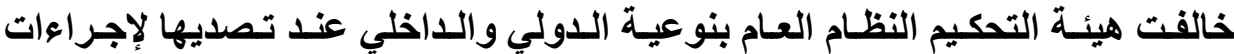
الإثبات، فهنا يتقرر بطلان حكمها' ') في الواقع يترتب علي مخالفة مبادئ التقاضسي الأساسية بطلان الحكم، مثل مخالفـة مبـدأ المواجهة وحقوق الـدفاع(؟)، ويعد مبـدأ المواجهة متعلقـا بالنظـام العـام

(1) CA Paris, 3 dec. 1965, op. cit., p. 22 op. cit., 14625, note Boulbes. Cass. 2e, 16 dec. 1985, op. cit., p. 390, CA Parism 2 fev. 1988, op. cit., p. 62, note Couchez.

(2) CA Paris, 7 janv. 1963, op. cit., p. 435, CA Paris, 14 fevr. 1985, op. cit., p. 325, note level. B. Moreau, A. Beregoi, et autre, arbitrage commercial, op. cit., no 212. 
الحمائي(')، وبالتالي يمكن الطعن في الحكم الذي يخل بهذا المبدأ بالبطلان علي أساس إخلاله بقاعدة تتعلق بالنظام العام(") وبالتـالي يجب علـي المحكم أن يحترم النظـام العـام الإجرائسي، لأسـه المـوطن الطبيعي لأكثر ضمانات التقاضي الأساسية أهمية هو ما يعرف بالنظام العام الإجرائي، فينبغي علي المحكم أن يضع من القواعد الإجرائية ويطبقها بما يكرس هذه الفكرة، وإلا الإنا كان حكمه عرضه للبطلان وعدم التنفيذ. و هناك ما يعرف بالنظام العام الدولي والنظام العام الداخلي، وهي تفرقة مسلم

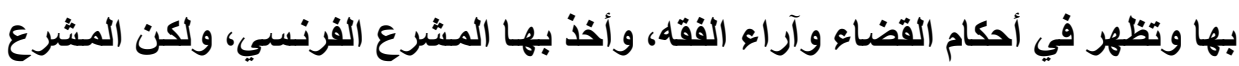

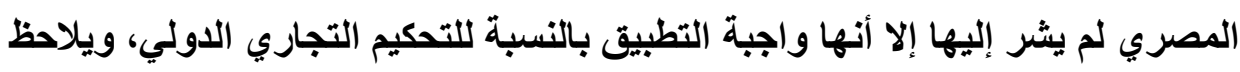

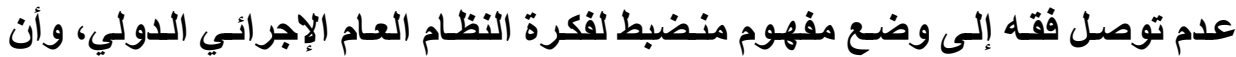
أغلب الأمثله التي ساقها هذا الفقه لما أسماه بالنظام العام الإجرائي الدولي، مثل مبلدأ

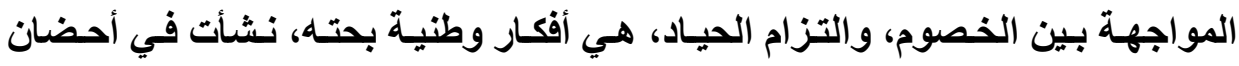
قانون المرافعات، وتقبلها الفقه والقضاء الدوليان بقبول حسن، وهي في حقيقتها ضمانات التقاضي الأساسية في خصومة التحكيم(").

(1) B. Moreau, A. Beregoi, et autre, id., no 211.

(r) دا دزمي عبد القتاح، واجب القاضي في تحقيق مبدأ المواجهة باعتباره أهم تطبيق لحق الدفاع،

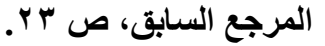

CA Paris, 3 dec. 2002, op. cit., p. 931.

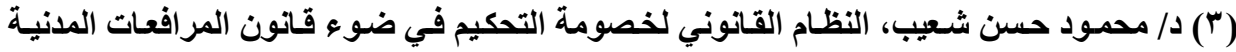

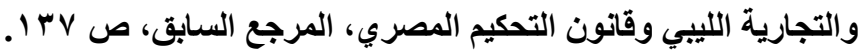




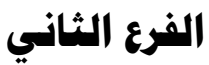

\section{عدم الرقابة علي السلطة التقديرية لهيئة التمكيم في الإثبات}

سنثير إلى الأسساس القانوني لعدم الرقابة علي سلطة المحكم التقديرية في

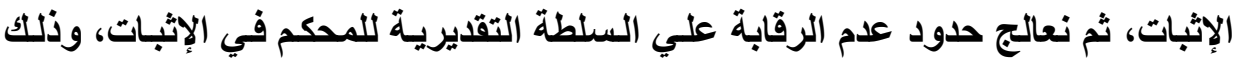

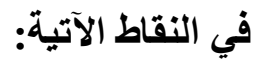

أولا: الأساس القانوني لعدم الرقابة علي سلطة المكم التقديرية في الإثبات. في الواقع يختلف سلطة المحكم عن القاضــ المدني فيمـا يتعلق بالسلطة التقديرية في الإثبات، حيث إن المحكم يتمتع بحرية كاملة في تكوين عقيدته علي عكس التهن القاضي العدني فهو مقيد في الإثبات بطرق معينة. ومعني ذلك أن المحكم يوجه تحقيقه

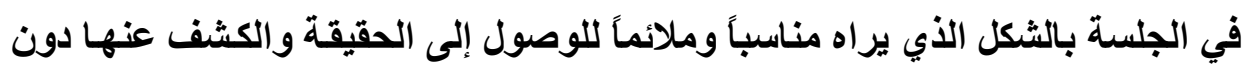
أن يتقيد في ذلك باتباع وسائل معينة للكثف عنها.

ويلاحظ أن المشرع المصري نص صراحة في المادة به تدكيم علي عدم قابلية

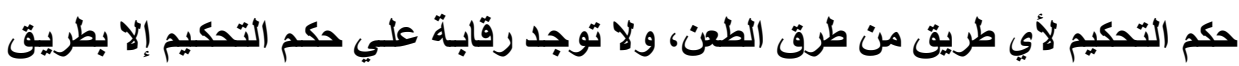
دعوي البطلان، وحالات البطلان منصوص عليها علي سبيل الحصر في المـادة به

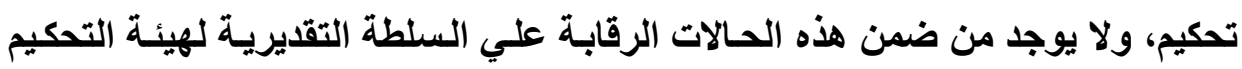

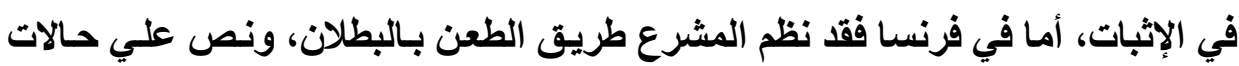

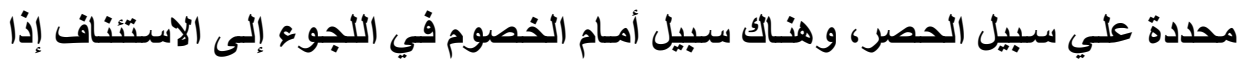

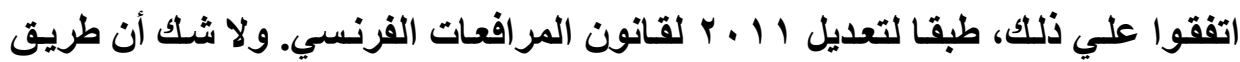
الاستناف يسمح للقاضي أن يراقب تقدير المحكم من حيث الواقع والقانون. لا شك السلطة التقليرية لهيئة التحكيم في الإثبات لا تتأثر بنوع التحكيم، فللهيئة سلطة تقديرية سواء كان التحكيم مقيد أو حرا، وسواء كان التحكيم داخليا أو دوليا، 
وذلك لأن هيئة التحكيم تقوم في جميـع الحسالات بالبحث عن الحقيقـة وتقيـيم أدلـة الخصوم، والوصول إلى حل عادل للنزاع('). وإن كـان للهيئة سـلطة تقديريـة أوسـع في هي حالة التحكيم مع التفويض بالصلح أو التحكيم الحر أو المطلق. ولهيئة التحكيم في كافة الأحوال السلطة التقديرية في تحديد مضمون المستندات ومحتواهـا ومدي لازم التبادل بين الأطر اف بشأنها، تحقيقا لمبدأ المواجهة(). ولا رقابة لمحكمة البطلان علي سلطة هيئة التحكيم في هذا الشأن، فهي سلطة مطلقة لها بشرط مراعـاة المبادئ الأسساسية

للتثاضي.

وإذا كان الثابت أن المحكم يتمتع بلور أيجابي في البحث عن الحقيقة، ممـا حدا

بالمشرع إلى أن يحرره من قيود الإثبات التي يتقيد بها القاضي المدني، فإن ذلك يرجع بصفه أساسية إلى أن الخصومة التحكيمية تتعلق بالمصالح الخاصة بالأفراد. وإذا كانت القاعدة الذهبية في التحكيم هي حرية المحكم في تكوين عقيدته واقتناعه. وبالتالي هذه السلطة التقديرية تتميز بأن إرادة المحكم لا تكون حرة في تحديد غأياتها، وانمـا فقط حرية اختيار السلوك الملائم للغائيات التي يحددها القانون("). ولا تعني السلطة التقديرية بصفة عامـة عدم خضوع النشاط تمامـا للتنظيم التشريعي، وإنمـا يمكن أن يقيـدها المشرع في شكلها، أو سببها أو محلها، ويترك مجـالا تقديريا جزئيـا في إصدارها أو

مضمونها.

(1) CA Paris, 12 juill. 1971, op. cit., p. 74.

(2) Id.

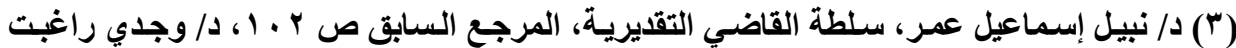

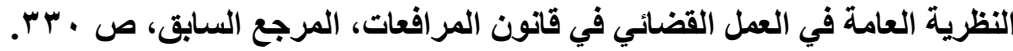


وإرادة المحكم تكون مستقلة بالقدر الذي تثتمتع فيـه بسلطة تقديريسة، لأنهـا تفرض حينئذ بنفسها لنفسها قاعدة سلوكها. قاعدة السلوك هذه تستمدها من طبيعتها الأتية ومن الأهداف الموضوعية التي ترمي إليها.

ويرجع أساس سلطة هيئة التحكيم التقديريـة إلى أنـه من الضروري منـح هيئة التحكيم سلطة إتمام مهمتها بإصدار حكم ينهي موضوع النزاع وذلك بتطبيق القواعد المختارة علي موضوع النزاع، ولكي يطبق المحكم القواعد المختارة لابد من أن يقوم بنشاط ذهني للتأكد من توافر مقتضيات أعمال القواعد، يتعلق هذا النشاط ذهني بتقدير صحة الوقائع، وكونها منتجة أو غير منتجـة، وكونها مطابقة أو غير مطابقة للنموذج في القاعدة الموضوعية أيـا كانـت هذه القاعدة قانونيـة أو عرفيـة أو قواعد القـانون

$$
\text { الطبيعي وقواعد العدالة. }
$$

والواقع أن السلطة التقديرية للهيئة التحكيم تجد أساسـها في نصوص المشرع واتفاق الأطراف علي التحكيم(')، حيث خول المشرع لهيئة التحكيم سلطة الفصل في النزاع، بعد اتفاق الأطر اف علي ذلك، وقد خول الأطراف سلطة لهيئة التحكيم للفصل في نزاع معين بمقتضي اتفاق التحكيم. وهذه السلطة تتلخص في القيام بمجموعة جهود ذهنية بهدف تقدير إمكانية توليد نزاع ما لأثر قانوني معين. أي ترمي هذه السلطة إلى ملى

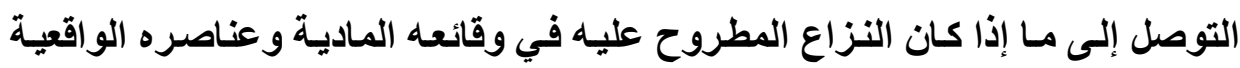
يعتبر صالحا أو غير صالح لتوليد الأثر القانوني الأي يطلبه المتقاضون أم لالَ). وهذه السلطة تكون مقيدة عندما يوجد شروط معينة لمباشرتها وتكون تقديريـة حينمـا يترك المشرع أو الأفر اد لها مجـالا حرا للتقدير، وعلـي ذلك يمكن القول بـأن (1) CA Paris, 15 mai 1984, op. cit., p. 287.

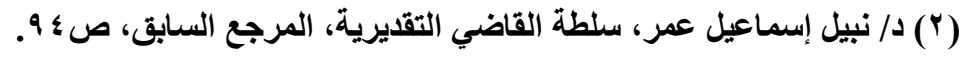

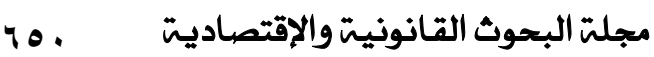


السلطة تكون تقديريـة حينمـا يترك لهيئة التحكيم عـادة الحريـة لتقدير مناسبة إعمـال قاعدة قانونية معينة علي واقع معين. وتمارس هذه السلطة في مجال الواقع وليس في

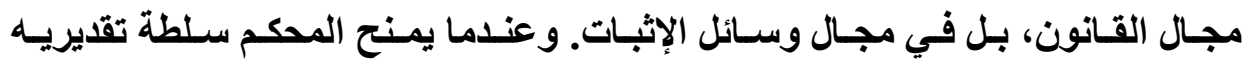
فـالمنطق يقتضي عدم رقابتهـه والقول بخـلاف ذلك يؤدي إلى إنهاء الآثـار الإنجابيـة للسلطة التقديرية للمحم، فالرقابة تتنقي مع السلطة التقديرية.

وامتناع محكمة البطلان عن رقابة السلطة التقديرية يرجع إلى أن هذا المحكمة تواجه حقيقة موضوعية تعترض رقابتها، ويقصد بهذه الحقيقة ذات السلطة التقديريـة

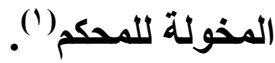
ثانيا: حدود عدم الرقابة علي الساطة التقديرية للهمكم في الإثبات يثار التساؤل هل كل أعمـال المحكم في الإثبات غير قابلة للرقابـة؟ في الواقع يجب علينا أن نفرق بين الفروض الآتية:

الفرض الأول: في الأحوال التي تتعدم فيها سلطة المحكم التقديريـة يكون هنـاك رقابـة مـن القضاء علـي سـلطة المحكم، فمـثلا إذا نـص المـشرع علـي شـروط معينـة للإقرار، فـلا يكون للمحكم سـلطة في هذه الحالة، ودوره يقف عند التحقق مـن هذه الشروط، والخطأ فيها يترتب عليـه بطلان حكم التحكيم. وذلك لأن عمل المحكم يكون تقريرياً يهدف إلى إعلان إرادة المشرع أو إرادة الخصوم فقط، ولا دخل لإرادته في هذا العمل. فمثلا يقوم المحكم بإعلان إرادة المشرع في حالة انقطاع الخصومة قانونـا طبقا لنص المـادة ^ ب تحكيم، ففـي هذه الأحوال لا يوجد سـلطة تقديريـة للمحكم، ويخضع لرقابة القضاء في هذه الحالة.

(1) CA Paris, 15 mai 1984, op. cit., p. 287. 
الفرض الثاني: في حالة تمتع المحكم بسلطة تقديرية غير كاملة فإنها يخضع إنها

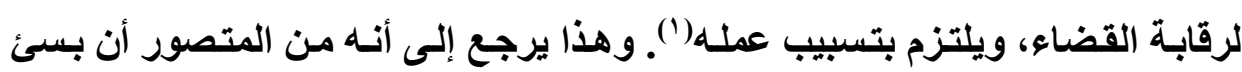

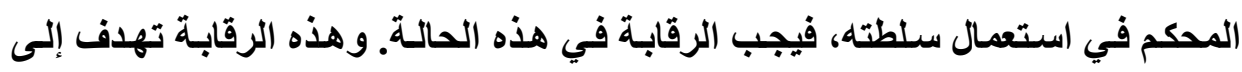

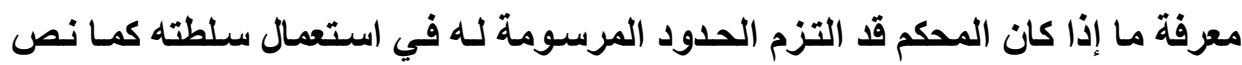
عليها القانون أم لام).

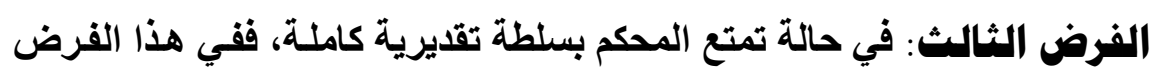

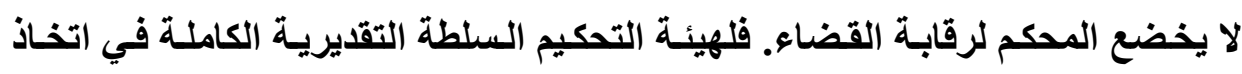

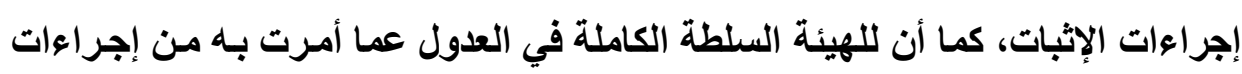

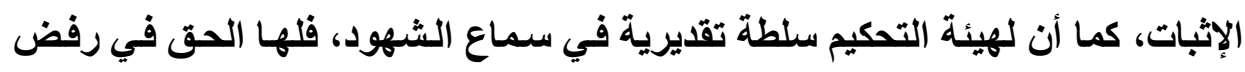

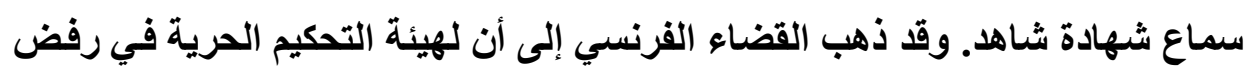

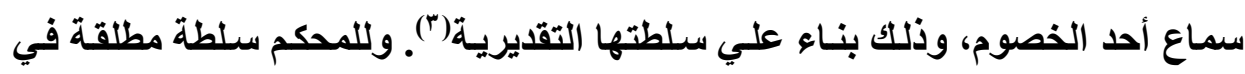

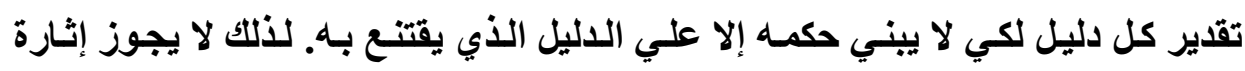
المنازعة أمام محكمة البطلان في تقدير المحكم لثهادة الثهود (4).

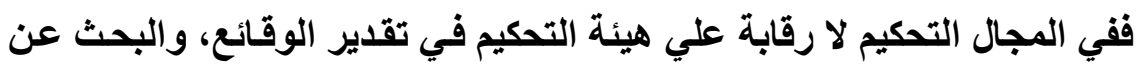

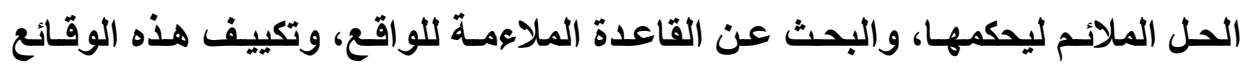

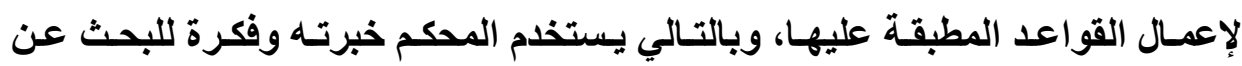

$$
\text { الحقيقة، ويستتذ إلى وسائل منطقية للوصول إلى الأحكام. }
$$

(3) CA Paris, 15 mai 1984, op. cit., p. 287; CA Paris, 12 mars 1998, Rev. Arb., 1999, p. 95, note flecheux.

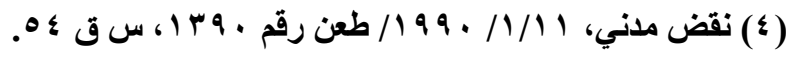


وإذا كان المحكم يتمتع بسلطة تقديرية بهذف حل النزاع المطروح عليه، ولكن هذه الحريـة تتقيـل بمحل هذا النشاط، سـواء كـان المحل هو مجرد وقـائع أو قواعد قانونية(') فوقائع النزاع التي يطرحها الخصوم علي المحكم يكون إزاءها محأيدا، حيث للخصوم السيادة علي هذه الوقائع، يطرحونها منها ما يشاؤون ويتركون منها في الظل بعيدا عن ساحة التحكيم ما يريدون. فالمحكم لا يستطيع أن يتجاوز هذا الإطـار الواقعي

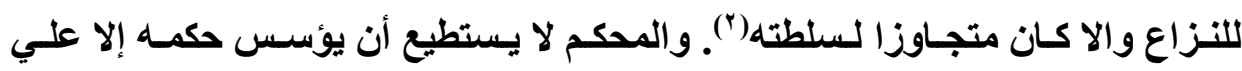
الوقائع مطروحة عليه بطريقة قانونيـة، وعبء الادعـاء بالوقائع المتنـازع عليها يقع علي عاتق الخصوم يتحلل إلى عنصرين: ادعاء الوقائع المتنـازع عليها، إثبات هذه الوقائع، وللمحكم حرية التقدير في بيان الوقائع التي تتعلق بالدعوي ومنتجـة فيها، الا أن هذه الحرية يريد عليها العديد من القيود، فجيب احترام القواعد الموضوعية في الإثبـات التـي تحدد طرق الإثبـات المتفق عليهـا، وكذلك هـو مقيد بـاحترام القواعد الإجرائية في هذا المجـال. ومقيـل بعدم القضاء بعلمـه الثخصي، ومـن خـلال الوقائع

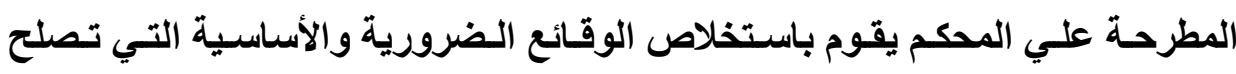
كوقائع ذات دلاله لتحقيق الفروض القانونية وإصدار حكم، وله سلطة تقديرية في ذلك لا رقابة عليه من محكمة البطلان.

والواقع أن الصحة أو الخطأ الذي قد يشوب اعمـال السلطة التقديريـة للمحكم، ويتولد ذلك نتيجة للفروق الفرديـة التي تختلف من محكم إلى آخر، ونتيجة للمستوي الأهني الأي يختلف من محكم إلى آخر. والسلطة التقديريـة لهيئة التحكيم، هي نشاط عقلي يجد مجـال أعمالـه في نطاق عناصر ماديـة. هذه العناصر الماديـة إمـا مجردة 
ومنظمـة في نص تشريعي. وأمسا في مرحلة أولـي، ماديـة وغير منظمـة تطرح علـي

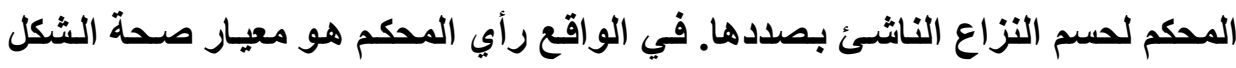

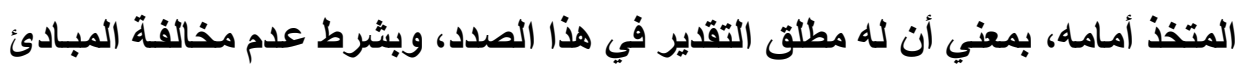

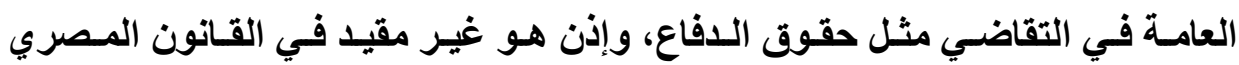
بنصوص المرافعات التي توجب الحكم ببطلان الإجراءات.

ورقابة محكمة البطلان علي أسساس بطلان الإجراءات التي بني الحكم عليها،

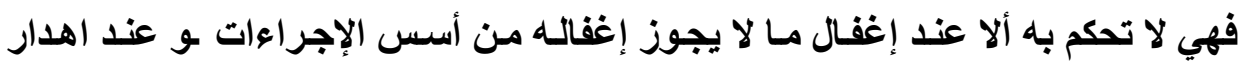

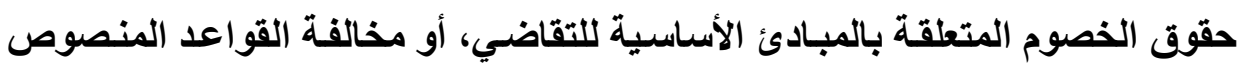

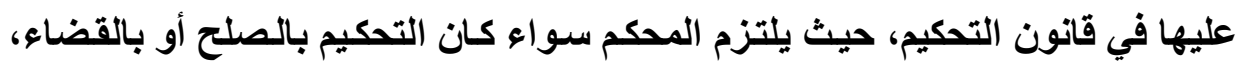

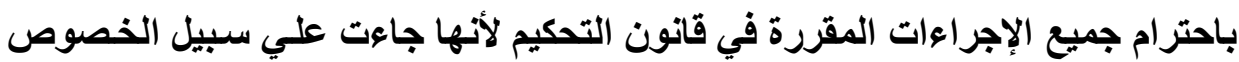

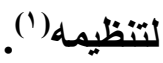

ونخلص من ذلك إلى أن علي المحكم أن يحكم في اللاعوي حسب العقيدة التي

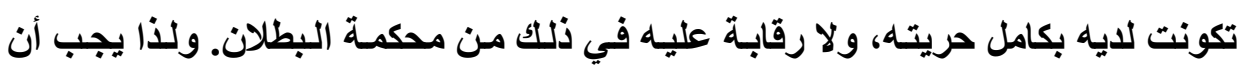
يبني الحكم علي العدالة، وأن يكون ثبوت إسناد الفعل إلى الأطراف مؤكدا أي مبنيا علي

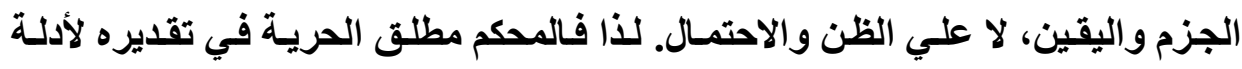

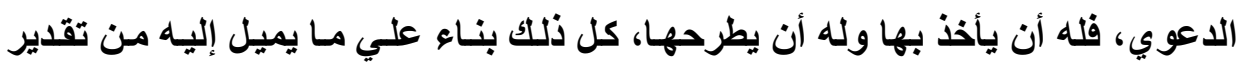

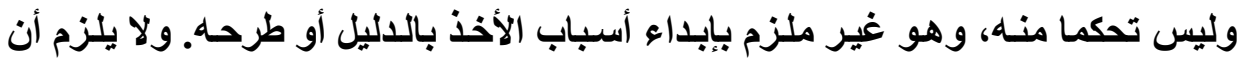

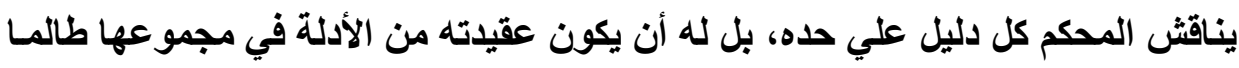


أنها منتجة في إثبات اقتناعه، مؤدي ذلك أنه لا يجوز تقيد المحكم في الحكم بقرائن أو افتراضات قانونية. وحريـة المحكم في تكوين عقيدته يشترط أن تمسارس في ظل مجموعـة مـن

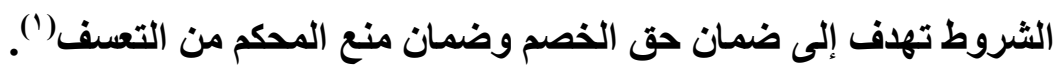

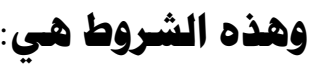
1 - يجب أن يتولد اقتناع المحكم من أدلة طرحت في الجلسة، وبالتالي لا يجوز للمحكم

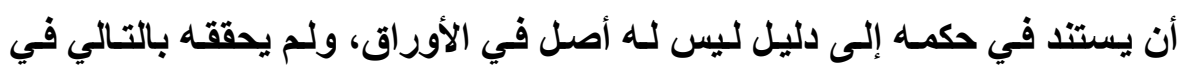
الجلسه، ويقع بذلك الحكم باطلا اذا استتد علي شهادة شـاهد لم تدون في الأوراق.

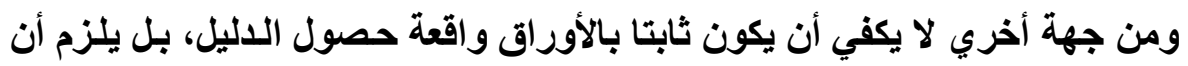
يكون ما استمده المحكم من هذا الدليل قائما فعلا في الأوراق. أي يلزم أن أن يستبين من الأوراق عينها قيام علاقة السببيه بين النتيجة التي توصل إليها وبين الدليل

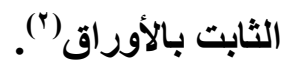
ونري أن المحكم ليس ملزما باخذ اللاليل بأكمله أو طرحه بأكمله، بل من حقه أن

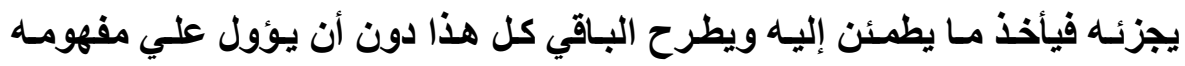

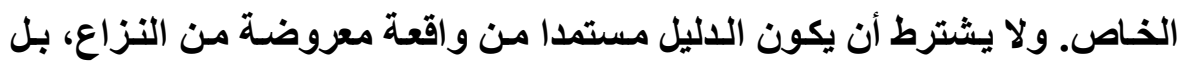

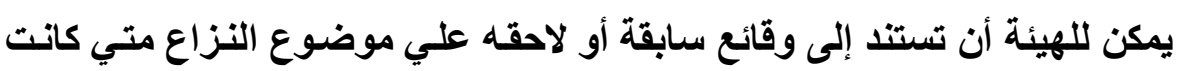

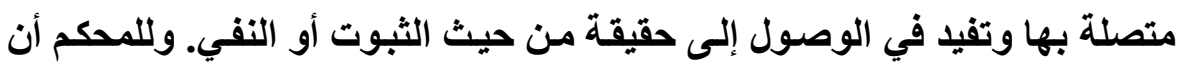


يستعين في تكوين اقتناعه بالقرائن التي تعزز الأدلة وتساندها، غير أن استعانة الهيئة بالقرائن المختلفة يجب أن تكون لتعزيز أدله تحقق شرط الاستناد إليها. r- يجب أن يكون اقتناع المحكم مبنيا علي دليل مستمد من إجراء صحيح، فلا يجوز الاستناد إلى دليل استمد من إجراء باطل وإلا أبطل معل الحكم، وذلك تطبيقا لقاعدة ما بني علي الباطل فهو باطل. فنلاحظ أن سلطة هيئة التحكيم مقيدة بالنسبة لأدلة الإثبات القانونية مثل الإقرار، حيث تنحصر سلطة الهيئة في التأكد من توافره. إذا فالفال ليس للمحكمة سلطة في عدم الأخذ به. وقد ذهبت محكمة النقض إلى أن "المقرر أن محكمة الموضوع لا تلتزم بالرد إلا على الدفاع الجوهري الذّى يقدم الخصم لها لها

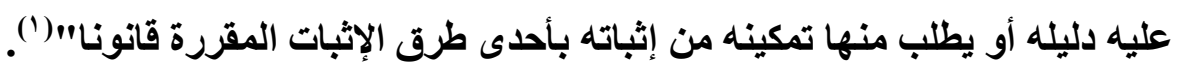

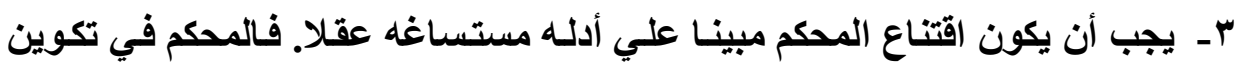
عقيدته وإن كان حرا في اختياره للأدلة التي يطمئن إليها في حكمـه الا أن ذلك فئك

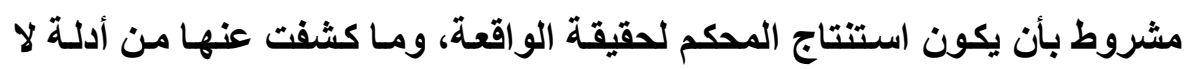

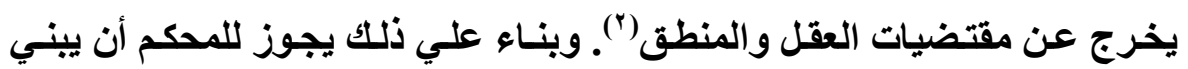
عقديته علي الثقافه العامة السائدة والتي يفترض علمها في كل شخص يتواجد في في

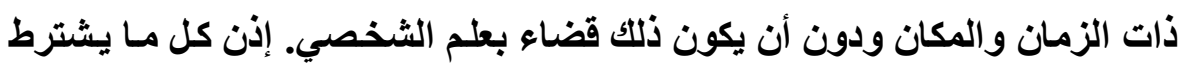

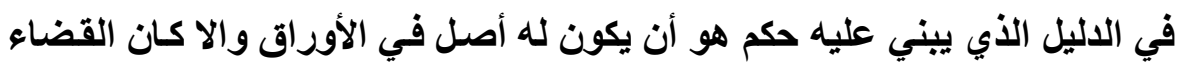
معيبا يستوجب نقضه. 


\section{خلاصة النصل الثاني}

خلصنا مما سبق إلى أنه في المجال التحكيم لا رقابة علي هيئة التحكيم في تقدير

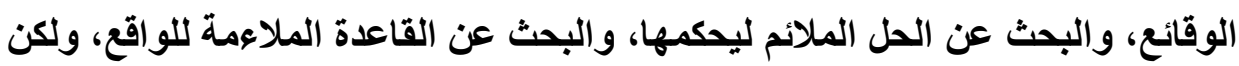
حرية هيئة التحكيم ليست مطلقة، فهنـاك ضوابط تلتزم بها هيئة التحكيم عند قيامها بالإثبات في خصومة التحكيم، وهذه الضوابط تعد قيودا علـي سلطة هيئة التحكيم،

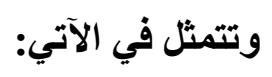

- مراعاة المبادئ الأساسية في التقاضي، والتي تتمثل في حقوق الدفاع والمساواة و المواجهة، والتحقيق الجامعي في حالة تعدد المحكمين، والحياد. التزام هيئة التحكيم بإجراءات الإثبات التي اتفق عليها التيا الخصوم.

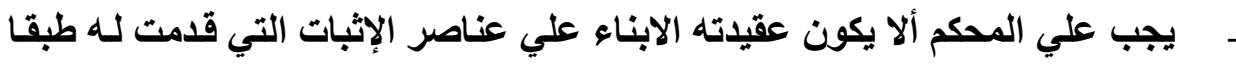

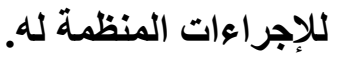
- ضرورة اثتتراك جميع المحكمين في اتخاذ إجراءات الإثبات، وذلكك في الأحوال التي

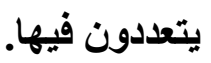
وقد خلصنا كذلك في هذا الفصل إلى أن هناتك رقابة علي سلطة هيئة التحكيم، وهذه الرقابـة محدود علـي سبيل الحصر في النظام المصري، وتتمثّل في دعوي البطلان، علي عكس النظام الفرنسي الذي أجـاز بنـاء علي اتفـق الخصوم اللجوء إلى الفى

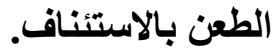

وقد عالجنـا في هذا البحثث إجراءات الرقابـة علـي حكم التحكيم. مسن حيث

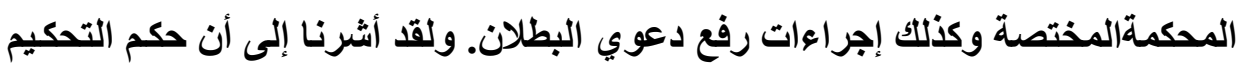

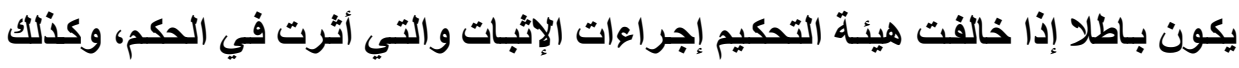
حقوق الدفاع ومبدأ المواجهة والتحقيق الجماعي، والحياد. 
ولقد خلصنا إلى أن المحكم يقوم بعمل شديد التعقيد، فهو يفحص الوقائع، وهو مقيد بالوقائع، لا يستطيع ابدا تجاوزها، وهو يبحث في إثبات هذه الوقائع، ويستخلص

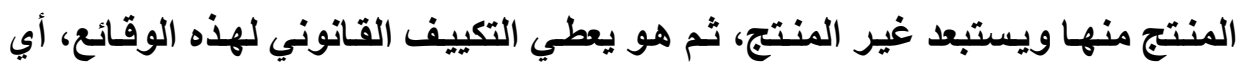
يطابق بينها وبين ما هو ثابت في الفرض النموذجي المجرد القائم في القاعدة القانونية الموضوعية أو العرفية أو قواعد العأدلة والقانون الطبيعي. فإذا تطابق الواقع المجرد مـع الواقع المحدد، منـح المحكوم لـه الحمائة التحكيميـة. ولا رقابـة علـي المحكم في لهي نشاطه الذهني في الإثبات.

كما لاحظنا أنه لا رقابة علي هيئة التحكيم في تقدير الوقائع، والبحث عن الحل

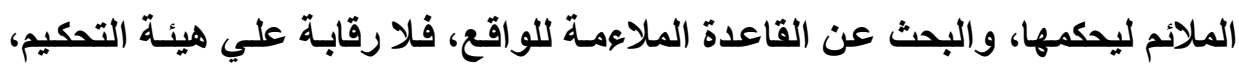
بشأن اتخاذ إجراءات الإثبات المناسبة، كذلك الأخذ بنتيجة الإجراء أو العدول عنها، كما لا رقابه علي العدول عن إجراعات الإثبات. ومبدأ عدم مراقبة هيئة التحكيم في سلطتها التقديرية، وإن كان يحمل في طياتها بعض مخاطر التحكم أو الخطأ في التقدير، إلا أن هذا المبدأ يتفق مع طبيعة التحكيم، وكما أن الخصوم علي علم مسبقا بهذا الأمر، وقد بـد قبلوه، وذلك لما يحققه التحكيم من مميزات كثيرة، ومن أهما السرعة والسرية وبساطة الإجراءات، وكما يخفف من هذه المخاطر أن التحكيم لا يكون في المسائل التي تتعلق

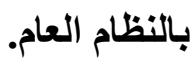




\section{نتائج البحث}

من خلال هذا البحث، يمكنتا الخروج بالعديد من النتائج علي السلطة التقيرية

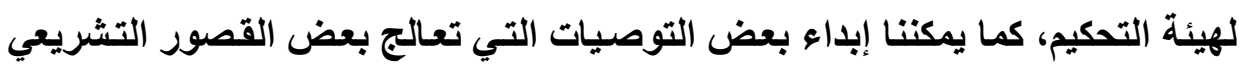
في معالجة هذا الموضوع، وذلتك علي النحو التالي:

\section{أولا: ملاحظات البحث}

1- لقد توصلنا إلى أن المقصود بالسلطة التقديرية لهيئة التحكيم في الإثبات، هي حرية ومكنة هيئة التحكيم في القيام بعطلية نشاط ذهني يعتمد علي استتباط من الدليل المقبول الاحتجاج به، إلى القتاعة التي تدفع الهيئة إلى الحكم علي نحو معين، بعد بعدي تقدير ها كفاية الاليل وقوة الدليل في الوصول إلى حقيقة النزاع.

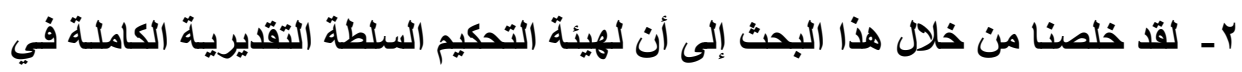
اتخاذ إجراءات الإثبات، سواء من تلقاء نفسها أو بنـاء علي طلب أطراف اتفـاق

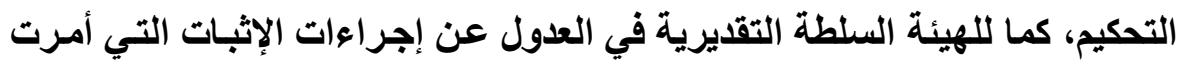

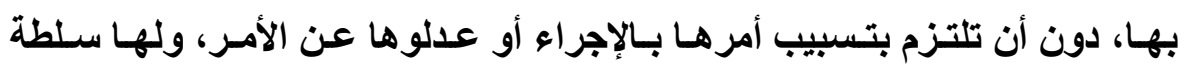

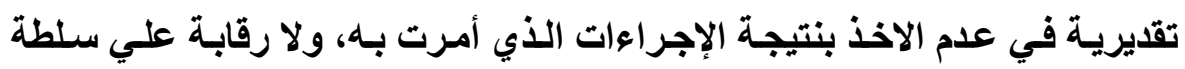

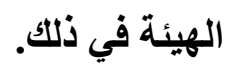

r- لقد لاحظنا من خلال هذا البحث أن هيئة التحكيم تملك اتخـاذ كافة إجراءات الإثبات

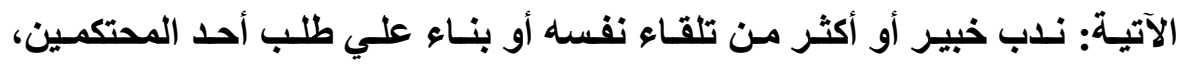

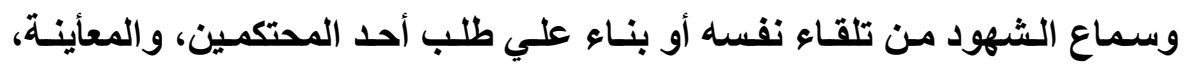

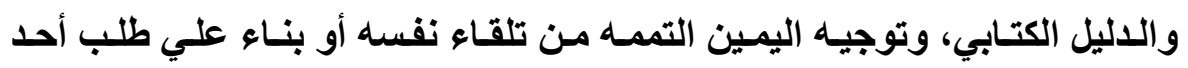
المحتكمين. وتوجيه اليمين الحاسمة بنـاء علي طلب أحد المحتكمين، ولا يختلف الفيل 
سلطة هيئة التحكيم في ذلك عن سلطة قضاء الدولة، وذلك بالنظر إلى قوة كل دليل وأهميته في تكوين اقتناعها.

ء - ولقد توصلنا إلى أن خصائص الإثبات أمام هيئة التحكيم لها طبيعه خاصـة، تتميز عن الإثبات الذي يجري أمام قضاء الدولة. كمـا أن أدلة الإثبات وإن كانت متشابه

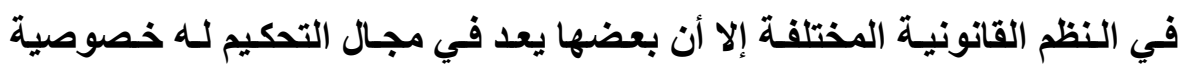

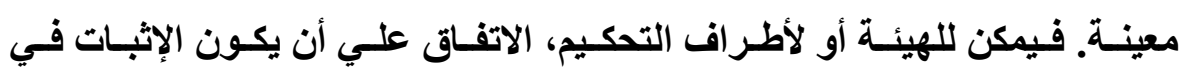
التصرفات القانونية بكافة طرق الإثبات. كمـا أنـه لا يفترض علم المحكم بالقانون الأجنبي فيجب إثباته أمام هيئة التحكيم عن طريق الخصوم.

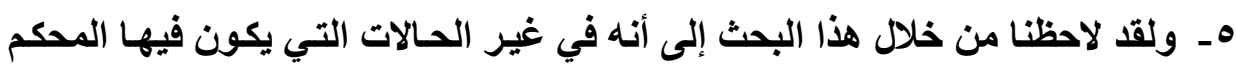
مفوض بالصلح، فإنه يلتزم بتطبيق قواعد الإثبات الموضوعية، وهو في هذا العمل ليس مجرد آلة، بل هو صاحب نشاط هذا النشاط يوجد به جاتب تقديري دائما، هذا لهات التقدير يظهر في كافة مراحل الإثبات، ففي مجال الوقائع يقوم المحكم بعمل تقديري

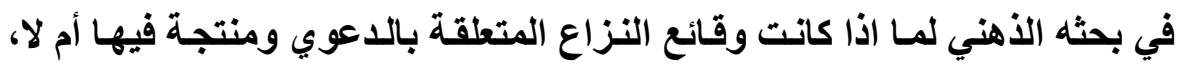
صحيح أنه يوجد في هذا المجال العديد من القيود التي ترد علي سلطة المحكم في

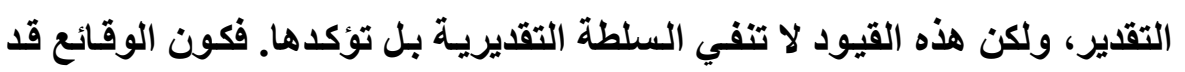
طرحت علي المحكم من جانب الخصوم، وكون هذه الوقائع مستمدة من الأوراق

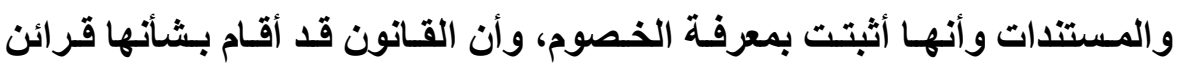
قانونية تعفي من الإثبات، كل ذلك يعتبر قيودا ترد علي سلطة المحكم التقديرية، وميع ذلك فهذه القيود لا تنفي هذه السلطة بل تؤكدها. فعمل المحكم في جوهره

$$
\text { نشاط ذهني إرادي يقوم به. }
$$

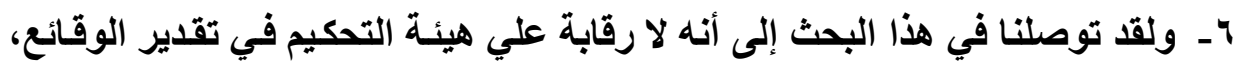

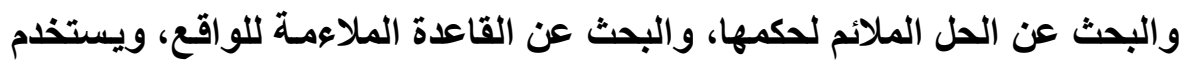


المحكم في ذلك خبرتهـ وفكره للبحث عن الحقيقة، ويستنـ إلى وسـائل منطقية للوصول إلى الأحكام.

V- ولقد خلصنا من هذا البحث إلى أنه إذا كانت هيئة التحكيم تملتك السلطة التقديرية

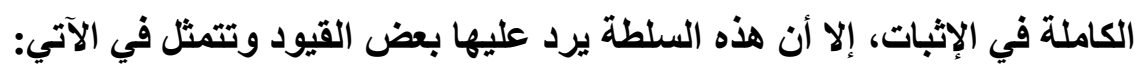

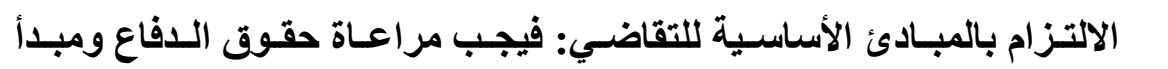
المواجهة بين اططراف التحكيم والمساواة. ـالالتزام بالحياد في الإثبات: يمتتع علي المحكم أن يكون عقيدته وفقا لمعلوماته الثخصية التي حصلها من واقع النزاع، والا كان قراره معيبا بعيب تجاوز

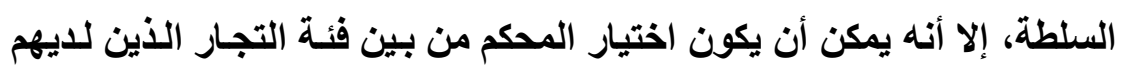

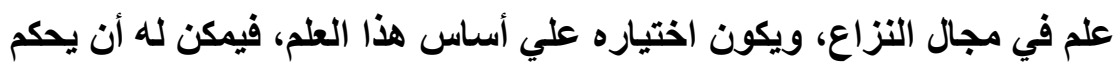

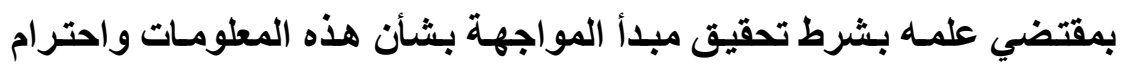
حقوق الدفاع.

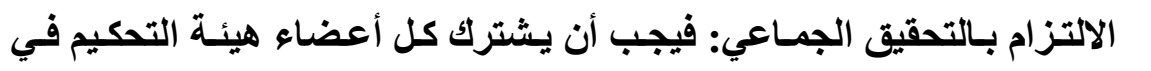

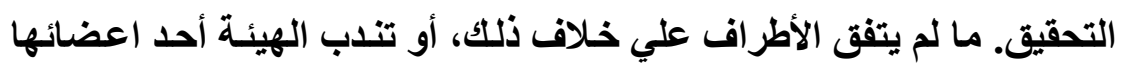

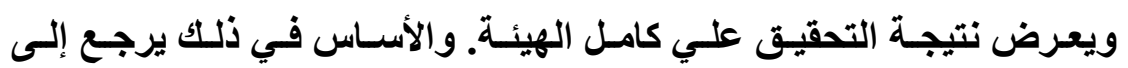
اثشتراكهم جميعا في نظر النزاع باعتبار هم هيئة وأحداه.

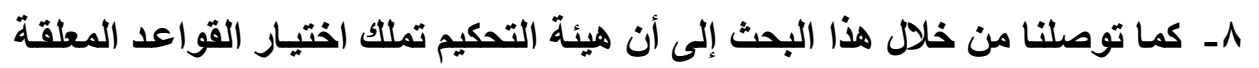

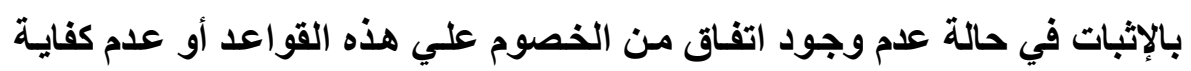

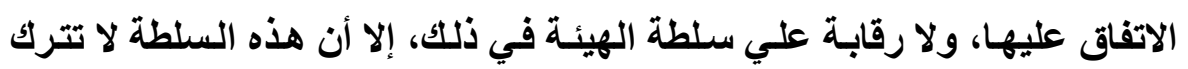

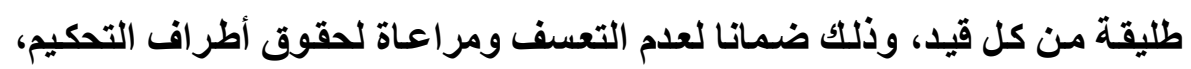
ويمكن رصد أهم القيود الواردة في هذا الثأن بما يلي: 
القيد الأول: الالتزام بما هو منصوص عليه في قانون التحكيم: القواعد المتعلقة بالإجراءات المنصوص عليها في قانون التحكيم تعد الحد الأدنى الذي يجب أن يلتزم به المحكمين.

القيد الثاني: ملاعمة الإجراعات للنزاع: ينبغي علي هيئة التحكيم أن تأخذ بعين الاعتبـار عناصر الملاءمـة، وملاعمـة الإجراءات لطبيعة النزاع، وهي سلطة موضوعيه لا تقوم علي الاعتبار الشخصي التقديري لوجهة نظر المحكمين، ومع إقامة التوازن بين مختلف عناصر شريعة التحكيم من

$$
\text { سرعة وسرية ومرونة. }
$$

9ـ ـ لقد توصلنا إلى أن هيئة التحكيم تلتزم باتفاقات الخصوم فيما يتعلق بقواعد الإثبات الواجبة التطبيق علي النزاع، ومخالفة ذلك يترتب عليه البطلان، بشرط ألا يخـالف هذا الاتفاق القواعد المتعلقة بالنظام العام. • 1 - لقد توصلنا في النظام المصري إلى أن هيئة التحكيم لا تملك سلطة الجبر في مواجهة طرفي التحكيم في الإثبات، فإذا امرت هيئة التحكيم بـإجراء من إجراءات الإثبات، مما ياخل في سلطتها الأمر به، ولم يستجب أحد طرفي التحكيم لمـا طلب منه، فإن للهيئة أن تفصل في الاعوي بـالنظر إلى الأدلة المتاحة أمامها، أو تحكم بإنهاء إجراءات التحكيم لعدم كفاية الأدلة، ولا يجوز لها اللجوء إلى القضاء لإلزام

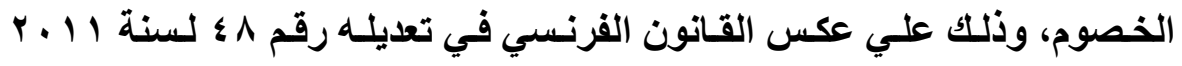
والذي منح لهيئة التحكيم سلطة في توقيع الجزاءات علي الخصم، كما هو الشأن بالنسبة لقاضي الدولة. 1 - - لقد توصلنا إلى أنه في النظام المصري، لا تملك هيئة التحكيم سلطة الجبر في

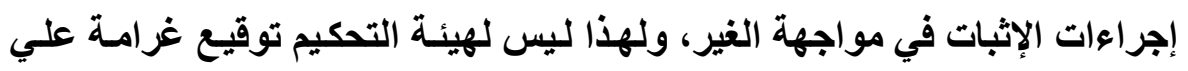


من لم يحضر من الشهود أو من يمتنع منهم عن الاجابة علي مـا توجيهه لله من أسـئلة، ولا إجبار الشاهد علي حلف اليمسين، وعلي الهيئة عندئــ أن تطلب من رئسيس المحكمـة المشار إليها في المسادة 9 تحكيم، الحكم علـي مـن يتخلف مسن

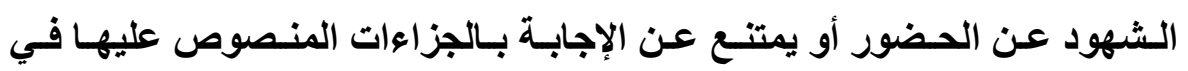

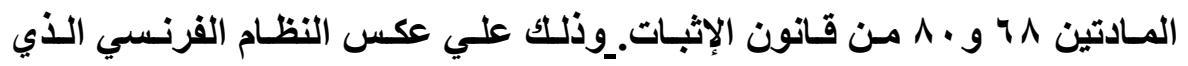
أعطي لهيئة التحكيم سـلطة الجبر في هذا الفرض طبقا لتعديل رقم 1 ؛ لسنة

r ا ـ لقد توصلتا في هذا البحث إلى التزام هيئة التحكيم ببعض القواعد الأساسية في الإثبات، سواء من حيث عبء الإثبات، و من حيث عناصر الإثبات التي قدمت لله

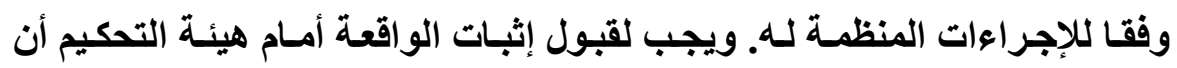
يكون من الجائز إثباتها، ومجدية، ومحددة، ومتعلقة بالاعوي ومنتجة فيها.

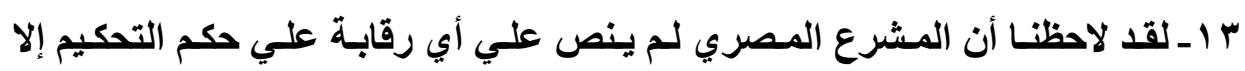
بطريق البطلان، وحالات البطلان محددة علي سبيل الحصر، ولا تتضمن الرقابـة علي تسبيب أحكام التحكيم، ولا الرقابة علي سلطة هيئة التحكيم في الإثبات، علي عكس النظام الفرنسي الذي أجاز للخصوم الاتفاق علي الطعن بالاستنئاف، وذلك

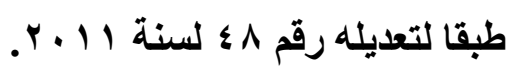
ـ ا ـ لقد توصلنـا إلى أنـه في النظـام المصري يمكن مراقبـة هيئة التحكيم في مجـال الإثبات من النواحي الآتية: - مـدي تطبيـق حقـوق الـدفاع والمواجهـة والمسـاواة والحيـاد أثنـاء إجـراءات

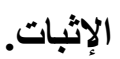
- مدي تطبيق أحكام قانون التحكيم واتفاق الأطراف بشأن قواعد الإثبات. - - مدي مخالفة هيئة التحكيم لقواعد الإثبات المتعلقة بالنظام العام. 
ه 1 ـ ولقد توصلنـا إلى أنـه بـالرغم مـن عدم النص الصريح علـي البطلان علي عدم تسبيب هيئة التحكيم لحكمها، إلا أنه يترتب البطلان علي عدم تسبيب حكم التحكيم في القانون المصري، وذلك لأن هيئة التحكيم تلتزم بأحكام القانون التحكيم، كما أن المشرع أمر الهيئة بالتسبيب، وإذا خالقت الهيئة نص المادة بـ تحكيم، ولم يوجد جزاء البطلان، فيترتب علي ذلك اعتبار كل نصوص قـانون التحكيم مكملـه لهيئة التحكيم وغير ملزمه لها، وهذا لـم يشر إليها المشرع المصري، بالإضـافة إلى أن البطلان هنـا يؤسس علـي أسساس بطـلان في الإجراءات أثر في حكم التحكيم المنصوص عليه في المادة به تحكيم.

ثانيا: الاقتراحات المتعاقة بالبمث لقد لاحظنا أثناء عرضنا للبحث أن هناك بعض القصور في بعض المسائل تحتـاج إلى إعادة النظر فيها، ويتمثل ذلك في الآتي: 1 ـ لقد نصت المادة جّ من قانون التحكيم المصري علي أن " وعلى كل من الطرفين

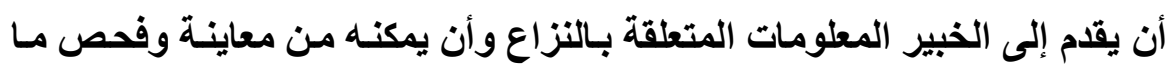
يطلبه من وثائق أو بضائع أو أموال أخرى متعلقة بـالنزاع وتفصل هيئة التحكيم في كل نزاع يقوم بين الخبير وأحد الطرفين في هذا الشأن"، في الواقع هيئة

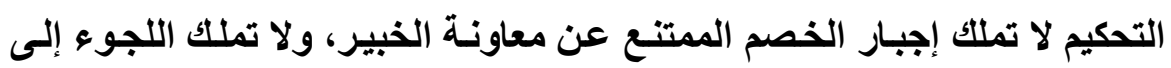
القضاء في هذه الحالة لإجبار الخصم علي المعاونـة،ولم ترتب المسادة أي أثر لتخلف الخصم أو امتناعه عن القيام بـالإجراء الذي طلبه منـه الخبير، فلم تعتبر هذا التصرف من قبل الخصم قرينة ضده. ونري أنـه يفضل إعـادة النظر في المـادة وب مـن قانون التحكيم المصري، لأن النص الحسالي سيفقد جاتبـا هامـا مـن فاعليته في شـأن الخبرة، لأن أداء الخبير 
لمهمته سيتوقف رهنـا في نهأيسة المطـاف علـي مشيئة الخصوم الذين كثير ا مـا يختلفون ويلجـأون إلى إعاقـة عمـل الخبير إذا شـعروا أن تقريـره لـن يكون في صالحهم، وهذا ما يدعو إلى ضرورة النظر في هذه المادة، بما يكفل لهيئة التحكيم سلطة إجبار الخصم علي معاونـة الخبير. ونقترح أن يـرد في نص هذه هذه المـادة الآتي" لهيئسة التحكيم أن تحكم بالغزامـة أو تاخذ بصحة المستتد إذا تخلف أحد الخصوم عن مساعدة الخبيز أو عدم تقديم المستتد المكلف بتقديمه، ويمكن أن يعفي من ذلك إذا امتثل لطلب الخبير وأبدي عذراً مقبولاً". ץ ـ لمدة التحكيم اهمية في مجال التحكيم، وقد تستغرق خصومة التحكيم مدة طويلة لأسباب لا دخل لهيئة التحكيم فيها، لذا نقترح إضافة نص في قانون التحكيم يقضي ولمي بعدم احتسـاب مـدة مباشـرة الخبير لمهمتـه ضـمن ميعـاد التحكيم، خاصـة وأن الاستعانة بالخبير تأخذ مدة طويلة في إعداد تقريره، وهذا المدة تحتسب من مدة

$$
\text { التحكيم في النص الحالي. }
$$

r- نظرا لأهمية سلطة الأمر في مجال التحكي، نري أنـه يفضل أن يمنح المشرع المصري هيئة التحكيم سلطة الالزام في مجال الإثبات في مواجهة أطراف التحكيم

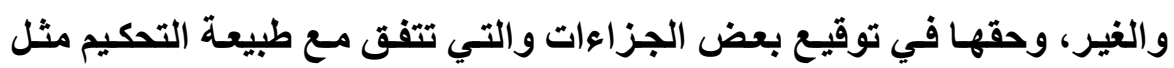
الغرامة التهديدية، وذلك تحقيقا لفاعلية نظـام التحكيم، وهذا مـا أخذ بـه المشرع

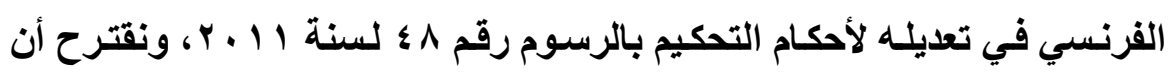
ينص المشرع في قانون التحكيم علي حق هيئة التحكيم في جبر الأطراف علي تقديم مستند تحت يده، وبالنسبة للغير يمكن لها أن تلجأ إلى القضاء من تلقاء نفسها في هذا الثأن، لأن الغير ليس طرفا في اتفاق التحكيم.

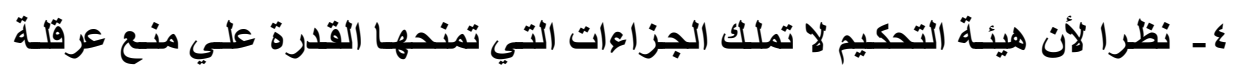
إجراعات التحكيم، لذا نقترح أن ينص المشرع علي بعض الجزاءات التي تملك هلي 
هيئة التحكيم، فإذا ارتكب أحد الخصوم مـا يبرر معاقبته لعرقة إجراعات الإثبات علـي خصمه جـاز أخذـ سـلوكه كقرينـة ضــده، أو جـاز الإثبـات بشههادة الشهود والقرائن في الأحوال التي ما كان يجوز فيها ذلك، أو جاز للمحمم أن يعتبر صورة الورقة التي قدمها خصمه صحيحة مطابقة لأصلها، في حالة امتــاع الخصم عن تقديم ورقة منتجة تحت يده. هـ ـ إذا كانت هيئة التحكيم تملكك سـلطة تقديريـة واسعه في مجـال التحكيم، وهذا قد يؤدي إلى التحكيم وعدم تدارك خطأ الهيئة ممـا يضر بمصلحة الخصوم، وخاصـة وأن قانون التحكيم المصري لا يسمح إلا بـالاعتر اض بطريق البطلان، فنري أنها يكون من الأفضل أن يسمح المشرع المصري للخصوم الاتفـق علي اللجوء إلى الحى الاستئناف، حيث يكون الأصل هو دعوي البطلان، ولكن يمنح الخصوم الحق في الاستنئاف إذا اتفقوا صراحة علي ذلك، وذلك التعديل يؤدي إلى تمكين الخصوم من التقاضـي علـي درجتين، وحمأيتهم من خطأ هيئة التحكيم، وهذا مـا أخذ بـه اله

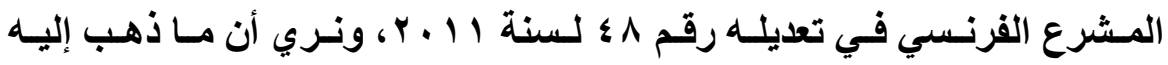
المشرع الفرنسي في تعديله الأخير يتفق مع طبيعه التحكيم، حيث لا يجوز الطعن في الحكم الصادر إلا بالبطلان، ولكنه راعي ذلك سلطة الأطر اف في التحكيم. 7- ونري أنه نظرا لأن حكم التحكيم فى أغلب نظم التحكيم غير قابل لطعن عليه إلا بـدعوى البطلان ولأسبباب محددة على سبيل الحصر، فالحكمـة تقتضى أن يتجـه قضاء الدولة إلى إعطاء مفاهيم مرنة لأسباب الطعن بالبطلان، حتى تستوعب كافة احتمالات الخطأ التى يمكن أن تصيب الحكم. ونري أنها يفضل أن ينص المشرع علي بطلان حكم التحكيم لعدم تمكين الخصوم من ممارسـة حقوقهم في الإثبات، والخطأ في قواعد الإثبات وكـان لها أثر في الحكم، لأنها لا يمكن قبول حكم من 
محكَّم غير عادل، ولم يتمكن الخصوم من ممارسة حقوقه في الإثبات لسبب خارج عن إرادته أثناء خصومة التحكيم. V- نظرا لأهمية التسبيب، لذا نقترح أن ينص المشرع المصري في قانون التحكيم صراحة علي البطلان لعدم تسبيب الحكم إلا إذا أعفي الأطراف هيئة التحكيم من التسبيب أو كان القانون الواجب التطبيق لا يشترط التسبيب، خاصـة وأن المشرع

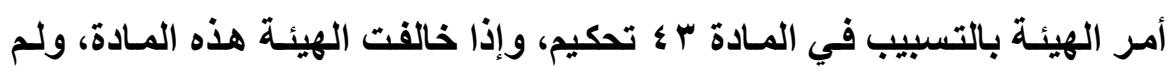
يوجد جزاء البطلان، فيترتب علي ذلك اعتبار كل نصوص قانون التحكيم مكملة لهيئة التحكيم وغير ملزمـه لها. كمـا أن التسبيب يمنع هيئة التحكيم من التحكيم ويمنتح الأطراف سلطة في الرقابة علي إجراعات الإثبـات التي قامت بيها هيئة التحكيم. ونري أن يكون النص علي التحقق من وجود التسبيب وعدم الانعدام، سواء أكـان انعداماً كلياً أو جزئياً، ولا رقابـة مـن حيث كفايـة التسبيب ومنطقيـة التسبيب، فالرقابـة تكون شكلية علـي الأسبباب. وذلك لأن محكمة البطلان ليس وليس طريقا للاستئناف ضد حكم التحكيم، فلا يجوز لها أن تقوم بدور محكمة الاستئناف، لأن ذلك يخالف اتجاه المشرع المصري في شأن تنظيمه لاعوي البطلان. وقد أخذ المشرع الفرنسي بهذا الاتجاه فنص صراحة علي بطلان حكم التحكيم لعدم تسبيبه.

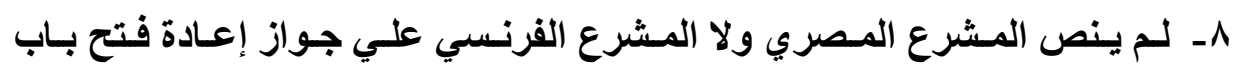
المرافعة بقرار من هيئة التحكيم، وذلك لوجود أدله تري أنها ضرورية للحكم في

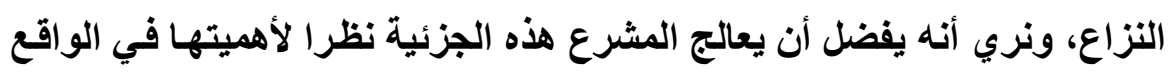
العملي، خاصة وأن هيئة التحكيم لا تلتزم بتطبيق قواعد قانون المر افعات، كما أنه لا يجوز استئناف الحكم الصادر من الهيئة في النظام المصري، فلا يمكن للخصوم

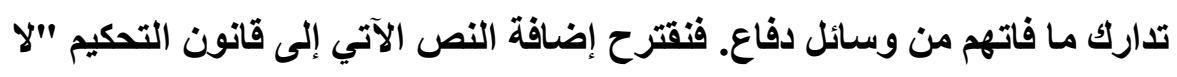


يجوز بعد ققل المرافعات تقديم أي مذكرة أو حجة أو أي دليل بخصوص المسائل التي سيتم الفصل فيها بحكم، إلا إذا طلبت هيئة التحكيم أو سمحت به".

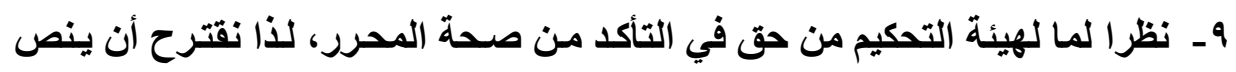
المشرع المصري علي حق هيئة التحكيم في تحقيق الخطوط الأصلية والمضاهاة ودعوي التزوير، وهذا ما أخذت به المـادة • V ا ا من قانون المرافعات الفرنسي

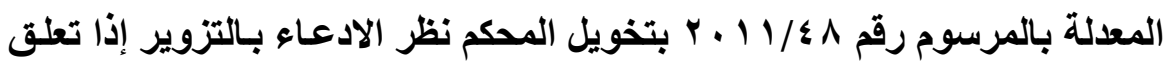

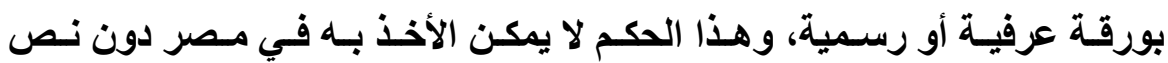
تشريعي.

ـ ـ لليمين في الإثبات أهمية كبيرة، لذا نقترح أن ينص في قانون التحكيم علي حق هيئة التحكيم في توجيه اليمين إلى أحد الخصوم خاصة اليمين المتممـه، وبالنسبة لليمين الحاسمة يكون بناء علي طلب الطرف الآخر.

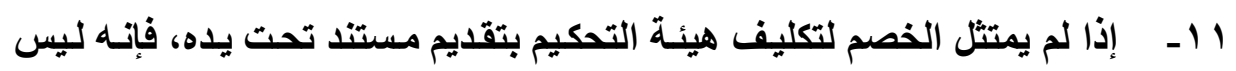
لهيئة التحكيم أن تلزمه بتقديمه، وفقا للمادة بr ب إثبـات إذ ليس لها سـلطة الأمر، وليس لهيئة التحكيم أن تلجأ إلى المحكمة التي تنص عليها المـادة 9 تحكيم لإلزام الخصم بتنفيذ الأمر الصادر له من الهيئة بشأن الإثبات، إذ لم يخولها المشرع هذه إله

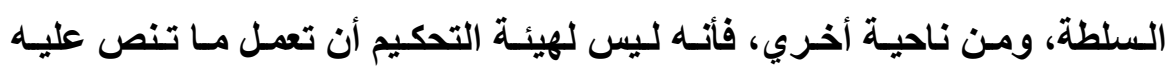

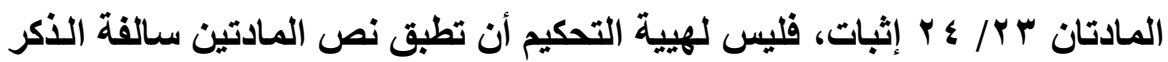

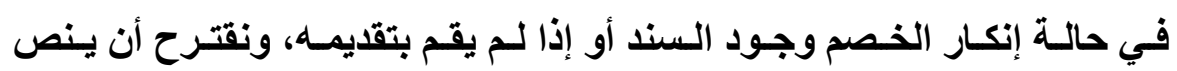
المشرع علي حق هيئة التحكيم في اللجوء الي القضاء في مثل هذه الحالة لأعمـال نص المادتين rrr، ع ع من قانون الاثبات. 


\section{قائمة المراجع}

\section{أولاً: هراجع عرببة}

ا ـ د/ إبراهيم نجيب سـع، قاعدة لا تحكم دون سـماع الخصوم، منشأة المعـارف، .1911

Y. د/ أبو العلا النمر، دراسة تعليلية للمشكلات العملية والقانونية في مجـال التحكيم

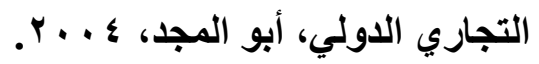

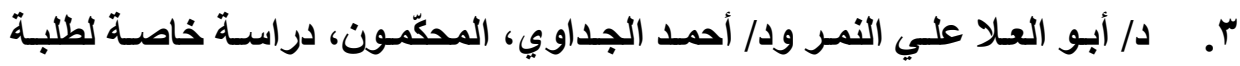

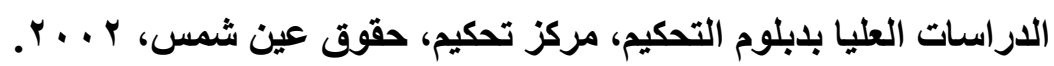

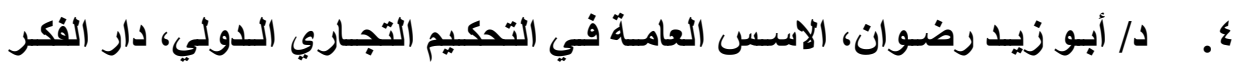

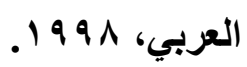

•.دأحمد إبراهيم عبد التواب، اتفـاق التحكيم والدفوع المتعلقة به، دار الجامعة

الجديد، 9 . . . .

7. د/ أحمد أبو الوفا، الإثبات في المواد المدنية والتجارية، المرجع السابق.

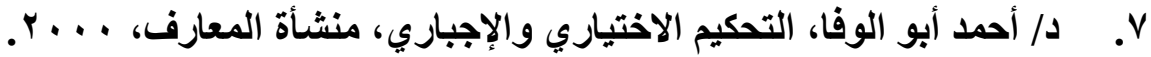

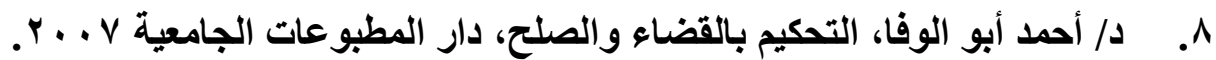

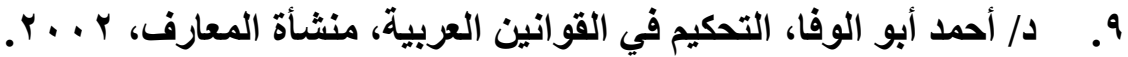
• 1 ـ د/ أحمد أبو الوفا، التعليق علي نصوص قانون الإثبات، ط؛، منشأة المعارف،

11. د أحمد أبو الوفا، التعليق علي نصوص قانون الإثبـات، مكتبـة الوفاء القانونية، .9 .17

Y I . د أحمد أبو الوفا، تكييف وظيفة المحكم، مجلة المحاماة، 90V 19 السنة السابعة والثلاثون، العدد السادس. 
rا 1. د د/ أحمد أبو الوفا، د/ طلعت محمد دويدار، التعليق علي نصوص قانون الإثبات،

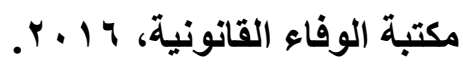

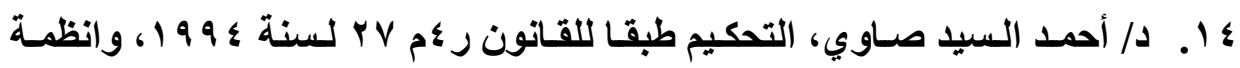

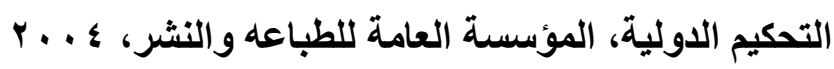

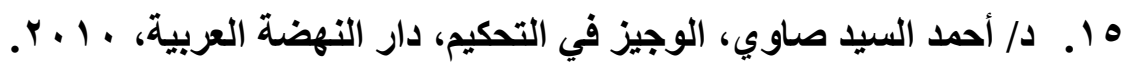

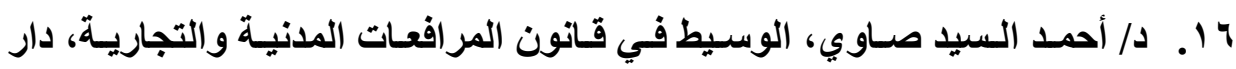
النهضة العربية، بدون سنه نشر.

IV

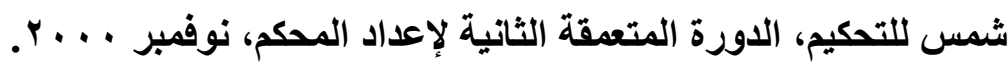

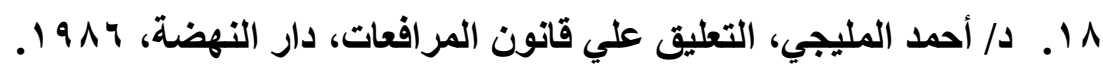

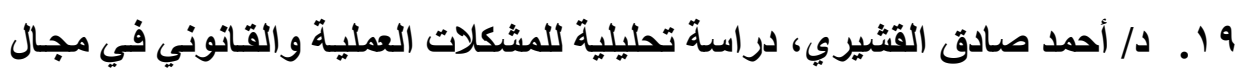

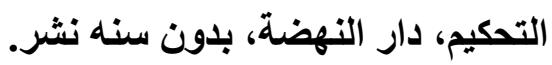

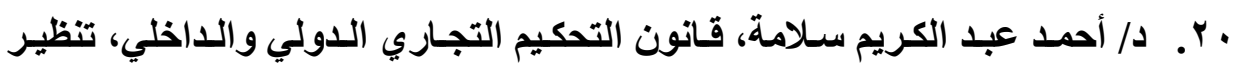

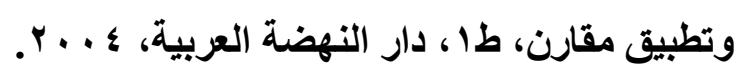

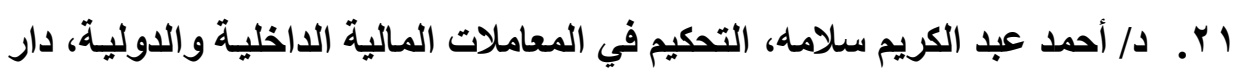
النهضة العربية، بدون سنة نشر.

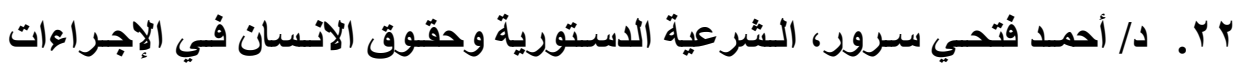

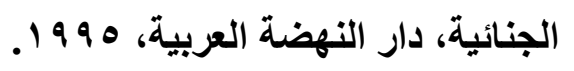

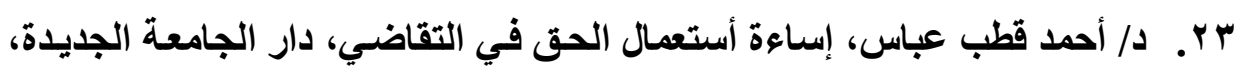
.r. . T

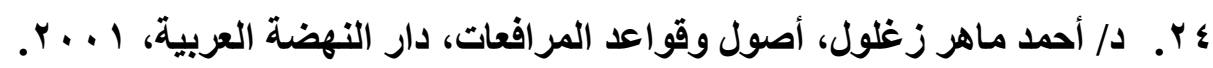

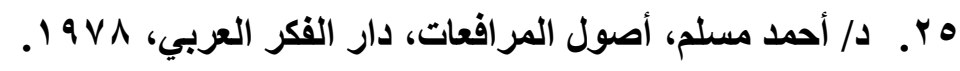
צY.

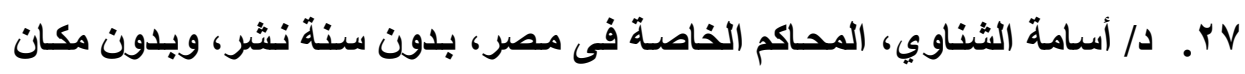
نثر. 


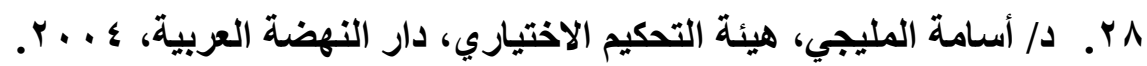

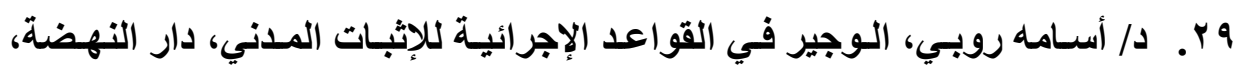
$r \cdot r$

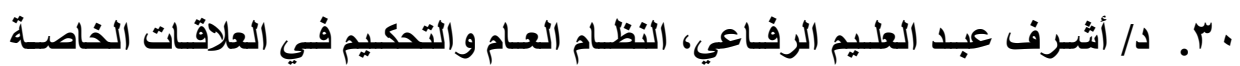

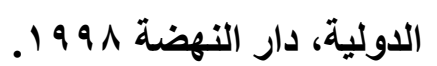

اسّ. د د/ أكثم الخولي، بدء التحكيم وسيره طبقا لنظام التوفيق والتحكيم التجـاري لغرفة

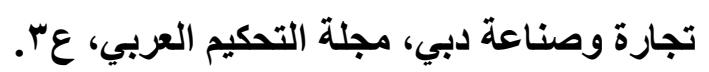

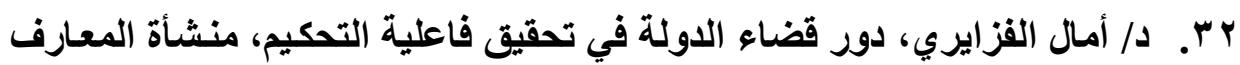

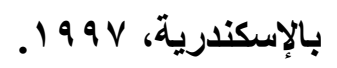

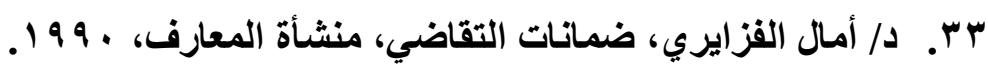

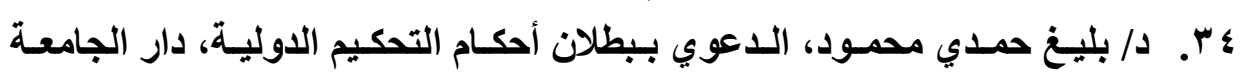

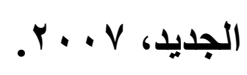

هـ. د/ جمال محمود الكردي، جنسية حكم التحكيم وأثرها في تحديد مركزه في الإقليم

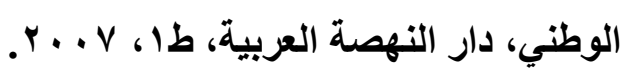

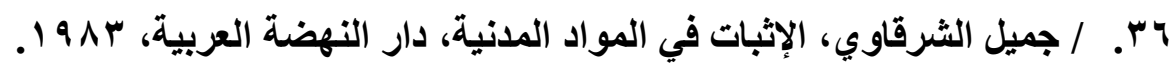

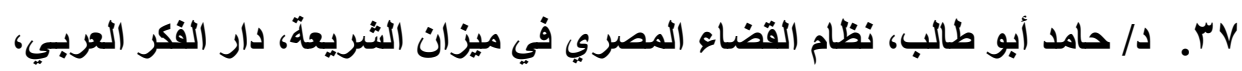
$.199 \mu$

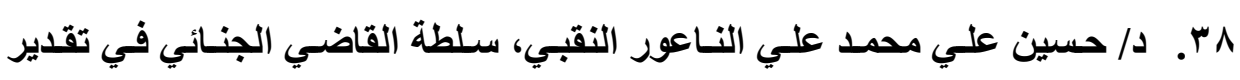

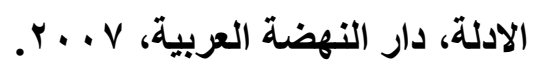

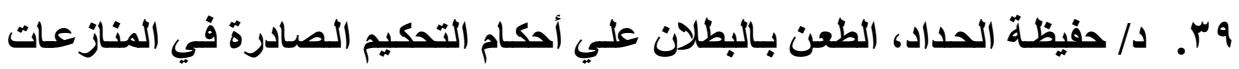

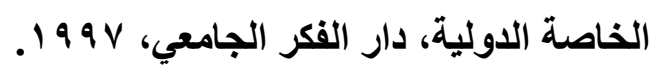

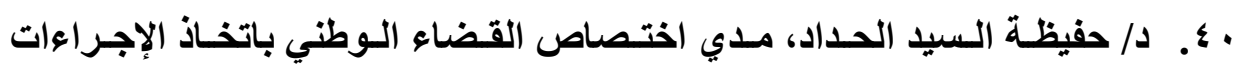

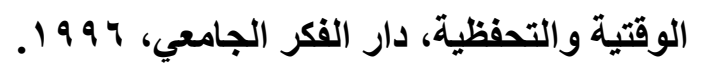

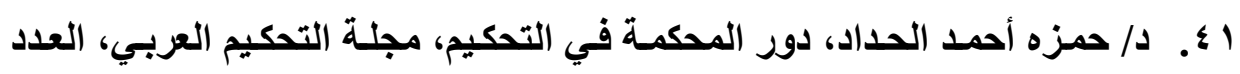

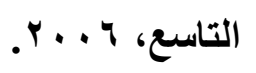


ץ ؟ـ. دـ/ خالد عبد العزيز أبو غابـه، التحكيم وأثره في فض المنازعـات، دار الفكر

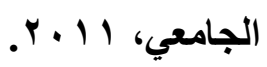

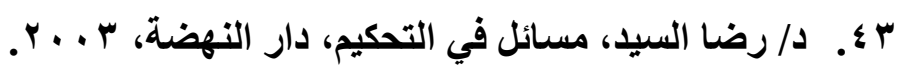

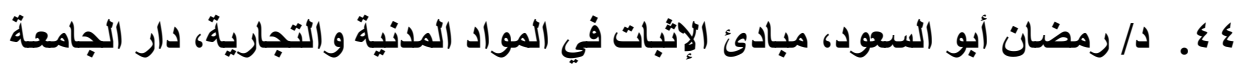

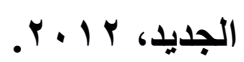

0 ؛ . د/ سامي محسن حسين السري، بعض الجوانب في القواعد الإجرائية المنظمـة

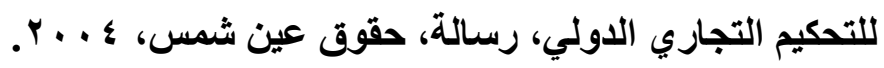

צ ؛. د/ سحر عبد الستار يوسف، دور القاضـي في الإثبات، دراسـة مقارنـة، رسـالة،

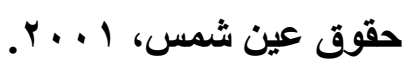

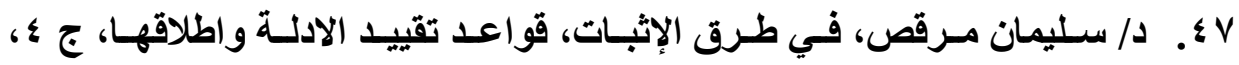

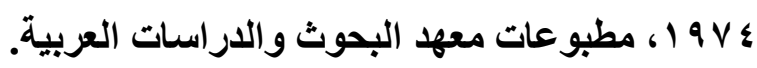

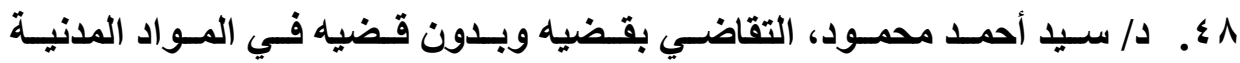

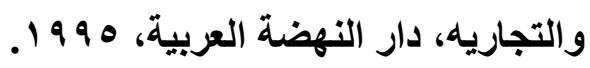

9 ؛. د/ سيد تمام، مبأ المواجهة في التحكيم، دار النهضة العربية، بدون سنة نشر.

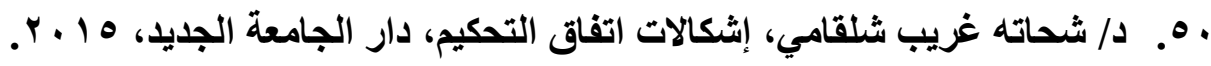

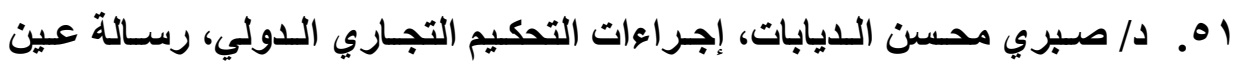

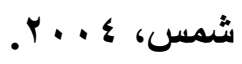

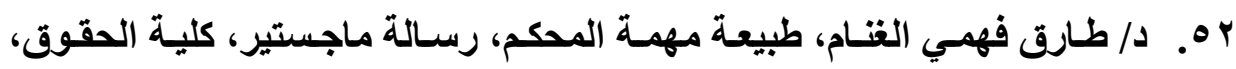

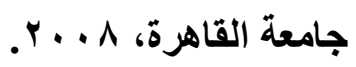

rه. د د/ طلعت محمد دويدار، تطور الحماية التشريعية لمبدأ حيدة القضاة، دار الجامعة

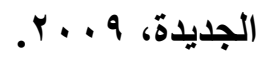

؛ ه. د/ طلعت محمد دويـار، ضمانات التقاضسي في خصومة التحكيم، دار الجامعة

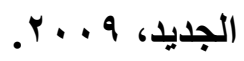

هـ. د/ عاشـور مبروك، التحكيم، المبـادى عالتى تحكم خصومة التحكيم، دار الفكر

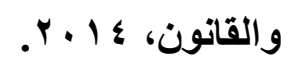


4ه. د/ عاشور مبروك، النظام الاجرائي لخصومة التحكيم، دارسـة تحليلية مقارنة،

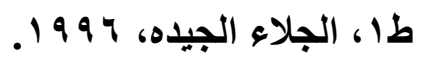

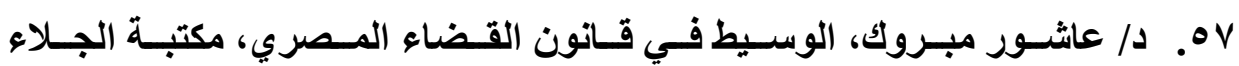

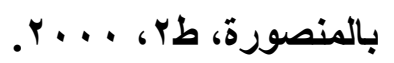

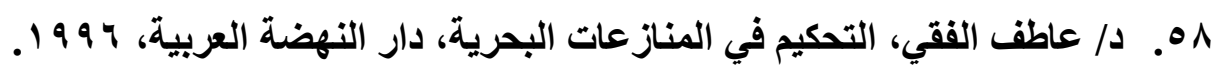

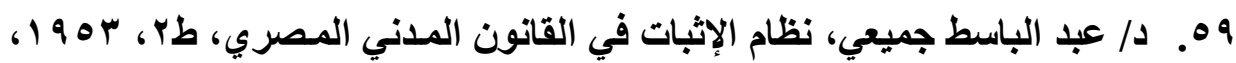
بلون دار نشر. • 7. د/ عبد الحكم فوده، البطلان في قانون المرافعات، دار المطبوعـات الجامعيـة، $.199 \mathrm{~V}$ الـ ـ د/ عبد الحكيم مصطفي عبد الرحمن، تعليق علي قانون التحكيم المصرى، رقم

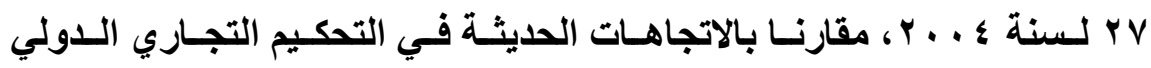

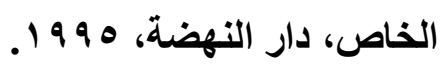

r r. . د/ عبد الحميد الأحدب، إجراعات المحاكمـة التحكيميـة الدولية وقواعد الإثبـات،

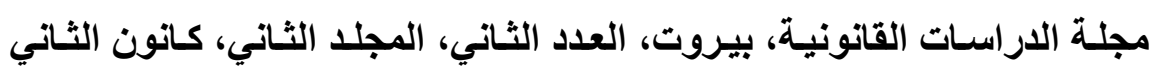

\section{.1999}

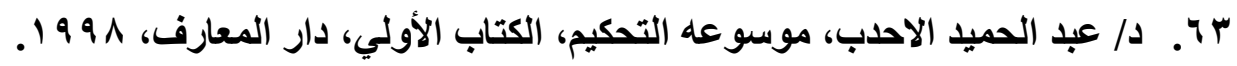

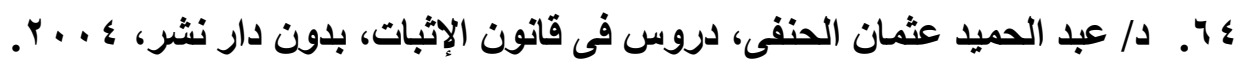

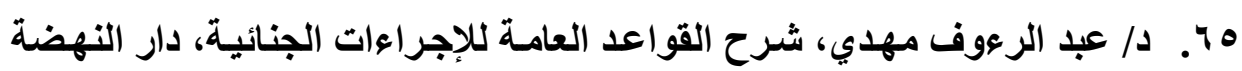

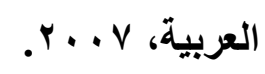

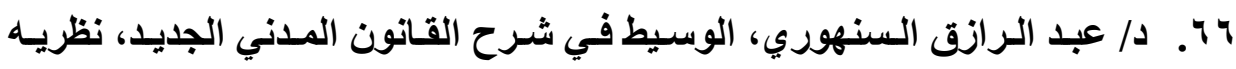

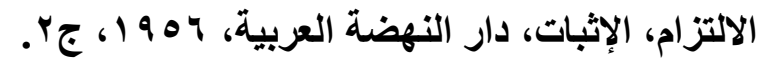

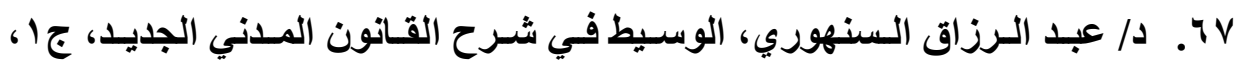

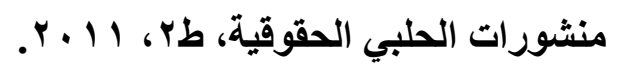

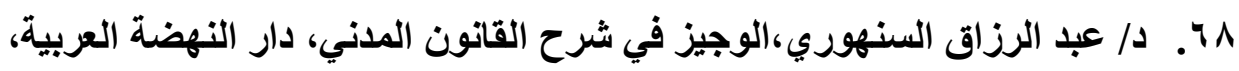


79. د/ عبد الغتي بسيوني عبد الله، مبدأ المسأواة أمام القضاء وكفالة حق التقاضس،

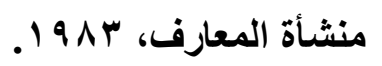

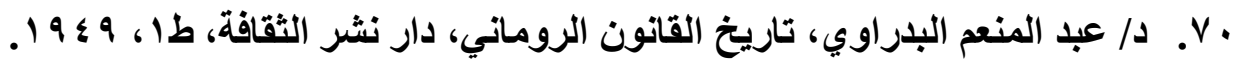

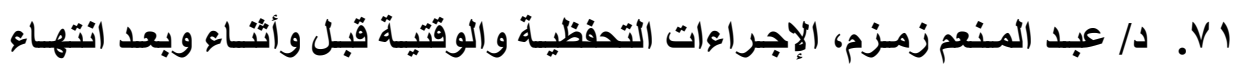

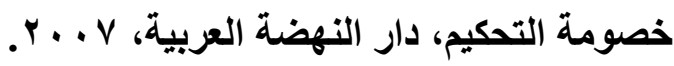

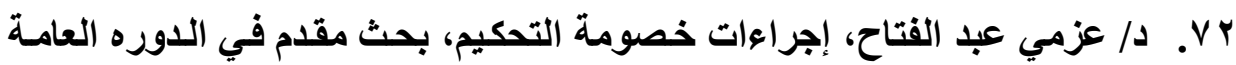
لإعداد المحكم، مركز تحكيم حقوق عين شمس.

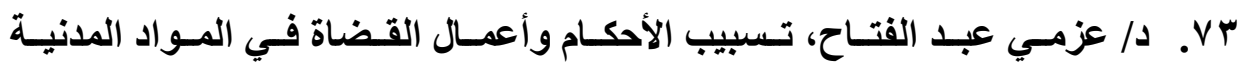

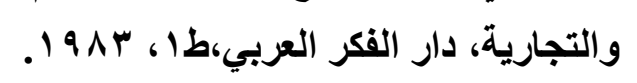

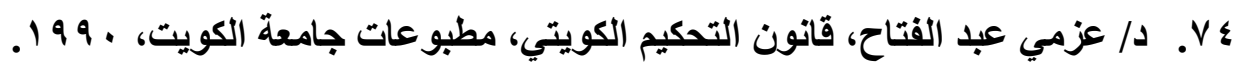

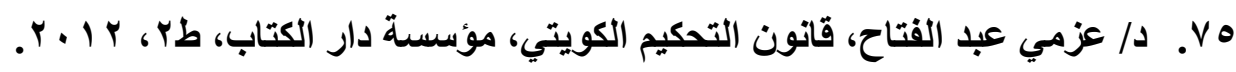

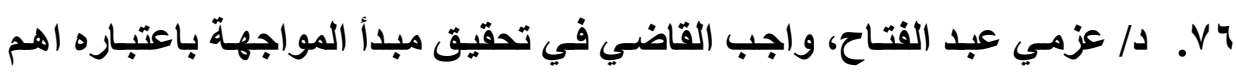

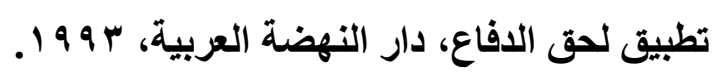

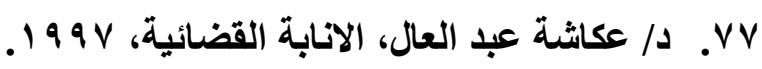

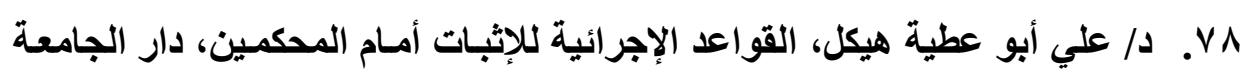

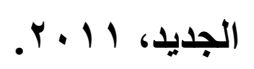

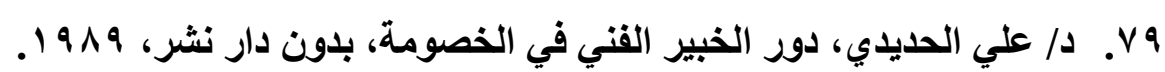

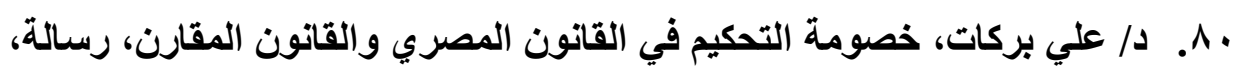

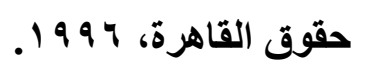

ای^. د/ علي بركات، خصومة التحكيم في القـانون المصري والمقـارن، دار النهضة

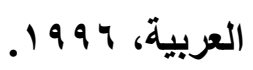

r r. . د/ علي هيكل، القواعد الإجرائية للإثبات أمام المحكمين، مرجع سابق.

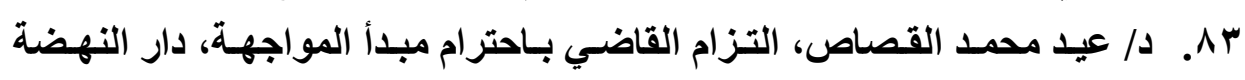

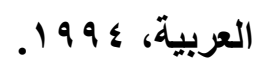


§^. د د/ فاطمة صلاح الدين، دور القضاء في خصومة التحكيم، دار النهضة العربية، $r+r$.

ه^. د د/ فتحي والي، التحكيم في المنازعات الوطنية والتجاريـة الدولية، علمـاوعملا،

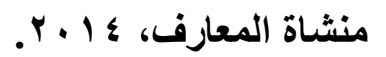

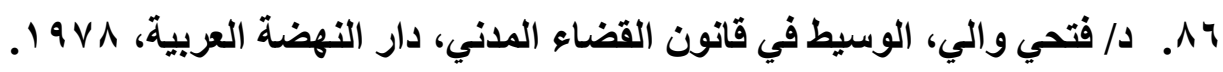
Av

$$
\text { r... V }
$$

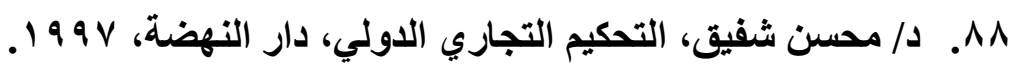

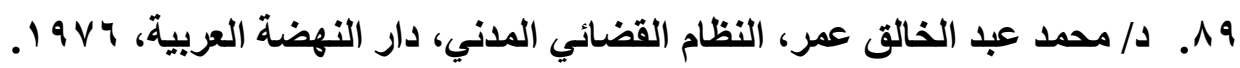

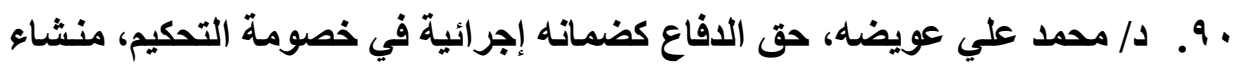

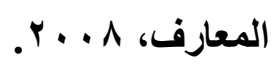

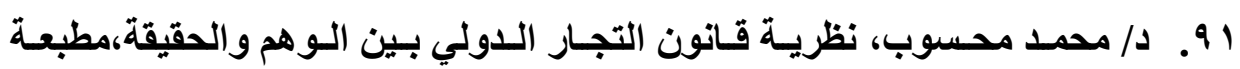

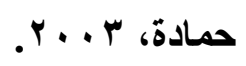

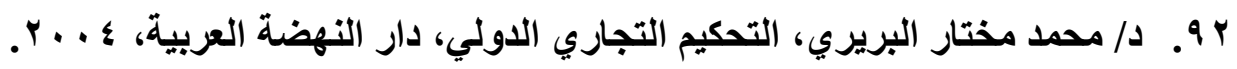

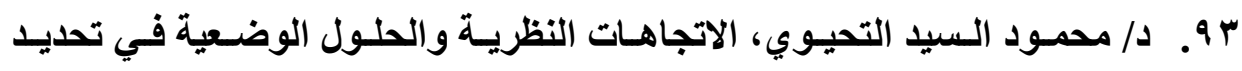
التنظيم الاجرائي لخصومة التحكيم، المرجع السابق.

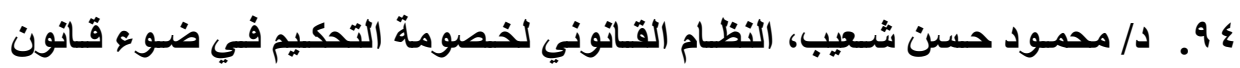

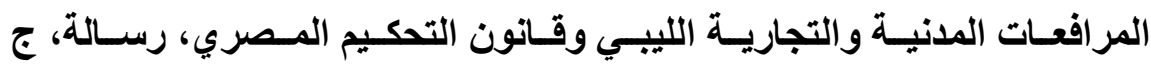

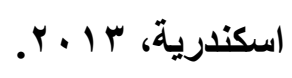

ه. 9 د محمـود سمير الشرقاوي، التحكيم التجـاري الـولي، دار النهضة العربيـة،

$$
.+11
$$

94.

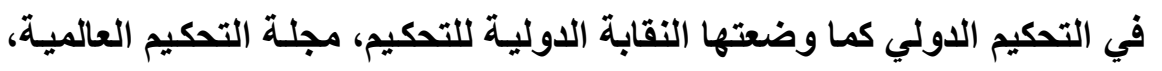

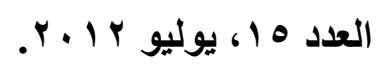

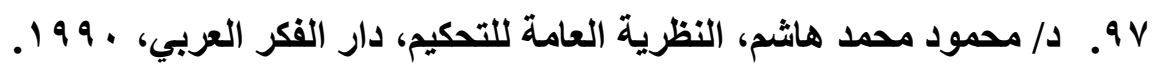




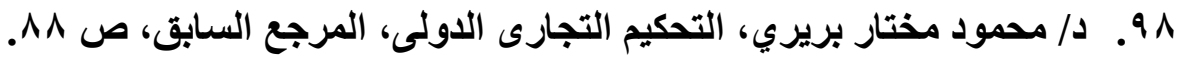

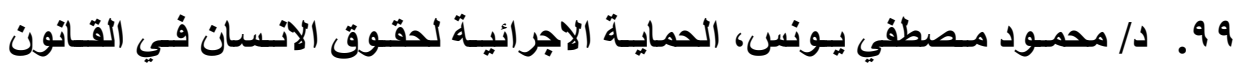

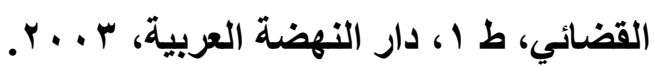

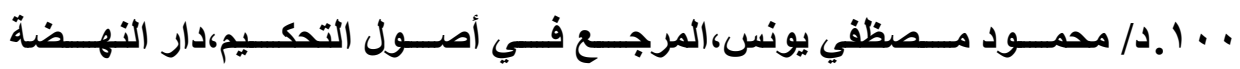

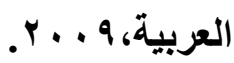

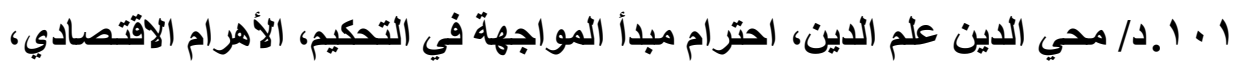

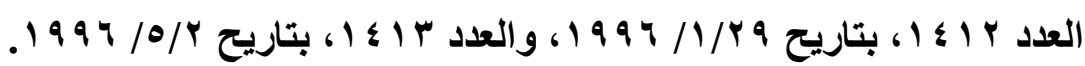

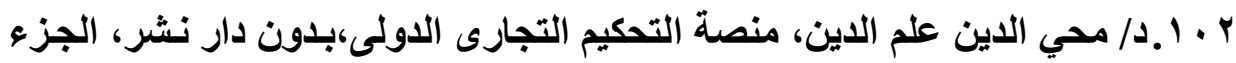

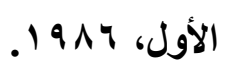

ץ • 1.د/ مختار بريري، التحكيم التجاري الدولي، المرجع السابق.

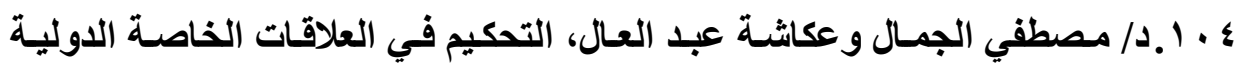

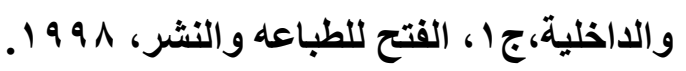

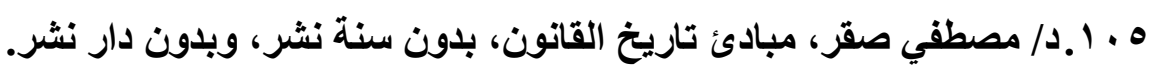

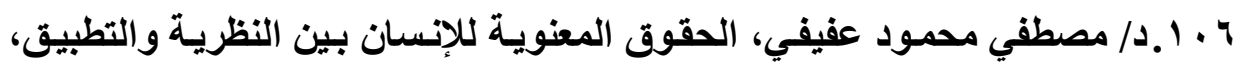
دار الفكر العربي، بدون تاريخ نشر.

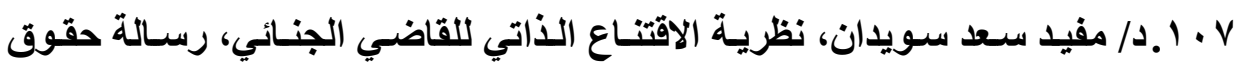

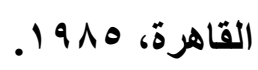
1 . 1 ـد/ منير يوسف حامد المناصير، سلطة المحكم في الإثبات في خصومة التحكيم

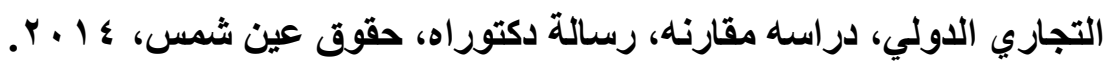

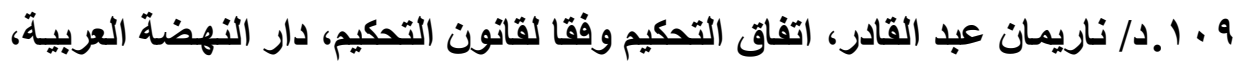
.1997 • 11 ـد/ نبيل إبراهيم سعد، الإثبات في المواد المدنية والتجاريـة، دار الجامعة الجديد،

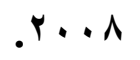
111 ـد نبيل إسماعيل عمر، التحكيم في المواد المدنية والتجاريـة الوطنية والدولية،

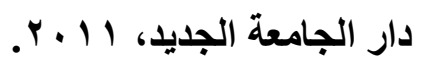




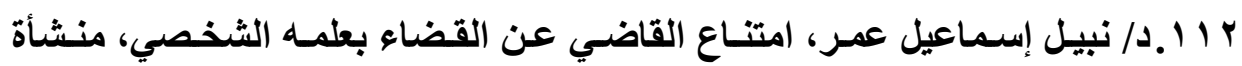

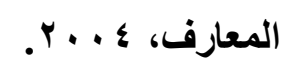

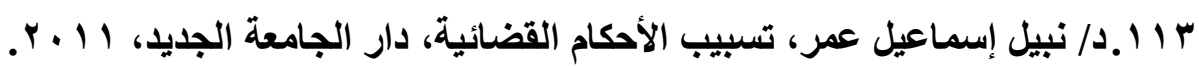

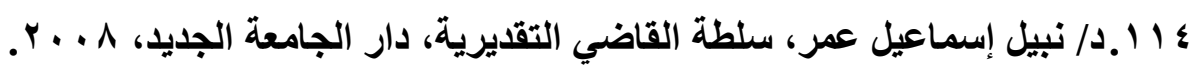

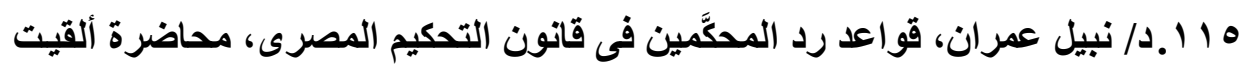

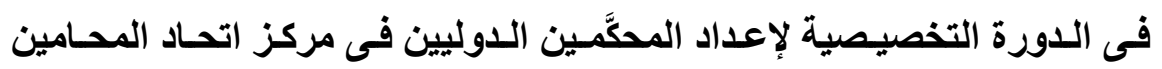

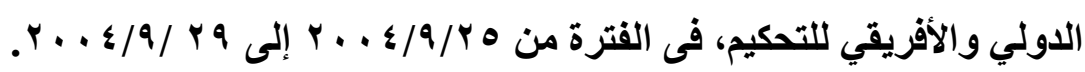

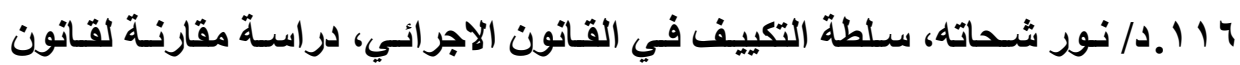

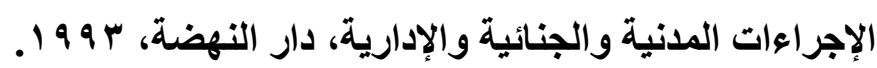

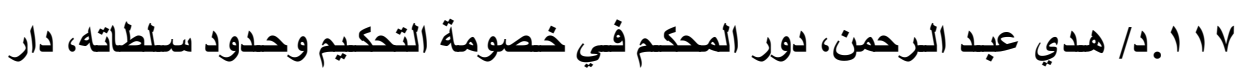

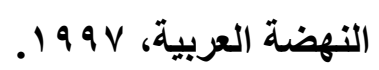

111 ـ/د/ وجدي راغب، النظريـة العامـة للعمل القضائي في قـانون المرافعـات، رسـالة

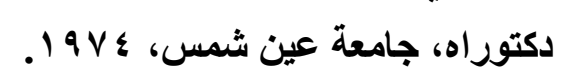

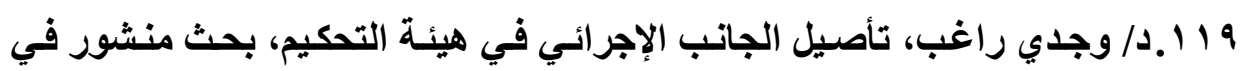

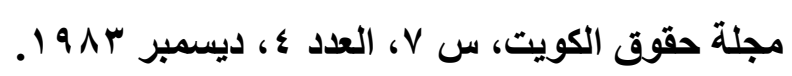

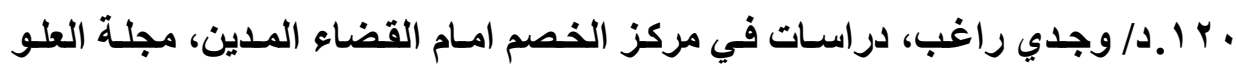

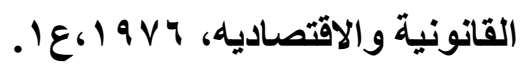

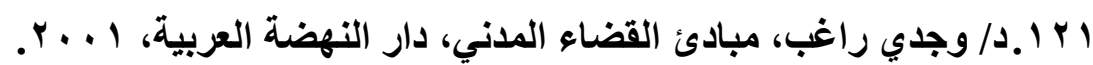

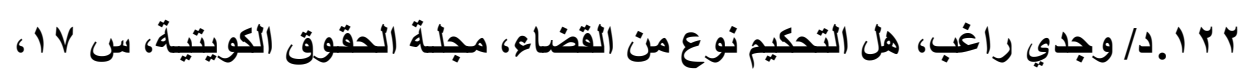

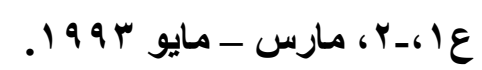

rr ا ـد/ ياسر عبد الهادي مصلحي سـلام، أثز الخطأ في إجراءات التحكيم علي حكم

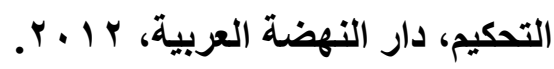

ثانيًا: مراجع أجنبية 
1. ANDRE, Du principe de la neutralité du juge dans l'instruction des affaires civiles, Paris, 1910.

2. BARRET-KRIEGEL B. Les droits de l- homme et le droit natural, Paris, PUF, 1989

3. B. Moreau, A. Beregoi, et autre, arbitrage commercial, D,. 2014.

4. Ch. JARROSSON, la notion d'arbitrage, préface de $B$. OPPETIT, LGDJ, 1987.

5. CH. PERELMAN et P. FORIERS, la motivation des decisions de jusitice, D., 1978.

6. Chainis, l- arbiter, le droit et la contradiction, Rev. Arb., 2010.

7. Charles JARROSSON, note sous Cass. 2e civ., 19 avril 1985, , Rev. Arb., 1986, p. 57, spec.

8. Charmont, La reconnaissance du droit naturel, 2 éd., Paris, 1927.

9. CHEVAILIER J., Cours de droit civil approfondi, la charge de la preuve, Les Cours de droit, 1959.

10. E. Loquin, 1- amiable composition en droit copmparé et international, Litec, 1981.

11.F.E. KLEIN, "autonomie de la volonté et arbitrage", Rev. crit. DIP, 1958.

12.FOUCHARD Ph., GAILLARD E. et GOLDMAN B., traite de l' arbitrage commercial international, LITEC, 1996.

13. Gerard couchez, procédure civil, 12e éd., Armand colin، 
14. H. SOLUS et R. PERROT, droit judiciaire prive, t.1, 1961.

15. Henri Bejoint, le Robert Methodique du france actuel.

16.J. L. DELVOLVE, " devoirs et responsabilités de l'avocat exerçant la fanction d arbitres", Rev. arb., 1984.

17.J. ROBERT, l'arbitrage droit interne et droit international privé, Dalloz., 6e éd.1993., p. 178

18. J. THORENS, I* arbitre international au point de rencontre des traditions de droit civil et de la common law, Melange, P. LALIVE, 1993.

19.J. VIATTE, «la récusation des arbitres», Gaz. pal, 1973, 2, doctr., 719

20.J.-Cl. DUBARRY et E. LOQUIN, «la désignation comme arbitre de l'avocat de l'une des parties", obs. sous CA Versailles, 14 novembre 1996, RTD com. 1997.

21. Kessed J., principe de la contradiction et arbitrage, Rev. arb., 1995.

22. Lecuyer, Arbitrage, J. cl., proc. Civ., fasc., 20, no 56.

23. Loen Mazeaud, J. Mazeaud et $F$. chabas, lécons de droit civile introduction a l- étude du droit, 12 èd. Montchrestien, 2000.

24. M. de BOISSESON, le droit français de l'arbitrage interne, droit international, préface de P. BELLET, GLN Joly, 1990.

25.M. HENRY, " Les obligations d'indépendance et d'information de l'arbitre à la lumière de la jurisprudence récente' Rev. arb., 1999. 
26. M. HENRY, Le devoir d'indépendance de l'arbitre, thèse, Paris, sous la direction de P. MAYER, soutenue le 28 novembre 1996.

27. M. Maurin, le rôle reateur du juge dans les jurisprudances canadienne et francaise comparées, paros Rousseau, 1938.

28.M-A. FRISON-ROCHE, «l'impartialité du juge», Recueil Dalloz, 1999, chronique.

29. Marcel Stati, Le standard juridique, These, Paris, 1927.

30. MOTULSKY, Relation méthodique de droit positif, these, loyon, 1947.

31. NORMAND, le juge et le litige; thèse, lille, 1965.

32.P. AZARD, l'immutabilité de la demande en droit judiciaire français, thèse, Paris, 1936.

33. P. LALIVE " sur l'impartialité de l'arbitre international en suisse' semaine judiciaire, 1990.

34. P. LEVEL, " Brèves réflexions sur l'office de l'arbitre", Mélanges Perrot, Dalloz, 1995.

35. Ph FOUCHARD, L· arbitrage commercial international, D., 1965.

36. Ph. BERTIN, $L \cdot$ indication du fondement juridique de la demande, Gaz pal, 1987, 2., p. 839.

37. Ph. GRANDUEAU, note sous la CA Paris, 28 octobre 1999 et CA Paris, 30 novembre, Rev. arb., 2000. 
38. Ph. Pinsolle et $\mathrm{R}$. Kreindler, les limites du role de la volonte des parties dans la conduit de $\mathrm{I} \cdot$ instance arbitrale, Rev. Arb., 2003,p.60.

39. $R$ PERROT, Principe de la contradiction et les faits dans le débat, RTD civ. 2011.

40.R. David, L'arbitrage dans le commerce international, Economica, 1982.

41.R. De GOUTTES, "L'impartialité du juge", Revue de science criminelle, 2003, p.63.

42. R. PERROT, I- application a l- arbitrage des regles de nouveua code de procedure civile, Rev. Arb., 1980، p. 643.

43. S. Guinchard, L- arbitrage et le respect du principe du contradictoire, Rev. Arb., 1997, p.1.

44. S. JOSSERAND, L'impartialité du magistrat en procédure pénale, préface de J. FRANCILLON, L.G.D.J., 1998.

45. T. Clay, L・ appui du juge à l- arbitrage, Cah. Arb., 2011.

46. T. CLAY, L'arbitre, D., 2001

47. VINCENT et GUINCHARD, procedure civile, 26 éd. Dalloz

48.V. VEEDER «la nouvelle loi anglaise sur l'arbitrage de 1996, la naissance d'un magnifique éléphant», Rev. arb. 1997.

49. $X$. de MELLO, «réflexion sur les règles déontologiques élaborées par l'international bar association pour l'arbitres internationaux», Rev. arb., 1988. 